
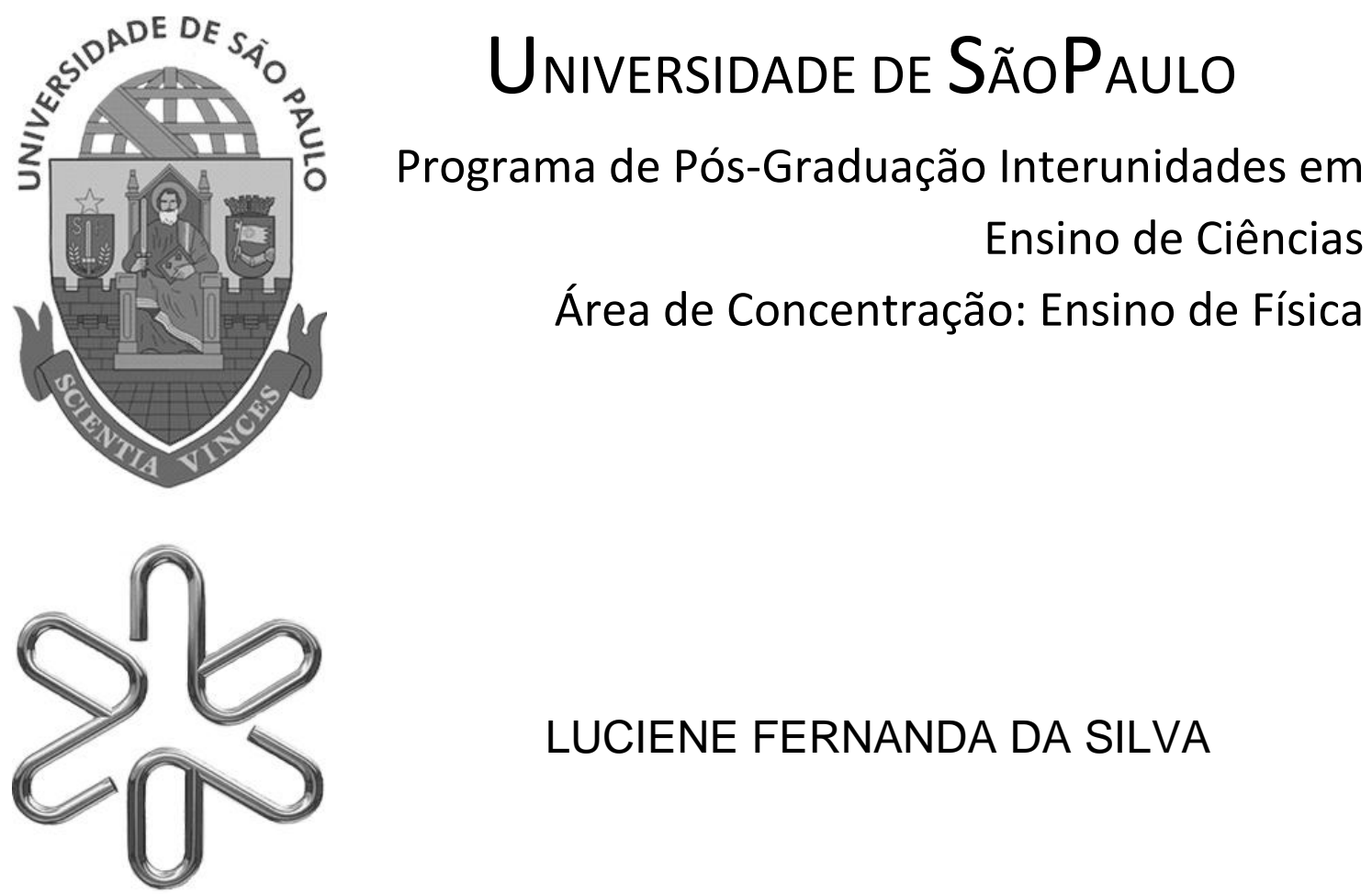

LUCIENE FERNANDA DA SILVA

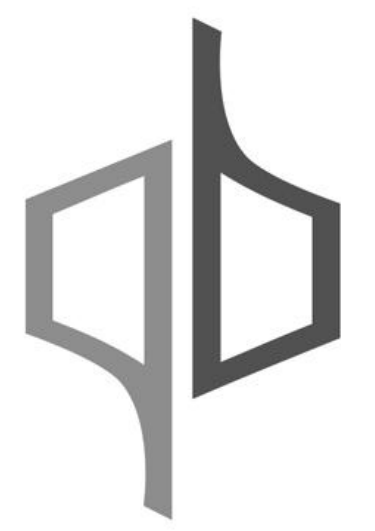

\title{
Mestrado profissional: impactos no desenvolvimento profissional dos professores de Física
}

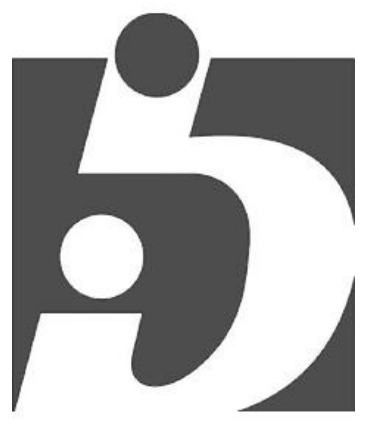

· FEUS P 


\section{Mestrado profissional: impactos no desenvolvimento profissional dos professores de Física}

\section{Versão Corrigida}

Tese apresentada ao Instituto de Física, ao Instituto de Química, ao Instituto de Biociências e à Faculdade de Educação da Universidade de São Paulo para a obtenção do título de Doutora em Ensino de Ciências

Área de concentração: Ensino de Física

Orientador: Prof. Dr. Alberto Villani 
Autorizo a reprodução e divulgação total ou parcial deste trabalho, por qualquer meio convencional ou eletrônico, para fins de estudo e pesquisa, desde que citada a fonte.

\section{FICHA CATALOGRÁFICA \\ Preparada pelo Serviço de Biblioteca e Informação do Instituto de Física da Universidade de São Paulo}

Silva, Luciene Fernanda da

Mestrado profissional: impactos no desenvolvimento profissional dos professores de física. São Paulo, 2019.

Tese (Doutorado) - Universidade de São Paulo. Faculdade de Educação, Instituto de Física, Instituto de Química e Instituto de Biociências.

Orientador: Prof. Dr. Alberto Villani

Área de Concentração: Ensino de Física.

Unitermos: 1. Física - Estudo e ensino; 2. Mestrado profissional; 3. Desenvolvimento profissional; 4. Formação de professores.

USP/IF/SBI-055/2019 


\section{AGRADECIMENTOS}

Agradeço a todas as pessoas que surgiram em meu caminho ao longo desses quatros anos e que me tocaram de todas as formas possíveis.

Agradeço aos amigos da USP que tanto me incentivaram a ingressar no doutorado, quanto a prestar concursos e expandir meus horizontes.

Agradeço a todos os professores que cederam entrevistas para a realização desse trabalho. Foi uma grande aventura conhecer tantas pessoas diferentes, cada uma com uma trajetória e percepções sobre seu trabalho e educação distintas. Através de nossos contatos, pude crescer como pesquisadora e também como professora de Física.

Agradeço aos colegas de trabalho e alunos do IFRJ pelas grandes oportunidades dadas dia após dia de me tornar uma profissional - e pessoa cada vez melhor.

Agradeço aos amigos e amigas íntimos, que mesmo não fazendo parte do universo da Academia, foram grandes portos seguros na minha vida para além deste trabalho. Agradeço aos amigos de São Paulo, Minas Gerais, Rio de Janeiro, Santa Catarina, Bahia, todos que se espalham por todo o Brasil e aqueles de além-mar.

Agradeço nominalmente ao orientador Alberto Villani e grupo de pesquisa, que mesmo eu estando distante, morando em outro estado, foram e sempre serão referências para mim.

Agradeço à família, principalmente por terem pavimentado o caminho que me trouxe até aqui. Agradeço a grande herança representada pela honestidade e pelo amor ao conhecimento que meu pai deu para mim.

Agradeço ao universo por cada desafio colocado em meu caminho, pois foram mais eles - do que as vitórias em si - que me tornaram o que sou hoje. Agradeço cada oportunidade, cada recurso enviado em meu benefício. Agradeço pelos sinais e pela poesia presentes em cada segundo de meu cotidiano.

Por fim, agradeço a todos aqueles - os que conheço e não conheço - que lutam por um Brasil mais justo e humanitário. São todos grandes inspirações. 
Apelidaram-me um dia de Ave-serena. Fui então observar a serenidade das aves. Observei noites e dias. E apreendi que, se a serenidade for a condição prima da ave, a ela, mesmo em momentos de profunda tormenta, caberá reaprumar o corpo, avaliar a condição de voo e de pouso, e seguir adiante. Se for dela a serenidade, mesmo quando em breves, raros, mas mortais instantes, suas penas, aquelas que recobrem o peito - exatamente na área do coração - se eriçarem diante à desventura de um espaço que ela não domina, e desconhece, caberá à ave esgotar a sua própria tormenta e se reerguer depois. À ave serena não é permitido cultivar o engano, ela sabe que o amor - dom maior da serenidade e do desespero - se realiza ou se anula por um triz. 


\section{RESUMO}

SILVA, Luciene Fernanda da. Mestrado Profissional: impactos no desenvolvimento profissional dos professores de Física. 2019. 320 f. Tese (Doutorado em Ensino de Ciências) - Instituto de Física, Instituto de Química, Instituto de Biociências e Faculdade de Educação - Programa Interunidades em Ensino de Ciências, Universidade de São Paulo, São Paulo, 2019.

Criados em 1995, como nova modalidade da pós-graduação stricto sensu brasileira, os cursos de Mestrados Profissionais (MPs) têm atualmente grande expressão no Sistema de Pós-graduação brasileiro, em especial na Área de Ensino, cujos MPs começaram a ser implantados em 2002. Os MPs têm a proposta de oferecer fundamentação teórica e metodológica aos profissionais para que possam responder às demandas de sua prática, com a obrigatoriedade da elaboração de um produto educacional. A partir de 2011, os Mestrados em Rede - programas de alcance nacional, realizados em polos credenciados e alocados em instituições de diferentes partes do país - se desenvolveram principalmente para atender professores de diferentes disciplinas de atuação. O Mestrado Nacional Profissional em Ensino de Física (MNPEF), coordenado pela Sociedade Brasileira de Física, por exemplo, iniciou suas atividades em 2013, atendendo aos professores de Física da educação básica. Utilizando-se como principais referenciais teóricos as dimensões do desenvolvimento profissional docente (BAROLLI et al., 2019) e de autoria docente (MAIA, 2017), essa pesquisa objetiva responder às seguintes questões: quais são os impactos de cursos de Mestrado Profissional estruturados de diferentes formas sobre o desenvolvimento profissional (em termos de formação e mudanças na prática profissional) de seus professorescursistas? Como os professores-cursistas interagem com currículo proposto e praticado nesses cursos? Para isso, analisamos em profundidade dois cursos de MP: um polo do MNPEF e um curso local implantado em uma instituição federal. A pesquisa foi realizada em etapas buscando a compreensão do funcionamento de cada curso e as atividades realizadas pelos professorescursistas e suas vivências pessoais, com a análise de inspiração fenomenológica de documentos que regem os cursos; entrevistas com coordenação e membros do corpo docente; análise de dissertações e produtos educacionais e, por fim, entrevistas realizadas com egressos. Os resultados da análise dos dois conjuntos de dados apontam para pequenas diferenças individuais de desenvolvimento profissional entre os egressos e no rumo que tomaram após a conclusão dos cursos. Entretanto, ambos os cursos alcançaram resultados semelhantes em termos de alcance e abrangência das dimensões de desenvolvimento profissional proporcionado aos entrevistados. A pesquisa contribui também apontando lacunas e questões para reflexão dos cursos de MP e também a importância da interação com colegas e corpo docente; da preocupação com a prática profissional docente e do contato com o mundo acadêmico e da pesquisa em ensino de Física como elementos essenciais para o desenvolvimento profissional dos egressos.

Palavras-chave: mestrado profissional, desenvolvimento profissional docente, formação de professores. 


\begin{abstract}
SILVA, Luciene Fernanda da. Mestrado Profissional: impactos no desenvolvimento profissional dos professores de Física. 2019. $320 \mathrm{f}$. Tese (Doutorado em Ensino de Ciências) - Instituto de Física, Instituto de Química, Instituto de Biociências e Faculdade de Educação - Programa Interunidades em Ensino de Ciências, Universidade de São Paulo, São Paulo, 2019.

Created in 1995, as a new modality of brazilian masters, the Professional Master's degree courses (MPs) currently have great expression in the Brazilian Postgraduate System, especially in the teaching area, whose MPs began in 2002. The MPs aim to offer theoretical and methodological foundation for professionals so they can respond to demands from their practice, with educational product elaboration liability. Succeeding 2011, the National Masters - carried out in accredited poles and alocated in institutions of different parts of the country - were developed mainly to attend different disciplines teachers. The National Professional Masters in Physics Teaching (MNPEF), coordinated by the Brazilian Physics Society, for instance, started its activities in 2013, attending physics teachers. Using as main theoretical framework the discussions about professional teacher development (BAROLLI et al., 2019) and teaching authorship (MAIA, 2017), this work aims to answer the following questions: what are the Professional Master's courses impacts in different professional development (in terms of training and practice changes) for the masters students that are also teachers? How do they interact with the proposed and practiced curriculum in these courses? For that purpose, we analyze in depth, two MP courses: one from MNPEF and a local course implanted in federal institution. The research was carried out in stages, seeking an understanding of both courses inner workings as well as activities carried out by teachers with their personal experiences and phenomenological based analysis for documents; interviews with faculty members and teachers; and educational products and essay analysis. The information found through analysis of the two data sets point to small individual differences in professional development among the graduated teachers and the course they took after completion. However, both processes achieved similar conclusion in professional development scope. The research outcome contributes pointing out MPs reflection gaps and questions as well as the interaction among colleagues and faculty importance; the concern with professional teaching practices, the contact with modern academic discussions and the Physics teaching research as essential elements for the professional development of teachers.
\end{abstract}

Keywords: Professional Master's Degree, professional development, teacher education. 


\section{LISTA DE FIGURAS}

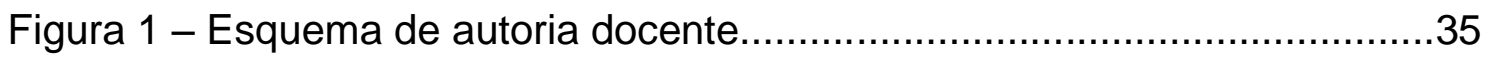

Figura 2 - Distribuição geográfica dos polos do MNPEF aprovados nos editais de credenciamento de 2013 a 2016 em IES

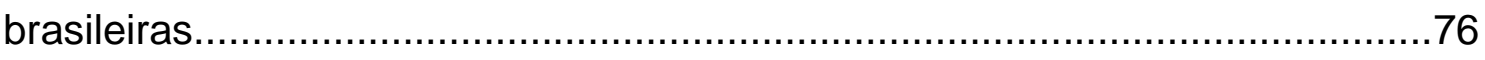

Figura 3 - Estrutura organizacional e administrativa do MNPEF em âmbito nacional (diagrama à esquerda) e local (diagrama à direita)...........................100 


\section{LISTA DE TABELAS}

Tabela 1 - Quadro de disciplinas obrigatórias e optativas da grade curricular (2014) do MNPEF. 103

Tabela 2 - Quadro de disciplinas ofertadas no MP.Local (2015)

Tabela 3 - Totais de créditos para o curso do MP.Local (2015)..... 119

Tabela 4 - Linhas de pesquisa e projetos associados (2015) do MP.Local....123

Tabela 5 - Dados, atualizados em junho de 2017, do corpo docente do polo do MNPEF 131

Tabela 6 - Dados, atualizados em junho de 2017, do corpo docente do MP.Local. 144

Tabela 7 - Problemas da prática docente apontados como motivadores para a realização dos PEs defendidos até 2017 no contexto do polo do MNPEF......168

Tabela 8 - Motivações apresentadas pelos professores egressos do polo do MNPEF para a construção dos PEs propostos 171

Tabela 9 - Problemas da prática docente apontados como motivadores para a realização dos PEs defendidos até 2017 no contexto do MP.Local... 194

Tabela 10 - Motivações apresentadas pelos professores egressos do MP.Local para a construção dos PEs propostos

Tabela 11 - Apresentação geral dos egressos do polo do MNPEF entrevistados. 215

Tabela 12 - Apresentação geral dos egressos do MP.Local entrevistados. 259 


\section{LISTA DE SIGLAS}

Anped

ANPG

ATPC

BID

BM

Capes

CEFET/RJ

CERN

CFE

CTS

DCNFP

DED

DEB

EBEF

EJA

ENMP

ENPEC

EPEF FOPROF

FUNDEF

GEOCAPES

GT

HFC

IES

IMPA

INEP

LDB

$M A(s)$

MBA

MEC

MNPEF (Profis)

$\mathrm{MP}(\mathrm{s})$

OBEDUC

OCDE

OEA

ONU

Parfor

$\mathrm{PCN}+$
Associação Nacional de Pós-graduação e Pesquisa em Educação

Associação Nacional de Pós-graduandos

Aula de Trabalho Pedagógico Coletivo

Banco Interamericano de Desenvolvimento

Banco Mundial

Coordenação de Aperfeiçoamento de Pessoal de

Nível Superior

Centro Federal de Educação Tecnológica Celso

Suckow da Fonseca

Organização Europeia para a Pesquisa Nuclear

Conselho Federal de Educação

(abordagem) Ciência-Tecnologia-Sociedade

Diretrizes Curriculares Nacionais para a Formação

de Professores

Diretoria de Educação a Distância

Diretoria de Formação de Professores da Educação

Escola Brasileira de Ensino de Física

Educação de Jovens e Adultos

Encontro Nacional dos Mestrados Profissionais

Encontro Nacional de Pesquisadores em Ensino de

Ciências

Encontro de Pesquisadores de Ensino de Física

Fórum Nacional dos Mestrados Profissionais

Fundo de Manutenção e Desenvolvimento do Ensino

Fundamental e da Valorização do Magistério

Sistema de Informações Georreferenciais da Capes

Grupo de Trabalho

História e Filosofia da Ciência

Instituições de Ensino Superior

Instituto Nacional de Matemática Pura e Aplicada

Instituto Nacional de Estudos e Pesquisas

Educacionais Anísio Teixeira

Lei de Diretrizes e Bases da Educação Nacional

Mestrado(s) Acadêmico(s)

Master of Business Administration

Ministério da Educação

Mestrado Nacional Profissional em Ensino de Física

Mestrado(s) Profissional(ais)

Programa Observatório da Educação

Organização de Cooperação e Desenvolvimento

Econômico

Organização dos Estados Americanos

Organização das Nações Unidas

Programa Nacional de Formação de Professores da

Educação Básica

Orientações Complementares aos Parâmetros

Curriculares Nacionais 


\begin{tabular}{|c|c|}
\hline $\mathrm{PE}(\mathrm{s})$ & Produto(s) Educacional(ais) \\
\hline PES & Prática de Ensino Supervisionada \\
\hline PhET & Physics Education Technology \\
\hline PNE & Plano Nacional de Educação \\
\hline PPC & Projeto Pedagógico dos Cursos \\
\hline PROEB & $\begin{array}{l}\text { Mestrados Profissionais para Professores da } \\
\text { Educação Básica }\end{array}$ \\
\hline PROEF & Mestrado Profissional em Educação Física Escolar \\
\hline ProfArtes & Mestrado Profissional em Artes \\
\hline PROFBIO & $\begin{array}{l}\text { Mestrado Profissional em Ensino de Biologia em } \\
\text { Rede Nacional }\end{array}$ \\
\hline PROFCIAMB & $\begin{array}{l}\text { Programa de Pós-graduação em Rede Nacional para } \\
\text { Ensino das Ciências Ambientais }\end{array}$ \\
\hline ProfHistória & Mestrado Profissional em Ensino de História \\
\hline PROF-FILO & Mestrado Profissional em Filosofia \\
\hline ProfLetras & Mestrado Profissional em Letras \\
\hline PROFMAT & $\begin{array}{l}\text { Programa de Mestrado Profissional em Matemática } \\
\text { em Rede Nacional }\end{array}$ \\
\hline PROFQUI & $\begin{array}{l}\text { Mestrado Profissional em Química em Rede } \\
\text { Nacional }\end{array}$ \\
\hline ProfSocio & $\begin{array}{l}\text { Mestrado Profissional em Ciências Sociais para o } \\
\text { Ensino Médio }\end{array}$ \\
\hline PSSC & Physical Science Study Committee \\
\hline SBF & Sociedade Brasileira de Física \\
\hline SBM & Sociedade Brasileira de Matemática \\
\hline SBQ & Sociedade Brasileira de Química \\
\hline SECADI & $\begin{array}{l}\text { Secretaria de Educação Continuada, Alfabetização, } \\
\text { Diversidade e Inclusão }\end{array}$ \\
\hline SNEF & Simpósio Brasileiro de Ensino de Física \\
\hline STF & Supremo Tribunal Federal \\
\hline TCC & Trabalho de Conclusão de Curso \\
\hline $\mathrm{TIC}(\mathrm{s})$ & Tecnologia(s) da Informação e Comunicação \\
\hline$U A B$ & Universidade Aberta do Brasil \\
\hline UDESC & Universidade do Estado de Santa Catarina \\
\hline UEPB & Universidade Estadual da Paraíba \\
\hline UFABC & Universidade Federal do $A B C$ \\
\hline UFF & Universidade Federal Fluminense \\
\hline UFLA & Universidade Federal de Lavras \\
\hline UFMG & Universidade Federal de Minas Gerais \\
\hline UFPR & Universidade Federal do Paraná \\
\hline UFRGS & Universidade Federal do Rio Grande do Sul \\
\hline UFRN & Universidade Federal do Rio Grande do Norte \\
\hline UNB & Universidade de Brasília \\
\hline UNESP & Universidade Estadual Paulista \\
\hline Unicsul & Universidade Cruzeiro do Sul \\
\hline UNIFRA & Universidade Franciscana \\
\hline UNIGRANRIO & Universidade do Grande Rio \\
\hline Unesco & $\begin{array}{l}\text { Organização das Nações Unidas para a Educ } \\
\text { Ciência e a Cultura }\end{array}$ \\
\hline
\end{tabular}




\section{Sumário}

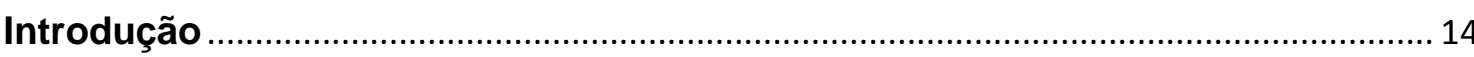

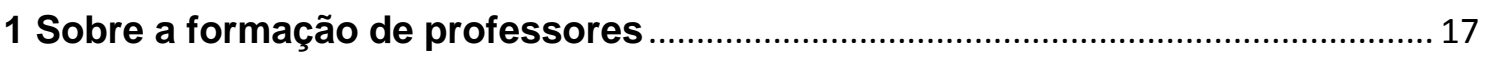

1.1 Concepções de formação em serviço............................................................... 19

1.2 Desenvolvimento profissional docente: síntese ............................................. 27

1.30 lugar do desenvolvimento profissional de professores ............................... 36

1.4 Formação continuada de professores nas políticas públicas de educação

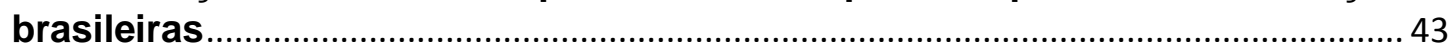

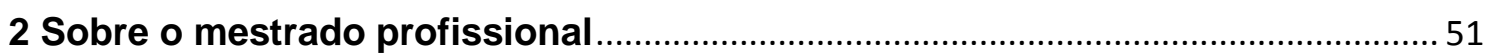

2.1 Histórico nacional e referências na legislação.................................................... 53

2.2 O Mestrado Profissional para Professores da Educação Básica ..................... 66

2.3 Revisão de literatura: mestrados profissionais e o desenvolvimento

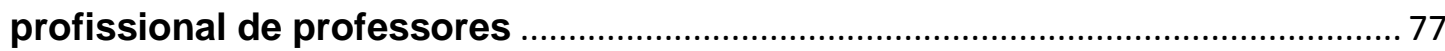

3 Proposição de pesquisa e seu percurso metodológico …...................................... 87

4 A pesquisa: realização, apresentação de dados, análises e discussões............. 95

4.1 Análise documental dos documentos dos cursos de MP ............................ 95

4.1.1 Análise documental dos documentos do curso do polo do MNPEF......96

4.1.2 Análise documental dos documentos do curso do MP.Local................ 109

4.1.3 Apreciações sobre a análise documental dos documentos dos cursos

4.20 corpo docente dos cursos de mestrado profissional .............................. 128

4.2.1 Corpo docente do polo do MNPEF: dados gerais e análise com elementos narrativos...

4.2.2 Corpo docente do MP.Local: dados gerais e análise com elementos narrativos

4.2.3 Apreciações sobre as análises das entrevistas realizadas com docentes

4.3 Análise documental dos produtos educacionais e dissertações defendidos nos cursos de mestrado profissional

4.3.1 Análise dos produtos educacionais e dissertações defendidos no polo do MNPEF até 2017.

4.3.2 Análise dos produtos educacionais e dissertações defendidos no MP.Local até 2017

4.3.3 Apreciação sobre a análise dos produtos educacionais e dissertações

5 Os egressos dos cursos de mestrado profissional..

5.10 desenvolvimento profissional de egressos do polo do MNPEF.

5.1.1 Análise com elementos narrativos de MNPEF.01: o professor astrônomo 
5.1.2 Análise com elementos narrativos de MNPEF.05: o professor reflexivo

5.1.3 Análise com elementos narrativos de MNPEF.07: o professor que encontra a superação.

5.1.4 Análise com elementos narrativos de MNPEF.08: o professor intelectual.

5.1.5 Análise com elementos narrativos de MNPEF.09: o professor interessado nos PEs.

5.1.6 Análise com elementos narrativos de MNPEF.10: o professor que se descobriu criativo

5.1.7 Análise com elementos narrativos de MNPEF.15: o professor que valoriza as relações

5.1.8 Análise com elementos narrativos de MNPEF.17: o professor que se tornou mais seguro de si.

5.1.9 Análise com elementos narrativos de MNPEF.19: o professor que se sentiu valorizado

5.1.10 Análise com elementos narrativos de MNPEF.28: o professor que

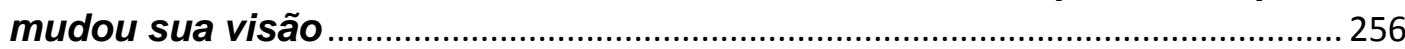

5.20 desenvolvimento profissional de egressos do MP.Local.......................... 258

5.2.1 Análise com elementos narrativos de MP.Local.01: o professor prático

5.2.2 Análise com elementos narrativos de MP.Local.02: o professor que seguiu carreira acadêmica.

5.2.3 Análise com elementos narrativos de MP.Local.03: o professor extrovertido.

5.2.4 Análise com elementos narrativos de MP.Local.04: o professor que busca desenvolver PEs

5.2.5 Análise com elementos narrativos de MP.Local.06: o professor que obteve ferramentas para seu trabalho..

5.2.6 Análise com elementos narrativos de MP.Local.12: o professor que mudou sua relação com os alunos

5.2.7 Análise com elementos narrativos de MP.Local.14: a professora que encontrou segurança.

5.2.8 Análise com elementos narrativos de MP.Local.15: a professora acadêmica

5.2.9 Análise com elementos narrativos de MP.Local.16: o professor universitário.

5.2.10 Análise com elementos narrativos de MP.Local.18: a professora pesquisadora.

5.3 Apreciações sobre as análises: o que revelam sobre os cursos de MP e o desenvolvimento profissional dos egressos.

6 Conclusões e perspectivas abertas pela pesquisa 298 
Referências

Apêndice 1 - Base do roteiro de entrevistas semi-estruturadas realizadas com os coordenadores dos cursos de MP

Apêndice 2 - Base do roteiro das entrevistas semi-estruturadas realizadas com os docentes dos cursos de MP

Apêndice 3 - Ficha de leitura utilizada para coleta de dados das dissertações e produtos educacionais dos cursos de mestrado profissional analisados...

Apêndice 4 - Base do roteiro das entrevistas semi-estruturadas realizadas com os egressos dos cursos de MP 


\section{Introdução}

Uma nova modalidade na pós-graduação stricto sensu brasileira é discutida e implementada a partir dos anos 1990: os Mestrados Profissionais.

Alvo de discussões controversas principalmente entre os pesquisadores da área de Educação e de Ensino de Ciências em seu início, é justamente nessa última área que se dá, a partir dos anos 2000, um crescimento acentuado na criação de cursos dessa modalidade. Seu formato, que se dirige ao apoio teórico e metodológico proporcionado ao profissional para a busca de soluções para problemas originados de sua própria prática, foi considerado, por seus defensores, como espaço privilegiado para promover a aproximação entre universidades e escolas de educação básica. Voltando à universidade e se envolvendo com a prática da pesquisa e o aprofundamento de sua formação acadêmica, os professores ingressantes nesses cursos teriam uma grande oportunidade de se desenvolverem profissionalmente, aprimorando seu trabalho nas escolas. A aposta nos Mestrados Profissionais em Ensino, recentemente ampliada pela criação dos Mestrados Profissionais em Rede, de alcance nacional, é expressão de outra expectativa: a de que esses cursos poderiam colaborar, por meio da formação dos professores titulados e da divulgação dos produtos educacionais produzidos pelos mesmos, a melhoria na qualidade da educação básica brasileira.

Após quase 20 anos da criação dos primeiros cursos de Mestrado Profissional dirigidos à professores de Física (são eles: o Mestrado Profissional em Ensino de Ciências e Matemática, da UFRN, e o Mestrado Profissional em Ensino de Física da UFRGS, ambos implementados a partir de 2002), e seis anos da implantação dos primeiros polos do Mestrado Nacional Profissional em Ensino de Física (MNPEF), promovido pela Sociedade Brasileira de Física (SBF), surge como problemática a avaliação do que se tem alcançado nesses cursos. Entre outros, surgem questionamentos sobre o auxílio que esses cursos têm prestado aos professores para se desenvolverem profissionalmente e solucionarem suas demandas da prática profissional; o efeito desses cursos nas mudanças promovidas em suas práticas (e o quanto essas mudanças se sustentam após a titulação dos professores); os usos dos produtos educacionais, resultado do trabalho dos mestres profissionais titulados; entre outros.

Indo além das avaliações periódicas da Capes e das autoavaliações realizadas da perspectiva institucional de cada curso, torna-se relevante a realização de 
investigações que envolvam estudos de caso realizados em profundidade. Essa categoria de pesquisa ajudaria a cobrir, também, lacunas que são observadas na área de investigação de Ensino de Ciências e Formação de Professores. Apesar do tempo de consolidação desses cursos e do investimento realizado neles, são poucos os trabalhos que investigam essas questões. Apenas para citar um exemplo mais recente, no XI ENPEC - Encontro Nacional de Pesquisadores em Ensino de Ciências, realizado em Florianópolis/SC, no período de 03 a 06 de julho de 2017, foram apresentados apenas quatro trabalhos que tiveram os mestrados profissionais em Ensino de Ciências como objetos de pesquisa. Observando os títulos desses trabalhos ${ }^{1}$, todos dedicados à investigação sobre as dissertações e produtos educacionais elaborados por professores no contexto desses cursos.

A pesquisa desenvolvida e apresentada nesta tese visou através de estudos de caso, investigar os impactos proporcionados por dois diferentes cursos de mestrado profissional no desenvolvimento profissional dos professores-cursistas, nomenclatura que será utilizada para nos referirmos aos professores titulados mestres nestes cursos. As questões de pesquisa formuladas são as seguintes: quais são os impactos de cursos de Mestrado Profissional estruturados de diferentes formas sobre 0 desenvolvimento profissional (em termos de formação e mudanças na prática profissional) de seus professores-cursistas? Como os professores-cursistas interagem com currículo proposto e praticado nesses cursos? Foram escolhidos dois cursos (um Mestrado Profissional Local, instalado em uma instituição federal desde 2008 e um polo do MNPEF, implantado em uma universidade federal em 2013) a fim de aprofundar os impactos de cada um para atender às demandas dos professores que optam por essa modalidade de formação continuada. Buscamos, nesta pesquisa, conhecer, analisar e avaliar as implicações de cada curso no desenvolvimento profissional de grupos de professores de Física egressos de cada um.

Nos capítulos que se seguem, portanto, são apresentadas: uma discussão aprofundada sobre Formação de Professores (em especial a modalidade de Formação em Serviço), na perspectiva de Desenvolvimento Profissional Docente (de onde deriva parte do referencial teórico utilizado para a análise dos dados de pesquisa); o histórico de discussões e legislação a respeito dos Mestrados Profissionais, em especial, os orientados aos professores de Física; o percurso metodológico de pesquisa; os

\footnotetext{
${ }^{1}$ São eles: "Os Mestrados Profissionais em Ensino de Ciências e seus Produtos Educacionais: Aplicabilidade e divulgação desse material na área da formação de professores"; "Produtos educacionais elaborados no Mestrado Profissional em Ensino: uma alternativa para reduzir a distância entre a pesquisa e a prática docente"; "Interdisciplinaridade e ensino de ciências: a presença da História Oral em dissertações do Mestrado Profissional" e "Características e especificidades das dissertações do Mestrado Profissional em Ensino de Física da UFRGS".
} 
resultados obtidos juntamente com a análise empreendida do conjunto de dados (documentos que regem os cursos, dissertações e produtos educacionais defendidos no período analisado, entrevistas com coordenadores e membros do corpo docente, entrevistas com egressos dos dois cursos); e, finalmente, as considerações finais com nossas respostas às questões de pesquisa e indicação de desdobramentos decorrentes da realização desta pesquisa. 


\section{Sobre a formação de professores}

No Brasil, pode-se afirmar que a formação de professores começa a ser pautada em discussões sobre políticas educacionais com a instituição das primeiras universidades (a partir da década de 1930), que basicamente se originaram da junção de faculdades isoladas já existentes, dedicadas à formação de profissionais liberais, com as Faculdades de Filosofia, Ciências e Letras, recém fundadas. A formação de professores remonta à origem de tais faculdades pois a elas seria atribuída a função de elemento integrador da universidade, por serem responsáveis por promover a pesquisa científica pura e a formação de professores para a escola secundária ${ }^{2}$ (SUCUPIRA, 1969). É nesse contexto que se institui o famoso modelo $3+1$ para a formação inicial de professores, que posteriormente, em especial a partir da década de 1980, é discutido e refutado com a proposição outros modelos para a formação docente, sob novas perspectivas.

Dito isso, embora de nível superior ${ }^{3}$, discussões que apontam a inadequação da formação oferecida objetivando a qualificação para o exercício docente são frequentes ao longo das décadas. A fragilidade nas proposições de formação de professores, pode ser, em parte justificada, por esta se constituir "dentro e fora da Universidade, uma formação de segunda categoria, face aos demais cursos superiores" (FÉTIZON, 1984, p. 164). Para Saviani (2009), entretanto, esse não seria um reflexo de descaso da universidade em relação à formação docente, mas uma consequência da luta entre dois modelos diferentes de formação, com a predominância daquele

[...] para o qual a formação de professores propriamente dita se esgota na cultura geral e no domínio específico dos conteúdos da área de conhecimento correspondente à disciplina que o professor irá lecionar. Considera-se que a formação pedagógico-didática virá em decorrência do domínio dos conteúdos do conhecimento logicamente organizado, sendo adquirida na própria prática docente ou mediante mecanismos do tipo "treinamento em serviço" (SAVIANI, 2009, p. 149).

\footnotetext{
${ }^{2}$ A escola secundária corresponde aos atuais ciclo II do ensino fundamental e ensino médio. ${ }^{3}$ Cabe ressaltar que a formação de nível superior, por muito tempo esteve reservada apenas aos professores dos anos finais do ensino fundamental e do ensino médio. Aos professores da educação infantil e dos anos iniciais do ensino fundamental era endereçado apenas 0 magistério de nível médio (realizada nas Escolas Normais). $\mathrm{O}$ acesso à formação em nível superior a esses professores é dado pela Resolução $n^{0} 01$ de 2006 do Conselho Nacional de Educação, o qual apresenta as Diretrizes Curriculares Nacionais para os cursos de graduação em Pedagogia, licenciatura.
} 
Os dois modelos de formação em disputa destacados por esse autor podem ser descritos como o modelo dos conteúdos culturais-cognitivos, defendido pelos docentes formadores de especialistas de um determinado campo do saber e o modelo pedagógico-didático, defendido pelos docentes especialistas da área de educação e formadores de professores (SAVIANI, 2009; MAZOTTI, 1993). Segundo o modelo dos conteúdos culturais-cognitivos, à formação de professores cabe fornecer-Ihe o domínio dos conteúdos específicos da área de conhecimento disciplinar que pretendem ensinar e aspectos de cultura geral. O ensino desses conteúdos decorreria do domínio deles, não necessitando aportes pedagógicos e didáticos. Em contrapartida, o modelo pedagógico-didático "considera que a formação do professor propriamente dita só se completa com o efetivo preparo pedagógico-didático" (SAVIANI, 2009, p. 149).

O trabalho dos professores efetivamente desempenhado nas escolas, porém, exige mais que o domínio do conhecimento tomado como objeto de ensino e do seu processo de ensino-aprendizagem; exigências estas que não necessariamente seriam atendidas pelos dois modelos de formação supracitados. As transformações sociais atuais aumentam a importância do papel social que os professores desempenham, já que eles têm se tornado "responsáveis pelo processo de socialização das crianças e jovens", realizada "crescentemente pela via escolar" (BARRETTO, 2011, p. 40). Uma nova postura passa a ser exigida do professor tanto em relação à questão didáticopedagógica quanto à diversificação de suas funções na escola (FORMOSINHO, 2009). É nesse sentido que Gatti (2010) defende que

a formação de professores (seja inicial ou continuada) não pode ser pensada como adendo das disciplinas científicas, mas a partir da função social própria à escolarização, que inclui tanto o conhecimento acumulado com os valores e práticas sociais (p. 553).

Neste contexto, não é mais possível vislumbrar "uma clara definição dos papéis profissionais, registrando-se a importância da flexibilidade do conhecimento e sua adaptabilidade a situações não previstas" (CUNHA, 2010, p. 129). Assim, os desafios que se apresentam ao trabalho docente lançam questionamentos acerca da definição de uma proposta de formação, já que esta não poderá basear-se mais em um constructo de conhecimentos estáticos e permanentes. Pelo contrário, "estará permanentemente em situações movediças, sofrendo alterações, dependendo das condições sócio-históricas do contexto onde se situa" (Ibid., p. 130). Isso significa a adoção da perspectiva de uma formação em um "paradigma do inacabamento" que pressupõe a aquisição de competências pessoais e profissionais "que se vão 
desenvolvendo (construindo) num contínuo e num espaço de intervenção aberto e reflexivo" (LEITÃO; ALARCÃO, 2006, p. 67).

É nesse sentido que a discussão sobre formação docente ultrapassa o período que denominamos de formação inicial (aquela que se dá antes da inserção no mercado profissional) e se localiza também na perspectiva de uma formação que também se dá em serviço. De fato, essa é uma exigência que não cabe apenas à profissão docente, mas a todas as profissões, principalmente no contexto neoliberal instaurado a partir do fim da década de 1990 e que adentra o século XXI.

Esse primeiro capítulo inicia-se com uma discussão ampla sobre a temática da formação docente, concentrando-se nas concepções das diversas perspectivas de formação em serviço e suas nomenclaturas e proposições de formatos. Nessa discussão, se questiona qual é o lugar privilegiado para a formação de professores que permite o enfrentamento dos problemas oriundos da prática em um cenário social e educativo cada vez mais complexo. No fechamento do capítulo, algumas considerações sobre políticas públicas brasileiras a respeito dessa formação são apresentadas.

\subsection{Concepções de formação em serviço}

Segundo Oliveira-Formosinho (2009), o movimento pela formação em serviço ${ }^{4}$ de professores iniciou-se nos Estados Unidos na década de 1970 e se espalhou pela Europa nas décadas de 1980 e 1990, decorrente "de um conjunto complexo de condições históricas, de natureza social, cultural, científica e educacional, que configuram a transição da modernidade para a pós-modernidade na educação" ( $p$. 221). Particularmente, à justificativa da proposição de opções de formação em serviço no contexto brasileiro, acrescenta-se o problema histórico da precariedade da formação pré-serviço muitas vezes inadequada ao exercício docente oferecida a nossos professores ${ }^{5}$ nos cursos de graduação (GATTI, 2008).

\footnotetext{
${ }^{4}$ No contexto desse trabalho, entende-se como "formação em serviço" qualquer proposta de formação (abrangendo, em especial, propostas mais formais como cursos e oficinas, mas também outras, em contextos mais diversificados como encontros pedagógicos, reuniões entre pares, congressos e seminários etc) que é orientada para professores que atuam em salas de aula da educação básica.

${ }^{5}$ Sem contar que parte do corpo docente atuante nos diferentes níveis da educação básica não possuem formação na licenciatura da área em que leciona. Segundo dados do Censo Escolar realizado pelo INEP em 2017, ainda eram $61 \%$ dos professores no ensino médio que não tinham formação adequada, ou seja, licenciatura na mesma área da disciplina que lecionam. No ensino fundamental, esse percentual era de $55,7 \%$ nesse mesmo ano. Como veremos
} 
De qualquer forma, independente da qualidade e adequação da formação préserviço, muitos autores (entre eles PONTE, 1998; TARDIF, 2002; NÓVOA, 2009), assumem que o professor, assim que encerra sua formação inicial e recebe sua habilitação profissional, não é um profissional completo, no sentido de estar totalmente formado, qualificado para a execução de seu trabalho com êxito.

Em outras palavras, a qualificação inicial, traduzida nos conhecimentos, habilidades e competências adquiridos antes e durante a formação inicial do professor, não é suficiente para prepará-lo para todos os aspectos do exercício de suas funções ao longo da carreira. Os conhecimentos profissionais, entendidos aqui como 0 conjunto de saberes, em um "sentido amplo, que engloba os conhecimentos, as competências, as habilidades (ou aptidões) e as atitudes" utilizados pelos professores "em seu espaço de trabalho cotidiano para desempenhar todas as suas tarefas" (TARDIF, 2000, p. 10), demandam

sempre uma parcela de improvisação e de adaptação a situações novas e únicas que exigem do profissional reflexão e discernimento para que possa não só compreender o problema como também organizar e esclarecer os objetivos almejados e os meios a serem usados para atingi-los (Ibid., p.7).

Observa-se, entretanto, que além do domínio dos conhecimentos profissionais, os professores devem refletir acerca do que embasa suas ações, o modo com o qual cumpre suas tarefas profissionais, e quais são os objetivos almejados a serem alcançados pelo seu trabalho. Segundo Day (2001), "adquirir as qualificações adequadas para se ser professor sempre foi uma condição necessária, embora insuficiente, para se ter êxito como profissional ao longo de toda uma carreira" (p. 24), pois

um bom ensino exige que os professores (re)analisem e revejam regularmente a forma como aplicam princípios de diferenciação, coerência, progressão, continuidade e equilíbrio, não só no "que" e no "como" ensinar, mas também no "porquê", ao nível de seus propósitos "morais" básicos (p. 25).

Portanto, os conhecimentos necessários para o exercício profissional não são simples aplicações práticas e estanques de uma teoria pré-estabelecida. O trabalho

mais adiante no texto principal, essa característica do corpo docente da educação básica brasileira motivou a implantação de políticas públicas ao longo do tempo que promoveram a formação na primeira, ou segunda, licenciatura. Dados disponíveis em: < http://portal.inep.gov.br/artigo/-/asset publisher/B4AQV9zFY7Bv/content/dados-do-censoescolar-ensino-medio-tem-61-de-docentes-com-formacao-adequada/21206 />. Acesso em: 11 jul 2019. 
docente exige do professor um esforço permanente de reelaboração desses conhecimentos, em termos de ações e de pensamentos que embasam essas ações. Processo o qual a formação inicial apenas dá início. É uma atividade "prática e deliberativa, com um claro componente ético" (MARCELO GARCÍA, 1999, p. 144), pois obriga o professor a realizar deliberações na busca de respostas a dilemas de cunho social, cultural ou pessoal que surgem no desempenho de suas funções, o que o conduz a uma constante transformação deliberativa de seus próprios conhecimentos (NÓVOA, 2009). Por esse motivo, os conhecimentos profissionais são "evolutivos e progressivos e necessitam, por conseguinte, uma formação contínua e continuada" (TARDIF, 2000, p. 7).

As primeiras propostas de formação de professores (tanto pré-serviço quanto em serviço), entretanto, seguiram um viés diferente das discussões empreendidas pelos autores acima referidos. Elas estiveram pautadas no que se denomina racionalidade técnica, modelo que tradicionalmente se tornou dominante. De acordo com Contreras (2012),

[...] a ideia básica do modelo de racionalidade técnica é que a prática profissional consiste na solução instrumental de problemas mediante a aplicação de um conhecimento teórico e técnico, previamente disponível, que procede da pesquisa científica. É instrumental porque supõe a aplicação de técnicas e procedimentos que se justificam por sua capacidade para conseguir os efeitos ou resultados desejados ( $p$. 101).

Dessa forma, a racionalidade técnica pressupõe a existência de uma ciência aplicada que embasaria a prática profissional docente. Sobre isso, o mesmo autor aponta três características que mostram os efeitos da consideração dessa ideia no desempenho profissional: 1. A prática e conhecimento teórico são hierarquizados com a prevalência do último; 2 . A ciência aplicada forneceria regras tecnológicas as quais

\footnotetext{
${ }^{6}$ Tardif não especifica, na referência consultada, o que entende por formação contínua e por formação continuada. Muitas vezes, os dois termos são utilizados indistintamente. Porém, consideramos pertinente atribuir significados delimitados aos dois termos, já que o autor citou as duas nomeações em seu texto (logo, elas não são, para ele, conceitos sinônimos). Especificamente, a formação contínua "é um fenômeno que ocorre ao longo de toda a vida e que acontece de modo integrado às práticas sociais e às cotidianas escolares de cada um, ganhando intensidade e relevância em algumas delas" (PASSOS et al., 2006, p. 195). A formação contínua, num sentido amplo, é representada por toda "atividade que o professor em exercício realiza com uma finalidade formativa - tanto de desenvolvimento profissional como pessoal, de modo individual ou em grupo - que se destina a uma realização mais eficaz de suas tarefas atuais ou o preparem para o desempenho de outras novas" (GARCíA ALVAREZ, 1987, p. 23 apud MARCELO GARCÍA, 1999, p. 136). Por sua vez, a formação continuada apresenta um sentido mais restrito e objetiva "alcançar níveis mais elevados na educação formal ou aprofundar como continuidade dos conhecimentos que os professores já possuem" (PRADA, 1997 apud COSTA, 2004, p. 66).
} 
seriam utilizadas na prática profissional como procedimentos e meios técnicos; 3 . Os fins que se pretendem com a atividade docente são fixos e bem definidos e podem ser alcançados sobre quaisquer condições desde que utilizadas tais regras tecnológicas.

Em suma, sob o olhar da racionalidade técnica

[...] o professor é visto como um técnico, um especialista que rigorosamente põe em prática as regras científicas e/ou pedagógicas. Assim, para se preparar o profissional da educação, conteúdo científico e/ou pedagógico é necessário, o qual servirá de apoio para sua prática. Durante a prática, professores devem aplicar tais conhecimentos e habilidades científicos e/ou pedagógicos (DINIZPEREIRA, 2014, p. 36)

Diniz-Pereira (2014), apoiado em outros autores ${ }^{7}$, identifica três modelos de formação de professores baseados no modelo de racionalidade técnica: o modelo de treinamento de habilidades comportamentais (cujo objetivo é treinar professores para adquirirem habilidades específicas e observáveis); o modelo de transmissão (no qual o conteúdo científico ou pedagógico é transmitido sem a preocupação com a prática de ensino) e o modelo acadêmico tradicional (no qual o domínio do conteúdo científico já seria suficiente para a prática docente).

Assim, nessa categoria, em termos de cursos de formação em serviço, encontram-se aqueles que, geralmente referidos por termos como capacitação, reciclagem ou treinamento, proporcionam aos professores conhecimentos técnicos produzidos por experts (em geral pesquisadores acadêmicos ou envolvidos com gestão educacional) para serem reproduzidos em suas salas de aula. Essa perspectiva, hegemônica, está presente em maior ou menor grau em diferentes propostas de formação, por conta de atividades com diferentes orientações planejadas e executadas nesses cursos. São, inclusive, propostas de formação geralmente realizadas fora do contexto profissional. Isso pode ser entendido tanto no sentido objetivo - que essas formações são realizadas fora da escola, em outros espaços quanto, e principalmente, no sentido figurado, do ponto de vista do conteúdo desses cursos que raramente fazem referência às problemáticas imediatas dos contextos de trabalho dos professores participantes.

Por resumir-se no domínio e aplicação de conhecimentos técnicos, sob a ótica da racionalidade técnica têm-se

uma visão dicotômica entre a formação inicial e a formação contínua, sustentada por uma concepção cumulativa do processo formativo em

\footnotetext{
${ }^{7}$ São eles: Avalos (1991), Tatto (1999), Zeichner (1983), Liston e Zeichner (1991), Tabacinick e Zeichner (1991); todos referenciados no trabalho de Diniz-Pereira (2014).
} 
que este é encarado como a adição de duas etapas complementares, relativamente estanques, articuladas de modo seqüencial e linear (CANÁRIO, 2002, p. 32).

Tal concepção cumulativa do processo formativo "nega a continuidade da formação como algo que é inerente a todo ciclo profissional" (Ibidem). Como consequência, a formação contínua assumiria um caráter compensatório, ao partir do princípio de que os professores têm deficiências e limitações que a formação inicial, incompleta e insuficiente, não lhe permitiu superar (OLIVEIRA-FORMOSINHO, 2009; CANÁRIO, 2002). Trata-se de uma formação continuada baseada no modelo do déficit (DAY, 2001; OLIVEIRA-FORMOSINHO, 2009). Toda a formação é planejada por terceiros (administradores, peritos) e abre-se pouco ou nenhum espaço para a avaliação das necessidades da prática feita pelos próprios professores. Dessa forma, a formação continuada do professor, nesses moldes, dificilmente considera demandas específicas oriundas de sua atividade profissional.

Entretanto, há outras propostas de formação continuada calcadas sob outros paradigmas. Canário (2016), ajuda-nos a compreender, historicamente, os movimentos que ajudaram a edificar tais paradigmas para a formação de adultos e de profissionais, em geral. No contexto de formação de adultos, inicialmente, o movimento de Educação Permanente, impulsionado pela Organização das Nações Unidas para a Educação, a Ciência e a Cultura (Unesco), contrapôs-se "às tradicionais práticas escolares, construindo e propondo uma nova visão global e englobada de educação" (CANÁRIO, 2016, p. 265). Essa nova concepção de educação,

[...] encarada como um processo contínuo que corresponde ao ciclo existencial, [...] surgiu como um princípio reorganizador de todo o percurso educativo, incluindo a fase escolar. O seu referente central é a pessoa como sujeito de formação, tendo esta por base três pressupostos: continuidade, diversidade e globalidade do processo educativo (Idem, p. 268-9, grifos do autor).

Nessa perspectiva, desloca-se o que historicamente pertencia ao campo do ensino para o campo da aprendizagem. Isso porque "o reconhecimento de que muito do que sabemos foi aprendido, mas não foi ensinado, remete para uma revalorização epistemológica da experiência" (Idem, p. 269, grifos do autor). Essa concepção será essencial para entender a perspectiva de formação de professores que está alinhada à epistemologia da prática (ou racionalidade prática) que será discutida adiante.

Como contraponto à racionalidade técnica, incapaz de "resolver e tratar tudo o que é imprevisível", as concepções de professor que têm como base a epistemologia 
da prática levam em consideração "aspectos da prática que têm a ver com o imprevisto, a incerteza, os dilemas e as situações de conflito" (CONTRERAS, 2012, p. 117). As ideias de autores como Schön (concepção do profissional reflexivo) e Stenhouse (concepção do professor pesquisador), entre outros, se enquadram sob um paradigma que leva em conta "a base reflexiva da atuação profissional" (Idem, p. 118) e, em última análise, podem ser assumidas sob a perspectiva da racionalidade prática aristotélica. Além disso, como também aponta Diniz-Pereira (2014), o trabalho de John Dewey, o qual valoriza os saberes originados da experiência, "é considerado a semente de muitos dos atuais escritos sobre o modelo da racionalidade prática em educação" (p. 37).

As ideias dos autores citados convergem para a noção de que da prática profissional docente emergem continuamente situações que exigem a "construção de uma compreensão do caso que seja simultaneamente uma construção do que se pretende, e não só do que se deve fazer" (CONTRERAS, 2012, p. 121), além da necessidade dos professores em "atender as circunstâncias que cada caso apresenta e não pretender a uniformização dos processos educativos, ou dos jovens" (Idem, p. 128). Isso porque, em Aristóteles, vemos que a prática (em contraposição com a técnica), dirige-se

a realizar na própria ação os valores que consideram corretos para ela, de forma que o que os fins fazem não é assinalar seus produtos ${ }^{8}$, mas caracterizá-la ou qualificá-la, isto é, descrever as características (ou princípios) por meio dos quais a ação deveria se guiar (Idem, p. 137).

A prática, portanto, ganha nesse contexto, centralidade maior em relação aos resultados de ensino pretendidos. Essa centralidade se revela, por exemplo, em Schön, que chega a enfatizar o conhecimento profissional que está na ação, um conhecimento que "não se aplica à ação, mas está tacitamente personificado nela" (Idem, p. 119) e portanto, que não precede à ação, ou está desvinculada dela. É o referido conhecimento na ação.

Por sua vez, Stenhouse acredita que

são a análise e a crítica da própria prática, em vez da especificação dos resultados, as que permitem melhorar a atuação dos professores e, por conseguinte, sua capacidade de criar situações regidas por valores e critérios educativos (Idem, p. 130).

\footnotetext{
${ }^{8}$ Foco que a técnica dá, já que esta visa a produção e em ter como fim um produto.
} 
Por esse motivo, propõe que professores examinem criticamente e sistematicamente a própria prática. Essa postura é relacionada com 0 desenvolvimento de sua atividade profissional e com o desenvolvimento curricular. Em relação ao desempenho profissional, para esse autor,

o processo de aperfeiçoamento profissional não se produz mediante a transmissão de teorias, mas questionando essas habilidades e recursos que refletem as capacidades pessoais com respeito à prática de ensino, ao conhecimento ministrado ou às pretensões educativas (CONTRERAS, 2012, p. 131).

Diniz-Pereira (2014) também identifica, com base em outros autores ${ }^{9}$, três modelos de formação de professores na perspectiva da racionalidade prática: 0 modelo humanístico (que concede a definição dos comportamentos a serem dominados aos próprios professores); o modelo de "ensino como ofício" (onde o conhecimento sobre ensino é obtido de uma análise cuidadosa de uma situação imediata) e o modelo orientado pela pesquisa (que procura auxiliar o professor a refletir sobre sua prática e trabalhar na solução de problemas através de pesquisas).

Observa-se, portanto, que nessa perspectiva o professor ganha centralidade e poder de decisão na definição das propostas de cursos de formação em serviço. Caracterizam-se por serem propostas que se contrapõem àquelas que vêm de "cima para baixo", típicas da racionalidade técnica. Dessa forma, apresentam-se como cursos que têm como ponto de partida ou fazem continuamente referência às práticas profissionais dos professores participantes. Cursos que se utilizam de metodologia como a de pesquisa-ação permitem aos professores maior autonomia para desenvolver e decidir os rumos de sua própria formação a partir do que identificam como situações problemáticas de suas práticas que demandam uma maior investigação para a busca de soluções. São propostas com potencial de envolver a comunidade escolar - além dos professores, individualmente ${ }^{10}$ - e impactar modos de organização escolar, além da prática docente.

Em relação à transformação da prática docente, é importante destacar os condicionantes externos à própria ação do professor que a limitam e podem a prejudicar. Contreras (2012), ao discutir os problemas relacionados à ideia da

\footnotetext{
${ }^{9}$ Dessa vez, Diniz-Pereira recorre a Zeichner (1983), Tatto (1999) e Tabachinick e Zeichner (1999), todos esses autores referenciados em seu trabalho.

${ }^{10}$ Embora, algumas das maiores críticas à perspectiva do professor reflexivo, apresentadas por Pimenta (2006) a partir de análises teóricas e pesquisas empíricas de diferentes autores sejam: "[...] o individualismo da reflexão, a ausência de critérios externos potenciadores de uma reflexão crítica, a excessiva (e mesmo exclusiva) ênfase nas práticas, a inviabilidade da investigação nos espaços escolares e a restrição desta nesse contexto" (p. 43).
} 
racionalidade prática, atenta para o cuidado que deve ser tomado com as "visões reducionistas da reflexão que não transcendam as implicações mais imediatas da ação em sala de aula, ou com o objetivo de evitar a absorção por retóricas de maior responsabilização sem aumentar a capacidade de decisão" (p. 153) dos professores. Por conta disso, a necessidade de se considerar a visão de uma racionalidade crítica na formação de professores que aponta para a problematização de visões sobre práticas de ensino que os professores possuem, o papel que atribuem a si mesmos, as suas concepções sobre a sociedade, a escola e o ensino, o desvelamento de relações de dominação presentes nas escolas, muitas vezes reforçadas inconscientemente pelos professores. Giroux, autor citado por Contreras (2012), discute a ideia do professor como intelectual crítico e transformador, que tem como compromisso:

\begin{abstract}
elaborar tanto a crítica das condições de trabalho quanto uma linguagem de possibilidades que se abram à construção de uma sociedade mais democrática e mais justa, educando seus alunos como cidadãos críticos e ativos, compromissados com a construção de uma vida individual e pública digna de ser vivida, guiados pelos princípios de solidariedade e de esperança (p. 177)
\end{abstract}

Para tanto, faz-se necessária uma reflexão crítica, que não se refere apenas à prática docente e as suas incertezas, mas que também se debruça sobre a análise e o questionamento das estruturas institucionais em que os professores trabalham:

Sob esta base de crítica da estrutura institucional, dos limites que esta impõe à prática, a reflexão amplia seu alcance, incluindo os efeitos que estas estruturas exercem sobre a forma pela qual os professores analisam e pensam a própria prática, bem como 0 sentido social e político aos quais obedecem (CONTRERAS, 2012, p. 179).

Contreras (2012) aponta, ainda, que "em virtude dessa pretensão de ir além das condições que já marcam a prática, tratando de desvelar sua origem sócio-histórica e os interesses a que serve, pode-se dizer que aquilo que move a reflexão crítica é a emancipação" (p. 181). Isso, pois, ao longo do tempo, diversas instituições e grupos sociais têm dominado e imposto seus interesses de diversas formas sobre as instituições educativas.

Recentemente, por exemplo, é observada a influência de instituições internacionais do meio econômico (tais como o Banco Mundial) nas políticas educacionais, inclusive às de formação de professores, de diversos países do mundo. Essa influência faz parte do movimento, a partir das décadas de 1980 e 1990, no qual 
as políticas e práticas de formação de adultos passam a ser submetidas à racionalidade econômica dominante (CANÁRIO, 2016). Nesse momento, emerge a concepção de Aprendizagem ao Longo da Vida, onde "a formação de adultos não é mais vista como um direito e passa a instituir-se como um dever em que cada indivíduo é o principal responsável pela sua inserção no mercado de trabalho" (Idem, p. 272-3). Agora, a formação profissional pauta-se num modelo de aquisição de competências, o que favorece a responsabilização individual. Nesse contexto, instituições internacionais multilaterais estiveram à frente de definições das políticas educacionais no mundo, entre elas: OEA - Organização dos Estados Americanos; BID - Banco Interamericano de Desenvolvimento; BM - Banco Mundial; OCDE Organização de Cooperação e Desenvolvimento Econômico, entre outras. Essas instituições promoveram exigências a serem atendidas por reformas educacionais por diversos países como modo de atender ao processo de globalização/mundialização (MAUÉS, 2003). Tais instituições têm se apropriado inclusive do discurso da racionalidade prática para controlar programas de formação de professores, mas, de fato, têm apoiado reformas conservadoras, construídas nos moldes da racionalidade técnica.

Programas de formação continuada no Brasil sofreram influência desses organismos, como será visto mais adiante, ao final do capítulo.

\title{
1.2 Desenvolvimento profissional docente: síntese
}

\begin{abstract}
A consciência do mundo e a consciência de si como ser inacabado necessariamente inscrevem 0 ser consciente de sua inconclusão num permanente movimento de busca (Paulo Freire).
\end{abstract}

Como já discutido, a formação docente não se encerra em sua etapa inicial, préserviço, de forma que o professor deverá investir de diferentes maneiras em sua formação permanente, ao longo de sua carreira. Pergunta-se: a que necessidades essa formação permanente, em serviço, deverá atender? De quais dimensões do trabalho docente ela se ocupará? Como ela se realizará? O conceito de desenvolvimento profissional docente auxilia na definição de respostas a esses questionamentos. 
Há diversas concepções de desenvolvimento profissional presentes na literatura, como nos aponta Marcelo (2009) e Oliveira-Formosinho (2009). Uma maneira de se aproximar do conceito é compreendê-lo

\begin{abstract}
como um processo contínuo de melhoria das práticas docentes, centrado no professor, ou num grupo de professores em interação, incluindo momentos formais e informais, com a preocupação de promover mudanças educativas em benefício dos alunos, das famílias e das comunidades. (OLIVEIRA-FORMOSINHO, 2009, p. 226).
\end{abstract}

A definição acima explicita características importantes dessa perspectiva de formação: ela se dá em um contexto, ou seja, é uma formação centrada na prática profissional do professor e sujeita a fatores externos como a cultura institucional constituída por ritos, normas e rotinas institucionais - que pode reconhecer, estimular ou bloquear possibilidades formativas (PASSOS, 2007); pode ser individual ou coletiva, envolvendo outros professores; inclui momentos formais, concretizados através de cursos, palestras, entre outras atividades, e informais, que incluem experiências vividas pelo professor em seu trabalho; e, por fim, assume um compromisso social ao objetivar o benefício da comunidade onde o professor se insere, ou seja, há uma preocupação com a aprendizagem do seu aluno.

Day (2001), por sua vez, traz uma compreensão de desenvolvimento profissional que explicita seu caráter contextual, de longo prazo que abrange muito mais que a aquisição de saberes objetivos (envolvendo conhecimentos e habilidades) necessários para o exercício da docência. Esse autor entende o desenvolvimento profissional como um

[...] processo através do qual os professores, enquanto agentes de mudança, revêem, renovam e ampliam, individual ou coletivamente, o seu compromisso com os propósitos morais do ensino, adquirem e desenvolvem, de forma crítica, juntamente com as crianças, jovens e colegas, 0 conhecimento, as destrezas e a inteligência emocional, essenciais para uma reflexão, planificação e prática profissionais eficazes, em cada uma das fases das suas vidas profissionais (DAY, 2001, p.20-21).

O conceito de desenvolvimento profissional ainda "inclui o de formação de professores, tanto inicial como contínua, como um processo dinâmico e evolutivo da profissão e função docente" (IMBERNÓN, 1998, p. 45, tradução nossa), portanto, ressalta a continuidade entre as etapas de formação. Assim, o desenvolvimento profissional é "uma perspectiva em que se reconhece a necessidade de crescimento e de aquisições diversas, processo em que se atribui ao próprio professor o papel de 
sujeito fundamental" (PONTE, 1994, p. 11), embora se observe "a importância de se conjugarem condições institucionais e recursos adequados para que este desenvolvimento possa ter lugar em condições favoráveis" (Ibid., p. 12).

Tendo essas características em conta, o desenvolvimento profissional se apresenta mais como um "processo de aprendizagem/crescimento" do que um "processo de ensino/formação" (OLIVEIRA-FORMOSINHO, 2009, p. 225).

Por envolver aprendizagem e crescimento, o desenvolvimento profissional promove mudanças no professor. No entanto, deve-se ter em mente que a mudança é "complexa, imprevisível e depende das suas experiências passadas (histórias de vida e de carreira), da sua disposição, das suas capacidades intelectuais, das condições sociais e do apoio institucional" (DAY, 2001, p. 38). Para se efetivarem, é importante o professor perceber a necessidade das mudanças no contexto em que se insere, pois "isso faz com que sejam assumidos novos papéis sendo as práticas adequadas estabelecidas em função dessa percepção das condições contextuais mutáveis" (MARCELO GARCÍA, 1999, p. 150).

Por este motivo e tendo também em conta a complexidade do ato educativo, o desenvolvimento profissional do professor requer fundamentos de diferentes fontes de conhecimento, sejam elas psicológicas, curriculares, organizacionais ou sociológicas (OLIVEIRA-FORMOSINHO, 2009), se estendendo ao "terreno das capacidades, habilidades e atitudes" num esforço de "questionar-se permanentemente os valores de cada professor e professora e da equipe coletivamente" (IMBERNÓN, 1998, p. 58, tradução nossa). Dessa forma, assume-se que

- desenvolvimento profissional assenta fundamentalmente na mudança de pensamento e da prática - e dos contextos em que ocorrem - no sentido de melhorar a qualidade das experiências de aprendizagem dos alunos $e$, consequentemente, proporcionar melhores oportunidades para atingirem melhores resultados (DAY, 2001, p. 293).

Também, devido a essa complexidade que leva o desenvolvimento profissional a abarcar inúmeras dimensões,

[...] é necessário ter claro que o desenvolvimento somente em uma das dimensões, como, por exemplo, a dos conteúdos básicos de cada disciplina ou área de atuação, não forma o professor, não habilita o coordenador a orientar professores e não possibilita ao gestor dirigir uma escola. Como dito, os saberes básicos de cada área devem estar articulados com os saberes da docência, da educação e com os saberes psicossociais, para que um formando, candidato a professor, ou um coordenador pedagógico ou ainda um gestor de escola alcance a sua profissionalidade na área de educação (SOUZA; PLACCO, 2016, p. 27). 
O processo de desenvolvimento profissional está intimamente relacionado à experiência profissional, pois ela conduz o professor a diferentes aprendizagens. No entanto, o simples acúmulo de experiência não é suficiente para o seu desenvolvimento profissional. Day (2001) aponta que não apenas a experiência deve ser levada em conta como condição para o desenvolvimento profissional, mas também:

- A articulação com as necessidades do professor em um determinado momento;

- O exercício da reflexão, que levanta questões a respeito de propósitos, práticas e contextos;

- A participação crítica de pares e terceiros;

- A articulação entre os conhecimentos da educação e sobre a educação que pode ser estimulada através de parcerias;

- O diálogo contínuo entre professor e escola;

- A participação em diferentes tipos de oportunidades de aprendizagem;

- A ênfase em conhecimentos essenciais para o desempenho das atividades do professor, como a gestão de classe e da escola; o conhecimento de sua disciplina; a necessidade de uma dedicação intelectual e emocional mais ampla;

- O reconhecimento por parte do professor de um plano de desenvolvimento pessoal ao longo de sua carreira.

Em outras palavras, o desenvolvimento profissional de um professor não ocorre espontaneamente ao longo de sua prática profissional, mas sim, este deve ser planejado intencionalmente. É relevante, para dar lugar a esse processo, o professor ter a possibilidade de participar em "um contexto que problematize sua prática, exercite sua capacidade reflexiva e ganhe consciência do seu fazer pedagógico, inclusive, orientando-o a favor da aprendizagem dos estudantes" (BAROLLI et al., 2017, p. 2).

Marcelo García (1999) acrescenta ainda a necessidade de integrar a formação de professores com quatro áreas teóricas e de investigação da Didática: a escola; o currículo e a inovação; o ensino; e os professores. Em sua concepção, o desenvolvimento profissional dos professores seria "uma encruzilhada de caminhos, como a cola que permite unir práticas educativas, pedagógicas, escolares e de ensino" (Ibid., p. 139, grifos do autor). Essa seria, então, uma forma de integrar saberes didáticos na formação de professores, bem como reconhecer as contribuições dessas 
áreas para a formação de professores como disciplina. Nesse sentido, o desenvolvimento profissional se realiza apoiado na relação entre teoria e prática. Marcelo García (1999), portanto, defende:

- O desenvolvimento profissional entrelaçado ao desenvolvimento da escola: o que significa "superar a concepção individualista e celular das práticas habituais de formação permanente" (p. 139), ao considerar o desenvolvimento do próprio contexto no qual o professor se insere;

- O desenvolvimento e inovação curricular como desenvolvimento profissional: sendo este determinado pelo grau de autonomia do professor para tomar decisões e a própria concepção de professor presente em propostas curriculares executadas pelo professor;

- O desenvolvimento profissional relacionado ao desenvolvimento do ensino: já que o desenvolvimento profissional tem como principal consequência o aperfeiçoamento do ensino. Além da própria aula, as estratégias de desenvolvimento profissional versariam também sobre dimensões ocultas do ensino (pensamento, juízos, tomada de decisões) dos professores e dos alunos, a concepção assumida de professor, o planejamento e a reflexão após a aula;

- O desenvolvimento profissional e o desenvolvimento da profissionalidade do professor: o desenvolvimento profissional relacionado às melhorias de condições de trabalho, possibilidades de maior autonomia e maior capacidade de ação dos professores tanto individual quanto coletivamente.

Levando em consideração conhecimentos, saberes e competências característicos da profissão docente, compilados por diferentes autores ${ }^{11}$, Barolli e colaboradores (trabalho apresentado inicialmente no ENPEC em 2017, atualizado e aprofundado no artigo publicado em 2019) objetivaram "alcançar um esquema de análise para a investigação do desenvolvimento profissional de professores de ciências" (2017, p. 5). Esse esquema de análise representa uma síntese da discussão de diversos autores sobre desenvolvimento profissional docente. Como ponto de partida para a elaboração do esquema de análise, esses pesquisadores concebem o desenvolvimento profissional como "um processo que se efetiva com base no diálogo com os vários interlocutores que interferem na atividade docente"

\footnotetext{
${ }^{11}$ Esses autores que são referenciados no trabalho de Barolli et al. (2017) são: Day (2001), Perrenoud (1999), Marcelo (1999, 2009), Ponte (1998), Villegas-Reimers (2003) e Nóvoa (2009).
} 
(BAROLLI et al., 2017, p. 5, grifos dos autores). Os interlocutores citados no artigo mais recente desses autores (2019) são a Academia; a Escola; e a Sociedade. Cada um dos interlocutores (ou seja, o contato com saberes próprios da Academia, com as questões que permeiam as atividades escolares e ainda com as questões que caracterizam o ofício no âmbito social) permitiria ao professor o crescimento em diferentes dimensões do desenvolvimento profissional.

Assim, a Academia permitiria o aprofundamento e atualização nas dimensões conhecimento científico e conhecimento pedagógico; a Escola, por sua vez seria a fonte do saber referente à participação na gestão e organização escolar. Além disso, a Escola junto com a Academia seriam as fontes de outras três dimensões, quais sejam, a organização e condução do ensino; a sustentação da aprendizagem dos alunos e a pesquisa sobre a própria prática. Por outro lado, o diálogo com a Sociedade seria a fonte de outra dimensão: a participação na responsabilidade social. Finalmente, no diálogo com Academia, Escola e Sociedade, o professor estará implicado no desenvolvimento do planejamento da sua carreira.

Abaixo discriminamos resumidamente o que esses autores consideram como indicadores de desenvolvimento profissional em cada uma dessas dimensões:

1. Atualização nos conhecimentos científicos: faz referência ao aprofundamento do professor em conhecimentos científicos específicos da disciplina que leciona, além de conhecimentos de outras disciplinas que não necessariamente fazem parte do currículo a ser ensinado, mas que estão relacionados com a Ciência (entre eles, incluem-se conhecimentos de História da Ciência, Filosofia e Sociologia da Ciência, aplicações tecnológicas, descobertas recentes da Ciência, entre outros);

2. Atualização nos conhecimentos pedagógicos: essa dimensão remete aos conhecimentos acerca de avanços nas áreas de Educação e Ensino de Ciências. Envolve o estudo e aprofundamento de abordagens alternativas para o Ensino de Ciências, de análise e produção de materiais didáticos e a implementação de práticas inovadoras em escolas;

3. Organização e condução do ensino: enfatiza a atualização de práticas de ensino, decorrente de aplicação de práticas diversificadas e/ou em conjunto com outros professores através do exercício da docência compartilhada. É decorrente da reflexão constante dos professores sobre a própria prática, e de quando se considera concepções prévias e diferentes ritmos de aprendizagem dos alunos;

4. Sustentação da aprendizagem dos alunos: diferencia-se da dimensão anterior, por estar relacionada às práticas que se aproximam mais do processo de 
aprendizagem e menos do de ensino. Nessa dimensão, prioriza-se as ações pedagógicas "no sentido de zelar pelo esforço do estudante em seu processo de aprendizagem", investir "em sua capacidade e direito de autoria em pensamento e ação" (BAROLLI et al., 2017, p. 7), além do respeito as suas demandas. Aqui, considera-se também

que o professor estabeleça uma relação amigável e reconheça no aluno sua potencialidade criativa e invista em sua capacidade e direito de autoria em pensamento e ação, procurando respeitar, inclusive, suas demandas (BAROLLI et al., 2017, p. 7);

5. Participação na gestão e organização escolar: essa dimensão considera "ações concretas que o professor realiza de forma a estabelecer um clima de colaboração com colegas e coordenadores e contribuir com uma participação regular na vida institucional da escola" (Idem);

6. Pesquisa sobre a própria prática: compreende "ações relacionadas à revisão de métodos, estratégias e rotinas de trabalho, participação em grupos colaborativos de professores, participação em grupos de pesquisa acadêmica etc" (Idem). Ressalta-se que o desenvolvimento dessa dimensão depende em muito do contexto de trabalho do professor, pois este deve the proporcionar condições para que ele possa se envolver no movimento de reflexão crítica sobre seu trabalho e the seja favorecida a oportunidade de adotar diferentes ações em vista de aperfeiçoamento das práticas. É importante destacar que a reflexão sobre a prática não é um processo trivial, requerendo uma organização sistemática para seu planejamento e, muitas vezes, a necessidade de diálogo com outros interlocutores;

7. Planejamento da carreira profissional: nessa dimensão, consideram-se ações do professor em busca de complementação de sua formação e o estabelecimento de metas profissionais e estratégias para alcançá-las. Como indícios de desenvolvimento nessa dimensão, temos: "a participação em cursos, em congressos e seminários científicos, em projetos da Secretaria de Educação, em iniciativas de valorização social e econômica (sindicatos dos professores, movimentos sociais)" (Idem);

8. Participação na responsabilidade social: relaciona-se com a aproximação do professor com a militância em prol da transformação da sociedade via justiça social. Nessa dimensão prioriza-se a conscientização do professor a respeito de que suas próprias escolhas e decisões cotidianas, em sala de aula ou além dela, que podem estar ligadas à posição conservadora de reprodução e continuidade das desigualdades, ou à perspectiva progressista de mudança e resistência. 
O caso particular do desenvolvimento profissional de um professor pode variar em termos de amplitude, ou seja, no número de dimensões sintetizadas acima que são afetadas quando o professor se envolve em um determinado contexto de formação por um período de tempo. Elas podem ser identificadas através dos indicadores de desenvolvimento profissional, também detalhadas em Barolli et al. (2019). No entanto, subsídios teóricos que nos permitam avaliar a intensidade com que cada uma das dimensões de desenvolvimento profissional é afetada também se fazem necessários. O esquema de análise para autoria docente no ensino de Ciências apresentado por Maia (2017) fornece dimensões e indicadores para avaliação desse aspecto, dando conta de fatores de natureza cognitiva e subjetiva que influenciam o desenvolvimento profissional docente.

O conceito de autoria docente é apresentado muitas vezes associado à produção docente relacionada ao seu próprio trabalho ou desenvolvimento profissional. No âmbito dos MPs, processo formativo eleito pela autora para o estabelecimento das dimensões de autoria docente, esta estaria relacionada a toda produção discente realizada no mestrado: artigos, trabalhos realizados em disciplinas, trabalhos apresentados em eventos acadêmicos, a proposta de aulas e, em especial, a dissertação e o produto educacional. A partir de análises de dados apresentados por trabalhos publicados que analisam o desenvolvimento profissional de professores neste contexto, Maia (2017) elabora os seguintes indicadores para explicitar a implicação ou o investimento do professor para alcançar o desenvolvimento favorecido em determinada atividade formativa:

1. Dedicação: caracteriza o esforço do professor para o desenvolvimento da tarefa formativa proposta durante a realização da atividade formativa em que participa. Indica desdobramentos em como se responsabiliza em ampliar seu repertório profissional, inovando-o. Assume três níveis: nula, passiva e ativa. Na dedicação nula, há o abandono ou rejeição do professor pelo que lhe é proposto. $\mathrm{Na}$ dedicação passiva, o esforço é comedido, de forma a atender estritamente ao que lhe é exigido. $\mathrm{Na}$ dedicação ativa, o professor sente-se motivado e estimulado pela atividade a investir maior energia para conquistar seus objetivos.

2. Responsabilidade: se ao ser introduzido a uma nova cultura didáticopedagógica, incorpora inovações a sua prática, o professor assume uma responsabilidade, respondendo pelo que produz. Há também três níveis possíveis para esse indicador: nula, eventual e sistemática. Quando a responsabilidade é nula, o professor não se sente compelido a replicar o que produz no contexto formativo em sua própria prática rotineira. $\mathrm{Na}$ responsabilidade eventual, o professor assume 
inovações em sua sala de aula em um período limitado no tempo, durante a realização do curso de formação ou, então, de forma pontual após a sua conclusão. A responsabilidade sistemática, no entanto, pressupõe a continuidade das práticas e projetos ao longo de sua carreira.

3. Inovação: é um indicador relacionado às produções e aos conhecimentos com os quais o professor entra em contato e que são relativamente diversificados. São quatro os distintos níveis possíveis: nula, técnica, reflexiva e criativa. A inovação nula pressupõe uma ausência de aproveitamento dos conhecimentos aprendidos no curso em suas aulas. Com uma inovação técnica, esses conhecimentos são agregados à prática, porém na forma de receituário, em desconsideração com as particularidades encontradas nas salas de aula. Quando o professor se propõe a entender, discutir e avaliar os novos conhecimentos e novas propostas de ensino, recriando-as e adaptando-as a sua realidade, alcança-se uma inovação reflexiva. A relação do professor com os novos conhecimentos alcançados na inovação criativa é semelhante à anterior, com a diferença de que nesse nível, se propõe a ir além daquilo que aprendeu, no sentido de atender às insatisfações que ainda derivam da sua prática.

A Figura 1, apresentada abaixo, resume o esquema de autoria docente apresentando seus indicadores e respectivos níveis:

Figura 1 - Esquema de autoria docente.

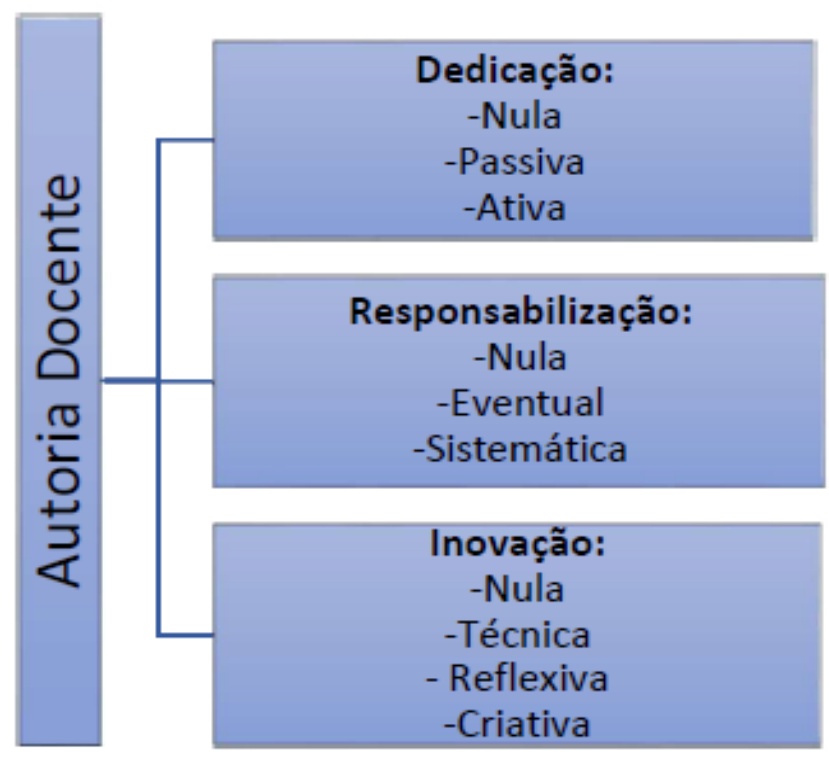

Fonte: MAIA (2017). 


\section{3 lugar do desenvolvimento profissional de professores}

Enquanto a formação inicial tem lugar no espaço dominado pela Academia (os cursos de licenciatura nas universidades), a formação em serviço poderá se desenvolver em diversos outros espaços ocupados pelos professores no exercício profissional. Em especial, a escola passa a ser valorizada como lugar prioritário para a promoção do desenvolvimento profissional, porém a volta à Academia (em cursos oferecidos pelas universidades) ou a dedicação a outros espaços de formação (como aqueles promovidos por sindicatos, Secretarias de Educação ou espaços não-formais de educação - ou seja, iniciativas que não necessariamente são realizadas na escola) também fornecem um leque de atividades planejadas que podem influir no desenvolvimento profissional dos professores que delas participam. Marcelo García (1999), ao apresentar uma classificação simples de modelos de desenvolvimento profissional, aponta essa diversidade de lugares de formação, que por sua vez, diversifica-se também em termos do modelo de formação priorizado na orientação da proposta realizada.

Essa classificação discrimina as atividades de desenvolvimento profissional tendo como critério os objetivos expressos por elas. São duas categorias possíveis: 1) atividades elaboradas por especialistas, cujo objetivo é permitir aos professores a aquisição de conhecimentos ou competências, ou 2) atividades cujo objetivo excede o domínio de conhecimentos ou competências pelos professores e que prioriza a implicação docente no planejamento e desenvolvimento do processo de formação. As duas categorias se aproximariam dos modelos de racionalidade técnica e racionalidade prática já discutidos. Cada modelo priorizaria dimensões específicas do desenvolvimento profissional.

Baseando-se na revisão elaborada por Sparks e Loucks-Horsley (1990) ${ }^{12}$, Marcelo García (1999) apresenta também os cinco principais modelos de desenvolvimento profissional: desenvolvimento profissional autônomo; desenvolvimento profissional baseado na reflexão, no apoio profissional mútuo e na supervisão; desenvolvimento profissional através do desenvolvimento e inovação curricular e a formação na escola; desenvolvimento profissional através de cursos de formação e desenvolvimento profissional através da investigação. Esses modelos podem também dar lugar a diferentes práticas, sejam elas alinhadas a uma perspectiva tecnicista, prática ou crítica. Isso depende em grande medida das

\footnotetext{
${ }^{12}$ SPARKS, D.; LOUCKS-HORSLEY, S. Models of staff development. In: Houston W. R. (Ed.). Handbook of Research on Teacher Education. New York, McMillan Pub., 1990. p. 234-251.
} 
intenções e interesses expressos pelas pessoas que as concebem ou que delas participam.

Entre as atividades e estratégias adotadas nesses diferentes modelos, citamos: estratégias que se utilizam da reflexão (redação e análise de casos, análise de biografias profissionais, análise de teorias implícitas dos professores), estratégias que promovem o apoio profissional mútuo (supervisão), a participação em projetos de inovação curricular, estratégias que promovam a investigação (pesquisa-ação), estratégias centradas na escola (desenvolvidas por um grupo de professores da escola com ou sem assessoria de um formador externo a ela) e cursos de formação (tipo de atividade mais tradicional).

Essa discussão, a respeito da diversidade de lugares e modelos de propostas de desenvolvimento profissional docente, se confronta com a crítica à efetividade dos cursos de formação após o ingresso na profissão. Cevallos e Passos (2012), retomando o porquê de se investir na formação continuada, argumentam que as

[...] novas demandas e exigências impressas pelo progresso das sociedades em transformação têm levado o professor a aprender a ensinar de forma diferente daquela com a qual foi ensinado. São muitos os desafios e sabe-se que os professores não foram suficientemente preparados para dar cumprimento a algumas tarefas que são absolutamente novas (p. 805).

Explicitam que a formação continuada ajudaria a modificar esse contexto, com a proposta de apoiar os professores a enfrentarem esses desafios. Porém:

[...] esses cursos não têm causado mudanças significativas no ambiente de trabalho. Uma das possíveis causas pode estar relacionada com 0 fato de as propostas de mudanças geralmente virem de fora e serem concebidas de "cima para baixo", sem que os professores sejam ouvidos e sem que se discutam os reais problemas por eles enfrentados em seu cotidiano escolar (Ibidem).

Essas autoras, portanto, chamam a atenção para o fato do pouco envolvimento dos professores no planejamento dessa formação ser um dos motivos que justificariam o fracasso desses cursos em relação à promoção de melhorias no trabalho dos professores. Para elas, faltaria aos cursos partir dos problemas enfrentados pelos professores no cotidiano escolar e propor discussões que viabilizassem a busca de soluções a esses problemas.

Tampouco, apenas a consideração da experiência profissional é suficiente para a adequação das propostas de formação, como a discussão levantada por Day (2001), a respeito de desenvolvimento profissional docente, já nos indicava. Schuck e 
colaboradores (2016) também argumentam que essas vivências e experiências são fundamentais, no entanto,

[...] visivelmente não se pode parar em nossas experiências vividas, permanecendo o desafio de buscar formação continuada e novas experiências que podem nos levar a reafirmar a própria identidade, ampliando a compreensão do contexto no qual estamos inseridos e possibilitando melhor interação com ele (p. 504, grifos nossos).

Dessa forma: ao mesmo tempo em que o desenvolvimento profissional deve encontrar como lugar de ponto de partida a própria experiência profissional, ou seja, a Escola; ele também deve transcender esse lugar. Esse argumento é coerente com o exposto por Barolli e colaboradores (2019), apresentado anteriormente, para quem as dimensões de desenvolvimento profissional se realizam no diálogo com os vários interlocutores que influenciam a atividade educacional, que vão além da Escola. O trânsito do professor nessas diversas esferas parece ser um pressuposto fundamental para ser levado em conta no planejamento das atividades formativas orientadas para o desenvolvimento profissional docente. Como proporcionar ao professor o acesso à essas diferentes esferas e o estabelecimento desses diálogos?

Esse acesso baseia-se na compreensão contextual de onde o professor está inserido, como exposto na citação de Schuck e colaboradores (2016) reproduzida acima. Essa compreensão pode ser alcançada pela pesquisa, ou melhor, pela adoção de uma postura investigativa em relação ao próprio trabalho. Isso porque, ao "[...] problematizar criticamente a realidade com a qual se defronta, adotando uma atitude ativa no enfrentamento do cotidiano escolar", o professor torna-se um "profissional competente que, por meio de um trabalho autônomo, criativo e comprometido com ideais emancipatórios, coloca-o como ator na cena pedagógica" (SANTOS, 2012, p. 23).

Os professores podem se relacionar com a pesquisa de diferentes formas basicamente como "consumidores" ou como "produtores" de pesquisa - e, como vimos, essa relação por si mesma já compreende dimensões do desenvolvimento profissional docente. Diretamente, como meio de atualização de conhecimentos científicos e pedagógicos e inovação de práticas de organização e condução de ensino e sustentação da aprendizagem ou como pesquisa da própria prática. Por conta disso, nos deteremos um pouco mais a essa discussão.

Numa primeira aproximação, questiona-se o conhecimento que os professores têm da pesquisa acadêmica e o uso que eles fazem de seus resultados - a perspectiva de "consumo" de pesquisas. As pesquisas, produzidas em grande parte 
por pesquisadores que compõem o quadro docente universitário, que mais se aproximariam do interesse dos professores seriam aquelas localizadas nas áreas de Educação, Ensino e da área disciplinar de atuação do professor, além de outras áreas afins que versam sobre o uso de novas Tecnologias da Informação e Comunicação na educação, Cognição, Psicologia etc.

Em geral, no contexto de formação inicial, a "integração entre ensino e pesquisa na universidade representa um grande problema que precisa ser superado" (SANTOS, 2012 , p. 23). Por sua vez, no contexto de formação continuada, o distanciamento muito comum entre universidades e escolas, muitas vezes colabora para 0 apartamento dos professores da pesquisa acadêmica - e mesmo, o distanciamento da pesquisa acadêmica da escola. Isso sem considerar as condições de seu trabalho que muitas vezes inviabilizam ao professor a prática de propostas inovadoras de ensino trazidas por algumas pesquisas acadêmicas (seja pela falta de recursos - materiais e humanos - ou pela falta de espaços e tempos adequados), ou ainda, inviabiliza o próprio estudo do professor de tais pesquisas que é dificultado principalmente pela enorme carga horária em sala de aula que ele tem que cumprir.

Apesar dessas limitações, existem propostas de formação continuada que se concentram em favorecer esse contato entre os professores de educação básica e a pesquisa acadêmica. Coutinho, Folmer e Puntel (2014), obtiveram como resultado da análise realizada de um programa de formação dessa natureza, que

[...] este contato com a produção acadêmica estimulou um processo de reflexão em torno dos métodos de ensino, dos conteúdos trabalhados e dos instrumentos de avaliação utilizados, além da apropriação e problematização, por parte dos professores, dessa produção (p. 781).

O contato com a pesquisa acadêmica apresenta-se, portanto, como um indicador de desenvolvimento profissional.

Muitas questões, entretanto, surgem a respeito dos impactos proporcionados ao trabalho docente resultantes dessa aproximação e da aplicação dessas pesquisas. $O$ senso comum de muitos professores os leva a rechaçar de imediato essas pesquisas acadêmicas, já que são tidas como desvinculadas do contexto real da prática docente. Assume-se, muitas vezes, que tais pesquisas se aplicam em condições idealizadas, muito raras nas escolas. É claro que isso não invalida o estudo dessas pesquisas ainda mais sob a perspectiva, como no programa estudado por Coutinho, Folmer e Puntel (2014), de se problematizar a produção dessas pesquisas. Porém, esse distanciamento - de contexto, e inclusive de linguagens - dificulta o acesso dos 
professores aos benefícios que podem decorrer desse contato entre eles e as pesquisas acadêmicas, principalmente em termos de incentivo à reflexão sobre e de revisões das práticas.

Por conta disso, discute-se na literatura modos de se aproximar os contextos acadêmicos de produção de pesquisa e o contexto prático e profissional do trabalho docente.

Zeichner (2010), ao evocar inúmeros tipos de colaboração entre universidades e escolas colocados em prática em cursos de formação inicial de professores nos Estados Unidos (entre eles, modelos de residência docente, experiências de inserção clínica, abordagens de ensino praticadas em escolas de aplicação criadas nas faculdades e nas universidades, criação de laboratórios de prática de ensino) enfatiza que eles

\begin{abstract}
focam mais na criação de novas espécies de papéis para os formadores de professores e nos meios de aproximar conhecimento acadêmico, profissional e derivado da comunidade no processo de formação de professores, do que na mudança estrutural das instituições de formação de professores (p. 486).
\end{abstract}

Por sua vez, utilizando o conceito de "terceiro espaço", Zeichner (2010) propõe a criação de espaços institucionais híbridos, no contexto da formação inicial, "que reúnem professores da Educação Básica e do Ensino Superior, e conhecimento prático profissional e acadêmico [...] de modos menos hierárquicos" (p. 487). O terceiro espaço, conforme exposto pelo autor, contrapõe-se às tentativas de parceria entre universidades e escolas que, orientados a partir da perspectiva da universidade, concentram esforços para fornecer um espaço de "aplicação da teoria" aos professores em formação inicial e, na perspectiva do professor de educação básica, co-formador dos professores em formação inicial, trazer-lhe os conhecimentos acadêmicos da universidade que lhe faltariam.

Diferentemente desta perspectiva, a criação de terceiros espaços entre universidades e escolas "incentivam um status mais igualitário para seus participantes", que se traduz numa "relação mais equilibrada e dialética entre o conhecimento acadêmico e o da prática profissional" (Idem, p. 487). Em defesa desses espaços híbridos de formação, o autor conclui:

Ainda que a criação desse tipo de espaços híbridos na formação de professores não aborde diretamente os problemas institucionais e culturais que persistentemente minam a qualidade da formação de professores em faculdades, universidades e escolas há muitos anos (por exemplo, seu baixo status, a falta de recompensa por um bom trabalho na formação do professor, a falta de financiamento 
adequado) ela cria espaços para a aprendizagem dos professores em formação de modo que tirem vantagem das múltiplas fontes de saber que podem, eventualmente, embasar um ensino de qualidade (p. 493, grifo nosso).

Diferentes configurações de terceiro espaço são exemplificadas pelo autor. Entre elas, há a instrução mediada e as experiências de campo, em que professores de educação básica, em colaboração com professores de ensino superior, passam a desempenhar um papel mais ativo na orientação de estágios de prática de ensino dos licenciandos - professores em formação inicial. Nesses exemplos, além do enriquecimento nos processos de formação inicial dos licenciandos, os professores do ensino superior e do ensino básico também teriam a oportunidade de evoluírem em suas formações profissionais, justamente por se encontrarem em interação em espaços de aprendizagem que agregam múltiplas fontes de saber. Assim, essa perspectiva do terceiro espaço poderia ser modelada para abraçar oportunidades de formação continuada e de desenvolvimento profissional para os professores já experientes envolvidos com a atividade.

Mais do que impactos pessoais para os participantes diretos, conforme outros autores chamam a atenção, a proximidade entre universidades e escolas acarretaria benefícios para ambos os espaços institucionais. As trocas de experiências entre as duas comunidades impactariam tanto a formação inicial em si, bem como o afinamento entre as questões de pesquisa da Academia e as questões problemáticas da profissão docente que urgem da prática. Essa aproximação Academia e Escola, favorece uma formação que permite "a aproximação do professor real, considerando seus conhecimentos e dando oportunidade para que esse se manifeste e passe a ter autoria nas questões sobre e da sua profissão" (NERES; NOGUEIRA; BRITO, 2014, p. 890).

É claro também que as possibilidades da relação entre pesquisa e prática docente, perpassam a adoção da perspectiva dos professores da Educação Básica como produtores de pesquisa, o que se aproxima da concepção do professor pesquisador. Na perspectiva do professor já inserido na profissão que busca modos de se apropriar e se envolver na produção de pesquisas que possam ajudá-lo a encontrar soluções para seus problemas da prática, o ingresso nos programas de pósgraduação surge como alternativa à precariedade de condições geralmente oferecidas nas escolas para o desenvolvimento de pesquisas. A modalidade de mestrado profissional desponta como espaço privilegiado para esse professor, devido a sua constituição "[...] como espaço de fomento à pesquisa com e para professores, além 
da inegável contribuição da diminuição da distância entre saber acadêmico e conhecimento prático" (NERES; NOGUEIRA; BRITO, 2014, p. 245).

O mestrado profissional foi criado como modalidade do Sistema Nacional de Pós-graduação brasileiro na década de 1990. Foi criado na expectativa de preencher

lacunas criadas por uma demanda latente, mais expressiva em determinadas áreas do conhecimento do que em outras, interessadas em avançar sob o aspecto de uma formação profissional altamente qualificada e também de uma produção intelectual com forte cunho de aplicação imediata, diferenciando-se daquela fundamentalmente acadêmica em função da clientela preferencial e do produto final a ser obtido (BARROS; VALENTIM; MELO, 2005, p. 130)

Por conta disso, apresenta grande penetração nas áreas de formação tecnológica e profissional. Como será visto adiante, também a área educacional encontra terreno fértil para desenvolver diferentes propostas de cursos de mestrado profissional que são oferecidos como opções de formação continuada aos professores em serviço. Nesse sentido, o mestrado profissional para professores se constitui como um lugar híbrido de formação continuada: se dá no espaço da universidade (do programa de pós-graduação), mas sem a desvinculação do professor-cursista de seu ambiente de trabalho. Contando também que a estruturação de muitos desses cursos prevê atividades que objetivam a aproximação com o contexto escolar, campo de trabalho dos professores.

Dessa forma:

O mestrado profissional constitui oportunidade de maior aproximação entre os trabalhos conduzidos pela universidade, às demandas espontâneas ou induzidas pela própria universidade existentes no campo social e profissional, demandas por soluções tecnológicas, sociais e em geral, estruturadoras do conhecimento nas atividades profissionais. Apresenta uma dimensão voltada à horizontalidade e verticalização do conhecimento e assim vital para as atuais necessidades do Brasil (QUELHAS; FARIA FILHO; FRANÇA, 2005, p. 98).

Ainda, enfatiza-se que

[...] não é o caso [...] de ensinar técnicas isso seria o objeto de um curso de especialização. No caso do mestrado profissional, o objetivo é um direcionamento claro para encontrar o caminho da resposta a uma pergunta específica proposta pela área profissional ou identificada pela Universidade como algo que deve ser investigado e solucionado naquela área (Ibid., p. 99). 
Por esse motivo, como Piquet, Leal e Terra (2005) apontam, na modalidade do mestrado profissional, "[...] as dissertações, geralmente são voltadas à interpretação da prática, ao delineamento de linhas de ação, mas sempre a partir do conhecimento de conceitos e teorias e da discussão de ideias" (p. 34). Em outras palavras, a pesquisa desenvolvida no âmbito de um curso de mestrado profissional é proposta a partir de um problema da prática profissional e a ela deve atender, porém, sendo embasada pelos conhecimentos teóricos proporcionadas pelo meio acadêmico. Essa aproximação favorece um "encurtamento dos prazos entre a investigação e a sua aplicabilidade" (PIQUET; LEAL; TERRA, 2005, p. 34), além de "ser o motor para a geração de tecnologias, em sua forma ampla, e sua transferência, alcançando assim a inovação" (NASCIMENTO; PIÑEIRO; RAMOS, 2013, p. 382).

Essa última característica dos mestrados profissionais, qual seja, a da concomitância entre vivência no mundo profissional e no mundo acadêmico (no sentido de que o mestrando continua trabalhando enquanto realiza o curso e sua pesquisa), especificamente para os professores, favorece "de forma mais rápida, não só uma valorização e um sentido maior do papel da pesquisa sobre a prática, como também uma repercussão mais imediata sobre o seu desempenho" (CEVALLOS; PASSOS, 2012, p. $819-820)$.

Essas seriam as principais potencialidades do mestrado profissional como lugar de formação continuada de professores e promotor de desenvolvimento profissional. Outras questões sobre a criação, conceituação, estruturação e demais desdobramentos para a formação docente, bem como algumas críticas aos mestrados profissionais serão discutidas em um capítulo próprio da tese. Por ora, cabe-nos colocá-lo como uma das opções de lugares de formação continuada que despontou recentemente no Brasil. A seguir, encerramos o capítulo expondo algumas considerações sobre as referências à formação continuada endereçada aos professores - em específico, os de Ciências - presentes nas políticas públicas de educação brasileiras.

\subsection{Formação continuada de professores nas políticas públicas de educação brasileiras}

Historicamente, antes da promulgação da última Lei de Diretrizes e Bases da Educação Nacional (LDB), Lei no 9.394, de 20 de dezembro de 1996, coexistiam duas orientações de formação continuada a partir dos anos 1970: a da reciclagem 
(preocupada na atualização dos professores em relação aos conhecimentos científicos produzidos nas universidades) e a da capacitação (onde se investia, além da atualização dos conteúdos, no treinamento dos professores para o domínio de técnicas e aplicações de recursos de ensino) (CASTRO; AMORIM, 2015). Essas duas vertentes,

[...] encontravam justificativa na evidente aceleração do ritmo de produção de conhecimentos e técnicas, que cada vez mais rapidamente se tornavam obsoletos, assim como na flagrante queda da qualidade da formação [inicial] dos professores, em razão do processo de proletarização do magistério iniciado ainda nos anos 1960 (Ibid., p. 44).

Esses eram os modelos oferecidos em cursos no contexto da formação do professor de Física, conforme nos apontam Pacca e Villani (2018). Na década de 1960, a preocupação para esta disciplina era com a formação inicial de professores na época, profissionais liberais de diferentes áreas tais como a engenharia, medicina e advocacia - via a adoção do material didático dos grandes projetos de Ensino, dos quais o PSSC (Physical Science Study Committee) foi pioneiro e:

Pretendia dar conta da precariedade da formação do professor,
incapaz de incorporar as mudanças ocorridas na ciência e as
novidades da tecnologia que já invadiam o cotidiano, com um material
pedagógico de qualidade científica, e em parte didática, capaz de
desencadear interesse para uma revisão da formação do professor
(Ibid., p. 58).

Sucedendo o PSSC, diversos outros projetos de ensino nacionais sugiram, focalizando mais no aluno com a instrução programada do que no professor, que atuaria como mero organizador da classe e atividades desempenhadas pelos alunos de modo autônomo em interação com os materiais. Segundo Pacca e Villani (2018), esses projetos sempre incluíam um treinamento para os professores oferecidos em oficinas de curta duração, "onde os professores, inscritos previamente, trabalhavam, no papel de alunos, com o material e as atividades programadas". A aplicação dos materiais nas salas de aula "seria o problema a enfrentarem sozinhos" (p. 59).

Já na década de 1980, com o processo de reabertura política (redemocratização no país), é apontada a intensificação de movimentos em prol da educação, marcados por "uma participação mais efetiva dos professores nas questões da educação" (ALFERES; MAINARDES, 2011, p. 2). Com isso, além de questões técnicas, começou-se a considerar o contexto socio-histórico na discussão sobre formação de professores. A reintrodução, no contexto acadêmico, de obras de Paulo Freire também 
colaborou para a nova orientação para formação que começava a surgir à época (CASTRO; AMORIM, 2015). As pesquisas desenvolvidas na época também contribuíram para essa mudança de paradigma no âmbito do Ensino de Física, principalmente com o advento da pesquisa na linha de concepções espontâneas, aquelas originadas do senso comum e que afetariam a aprendizagem dos conceitos científicos de forma adequada pelos alunos - e até mesmo pelos próprios professores. Assim, essa década

caracterizou-se pela produção de cursos curtos de Formação Continuada com o objetivo de aperfeiçoar e atualizar o professor de Física, passando a entender aqueles erros como modelos alternativos da Física, que deveriam ser reelaborados com o auxílio do professor. Ou seja, esse fato veio a acentuar o caráter de atualização ou aperfeiçoamento em vez de treinamento atrelado a projetos produzidos fora do ambiente pedagógico real (PACCA; VILLANI, 2018, p. 61)

Posteriormente, na década de 1990, fundamentada nas discussões levantadas por diversos autores, a formação continuada "passou a ser considerada uma das estratégias fundamentais para o processo de construção de um novo perfil profissional do professor" (ARAÚJO; ARAÚJO; SILVA, 2015, p. 59). Foi nessa década que, conforme discutimos na primeira parte do presente capítulo, "a formação permanente dos professores emerge, simultaneamente, como uma necessidade intrínseca dos sistemas de ensino e um direito de todos os professores" (Idem). Duas grandes tendências emergiram nesse período: "a primeira, de cunho mais conservador, [que considerava] o professor como sujeito passivo do processo formativo; a segunda, de caráter emancipatório, [que procurava] envolver o professor de forma mais significativa" (ARAÚJO; SILVA, 2009, p. 328).

Nessa década, a legislação brasileira impulsionou a expansão de programas de formação continuada para professores. Colares e Bryan (2014) destacam a LDB (Lei no 9.394/96); a Lei Federal no 9.424/96 (que regulamentou o Fundo de Manutenção e Desenvolvimento do Ensino Fundamental e da Valorização do Magistério - FUNDEF); a Resolução nº 03/97 do Conselho Nacional de Educação (que fixa Diretrizes para os Novos Planos de Carreira e de Remuneração para o Magistério dos Estados, do Distrito Federal e dos Municípios) e as Diretrizes Gerais da Rede Nacional de Formação Continuada de Professores.

Em relação à LDB vigente atualmente, Castro e Amorim (2015) mostram que o "texto se ocupa primeiro da formação continuada e capacitação, para só depois tratar da formação inicial" (p. 41). Isso, de acordo com Santos (2000), seria um efeito da 
influência do Banco Mundial nas políticas educacionais. A autora mostra que essa escolha pelo

[...] investimento na educação continuada é proposto pelo banco, na perspectiva de melhorar 0 desempenho docente mediante maior domínio que o professor/a venha a ter dos conteúdos das disciplinas e de estratégias pedagógicas para ministrá-las, instrumentalizando o docente para seguir diretrizes e normas curriculares (p. 174).

Os termos utilizados no texto da LDB para se referir à formação continuada de professores são diversos (capacitação em serviço - Art. 61, inciso I; aperfeiçoamento profissional continuado - Art. 67, Inciso II; treinamento em serviço - Art. 87) e, segundo Santos (2011),

mais que confusões terminológicas, esses conceitos traduziram uma concepção de formação e um perfil de professor que serviram de sustentação para o desenvolvimento de políticas de formação docente de caráter técnico-instrumental, orientadas por uma perspectiva compensatória de formação (p. 2).

As consequências dessa formação transparecem também nas Diretrizes Curriculares Nacionais para a Formação de Professores (DCNFP), as quais assumem "a competência como concepção nuclear na orientação do curso". Segundo Velloso (2012), nas prescrições das DCNFP é evidente:

[...] a tendência ao esvaziamento da formação docente, que, em detrimento da possibilidade de produção de conhecimentos e da formação do profissional crítico-reflexivo e transformador, privilegia a ótica da racionalidade técnica (p. 433).

Apesar de a LDB trazer alguns avanços em comparação às legislações anteriores, no que se refere à valorização profissional dos professores, Santos (2011), por outro lado frisa que "a determinação de princípios no âmbito legal não foi suficiente para concretizar o que estava prescrito" (p. 4). O quadro de desvalorização no qual os profissionais da educação já estão inseridos ainda carece de proposições de ações políticas concretas para sua superação. Castro e Amorim (2015), analisando o artigo $67^{13}$ da LDB, referente à valorização dos profissionais da educação ressaltam ainda que:

${ }^{13} \mathrm{O}$ art. 67 da LDB engloba as ações de valorização dos profissionais da educação. Seus incisos especificam: I - ingresso exclusivamente por concurso público de provas e títulos; II aperfeiçoamento profissional continuado, inclusive com licenciamento periódico remunerado para esse fim; III - piso salarial profissional; IV - progressão funcional baseada na titulação ou 
[...] o emprego do termo "aperfeiçoamento profissional continuado" em segundo lugar na lista de condições asseguradas aos professores, à frente das condições adequadas de trabalho, do piso salarial e da inclusão na carga horária de tempo empregado em estudo, planejamento e avaliação, permite supor que a LDB prioriza uma lógica de desenvolvimento da carreira que se reduz a aperfeiçoar práticas, acentuando um viés supostamente técnico para esse movimento, sem esclarecer, porém, como isso ocorrerá e a quem caberá a promoção de tal aperfeiçoamento (p. 43).

Nos últimos anos, programas nacionais de formação continuada do Ministério da Educação, em especial, programas implementados pela Capes, e programas regionais oferecidos no âmbito das Secretarias de Educação a nível estadual ou municipal promoveram, concomitantemente, esse aperfeiçoamento profissional aos professores de diferentes níveis de ensino da educação básica. Paralelamente às ações de formação desses agentes públicos, cabe destacar que o incentivo - e exigência - da formação permanente, aqueceu o crescimento do mercado destinado à formação continuada - em específico, dominada por instituições privadas que oferecem serviços de formação continuada para professores individualmente ou para redes de ensino. Salienta-se que o crescimento desse mercado reforça

o silenciamento da voz do professor na definição das políticas educacionais e o fortalecimento de uma concepção de formação continuada que, não raramente, tem se ocupado somente da certificação e/ou diplomação (SANTOS, 2011, p. 5).

Do lado das instituições públicas, essa certificação também é priorizada. Essa preocupação encontra expressão, inclusive, no Plano Nacional de Educação ${ }^{14}$ (PNE) mais recente (2014/2024) em duas de suas metas. Uma delas, a meta $15^{15}$, dispõe sobre a certificação em nível inicial, a fim de garantir a formação acadêmica adequada a todos os professores em exercício na educação básica, já que muitos ainda atuam lecionando disciplinas diferentes de sua formação inicial ou trabalham sem ter

habilitação, e na avaliação do desempenho; $\mathrm{V}$ - período reservado a estudos, planejamento e avaliação, incluído na carga de trabalho; VI - condições adequadas de trabalho.

${ }_{14}$ Página eletrônica governamental sobre o PNE (2014-2024) disponível em: < pne.mec.gov.br/>. Acesso em: 15 jun 2017.

${ }^{15}$ Meta 15: garantir, em regime de colaboração entre a União, os Estados, o Distrito Federal e os Municípios, no prazo de 1 (um) ano de vigência deste PNE, política nacional de formação dos profissionais da educação de que tratam os incisos I, II e III do caput do art. 61 da Lei no 9.394, de 20 de dezembro de 1996, assegurado que todos os professores e as professoras da educação básica possuam formação específica de nível superior, obtida em curso de licenciatura na área de conhecimento em que atuam. 
formação pedagógica, por não serem licenciados. Já a meta $16^{16}$ concentra-se na formação continuada com o destaque à qualificação pós-graduada dos professores.

Com uma trajetória histórica exitosa no fomento à pesquisa e à formação de pesquisadores no país, a Capes, a partir de 2007, assumiu também a responsabilidade sobre a formação de professores da educação básica. Desde então, a agência tem promovido diversos programas, tanto de formação inicial, quanto de formação continuada. Entre eles, destacam-se o Programa Nacional de Formação de Professores da Educação Básica (Parfor) e os Programas de Mestrado Profissional em Rede.

O Parfor foi instituído em 2009 com o objetivo de fomentar turmas especiais de licenciatura para professores em exercício em caráter presencial ou à distância. $\mathrm{O}$ programa visa atender a docentes em exercício na rede pública da educação básica sem formação superior na etapa em que atua na sala de aula, oferecendo cursos de primeira licenciatura; ou a docentes já licenciados, mas que atuam em área distinta da sua formação inicial (cursos de segunda licenciatura); ou, ainda, docentes graduados não licenciados, proporcionando a estes, formação pedagógica. O programa contou com 2.315 turmas concluídas em 2017 e 588 turmas em andamento no primeiro semestre de 2018, implantadas em 510 municípios, cobrindo um total de 22.506 professores cursando uma licenciatura em maio de 2018 e 44.843 já formados até esse mês ${ }^{17}$.

As propostas de Programas de Mestrado Profissional em Rede, por sua vez, visam atender professores já licenciados. Oferece a titulação em nível de pósgraduação stricto sensu, assim como os Mestrados Profissionais instituídos localmente por diferentes Instituições de Ensino Superior. Porém, ao contrário desses últimos,os Mestrados Profissionais em Rede têm alcance nacional, pois os cursos são oferecidos em polos credenciados de diferentes localidades que seguem uma matriz curricular comum. No capítulo 2, detalhamos as especificidades desses programas. O primeiro Mestrado Profissional em Rede, orientado para professores, foi o Programa de Mestrado Profissional em Matemática em Rede Nacional (PROFMAT), que iniciou suas atividades em 2011.

\footnotetext{
${ }^{16}$ Meta 16: formar, em nível de pós-graduação, $50 \%$ (cinquenta por cento) dos professores da educação básica, até o último ano de vigência deste PNE, e garantir a todos(as) os(as) profissionais da educação básica formação continuada em sua área de atuação, considerando as necessidades, demandas e contextualizações dos sistemas de ensino.

17 Dados disponíveis na página eletrônica da CAPES no link: < http://www.capes.gov.br/pt/educacao-basica/parfor/> . Acesso: 11 jul 2019.
} 
O fomento aos cursos de mestrado profissional estabelece um marco nos cursos de formação continuada acessíveis aos professores. No contexto brevemente discutido sobre as referências gerais à formação continuada de professores presentes na legislação brasileira e, em particular, no contexto dos professores de Ciências e Matemática, observa-se que anteriormente ao surgimento desses cursos de mestrado profissional, as opções de formação continuada dedicadas a esses professores eram dominadas por "propostas e projetos organizados de forma eventual e local" (VILLANI, 2016, p. 420). O formato hegemônico era o de cursos de especialização ou de aperfeiçoamento, dedicados a "aprimorar a formação científica e/ou as práticas docentes" (Ibidem.). Eram cursos que, em geral, não eram estáveis ou duradouros, logo, tinham alcance limitado na formação dos professores participantes. De modo geral, "o valor atribuído a esses cursos no meio educacional era pequeno, não somente por seu alcance e duração limitados, mas também por não terem uma avaliação externa padronizada" (VILLANI, 2016, p. 420). Outra alternativa de formação que os professores encontravam se dava em nível de pós-graduação stricto sensu onde poderiam realizar pesquisas - não necessariamente orientadas diretamente à prática profissional - orientados por pesquisadores, principalmente, das áreas de Educação ou Ensino de Ciências e Matemática.

Esse cenário incentivou a proposição desses novos formatos de formação continuada. Como exemplo, em relação ao primeiro Mestrado Profissional em Educação Matemática, instituído na PUC-SP, Pires e Iglioli (2013) observam que havia

[...] a demanda por um curso de Mestrado Profissional em Educação Matemática no estado de São Paulo [que] estava bem caracterizada pelas experiências de formação continuada de professores de Matemática desenvolvidas no âmbito de projetos como o PróCiências ${ }^{18}$ e o Programa de Educação Continuada da Secretaria da Educação do Estado de São Paulo (PEC). Essas experiências evidenciavam o grande interesse por cursos de pós-graduação por parte dos professores, particularmente das redes públicas, que buscavam novas formas de atualização (p. 1048).

No próximo capítulo, nos concentramos nessa nova modalidade de pósgraduação, o mestrado profissional, que foi instituída em atendimento às demandas formativas de outras áreas profissionais, mas que, no entanto, encontraram terreno

\footnotetext{
${ }^{18}$ O Pró-ciências (Programa de Apoio ao Aperfeiçoamento de Professores de Ensino Médio em Matemática e Ciências) foi uma iniciativa da Capes e da Secretaria Nacional de Ensino e Tecnologia do Ministério da Educação que teve como objetivo principal o aperfeiçoamento em serviço de professores do ensino médio (nas áreas de Matemática, Biologia, Física e Química), por meio do apoio à inovação pedagógica. Foi implantado em diferentes unidades da federação. Em São Paulo, teve o apoio da FAPESP, e envolveu projetos desenvolvidos entre os anos de 1996 e 2001.
} 
fértil frente a essas demandas latentes de formação continuada de professores de Ciências e Matemática. 


\section{Sobre o mestrado profissional}

As primeiras proposições do mestrado profissional (abreviado ao longo do texto como MP), mais recente modalidade do Sistema Nacional de Pós-graduação brasileiro, surgiram na década de 1990. Foi inspirada em movimentos estrangeiros, que no contexto das novas demandas do mercado produtivo apresentadas nessa década, pressionavam por modelos de formação pós-graduada que as atendessem de forma mais adequada, algo no que as já existentes especializações em nível lato sensu (entre eles os conhecidos $M B A s^{19}$ ) não estavam sendo bem-sucedidas. No contexto internacional, esse movimento dá início em 1993, quando

as 50 instituições mais representativas do universo internacional de escolas, como Bocconi, Harvard, Wharton, Insead e outras, reúnemse em Paris para discutir a crise dos MBAs e propor novos modelos de ensino, bem como estratégias de internacionalização e parcerias para a conquista de novos e antigos territórios sul-americanos, africanos e asiáticos (FISCHER, 2003, p. 120).

No contexto brasileiro, a pós-graduação existente, dividida entre as modalidades lato sensu (voltada para aprofundamento da qualificação profissional) e stricto sensu (voltada à formação acadêmica de pesquisadores) deixava descobertos, segundo Castro (2005), dois mercados: o das empresas que necessitavam de profissionais com a qualificação que ultrapassasse aquela oferecida à nível de graduação e o das instituições de ensino que precisavam de perfis de professores oriundos do mundo profissional, diferentes, portanto, dos mestres e doutores orientados para a pesquisa acadêmica. Melo e Oliveira (2005) destacam que a introdução dos cursos de MP na pós-graduação

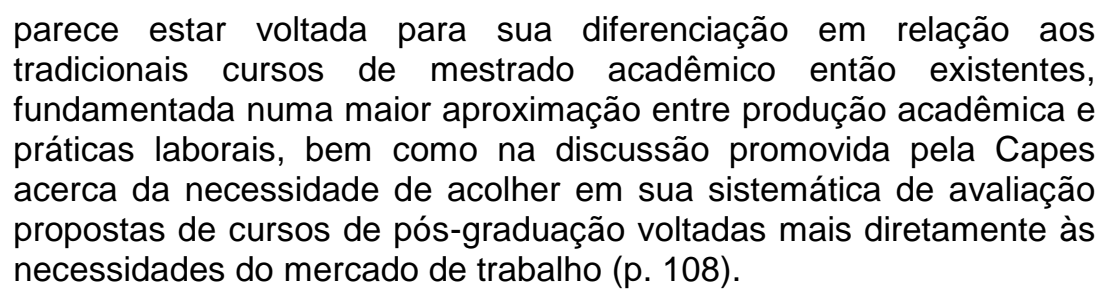

Já Barros, Valentim e Melo (2005) compreendem que a proposição dos MPs não foi movida unicamente pelos interesses em corresponder às exigências do mercado. Para os autores, o MP foi criado para atender à

\footnotetext{
${ }^{19}$ Abreviação de Master of Business Administration.
} 
[...] crescente demanda pela pós-graduação, em parte explicada pela acentuada expansão da graduação que a cada ano disponibiliza para o mercado um número cada vez maior de alunos; e as demandas provenientes dos setores público e privado, não apenas as de caráter eminentemente econômico, assim como as de cunho social, ambas a exigir um profissional com sólida formação para atuar além do mercado acadêmico (p. 124).

Dessa forma, o MP, diferentemente da modalidade acadêmica,

pode ser pensado como um tipo de formação pós-graduada que envolve uma grande diversidade de formatos específicos para o seu funcionamento. É a capacitação para a prática profissional transformadora por meio da incorporação do método científico. Voltase para um público preferencialmente oriundo de fora da academia e destina-se à gestão, produção e aplicação do conhecimento orientado para a pesquisa aplicada, a solução de problemas, a proposição de novas tecnologias e aperfeiçoamentos tecnológicos (BARROS; VALENTIM; MELO, 2005, p. 131).

Giacomazzo e Leite (2014) complementam a noção expressa acima ao destacarem que, no contexto do MP

[...] não se trata de ensinar técnicas, mas de direcionar problemas específicos, encontrando soluções ou respostas em temas localizados ou em áreas em que se buscam soluções em contextos reais - no campo profissional ou no contexto da Universidade [...] Trata-se, portanto, de um curso de mestrado dirigido a profissionais, com ênfase em conteúdos aplicados em atividades de pesquisa ( $p$. 476).

Apesar da demanda pelo mestrado profissional ter surgido especificamente de áreas diretamente relacionadas ao mercado produtivo e empresarial, o modelo foi amplamente adotado no contexto de formação de professores da educação básica em Ensino de Ciências e Matemática (além de outras disciplinas).

Nesse capítulo, pretende-se, primeiramente, fornecer uma visão sobre a história de sua implantação no Brasil, seguindo as referências à modalidade na legislação e as discussões empreendidas no contexto das instituições de ensino superior e da Capes. A seguir, concentramos a atenção no contexto da formação de professores da educação básica e discutimos como a proposta do MP foi moldada para atender às especificidades do público atendido. Por fim, com base em artigos levantados na literatura, apresentamos algumas discussões empreendidas a respeito do desenvolvimento profissional proporcionado aos professores nos MPs dedicados ao Ensino de Ciências e Matemática. 


\subsection{Histórico nacional e referências na legislação}

É consenso entre pesquisadores brasileiros a consideração do Parecer $n^{\circ}$ 977/1965, lavrado pelo então Conselho Federal de Educação (CFE), como o primeiro documento no Brasil em que se faz a referência à modalidade profissional de pósgraduação stricto sensu. Esse parecer ficou conhecido como Parecer Sucupira em referência à Newton Sucupira, relator do documento. Esse parecer visava regulamentar a pós-graduação incipiente no país à época. Inspirado principalmente pelo modelo de pós-graduação norte-americano, no qual os cursos de mestrado e doutorado poderiam orientar-se desde então como de pesquisa ou como profissional, esse documento considera o mestrado profissional como um grau terminal para ampliação e aprofundamento da formação profissional recebida nos cursos de graduação e que atestaria competência profissional em determinada área de atuação.

Em relação à essas primeiras definições da pós-graduação brasileira, é importante indicar que a diferenciação entre as duas modalidades de pós-graduação stricto sensu, subentendida em pareceres do CFE subsequentes ao de 1965, como o

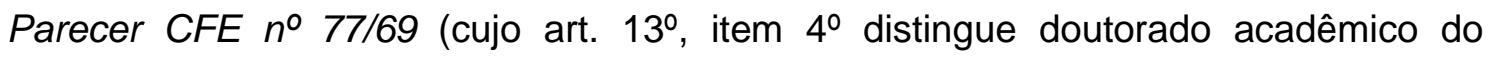
profissional por meio de nomenclaturas distintas) pareceu se dar mais em relação à área de conhecimento englobada pelo curso do que pela sua natureza, estruturação e objetivos. O trecho do Parecer CFE no 1683/74 destacada por Cury (2005) indica que o referido artigo do Parecer n 77/69 designa a nomenclatura "doutorado acadêmico" para cursos nas áreas de Letras, Ciências, Ciências Humanas, Filosofia e Artes; enquanto que a designação "doutorado profissional" seria atribuída às demais áreas orientadas à formação profissional (Medicina, Engenharia, Direito, Educação, entre outras). O mesmo deveria ocorrer para o nível de mestrado e suas diferenciações entre "mestrado acadêmico" e "mestrado profissional".

Porém, na prática, apesar da referência à modalidade profissional na pósgraduação stricto sensu presente no Parecer CFE $n^{\circ}$ 977/65, a formação profissional em nível de pós-graduação no Brasil permaneceu inicialmente concentrada nos cursos de especialização e aperfeiçoamento lato sensu. Os primeiros Planos Nacionais da Pós-graduação, articulados aos Planos Nacionais de Desenvolvimento, visaram primordialmente a formação de recursos humanos qualificados para as atividades docentes, de pesquisa e técnicas, concentrando-se na institucionalização, expansão e avaliação do sistema de pós-graduação no país (HOSTINGS, 2006) e privilegiando, dada a ênfase indicada acima, os cursos de pós-graduação stricto sensu de pesquisa (o que atualmente denominamos de acadêmicos). As décadas de 1970 e 1980 
presenciam a consolidação da pós-graduação com ênfase na formação de pesquisadores e o aumento na produção científica e no quadro docente para atuar nas universidades brasileiras em expansão. É o que afirmam sinteticamente Piquet, Leal e Terra (2005):

[...] vê-se que em sua origem [do sistema de pós-graduação do país], a capacitação de quadros profissionais mereceu a mesma atenção que a formação de quadros universitários. Foi nas décadas de 60 e, principalmente, na de 70 , que essa orientação se altera e o governo brasileiro passa a investir maciçamente na formação de profissionais de maior poder multiplicador - os professores do ensino superior para garantir a formação dos quadros de docentes e pesquisadores, essenciais para a expansão do próprio sistema e para a promoção da pesquisa científica e tecnológica no País (p. 32).

A década de 1990 culmina em um novo cenário, com a globalização e a ascensão do neoliberalismo. Em 1995, uma comissão designada pelo presidente da Capes, Abilio Baeta Neves, elabora o documento "Mestrado no Brasil - a situação e uma nova perspectiva" ${ }^{20}$ (CAPES, 2005a) que, apontando as novas necessidades demandadas à pós-graduação geradas por essas mudanças sociais e econômicas, destaca a importância da implementação de mestrados voltados à formação profissional e também estabelece critérios de reconhecimento, acompanhamento e avaliação desses cursos, de modo a considerar suas características particulares e ao mesmo tempo garantir a qualidade dos cursos de pós-graduação então vigentes. Em síntese, o documento coloca que

[...] a rápida evolução do conhecimento tem exigido dos graduados formação avançada e atualizada; em paralelo, as organizações governamentais e não-governamentais têm exigido constante elevação da qualidade e produtividade dos seus serviços. Em complemento, a abertura de mercado tem demandado das empresas um nível de competividade que as leva a buscar profissionais com formação pós-graduada, de preferência mestrado. A evolução do conhecimento, a melhoria do padrão de desempenho e a abertura do mercado induzem à busca de recursos humanos que permitam uma transferência mais rápida dos conhecimentos gerados na universidade para a sociedade (CAPES, 2005a, p. 140, grifos nossos).

Tais discussões no âmbito da Capes, em defesa da flexibilização do modelo de pós-graduação stricto sensu, culminam na publicação da Portaria $n^{\circ} 47 / 1995$, a qual

${ }^{20}$ Essa comissão foi constituída pelos professores: Silvino Joaquim Lopes Neto (Direito UFRGS); Luiz Bevilaqua (Engenharia Mecânica - UFRJ); Tânia Fischer (Administração UFBA); Jacques Marcovitch (Administração - USP); Virgílio Augusto F. Almeida (Comunicação - UFMG); Edson de Oliveira Nunes (Direito - Cândido Mendes), e foi presidida por Darcy Dillenburg, Diretor de Avaliação. 
determina a implantação "de procedimentos apropriados à recomendação, acompanhamento e avaliação de cursos de mestrado dirigidos à formação profissional". Dentre os pontos destacados na portaria ${ }^{21}$, pode-se inferir as seguintes diretrizes iniciais para os MPs:

1. A tendência na adoção de um processo de diferenciação a partir dos mestrados acadêmicos (de boa qualidade, atestada pela obtenção de altos conceitos nos processos de avaliação da pós-graduação conduzidos pela Capes) já estabelecidos nas instituições proponentes. Busca-se, com isso, "articular as atividades de ensino ${ }^{22}$ com as aplicações de pesquisas ${ }^{23}[\ldots]$ de forma diferenciada e flexível" (CAPES, 2005b, p. 147). Além disso, a preferência é dada aos orientadores que sejam docentes doutores, detentores de produção intelectual de alto nível. É permitida a admissão de docentes não-doutores, selecionados por qualificação profissional relevante para o curso, porém eles comporiam parcela restrita do corpo docente e lhes caberia a atuação como co-orientadores.

2. O início de um processo de diversificação do formato do trabalho final apresentado pelo estudante do curso (cujas possibilidades apontadas são ampliadas em regulamentação posterior, como será visto adiante). Essa diversificação visa proporcionar a sua adequação com a natureza do curso e sua proposta. A Portaria ํㅡㄴ 47/1995 especifica, como exemplo, os formatos de "dissertação, projeto, análise de casos, performance, produção artística, desenvolvimento de instrumentos, equipamentos e protótipos" (Ibidem).

3. A questão do autofinanciamento desses cursos é evocada na Portaria, que estimula a busca de "iniciativas de convênio com vistas ao patrocínio" (Ibidem, p. 148). O documento especifica, no entanto, que a Capes manteria apoio financeiro àqueles cursos onde o autofinanciamento não fosse de fácil concretização (que seriam cursos dedicados a segmentos de mercados profissionais como o setor de serviços ou com forte participação estatal. Contemplam-se, portanto, mestrados que atendem à professores da Educação Básica).

A proposta de criação de mestrados profissionalizantes (como foram denominados inicialmente ${ }^{24}$ ) foi submetida a críticas e foi rejeitada por uma parte da

\footnotetext{
${ }^{21}$ Os mesmos pontos presentes no documento "Mestrado Profissional no Brasil - a situação e uma nova perspectiva" (CAPES, 2005a).

${ }^{22}$ No curso de mestrado de caráter profissional.

${ }^{23}$ Essas, produzidas na instituição, no âmbito dos mestrados e doutorados acadêmicos.

${ }^{24}$ A designação atualmente disseminada - a de mestrados profissionais - é dada após a publicação da Portaria CAPES no 80/1998. Aparentemente, a nomenclatura foi modificada em virtude do termo "profissionalizante" ser associado com frequência à formação em nível Médio
} 
comunidade acadêmica. Menandro (2010) atribui a origem dessa divisão da comunidade acadêmica em relação aos MPs a fatores relacionados ao contexto específico de surgimento da proposta e às ambiguidades presentes nessa proposta inicial.

A proposta dos MPs ganhou força em um momento no qual ainda não havia se iniciado a grande expansão dos cursos de pós-graduação no nível de doutorado, o que significa que, nesse primeiro momento, os mestrados então existentes eram muito prestigiados (MENANDRO, 2010). Diante de uma proposta "não-acadêmica"25 e que visava flexibilizar o sistema de pós-graduação já bem estabelecido, surge, como consequência, uma disputa social na qual os mestres já titulados nesse período (ou seja, "mestres acadêmicos") temiam a desvalorização de seus títulos com o advento da nova modalidade de mestrado (RIBEIRO, 2010). A reação construiu-se, principalmente, em torno do receio da proliferação de cursos de baixa qualidade e titulação de mestres de formação duvidosa o que acarretaria na queda no prestígio da pós-graduação brasileira.

Certamente, os defensores da implantação dos MPs preocupavam-se com a qualidade dos cursos, de modo que a avaliação era uma das principais pautas de discussão. O sistema de avaliação dos cursos de pós-graduação então estabelecido se estruturava fortemente em torno da produção científica publicada, algo que não era condizente com a natureza dos MPs, o que gerou a dificuldade no estabelecimento de critérios para a avaliação dessa nova modalidade de curso de pós-graduação e reforçou a resistência a sua criação.

A fim de combater tal resistência, desde as primeiras discussões para 0 estabelecimento de critérios de avaliação dos MPs o pressuposto adotado baseou-se na adaptação do sistema de avaliação já consolidado - bem-sucedido na avaliação dos cursos acadêmicos. Nesse sentido, Salem (2012) aponta que "parece haver outra contradição entre o que se estabelece como padrão e como critério de avaliação no modelo acadêmico, com o que se espera do modelo profissional" (p. 230). Ao que

ou de Graduação (MENANDRO, 2010). Dessa forma, a compreensão dessa nomenclatura seria a de especialização profissional e não de qualificação do profissional já especializado.

${ }^{25}$ Essa concepção é debatida por Fischer (2005), para quem os "mestrados profissionais não são cursos não-acadêmicos, já que existem principalmente nos espaços da academia". Para a autora, no entanto, os MPs vão além da academia por dedicar-se aos profissionais e ao mundo profissional: "mestrados profissionais são experiências de inovação e reinvenção das práticas acadêmicas [...]" nas quais "profissionais experientes não vem aprender práticas, mas sim, iluminar a prática com teorias apropriadas" (p. 29). Nesse sentido, como também defendido por Ribeiro (2010), "os MP desnudam a postura acadêmica tradicional e são capazes, caso haja determinação para se travar o embate, de alterar a estrutura da produção científica do País" ( $p$. 448). 
parece, a insistência nesse pressuposto de avaliação dos MPs originou-se com a intenção de se criar um sistema de MPs que gozasse da mesma qualidade que os mestrados acadêmicos já estabelecidos. Isso é evidenciado na escolha pela equivalência entre os títulos das duas modalidades. Essa equivalência estava presente no documento "Mestrado Profissional no Brasil - a situação e uma nova perspectiva" (CAPES, 2005a), onde se lia que "a preservação da nomenclatura atual de titulação" sinalizava "o propósito de manter também os requisitos de qualidade acadêmica definidos para o mestrado na origem da pós-graduação" (p. 142).

A opção pela equivalência dos títulos das duas modalidades de mestrado, alimentaria, de fato, a reação contra os MPs. Menandro (2010) indica que teria sido divulgado pela Capes que "o título concedido pelo Mestrado Profissional não teria valor para a carreira acadêmica, assim como não permitiria pleitear ingresso no Doutorado" (p. 368), ou seja, o MP teria um caráter terminal de formação ${ }^{26}$ (posição defendida com base no entendimento de que, tendo em vista os propósitos do MP, não seria de interesse do "mestre profissional" o ingresso em um curso de doutorado ou a saída do mercado de trabalho para as universidades). Entretanto, dada a regulamentação dos MPs e a dita equivalência entre os títulos que conferem as mesmas prerrogativas entre os egressos de ambas as modalidades de mestrado, 0 detentor do título de "mestre profissional", caso desejasse, poderia "lecionar em uma universidade (pública ou privada)" (SALEM, 2012, p. 228).

Assim, a abertura para a admissão de profissionais sem titulação de doutorado no corpo docente dos MPs, e a possível migração de "mestres profissionais" como docentes de universidades, "em momento em que muitos grupos de instituições públicas e privadas, com tradição de pesquisa, ainda buscavam elevar a titulação de seus docentes" (MENANDRO, 2010, p. 369) reforçou a reação da comunidade acadêmica, que já atuava em cursos de pós-graduação acadêmicos, contra o MP.

Além disso, a distinção entre mestrados acadêmicos (MAs) e mestrados profissionais então em discussão com a proposição da modalidade profissional, trouxe à tona diversas "polaridades e falsas ou autênticas contradições: teoria e prática; produção de conhecimento e aplicação de conhecimento; formação intelectual e formação técnica" (SALEM, 2012, p. 228). Tais polaridades, conforme também apontado por Salem (2012) demonstram de forma implícita "uma cisão entre o 'mundo acadêmico' e o 'mundo social', como instâncias apartadas" (Idem). Nesse sentido, "[...] o mestrado acadêmico seria algo que pertence à academia, cujo caráter social não é

${ }^{26}$ Que foi explicitada posteriormente na Portaria no 80/1998. 
enfatizado. O profissional estaria dirigido para um mundo profissional externo à academia visando atender demandas sociais" (Idem, grifo da autora). Esse apontamento implica um entendimento específico sobre MA, adotado por autores que defendem, de modo geral, a modalidade profissional. É interessante notar, que apesar disso, como ressalta essa autora,

de um modo geral, na defesa dos MPs, percebe-se uma tendência de anular possíveis contradições entre a formação acadêmica e a profissional, buscando sempre mostrar conciliações entre as distintas propostas e possíveis controversas (Ibidem, p. 235).

Menandro (2010) mostra, ainda, que esse período coincide com uma fase de descaso governamental com as universidades públicas. O prestígio dos cursos de pós-graduação estabelecidos nessas universidades ajudava a amenizar os efeitos desse descaso. Porém, a expansão das instituições privadas, com pouca tradição de pesquisa, na área de pós-graduação, também ameaçava concorrer com esses cursos das universidades públicas, além de diminuir a qualidade da pesquisa científica produzida no país.

Em outras palavras: muitos temeram que, na contramão da elevação e da internacionalização da pós-graduação brasileira stricto sensu, o Mestrado Profissional exemplificasse a redução do nível de exigências que estaria permitindo a implantação de cursos de qualidade menor (MENANDRO, 2010, p. 369).

Outro aspecto que conferiu ambiguidade no entendimento a respeito dos MPs foi a falta de "clareza na explicitação dos elementos que diferenciavam o Mestrado Profissional dos bons cursos de especialização" (Ibidem, p. 368). Como já indicado, o sistema de pós-graduação brasileiro havia concentrado inicialmente a formação profissional nos cursos lato sensu. No entanto, ao contrário da pós-graduação stricto sensu, essa modalidade teve regulamentação específica tardia, além de carecer do estabelecimento de processos de avaliação e regulamentação de cursos (FREITAS; CUNHA, 2009). Desse modo, o MP "viria a suprir a lacuna existente no sistema em relação à qualidade da pós-graduação lato sensu. [...]" e assim, "o profissional [...] buscaria o aperfeiçoamento dos seus estudos, num programa que teria uma rígida avaliação da comunidade acadêmica, garantindo assim sua qualificação" (SILVEIRA; PINTO, 2005, p. 39). Os críticos ao MP, no entanto, questionaram o desinteresse em fortalecer essa modalidade de curso já existente e controlar a expansão de cursos de 
especialização e aperfeiçoamento de baixa qualidade, ao invés de criar uma nova modalidade de cursos para formação profissional ${ }^{27}$.

Por fim, o estímulo ao autofinanciamento dos cursos de MP presente na Portaria no 47/1995 reacende o debate sobre a gratuidade do ensino superior (MENANDRO, 2010). Além disso, a natureza dos MPs, no que concerne à possibilidade de parcerias entre universidade e empresas privadas do setor produtivo, também justificou a resistência aos MPs, pois elas colocariam a universidade pública a serviço do setor privado, o que estaria em desacordo com o compromisso social dessas instituições ${ }^{28}$.

Diante desses embates, poucas foram as propostas de cursos de mestrado profissional submetidas para análise da Capes nesses primeiros anos. Em 1998, dispunha-se de um total de 21 programas em todas as áreas que apresentavam cursos de mestrado, doutorado e mestrado profissional (ou apenas de mestrado acadêmico e mestrado profissional) ${ }^{29}$, número inexpressivo frente ao total de 1258 programas stricto sensu já implantados à época.

Por conta das discussões sobre o MP, a Capes publica, em 1998 a Portaria $n^{\circ}$ 80 (CAPES, 2005c), que dispõe sobre os pressupostos e procedimentos para a recomendação, acompanhamento e avaliação de cursos de Mestrado Profissional. Essa portaria reforça características do mestrado profissionalizante (nomenclatura ainda utilizada em referência aos MPs) explanadas na portaria anterior de 1995 (as questões do corpo docente composto predominantemente por doutores, mas com a possibilidade da admissão de profissionais com qualificação e experiência condizentes com a proposta do curso - e com possibilidade da adoção de regime parcial de trabalho para estes docentes; a diversidade de formatos de apresentação do trabalho final permitidos; o incentivo ao autofinanciamento motivado pelo estabelecimento de

\footnotetext{
${ }^{27}$ Um contra-argumento a essa crítica pode ser encontrado em Piquet, Leal e Terra (2005), que recorrendo à Gazzola (2003), apontam uma "diferença conceitual entre os dois tipos de curso" que, portanto, vão além de diferenças de ordem burocrática. Segundo esses autores "os cursos de especialização possibilitam a verticalização do conhecimento em uma subárea específica, visando uma qualificação circunscrita. O objeto de um curso de especialização é, portanto, o de ensinar técnicas. Já os mestrados profissionais podem ser vistos como cursos que, a partir de uma visão horizontal do saber consolidado em um campo disciplinar com as evidentes relações interdisciplinares, busca enfrentar problemas concretos, utilizando, de forma direcionada, o conhecimento existente para equacionar tais problemas. Seu objeto é a aplicação, em um campo profissional definido, de conhecimento e métodos científicos atualizados" (p. 33).

${ }^{28}$ Ribeiro (2005), nesse quesito, não vê contradições em se apostar no desenvolvimento econômico e no desenvolvimento social, no âmbito dos MPs, desde que, inclusive, o "diálogo ocorra constantemente entre ambas as vertentes" (p. 9).

${ }^{29}$ Fonte: GEOCAPES. Disponível em: <geocapes.capes.gov.br/>. Acesso em: 24 abr. 2017. Os programas que abrigavam mestrados profissionais em 1998 estavam assim distribuídos entre as Grandes Áreas: Ciências da Saúde (5); Ciências Exatas e da Terra (3); Ciências Humanas (0); Ciências Biológicas (1); Ciências Agrárias (0); Engenharias (5); Ciências Sociais e Aplicadas (6); Linguística, Letras e Artes (0); Multidisciplinar (1).
} 
convênios), porém reforça, em sua proposição "a necessidade da formação de profissionais pós graduados aptos a elaborar novas técnicas e processos"; o caráter de terminalidade; a articulação do ensino com a aplicação profissional em sua estrutura curricular; maior abertura para instituições proponentes, desvinculando a oferta de cursos de MP exclusivamente à existência de cursos acadêmicos de excelência na instituição, para considerar que

[...] as instituições cujo financiamento de cursos de pós-graduação stricto ou lato sensu, ou a realização de pesquisa e prestação de serviços em campo de conhecimento afim, revelem claramente qualificação científica, tecnológica e/ou artística presumem-se qualificadas também para a oferta de mestrado profissionalizante (CAPES, 2005c).

Observa-se, ainda, a preocupação, no estabelecimento de procedimentos de acompanhamento e avaliação desses cursos, de utilizar critérios pertinentes as suas peculiaridades. Assim, buscava-se valorizar "a produção técnico-profissional decorrente de atividades de pesquisa, extensão e serviços prestados" (CAPES, 2005c, art. $4^{\circ}, \S 2^{\circ}$, grifo nosso). A expressão grifada no trecho reproduzido não estava presente na Portaria $n^{0} 47 / 1995$, tendo sido acrescentada a essa nova portaria.

E então, a partir de 2000 , os cursos de mestrado profissional passam a ser amplamente estimulados e implementados. Barros, Valentim e Melo (2005) apontam que a expansão verificada nesse período se deu tanto em áreas profissionalizantes (como Engenharia, área da Saúde, Administração e Economia) bem como em outras, voltadas à temáticas mais acadêmicas (como Sociologia, Teologia, Física, Matemática, Química). Esses autores consideram que as várias propostas de cursos de áreas diversas, não necessariamente diretamente envolvidas com o mundo produtivo, sinalizam uma preocupação de seus proponentes em promover, com maior rapidez, a apropriação, pela sociedade, dos resultados de pesquisas da área em questão.

Ainda assim, tal expansão se dá sem livrar-se das inúmeras críticas e reações. Associações tais como a Anped (Associação Nacional de Pós-graduação e Pesquisa em Educação) e a ANPG (Associação Nacional de Pós-graduandos) se posicionaram contra os MPs, criticando a abertura ao autofinanciamento desses cursos (que, no entendimento dos refutadores, poderia desencadear um processo de "privatização interna" do ensino superior brasileiro, ainda mais associado ao menor investimento 
público na pós-graduação da época), e com o receio da menor qualidade de formação oferecida e do perigo de uma "mercantilização do ensino" (MELO; OLIVEIRA, 2005) ${ }^{30}$.

A primeira referência legal mais completa em relação aos mestrados profissionais é a Portaria Normativa no 17 de 2009 (BRASIL, 2009), que dispõe sobre o mestrado profissional no âmbito da Capes, estabelecendo com detalhes suas características, objetivos, e procedimentos para oferta e avaliação de cursos. Nessa portaria, observa-se, conforme síntese de Martins e Ribeiro (2013), "a ênfase na aplicação dos conhecimentos para a atuação profissional e a preocupação com a regulamentação da avaliação dos cursos", além da "relevância da inovação aliada à formação" (p. 428). Os pontos destacados por esses autores são detalhados a seguir, de acordo com nossa leitura da portaria.

No art. $3^{\circ}$ da referida portaria se fornece um panorama do escopo dos cursos de MP. A aproximação entre os mundos da pesquisa e o profissional é enfatizada:

O mestrado profissional é definido como modalidade de formação pós-graduada stricto sensu que possibilita:

I - a capacitação de pessoal para a prática profissional avançada e transformadora de procedimentos e processos aplicados, por meio da incorporação do método científico, habilitando o profissional para atuar em atividades técnico-científicas e de inovação;

II - a formação de profissionais qualificados pela apropriação e aplicação do conhecimento embasado no rigor metodológico e nos fundamentos científicos;

III - a incorporação e atualização permanentes dos avanços da ciência e das tecnologias, bem como a capacitação para aplicar os mesmos, tendo como foco a gestão, a produção técnico-científica na pesquisa aplicada e a proposição de inovações e aperfeiçoamentos tecnológicos para a solução de problemas específicos (BRASIL, 2009).

Por sua vez, os objetivos determinados para o MP, expostos no artigo $4^{\circ}$ fazem extenso uso de termos próprios do mundo produtivo e empresarial, tais como competitividade, inovação, desenvolvimento, produtividade, eficácia e eficiência. No referido artigo, lê-se que os MPs têm como objetivo a capacitação de "profissionais qualificados" que dominam e exercitam "a prática profissional avançada e transformadora de procedimentos, visando atender demandas sociais, organizacionais

30 Em 2017, a discussão do autofinanciamento para cursos de pós-graduação em universidades públicas volta à tona com a decisão do Supremo Tribunal Federal (STF) autorizando a cobrança de mensalidades de cursos lato sensu. $\mathrm{Na}$ discussão, um dos ministros, Gilmar Mendes, chegou a sugerir também a cobrança dos cursos de mestrado e doutorado, ideia que, no entanto, foi rechaçada pela maioria dos ministros nesse julgamento. Fonte: $\quad<$ http://g1.globo.com/politica/noticia/stf-permite-a-universidade-publica-cobrarmensalidade-em-cursos-de-especializacao.ghtml />. Acesso em: 28 abr. 2017. 
ou profissionais e do mercado de trabalho". São espaços nos quais há a transferência de "conhecimento para a sociedade", no ensejo de atender a "demandas específicas e de arranjos produtivos com vistas ao desenvolvimento nacional, regional ou local". Empenha-se também "melhorar a eficácia e a eficiência das organizações públicas e privadas por meio da solução de problemas e geração e aplicação de processos de inovação apropriados", além de, assim, "contribuir para agregar competitividade e aumentar a produtividade em empresas, organizações públicas e privadas" (BRASIL, 2009).

Além desses pontos explicitados, que podem ser considerados como "novidade" em comparação às portarias anteriores ${ }^{31}$, a Portaria no 17/2009 também fornece informações sobre os procedimentos de proposição de novos cursos, acompanhamento e avaliação dos mesmos com muito mais detalhes. Apresenta-se nessa portaria, por exemplo, uma diversidade maior de formatos aceitos como Trabalho de Conclusão final dos cursos de MPs:

[...] o trabalho de conclusão final do curso poderá ser apresentado em diferentes formatos, tais como dissertação, revisão sistemática e aprofundada da literatura, artigo, patente, registros de propriedade intelectual, projetos técnicos, publicações tecnológicas; desenvolvimento de aplicativos, de materiais didáticos e instrucionais e de produtos, processos e técnicas; produção de programas de mídia, editoria, composições, concertos, relatórios finais de pesquisa, softwares, estudos de caso, relatório técnico com regras de sigilo, manual de operação técnica, protocolo experimental ou de aplicação em serviços, proposta de intervenção em procedimentos clínicos ou de serviço pertinente, projeto de aplicação ou adequação tecnológica, protótipos para desenvolvimento ou produção de instrumentos, equipamentos e kits, projetos de inovação tecnológica, produção artística, sem prejuízo de outros formatos, de acordo com a natureza da área e a finalidade do curso, desde que previamente propostos e aprovados pela CAPES (art. 7ํㅗㅇ $§ 3^{\circ}$, BRASIL, 2009).

Essa diversidade, certamente atende à um "ajuste ao MP" e será uma característica que acentua "sua distância do modelo acadêmico [...] adaptando-o mais

\footnotetext{
${ }^{31}$ Ou melhor, um aprofundamento das ideias já latentes nas Portarias de 1995 e 1998, onde já havia referências às compreensões do MP como um espaço que permitiria a transferência mais rápida de conhecimentos da universidade para a sociedade (viés de "aplicação de pesquisas no mundo profissional", com foco em seu produto) e que permitiria ao mestre profissional a qualificação para a aplicação de conhecimentos e métodos científicos atualizados no confronto com um problema da prática profissional (viés que enfoca o processo de formação do mestre profissional e a sua qualificação).
} 
propriamente às áreas de saber técnico ou aplicado, ainda que tendo validade para todas" (SALEM, 2012, p. 233) ${ }^{32}$.

Apresentam-se também indicadores para o acompanhamento e avaliação trienal $^{33}$ dos cursos que englobam, I. "produção intelectual e técnica pertinente à área" (englobando, tal como para o trabalho final de curso, uma diversidade de formatos, desde artigos a patentes, softwares, aplicativos, materiais didáticos, criações artísticas etc); II. "informações sobre o destino dos egressos do curso, empregabilidade e trajetória profissional"; III. Informações que "constem de relatórios e pareceres das comissões examinadoras de avaliação dos trabalhos de conclusão do mestrado dos estudantes" e IV. a "dimensão e eficácia dos processos de interação com organizações, empresas e instituições da área de especialização e atuação do curso" (BRASIL, 2009).

Em relação à questão do autofinanciamento do MP, a Portaria nº 17/2009 reforça o que já havia sido estabelecido anteriormente: "salvo em áreas excepcionalmente priorizadas, o mestrado profissional não pressupõe, a qualquer título, a concessão de bolsas de estudo pela CAPES" (art. 11, BRASIL, 2009). Subentendem-se como "áreas excepcionalmente priorizadas", "o caso concreto dos PROFS - programas formados por redes institucionais com bolsas da CAPES para professores em exercício na rede pública" (SILVA, 2016, p. 21). Na próxima seção, aprofundamos a discussão sobre a criação e consolidação de tais MPs em Rede, referidos pela autora citada como "PROFS".

Por fim, podemos apontar que a Portaria no 17/2009 ajudou na legitimação dos MPs no Sistema Nacional de Pós-Graduação ilustrada pelo aumento de propostas de cursos novos de MP submetidos à Capes. Conforme análise de Silva (2016),

No ano de 2009, ano em que o MP foi regulamentado pela Portaria $\mathrm{n}^{\circ}$ $17 / 2009$, houve um crescimento de $11,5 \%$ na implantação de cursos de MP, com 338 cursos novos implantados neste ano de 2011, um aumento de $37 \%$ em relação ao ano anterior. Este aumento pode ser visto como um reflexo da regulamentação pela Portaria no 17/2009, pois no ano imediatamente seguinte aumentaram o número de propostas de cursos novos submetidas, o que refletiu no aumento de cursos implementados em 2011 (p. 46).

\footnotetext{
${ }^{32}$ Nesse quesito, Salem (2012) levanta uma questão interessante. Tendo em vista a relação íntima entre forma e conteúdo, questiona "o quanto essa abertura interfere na própria natureza da formação, indo além da forma e tendo imbricações maiores nos conteúdos" (p. 233).

${ }^{33}$ Em 2014, o Conselho Superior da CAPES decidiu que a avaliação do Sistema Nacional de Pós-graduação passa a ser quadrienal. A primeira edição da avaliação quadrienal ocorre em 2017, versando sobre dados e informações dos anos 2013, 2014, 2015 e 2016. Fonte: < www.capes.gov.br/>. Acesso em: 24 abr. 2017.
} 
De modo geral, em termos quantitativos, e considerando o período desde a criação dos primeiros cursos de MP, de 1999 a 2011, os programas com oferta de cursos de MPs tiveram um salto de cerca de $1000 \%$, indo de 28 para 329 programas de todas as áreas nesse período. Destaca-se a participação das instituições privadas na oferta desses cursos. Em 1999, elas já abrigavam um pouco mais de um quinto dos MPs existentes. Em 2011, essas instituições ofereciam $37,1 \%$ dos cursos de MP, frente a, em termos de comparação, 13,1 \% dos mestrados acadêmicos e, ainda, 16,9 $\%$ dos cursos de doutorado em funcionamento em todo o país. Em termos de titulações, a diferença entre as instituições privadas e públicas é praticamente inexistente, já que àquelas corresponde $47,5 \%$ dos titulados mestres profissionais frente aos $52,5 \%$ de titulados em instituições públicas. Além, disso, o maior crescimento de MPs no período se dá nas grandes áreas Multidisciplinar, seguido das Ciências Sociais Aplicadas e Ciências da Saúde (CIRANI; CAMPANARIO; SILVA, 2015). Os dados mais atualizados disponíveis no sistema GEOCAPES (Sistema de Informações Georreferenciais) ${ }^{34}$ apontam para 739 cursos de MP em 2017. Em seis anos, no período de 2011 a 2017, o número de cursos de MPs oferecidos por instituições públicas e privadas em todas as áreas mais que duplica.

No ano de 2017, entretanto, a Portaria no 17/2009 foi revogada pela Capes por meio da Portaria no 389, de 23 de março de 2017 (BRASIL, 2017a), criando a modalidade de doutorado profissional que visa atender aos mesmos objetivos já estabelecidos para o MP na Portaria no 17/2009. Esta portaria não regulamenta ou disciplina a oferta, a avaliação e o acompanhamento dos programas de mestrado e doutorado profissional, determinando à Capes o prazo de 180 dias para emitir portaria específica para isso. Tal portaria é emitida em 28 de junho de 2017 sob o $n$. 131 (BRASIL, 2017b), onde há a indicação de que a regulamentação de submissão de novos cursos de pós-graduação na modalidade profissional e critérios de avaliação periódica com atribuição de notas seriam apontadas em Documentos de Área ${ }^{35}$. Essa determinação foi ao encontro de discussões realizadas no período no âmbito do FOPROF (Fórum Nacional dos Mestrados Profissionais) como se pode verificar em temas levantados nos últimos Encontro Nacional dos Mestrados Profissionais $(E N M P)^{36}$. Com as portarias citadas, iniciou-se um novo capítulo da trajetória de

\footnotetext{
${ }^{34}$ Disponível em: <http://geocapes.capes.gov.br/>. Acesso em: 02 abr. 2019.

${ }^{35}$ Foi consultada a página da área 46 (Ensino) no site da CAPES, onde não foi possível localizar o Documento de Área publicado em data posterior à referida portaria n. 131/2017, para estudo de tais determinações para avaliação de propostas de cursos da modalidade profissional.

${ }^{36}$ O IX ENMP, realizado na Bahia em 2015, teve em sua programação uma roda de discussão com o tema "Vivências Internacionais, Experiências e Expectativas sobre Doutorado na Pósgraduação Profissional", que contou com a participação de "representantes da academia e
} 
estabelecimento de cursos da modalidade profissional em nosso Sistema Nacional de Pós-graduação.

Finalmente, em atendimento à demanda da comunidade acadêmica por mais detalhes para a apresentação de propostas de criação de novos cursos profissionais, em novembro de 2018, a Capes cria um grupo de trabalho para atualizar a portaria $\mathrm{n}$. 131 de $2017^{37}$. Como resultado, há a publicação da Portaria n. 60 de 20 de março de 2019 (BRASIL, 2019), a mais recente sobre o tema. Nela, os objetivos dos cursos de mestrado e doutorado profissionais são atualizadas, conforme disposto abaixo:

I - capacitar profissionais qualificados para práticas avançadas, inovadoras e transformadoras dos processos de trabalho, visando atender às demandas sociais, econômicas e organizacionais dos diversos setores da economia;

II - transferir conhecimento para a sociedade de forma a atender às demandas sociais e econômicas, com vistas ao desenvolvimento nacional, regional e local;

III - contribuir para agregação de conhecimentos de forma a impulsionar o aumento da produtividade em empresas, organizações públicas e privadas;

IV - atentar aos processos e procedimentos de inovação, seja em atividades industriais geradoras de produtos, quanto na organização de serviços públicos ou privados;

$\mathrm{V}$ - formar doutor com perfil caracterizado pela autonomia, pela capacidade de geração e transferência de tecnologias e conhecimentos inovadores para soluções inéditas de problemas de alta complexidade em seu campo de atuação (Art. 2ํㅡ, BRASIL, 2019).

Ainda, há indicações gerais sobre itens que devem ser abordados em propostas de criação de novos cursos profissionais; a formação do corpo docente (onde se estabelece a possibilidade da admissão de até $30 \%$ de docentes com experiência profissional reconhecida na área de atuação, porém sem título de mestre ou doutor) e, por fim, orientações gerais sobre os trabalhos de conclusão de curso. Cabe ressaltar que não há uma especificação explícita entre o que se espera de cada nível de curso profissional (entre mestrado e doutorado profissional), e a desobrigação clara da Capes em relação ao financiamento dos cursos, sem distinguir cursos de áreas

outras instituições ofertantes de programas inovadores de doutorados ligados aos mundos do trabalho no país e no exterior". Já o X ENMP, realizado em Brasília em 2016, teve uma mesa redonda com o tema "Construção do Doutorado Profissional". Fonte: <http://www.foprof.org.br/index.html/>. Acesso em: 24 abr. 2017.

37 Redação CCS/CAPES. Grupo de trabalho analisará mestrado e doutorado profissionais. Notícias Fundação CAPES, Brasília, publicado em 19 nov 2018. Disponível em: $<$ http://www.capes.gov.br/sala-de-imprensa/noticias/9181-grupo-de-trabalho-analisaramestrado-e-doutorado-profissionais />. Acesso em: 28 mar 2019. 
consideradas prioritárias, como se lê em seu art. 8: "As propostas de cursos novos apresentadas serão avaliadas exclusivamente quanto ao seu mérito, não implicando, necessariamente, caso sejam aprovadas, em apoio financeiro pela CAPES" (Art. 8o, BRASIL, 2019).

\subsection{O Mestrado Profissional para Professores da Educação Básica}

Os primeiros embates contra o MP quando da publicação das Portarias n47/1995 e no 80/1998 tiveram como autores, principalmente, membros da comunidade acadêmica da área de Educação. Entretanto, como aponta Salem (2012), o grande "boom" dos MPs se deu justamente na área de "Ensino de..." a partir dos anos 2000.

Para compreender esse cenário, é preciso considerar que havia uma cisão entre pesquisadores da área de Educação e pesquisadores da área de Ensino de Ciências e Matemática, sendo que estes últimos

se queixavam de que os critérios de avaliação de suas pesquisas [consideradas no contexto da área de Educação] não considerariam de forma adequada as características da linha de pesquisa e, em particular, o papel do conhecimento científico (VILLANI, 2016, p. 430).

Dessa forma, esses pesquisadores não formavam uma área homogênea, de modo a nem sempre compartilhar das mesmas posições. Em relação à proposta de criação de MPs, enquanto os pesquisadores da área de Educação a rechaçavam pois acreditavam que ela seria "uma forma de baratear o rigor das pesquisas de pósgraduação e, sobretudo, um instrumento de domesticação dos professores para atender às exigências do mercado e dos organismos internacionais que o sustentam" (VILLANI, 2016, p. 421), alguns pesquisadores da área de Ensino de Ciências e Matemática "vislumbraram o MP como uma iniciativa que reduziria a distância entre a Universidade e a Escola" (Ibidem, p. 421). Destaca-se também, como refutação à implantação dos MPs, a de que "sua concepção estaria vinculada a hipótese de que o professor é o único responsável pelo desempenho de seus alunos" (SCHÄFER, OSTERMANN, 2013, p. 288). O fato de o MP ser uma modalidade de formação individual reforça essa concepção.

A avaliação dos impactos das pesquisas realizadas pela comunidade acadêmica da área na prática educativa dos professores de educação básica era um tema muito discutido pelos pesquisadores em Ensino de Ciências nesse período. Delizoicov 
(2004) destaca que "nos últimos EPEFs ${ }^{38}$ (nos anos de 2000 e 2002), mesas redondas foram organizadas com a finalidade de se abordar o tema da relação pesquisa em Educação e Ensino de Ciências" (p. 152). Baseando-se na defesa dos MPs de Moreira $(2004)^{39}$, um dos incentivadores da criação dos MPs em Ensino, esse debate sobre a distância entre pesquisa acadêmica e práticas de sala de aula pareceram fundamentais para a adesão de grupos de pesquisadores para a proposta dos MPs justamente na tentativa de encontrar uma nova forma de responder a esse anseio de aproximar professores e escolas da pesquisa acadêmica, em especial ao envolver o professor com a produção de pesquisa que buscasse responder a um problema de sua prática profissional. É uma perspectiva diferente daquela já realizada em cursos de especialização e de formação continuada existentes à época, os quais

quando não convenientemente [...] planejados juntamente com o professor e considerando as condições em que está atuando na escola, [tinham] pouca influência na implantação de novas práticas na perspectiva de almejadas mudanças (DELIZOICOV, 2004, p. 153).

Junto a isso, sob o aspecto político da época,

[...] a aprovação e implementação dos cursos de MP-ECM [Mestrados Profissionais em Ensino de Ciências e Matemática], que eram rejeitados pela área da Educação, foi possível graça a uma operação política, a criação de uma nova área de pós-graduação, em Ensino de Ciência e Matemática (área 46 da $\mathrm{CAPES}^{40}$ ), que conseguiu funcionar congregando alguns MP-ECM [Mestrados Profissionais em Ensino de Ciências e Matemática] e alguns cursos acadêmicos que abandonaram a área de Educação para aderir à nova área (VILLANI, 2016, p. 430).

Assim, os primeiros cursos de MP na área de Ensino de Ciências (ou, particularmente, Ensino de Física) surgiram após o ano 2000 em diferentes instituições do país (NASCIMENTO, 2013). Foram eles:

\footnotetext{
${ }^{38}$ Encontro de Pesquisadores de Ensino de Física, evento organizado pela SBF a cada 2 anos.

39 Inicialmente, Moreira defendia que o MP "em nenhum instante e de nenhuma forma" separaria "formação profissional a que se dirige e a pesquisa associada ao que ela envolve" (2004, p. 133). Conforme Villani e colaboradores (2017), o pesquisador parece mudar de posição alguns anos depois já que este passa a acreditar que "o foco do mestrado profissional em ensino deve estar na aplicação do conhecimento, não na produção do conhecimento" (MOREIRA; NARDI, 2009, p. 5). Esses autores apostam que "as dificuldades encontradas na elaboração dos produtos educacionais e a grande variedade de interpretações sobre essa produção tenham influenciado (essa) mudança, privilegiando demasiadamente o aspecto técnico em relação ao de pesquisa" (VILLANI et al., 2017, p. 157).

${ }^{40}$ A área 46 foi criada pela CAPES em 2000. Em 2011 ela foi substituída pela Área de Ensino, inserida na Grande Área Multidisciplinar.
} 
- Mestrado Profissional em Ensino de Ciências e Matemática, na UFRN, e Mestrado Profissional em Ensino de Física da UFRGS, ambos criados em 2002;

- Mestrado Profissional em Ensino de Ciências e Matemática, no CEFET/RJ ${ }^{41}$, e Mestrado Profissional em Ensino de Ciências, na UnB, criados em 2003;

- Mestrado Profissional em Ensino de Ciências e Matemática, na Unicsul, e Mestrado Profissional em Ensino de Física e Matemática, na UNIFRA, ambos criados em 2004 em instituições privadas.

Ao longo desses anos, os cursos de mestrado profissional na área de Ensino de Ciências se expandiram em número e abrangência nacional. Os últimos dados disponibilizados na Plataforma Sucupira ${ }^{42}$, referentes aos dados do quadriênio 2017 (2013-2017), mostram que do total de cursos de MP da Grande Área Multidisciplinar ${ }^{43}$ (237 cursos) representam cerca de $28,1 \%$ do número total de cursos de MP, 843 contabilizando todas as Grandes Áreas; por sua vez os 93 cursos da Área de Ensino representam pouco mais de um terço $(39,2 \%)$ do número total de cursos de MP da Grande Área Multidisciplinar.

Cabe ressaltar que, embora na Área de Ensino sejam incluídos MPs de Ensino de outras disciplinas (Letras, História e outras), os de Ciências (Física, Química ou Biologia) e Matemática são mais numerosos, dada a consolidação de tais MPs em processo desde os anos 2000 no contexto da Área 46 de Ensino de Ciências e Matemática. Especificamente, a região Sudeste, em 2013, abrigava 34 cursos de MP da Área de Ensino, sendo estes distribuídos da seguinte maneira em cada estado: RJ - 12 cursos; SP - 10 cursos; MG - 8 cursos e ES - 4 cursos.

Além das propostas de cursos de MPs autônomos de instituições específicas (os quais podemos denominar como Mestrados Profissionais Locais), a Capes começou a fomentar a partir de 2011 os Mestrados Profissionais em Rede Nacional na Área de Ensino. A principal característica desses Mestrados Profissionais Nacionais é a sua oferta em uma rede de instituições participantes de diferentes regiões do Brasil, que aderem a uma matriz curricular única, comum a todas essas instituições. Além disso, a coordenação do programa como um todo é centralizada em uma instituição coordenadora.

\footnotetext{
${ }^{41}$ O Programa deixou de oferecer novas vagas desde 2016.

${ }^{42}$ Disponível em:

$<$ https://sucupira.capes.gov.br/sucupira/public/consultas/coleta/programa/quantitativos/quantitat ivoAreaAvaliacao.jsf\#/>. Acesso em: 21 abr. 2019.

Que abrange as seguintes áreas: Biotecnologia, Ciências Ambientais, Ensino, Interdisciplinar, Materiais.
} 
O primeiro desses programas a ser aprovado pela Capes foi o Mestrado Profissional em Matemática em Rede Nacional (PROFMAT), coordenado pela Sociedade Brasileira de Matemática (SBM), com apoio do Instituto Nacional de Matemática Pura e Aplicada (IMPA). Iniciou suas atividades em 2011 e caracterizou-se por ser um programa de mestrado semipresencial com oferta nacional, formado por uma rede de Instituições de Ensino Superior no contexto da Universidade Aberta do Brasil (UAB) ${ }^{44}$. Nessa primeira iniciativa de Mestrado Profissional em Rede, notam-se características que mais tarde irão se repetir na proposição de outros programas em rede: primeiramente, chama-se a atenção a ausência de pesquisadores em Educação Matemática como colaboradores da proposta apresentada à Capes ${ }^{45}$; o protagonismo de doutores da área de Matemática Pura, que também compõem grande parte do corpo docente ${ }^{46}$; a matriz curricular do programa que enfatiza os conteúdos disciplinares, fazendo pouca referência à conteúdos pedagógicos ou à prática profissional docente; a disponibilização de recursos e bolsas para os professores cursistas. Em suma, "[...] essa iniciativa chamou atenção, sobretudo por sinalizar que era possível evitar o processo comum de aprovação do MP e encontrar atalhos privilegiados, inclusive quanto ao financiamento" (VILLANI, 2016, p. 425).

A Capes disponibiliza em seu portal uma página específica dos Mestrados Profissionais para Professores da Educação Básica - $\mathrm{PROEB}^{47}$. Na página, especificase que os PROEB tem "por objetivo a formação continuada stricto sensu dos professores em exercício na rede pública de educação básica, em conformidade com a política do Ministério da Educação - MEC, mediante apoio às instituições de ensino superior (IES) ou redes de instituições associadas do País, responsáveis pela implantação e execução de cursos com áreas de concentração e temáticas vinculadas diretamente à melhoria da Educação Básica". O apoio da Capes a esses programas dá-se através da concessão de bolsas e fomento aos cursos de MP. Na página também encontramos os objetivos do PROEB que tem

44 Dados retirados do site oficial do PROFMAT. Disponível em: <http://www.profmatsbm.org.br/>. Acesso em: 28 abr. 2017.

${ }^{45}$ A essa comunidade, coube apenas uma consulta avaliativa da proposta quando do seu encaminhamento para apreciação no Conselho Técnico-Científico (CTC), feita por meio da representação da Sociedade Brasileira de Educação Matemática (SBEM). Críticas à proposta disponível em: <http://www.sbembrasil.org.br/sbembrasil/index.php/noticias/358-sbem-frente-aproposta-de-mestrado-profissional-da-sbm/>. Acesso em: 01 mai. 2017.

${ }^{46} \mathrm{O}$ que já era uma realidade no contexto dos MPs Institucionais. Inclusive, segundo Villani (2016), a abertura para o credenciamento de pesquisadores em ciências como docentes e orientadores dos MPs em Ensino - rompendo, portanto "com a tradição dos cursos de Mestrado e Doutorado Acadêmicos, nos quais o orientador somente podia ser credenciado se tivesse o título de doutor na área de pesquisa ou fosse reconhecido como especialista de renome dela" (p. 430) - foi fundamental para garantir a continuidade dos cursos de MP.

47 Disponível em: <https://www.capes.gov.br/educacao-a-distancia/proeb/>. Acessado em: 21 abr. 2019. 
[...] como finalidade a melhoria da qualidade do ensino nas escolas de Educação Básica Pública Brasileira, à medida que:

- Promove a formação continuada de professores das redes públicas de educação, no nível de pós-graduação stricto sensu, nas áreas da Educação Básica Brasileira;

- Institui uma rede nacional para oferta de programas de mestrados profissionais promovidos por instituições de ensino superior públicas brasileiras de notória tradição na área de formação de professores e que sejam partícipes do Sistema Universidade Aberta do Brasil;

- Valoriza as experiências advindas da prática do professor ao mesmo tempo que colabora, através dos trabalhos realizados, para o desenvolvimento de materiais e estratégias didáticas que ensejam a melhoria do desempenho de aprendizagem dos alunos;

- Cria uma rede de reflexão sobre a realidade do Ensino Básico Público Brasileiro apontando perspectivas de mudanças e respostas aos problemas do cotidiano da escola e da sociedade.

A implementação do PROFMAT foi seguida pela proposição de outros programas em rede direcionados a professores de outras disciplinas escolares. São eles $^{48}$ :

- O Programa de Pós-graduação em Rede Nacional para Ensino das Ciências Ambientais (PROFCIAMB), aprovado em 2015, deu início às atividades em janeiro de 2016. Articulado por meio de uma parceria da Agência Nacional de Águas com a Capes com o objetivo de ofertar a formação em nível de MP aos professores de educação básica e profissionais que atuem em espaços não formais e/ou não escolares $^{49}$;

- O Mestrado Profissional em Letras (ProfLetras), coordenado pela Universidade Federal do Rio Grande do Norte (UFRN), que também conta com a participação de instituições de ensino superior públicas no âmbito da UAB. É direcionado para professores de Língua Portuguesa do Ensino Fundamental e iniciou suas atividades em 2013;

- O Mestrado Nacional Profissional em Ensino de Física (ProFis - MNPEF), coordenado pela Sociedade Brasileira de Física (SBF), iniciou suas atividades também em 2013;

- O Mestrado Profissional em Artes (ProfArtes), coordenado pela Universidade do Estado de Santa Catarina (UDESC), tem como público alvo, professores de Artes da Educação Básica pública. Tem estrutura semipresencial contando com a 
associação de 11 universidades públicas de diferentes regiões do Brasil. O primeiro edital de processo seletivo foi publicado em 2014, e as seleções foram temporariamente suspensas, devido a não liberação de novas bolsas da Capes e do orçamento do período de 2016/2017 $7^{50}$, sendo retomadas em 2018 com a divulgação de novo edital;

- O Mestrado Profissional em Ensino de História (ProfHistória), curso presencial ofertado a professores de História que atuam na Educação Básica, é coordenado pela UFRJ. Iniciou suas atividades em 2014;

- O Mestrado Profissional em Ensino de Biologia em Rede Nacional (PROFBIO), coordenado pelo Instituto de Ciências Biológicas da Universidade Federal de Minas Gerais (UFMG), é também ofertado em formato semipresencial no contexto da UAB e com a participação de 18 instituições associadas. É orientado para professores de Biologia das redes públicas de ensino e teve seu primeiro edital de processo seletivo publicado no primeiro semestre de $2017^{51}$;

- O Mestrado Profissional em Filosofia (PROF-FILO), destinado a professores de Filosofia do Ensino Médio ou Fundamental, é ofertado de forma predominantemente presencial em 17 IES associadas. Sua coordenação é sediada na Universidade Federal do Paraná (UFPR). O primeiro edital para processo seletivo foi lançado em 2016, com início das aulas da primeira turma selecionada no primeiro semestre de $2017^{52}$;

- O Mestrado Profissional em Química em Rede Nacional (PROFQUI), programa de pós-graduação semipresencial, coordenado pelo Instituto de Química da UFRJ, em parceria com a Sociedade Brasileira de Química (SBQ). Conta com a adesão inicial de 18 instituições de ensino superior com oferta do curso no contexto da UAB. No primeiro semestre de 2017 foi publicado o primeiro edital para processo seletivo discente, para início do curso previsto para o segundo semestre desse ano ${ }^{53}$;

- O Mestrado Profissional em Ciências Sociais para o Ensino Médio (ProfSocio), coordenado nacionalmente pela Universidade Federal do Ceará, é ofertado em formato semipresencial para professores de Sociologia do ensino médio. O primeiro

\footnotetext{
50 Informação contida no site oficial do ProfArtes. Disponível em: <http://www.ceart.udesc.br/profartes />. Acesso em: 28 abr. 2017.

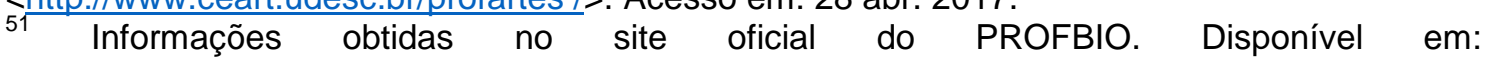
<https://www.profbio.ufmg.br/>. Acesso em: 29 abr. 2017.

52 Informações obtidas no site oficial do PROF - FILO. Disponível em: $<$ http://www.humanas.ufpr.br/portal/prof-filo/>. Acesso em> 29 abr. 2017.

${ }^{53}$ Informações obtidas no site oficial do PROFQUI. Disponível em: <https://profqui.iq.ufrj.br/>. Acesso em: 29 abr. 2017.
} 
processo seletivo foi lançado no final de 2017, para formação de turma para o primeiro semestre de $2018^{54}$.

- O Mestrado Profissional em Educação Física Escolar (PROEF), sob coordenação nacional da Universidade Estadual Paulista (UNESP), teve seu primeiro processo seletivo no final de 2016, mas ainda as aulas da primeira turma selecionada não se iniciaram ${ }^{55}$.

Todos os citados programas de Mestrado Profissional em Rede são geridos pela Diretoria de Educação a Distância (DED) da Capes e estão inseridos no compromisso assumido para a indução e fomento à formação inicial e continuada de profissionais do magistério, competências assumidas pela nova organização da agência dada pela Lei $n^{\circ}$ 11.502, de julho de 2007. No contexto dessa lei, foram criadas duas diretorias específicas, a Diretoria de Formação de Professores da Educação (DEB ${ }^{56}$ ) e a Diretoria de Educação a Distância (DED) já citada acima. Mais tarde, a Política Nacional de Formação de Profissionais do Magistério da Educação Básica, Decreto $n^{\circ}$ 6.755, de janeiro de 2009, vem reforçar esse compromisso. Entre seus objetivos, destaca em seu artigo $3^{\circ}$, inciso $\mathrm{V}$ : "promover a valorização do docente mediante ações de formação inicial e continuada que estimulem o ingresso, a permanência e a progressão na carreira" (BRASIL, 2009). O Decreto no 8.752, de 9 de maio de 2016, que revoga o Decreto anterior, atualiza a Política Nacional de Formação de Profissionais da Educação Básica, reforça o compromisso anterior e faz referência explícita aos cursos de mestrado (acadêmico e profissional) como iniciativa a ser prevista no Planejamento Estratégico Nacional.

As bases legais para o cumprimento da nova competência assumida pela Capes em 2007 se iniciou no ano anterior, com a Lei no 11.273, de fevereiro de 2006, que autorizou a concessão de bolsas de estudo e pesquisa a participantes de programas de formação inicial e continuada de professores para a educação básica. No contexto específico dos professores matriculados em cursos de MPs, a concessão de bolsas foi regulamentada primeiramente pela Portaria no 286, de março de 2011 (que teve redação alterada pela Portaria $n^{\circ} 478$, de abril de 2011). O conteúdo da Portaria $n^{\circ}$ 286/2011 envolve: o estabelecimento da vigência de bolsa com início em março de cada ano a um máximo de 24 meses; o acúmulo de bolsa com salário da escola de

\footnotetext{
54 Informações obtidas no site oficial do ProfSocio. Disponível em: <http://www.profsocio.ufc.br/>. Acesso em: 21 abr. 2019.

${ }^{55}$ Informações disponíveis em: <https://www.vunesp.com.br/ibci1601/>. Acesso em: 29 abr. 2017.

${ }^{56}$ A sigla DEB faz referência ao primeiro nome dessa diretoria (Diretoria de Educação Básica Presencial). A nova nomenclatura foi dada pelo Decreto ํㅜ․692/2012.
} 
rede pública à qual o professor estivesse vinculado; o compromisso de que os contemplados com a bolsa continuassem atuando pelo período de no mínimo cinco anos como professores da Rede Pública após a aquisição da titulação. Inicialmente, a redação da Portaria no 286/2011 privilegiava os matriculados em MPs "devidamente aprovados pela Capes na modalidade de educação a distância via Universidade Aberta do Brasil (UAB)" (art. 1², BRASIL, 2011a, grifos nossos). Dessa forma, MPs presenciais, em especial os já existentes implementados localmente em instituições específicas (os referidos Mestrados Profissionais Locais, em contraponto aos Mestrados Profissionais em Rede, de abrangência nacional) não seriam contemplados por essa portaria. Os Mestrados Profissionais em Rede presenciais (como o MNPEF), que seriam criados posteriormente, também não seriam contemplados. A Portaria $n^{\circ}$ 478/2011 dá nova redação aos artigos da Portaria n 286/2011, de modo a abranger também a categoria de MPs em Rede presenciais e os MPs Locais.

Ainda com relação às bolsas concedidas para professores matriculados em cursos de MP e, tendo em vista o cenário de restrição orçamentária do período, em 2017 é publicada a Portaria no 61, de 22 de março de 2017, onde são definidos critérios de concessão de bolsas e pagamento de custeio a docentes regularmente matriculados e em efetiva regência nas redes públicas de ensino nacionais vinculados aos Programas de Mestrado Profissional em Rede custeados pela Capes (PROEB ${ }^{57}$ ). A portaria refere-se a cotas de bolsas por IES (concedidas de acordo com disponibilidade orçamentária) e estabelece o cumprimento das seguintes exigências pelos candidatos às bolsas: a comprovação de efetiva docência na rede pública de ensino básico; a comprovação de aprovação em estágio probatório (restringindo assim a concessão de bolsas somente a professores que compõem o quadro permanente de servidores da rede pública de ensino); após o término do curso, a disponibilização de currículo com a finalidade de atuação na função de tutor no âmbito do Sistema UAB. A portaria, por fim, ressalta a consideração, por parte das IES, a fins de seleção e classificação dos candidatos para a concessão de bolsas, critérios de caráter socioeconômico e eventuais situações de vulnerabilidade social.

É importante observar, com base nas portarias que regem a concessão de bolsas para professores-cursistas de MPs, que existem indicações de alguns autores de que o PROEB, que deveria reger essa concessão de bolsas, foi implantado

\footnotetext{
${ }^{57}$ Programa de Mestrado Profissional para Qualificação de Professores da Rede Pública da Educação Básica. Segundo regulamento publicado por meio da Portaria no 209, de 21 de outubro de 2011, o PROEB "tem por objetivo exclusivo fomentar a manutenção e desenvolvimento dos programas de pós-graduação em Mestrado Profissional, para qualificação de docentes do ensino básico das redes públicas, recomendados pelo Conselho TécnicoCientífico de Educação Superior da CAPES" (art. 2 ${ }^{\circ}$, BRASIL, 2011b).
} 
tardiamente (de fato, implantado a partir de 2017, com a Portaria ํㅜ 61, de 22 de março de 2017), o que evidenciou

\begin{abstract}
de certa forma, mudança de estratégia pela Capes no financiamento dos mestrados profissionais com foco na educação básica. Tal situação tem prejudicado o funcionamento dos programas que não têm sido contemplados com financiamento por parte daquela coordenação (NERES; NOGUEIRA; BRITO, 2014, p. 251).
\end{abstract}

Apesar disso, é possível verificar, na prática, que os MPs em Rede (ou, melhor dizendo, alguns desses MPs em Rede) foram privilegiados com respeito ao financiamento e concessão de bolsas a seus professores-cursistas.

As considerações traçadas até o momento, dão um panorama geral da criação dos MPs em Rede. Dentro do escopo dessa tese, chamamos a atenção para o Mestrado Nacional em Ensino de Física (ProFis - MNPEF).

O MNPEF foi proposto por membros da SBF e teve como inspiração principal o PROFMAT. Ao contrário da comunidade de pesquisadores da área de Matemática, que dispõem de duas sociedades, a Sociedade Brasileira de Matemática, para pesquisadores de Matemática Pura e Sociedade Brasileira de Educação Matemática, para pesquisadores da Educação Matemática, a SBF abriga ao mesmo tempo pesquisadores em Física e em Ensino de Física. Por conta disso, a articulação da proposta do MNPEF "foi bem mais complexa e sofisticada do que a do PROFMAT" (VILLANI, 2016, p. 426), contando com a participação dos pesquisadores em Ensino de Física no processo de submissão à Capes. O projeto do MNPEF (nomeado ProFis no âmbito da Capes, por conta da identidade na nomenclatura dos MPs em Rede orientados para professores da Educação Básica),

foi elaborado principalmente pelo fundador do MPEF [Mestrado Profissional em Ensino de Física] da UFRGS repetindo a estrutura curricular desse último, porém com um enfoque um pouco maior nas disciplinas de conteúdo" (VILLANI, 2016, p. 426).

A proposta do MNPEF foi rechaçada por grande parte dos pesquisadores em Ensino de Física, como é registrado em uma carta aberta redigida por ocasião do XIV Encontro Nacional de Pesquisa em Ensino de Física (EPEF) ${ }^{58}$. Nessa manifestação, é denunciada a proposição como autoritária, por não ter incorporado contribuições de pesquisadores em Ensino de Física associados e não ter passado por processos amplos de discussão entre os membros da sociedade. A proposta foi considerada

\footnotetext{
${ }^{58}$ Disponível em: <https://sec.sbfisica.org.br/eventos/epef/xiv/manifestacao.pdf />. Acesso em: 01 mai. 2017.
} 
inadequada por ser limitada a respeito do diagnóstico dos problemas educacionais e desconsiderar conhecimentos construídos e acumulados nas áreas de pesquisa em Ensino de Física e Formação de Professores. Criticou-se também a proposição de modelo único incapaz de atender à diversidade de contextos e problemas educacionais do país. Por fim, temia-se que o MNPEF chegasse a colocar em risco o desenvolvimento de MPs da área de Ensino de Ciências e Matemática já existentes (ou seja, os MPs Locais da área). Outras críticas e protestos podem ser observados no mural do sócio da SBF ${ }^{59}$.

Porém, resistindo às críticas,

[...] a Diretoria da entidade conseguiu garantir a participação na Comissão de Pós-graduação do MNPEF de vários pesquisadores em ensino de Física e a adesão de alguns cursos que precedentemente eram MP em Ensino de Física autônomos. Ao se tornarem polos do MNPEF estes cursos ganharam uma bolsa para cada professor atuante no ensino público e conseguiram manter quase totalmente sua estrutura (VILLANI, 2016, p. 426).

Assim, desde 2013, o MNPEF vem se consolidando, contando atualmente com a participação de 60 polos instalados em 54 IES públicas federais e estaduais (algumas dessas instituições possuem polos localizados em campi diferentes) localizadas em todas as regiões do país ${ }^{60}$. A Figura 2 indica a localização da totalidade dos polos instaurados até o final de 2016. 937 />. Acesso em: 01 mai. 2017.

${ }^{60}$ Informações obtidas online, disponíveis em: <http://www1.fisica.org.br/mnpef/?q=polos/todos 1>. Acessado em 28 fev 2017. 
Figura 2 - Distribuição geográfica dos Polos do MNPEF aprovados nos editais de credenciamento de 2013 a 2016 em IES brasileiras

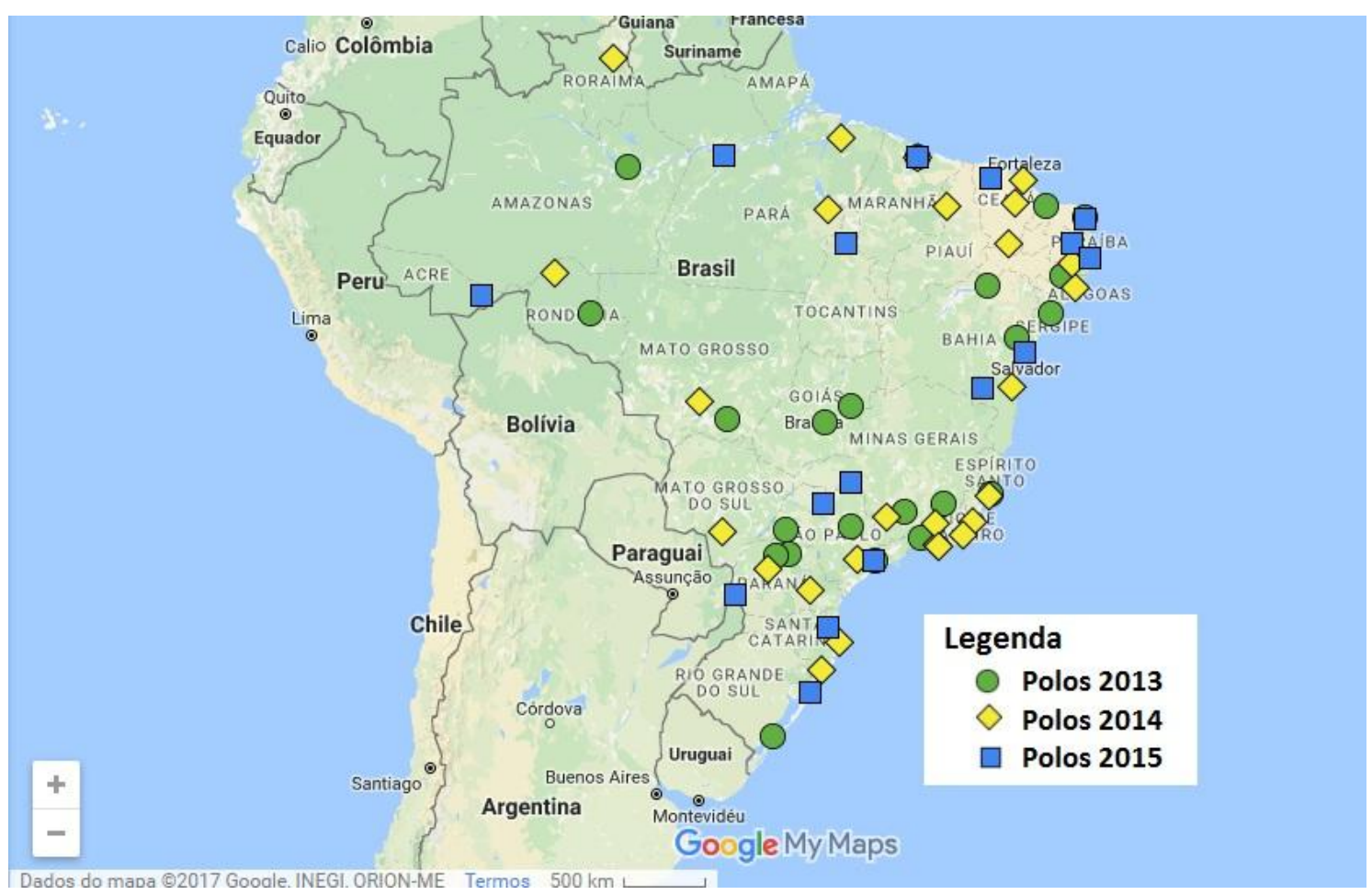

Fonte: Autoria desconhecida. Mapa com dados disponível em: <http://migre.me/w9m5l/>. Acessado em: 28 fev 2017.

A consulta à Plataforma Sucupira ${ }^{61}$ revela o registro de 1617 professores na situação de "matriculados" nos 60 polos do MNPEF no início do ano de 2019. As primeiras titulações foram realizadas no ano de 2015. A Plataforma Sucupira permite a consulta de dados para os anos de 2017, 2018 e 2019. Nestes três anos, até abril de 2019, foram titulados um total de 482 professores. Neste mesmo período foram registradas 226 evasões (desligamento ou abandono do curso).

Indo além desses números, a abrangência nacional do Programa expressa pelo grande número de polos envolvidos, já nos dá uma indicação do potencial impacto que esses MPs têm sobre a formação continuada de professores de Física no Brasil. Tendo em vista a meta, comum a todos os programas de MP em Ensino (tanto os Locais quanto os em Rede), de proporcionar qualificação profissional para esses professores, a próxima seção apresenta um levantamento de tal impacto formativo apresentado em publicações acadêmicas.

${ }^{61}$ Disponível em: <https://sucupira.capes.gov.br />. Acesso em 21 abr. 2019. 


\subsection{Revisão de literatura: mestrados profissionais e o desenvolvimento profissional de professores}

A despeito do apoio de parte da comunidade acadêmica em Ensino de Ciências que investiu na estruturação e criação de inúmeros MPs Locais, a iniciativa foi alvo de críticas em relação ao currículo desses cursos. Essas críticas apontaram

a distância entre a proposta do MP e as exigências de uma formação de professores: era questionada a capacidade do professor selecionar conteúdos, organizar situações de aprendizagem promovendo efetivamente a alfabetização científica dos alunos (VILLANI, 2016, p. 422).

Tais questionamentos - que se repetiram no contexto mais recente da proposição e implantação dos MPs em Rede - nos levaram a consultar a literatura acadêmica em busca do que se tem investigado em relação ao desenvolvimento profissional proporcionado pelos MPs aos professores que vêm se titulando como mestres profissionais. Quais são as contribuições dos MPs em Ensino de Ciências e Matemática ${ }^{62}$ para o desenvolvimento profissional docente?

Visando proporcionar um panorama dos resultados e discussões empreendidas em artigos que se dedicam, direta ou indiretamente, a essa questão, realizamos uma busca nos principais periódicos da área de educação e ensino de ciências. Esses trabalhos são referenciados ao longo do texto juntamente com a meta-análise realizada por Villani e colaboradores (2017). Esse último artigo discute a produção científica que se dedicou à temática dos MPs em Ensino publicada em periódicos de Educação e Ensino de Ciências, avaliadas de A1 a B4 no Qualis da Capes e publicadas entre 2000 e 2015. Os outros trabalhos aos quais fazemos referência não fizeram parte do corpus da meta-análise empreendida por estes pesquisadores.

Inicialmente, é importante destacar uma observação realizada por Villani et al. (2017). A quantidade de trabalhos, que se dedicam à discussão sobre os MPs, levantados pelos pesquisadores nos periódicos consultados, foi limitada. Eles atribuem esse fato tanto à "inovação representada por esse programa" quanto às "dificuldades em avaliar o seu impacto na formação docente" (p. 131).

${ }^{62}$ Devido à proximidade entre as duas comunidades de pesquisadores (os de Ensino de Ciências e os de Ensino de Matemática), resgatamos aqui também alguns trabalhos que se dedicaram à análise do desenvolvimento profissional de professores-cursistas de MPs em Educação Matemática. 
Embora seu objetivo tivesse sido consultar as publicações que expusessem concepções acerca do MP em geral (e não especificamente sobre os MPs em Ensino de Ciências e Matemática), Salem (2012) também encontra poucas publicações que discutem a proposta de mestrado profissional. Essa autora observa que quase todos os trabalhos são de autores que apóiam e defendem em seus trabalhos o projeto de implantação dos MPs, mesmo que apresentando críticas pontuais ao seu desenvolvimento. A interpretação dada foi a de que a escassez de publicações sobre MPs seria "decorrente da incipiência mesmo dessas reflexões nos meios acadêmicos ou das dificuldades de espaços de reflexão e de divulgação" (p. 235).

Iniciamos a apresentação sintética dos resultados dos trabalhos consultados com Cevallos (2011) e Pires e Igliori (2013), autoras que analisaram o desenvolvimento profissional proporcionado pelo MP em Educação Matemática, da PUC/SP, primeiro curso de mestrado profissional dessa área implantado em 2002. O MP analisado por essas autoras, apresenta como eixos estruturantes a "adoção da concepção de desenvolvimento profissional, articulação entre conhecimentos teóricos e práticos, inserção dos professores na pesquisa acadêmica preservando seus vínculos com as práticas docentes" (PIRES; IGLIORI, 2013, p. 1049). Os professorescursistas desse MP, segundo essas pesquisadoras, relataram que a escolha em ingressar nesse curso especificamente, foi motivada pela articulação entre as áreas da Educação e Matemática promovidas no curso. Tinham interesse em atualização, ampliação dos conhecimentos e na reflexão sobre a própria prática com a expectativa de torná-la melhor. Muitos já atuavam ou tinham interesse em atuar no Ensino Superior. Disseram ter alcançado com o curso a ampliação e atualização de conhecimento específico e pedagógico, além da oportunidade de ressignificar a própria prática, direcionando o olhar para a aprendizagem dos alunos. Essa postura foi apoiada pela utilização de novas metodologias e estratégias de ensino apresentadas e discutidas no decorrer do curso, com destaque para o uso de novas tecnologias nas aulas. Há relatos também de atuação dos professores como formadores de outros professores em suas escolas de origem em momentos de encontros coletivos com outros professores como o $\mathrm{ATPC}^{63}$, destacando um efeito multiplicador do MP em questão. Em suma, é possível perceber que os professores entrevistados destacam impactos em diversas dimensões de desenvolvimento profissional que colaboraram para que os professores-cursistas percebessem "a necessidade de mudança de sua relação com o conhecimento, com a necessidade de aprender a aprender, e de

\footnotetext{
${ }^{63}$ Sigla utilizada para Aula de Trabalho Pedagógico Coletivo, momento em que professores de uma mesma escola reúnem-se para discutir questões pedagógicas do trabalho cotidiano escolar, além de proporcionar momentos de formação continuada.
} 
buscar, com certa autonomia, as informações de que precisam para sua atuação profissional" (PIRES; IGLIORI, 2013, p. 1066). Essas últimas autoras destacam também que

foi possível perceber que eles [professores] valorizaram não somente as "aulas", mas, também, demonstraram interesse por outras atividades curriculares [do MP] como: seminários, palestras, levantamentos sobre projetos pedagógicos e curriculares nas escolas (p. 1060).

Por sua vez, Cevallos (2011) destacou que as pesquisas realizadas pelos professores-cursistas, vinculadas, em sua maioria, à Educação Básica, proporcionaram a eles "um olhar mais refinado sobre as questões da prática, apoiado na realidade do trabalho que esses docentes vivenciam" (p. 221). A pesquisa assim realizada, como processo de reflexão da própria prática, permitiu aos professorescursistas sistematizarem "as situações concretas de ensino de maneira mais reflexiva, procurando formas de atuação mais apropriadas e significativas para os alunos" ( $p$. 222). Os resultados destacados nessas duas pesquisas demonstram, portanto, a importância, para o desenvolvimento profissional, das atividades desempenhadas no decorrer do curso que vão além das disciplinas previstas em sua matriz curricular.

Alguns resultados obtidos na pesquisa de Shuck e colaboradores (2016) vão ao encontro dos apontamentos anteriormente destacados. Ao investigar quais concepções, culturas, epistemologias, práticas e saberes pessoais e profissionais favorecem a aprendizagem de professores em formação de um MP em Ciências Exatas de uma instituição comunitária do Sul do Brasil, os pesquisadores destacaram quatro aspectos: a vivência em um ambiente positivo, onde os professores-cursistas encontram espaços para discussões e trocas de experiências; a preocupação em considerar os "aspectos holísticos envolvidos na aprendizagem" (p. 503), de modo a abranger a preocupação com a formação integral, que vá além dos conteúdos específicos de ciências exatas, e os quais possam responder aos seus anseios da prática; o uso de nova tecnologias, como ferramentas que oferecem a oportunidade de melhorar ainda mais o ensino; e, por fim, a percepção da necessidade de maior aprofundamento teórico que possa fundamentar sua prática.

Na meta-análise empreendida por Villani e co-autores (2017) foram analisados 26 artigos considerados trabalhos de pesquisa. Os autores desses trabalhos de pesquisa puderam ser separados em dois grupos, cada qual estudando o MP de perspectivas diferentes: o primeiro grupo são de autores que investigam o próprio programa do qual fazem parte (como docentes, colaboradores ou discentes); o 
segundo grupo é composto por pesquisadores que buscam analisar questões gerais sobre MPs e não sobre um programa específico. Esse último grupo foi responsável pela publicação de 11 trabalhos onde estão presentes discussões "sobre o impacto na formação continuada de professores, a especificidade dessa modalidade e as questões referentes a sua legislação" (p. 133). Ao longo do trabalho de meta-análise, foram definidas duas categorias de trabalhos: "A natureza ampla do Mestrado Profissional em Ensino de Ciências: estrutura, especificidade e efetividade" e "O Mestrado Profissional em Ensino de Ciências e o Desenvolvimento Profissional Docente".

$\mathrm{Na}$ primeira dessas categorias, são apresentados trabalhos que discutem a estrutura dos cursos (discussão curricular); a sua especificidade (em especial as diferenças e semelhanças entre MAs e MPs) e a sua efetividade (capacidade do MP em atender às diretrizes de formação de professores e à melhoria da qualidade da educação básica). Dentre as discussões trazidas pelos artigos dessa categoria, destaca-se a discussão empreendida inicialmente por Ostermann e Rezende (2009), e retomada pelas mesmas autoras anos depois (2015). A posição delas é a de que os MPs em Ensino de Ciências

são conduzidos por meio de uma perspectiva tecnicista que não considera a realidade da escola pública brasileira, privilegiando a formação docente em detrimento das questões pedagógicas e dos aspectos relacionados à área de Ciências Humanas (VILLANI et al., 2017, p. 139).

Na meta-análise, questiona-se, entretanto, essa crítica das autoras, em primeiro lugar, pois elas se baseiam exclusivamente nas propostas e objetivos de um curso específico de MP (o de Ensino de Física da UFRGS) que não é o único representativo dos diversos MPs em Ensino de Ciências instalados no país. Essa afirmação, portanto, não poderia ser generalizada para todos os MPs em Ensino de Ciências.

Além da discussão sobre o caráter de racionalidade técnica presente em algumas propostas de MP em Ensino de Ciências, nessa categoria também estão presentes alguns trabalhos que analisam os Produtos Educacionais de egressos dos cursos, no entanto com maior

preocupação de divulgar as produções dos diversos cursos em relação à natureza dos produtos educacionais do que analisar seus potenciais efeitos ou contribuições ao desenvolvimento profissional dos mestrandos (VILLANI et al., 2017, p. 146). 
O produto educacional é destacado como uma das maiores contribuições dos MPs para o Ensino de Ciências, sendo um dos critérios de julgamento de nota dos MPs, a divulgação dos produtos educacionais de egressos nas páginas de internet dos cursos $^{64}$. Segundo Guerra (2016), no documento da área de Ensino da Capes de 2013, "compreende-se que essa divulgação é fundamental para garantir o impacto desses mestrados na educação brasileira" (p. 197). Essa posição é questionável, já que os artigos acadêmicos (muitos originários de produção realizada nos contextos de Mestrados ou Doutorados Acadêmicos) sempre estiveram disponíveis em meios eletrônicos de livre acesso, porém, como já exposto, as pesquisas acadêmicas impactam muito pouco a prática dos professores nas salas de aula, por diversos outros motivos. Talvez, objetiva-se que os produtos educacionais sejam mais acessíveis aos professores da educação básica (ao menos em termos de linguagem). Porém, como coloca Guerra (2016), da ênfase nesse aspecto da avaliação dos MPs, "compreende-se que a apresentação do produto educacional da dissertação tem por pressuposto que tais materiais possam por si só impactar o ambiente educacional" ( $p$. 201), o que, sabemos, é uma posição ingênua, já que a utilização desses materiais que, em geral, têm caráter inovador, seja nos temas abordados ou na metodologia e nos recursos utilizados, depende do professor que se propõe a adotá-los em sua prática; afinal de contas, é ele mesmo que deverá utilizar de sua autonomia para buscar e optar por determinada atividade divulgada em um produto educacional, de acordo com os objetivos pretendidos por ele em sua prática e com seu domínio em relação ao assunto abordado e aos recursos utilizados. Sem contar que aspectos objetivos do contexto de aplicação (número de alunos por sala, disponibilidade de materiais e recursos específicos), sobre os quais nem sempre o professor tem controle, podem impossibilitar a realização de atividades propostas em produtos educacionais ${ }^{65}$. Além disso, os produtos educacionais são desenvolvidos para supostamente responder a um problema originado de um contexto específico,

\footnotetext{
${ }^{64}$ Provavelmente, por isso, a primeira preocupação dos artigos levantados por Villani e colaboradores (2017) que fazem referência ao produto educacional, seja justamente a sua divulgação.

${ }^{65}$ A respeito da expectativa de que os MPs auxiliem na melhoria da educação brasileira, Araújo e Amaral (2006) trazem resultados que nos ajudam a pensar em qual porção dos aspectos problemáticos da atividade docente esses cursos realmente teriam influência. Os pesquisadores, ao aplicar um questionário aberto a 58 mestrandos do MP em Ensino de Ciências e Matemática da Unicsul, obtêm vinte categorias diferentes de resposta para os problemas e dificuldades enfrentados por esses professores no exercício da atividade docente. Tais categorias indicam que "as dificuldades enfrentadas são decorrentes de diversos fatores e apresentam variadas naturezas, requerendo, portanto, distintas ações que possibilitem minimizar os seus efeitos, algumas das quais sendo diretamente afetadas pelas atividades realizadas como parte do programa de mestrado da Unicsul, enquanto outras demandam inclusive ações políticas para a sua efetivação" (p. 155, grifos nossos).
} 
portanto, nem sempre será adequado para ser reproduzido, com sucesso, em outro contexto.

Assim, tanto as pesquisas que indicam o uso (e acesso, em diferentes sentidos) de produtos educacionais por professores em geral (titulados - ou não - mestres profissionais) e a investigação sobre o processo de elaboração dos produtos educacionais pelos professores mestrandos despontaram como relevantes para pontuar o quanto a elaboração dos, e o acesso aos produtos educacionais podem, de fato, impactar a educação brasileira, conforme pretendido pela Capes em relação aos MPs, no caso, através do impacto na prática educativa dos professores envolvidos na produção ou "consumo" de tais produtos educacionais. A investigação sobre tais temáticas, se desdobra em diferentes objetivos, por exemplo, averiguar as relações entre o produto educacional desenvolvido nos MPs e o problema (da própria prática ou não) que o professor mestrando se propôs a responder com o desenvolvimento de tal produto educacional, o que nos permitiria levantar os impactos dessa atividade, tão característica dos MPs, no seu desenvolvimento profissional docente. Essas pesquisas proporcionariam também um modo de avaliar, de forma mais qualificada, se o MP em questão estaria mais próximo de uma perspectiva de racionalidade técnica (no sentido do professor simplesmente "aplicar" conhecimentos oriundos de pesquisas realizadas por outrem em seu contexto educacional ${ }^{66}$ ) ou de proporcionar ao professor a realização de uma pesquisa de sua própria prática de forma mais autônoma. Tratase de um aspecto da investigação sobre MPs em Ensino de Ciências que permanece em aberto na literatura consultada, pois nenhum dos trabalhos que se dedicam à discussão sobre produtos educacionais dos MPs em Ensino levantados na literatura se ocupa a responder questões de pesquisa que se aproximam das questões levantadas.

Pilatti e colaboradores (2015), em artigo que não fez parte da meta-análise (VILLANI et al., 2017), apesar de não se dedicarem a essa problemática mais específica no que diz respeito à relação entre 0 produto educacional e 0 desenvolvimento profissional do professor, apresentam uma análise mais abrangente

${ }^{66}$ O que se revelaria também na ênfase ao como ensinar e não ao porquê ou ao quê (OSTERMANN, REZENDE, 2009). Cabe ressaltar, no entanto, que não necessariamente a obrigatoriedade do produto educacional no MP significaria a ausência de "reflexão sobre o problema educacional vivido pelo professor em uma dada realidade escolar e sobre as finalidades da educação em ciências na contemporaneidade" como colocado pelas autoras (2015, p. 555). Isso porque, "não necessariamente o produto constituirá um material didático imediatamente aplicável em sala de aula. Pode, outrossim, tornar-se um material de consulta para a reflexão da prática docente, seja buscando identificar, por exemplo, de que concepção de determinada área se parte, seja procurando pensar o próprio papel do professor no ato de ensinar" (BRANDÃO, DECCACHE-MAIA, BOMFIM, 2013, p. 334). 
que aqueles trabalhos presentes na meta-análise acima referida, com resultados pertinentes que proporcionam direcionamentos às questões propostas. Ao realizar um levantamento de produtos educacionais em 15 programas que oferecem o MP em Ensino de Matemática, o primeiro ponto que chamou a atenção dos pesquisadores é a pouca diversidade nos formatos propostos de produtos educacionais, os quais se concentraram nos formatos de propostas de atividades, manual e livro. A interpretação dada é a de que a concentração nesses formatos "pode estar ocorrendo por serem produções menos complexas, pois, em grande parte, tratam de uma produção escrita, relatando uma proposta de atividade organizada pelo acadêmico e aplicada durante sua pesquisa" (p. 352). Além disso, associa-se essa escolha ao atendimento da premissa indicada por Moreira e Nardi (2009) de que o produto educacional deve ser planejado de forma que possa ser "disseminado, analisado e utilizado por outros professores" (p. 4), embora possa ser questionado o acesso a tais produtos educacionais pois, como observaram os autores desse artigo, nem todos os programas de MP analisados os disponibilizaram, de forma atualizada, em suas páginas na internet.

Voltando à segunda categoria da meta-análise de Villani e co-autores (2017) "O Mestrado Profissional em Ensino de Ciências e o Desenvolvimento Profissional Docente" - encontramos trabalhos e discussões mais próximas de nosso interesse. A sistematização realizada busca inferir possibilidades de desenvolvimento profissional com base em aspectos descritos nos artigos a partir da perspectiva de que os MPs buscam configurar um contexto que permita ao professor se desenvolver profissionalmente, ou seja, buscam um contexto "que problematize sua prática, exercite sua capacidade reflexiva e proporcione consciência do seu fazer pedagógico, inclusive orientando-o a favor da aprendizagem dos estudantes" (p. 146). Na metaanálise, os 11 artigos dessa categoria são apresentados e seus resultados são discutidos seguindo por base as dimensões de desenvolvimento profissional: atualização dos conhecimentos científicos, atualização dos conhecimentos pedagógicos, organização e condução do ensino, sustentação da aprendizagem dos alunos, participação na gestão e organização escolar, investigação sobre a própria prática, planejamento da carreira profissional e participação na responsabilidade social (BAROLLI et al., 2017).

Ao final, os autores observam que

a despeito das controvérsias apontadas na categoria anterior [A natureza ampla do Mestrado Profissional em Ensino de Ciências: estrutura, especificidade e efetividade], todos os artigos reunidos nesta segunda categoria consideram que os MPEC [Mestrados 
Profissionais em Ensino de Ciências] se constituem em espaços formativos com potencial para que os professores se desenvolvam profissionalmente em diferentes dimensões da carreira docente (VILLANI et al., 2017, p. 154).

Os artigos da categoria analisaram diferentes cursos (quatro na região sudeste UFF, CEFET-RJ, Unicsul e UNIGRANRIO, dois na região nordeste - UEPB e UFRN, e um na região Sul - UFRGS $)^{67}$, de modo que é considerado que "a ênfase dada às possíveis dimensões de desenvolvimento profissional é bastante dependente da maneira pela qual os cursos concebem e organizam esses espaços formativos" (VILLANI et al., 2017, p. 154). Assim, diferentes MPs pareceram proporcionar o desenvolvimento profissional em diferentes dimensões, em especial, nas seguintes: atualização de conhecimentos científicos, atualização de conhecimentos pedagógicos, organização e condução de ensino, investigação sobre a própria prática e planejamento da carreira profissional. A dimensão atualização de conhecimentos pedagógicos é destacada como "aquela que os professores têm se desenvolvido com maior frequência" (Ibidem, p. 154). Nota-se, portanto, a ausência de impactos analisados em relação ao desenvolvimento das dimensões sustentação da aprendizagem dos alunos, participação na gestão escolar e participação na responsabilidade social, dimensões as quais não são centradas apenas no próprio professor em formação, e envolvem outros sujeitos que atuam no ambiente escolar (alunos, outros professores, membros da equipe gestora, pais e responsáveis pelos alunos...).

Concluindo, com base nos artigos do corpus de pesquisa, Villani et al. (2017) enfatizam que

[...] as controvérsias identificadas quanto ao MP em Ensino de Ciências têm subjacentes concepções distintas acerca do desenvolvimento profissional docente que esta modalidade de pósgraduação poderia ou deveria contribuir. Nos vários artigos [...], essas concepções, em geral não são muito explicitadas: algumas vezes os autores privilegiam a inovação técnica, outras não abrem mão da reflexão. Além disso, há um questionamento implícito dos saberes que deveriam ser aprimorados, restringindo-se, via de regra, ao aprimoramento científico e educacional e, desse modo, menos abrangente em relação àquele que apresentamos como nosso referencial de análise (p. 155).

\footnotetext{
${ }^{67}$ A partir desse dado, é possível perceber que as análises sobre os impactos dos MPs na formação de professores ainda se restringem a um conjunto específico de cursos localizados apenas nas regiões Sudeste, Sul e Nordeste.
} 
É interessante também destacar o que os autores enfatizam como características relevantes que influenciam na formação pretendida do MP. Apesar de muitos outros autores destacarem a obrigatoriedade do produto educacional como principal característica dos $\mathrm{MPs}^{68}$, essa não é a única atividade em que os professores-cursistas estão envolvidos no contexto do MP,

pois mesmo que os cursos não organizem suas estruturas curriculares com grande diversidade de atividades - seminários, participação em eventos da área, fóruns de discussão, entre outros todos os cursos precisam oferecer disciplinas de natureza científica e pedagógica (VILLANI et al., 2017, p. 155).

E nesse sentido, essas disciplinas também têm o potencial, privilegiando uma ou outra dimensão, de colaborar com o desenvolvimento profissional dos professorescursistas. Por fim, é destacada também a importância do processo de orientação do docente orientador do MP como

fator fundamental para que o professor crie e elabore o produto educacional e, mais especificamente, para que com isso sejam criadas condições efetivas de desenvolvimento profissional para além daquilo que o professor já traz de sua trajetória (VILLANI et al., 2017, p. 156).

Em relação à orientação, questiona-se a adequação de um acompanhamento realizado por um docente que tenha experiência na educação básica, ou que esteja envolvido com a área de pesquisa em Ensino de Ciências, em relação ao acompanhamento realizado por um docente especialista da área de Ciências, sem necessariamente ter experiência na educação básica ou com pesquisa em Ensino de Ciências.

De qualquer forma, interessante observar, mesmo nos casos nos quais os orientadores são pessoas experientes ou qualificadas na área de Ensino de Ciências, a possibilidade de que,

[...] considerando que o mestrado profissional é uma experiência de inovação e reinvenção em que os alunos vêm iluminar as suas práticas com as teorias, as instituições proponentes dessa modalidade de ensino [aprendam] muito, tendo praticantes [ou seja, professores experientes da educação básica] como alunos (MACIEL, NOGUEIRA, 2012, p. 469).

Como síntese, observamos que, apesar da dificuldade de avaliar os impactos na formação docente (VILLANI et al., 2017), as pesquisas ajudam a desenhar um

${ }^{68} \mathrm{O}$ que suscita grandes discussões, como as já referidas no corpo do texto. 
panorama do que os professores que cursaram MPs alcançaram em termos de formação e melhorias de práticas docentes. A articulação entre as áreas pedagógica e disciplinar promovida nos cursos e o viés de reflexão sobre a própria prática, proporcionaram a ampliação e atualização de conhecimentos e o processo de ressignificação de práticas docentes, orientando-as à aprendizagem dos alunos, conforme indicado em Cevallos (2011) e Pires e Igliori (2013). Foram impactos que puderam ser gerados a partir da vivência com outros professores em ambiente promotor de trocas; da preocupação dos formadores atuantes nos cursos com uma formação docente holística, incluindo a preocupação de fundamentar teoricamente a prática; além do uso de novas tecnologias (SHUCK et al., 2016). Em termos das dimensões de desenvolvimento profissional é importante destacar que os professores poderão estar envolvidos, no contexto dos MPs, com maior frequência com a atualização de conhecimentos pedagógicos ao passo que é identificado nas pesquisas pouco envolvimento dos professores com as seguintes dimensões: sustentação da aprendizagem, participação na gestão e organização escolar e participação na responsabilidade social (VILLANI et al., 2017). 


\section{Proposição de pesquisa e seu percurso metodológico}

A implantação dos MPs abriu novas possibilidades de práticas no contexto de formação continuada de professores de Ciências e, em especial, os de Física. Surge como proposta que aproxima grupos de pesquisa que atuam em universidades e professores da educação básica, criando um diálogo que beneficiaria a ambos. Também surge como oportunidade para a certificação dos professores em nível de pós-graduação e como locus privilegiado de desenvolvimento profissional, além de espaço para qualificação e produção de pesquisa por parte dos professores participantes, além de proporcionar a ampliação de produção técnica na área de Ensino, por conta dos produtos educacionais obrigatórios nesses cursos. Porém, ainda, "[...] o estudo da natureza, estruturação, funcionamento e impacto desses cursos na realidade escolar carecem de estudos sistemáticos" (NARDI, 2011, p. 65).

Pesquisas que preencham essa lacuna são demandadas para a reflexão do que já se obteve como resultados nesses cursos e quais são as novas perspectivas que se abrem atualmente para eles. Schäfer e Ostermann (2013) apontam que

[...] vários autores alertam quanto à necessidade de uma reflexão aprofundada sobre a natureza dos cursos de Mestrados Profissionais em Ensino e sobre a avaliação dessa modalidade de formação, tomada a partir de novos parâmetros, que elucidem o possível impacto na sociedade brasileira, medido, necessariamente, a partir de uma avaliação investigativa (Fischer, 2005; Negret, 2008; Ostermann e Rezende, 2009) ${ }^{69}$ (p. 288).

Embora uma das preocupações centrais dos pesquisadores seja em como avaliar a inserção da pesquisa realizada no âmbito dos MPs em Ensino e os produtos decorrentes dela na sala de aula (NARDI, 2011), nos debruçamos em um nível mais abrangente, centrando-se no desenvolvimento profissional do professor que cursou um MP em Ensino. A avaliação da pesquisa e dos produtos educacionais desenvolvidos pelos professores sujeitos dessa pesquisa serão apenas um dos itens investigados que visam avaliar o impacto do curso nas dimensões de seu desenvolvimento profissional.

O trabalho de pesquisa aqui proposto pretende construir uma visão diferenciada sobre os impactos no desenvolvimento profissional de professores egressos de cursos

\footnotetext{
${ }^{69}$ As referências de Fischer (2005) e Ostermann e Rezende (2009) são as mesmas realizadas na tese. A referência de Negret (2008) realizada pelas autoras é a seguinte:

Negret, F. (2008). A identidade e a importância dos mestrados profissionais o Brasil e algumas considerações para a sua avaliação. Revista Brasileira de Pós-Graduação, 5, 10, 217-225.
} 
de mestrado profissional. Maciel e Nogueira (2012) ajudam a justificar a proposição. Segundo esses autores:

[...] estudos que apontam os significados que os egressos de programas de mestrado profissional atribuem à sua experiência durante e após a conclusão do curso permitem conhecer o resultado da formação, os ganhos e os desafios que enfrentam, oferecendo um rico material às instituições proponentes. Representam outro olhar avaliativo, complementar ao do de indicadores estabelecidos pela Capes. Ao comparar os objetivos da oferta com a experiência dos egressos, é possível avaliar se o projeto atingiu seus propósitos, se capacitou seus alunos para uma prática profissional avançada e transformadora (p. 463).

Os debates provocados principalmente pela implantação do MNPEF, que polarizaram a discussão protagonizada por pesquisadores da comunidade de Ensino de Física e pesquisadores das áreas específicas da Física (SALEM, 2012; VILLANI, 2016), sugerem, indo além da discussão sobre as concepções de formação continuada ora defendidas ou refutadas por cada um desses grupos, uma disputa entre essas diferentes comunidades de pesquisadores pelo controle sobre a formação de professores de Física. Assim, tendo como palco o mundo acadêmico, e sendo as discussões empreendidas essencialmente teóricas, poucos impactos seriam verificados na formação continuada dos professores de Física que participam desses cursos.

Nossa hipótese inicial buscou sair da esfera do proposto e verificar o que é praticado nos cursos e seus efetivos impactos na formação dos egressos de dois cursos diferentes, sendo o primeiro um pólo do MNPEF e o segundo um MP.Local. Conforme apontado na revisão de literatura deste trabalho, Villani et al. (2017) analisaram artigos que consideraram que os MPs em Ensino de Ciências têm o potencial de proporcionar aos professores o desenvolvimento em diferentes dimensões de desenvolvimento profissional. Os mesmos autores apontaram que a ênfase dada nas dimensões são dependentes da forma em que os cursos se organizam. Dessa forma, partimos da hipótese inicial de que tanto o MP.Local quanto o pólo do MNPEF proporcionam o desenvolvimento profissional dos professores participantes dos cursos oferecidos, porém com uma possível diferença entre eles relacionado às dimensões trabalhadas. Tivemos o interesse, portanto, de entender, a partir das diferenças nas concepções, estruturações e realizações dos dois cursos quais são as ênfases de cada um e o que proporcionou, entre as características de cada espaço formativo, os resultados alcançados em cada contexto. 
Isso exposto, formulamos as seguintes questões centrais que guiam a presente pesquisa: quais são os impactos de cursos de MP estruturados de diferentes formas sobre o desenvolvimento profissional (em termos de formação e mudanças na prática profissional) de seus professores-cursistas? Como os professores-cursistas interagem com currículo proposto e praticado nesses cursos?

Dessa forma, é de nosso interesse, como objetivo geral de pesquisa, investigar os efeitos da participação no curso de mestrado profissional no desenvolvimento profissional (envolvendo a formação e a prática profissional) dos professores egressos. Entendemos que tais efeitos para o professor-cursista não dependem unicamente de critérios objetivos que possam ser estabelecidos pelos currículos dos cursos de MP, e sim que eles dependem em grande medida de uma complexa conjunção entre a história de vida dos próprios professores-cursistas e do que encontram, em termos de processos formativos (o currículo do curso, as atividades que o curso engloba, como ele está estruturado, o que é valorizado - ou não - pelo corpo docente/discente daquele curso, as relações institucionais construídas, etc) nesses cursos. De fato, podem ser influenciados pela concepção de MP adotada para estruturação de um dado curso mas, principalmente, pelas rotinas e procedimentos adotados no seu cotidiano e a adaptação das propostas com relação ao perfil do professor-cursista e o que ele demandaria do curso em termos de formação.

Assim, nossa percepção do que é o currículo dos cursos estudados se aproxima ao adotado no trabalho desenvolvido por Milheiro (2017), no qual a autora desenvolve também dois estudos de caso para avaliar o impacto da formação pós-graduada nos professores e nas escolas em Portugal. A pesquisadora adota a

\begin{abstract}
definição de currículo como o conjunto de aprendizagens realizadas e de competências desenvolvidas pelo aprendente desde que entra até que sai de um processo de ensino-aprendizagem formal, contextualizado histórica e socialmente. [Posiciona-se], pois, numa perspetiva que reflete o próprio desenvolvimento curricular e o seu impacto, ou seja, o processo no qual o aluno está ou esteve envolvido e a projeção que é feita do currículo oficial, real e oculto nas diferentes práticas profissionais. Assim, analisar os efeitos da formação sobre os indivíduos que a frequentaram é compreender a importância que o currículo teve para aquelas pessoas e averiguar sobre os seus potenciais efeitos no desempenho profissional é "entrar" no currículo dos cursos de FPG [Formação Pós-graduada], ponderando se e em que medida aquilo que se faz e o modo como se faz poderá ser consequência do próprio currículo (MILHEIRO, 2017, p. 16, grifos nossos).
\end{abstract}

Torna-se premente também a especificação do que entendemos por impacto. Também nos baseando em Milheiro (2017), que por sua vez se baseia nos estudos de 
Roldão et al. $(2000)^{70}$, define-se como impacto "as consequências em determinada realidade passíveis de observar, seja direta ou indiretamente, com uma durabilidade significativa e que se assuma como contributo para a modificação dessa mesma realidade" (p. 34).

Por esse motivo, para alcançar os objetivos delineados para a presente pesquisa, optamos pela abordagem qualitativa, pois seu interesse central está "em uma interpretação dos significados atribuídos pelos sujeitos às suas ações em uma realidade socialmente construída" (MOREIRA, 2011, p. 76, grifo do autor). Em especial, debruçamo-nos na realização de estudos de caso (ANDRÉ, 2013), afim de conferir a profundidade requerida para a análise da problemática escolhida, investigando e relatando dados colhidos das suas várias dimensões. Em específico, selecionamos como objetos de pesquisa, dois diferentes programas de MP, que expressam diferentes motivações e configurações, que se traduzem de diferentes concepções de formação continuada de professores. Trata-se de um curso de Mestrado Profissional Local, criado em uma instituição federal e de um polo do MNPEF, localizado em outra instituição federal.

A fim de se estabelecer um itinerário de pesquisa, agrupamos os objetivos específicos da seguinte forma:

- As histórias e trajetórias dos referidos cursos de MP: levantar dados que embasam a elaboração de narrativas nas quais elucidamos a criação desses cursos, os sujeitos envolvidos, os acontecimentos mais relevantes que fizeram parte das trajetórias dos cursos e que colaboraram para a construção de suas identidades. Traçar a partir desses dados um panorama que ilustre a(s) concepção(ões) sobre a(s) qual(is) o curso de MP está estruturado;

- As rotinas e procedimentos estabelecidos nos cursos de MP: investigar os procedimentos e normas estabelecidas em cada curso e como essas estruturas retratam as relações estabelecidas, principalmente, entre corpo docente e discente. Analisar as produções docentes e discentes, em especial, avaliando a natureza dos produtos educacionais defendidos pelos egressos, buscando também indícios de desenvolvimento profissional;

- Perfil e histórias de formação dos professores egressos: levantar o perfil dos professores egressos, seu envolvimento com o curso de MP e analisar os impactos nas atividades profissionais dos egressos, buscando identificar se, e em qual medida, 70 ROLDÃO, M. et al. Avaliação do Impacto da Formação: Um Estudo dos Centros de
Formação da Lezíria e Médio Tejo 1993-1998. Lisboa: Edições Colibri, 2000. 
eles podem ser atribuídos à formação proporcionada pelo curso de MP frequentado pelo professor entrevistado.

Os objetivos específicos nos permitem planejar o percurso metodológico da pesquisa aqui empreendida. Inicialmente, numa primeira aproximação, aprofundamos a discussão sobre a problemática investigada consultando os principais autores brasileiros e estrangeiros que a discutem em seus trabalhos. Através de pesquisas bibliográficas realizadas no Portal Periódicos da Capes $^{71}$ e nas bibliotecas, levantamos trabalhos relevantes sobre as temáticas de fundo dessa problemática, quais sejam: formação docente, formação continuada, desenvolvimento profissional docente e mestrado profissional. É importante destacar que esse estudo teórico é realizado ao longo de toda a pesquisa desde o seu início. Objetivamos com isso, a aquisição de uma sólida base teórica com a finalidade tanto de fomentar o olhar da pesquisadora na coleta e análise dos dados empíricos, quanto de permitir novas reflexões teóricas a partir desses dados. São trabalhos que embasaram os textos apresentados nos capítulos precedentes e outros que são utilizados para embasar discussões com base nos dados apresentados nos outros capítulos.

Para a coleta de dados e na necessidade de se levar em conta, em um estudo de caso o "seu contexto e a multiplicidade de elementos que o compõem" (ANDRÉ, 2013, p. 98), foi adotado os seguintes procedimentos para cada estudo de caso:

1. Análise documental: envolveu, como corpus de pesquisa, documentos que regulamentam o funcionamento do MP (tais como normas do curso, regulamentos, projetos de curso, matriz curricular, etc); além daqueles decorrentes das atividades realizadas no curso, em especial, a produção discente (dissertações e produtos educacionais). Foram levados em conta documentos "extra-oficiais" disponíveis, por exemplo, nas páginas oficiais online dos programas, tais como: comunicações de coordenadores e publicações diversas. Esse corpus foi construído de modo a permitir uma visão geral da trajetória e estruturação dos cursos, além da análise da produção discente;

2. Entrevistas semi-estruturadas: a opção em se realizar entrevistas semiestruturadas, é que nesse tipo de entrevista "fica-se com a certeza de se obter dados comparáveis entre os vários sujeitos" (BOGDAN; BIKLEN, 1994, p. 135, grifo dos autores) devido ao uso do roteiro de perguntas pré-estabelecido. Apesar do uso desse roteiro pré-estabelecido, são relativamente abertas e fluidas, de modo a permitir a percepção das interpretações dadas por cada sujeito entrevistado sobre o assunto

\footnotetext{
${ }^{71}$ Disponível em:<http://www.periodicos.capes.gov.br/>. Acesso em 29 jun 2017.
} 
discutido. Buscamos a realização de entrevistas com o maior número de sujeitos de cada curso, com objetivos ligeiramente diferentes em relação à categoria a que cada sujeito pertence (se docente ou egresso do curso estudado). Entrevistas essas que foram gravadas, com o consentimento dos entrevistados, e posteriormente integralmente transcritas para análise. Assim, foram realizadas entrevistas com:

- Os coordenadores dos cursos: para obter a percepção destes relativos ao envolvimento no MP; a como o curso é estruturado e como ele efetivamente funciona; qual foi a história de criação e consolidação do MP em que atua;

- Membros do corpo docente dos cursos: a fim de se perceber como esses formadores se envolveram nas disciplinas e demais atividades do curso, como foram os processos de orientação e produção das dissertações e produtos educacionais de seus orientandos, qual foi a concepção de formação que pretenderam com sua atuação junto aos professores-cursistas;

- Egressos dos cursos: com o objetivo de obter informações sobre as expectativas e demandas desses professores em relação ao curso de MP; o que aprenderam ao longo do curso e quais foram efetivamente os impactos da realização do curso em sua prática profissional.

3. Observaç̃̃es: decorrentes de oportunidades que surgiram ao longo do desenvolvimento da pesquisa para maior inserção no contexto de realização dos cursos de MP, para efeito de observação das atividades realizadas, tais como seminários, aulas, defesas e eventos diversos. Os dados coletados nessa categoria foram mais diversificados, e dependeram também da disponibilidade de participação de tais atividades. A coleta de dados nesse quesito se baseou em registros realizados em diário de campo. Alguns desses dados aparecem ao longo da análise de dados das etapas de pesquisa apresentadas anteriormente.

Reforça-se que esses níveis de coleta de dados se sucederam de modo que dados e reflexões realizadas em uma etapa apontassem caminhos de investigação por meio de perguntas incluídas nas etapas sucessivas. Portanto, a perspectiva adotada não foi a de acumulação de dados e análises realizadas em etapas independentes uma da outra. Esperou-se que dados obtidos em etapas posteriores nos levassem à melhor compreensão de resultados de etapas iniciais, levando-nos a executar espirais de análise e reflexão em busca das respostas às questões de pesquisa propostas. Os indicativos derivados de cada etapa de pesquisa para aprofundamento na próxima, e a elucidação de questões são expostos ao longo da apresentação de dados e análises. Empreendemos, portanto, uma pesquisa qualitativa concebida em uma 
trajetória circular em torno do que se deseja compreender, não se preocupando única e/ou aprioristicamente com princípios, leis e generalizações, mas voltando o olhar à qualidade, aos elementos que sejam significativos para o observador-investigador (GARNICA, 1997, p. 111).

Nesse sentido, a pesquisa aqui empreendida configurou-se como o estudo de um "fenômeno situado", ou seja, estudos de caso a partir de uma postura de pesquisa qualitativa de inspiração fenomenológica e contextualizada, onde o pesquisador, escolhendo um tema para investigação, busca compreender o fenômeno colocando-o em suspensão. Nesse processo, buscou-se "sua essência ou estrutura, que se manifesta nas descrições ou discursos de sujeitos" (GARNICA, 1997, p. 115). Dessa forma, a etapa de entrevistas semi-estruturadas com egressos planejada para a pesquisa adquiriu importância central, já que se buscou apreender aspectos do fenômeno, qual seja, os impactos no desenvolvimento profissional desencadeado pelos cursos de MP, por meio do que dele diziam os sujeitos nele imersos. Num primeiro nível, a partir das descrições conforme informadas pelos sujeitos, aprofundaram-se as análises e questionamentos realizados no decorrer da investigação, que culminam nas análises ideográfica, onde unidades de significados das transcrições das descrições informadas pelos sujeitos de pesquisa são selecionadas e organizadas em categorias; e nomotética, onde se mobilizaram bases teóricas sobre o fenômeno estudado (GARNICA, 1997). Nesse percurso, caminhou-se da análise particular para o geral, ressaltando-se que nesse processo, "compreensões nunca serão definitivas, mas formam-se cada vez mais elaboradamente" (p. 120).

O detalhamento sobre os instrumentos de coleta de dados utilizados em cada um desses níveis dos estudos de caso e sobre o processo de constituição e análise desses dados são fornecidos ao longo dos capítulos, juntamente com a apresentação dos dados obtidos e análises efetuadas a partir deles.

Por fim, coerente com a perspectiva de pesquisa qualitativa adotada, é importante salientar que a opção pelo estudo de caso de dois diferentes cursos de MP não objetivou uma comparação entre eles no sentido de julgá-los um melhor do que o outro. A polêmica que girou em torno da criação do MNPEF originou-se em grande parte pela comparação da proposta com referenciais teóricos ideais de formação de professores em serviço. Não julgaremos o mérito da proposta do MNPEF ou de como vem sendo realizado unicamente a partir desses referenciais. Buscaremos ter uma ideia concreta do que foi realizado no caso do polo estudado no período especificado, o confrontando com resultados obtidos por outro MP já consolidado. Estes resultados, portanto, tornam-se uma nova referência, no sentido de buscarmos o que há de 
positivo e o que há de negativo em cada um, avaliando o que há de complementar entre eles. Buscaremos, nessa análise, ultrapassar as análises comuns existentes entre defensores e críticos do programa, de modo a elucidar o que de fato foi alcançado no contexto de um dos polos do MNPEF e de um MP.Local.

Assim, buscaremos investigar quais são as contribuições de cada um dos cursos estudados aos seus professores-cursistas, em termos de desenvolvimento profissional. Caso as contribuições desses dois programas sejam semelhantes, podese questionar a opção política realizada em relação ao grande aporte financeiro fornecido aos Mestrados em Rede, incluindo-se o MNPEF, e o pouco investimento dado aos MPs Locais. Nesse caso, porque não continuar a investir no que estaria já bem estabelecido e consolidado? Por outro lado, os MPs Locais, mesmo que suficientemente financiados, poderiam obter a mesma colaboração de pesquisadores em Física do que o MNPEF? No caso de as contribuições serem diferentes, novamente, para não correr o risco de recair na falácia de se comparar os programas e hierarquizá-los em termos de "qualidade", concentramos a atenção no público atendido por cada um desses cursos. Têm exatamente o mesmo perfil? Possuem as mesmas motivações para ingressar no curso de MP? Apresentam as mesmas demandas aos dois cursos? Nesse sentido, temos a perspectiva de notar se o curso, independentemente de sua estrutura ou de seus pressupostos, atende a essas demandas específicas do público recebido. Há uma adequação de cada MP com relação ao que os professores esperam do curso? 


\section{A pesquisa: realização, apresentação de dados, análises e discussões}

Inicialmente, será apresentada a análise documental completa dos documentos que regulamentam cada curso analisado. Essa análise nos permitiu vislumbrar um panorama dos pressupostos adotados e da organização e do funcionamento dos cursos. Nessa primeira etapa de pesquisa, algumas questões foram abertas, as quais foram incluídas nas etapas posteriores de pesquisa (em especial na realização das entrevistas semi-estruturadas). A organização e o funcionamento dos cursos também pôde ser descrita e compreendida a partir de entrevistas semi-estruturadas realizadas com os coordenadores de cada curso ${ }^{72}$ à época da realização da coleta de dados para esta pesquisa e com membros do corpo docente. A caracterização desses sujeitos entrevistados são apresentados juntamente com os dados obtidos nas entrevistas.

$\mathrm{Na}$ sequência, apresentamos os procedimentos e a caracterização da análise documental empreendida a partir dos produtos educacionais e dissertações defendidas nos cursos de MP. Os procedimentos e dados obtidos a partir das entrevistas semi-estruturadas realizadas com egressos de ambos os cursos são apresentados em um capítulo a parte, em termos de organização da apresentação de dados e discussões. Os conjuntos de dados de cada etapa de pesquisa são acompanhados de sínteses gerais.

\subsection{Análise documental dos documentos dos cursos de MP}

Apresentamos e analisamos na sequência os dados obtidos na etapa de leitura minuciosa dos documentos que norteiam o funcionamento dos cursos de MP selecionados para estudo nesta tese. Fazem parte do corpus analisado, os regimentos gerais dos cursos, regulamentos ou normas específicas, matrizes curriculares, editais de processo seletivo, entre outros.

Esse corpus foi levantado e analisado de forma a possibilitar a construção do perfil do curso estudado, a nossa primeira aproximação a esses cursos. Através desses documentos, é possível identificar a sua estrutura organizacional burocrática, as diretrizes gerais de seu funcionamento (observadas nos regulamentos e normas) e o perfil de formação objetivado pelo curso (principalmente através da análise de como

\footnotetext{
${ }^{72}$ Por ocasião da finalização desta tese, um dos coordenadores entrevistados já não exercia a função.
} 
sua estrutura curricular é proposta, mas também através do perfil de ingressante que é implicitamente expresso em editais de processo seletivo).

Apresentamos, em subitens separados, uma síntese dos dados obtidos na leitura cruzada entre os documentos do corpus de cada curso. Cabe ressaltar que a descrição desses dados é apresentada de forma mesclada a elementos de análise dos mesmos, onde algumas relações com o referencial teórico dessa pesquisa e considerações críticas puderam ser construídas. Apreciações gerais sobre esses resultados, que indicam direcionamentos para as etapas subsequentes da pesquisa, são expostas no último subitem da presente seção.

\subsubsection{Análise documental dos documentos do curso do polo do MNPEF}

O corpus de pesquisa documental do curso oferecido pelo polo do MNPEF, é composto pelos seguintes documentos, todos disponíveis no site do MNPEF coordenado pela $\mathrm{SBF}^{73}$, salvo indicação:

- Regimento Geral do MNPEF;

- Regulamento Específico do polo do $\mathrm{MNPEF}^{74}$;

- Matrizes curriculares do curso de 2013 e 2014 (vigente em 2017);

- Documentos emitidos pela Comissão de Pós-Graduação do MNPEF (CPG/MNPEF) e disponibilizados publicamente no site. Tais documentos incluem orientações sobre currículo e comunicados;

- Editais, geral e local, de processos seletivos.

No Regimento Geral do MNPEF, aprovado em dezembro de 2015 pelo Conselho da SBF, são definidas as diretrizes gerais de estrutura e funcionamento do curso nos polos. Nesse documento são definidos: objetivos do curso; estrutura geral dos polos; atribuições, regras de credenciamento e outras diretrizes que concernem aos docentes orientadores do MNPEF; estrutura da administração nacional do MNPEF (composição e atribuições do Conselho de Pós-graduação e Comissão de Pós-graduação); definições gerais a respeito do regime didático; determinações gerais a respeito de etapas de ingresso no curso (processo seletivo) e conclusão do curso (bancas examinadoras, diploma).

\footnotetext{
${ }^{73}$ Disponível em: <http://www1.fisica.org.br/mnpef/>. Acessado em: 27 fev 2017.

${ }^{74}$ Cedido gentilmente pelo coordenador do curso em março de 2017.
} 
Os objetivos do MNPEF são definidos logo na primeira seção desse documento: "[...] Este mestrado nacional constitui um sistema de formação intelectual e de desenvolvimento de técnicas e produtos na área de Ensino de Física que visam a habilitar ao exercício altamente qualificado de funções envolvendo o ensino de Física na Educação Básica" (Art. 1). Não há, no texto do Regimento Geral, indicação do que os idealizadores do MNPEF assumem como "formação intelectual". A ênfase é colocada na aquisição técnica (que nos remete, em um primeiro momento, às metodologias de ensino e aos conteúdos específicos de Física ${ }^{75}$ ) e ao desenvolvimento de produtos, na forma dos produtos educacionais, requisito para aquisição do título final de mestre. Essa ênfase é também expressa no art. 2:

O MNPEF objetiva a melhoria da qualificação profissional de professores de Física em exercício na Educação Básica visando tanto ao desempenho do professor no exercício de sua profissão como ao desenvolvimento de técnicas e produtos para a aprendizagem de Física (grifos nossos).

O perfil do público-alvo desejado para ingressar no curso é indicado nos editais de processos seletivos. No ponto 2.2 do edital do processo seletivo de $2017^{76}$, lê-se:

Poderão participar do processo seletivo os candidatos que estejam em efetivo exercício de docência em Física na educação básica ou superior, ou em Ciências no nível fundamental, e sejam portadores de diplomas de graduação em Física (Licenciatura ou Bacharelado) ou áreas afins, em cursos reconhecidos pelo Ministério da Educação, ou estudantes do último semestre desses cursos.

Essa redação mantém-se a mesma desde o primeiro edital de processo seletivo realizado em 2013. O MNPEF objetiva, assim, atender professores que estejam em efetivo exercício de docência lecionando Física (ou Ciências) em qualquer um dos níveis (da educação básica ou superior) e que tenham formação inicial em Física ou em áreas afins. Os editais abrem margem também para a admissão de professores recém-formados, ao permitir a inscrição de estudantes do último semestre do curso de graduação no processo seletivo para o mestrado.

Nenhum edital de processo seletivo realizado entre os anos de 2013 a 2017 faz referência à concessão de bolsas para professores-cursistas. Porém, o Comunicado

${ }^{75}$ Como será explicitado adiante, a matriz curricular do MNPEF prioriza o domínio dos conteúdos de Física.

76 Edital disponível em: <http://www1.fisica.org.br/mnpef/?q=ps/2017/editais-nacionais/>. Acesso em: 11 mar. 2017. 
03/2015 da CPG/MNPEF ${ }^{77}$ deixa indicada a possibilidade de concessão de bolsas para professores da rede pública de educação básica.

O processo seletivo para admissão ao MNPEF é nacional, coordenado por uma Comissão Nacional do MNPEF e executado por uma Comissão de Seleção do Polo. Desde o primeiro processo seletivo, em 2013, as etapas de seleção são as mesmas: a primeira etapa consiste em uma Prova Escrita Nacional elaborada pela Comissão Nacional e a segunda etapa consiste de uma Prova de Defesa de Memorial, realizada pela Comissão de Seleção do Polo.

A composição da Prova Escrita Nacional variou um pouco entre os processos seletivos. Em 2013, ela era composta por 24 questões de múltipla escolha e dois problemas de resposta livre. Nos anos de 2014, 2015 e 2016, eram 25 questões de múltipla escolha. Por fim, em 2017, foram 20 questões de múltipla escolha. As questões presentes na prova escrita exigem conteúdos de Física Geral, presentes em livros textos geralmente adotados em cursos de graduação, como os indicados na bibliografia dos editais do MNPEF (livros de autores como Halliday, Nussenzveig e Tipler). Nessas provas, apenas uma questão (dissertativa, contida na prova de 2013) envolvia uma situação-problema de Ensino de Física. Já na Prova de Defesa de Memorial, o candidato deve discorrer oralmente sobre sua trajetória profissional e o plano de trabalho a ser desenvolvido no mestrado. Nessa etapa, leva-se em conta o desempenho acadêmico, a experiência profissional e a produção intelectual e técnica do candidato afim de avaliar a preparação do candidato para integralizar o curso no prazo de dois anos, "bem como a possibilidade que venha a contribuir para a melhoria do ensino de Física no sistema educacional ${ }^{78 "}$ (item 4.13.1 do edital de 2017).

A organização da estrutura administrativa do MNPEF é centralizada, conforme expresso na seção "IV - Da Administração" do Regimento Geral. A coordenação geral do MNPEF compete ao Conselho de Pós-graduação, ao qual atribuem-se funções normativas, e à Comissão de Pós-graduação (CPG/MNPEF), por sua vez, com funções executivas. Os cargos dessas duas esferas organizativas são ocupados por indicação: os oito membros do Conselho de Pós-graduação, sendo destes, quatro docentes do MNPEF, são indicados pelo Conselho da SBF (Art. 14); quanto à CPG/MNPEF, quatro membros (destes, dois coordenadores de polos) são indicados também pelo Conselho da SBF e os seis membros restantes são indicados pelo

\footnotetext{
${ }^{77}$ Disponível em: <http://www1.fisica.org.br/mnpef/sites/default/files/Comunicado MNPEF-SBF03-2015.pdf /> . Acesso em: 07 mai 2017.

${ }^{78}$ Observa-se esse "espírito" de busca da melhoria do Ensino de Física no sistema educacional brasileiro em outros documentos e em declarações dos idealizadores e demais envolvidos na criação e realização do MNPEF.
} 
Conselho de Pós-graduação (Art. 17). Além disso, o Conselho de Pós-graduação é presidido pelo coordenador da CPG/MNPEF, que, por sua vez, é também designado pelo Conselho da SBF. Em cada polo, localizado em IES espalhadas em diversas regiões do Brasil, há uma coordenação local. A organização de "atividades de ensino, pesquisa e orientação"79 é articulada pela administração nacional com as coordenações locais dos polos (Art. 13, $\S 1^{\circ}$ ). A organização de tais coordenações locais é definida nos regulamentos específicos de cada polo.

O Regulamento Específico do Polo do MNPEF estudado, estabelece como organização acadêmica e administrativa, a existência de um Plenário do Polo, composto pelo corpo docente credenciado junto ao Polo e por representantes do corpo discente em número que não ultrapasse $1 / 5$ do número de membros desse corpo docente, conforme indicado no art. 15 do referido documento, e de um Colegiado, do qual são membros o coordenador e subcoordenador, três representantes do corpo docente e um representante discente e respectivos suplentes, eleitos entre seus pares (Art. 16). As atribuições do Plenário são normativas (dentro dos limites estabelecidos pelos documentos a que deve estar submetido, quais sejam, o Regimento Geral do MNPEF e o Regimento de Pós-graduação da Universidade que sedia o Polo) e as do Colegiado são executivas. Cabe ressaltar que o Regulamento Específico do Polo, em seu art. 3, permite o estabelecimento de convênios com outras IES, de forma a admitir o credenciamento de docentes de instituições vizinhas à Universidade sede do polo ${ }^{80}$. Os docentes de outras IES podem fazer parte do Colegiado (desde que eleitos por seus pares, conforme já explicitado), porém são elegíveis para os cargos de coordenação e subcoordenação apenas os membros do Colegiado que estejam lotados na Universidade sede do polo (Art. 19 do Regulamento Específico do Polo).

A Figura 3 ilustra a estrutura administrativa do MNPEF descrita, tanto no âmbito nacional quanto no âmbito local do polo analisado.

\footnotetext{
${ }^{79}$ Não há menção ao desenvolvimento de atividades de extensão em nenhum dos documentos oficiais analisados do MNPEF.

${ }_{80} \mathrm{O}$ que ocorre, como visto adiante. Há docentes credenciados como orientadores permanentes do programa que são membros do quadro docente de instituições conveniadas.
} 
Figura 3 - Estrutura organizacional e administrativa do MNPEF em âmbito nacional (diagrama à esquerda) e local (diagrama à direita)

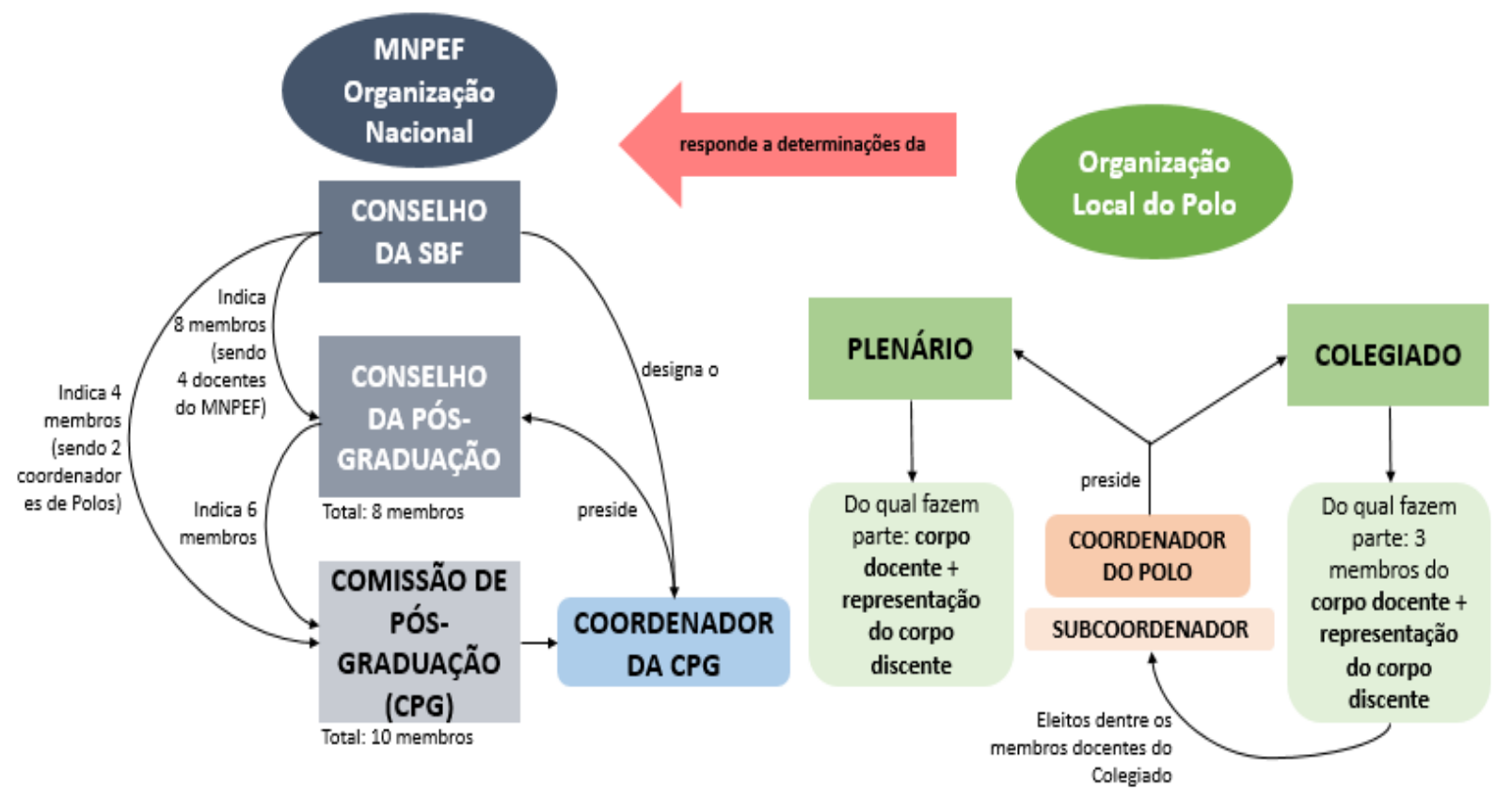

Fonte: elaborado pela autora.

Os polos do MNPEF são definidos mediante a submissão e análise de propostas das IES para a abertura de polos, conforme estabelecido no Regimento Geral do MNPEF. Tais propostas são recebidas e avaliadas pela CPG/MNPEF de acordo com editais que são regularmente abertos para recebê-las (Art. 3). Até o momento, já foram abertas três chamadas públicas para credenciamento de polos (nos anos de 2013, 2014 e 2015) totalizando 60 polos instalados em 54 IES públicas federais e estaduais (algumas dessas instituições possuem polos localizados em campi diferentes) localizadas em todas as regiões do país ${ }^{81}$.

Cada polo do MNPEF deve congregar seis ou mais doutores em Física ou em Ensino de Física (Art. 5, do Regimento Geral). Ressalta-se que o Regimento Geral não obriga a adesão de docentes da área de Ensino de Física como parte do corpo docente do polo. No caso específico do polo estudado, sua fundação contou com oito docentes inicialmente credenciados, sendo um deles pós-graduado na área de Ensino e outro formado na licenciatura em Física (porém com pós-graduação em pesquisa de áreas específicas da Física).

Dentre os docentes credenciados no polo, um assume a coordenação, cujas atribuições giram em torno da execução das normas e determinações da

\footnotetext{
${ }^{81}$ Informações obtidas online, disponíveis em: <http://www1.fisica.org.br/mnpef/?q=polos/todos 1>. Acessado em 28 fev 2017.
} 
CPG/MNPEF, ao qual é submetido, para a realização plena das atividades do MNPEF em cada local (Art. 6). Dentre estas atribuições, aparece em destaque a garantia de "oferta de, no mínimo 32 (trinta e dois) créditos em disciplinas do MNPEF ao longo de cada período de 2 anos" (Art. 6, inciso II). Os créditos obrigatórios para a obtenção do título se dividem entre créditos de disciplinas obrigatórias (num total de 20 créditos); de estágio supervisionado (4 créditos) e em disciplinas opcionais (8 créditos) (Art. 22). A matriz curricular do MNPEF $^{82}$ indica como obrigatórias as seguintes disciplinas: Estágio Supervisionado; Termodinâmica e Mecânica Estatística; Eletromagnetismo; Mecânica Quântica; Física Contemporânea (cuja ênfase pode ser escolhida dos temas Física de Partículas, Espaço-Tempo, Física da Matéria Condensada, Física de Sistemas Complexos ou Biofísica, a depender do polo e das áreas de pesquisas dos orientadores credenciados no MNPEF e a pesquisa em Física desenvolvida na IES que o sedia). Todas essas equivalem ao cumprimento de 4 créditos cada (carga horária de $60 \mathrm{~h}$ ). Completam o rol das disciplinas obrigatórias, outras duas com a atribuição de 2 créditos (carga horária de 30 h) cada: Marcos no Desenvolvimento da Física e Fundamentos Teóricos em Ensino e Aprendizagem. Em síntese, temos um total de 16 créditos de disciplinas que focam conteúdo específico de Física; 4 créditos de disciplinas que focam conteúdos de interesse direto para a prática de sala de aula e 4 créditos de prática de estágio, na qual o mestrando implementa "alguma estratégia inovadora no ensino de Física com o orientador como observador participante, pelo menos em alguns momentos dessa implementação" (conforme ementa da disciplina de Estágio Supervisionado).

Cabe ressaltar que, segundo Moreira (o coordenador da CPG/MNPEF desde 2013), em seu texto "Orientações sobre o currículo do MNPEF", publicado em $2015^{83}$, essa prática de estágio presente no currículo do MNPEF é distinta do estágio na licenciatura. A ênfase está no acompanhamento da prática docente por parte do orientador do Polo, como estratégia para aproximar o docente da universidade da prática docente nas escolas de Educação Básica:

Talvez o estágio supervisionado devesse ser chamado de acompanhamento da prática pedagógica. E por que isso? Porque o(a) orientador(a) não conhece a escola, não sabe qual é a realidade onde atua o mestrando. Então, o estágio supervisionado é uma

\footnotetext{
${ }^{82}$ Documento disponível em: <http://www1.fisica.org.br/mnpef/?q=grade-curricular />. Acessado em: 28 fev 2017.

${ }^{83}$ Esse texto parece ter sido elaborado de forma a complementar e esclarecer eventuais dúvidas de coordenações locais dos Polos relativas às orientações de currículo aprovadas pela CPG. O texto está disponível em: <http://www1.fisica.org.br/mnpef/?q=orienta\%C3\%A7\%C3\%B5es-sobre-o-curr\%C3\%ADculo />. Acessado em: 28 fev 2017.
} 
oportunidade para que o(a) orientador(a) vá a escola e acompanhe a prática do mestrando. Isso pode ocorrer umas poucas vezes, até mesmo uma só se a escola estiver muito longe, o importante é que o(a) orientador(a), que é docente universitário, conheça a escola, entenda o que é ensinar Física na Educação Básica (MOREIRA, 2015).

Moreira, ainda no mesmo texto, esclarece a escolha do MNPEF em enfatizar conteúdos de Física apesar das críticas da comunidade de pesquisadores de ensino de Física, que ressaltam o caráter conteudista da proposta curricular do MNPEF:

Comecemos pelos conteúdos. [...] De fato, ela [a proposta curricular do MNPEF] é conteudista, mas não do tipo conteúdo pelo conteúdo. Conteúdos são importantes, competências sem conteúdos não existem. Mas são importantes do ponto de vista conceitual, fenomenológico e da transferência didática para a sala de aulas do século XXI. [...] É claro que algum formalismo é necessário, mas a ênfase não deve estar no formalismo. [...] $O$ importante é que os professores alunos aprendam esses conteúdos de maneira significativa e sejam capazes de abordá-los com seus alunos no Ensino Médio. É preciso dizer não ao formalismo. Esses professores não serão físicos e seus alunos também não (MOREIRA, 2015).

A justificativa do coordenador da CPG/MNPEF em relação ao currículo do curso também gira em torno da percepção de que, segundo suas próprias palavras, "muitos dos professores de Física estão mal-formados, têm deficiências em Física e Matemática. Nosso problema é recuperá-los, ajudá-los a superar tais deficiências" (MOREIRA, 2015). Assim, o MNPEF, como esse excerto escrito por um de seus fundadores parece indicar, é proposto baseando-se no modelo de déficit (DAY, 2001; OLIVEIRA-FORMOSINHO, 2009): deve ter como um dos maiores objetivos sanar deficiências da formação inicial dos professores-cursistas.

É preciso reconhecer que o texto do coordenador revela a preocupação de que as disciplinas tenham como efeito uma aprendizagem significativa por parte dos professores alunos, caracterizando-a como um domínio conceitual e fenomenológico e uma correspondente competência para sua transposição na sala de aula. No entanto, permanece a dúvida sobre como o corpo docente, formado marjoritariamente por pesquisadores em Física, muitos dos quais com pouca experiência na formação de professores, vai conseguir ajudar os professores-cursistas nessa tarefa. Não parece haver na documentação do curso nenhuma discussão a respeito desse problema. No entanto, em alguns casos foram programadas atividades específicas (seminários, oficinas, workshops,) relacionadas com este tema. Para tanto parecem muito 
importantes espaços para o diálogo entre docentes e alunos professores, para construir atividades eficientes e satisfatórias para ambos.

Completando a matriz curricular, temos o oferecimento de disciplinas optativas, separadas em dois módulos: (a) Experimental/computacional: Atividades experimentais para o Ensino Médio e Fundamental; Atividades Computacionais para o Ensino Médio e Fundamental e (b) Ensino: Processos e Sequências de Ensino e Aprendizagem em Física no Ensino Médio; Física no Ensino Fundamental em uma perspectiva multidisciplinar (todas essas disciplinas com 4 créditos cada). $O$ discente deve cursar uma disciplina de cada módulo. A Tabela 1 apresenta o quadro completo de disciplinas obrigatórias e optativas da grade curricular do MNPEF.

Tabela 1 - Quadro de disciplinas obrigatórias e optativas da grade curricular (2014) do MNPEF.

Disciplinas obrigatórias (créditos)

$\begin{array}{ll}\text { Termodinâmica e Mecânica Estatística (4) } & \text { Marcos no desenvolvimento da Física (2) } \\ \text { Eletromagnetismo (4) } & \begin{array}{l}\text { Fundamentos Teóricos em Ensino e } \\ \text { Aprendizagem (2) }\end{array} \\ \text { Mecânica Quântica (4) } & \text { Estágio Supervisionado (4) } \\ \text { Física Contemporânea (4) } & \end{array}$

Disciplinas Optativas: módulo Experimental/Computacional (créditos)

Atividades Experimentais para o Ensino Médio e Fundamental (4)

Atividades Computacionais para o Ensino Médio e Fundamental (4)

Disciplinas Optativas: módulo Ensino (créditos)

Processos e Sequências de Ensino e Aprendizagem em Física no Ensino Médio (4)

Física no Ensino Fundamental em uma perspectiva multidisciplinar (4)

Fonte: MNPEF-SBF. Disponível em: <http://www1.fisica.org.br/mnpef/?q=grade-curricular/> Acesso em: 11 mar. 2017.

Além do cumprimento dos créditos, para a obtenção do título de Mestre "são necessários o desenvolvimento de um produto educacional e uma dissertação de mestrado em que estejam descritos os processos que culminaram neste produto e sua aplicação em situações de ensino" (Art. 23). No Regimento Geral não há especificações sobre o que se entende por e o que, concretamente, pode ser considerado como produto educacional. É ausente no art. 23 a orientação explícita da realização de pesquisas pelos professores para o planejamento dos produtos 
educacionais ou para avaliação dos mesmos em situações educacionais reais, já que a expressão utilizada remete apenas à descrição dos processos de trabalho pelos professores.

No texto, já citado, "Orientações sobre o currículo do MNPEF", Moreira expõe o que é esperado como produto educacional do MNPEF, enfatizando o seu caráter de inovação para as práticas de sala de aula dos professores da escola de educação básica:

O MNPEF não tem como foco a pesquisa em ensino de Física, mas sim o desenvolvimento de produtos educacionais, a implementação desses produtos em sala de aula e um relato de experiência dessa implementação. [...] O produto educacional pode ser um aplicativo, um texto para o professor, um vídeo, uma estratégia didática, o uso do computador, do celular, etc., em sala de aula para ensinar Física. As possibilidades são muitas, o importante é inovar, gerar um produto, usá-lo em situação real de sala de aula e relatar (na dissertação) o que aconteceu (MOREIRA, 2015, grifo nosso).

Há um entendimento por parte das discussões expostas em capítulos anteriores sobre a natureza e constituição dos MPs que os apontam como cursos onde, em contraponto aos MAs e cursos de Doutorado, não é exigida a produção de pesquisas acadêmicas em Ensino de Física. O próprio coordenador da CPG/MNPEF reforça isso, no trecho destacado da citação acima. Porém, Moreira não descarta a importância das pesquisas acadêmicas, ao colocá-las como ponto de partida para a formação do professor no contexto do MNPEF, ao apontar que

[...] resultados de pesquisa em ensino de Física há muitos, desde os anos setenta do século passado, mas esses resultados não chegam à sala de aulas de Física, ficam nas revistas. O MNPEF é uma boa oportunidade de trazer esses resultados às aulas de Física.

Dessa forma, o MNPEF se constituiria em locus privilegiado onde professores de escolas de educação básica, em geral alheios aos resultados das pesquisas acadêmicas porque distantes do contexto onde são produzidas, poderiam acessar tais conhecimentos. Ao conhecer os resultados das pesquisas atuais em Ensino de Física, o professor teria a oportunidade, a partir de sua formação no MNPEF, de aplicá-las para transformação de suas práticas docentes.

Certamente que, do ponto de vista do desenvolvimento profissional esperado para os professores-cursistas pelo seu envolvimento com o MP, a ampliação do conhecimento acadêmico (tanto científico - ou seja, da área disciplinar - quanto pedagógico - o que o contato com pesquisas da área de Ensino de Física poderia 
proporcionar) é um dos objetivos a se atingir e que será avaliado como dimensão de análise do desenvolvimento profissional dos professores-cursistas que serão entrevistados para a realização dessa pesquisa. No entanto, ressalta-se de antemão, que essa mesma ênfase na importância de pesquisas acadêmicas presentes no discurso propagado pelo coordenador da CPG/MNPEF não parece ser favorecida pelo desenho curricular adotado no MNPEF.

Dentre as disciplinas, sejam obrigatórias ou optativas, constantes na matriz curricular do MNPEF, não há nenhuma que objetive, explicitamente, a aproximação do professor-cursista com a literatura acadêmica atualizada sobre Ensino de Física. Mesmo a disciplina obrigatória Fundamentos Teóricos em Ensino e Aprendizagem, onde poderiam ser selecionados e discutidos tópicos de pesquisas recentes da área, de acordo com o interesse imediato dos professores-cursistas, sua ementa silencia sobre essa possibilidade, já que a disciplina se concentra em "familiarizar professores de Física em serviço com noções básicas de teorias de aprendizagem e ensino como sistema de referência para sua ação docente e análise de questões relativas ao ensino da Física" (conforme a ementa da disciplina na matriz curricular do MNPEF de 2014). Além disso, a abordagem de temáticas específicas do Ensino de Física dificilmente encontra espaço na disciplina com carga horária de 2 créditos, que visa cobrir teorias de ensino de aprendizagem que vão das primeiras teorias behavioristas à pedagogia de Freire $^{84}$. Além dessa disciplina obrigatória, tópicos de pesquisa encontrariam espaço na disciplina optativa Processos e Sequências de Ensino e Aprendizagem em Física no Ensino Médio.

É provável que o contato com essa literatura acadêmica específica do Ensino de Física seja mais intenso na etapa de levantamento bibliográfico realizado individualmente pelos professores-cursistas para o planejamento e desenvolvimento do produto educacional. A pesquisa de campo junto ao corpo docente e discente do polo do MNPEF detalha como ocorre esse contato dos professores-cursistas com a pesquisa acadêmica ao longo do curso, o que não foi possível perceber apenas com essa análise documental.

\footnotetext{
${ }^{84}$ A exceção ocorre na adição do tópico "aprendizagem baseada em games" na ementa dessa disciplina. Há pesquisas acadêmicas na área de Ensino de Física (ou melhor, de Ensino de Ciências, em geral) sobre o uso de games como estratégias para o ensino de conceitos de Física. A escolha desse tópico em específico parece ser motivada pela ênfase na inovação das metodologias utilizadas em sala de aula - com a adoção de TICs - dada no MNPEF que transparece, por exemplo, no estabelecimento das linhas de pesquisa do curso (há uma linha específica para TICs, mas nenhuma outra para qualquer outro tipo específico de metodologia de Ensino de Física).
} 
A análise empreendida acima aponta, enfim, que o modo pelo qual o MNPEF se estrutura e o currículo que é proposto no programa parecem reforçar o modelo tecnicista de formação do professor de Física. Nesse modelo, o professor é considerado um técnico que aplica resultados de pesquisa produzida por outros (no caso, pesquisadores acadêmicos em Ensino de Física) na elaboração de seus produtos educacionais. Nesse sentido, o MNPEF não parece favorecer, dada sua matriz curricular, a aquisição de uma visão crítica ou ao menos de um conhecimento geral sobre tal produção científica e as relações entre essas pesquisas e o contexto de aplicação real de sala de aula. Acrescenta-se ainda, que o fato de não haver representação do corpo discente nos órgãos máximos (em âmbito nacional) do MNPEF, reforça essa concepção. A ausência dessa representação discente acarreta limitações na participação dos professores-cursistas na construção do curso. Cabe verificar se, apesar da falta de representantes discentes, o Conselho e/ou a CPG/MNPEF adota alguma medida para ouvir as demandas e avaliações sobre o curso realizadas pelos próprios professores-cursistas. Esse tipo de ação não é previsto em nenhum dos documentos analisados, porém há a possibilidade de existir alguma iniciativa concreta da administração do MNPEF que caminhe nessa direção. É algo que apenas a pesquisa de campo empreendida nesse trabalho pode indicar.

Ainda sobre a produção de trabalhos de pesquisa no contexto do MNPEF, o Comunicado 09/2015 85 emitida pela CPG/MNPEF reforça a concepção de que

Artigos podem resultar da dissertação, mas não é o objetivo do MNPEF. No MNPEF não se deve forçar a 'pesquisa' e o 'paper'. Devemos fugir da cultura publicacionista que assola a academia, a universidade. Se resultarem artigos ótimo, mas devem ser uma consequência natural de um bom trabalho voltado para o ensino de Física em sala de aula. Vamos criar uma revista para isso, a Revista do Professor de Física, mas insistimos que deve ser uma consequência natural de um bom trabalho. Sites dos Polos também são espaços para divulgar os produtos. A divulgação é importante, mas não na linha do publicacionismo, dos papers, que nunca chegam à sala de aula, aos professores (CPG/MNPEF, 2015).

Nesse excerto, percebe-se um contraponto entre a publicação de papers (relacionado à publicação de pesquisa acadêmica) e a publicação dos produtos educacionais desenvolvidos pelos professores no contexto do MNPEF. Tal divulgação é desejada e incentivada (inclusive com a criação de uma revista direcionada para

85 Disponível em: <http://www1.fisica.org.br/mnpef/?q=comunicados/>. Acesso em: 11 mar 2017. 
isso ${ }^{86}$ ) com a esperança de que a busca por visibilidade para o trabalho desenvolvido no contexto do MP, alcance o público-alvo desses produtos, os professores de Física em geral.

Dando continuidade à análise geral das determinações constantes no Regimento Geral do MNPEF, ainda em relação à conclusão do curso, espera-se que os professores-cursistas o realizem em quatro semestres. Porém, é aberta a possibilidade para que a Coordenação do polo possa "estendê-lo até o máximo de seis semestres por solicitação encaminhada pelo orientador, devidamente justificada, satisfeitas as normas da IES sede do polo" (Art. 26). No Regimento há também a determinação de que todos os estudantes do MNPEF apresentem "um plano de trabalho aprovado pela Coordenação do Polo em até um ano após seu ingresso no curso" (Art. $\left.27^{\circ}\right)$. Não há especificação explícita do que se trata esse plano de trabalho, nem como é feita essa avaliação da Coordenação do polo para sua aprovação. Com respeito à avaliação processual da elaboração do produto educacional, o Regulamento Específico do Polo estudado estabelece um formulário para acompanhamento do progresso dos trabalhos que é preenchido e entregue à Secretaria do Polo todo final de período letivo, até a conclusão do curso e apresentação do produto educacional (Art. 11). O Regulamento também não detalha como é realizada a avaliação desse formulário e quais são, afinal, os itens avaliados.

Quanto à banca examinadora do conjunto dissertação e produto educacional, o Regimento Geral do MNPEF determina que esta deve ser composta por três doutores, ao menos um externo ao programa (Art. 28). Dessa forma, ela guarda semelhanças com o processo de defesa de dissertação acadêmica, pois além disso é formalizada em ato público onde o discente apresenta seu trabalho e é arguido pelos membros da banca (Art. 29). A banca examinadora indicada para cada defesa deve ser apreciada e aprovada pela CPG/MNPEF (Art. 28, $\S 2^{\circ}$ ). As versões finais em formato digital da dissertação e do produto educacional devem ser encaminhadas à Secretaria do MNPEF (Art. 31, § único), que os disponibiliza em uma plataforma do site do MNPEF $^{87}$.

\footnotetext{
${ }^{86}$ A Revista do Professor é uma publicação quadrimestral que objetiva divulgar trabalhos que contribuam para o ensino de temas de Física nos diferentes níveis de ensino. A primeira chamada de trabalhos para comporem o primeiro número da revista foi publicada em fevereiro de 2017. A Revista do Professor pode ser acessada em: <http://periodicos.unb.br/index.php/rpf/index/>. Acesso em: 11 mar 2017.

${ }^{87}$ As dissertações e produtos educacionais do MNPEF podem ser levantados no endereço $<$ http://www1.fisica.org.br/mnpef/?q=defesas />, onde pode-se realizar a busca filtrando-a por Polo e/ou por ano de defesa. Acessado em: 28 fev 2017.
} 
Por fim, os diplomas do MNPEF são emitidos pelas IES que sediam os polos (Art. 32) e constam do título de "Mestre em Ensino de Física" (Art. 33). No Regulamento Local do Polo, a obtenção do título é condicionada ao cumprimento das exigências quanto a créditos e exames (constantes no Regimento Nacional do MNPEF) com o acréscimo da demonstração de conhecimento de uma língua estrangeira (Art. 25, inciso IV), exigência do Regulamento de Cursos de Pósgraduação da IES sede do Polo.

Há três vertentes nas linhas de pesquisa do MNPEF utilizadas para classificar as dissertações e os produtos educacionais desenvolvidos. São elas: (1) Física no Ensino Fundamental (Área de concentração: Física na Educação Básica); (2) Física no Ensino Médio (Área de concentração: Física na Educação Básica); (3) Processos de Ensino e Aprendizagem e Tecnologias de Informação e Comunicação no Ensino de Física (Área de concentração: Formação de professores de Física em nível de mestrado). Na descrição das linhas de pesquisa, ressalta-se o "desenvolvimento de produtos e formas de abordagem visando conteúdos de Física adequados a estudantes do Ensino Fundamental, de forma integrada com outras disciplinas" na primeira; a "atualização do currículo de Física para o Ensino Médio de modo a contemplar resultados e teorias da Física Contemporânea" na segunda e o "desenvolvimento de produtos e processos de ensino e aprendizagem que utilizem tecnologias de informação e comunicação" na terceira ${ }^{88}$. Disto, depreende-se que todas as linhas de pesquisa do MNPEF estão centradas no desenvolvimento de produtos e processos de ensino, estando alinhadas, portanto com o objetivo geral do MNPEF. Há apenas uma linha, a terceira, com metodologia de ensino própria (ou seja, a adoção do uso de TICs para a elaboração dos processos de ensino). As outras duas permitem trabalhos de onde podem emanar propostas metodológicas mais abrangentes e diversificadas.

Por fim, é possível verificar no site oficial do MNPEF, um esforço de sua Coordenação Geral na promoção de eventos sob a forma de workshops e de escolas. Nos primeiros anos do MP, em 2014 e 2015, foram realizados quatro workshops, com apresentação de trabalhos, palestras, mesas redondas e reuniões de coordenadores dos polos. Cada workshop foi realizado em diferentes regiões do Brasil, congregando diferentes grupos de polos. Os dois primeiros workshops, em 2014, aconteceram na UFLA, em Lavras (MG) e no XXXII Encontro de Físicos do Norte e Nordeste, em João Pessoa (PB). Os outros, realizados em 2015, ocorreram na UnB, em Brasília (DF) e na

88 Documento disponibilizado online pela SBF e disponível em: $<$ http://www1.fisica.org.br/mnpef/sites/default/files/Linhas MNPEF.pdf/>. Acesso em: $28 \mathrm{fev}$ 2017. 
UFABC, em Santo André (SP). Nesses dois anos também foram realizadas duas edições da Escola Brasileira de Ensino de Física, na UFABC, em Santo André (SP). Destinados prioritariamente para professores docentes do MNPEF (com participação de professores de Física do Ensino Médio e estudantes de pós-graduação em Ensino de Física restringida à disponibilidade de vagas), esses eventos tiveram como objetivo central

contribuir para uma mudança de paradigmas no ensino de Física, em especial nas disciplinas do MNPEF: sair do paradigma da narrativa, centrado no professor e baseado em aulas expositivas e listas de problemas, e passar para o paradigma da aprendizagem ativa centrado no aluno e baseado em atividades colaborativas, na diversidade de estratégias de ensino e de recursos instrucionais (COMISSÃO ORGANIZADORA I EBEF, 2014). ${ }^{89}$

\subsubsection{Análise documental dos documentos do curso do MP.Local}

O corpus de pesquisa documental do curso de MP.Local é composto pelos seguintes documentos:

- Normas do Programa90;

- Regulamento Geral da Pós-graduação Stricto Sensu da instituição ${ }^{91}$;

- Projeto Pedagógico dos Cursos (PPC) do MP.Local ${ }^{92}$;

- Editais de processos seletivos encontrados no portal da instituição ${ }^{90}$;

- Ementário de disciplinas do MP.Local ${ }^{90}$;

- Três artigos publicados por membros do corpo docente do MP.Local que trazem, ao mesmo tempo, dados objetivos sobre a estruturação do Programa, além de concepções e ideias próprias desses docentes que orientaram (e orientam) a sua construção. Eles são referenciados eventualmente ao longo dessa seção para embasar e/ou complementar determinadas análises empreendidas. A fim de proteger

${ }^{89}$ Retirado do site do evento, disponível em: <https://sites.google.com/site/1ebefis/home />. Acesso em: 17 mar. 2017. A mesma redação é dada na apresentação do II EBEF, disponível em: <http://eventos.ufabc.edu.br/2ebef//>. Acesso em: 17 mar. 2017.

${ }_{90}$ A versão analisada nesse trabalho é a publicada em 2015, disponível no site da instituição

${ }^{91}$ Disponível no site da instituição e acessada no primeiro semestre de 2017 para a realização deste estudo.

92 Anexo à Resolução oㅡ 21 de 15 de julho de 2015, gentilmente cedido pela secretaria do MP.Local. 
a identidade dos docentes e do MP.Local, referimos esses artigos como "Artigo 1" (publicado em 2011), "Artigo 2" (publicado em 2013) e "Artigo 3" (publicado em 2018).

O MP.Local tem a particularidade de congregar cursos de MP, MA e de Doutorado Profissional (recentemente aprovado com primeira turma em 2019). Além disso, diferentemente do MNPEF, é um programa de pós-graduação em Ensino de Ciências e não especificamente em Ensino de Física, o que lhe confere natureza interdisciplinar, como especificado no art. 3ํㅡㄹ das Normas do Programa. Nesse artigo, são especificados os seguintes objetivos para o programa:

I. Aprofundar os conhecimentos adquiridos na graduação;

II. Desenvolver capacidades técnicos-profissionais em ensino de ciências;

III. Promover a competência pedagógica, ética e científica, contribuindo para a formação de docentes e pesquisadores em ensino de ciências;

IV. Qualificar profissionais de alto nível para que possam atuar como pesquisadores autônomos e/ou como docentes (grifos nossos).

Esses objetivos são, em parte, reflexos da missão do MP.Local estabelecida no seu PPC. Elementos relativos ao caráter interdisciplinar do MP.Local e que se referem à extensão também são contemplados:

- Proporcionar formação acadêmica de qualidade a todos que desejam desenvolver 0 ensino e a aprendizagem em ciências, especialmente aos professores que buscam refletir sua prática.

- Impulsionar a Pesquisa em Ensino de Ciências, na interlocução com outras áreas do conhecimento.

- Contribuir para a formação de professores e pesquisadores que possam atuar na educação formal e/ou não-formal, no sentido de transformar a realidade muitas vezes marcada pela precariedade em relação ao ensino de ciências e de matemática.

- Refletir e debater os aspectos sociopolíticos da educação em ciências.

- Realizar divulgação científica, produzir materiais e procedimentos didáticos (p. 13).

Tendo em vista tais objetivos estabelecidos, assim como no MNPEF, o MP.Local também objetiva fornecer subsídios para a melhoria da prática profissional dos professores (art. 3ํㅡㄴ inciso II, das Normas do Programa), porém promovendo outras competências além da técnica (art. $3^{\circ}$, inciso III). Nesse sentido, o seu PPC reforça que "os objetivos do [MP.Local] estão em confluência com os domínios de ensino, pesquisa e extensão, com vistas a promover a melhoria do ensino de ciências nas 
redes públicas e privadas" (p. 18, grifos nossos). Isso reforça a semelhança com o MNPEF, pois ambos os programas têm o objetivo maior de impactar as salas de aula promovendo a melhoria do Ensino de Ciências, porém o MP.Local, ao invés de enfatizar apenas o elemento "ensino" (no sentido de visar ao "desempenho do professor no exercício da sua profissão"), busca abranger concomitantemente as dimensões de ensino, pesquisa e extensão. A dimensão "extensão" é destacada no mesmo documento como necessária para o alcance dos objetivos do MP.Local:

[...] confiamos que esses objetivos só poderão ser alcançados com o efetivo exercício de atividades voltadas para a extensão, tanto com o propósito de ampliar nossas ações de caráter formativo, quanto na perspectiva estrita de divulgar nossos estudos e discussões para escolas de ensino básico da rede pública da [região] por meio de diferentes formas de atuação (palestras, workshops, desenvolvimento de projetos, entre outras ações) (p. 18-19, grifos nossos).

Diferentemente do MNPEF, o MP.Local coloca também como objetivo a formação para a pesquisa, além da docência (art. 3ํㅜㄴ inciso IV, das Normas do Programa). A formação para a pesquisa e a ênfase em extensão se refletem também no seguinte artigo das Normas do Programa: "Os cursos do [MP.Local] possuem ênfase em ensino-aprendizagem, formação de professores, divulgação científica e produção de material didático" (art. $4^{\circ}$, grifos nossos).

Esse programa, portanto, se caracteriza por apresentar objetivos mais abrangentes que os do MNPEF, certamente por abrigar, além do MP, um curso de MA e o doutorado profissional. Ressalta-se que os artigos supracitados das Normas e as referências ao PPC não fazem distinções entre o curso profissional e o acadêmico, onde se infere que os objetivos gerais expostos são almejados por ambos. As imbricações entre o MP e o MA surgem em outras esferas do Programa, como será indicado ao longo da análise.

$\mathrm{Na}$ introdução do $P P C$ analisado, encontram-se dados sobre os debates realizados por ocasião da expansão do Programa com a criação do MA (implementado apenas a partir de 2014, seis anos após a criação do Programa com o MP, em 2008). Um Grupo de Trabalho (GT) composto por docentes credenciados no Programa e outros docentes da instituição (inclusive de outros campi onde há cursos de especialização lato sensu em Ensino de Ciências ${ }^{93}$ ) encabeçaram tais discussões, realizadas entre 2012 e 2013. Na expectativa de ampliar o Programa e também de

${ }^{93}$ Esses cursos são os seguintes: Especialização em Ensino de Ciências com Ênfase em Biologia e Química, e Especialização em Ensino de Ciências e Matemática. 
expandi-lo para outros campi $i^{94}$ da instituição, o GT investiu na defesa de "não migração" do MP para o MA (ou seja, se posicionaram contra a supressão do curso profissional para a criação do acadêmico) e da "garantia de uma coexistência equilibrada dos dois cursos em um Programa que os pressupõe sem predileção, garantindo-os identidades próprias" (p. 6). Há uma preocupação de os cursos não "concorrerem" entre si, seja disputando o mesmo público-alvo ou a atenção dos docentes do Programa.

Essas identidades próprias são parcialmente reveladas nas diferenças entre 0 MP e o MA marcadas nas Normas sempre através de adendos especificados para o MP, como será indicado mais adiante. Em outras palavras, o MP.Local é um curso que segue as mesmas normas do MA do mesmo Programa, acrescidas de outras específicas para o MP.

No "Artigo 2" (2013), os docentes nos auxiliam a marcar com maior ênfase essas identidades do MA e do MP. Os autores indicam que, pensando na diferenciação dos objetivos de cada curso, o corpo docente do MP.Local adotou o posicionamento de irem contra a adoção de características que confiram dualidades entre o MA e o MP. Assim, rejeitam o MA como propedêutico para o doutorado e lugar de pesquisa básica, enquanto o MP seria voltado para a formação técnica e pesquisa aplicada. A fim de diferenciar os objetivos dos cursos, assumem que "o MP tem um olhar especialmente qualificado para a extensão, sem que isso signifique tratar de forma secundária a proximidade do ensino e da pesquisa" e cuja "característica extensionista" ganha forma, justamente, "através da confecção do produto educacional" (p. 329, grifos nossos). Enquanto, para o MA, "não há expectativa de que o mestrando [...] se incline para algum lado da tríade ensino, pesquisa e extensão, pois o foco é o próprio percurso da pesquisa, a construção do projeto, a formação do curso e a relação com o orientador" (p. 330), para o MP, "o produto educacional é o objetivo principal", que deve vir "seguido de uma dissertação" (p. 329) relacionada a esse produto.

O art. 6ำ das Normas do curso é expressão dessas diretrizes. O referido artigo, determina que para o MP, "a dissertação será uma reflexão fundamentada sobre o produto educacional que deverá contemplar, no mínimo, um dos formatos" dentre os seguintes:

I. Mídias educacionais (vídeos, simulações, animações, experimentos virtuais, áudios, objetos de aprendizagem, aplicativos de modelagem,

\footnotetext{
${ }^{94}$ Que pareceu começar a se concretizar em 2016, com o lançamento de Processo Seletivo Interno para Credenciamento de Docentes de Programa de Pós-graduação Stricto Sensu em Ensino de Ciências Mestrado Acadêmico e Mestrado Profissional.
} 
aplicativos de aquisição e análise de dados, ambientes de aprendizagem, páginas de internet e blogs, jogos educacionais etc.);

II. Protótipos educacionais e materiais para atividades experimentais;

III. Propostas de ensino (sugestões de experimentos e de outras atividades práticas, sequências didáticas, propostas de intervenção etc.);

IV. Materiais textuais (manuais, guias, textos de apoio, artigos em revistas técnicas ou de divulgação, livros didáticos, paradidáticos, histórias em quadrinhos etc.);

V. Materiais interativos (jogos, kits e similares);

VI. Atividades de extensão (exposições científicas, cursos de curta duração, oficinas, ciclos de palestras, exposições, atividades de divulgação científica etc.);

VII. Desenvolvimento de aplicativos;

VIII. Organização de eventos;

IX. Programas de rádio e TV.

No edital de processo seletivo para o MP.Local ${ }^{95}$ inferimos o perfil de ingressante almejado. O edital admite como candidatos, provavelmente dada a natureza interdisciplinar do programa, graduados de outras áreas que não a licenciatura (porém a preferência é dada aos licenciados, através de uma maior pontuação ao título de licenciatura na etapa de análise de currículo), porém devem ser "profissionais [...] que atuem na educação científica, especialmente os professores das Ciências da Natureza e Matemática atuando na educação básica, no ensino superior ou no ensino nãoformal de ciências" (item 1.2 do edital $n^{\circ}$ 60/2016). Observa-se também que 0 programa reserva $5 \%$ das vagas oferecidas no processo seletivo aosb candidatos declarados Pessoas com Deficiência e $15 \%$ das vagas para autodeclarados negros ou indígenas ${ }^{96}$.

O processo seletivo para ingresso no MP.Local é composto por três etapas, todas com mesmo peso para composição da nota final (com exceção do exame de proficiência em Língua Inglesa): 1. Prova escrita de caráter eliminatório/classificatório: avalia conhecimentos específicos através de questões discursivas. A bibliografia indicada no edital é composta por artigos da área de Ensino de Ciências que abordam temas sobre pesquisa em ensino, história e filosofia da ciência, currículo, ensino por investigação, CTS e análise de livro didático; 2. Exame de Proficiência em Língua Inglesa de caráter obrigatório, mas não eliminatório. Caso o ingressante não seja avaliado como apto (nota no exame abaixo de 6,0) nesse primeiro exame, poderá

\footnotetext{
${ }^{95}$ Foi analisado o edital no 61/2016, disponível no site da instituição e acessado no primeiro semestre de 2017 para a realização desta pesquisa.

${ }_{96}$ Diretrizes comuns aos concursos públicos de cargos de instituições federais.
} 
realizar até dois outros exames antes de seu Exame de Qualificação; 3. Análise de currículo e arguição, de caráter eliminatório e classificatório, onde o candidato é pontuado pela sua formação acadêmica, produção acadêmica e técnica e experiência profissional e é arguido pela banca examinadora também pelos motivos e expectativas em ingressar no MP. Observa-se que na tabela de pontuação utilizada para avaliação do currículo, a produção acadêmica (artigos publicados em periódicos ou anais de eventos ou, ainda, resumos publicados em anais de eventos) é mais valorizada (quantitativamente, pontua cinco vezes mais) que a produção técnica (onde se considera produtos educacionais desenvolvidos, palestras e/ou cursos proferidos, patentes ou registros de software educativo). Em relação à pontuação relativa à experiência profissional, valoriza-se experiência na educação básica, no ensino superior, em espaços não-formais e como bolsista de iniciação científica ou iniciação à docência da mesma forma. Assim, não necessariamente os recém-formados se encontrarão em desvantagem em relação aos candidatos que já tenham alguns anos de experiência profissional após graduados.

Quanto à oferta de bolsas, além daquelas especificadamente ofertadas pela Capes para o MA, há quatro bolsas institucionais fomentadas pelo campus (em atendimento à alunos tanto do MA como para o MP), ofertadas a partir de 2015 , segundo o PPC do curso. Não há especificações, nos documentos analisados, do procedimento adotado para a seleção desses bolsistas.

A organização administrativa do MP.Local, conforme exposta nas Normas do Programa consiste em um Colegiado do [Programa] (CPG-[Programa]) que é composto pelos Colegiados dos Programas de Pós-Graduação das modalidades Profissional e Acadêmico (art. 13). Portanto, é constituído pelos coordenadores dos cursos que constituem o Programa (cuja atuação na presidência da CPG-[Programa] é alternada entre eles a cada seis meses); por todos os docentes permanentes dos cursos e por um representante discente de cada curso, eleito entre os seus pares (art. 14). Os coordenadores de curso, por sua vez, são docentes permanentes do MP.Local e servidores efetivos da instituição e são eleitos pelos membros docentes que compõem o CPG-[Programa] (Art. 19, $§ 1^{\circ}$ ). As atribuições do CPG-[Programa] envolvem a execução dos cursos e seu acompanhamento. Além das funções executivas, aos coordenadores dos cursos do MP compete representar o Programa e/ou o curso que coordena junta à órgãos colegiados, ao campus e a Pró-Reitoria de Pesquisa, Inovação e Pós-Graduação da instituição. Diferentemente do MNPEF, há uma proximidade entre as decisões sobre o MP e sua execução, no sentido de que 
são os próprios docentes e discentes envolvidos no CPG-[Programa] que pensam, vivem e avaliam o curso.

O corpo docente é composto por doutores ou livre-docentes, majoritariamente servidores da própria instituição. Há a possibilidade, através de estabelecimento de termo de cooperação ou convênios, do credenciamento de docentes de outras instituições (art. 21, das Normas). Os docentes podem se credenciar como permanentes, quando colaboram regularmente com as atividades do curso; colaboradores, quando atuam de forma complementar ou eventual e visitante, no caso de docente que possui vínculo com outra instituição, mas passa a atuar de forma regular no curso (art. 22). Dentre as exigências e atribuições de todo docente do [Programa], especificadas no artigo 24 das Normas, destaca-se, no inciso II, a exigência de "ter produção acadêmica e técnica relevante e continuada em Ensino de Ciências, considerando o documento da área de Ensino (CAPES/MEC)" (grifos nossos). No artigo 30, a respeito de credenciamento e recredenciamento de docentes, enfatiza-se que essa avaliação, de responsabilidade do CPG-[Programa], se dá "com base na produção acadêmica e técnica na área de Ensino" (grifos nossos).

Esses artigos enfatizam a preocupação em compor o corpo docente do programa com sujeitos que tenham uma trajetória já estabelecida no campo da pesquisa em Ensino de Ciências. Isso porque, em relação aos docentes credenciados até 2017 no MP.Local, observamos uma diversidade de formações acadêmicas, que podem ser verificadas no edital do processo seletivo de 2016 (edital no 60/2016), na seção de apresentação do corpo docente e as linhas de pesquisa em que cada um atua. Entre esses docentes, há doutores em áreas de pesquisa específicas (Física, Química, Antropologia Social, Ecologia, Ciências Sociais, Ciências, Ciências Físicas, Ciências em Engenharia Nuclear) e com formação em áreas da Educação (e Ensino de Biociências e Saúde, Educação em Ciências e Saúde). A admissão de docentes com formações diversas favorece o caráter interdisciplinar do Programa.

A matriz curricular também é estruturada com base na interdisciplinaridade. $O$ $P P C$ especifica a busca de "um equilíbrio entre os dois cursos de mestrado e o doutorado" (p. 22) em sua estrutura curricular de forma a:

I. materializar uma proposta integrada de matriz curricular entre o MP e o MA, mas, ao mesmo tempo, garantindo suas especificidades;

II. incluir mais discussões de cunho ético, filosófico, epistemológico e/ou sociológico inseridas na Educação em Ciências;

III. aproximar temas de fronteiras às questões de ensino e aprendizagem em Ciências 
IV. garantir diálogo mais próximo entre Humanidades e Ciências Naturais;

V. não desassociar a pesquisa em Ciências (e, consequentemente, o pesquisador) da pesquisa em Educação em Ciências (e, consequentemente, do Educador em Ciências) (p. 23).

Ao seguir essas diretrizes para a construção das disciplinas oferecidas no Programa, vemos que o corpo docente está interessado em conciliar a convivência do $M P$ e do MA no mesmo Programa, e não de contrapor as duas modalidades de mestrado, um direcionamento que evita a cisão entre teoria e prática e que se distancia de propostas utilitaristas, mercadológicas e oportunistas ("Artigo 1", 2011). A oposição à crítica de os MPs serem orientados para aplicações pragmáticas é explícita no item $V$, destacado acima, onde se determina a não separação entre "pesquisa em Ciências" e a "pesquisa em Educação em Ciências". Assim, a expectativa não é que os professores (Educadores em Ciência) tenham acesso ao que pesquisadores (outros especialistas que não eles mesmos) produzem em termos de pesquisa em Ensino de Ciências e as aplique em seu mundo profissional (algo almejado no contexto do MNPEF). A expectativa do Programa, implícita nessas diretrizes, é a de sobrepor os dois "mundos" (o do pesquisador e o do educador) de forma mais entrelaçada possível. Os professores-cursistas do MP.Local não apenas executarão o que foi pesquisado por outrem (pesquisadores), mas poderão obter conhecimentos que os permita eles mesmos serem pesquisadores. A formação oferecida no Programa é "ampliada e estabelecida por meio da pesquisa necessária para elencar problemas e encaminhar propostas/soluções" (p. 18, do PPC), de modo que no MP qualifique-se professores "que desejem fazer pesquisa aplicada na área de Ensino de Ciências" (p. 19, do PPC, grifos nossos).

A organização das disciplinas busca atender às identidades de cada curso ofertado no Programa. As disciplinas que refletem a identidade do MP, todas de 2 ou 3 créditos, são estruturadas em:

(a) Estudos/Debates Conceituais em __: disciplinas obrigatórias, mais genéricas, mais conceituais, de caráter mais formativo (interseção entre o MP e o MA);

(b) Tópicos de/em : disciplinas eletivas, de escolha específica de acordo com o perfil do mestrando dentro das linhas e dos projetos, que tratam de uma primeira aproximação com tópicos da pesquisa em Ensino de Ciências (identidade do MP) (p. 23, do $P P C$, grifos nossos)

A Tabela 2 expõe todas as disciplinas ofertadas no Programa que os professores-cursistas matriculados no MP podem cursar. 
Tabela 2 - Quadro de disciplinas ofertadas no MP.Local (2015)

\begin{tabular}{|c|c|c|c|c|}
\hline DISCIPLINA & NÚCLEO & CURSO & SITUAÇÃO & CRÉDITOS \\
\hline \multirow{2}{*}{$\begin{array}{l}\text { Conceitos fundamentais } \\
\text { de ensino de ciências }\end{array}$} & \multirow[t]{2}{*}{ Comum } & \multirow[t]{2}{*}{ MP/MA/D } & Obrigatória (M) & \multirow[t]{2}{*}{2} \\
\hline & & & Optativa (D) & \\
\hline \multirow{2}{*}{$\begin{array}{c}\text { Formação de } \\
\text { professores de ciências }\end{array}$} & \multirow[t]{2}{*}{ Comum } & \multirow[t]{2}{*}{ MP/MA/D } & Obrigatória (M) & \multirow[t]{2}{*}{2} \\
\hline & & & Optativa (D) & \\
\hline $\begin{array}{l}\text { Metodologia da } \\
\text { pesquisa }\end{array}$ & Comum & MP/MA & Obrigatória & 2 \\
\hline $\begin{array}{l}\text { Debates conceituais no } \\
\text { ensino de física }\end{array}$ & Específico & MP/MA & Obrigatória & 2 \\
\hline $\begin{array}{l}\text { Debates conceituais no } \\
\text { ensino de química }\end{array}$ & Específico & MP/MA & Obrigatória & 2 \\
\hline $\begin{array}{l}\text { Debates conceituais em } \\
\text { educação ambiental }\end{array}$ & Específico & MP/MA & Obrigatória & 2 \\
\hline $\begin{array}{l}\text { Currículo e programas } \\
\text { do ensino de ciências }\end{array}$ & Específico & MP/MA/D & $\begin{array}{l}\text { Obrigatória (MP) } \\
\text { Optativa (MA/D) }\end{array}$ & 2 \\
\hline Divulgação científica & Específico & MP/MA/D & $\begin{array}{l}\text { Obrigatória (MP) } \\
\text { Optativa (MA/D) }\end{array}$ & 2 \\
\hline $\begin{array}{l}\text { Ciências: debates } \\
\text { éticos, históricos e } \\
\text { epistemológicos }\end{array}$ & Comum & MP/MA & $\begin{array}{l}\text { Obrigatória (MP) } \\
\text { Eletiva I (MA) }\end{array}$ & 2 \\
\hline $\begin{array}{l}\text { Ética, Educação e } \\
\text { Sociedade }\end{array}$ & Comum & MP/MA/D & $\begin{array}{l}\text { Optativa (MP/D) } \\
\text { Eletiva I (MA) }\end{array}$ & 2 \\
\hline Políticas educacionais & Comum & MP/MA/D & Optativa & 2 \\
\hline $\begin{array}{l}\text { Ciência, tecnologia e } \\
\text { sociedade }\end{array}$ & Comum & MP/MA/D & Optativa & 2 \\
\hline $\begin{array}{l}\text { Produção de material } \\
\text { didático }\end{array}$ & Comum & MP & Obrigatória & 2 \\
\hline $\begin{array}{l}\text { Informática aplicada ao } \\
\text { ensino de ciências }\end{array}$ & Comum & MP & Obrigatória & 2 \\
\hline $\begin{array}{l}\text { Desenvolvimento de } \\
\text { Produtos Educacionais }\end{array}$ & Comum & MP & Optativa & 2 \\
\hline
\end{tabular}




\begin{tabular}{|c|c|c|c|c|}
\hline & & & & (continuação) \\
\hline $\begin{array}{l}\text { Tópicos de Física } \\
\text { Clássica }\end{array}$ & Específico & MP & $\begin{array}{l}\text { Obrigatória } \\
\text { alternativa }\end{array}$ & 2 \\
\hline $\begin{array}{c}\text { Tópicos de Física } \\
\text { Quântica }\end{array}$ & Específico & MP & $\begin{array}{l}\text { Obrigatória } \\
\text { alternativa }\end{array}$ & 2 \\
\hline Tópicos em química I & Específico & MP & $\begin{array}{l}\text { Obrigatória } \\
\text { alternativa }\end{array}$ & 2 \\
\hline Tópicos em química II & Específico & MP & $\begin{array}{l}\text { Obrigatória } \\
\text { alternativa }\end{array}$ & 2 \\
\hline $\begin{array}{l}\text { Tópicos em educação e } \\
\text { saúde }\end{array}$ & Específico & MP & $\begin{array}{l}\text { Obrigatória } \\
\text { alternativa }\end{array}$ & 2 \\
\hline $\begin{array}{c}\text { Tópicos em educação } \\
\text { ambiental }\end{array}$ & Específico & MP & $\begin{array}{l}\text { Obrigatória } \\
\text { alternativa }\end{array}$ & 2 \\
\hline $\begin{array}{l}\text { Prática de Ensino } \\
\text { Supervisionado I }\end{array}$ & $\begin{array}{l}\text { Pesquisa e } \\
\text { Extensão }\end{array}$ & MP & Obrigatória & 2 \\
\hline $\begin{array}{l}\text { Prática de Ensino } \\
\text { Supervisionado II }\end{array}$ & $\begin{array}{l}\text { Pesquisa e } \\
\text { Extensão }\end{array}$ & MP & Obrigatória & 2 \\
\hline $\begin{array}{l}\text { Dissertação de } \\
\text { Mestrado I }\end{array}$ & $\begin{array}{l}\text { Pesquisa e } \\
\text { Extensão }\end{array}$ & MP/MA & Obrigatória & 3 \\
\hline $\begin{array}{l}\text { Dissertação de } \\
\text { Mestrado II }\end{array}$ & $\begin{array}{l}\text { Pesquisa e } \\
\text { Extensão }\end{array}$ & MP/MA & Obrigatória & 3 \\
\hline $\begin{array}{l}\text { Dissertação de } \\
\text { Mestrado III }\end{array}$ & $\begin{array}{l}\text { Pesquisa e } \\
\text { Extensão }\end{array}$ & MP/MA & Obrigatória & 3 \\
\hline $\begin{array}{l}\text { Dissertação de } \\
\text { Mestrado IV }\end{array}$ & $\begin{array}{l}\text { Pesquisa e } \\
\text { Extensão }\end{array}$ & MP/MA & Optativa & 0 \\
\hline $\begin{array}{l}\text { Dissertação de } \\
\text { Mestrado V }\end{array}$ & $\begin{array}{l}\text { Pesquisa e } \\
\text { Extensão }\end{array}$ & MP & Optativa & 0 \\
\hline
\end{tabular}

Fonte: Projeto Pedagógico do [Programa] (Anexo à Resolução no 21 de 15 de julho de 2015).

O professor-cursista matriculado no MP.Local tem que cumprir o total de créditos em cada núcleo e situação de disciplinas como apresentado na Tabela 3: 
Tabela 3 - Totais de créditos para o curso do MP.Local (2015).

\begin{tabular}{ll}
\hline TOTAL MÍNIMO DE CRÉDITOS & CRÉDITO \\
\hline $\begin{array}{l}\text { 10 disciplinas obrigatórias, excetuando-se } \\
\text { Dissertação de Mestrado I, II e III e PES I e II }\end{array}$ & 20 \\
2 disciplinas obrigatórias alternativas & 4 \\
2 disciplinas optativas, excetuando-se Dissertação & 4 \\
de Mestrado IV e V & \\
Dissertação de Mestrado I, II e III & 9 \\
Prática de Ensino Supervisionado I e II & 4 \\
TOTAL DE CRÉDITOS DO MESTRADO \\
PROFISSIONAL
\end{tabular}

Fonte: Projeto Pedagógico do [Programa] (Anexo à Resolução no 21 de 15 de julho de 2015).

Qualitativamente, a análise do Ementário das disciplinas do MP, nos indica a predominância de disciplinas onde há discussões sobre processo de ensinoaprendizagem (exemplo, disciplinas Conceitos fundamentais do ensino de ciências e Produção de material didático) não necessariamente em termos de teorias de aprendizagem (oriundas da Psicologia), mas de um ponto de vista, digamos, mais próximo da prática profissional. Há disciplinas que abordam diferentes metodologias de ensino (como as disciplinas Informática aplicada ao ensino de ciências e Ciência, tecnologia e sociedade); que levantam discussões históricas e epistemológicas sobre a Ciência (disciplinas Ciências: debates históricos, éticos e epistemológicos e Debates conceituais no ensino de física); e que promovem discussões mais abrangentes sobre educação (disciplinas Formação de professores de ciências; Políticas educacionais e Currículo e programas do ensino de ciências), incluindo até mesmo discussões éticas (disciplina Ética, educação e sociedade). Com base nesse panorama, depreende-se que a ênfase da matriz curricular do MP.Local não está na abordagem de conteúdos específicos de Física (tratados em apenas duas disciplinas: Tópicos de física clássica e Tópicos de física quântica), mas sim, encontra-se diluída na diversidade de temas levantados. Inclui-se nesses temas discussões sobre pesquisa (disciplina Metodologia de pesquisa) e sobre o produto educacional (disciplina Desenvolvimento de produto educacional). 
Especificamente sobre a produção acadêmica e técnica ${ }^{97}$, é possível observar nas Normas do Curso a expectativa de produção discente, já que "as produções acadêmicas, técnicas e educacionais dos docentes deverão, preferencialmente, ter discentes do [Programa] como coautores" (art. 33, grifos nossos). Na realidade, a apresentação de documento que comprove a "submissão de, pelo menos, um (1) artigo a um periódico com Qualis que atenda aos critérios para ser classificado entre os estratos A1 e B3 da área de Ensino (área 46) da CAPES" (art. 58, § 1º, inciso I) é exigência mínima para o agendamento da defesa pública de dissertação de mestrado. A aproximação com o modus operandi acadêmico se evidencia também com a exigência de se "ter assistido a, pelo menos, duas (2) defesas de dissertação de mestrado ou tese de doutorado do [Programa]" (art. 58, $\S 1^{\circ}$, inciso II).

Com a preocupação de atender, no MP, ao "mestrando trabalhador, engajado nas questões que cercam a sua condição de professor, com todas as suas dificuldades [...] riqueza de exemplos e de vontade de resgatar o seu papel na sociedade"; sob a motivação de promover "a crítica e reflexão constantes" ("Artigo 1", 2011 , p. 11) e, ainda, criticando a oposição realizada ao MP a partir do ponto de vista do MA, que acreditam fortalecer "a cisão entre teoria (mérito atribuído ao 'acadêmico') e prática (tarefa atribuída ao Profissional)" é que membros do corpo docente dizem "que a forma encontrada para enfrentar todos esses desafios [...] foi a de pecar por excesso de rigor" (p. 12). Esse rigor transparece nas exigências realizadas aos docentes (nos processos de (re)credenciamento) e aos discentes (disciplinas, atividades acadêmicas, produções, elaboração de dissertação e produto educacional); mecanismos com critérios próximos dos adotados por cursos acadêmicos conceituados. Em sua própria avaliação, parte do corpo docente do MP.Local acredita que "esse pecar por excesso (exigir a dissertação e o produto)" - apesar desse modelo "muitas vezes, apresentar-se árduo para orientando e orientador" - "foi o que deu qualidade ao curso" ("Artigo 2", 2013, p. 323). Essa qualidade é atestada pela boa avaliação alcançada pelo curso na avaliação quadrienal feita pela Capes: nota $5^{98}$.

Devido à exigência da elaboração da dissertação em conjunto com o produto educacional, a duração máxima de conclusão do MP é de 30 meses, enquanto que para o MA é de 24 meses. Ambos os cursos contam com a possibilidade de

\footnotetext{
97 "Entende-se por produção técnica/educacional, em um mestrado profissional na área de Ensino, os itens descritos no documento da área (CAPES - Área Ensino), dentre eles manuais, aplicativos, materiais didáticos, relatórios técnicos, vídeos, DVDs, protótipos, textos paradidáticos, artigos sobre relatos de experiências didáticas e materiais de divulgação científica, entre outros" (art. 36, das Normas do Curso).

${ }_{98}$ Sendo que a nota máxima que pode ser atribuída aos mestrados profissionais é cinco (5). A referida avaliação quadrienal é do ano de 2017 (Fonte: Plataforma Sucupira, CAPES).
} 
prorrogação por até 6 meses a critério do CPG-[Programa] (art. 9 das Normas do Programa).

Nesse período determinado, os professores-cursistas devem cumprir com as exigências de créditos mínimos em disciplinas, e obter êxito em três etapas de avaliação obrigatórias em diferentes momentos do curso (que também se aproximam de avaliações tipicamente executadas em cursos acadêmicos). São elas:

- Seminário de Projeto de Pesquisa: atividade obrigatória para os cursos de pós-graduação stricto sensu da instituição (capítulo IV, do Regulamento Geral). No [Programa], seu "objetivo principal é avaliar a pertinência e o potencial para o desenvolvimento do projeto de pesquisa de mestrado" (art. 42, das Normas do Programa). Está vinculada à disciplina de Dissertação de Mestrado I (art. 43) e consiste em exposição oral do projeto de pesquisa pelo aluno, seguida de arguição da Comissão de Avaliação, constituída por dois doutores credenciados no Programa (Art. 43, 46). Nesse processo, os seguintes aspectos são avaliados:

clareza na escrita e na exposição oral, capacidade de síntese, potencial para obtenção do produto educacional no caso do aluno de mestrado profissional, prazo para obtenção de dados preliminares para o exame de qualificação e para a defesa da dissertação de mestrado [...] e contribuição para área de Ensino de Ciências (art. 47).

- Exame de qualificação ${ }^{99}$ : etapa obrigatória prevista também no Regulamento Geral (capítulo V). Tem como objetivo "avaliar o desenvolvimento da pesquisa". Avaliase "a qualidade do material resultante da execução parcial do projeto de pesquisa e a possibilidade de o discente defender sua dissertação de mestrado [...] no prazo" (art. 50). O Exame de Qualificação é uma das atividades obrigatórias da disciplina Dissertação de Mestrado II, é fechado ao público e tem "caráter de uma reunião de trabalho" (art. 51). A Comissão de Avaliação dessa etapa é composta por dois docentes doutores credenciados no [Programa], um deles tendo, obrigatoriamente, participado da Comissão de Avaliação do Seminário de Projeto de Pesquisa do aluno; além do orientador (art. 52).

- Defesa: culmina a conclusão do curso, portanto, deve ser realizada após o cumprimento de "todos os créditos exigidos para o curso e as exigências curriculares", além de comprovar atuação no [Programa] (participação como ouvinte de ao menos

${ }^{99}$ Nas Normas do Programa não há referência à avaliação do produto educacional nem na etapa de Exame de Qualificação, nem na Defesa. Subentende-se, apesar disso, que ele é avaliado em conjunto com a dissertação, admitindo a complementaridade entre essas duas produções no contexto do MP. 
duas defesas de mestrado) e a produção acadêmica (submissão de ao menos um artigo) (art. 58). Na defesa, o discente apresenta uma dissertação de mestrado que poderá ser redigida na forma de texto monográfico ou de encarte de artigos científicos relacionados ao objeto de investigação da pesquisa (art. 55). A Banca Examinadora de Mestrado é composta por três membros titulares: o orientador (presidente da Banca), um membro interno (docente credenciado no [Programa]) e um membro externo (credenciado em outro Programa de Pós-graduação Stricto Sensu da área de Ensino) (art. 56). A avaliação considera os seguintes aspectos: clareza e coerência na escrita da dissertação ou tese e na exposição oral e contribuição para a área de Ensino de Ciências (art. 59).

Cumpridas todas as etapas de avaliação com êxito, o discente faz jus ao título de "Mestre em Ensino de Ciências", título comum tanto à concluintes do MP, quanto do MA.

As dissertações e produtos educacionais realizados no MP.Local são vinculados a projetos de pesquisa, por sua vez associados a linhas de pesquisa. Das três linhas de pesquisa "que refletem os projetos de pesquisa do corpo docente e as disciplinas dos cursos [Programa]" (PPC, p. 17), duas abrangem a produção do MP: (I) Processos de ensino e de aprendizagem e produção de material didático para o ensino de ciências e (II) Formação de professores de ciências $^{100}$. Cada uma dessas linhas de pesquisa se desdobram em Projetos de Pesquisa: (A) Processo de ensino e aprendizagem no ensino da saúde e do ambiente e (B) Processos de ensino e aprendizagem no ensino de ciências da natureza, para a linha (I); (C) Divulgação científica na formação de professores de ciências e (D) Formação de professores de ensino de ciências, para a linha (II). Essas linhas de pesquisa e projetos vinculados alteraram-se ao longo do processo de consolidação do MP.Local, tendo em vista o perfil do ingressante no curso demandar ajustes, "no sentido de melhorar o atendimento das expectativas do público interessado, além de contribuir, de forma mais eficiente, para as demandas de educação e formação de professores de ciências da região no qual o curso está localizado" ("Artigo 1", 2011, p. 13-14). Especificamente, as linhas de pesquisa sofreram modificações e chegaram ao formato atual "para que maior atenção seja dada ao ensino formal, além de associar ao projeto de educação ambiental a discussão de educação em saúde" (Ibidem, p. 14). A Tabela 4 sintetiza essas informações e dá mais detalhes sobre os projetos de pesquisa associados a cada linha.

100 A terceira linha de pesquisa, (III) Reflexões sobre o ensino de ciências na contemporaneidade é exclusiva do mestrado acadêmico. 
Tabela 4 - Linhas de pesquisa e projetos associados (2015) do MP.Local.

Linha de pesquisa (I) - PROCESSOS DE ENSINO E DE APRENDIZAGEM E PRODUÇÃO DE MATERIAL DIDÁTICO PARA O ENSINO DE CIÊNCIAS

Objetiva fomentar estudos em ensino de ciências nos seus aspectos, abordando as práticas pedagógicas desenvolvidas em sala de aula e a produção de material didático entre outros elementos.

PROJETOS DE PESQUISA ASSOCIADOS

\section{(A) PROCESSOS DE ENSINO E APRENDIZAGEM NO ENSINO DE SAÚDE E DO AMBIENTE}

Avalia as mediações efetuadas pelos professores de ciências nas diretrizes curriculares, associando os aspectos do ambiente e da saúde, além de refletir sobre os elementos históricos e sociológicos da construção do conhecimento científico, no que tange as temáticas citadas.

\section{(B) PROCESSOS DE ENSINO E APRENDIZAGEM NO ENSINO DE CIÊNCIAS DA NATUREZA}

Discute o ensino de física e química, complementando e aprofundando conhecimentos adquiridos na graduação, com vistas a avaliar a utilização de recursos de informática, multimídia e vídeo, além do desenvolvimento de materiais didáticos e experimentos.

Linha de pesquisa (II) - FORMAÇÃO DE PROFESSORES DE CIÊNCIAS

Discute a formação inicial e continuada de professores de ciências, a partir da análise curricular e histórica bem como os processos de divulgação e popularização da ciência envolvidos nesse processo de formação dos professores.

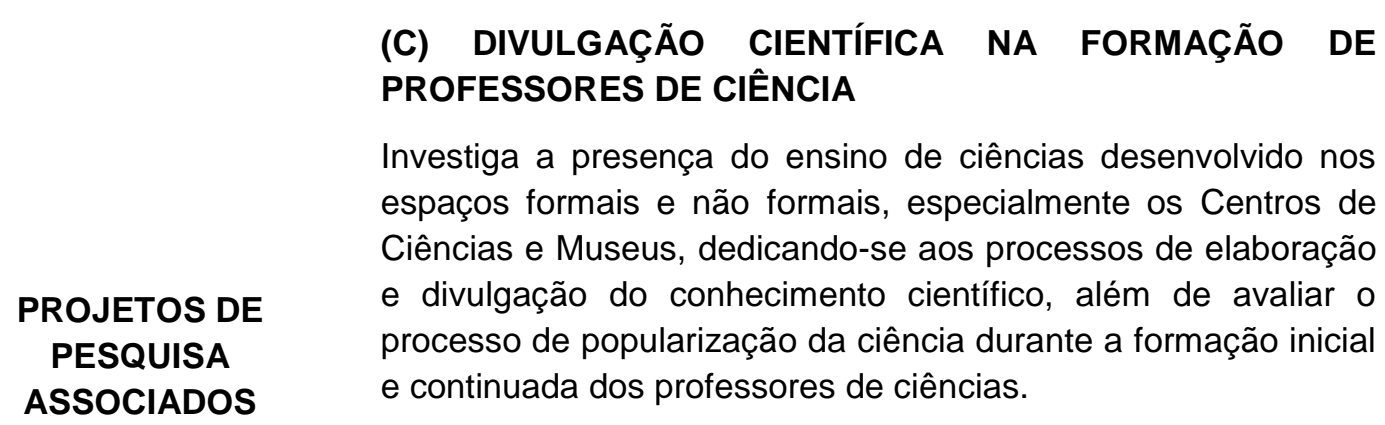

\section{(D) FORMAÇÃO DE PROFESSORES DE ENSINO DE CIÊNCIAS}

Investiga as ações de ensino de ciências desenvolvidas nos espaços formais de ensino, analisando aspectos referentes à formação inicial e continuada dos professores de ciências.

Fonte: Projeto Pedagógico do [Programa] (Anexo à Resolução no 21 de 15 de julho de 2015) e

Processo seletivo para o MP.Local (Edital ํㅜ 61/2016). 
Descrevemos também a infraestrutura oferecida pelo MP.Local para a realização dos cursos. Tal infraestrutura foi conquistada com o apoio aos projetos fomentados pela Fundação de Amparo à Pesquisa do Estado, enumerados no PPC do MP.Local. Os laboratórios estruturados no âmbito do MP.Local são associados ao Laboratório de Estratégias Didáticas (LED) e trabalham de forma integrada. São eles: o Núcleo de Criação Áudio-Visual (NUCA), que ainda conta com a parceria do curso de graduação em Produção Cultural do campus; o Laboratório de Produção Gráfica (LPG), minigráfica que auxilia na produção dos produtos educacionais; o Laboratório de Estratégias Virtuais de Aprendizagens (LEVIA) e, por fim, o Laboratório de Ambiente e Saúde (LAS).

Por fim, apontamos que no início de 2019, é lançado o primeiro processo seletivo do Doutorado Profissional em Ensino de Ciências do programa (Edital no 001/2019, disponibilizado no site da instituição). O objetivo do curso de Doutorado Profissional, de acordo com esse edital é

[...] formar profissionais pesquisadores que possam conduzir projetos de desenvolvimento e investigação e produzir conhecimento de forma autônoma, aprofundando conhecimentos científicos, culturais, artísticos e/ou tecnológicos por meio de um estudo prático e/ou metodológico, com base em um referencial teórico, tendo como finalidade a elaboração e apresentação de uma tese e um produto educacional (art. 1.1).

Apesar de indefinições decorrentes de falta de clareza ainda presentes em documentos oficiais e discussões no âmbito da Capes em relação ao que se espera para o perfil de um doutorado profissional e questionando posicionamentos apontados na comunidade de pesquisadores em Educação que rechaçam a modalidade profissional como vinculada (e submissa) ao setor produtivo ("Artigo 3", 2018), este programa sai na vanguarda na proposição e aprovação do primeiro curso de doutorado profissional da área, sobre o propósito de se equiparar as modalidades acadêmica e profissional com o oferecimento dos níveis de mestrado e doutorado. A expectativa é a de que se ofereça aos professores já mestres profissionais, a oportunidade de formação em nível de doutorado na mesma modalidade,

compreendendo que para os DP [doutorados profissionais] deve-se oportunizar mais tempo de reflexão e ação aos professores pósgraduandos, expondo-os ao debate, possibilitando mais imersão no campo de pesquisa-trabalho, despertando preocupação com o rigor teórico-metodológico, provocando recorrência aos incômodos que resultam na pergunta de pesquisa (o problema) relacionada à sua prática cotidiana (Ibid., p. 67). 


\subsubsection{Apreciações sobre a análise documental dos documentos dos cursos}

As análises empreendidas a partir dos dados obtidos na análise documental nos permitem compreender que há diferenças fundamentais na concepção, nas finalidades e no modus operandi dos cursos de MP investigados.

Essas diferenças aparecem em diversos aspectos da estruturação e rotina dos programas e podem ser consideradas mais ou menos subjetivas. Elas aparecem, por exemplo:

- na própria concepção dos programas, tendo em conta seus objetivos e finalidades: no MNPEF, a ênfase recai em desenvolvimento de técnicas e produtos e formação para a melhoria do desempenho do professor de Educação Básica (privilegiando os processos de ensino, portanto), enquanto no MP.Local, busca-se desenvolver também capacidades técnicas e profissionais, porém em uma perspectiva mais abrangente ao privilegiar a formação de competências pedagógicas, éticas e científicas, integrando ensino, pesquisa e extensão, além de aproximar a formação do professor de educação básica à de um pesquisador;

- na concepção de matriz curricular: onde se verifica o foco em disciplinas de conteúdo específico de Física no MNPEF e em disciplinas que favoreçam a interdisciplinaridade e discussões de cunho ético, filosófico, epistemológico e sociológico no MP.Local;

- no acompanhamento e avaliação do desenvolvimento do produto educacional e da dissertação: que, no contexto do MP.Local, de certa forma aproxima-se de um mestrado acadêmico, com a realização, por exemplo, de Exame de Qualificação, etapa não exigida no MNPEF, além da existência de outras exigências no MP.Local como a submissão de artigo para a defesa de dissertação e produto educacional;

- no perfil do corpo docente credenciado em cada programa: diferentemente do MP.Local, programa que estabelece, como critério para credenciamento, a obrigatoriedade de produção acadêmica e técnica em Ensino de Ciências, o MNPEF dá margem para a participação de docentes de áreas específicas da Física que não necessariamente têm experiência prévia com a área de Ensino;

- no perfil do corpo discente ingressante em cada programa: que se exprime de modo indireto no modo em que os processos seletivos de ambos os programas são organizados. A prova escrita do MNPEF, de um lado, aborda os conteúdos específicos típicos de disciplinas de Física Geral, enquanto o MP.Local, por outro lado, tem como 
bibliografia de sua prova escrita artigos da área de pesquisa em Ensino de Ciências. Essa diferença entre os processos seletivos pode ser determinante para a seleção, por exemplo, no MP.Local, de professores que já tenham contato prévio e mais aprofundado com a área de pesquisa em Ensino;

- no entendimento do papel da pesquisa na formação do professor-cursista de cada um dos programas: que é diferenciada principalmente pela proximidade entre MP e MA no contexto do MP.Local, o que não ocorre com o MNPEF; entre outras.

O perfil dos MPs analisados, enfim, nos leva a diferenciá-los considerando o grau de exigência e de flexibilidade de cada um. Levando em conta as características depreendidas dessa análise documental, o MP.Local apresenta-se como um curso exigente em suas atividades acadêmicas propostas, porém flexível, por tratar-se justamente de um MP Local, a proximidade entre corpo docente e discente parece permitir um maior diálogo e possibilidades de ajustes de modo a atender da melhor forma possível as demandas dos professores-cursistas e as finalidades de formação pretendidas no curso, o que de fato ocorre, por exemplo na determinação das linhas e projetos de pesquisa do Programa. O MNPEF, por outro lado, pode ser descrito como um curso prescritivo, por conta da rigidez de suas atividades propostas. Por ser um MP de abrangência nacional e com gestão centralizada, a distância entre corpo discente atendido e corpo docente que efetivamente pensa o curso (essencialmente membros do Conselho de Pós-graduação do MNPEF) pode dificultar o diálogo que indicaria as demandas dos professores-cursistas e a avaliação da efetividade das atividades desenvolvidas nos polos para o alcance das finalidades pretendidas pelo curso.

Por fim, no contexto geral da pesquisa empreendida, a análise documental dos MPs, como uma primeira etapa de pesquisa, nos permitiu elaborar questionamentos particulares, que auxiliam na busca de respostas à questão de pesquisa da tese. Esses questionamentos são respondidos com o auxílio dos dados obtidos nas outras etapas de pesquisa empírica com os sujeitos de pesquisa (docentes, discentes e egressos dos cursos) e na análise da produção dos cursos (dissertações e produtos educacionais). Entre os questionamentos surgidos no processo dessa análise, temos:

No contexto do MNPEF:

- Como é estabelecido o contato dos professores-cursistas com a pesquisa da área de Ensino de Ciências?

- Qual é a dinâmica estabelecida entre os professores-cursistas e os orientadores que não têm formação específica na área de Ensino de Ciências? Em 
qual medida os orientadores conhecem questões relacionadas ao Ensino e a realidade das escolas que os professores-cursistas trabalham? O acompanhamento do Estágio Supervisionado colabora para a ampliação desses conhecimentos por parte do corpo docente do curso?

- Há algum mecanismo que permita que o corpo discente dos mais diversos polos possa levantar reivindicações a serem consideradas pela gestão central (Conselho e Comissão de Pós-graduação) do curso?

- Como é realizada a avaliação do plano de trabalho dos professores-cursistas ao longo do curso?

- A produção dos professores-cursistas reflete o objetivo de que ocorra a mudança de paradigma no ensino de Física, para o "paradigma da aprendizagem ativa", como defendido nos eventos promovidos pelo MNPEF? Isso se reflete na prática profissional dos professores e no seu desenvolvimento profissional?

- No âmbito do polo, qual é a infraestrutura oferecida aos professores-cursistas que apoiam sua formação nas disciplinas e o desenvolvimento do produto educacional?

No contexto do MP.Local:

- Como os docentes e discentes do MA e do MP se relacionam no programa? Quais seriam as influências da aproximação com o MA no desenvolvimento profissional do professor-cursista do MP?

- Quais são as relações entre o ensino, pesquisa e extensão no MP?

- No que as atividades ditas de extensão promovidas pelo programa podem impactar no desenvolvimento profissional dos professores-cursistas? Há impactos diretos nas escolas?

- Como é o diálogo entre docentes e discentes? Como é o processo de orientação?

- Como é concretizada a interdisciplinaridade preconizada pelo programa?

- No que a produção acadêmica exigida do professor-cursista impacta em seu desenvolvimento profissional? 


\subsection{0 corpo docente dos cursos de mestrado profissional}

Nessa seção é apresentado o levantamento de dados junto ao corpo docente de cada curso de MP. Aqui, os dados são compostos por informações objetivas que ajudam a caracterizar o corpo docente dos cursos (número de docentes em cada curso, apontamentos sobre formação inicial, pós-graduada e sobre projetos de pesquisa e produções acadêmicas, e linhas de pesquisa em que atuam). Essas informações foram levantadas nos documentos oficiais dos cursos, em suas páginas na internet e na plataforma Lattes. Dados obtidos de entrevistas semi-estruturadas realizadas com membros do corpo docente e coordenadores de cada curso também são apresentados em forma de análises com elementos narrativos.

A base do roteiro utilizado em cada uma das entrevistas com os coordenadores é apresentada abaixo, no apêndice 1 . O roteiro foi montado a partir de perguntas gerais (destacadas no quadro apresentado no apêndice 1), em torno das quais se desdobraram outras questões específicas, a fim de detalhar o tema levantado por cada pergunta geral. Todas essas perguntas foram pensadas de modo a possibilitar a coleta de dados que permitissem o cumprimento dos objetivos delimitados para a pesquisa.

Ressalta-se que não foram realizadas todas as perguntas do quadro ipsi litteris. As perguntas que se desdobram das gerais têm papel de auxiliar na coleta e posterior constituição dos dados mais relevantes para a análise que se pretende realizar. Muitas perguntas não precisaram ser realizadas, pois o(a) entrevistado(a) falou espontaneamente sobre alguns temas que eram importantes para a pesquisa, sem que este precisasse ser perguntado. Lembrando também que, por se tratar de entrevistas semi-estruturadas, houve a flexibilidade na elaboração de outras perguntas e comentários que não estavam contidos no roteiro base e que surgiram no momento da entrevista.

Além das perguntas apresentadas, o roteiro também foi composto por perguntas particulares para cada coordenador entrevistado. Foram perguntas que abordaram especificidades de cada curso. Elas surgiram da análise documental e visaram esclarecer dúvidas e levantar as percepções dos coordenadores sobre alguns aspectos dos cursos.

O apêndice 2 apresenta as perguntas formuladas como base para o roteiro de entrevistas realizadas com membros do corpo docente dos cursos. Mais uma vez, perguntas específicas puderam ser acrescentadas ao roteiro dirigido para a entrevista 
de determinado docente, tendo em vista as especificidades do curso ao qual pertence, ou de sua formação ou atuação acadêmica e profissional.

A fim de permitir uma aproximação mais clara com os dados coletados nas entrevistas e de sintetizá-los, já efetuando um primeiro nível de análise em busca de respostas à questão de pesquisa, ou, ainda, indicações para a realização das outras etapas de pesquisa, optamos pela elaboração de uma análise da trajetória dos professores com a articulação de seus depoimentos em entrevista em análises com elementos narrativos, reconstruindo, de modo coerente, a história dos cursos de MP estudados e as experiências vividas pelos docentes desses cursos, além de suas concepções e visões sobre sua atuação e a formação proporcionada aos professorescursistas no contexto de cada curso.

Essa escolha é embasada na ideia de que as narrativas permitem o estudo das inúmeras formas como os seres humanos experimentam o mundo (GALVÃO, 2005). A linguagem apresenta uma "potencialidade de organização de sentido que, posta em prática [...] traz à superfície imagens, histórias que foram sendo cruciais ao longo de um percurso pessoal" (p. 328). Enquanto as pessoas contam suas histórias de vidas baseadas na experimentação do mundo, o "investigador que utiliza o método da narrativa as descreve e faz construção e reconstrução das histórias pessoais e sociais, de acordo com um modelo interpretativo de acontecimentos" (GALVÃO, 2005, p. 328).

Há dois diferentes enfoques sobre as narrativas (PEREIRA, $2006^{101}$ apud FREITAS; FIORENTINI, 2007): a análise de narrativas e a análise narrativa. A análise de narrativas utiliza as narrativas como dados da pesquisa e elas são objetos das análises. A análise narrativa gera uma narrativa como produto da análise que é construída com base em descrições de eventos e outros acontecimentos. $\mathrm{Na}$ análise narrativa, "o narrador fornece tanto o contexto como a interpretação, permitindo ao pesquisador uma compreensão mais orgânica e histórica do processo de vir a ser e de desenvolver-se professor" (FREITAS; FIORENTINI, 2007, p. 66). É inspirado nesse último enfoque que acrescentamos à análise os elementos narrativos que são apresentados a seguir.

Por fim, as análises com elementos narrativos escritas no contexto desse trabalho apresentam características específicas que surgiram da adequação aos dados obtidos e dos objetivos de pesquisa. Assim, essas análises, como será visto adiante, são mais descritivas e interpretativas. Não se constituem, portanto, de um

\footnotetext{
${ }^{101}$ PEREIRA, J. E. D. Pesquisa de histórias e vida e os contextos sócio-culturais na formação docente. In: Encontro Nacional de Didática e Prática de Ensino (ENDIPE), 13, 2006, Recife. Anais..., Recife, 2006. CD-ROM.
} 
enredo próprio com início, meio e fim e que tem como objetivo ilustrar, em etapas, o desenvolvimento de um processo mais ou menos linear, como em narrativas comuns. Foram construídas a partir de dados que se constituem unidades de significado por responderem perguntas específicas do roteiro de entrevistas, e foram interpretadas com base em análise de etapa anterior e de referencial teórico pertinente.

\subsubsection{Corpo docente do polo do MNPEF: dados gerais e análise com elementos narrativos}

O polo do MNPEF investigado iniciou suas atividades em 2013, contando com um corpo docente que envolvia oito membros. Desses docentes iniciais, apenas um não permaneceu no quadro de docentes permanentes, tendo se desligado do Programa. Com o passar dos anos, outros docentes foram credenciados. Os dados atualizados (de junho de 2017) obtidos na consulta realizada na Plataforma Sucupira $^{102}$, da Capes, nos indicam a composição do corpo docente do programa em 2017. A fim de manter a identidade dos docentes em sigilo, utilizamos para nos referenciar a cada um, uma sigla que se inicia com Do.MNPEF (para identificar que trata-se de um docente do Polo do MNPEF), seguida de uma numeração "01", "02", "03" etc. Na Tabela 5 dispomos da identificação de cada docente, sua situação de credenciamento junto ao programa (como docente permanente, colaborador ou visitante) e da especificação de formação básica e pós-graduada e de produção de pesquisa de cada um. Esses últimos dados foram todos obtidos por meio de consultas à Plataforma Lattes.

\footnotetext{
102 Dados acessados na opção "Coleta Capes". Disponível em: <https://sucupira.capes.gov.br />. Acesso em: 26 jun 2017.
} 
Tabela 5 - Dados, atualizados em junho de 2017, do corpo docente do polo do MNPEF.

\begin{tabular}{|c|c|c|c|c|}
\hline DOCENTE & $\begin{array}{l}\text { SITUAÇÃO } \\
\text { NO } \\
\text { PROGRAMA } \\
\text { (ANO DE } \\
\text { CREDENCIA } \\
\text { MENTO) }\end{array}$ & $\begin{array}{l}\text { FORMAÇÃO } \\
\text { INICIAL }^{103}\end{array}$ & $\begin{array}{l}\text { FORMAÇÃO PÓS- } \\
\text { GRADUADA }\end{array}$ & $\begin{array}{c}\text { PRODUÇÃO GERAL } \\
\text { DE PESQUISA }\end{array}$ \\
\hline $\begin{array}{l}\text { Do.MNPEF- } \\
01^{*}\end{array}$ & $\begin{array}{c}\text { Permanente } \\
\text { (2013) }\end{array}$ & $\begin{array}{l}\text { Bacharelado } \\
\text { em Física; } \\
\text { Licenciatura } \\
\text { em } \\
\text { Matemática }\end{array}$ & $\begin{array}{c}\text { Mestrado Profissional } \\
\text { em Ensino de Física e } \\
\text { Matemática; } \\
\text { Doutorado em História } \\
\text { das Ciências e das } \\
\text { Técnicas e } \\
\text { Epistemologia }\end{array}$ & $\begin{array}{l}\text { Na área de Ensino, } \\
\text { envolvendo temas } \\
\text { como Formação de } \\
\text { Professores e História } \\
\text { e Filosofia da Ciência }\end{array}$ \\
\hline $\begin{array}{l}\text { Do.MNPEF- } \\
02\end{array}$ & $\begin{array}{c}\text { Permanente } \\
\text { (2013) }\end{array}$ & $\begin{array}{l}\text { Licenciatura } \\
\text { em Física }\end{array}$ & $\begin{array}{c}\text { Mestrado e Doutorado } \\
\text { em Física }\end{array}$ & $\begin{array}{c}\text { Na área de Física, } \\
\text { com ênfase em Física } \\
\text { Estatística }\end{array}$ \\
\hline $\begin{array}{l}\text { Do.MNPEF- } \\
0^{\star 3^{\star *}}\end{array}$ & $\begin{array}{c}\text { Permanente } \\
\text { (2015) }\end{array}$ & $\begin{array}{l}\text { Graduação } \\
\text { em Física }\end{array}$ & $\begin{array}{l}\text { Mestrado em Física, } \\
\text { Doutorado em } \\
\text { Geofísica }\end{array}$ & $\begin{array}{l}\text { Na área de Física. } \\
\text { Projeto de extensão } \\
\text { em área de Ensino. }\end{array}$ \\
\hline $\begin{array}{l}\text { Do.MNPEF- } \\
04\end{array}$ & $\begin{array}{c}\text { Permanente } \\
\text { (2013) }\end{array}$ & $\begin{array}{l}\text { Graduação } \\
\text { em Física }\end{array}$ & Doutorado em Física & $\begin{array}{l}\text { Grande parte na área } \\
\text { de Física, mas com } \\
\text { participação em } \\
\text { alguns projetos de } \\
\text { Ensino }\end{array}$ \\
\hline $\begin{array}{l}\text { Do.MNPEF- } \\
05\end{array}$ & $\begin{array}{c}\text { Permanente } \\
\text { (2013) }\end{array}$ & $\begin{array}{l}\text { Bacharelado } \\
\text { em Física }\end{array}$ & $\begin{array}{l}\text { Mestrado e Doutorado } \\
\text { em Ciências Físicas }\end{array}$ & $\begin{array}{l}\text { Grande parte na área } \\
\text { de Física, mas com } \\
\text { participação em } \\
\text { alguns projetos de } \\
\text { Ensino }\end{array}$ \\
\hline $\begin{array}{l}\text { Do.MNPEF- } \\
06\end{array}$ & $\begin{array}{c}\text { Permanente } \\
\text { (2013) }\end{array}$ & $\begin{array}{l}\text { Bacharelado } \\
\text { em Física }\end{array}$ & $\begin{array}{l}\text { Mestrado e Doutorado } \\
\text { em Física Básica }\end{array}$ & $\begin{array}{l}\text { Grande parte na área } \\
\text { de Física, alguns } \\
\text { artigos e trabalhos } \\
\text { apresentados em } \\
\text { congressos na área de } \\
\text { Ensino }\end{array}$ \\
\hline
\end{tabular}

(continua)

\footnotetext{
${ }^{103}$ Alguns docentes identificam no currículo Lattes a formação inicial apenas como "graduação em Física", sem distinguir bacharelado de licenciatura.
} 
(continuação)

$\begin{array}{cccc}\text { Do.MNPEF- } & \text { Permanente } & \begin{array}{c}\text { Graduação } \\ \text { em Física }\end{array} & \begin{array}{c}\text { Mestrado e Doutorado } \\ \text { em Física }\end{array}\end{array}$

\section{DO.MNPEF- \\ Permanente} $08^{\star \star *}$ (2015)
Do.MNPEF- Permanente 09 **
Do.MNPEF- Permanente $10^{\star \star \star *}$
(2015)

Do.MNPEF-

11

Permanente

(2013)

\section{Graduação em Física}
Mestrado e Doutorado em Engenharia Nuclear

Bacharelado em Física
Mestrado e Doutorado
em Física
em Física
edo e Doutorado
Mestrado e Doutorado em Física

$\mathrm{Na}$ área de Física.

Projetos de Pesquisa

na produção de

materiais didáticos

Na área de Física

Graduação
em Física

Graduação

em Física
Na área de Física.
Participação em projetos de extensão de divulgação científica
Na área de Física.
Participação em projeto de extensão de divulgação científica e orientação de projetos de alunos do ensino médio.

*Instituição conveniada A - campus 1

**Instituição conveniada A - campus 2

***Instituição conveniada B

**** Instituição conveniada C

Cabe registrar que houve dificuldades para a realização desta etapa de pesquisa. A primeira entrevista foi realizada no final de 2016, com o membro do corpo docente identificado por Do.MNPEF-07, coordenador do curso naquele momento. No entanto, não obtivemos respostas ao contatar outros diferentes membros, através de seus emails institucionais em diferentes momentos da realização da pesquisa, para o agendamento de entrevistas. Outra entrevista, além da realizada com Do.MNPEF-07, só foi possível pouco antes da conclusão desta tese, no primeiro semestre de 2019, com a docente identificada por Do.MNPEF-01.

No decorrer do trabalho, descobrimos que a recusa à participação de pesquisas havia sido uma decisão coletiva do Colegiado do Polo, por meio da consulta à Ata da 17ª Reunião Ordinária do Colegiado do MNPEF, realizada em agosto de 2018. A ata encontra-se disponível publicamente no site da instituição que sedia o polo. Nela encontra-se a decisão tomada pelos membros participantes: 
No item 10 [da pauta daquela reunião], o presidente da reunião falou sobre os convites recebidos para discentes e docentes participarem de pesquisas de mestrado e doutorado referentes ao MNPEF, onde é solicitado que se responda um formulário com várias perguntas a respeito do curso como um todo. O Colegiado discutiu sobre as consequências e as implicações dessas pesquisas para o PROFIS de uma maneira em geral. O Colegiado aprovou por unanimidade que alunos que recebam e-mails solicitando participação em pesquisa não devem responder e devem comunicar à Coordenação do Polo para ciência e tomada de decisão. (ata da $17^{\mathrm{a}}$ Reunião Ordinária do Colegiado do MNPEF, grifos nossos)

Dessa forma, os dados desta etapa de pesquisa referentes ao MNPEF são parciais, dado a baixa adesão dos docentes na participação da pesquisa. Algumas dificuldades desse tipo também foram encontradas na última etapa de pesquisa, com o convite aos egressos para a realização de entrevistas. Um dos egressos contatados também declinou de sua participação se referindo à decisão do polo, outros, não deram nenhuma resposta aos nossos contatos.

Com relação à entrevista realizada com o coordenador Do.MNPEF-07, ao roteiro de perguntas básicas da entrevista realizada com o coordenador (apresentado no início do capítulo), acrescentaram-se questões específicas sobre: o fato desse curso em especial envolver um convênio formado por diferentes instituições; atividades do coordenador no polo; como o polo se adapta à organização centralizadora do MNPEF, que, entre outras coisas, acarreta na proposta curricular inflexível; a questão de financiamento do curso; e a participação em eventos promovidos pela CPG/MNPEF. $\mathrm{Na}$ entrevista com a docente Do.MNPEF-01 foi utilizado como base o roteiro direcionado aos docentes apresentado anteriormente.

Apresentamos na sequência a análise com elementos narrativos derivada da transcrição integral e leitura analítica das duas entrevistas. Ao longo da análise destacamos falas da transcrição original das entrevistas, como dados que embasam os pontos relatados. Além disso, da análise empreendida, novos questionamentos surgiram. Devido à escolha metodológica de encaminhamento do percurso de pesquisa (a ideia de construção de espirais de acordo com a qual cada ciclo de análise fornece pequenos questionamentos que orientarão e enriquecerão o novo ciclo de coleta de dados - de modo que coleta de dados e análises sejam feitos concomitantemente de forma cada vez mais abrangente), optamos por sublinhar esses questionamentos, a fim de não os perder de vista. Eles serão sintetizados ao final da seção.

O primeiro grupo de docentes envolvidos na criação do polo (aqueles que estão credenciados no programa desde 2013) já tinha interesse em atuar com a área de Ensino de Física da educação básica, apesar de, como é possível visualizar na Tabela 
5, apenas uma docente (Do.MNPEF-01) desse grupo (docente de uma instituição conveniada) ter formação acadêmica nessa área. Do.MNPEF-01 conta que sua participação foi fundamental para a criação do polo, principalmente por, como Do.MNPEF-07 apontou, ser a responsável, desde os primeiros anos do curso, pelas disciplinas de conteúdo não relacionado à Física Básica da matriz curricular de disciplinas obrigatórias do MNPEF (as disciplinas Fundamentos Teóricos em Ensino e Aprendizagem e Marcos no desenvolvimento da Física). O restante dos docentes tem formação na área de Física (comumente referida de "área dura"), embora alguns deles já se envolvessem com projetos de extensão de Ensino.

Essa é a característica da formação dos docentes dessa instituição já que nesse campus só há o curso de Bacharelado em Física. Em particular, os docentes, mais próximos de escolas de educação básica devido aos projetos de extensão, percebiam uma demanda latente dos professores de Física dessas escolas. Essa demanda, sob o ponto de vista de Do.MNPEF-07, era movida principalmente pela procura por novas metodologias de ensino que os ajudassem a despertar o interesse pela Física nos estudantes da educação básica:

Do.MNPEF-07: [...] nós tínhamos uma demanda que a gente sentiu que estava represada de professores da região para conseguir introduzir metodologias na sala de aula que diferenciasse [as aulas para os] alunos. Os professores em geral que vêm fazer esse mestrado tem certa frustração até... Você sente uma angústia, quando a gente faz uma entrevista de seleção a gente sente nitidamente... Você sente uma angústia, porque "eu não consigo capturar a atenção de meus alunos e estou querendo fazer uma coisa diferente e eu não sei como é que vou fazer". E nós aqui, a gente olhou e falou, "bom, a gente tem a capacidade de proporcionar isso de alguma maneira".

Assim, a demanda dos professores percebida por Do.MNPEF-07, estaria relacionada, em termos do desenvolvimento profissional, principalmente ao aprimoramento das dimensões atualização de conhecimentos pedagógicos, organização e condução de ensino (reveladas na busca por novas metodologias de ensino) e sustentação da aprendizagem (por sua vez, revelada no desejo de despertar interesse para o estudo nos alunos).

Posteriormente, após a implantação do polo do MNPEF no campus ficaria claro ao corpo docente que o curso atenderia não apenas os professores de Física das cidades vizinhas, mas também professores de regiões um pouco mais distantes. Isso é destacado como indicador da demanda supracitada e justifica a criação do polo do MNPEF nessa instituição em específico. 
Destacou-se também como motivação do grupo docente na implantação do polo, a possibilidade de tornar institucionais as iniciativas individuais de aproximação com escolas de educação básica:

Do.MNPEF-07: Tinha mais um envolvimento dos professores [da universidade] do que da instituição com as escolas. E aí quando a gente abriu o polo, a gente até viu que seria legal, porque a gente poderia ter o envolvimento institucional mesmo e mais amplo do que simplesmente o que uma pessoa consegue fazer com uma ou outra escola.

Inclusive, a manifestação de interesse da instituição em sediar um polo do MNPEF ocorreu por iniciativa do grupo de professores interessado no Ensino, que é apenas uma parte dos docentes de Física da instituição. Por conta do curso de Especialização em Ciências de sua instituição, Do.MNPEF-01 conta que existia uma parceria anterior entre os docentes de sua instituição e do restante do corpo docente lotados na instituição que sedia o polo do MNPEF. Com a notícia da criação do MNPEF, viram o potencial de se instalar um polo do MP na cidade. Como na instituição de Do.MNPEF-01 a proposta seria inviável por conta do baixo número de doutores na área à época, a parceria institucional foi atraente para todos. $\mathrm{Na}$ realidade, por essas dificuldades de seu campus, Do.MNPEF-01 relata que o convênio institucional não foi imediato, embora ela fosse docente convidada do curso desde seu início.

Na instituição de Do.MNPEF-07, que se estabeleceu como instituição sede do MNPEF e que, diferentemente da instituição conveniada de Do.MNPEF-01, não oferecia cursos de licenciatura, muitos docentes davam mais valor à pesquisa básica e, apesar de não se oporem a essa iniciativa de criação do polo, não consideraram participar do programa: "[a iniciativa] foi bem vista em geral, mas nós não conseguimos converter corações e mentes, por exemplo, para pegar gente que não era, que não dá tanta importância à área de ensino, e começar a fazer dar" (Do.MNPEF-07). Após as primeiras defesas, entretanto, o programa passou a ter maior visibilidade entre docentes de outros departamentos (Química e Matemática) também interessados em Ensino e em implantar cursos de MP em Rede para professores das áreas em que atuam.

Apesar da expectativa citada de envolvimento institucional na aproximação com as escolas com a criação do MP, as entrevistas realizadas com o coordenador Do.MNPEF-07 e a docente Do.MNPEF-01 não forneceram dados suficientes para saber: 1 . Como é o envolvimento dos docentes com as escolas de educação básica nas quais trabalham os professores-cursistas que orientam no MP; 2 . O que significou 
em termos concretos o envolvimento institucional nos projetos que passaram a ser desenvolvidos nas escolas de educação básica no contexto do MP.

Pela matriz curricular do MNPEF, vimos que a aproximação do docente orientador com a realidade da escola de educação básica se daria de forma direta por meio da disciplina de Estágio Supervisionado, onde se espera que ele vá acompanhar a aplicação do produto educacional pelo professor-cursista. O objetivo desse acompanhamento, segundo os idealizadores do programa, como vimos na análise documental, seria o de abrir uma possibilidade de o orientador da universidade conhecer a realidade da educação básica. Do.MNPEF-07 entende que a presença do orientador na escola teria como finalidade "acompanhar a aplicação do produto e corrigir eventuais desvios de rota”. É possível perceber o entendimento de uma perspectiva mais centrada na elaboração do produto e não como oportunidade para o conhecimento do contexto de aplicação desse produto. De qualquer forma, o coordenador relatou que na maior parte das vezes os orientadores do MNPEF não acompanham seus orientandos nas escolas, devido às outras tarefas que devem cumprir na universidade (outras orientações, disciplinas, reuniões, pesquisa...). Também porque muitos professores-cursistas vêm de cidades mais distantes da sede do polo, o que dificulta a logística. Questiona-se assim se a relação com as escolas de educação básica realmente mudou em algum aspecto com a implantação do MP. Também questiona-se como os orientadores poderiam "corrigir eventuais desvios de rota" já que a maioria deles não teria formação acadêmica na área de ensino, nem experiência na educação básica.

Motivações pessoais são fundamentais para justificar o envolvimento individual dos docentes no projeto de instauração do polo. Do.MNPEF-01 tinha formação diferenciada com relação ao restante do corpo docente inicial do polo, pois além de ser da área de Ensino de Física, tinha realizado uma pós-graduação em um mestrado profissional de outra instituição federal, tendo um interesse na área de formação de professores. Particularmente, ela dá uma grande importância às ações de formação continuada e aos MPs, dada a escassez dessas políticas no passado e sua própria vivência em se formar no nível de pós-graduação conciliando os estudos e a pesquisa com seu trabalho profissional. Visualiza a proposta dos MPs como "uma das políticas, uma das ações ou uma das 'soluções', entre aspas, que se encontrou ao longo do tempo para eu ver pessoas que eu vejo como eu, tendo oportunidade de fazer mestrado" (Do.MNPEF-01).

Para Do.MNPEF-07, essa motivação veio de uma "crise pessoal muito grande", decorrente do início de suas atividades docentes no curso de Bacharelado em Física. 
Ele conta que na primeira disciplina que lecionou nesse curso, de Física I, aprovou apenas cinco discentes, do total de 60 . Esse fato motivou um momento de reflexão que o levou a pesquisar estratégias diferenciadas para o ensino de graduação:

Do.MNPEF-07: Como é que eu passo num concurso para ser professor e reprovo [...] cinqüenta e tantos de uma turma de 60? Entrei em crise! Aí que eu fui tropeçar no peer instruction, no just in time, e a segunda turma de Física I que eu peguei, eu já entrei nesse método de ensino [...] ele diverge fortemente do cuspe e giz. Então eu já estava nesse espírito.

O "espírito" referido por Do.MNPEF-07 é aquele que foi cultivado, em sua visão, no polo do MNPEF: envolve a implementação de metodologias e abordagens de ensino diferenciadas das tradicionais (o "cuspe e giz"), numa perspectiva de renovação das práticas de ensino em busca de melhores resultados de aprendizagem. Por conta dessa experiência prévia com uma nova metodologia em substituição das aulas tradicionais, Do.MNPEF-07 se sente motivado em participar da criação do polo do MNPEF.

É importante destacar qual é o entendimento, por parte do coordenador, do "espírito do curso", expressão que ele utiliza várias vezes ao longo da entrevista. Ao discutir sobre a estrutura do curso, mais especificamente sobre sua matriz curricular, o entendimento que ele dá a esse termo fica explícito: o espírito do curso do MNPEF, estaria relacionado a promover discussões - no âmbito das disciplinas e no desenvolvimento do produto educacional - sobre metodologias de ensino diferenciadas que podem ser aplicadas diretamente em contexto de sala de aula da educação básica: "a gente sempre tenta [...] chegar e dar atividades para eles [professores-cursistas] durante as aulas que a gente [fala] 'olha, isso daqui dá para você usar na sua sala de aula'" (Do.MNPEF-07). É, de certa forma, uma preocupação pela ampliação do repertório didático dos professores, o que implicaria em impactos na dimensão organização e condução de ensino de desenvolvimento profissional. Em relação às disciplinas, o coordenador explica que "o espírito próprio das disciplinas não é fazer o professor virar um fazedor de contas". Porém, revela que isso tem se tornado um "dilema" para o corpo docente, pois diz que "estamos sentindo que nossos alunos saem daqui, mas ainda não conseguem fazer essas contas básicas de maneira apropriada e a gente está nesse dilema agora. Como é que a gente vai conseguir ser conteudista sem violar o espírito do MNPEF" (Do.MNPEF-07). Isso revela preocupação dos docentes em o curso obter também sucesso na atualização dos conhecimentos científicos dos professores-cursistas. Inclusive sendo essa a ênfase dada, como já vimos na análise documental, pela matriz curricular do curso. 
Do.MNPEF-01 concorda com a visão de Do.MNPEF-07 a respeito da necessidade de aprofundamento nos conteúdos específicos de Física. Porém traz também a questão de se apoiar nas disciplinas a formação para a pesquisa em Ensino de Física:

Do.MNPEF-01: Eu dou aqui o meu depoimento de achar que a gente precisava de mais espaços para demandas naturais da pesquisa em Ensino de Física. Que eu entendo como não contempladas da forma como penso que deveriam ser. [...] Eu acho que tinha que ter mais disciplinas de ensino, ou de História e Filosofia, enfim, que abordassem outros assuntos que o quê tem. Mas eu sou muito segura em te dizer que tem que ter bastante conteúdo técnico sim. Não abro mão disso não. [...] Não acho que seja ou um ou outro, eu acho que é um e outro. Bem demarcado. Por quê? Porque a gente sabe a história de formação inicial [...] de nossos professores. [...] A gente tem um problema sério, porque o nosso ensino tradicional parou no século XIX, a gente está no século XXI. E o nosso professor não foi preparado para trabalhar nem o século XX. [...] Eu acho que às vezes isso poderia ser um pouco reavaliado. Talvez a "dureza"... O nível de exigência técnica... Mas que tem que ter essa discussão, tem que ter. [...] só acho que a gente deixa também um espaço pequeno, [...] para as disciplinas que não são técnicas.

Agora, em relação ao impacto desse espírito na prática profissional dos professores-cursistas, temos a indicação de que não é total. Do.MNPEF-07 nos indica isso quando destaca a disciplina que aborda o desenvolvimento histórico da Física (Marcos no desenvolvimento da Física), que diz ser algo que chama muito a atenção dos professores, pois "gostam dessa parte histórica da Física [...] para contar para os alunos deles". No entanto... "se você for trabalhar dentro de uma perspectiva histórica, muitos [...] deles [professores] acham que vai confundir o aluno. Porque vai. Porque o aluno vai querer aquilo que está no livro. E o desenvolvimento histórico não é o que está ali no livro" (Do.MNPEF-07). Esse dado revela que a mudança nas práticas docentes não é implicação direta do acesso ao conhecimento e às metodologias inovadoras. A dependência do livro didático que, no caso, nem sempre abordam questões de História da Física, e que, por conta disso, na visão desses professores, atrapalharia no processo de aprendizagem dos alunos confundindo-os, mostra a insegurança que eles podem sentir no processo de desenvolvimento de novas metodologias, que, a princípio, os agrada. Questiona-se: o curso está realizando que tipo de ação para ajudar os professores a enfrentar essas inseguranças? Há a consciência dessas dificuldades por parte do corpo docente? Esse é um aspecto fundamental que influencia nos impactos que esse MP tem para o desenvolvimento profissional dos professores, e para que os objetivos estabelecidos nesse MP possam ser alcançados. 
Apesar disso, na visão do coordenador entrevistado, ele avalia positivamente o sucesso do curso em termos do alcance desses objetivos. Os indicadores de sucesso são as mudanças das práticas relatadas por egressos e os "produtos derivados" do mestrado, em forma de trabalhos apresentados em congressos como o SNEF ${ }^{104}$. A motivação e interesse dos professores-cursistas é alta na medida em que muitos ainda mantêm contato com os docentes do curso após a defesa de suas dissertações. A criação do Simpósio de Ensino de Física do polo foi uma ideia levantada por Do.MNPEF-01 e outros docentes que parece fundamental para favorecer esse contato. Do.MNPEF-01 coloca essa questão como a construção de um centro de referência da região para a Pesquisa em Ensino de Física:

Do.MNPEF-01: Eu acho que a gente já conseguiu fazer uma "diferenciazinha" sim, em particular [na região], que é uma causa também, a gente começou a demarcar esse espaço de pesquisa em Ensino de Física [na região], porque a gente não tinha isso lá. A gente na verdade nem tinha curso de Física na região. [...] A ideia era atender o público da região [...] e arredores, nesse sentido de a gente qualificar e trazer para a vida acadêmica, tanto que a gente criou eventos, que é o [Simpósio de Ensino de Física] [...] a ideia é fazer um pouco... O nosso sonho, como a gente vê um espaço [...] que a gente vê em SP, em alguns espaços do interior do país, criar ali um centro de referência em Ensino de Física. Agora a gente já tem um número de mestrandos suficientes.

Porém, em relação às mudanças de práticas de sala de aula, ponto central do MP na concepção do coordenador (como exposto adiante), "nem tudo são flores" (Do.MNPEF-07):

Do.MNPEF-07: Pelo que eu sei, que eu já conversei com vários alunos [professores-cursistas], a prática de sala de aula mudou bastante, de vários deles. Outros acabam voltando às práticas anteriores... [...] Por quê? Porque esse contato [com a universidade] é fundamental. Fora daqui, por mais que ele já tenha, que ele já tenha pegado um momento, pegado um " $\mathrm{V}_{0}$ ", eu acho que faria muito bem continuar com esse trabalho com a universidade. Mas pelo menos, durante esse tempo que eles estão aqui, eles transformam bastante a prática de sala de aula deles. Acho que, durante esse tempo que eles estão aqui, é até mais fácil eles transformarem isso aí, porque eles chegam lá [na escola de educação básica] com o "pedigree" do mestrado. [...] Um gestor com uma mínima visão estratégica vai entender que isso é bom para a escola.

O envolvimento com o curso, a presença nas atividades do polo faz diferença ao longo do curso, antes da defesa. Por exemplo, a opção por manter disciplinas durante todos os semestres do curso é importante pois, como colocado pelo coordenador, "enquanto os alunos têm uma ligação formal com os polos, uma ligação ainda que burocrática com o polo, eles se envolvem [na produção da dissertação e produto

\footnotetext{
${ }^{104}$ Simpósio Nacional de Ensino de Física, evento promovido pela SBF que tem como públicoalvo principalmente os professores de educação básica e é realizado a cada dois anos em diferentes instituições brasileiras.
} 
educacional]. Mas terminou essa ligação, muitos deles tendem a relaxar" (Do.MNPEF07). Provavelmente, esses professores acabam cedendo à rotina estabelecida nas escolas ou às dificuldades que acabam encontrando. Do.MNPEF-01 coloca que o conteúdo técnico é importante para os professores, mas enfatiza outro aspecto na formação do mestrando, que pode sustentar essas mudanças na prática e, afinal de contas, sustentar a formação adquirida que deve ir além da renovação das práticas docentes em sua visão:

Do.MNPEF-01: [O mestrado] dá uma bagagem, ele complementa a bagagem técnica do professor, isso já por si faz muita diferença. [...] a gente vê que tem muita defasagem de ordem técnica, e que isso vai espelhar profundamente na sala de aula na hora de ministrar conteúdos mesmo. [...] Mas eu acho que a gente tem que querer muito mais do que isso [...] Eu acho que eles precisariam um banho de pesquisa em Ensino de Física maior. Acho que se a gente desse conta disso, poderia fazer muita diferença sim, para que eles se sentissem o que são, porque na verdade, eles são mestres em Ensino de Física. No MP em Ensino de Física. Acho que inclusive os produtos talvez tivesse maior fundamentação...

Nesse sentido, com base no trecho destacado, vemos que Do.MNPEF-01 considera fundamental o contato com a área de pesquisa e o cuidado com a fundamentação teórica adotada pelos professores para realização dos produtos educacionais.

Já para Do.MNPEF-01, o que entende como características essenciais no mestrado profissional aborda justamente a ênfase na mudança de práticas através da implementação de metodologias e abordagem de ensino diferenciadas. Basicamente, Do.MNPEF-07 entende o MP como um "mestrado extremamente aplicado":

Do.MNPEF-07: No MP, a ideia não é tanto que você se foque nos aspectos teóricos, na teoria de aprendizagem, quanto na aplicação, talvez, e não necessariamente na aplicação de uma teoria da aprendizagem em sala de aula. Mas a ideia é que você venha com o que a gente chama de... e é uma palavra que muita gente daqui não gosta... o tal do produto educacional.

A fala acima destaca o desenvolvimento do produto educacional como um diferencial do MP. No entendimento do coordenador, há uma cisão entre teoria e prática, já que a criação do produto não exigiria um aprofundamento teórico. A expressão grifada mostra que é um termo/conceito que é provavelmente criticado por alguns membros do corpo docente, entre eles Do.MNPEF-01, que valoriza o aprofundamento do trabalho através da pesquisa bem fundamentada. A diferença de concepção desses dois docentes pode ser atribuída à formação distinta de cada: enquanto Do.MNPEF-07 teve um envolvimento prioritariamente em Física básica ao longo de sua formação, Do.MNPEF-01 é também licenciada, tem experiência em 
escolas como professora e formadora de professores, além de formação pósgraduada e desenvolvimento de pesquisas na área de ensino. A fala destacada de Do.MNPEF-01 nos remete novamente ao questionamento anteriormente apontado: como os docentes - sem formação acadêmica ou experiência em ensino - pode apoiar a formação dos professores e a construção dos produtos educacionais? Se não dão tanta importância para a fundamentação teórica, em que se apoiam para orientar os mestrandos?

O produto educacional foi a dificuldade enfrentada por esse corpo docente destacada principalmente na implantação do Polo do MNPEF por conta da percepção de que "[...] a parte teórica está lá presente, porque afinal de contas [...] você não concebe um produto educacional aleatoriamente. Se não fica uma coisa de tentativa e erro. Sem fundamento...", porém "não precisa entrar em grande profundidade [nesse fundamento teórico]" (Do.MNPEF-07). Logo, qual é a "dosagem teórica” correta que deve ser dada para a produção do produto educacional? Como o corpo docente foi lidando com isso? Do.MNPEF-01, pelas declarações indicadas, difere da concepção apresentada por Do.MNPEF-07 por priorizar tal fundamentação teórica, para evitar uma "discussão mais rasa" na produção acadêmica dos mestrandos.

Outra dificuldade relacionada tem a ver com a escolha do projeto a ser elaborado. Conta o coordenador que "nós tínhamos trabalhos que eram absolutamente megalomaníacos no começo em mente".

Do.MNPEF-07: Mesmo nós aqui [corpo docente], pois é uma experiência você orientar um trabalho desses. É uma experiência totalmente sui generis para a maioria de nós, porque não tem formação em educação, não tem essa prática de sala de aula [...] $A$ gente tem projetos lindos na nossa cabeça que vão ser maravilhosos, numa escola maravilhosa. Mas quando a gente chega na escola da vida real, começa a ver vários entraves. Muitos entraves que aí você acaba tendo de adaptar o seu projeto.

O fato da maioria do corpo docente não ser da área de Educação/Ensino de Física e ter pouca ou nenhuma experiência em projetos de Ensino resulta na dificuldade sentida inicialmente na orientação dos projetos. O trecho grifado na fala de Do.MNPEF-07 apresenta a seguinte ordem lógica: no MP, primeiro tem-se uma ideia "na cabeça" para depois ser aplicado na "vida real", expressando uma concepção aplicacionista. É uma ideia contrária do que defendido hegemonicamente como entendimento do MP: a de que se busca, no projeto de elaboração do produto educacional, a solução para um problema previamente encontrado na prática docente. É um ponto interessante que seria investigado junto ao corpo docente, pois é uma concepção que influencia a orientação que dão para a elaboração das dissertações e produtos educacionais. Por conta da dificuldade que tivemos, como relatado no início 
da apresentação dessa análise, não pudemos coletar a visão de outros docentes sobre esse ponto. Retornaremos a discutir essa questão na análise de dados da Etapa 3 da pesquisa, a análise dos produtos educacionais e dissertações.

A demanda dos professores que procuram o curso de MP, percebida por Do.MNPEF-07, parece estar diretamente ligada ao produto educacional, se a sua elaboração significa investigar novas metodologias que ajudem o professor a combater o desinteresse dos estudantes nas suas aulas. Em contraponto ao mestrado acadêmico (no qual o aprofundamento teórico é a sua principal característica), o mestrado profissional nesses termos, seria mais adequado no atendimento à demanda dos professores de educação básica, pois este proporcionaria o aprofundamento de conhecimentos (dimensão de desenvolvimento profissional atualização de conhecimentos pedagógicos - a que é referida por Do.MNPEF-07 quando se refere à "teorias de aprendizagem"), visando diretamente sua prática de sala de aula (dimensão de desenvolvimento profissional organização e condução de ensino):

Do.MNPEF-07: Eu acho particularmente que a gente não pode ficar num purismo de querer que todos os professores tenham 0 conhecimento em profundidade de todas as teorias de aprendizagem. Mas uma coisa que o nosso MP fornece aos professores, por exemplo nisso, é justamente essa coisa de ir atrás, de pesquisar, de tentar relacionar uma prática com uma teoria de aprendizagem. [...] $\mathrm{E}$ até muitos deles [professores-cursistas] gostam muito da ideia, porque vai fazer uma coisa que vai ser aplicada em sala de aula e que ele vai incorporar na prática dele. O que não é necessariamente o caso de um MA. Por isso que eu falo: muitos de nossos professores de segundo grau querem aprender, eles querem ir além do ponto onde eles estão. Até em termos de conhecimento mesmo, de aprender coisas novas. Mas ao mesmo tempo eles querem uma coisa que seja palpável para eles em termos de aplicar em sala de aula.

Do.MNPEF-01, apesar de ter visão ligeiramente diferente que Do.MNPEF-07 em relação ao que caracteriza o curso de MP, e quais seriam seus objetivos primordiais, conforme apresentado, organiza suas disciplinas de forma coerente a abraçar justamente as duas principais ideias: a relação com a prática em sala de aula e a formação para pesquisa. Ao explicar a sua atuação na disciplina Fundamentos Teóricos em Ensino e Aprendizagem, a docente explica:

Do.MNPEF-01: Eu sempre procurei ministrar essa disciplina falando assim: "nós vamos discutir, mas nós vamos discutir na sala de aula! Nós vamos olhar para a sala de aula de Física! [...] Na verdade eu dou um plus na disciplina, porque eu fico quase obcecada mesmo. Em que tudo que a gente está discutindo, tem um impacto prático na sala de aula daquele professor. [...] Nós fazemos roda de discussão sobre aqueles autores, sempre trazendo esse viés, a parte de fundamentação, a teoria de aprendizagem, mas como é que aquilo impacta na sala de aula. [...] eu cheguei a participar de bancas de alguns alunos, eu também orientei, que puxaram as teorias da 
aprendizagem como uma das fundamentações para suas propostas, para seus produtos.

Do.MNPEF-01: [...] porque eles não têm nenhuma disciplina que os introduza no universo da pesquisa em Ensino de Física, eu trago esse papel para mim também. Então eu começo as minhas aulas falando da pesquisa em Ensino de Física... Dos eventos, dos periódicos, das temáticas de investigação principais, e eu vou, à medida que estou trabalhando com eles os tipos de Metodologias de Ensino que são muito diferentes das Metodologias de Física pura...

Também é possível vislumbrar nesse MP, indicadores de impactos na dimensão planejamento da carreira profissional, que, no entanto, é mais explícita no caso de poucos professores, pois, "para alguns deles pelo menos, o MP acaba sendo uma ponte para o prosseguimento para uma carreira acadêmica" (Do.MNPEF-07). coordenador relata que ex-alunos do polo "estão engatando outras pós-graduações". Isso porque:

Do.MNPEF-07: [...] para quem está muito longe na sala de aula, [cursar o MP] é uma maneira de você voltar para a Academia e começar a ter contato com essa cultura acadêmica da pesquisa, da busca de referências bibliográficas, de olhar várias referências. Ao mesmo tempo supre a demanda, ajuda a aliviar um pouco a angústia por você ver uma coisa que tem retorno e quase imediato na sua sala, nesse sentido, e para quem já tem a sementinha, [...] pode continuar na área acadêmica.

Por último, as dificuldades enfrentadas pelo coordenador envolvem o "engessamento" provocado pelo fato de tudo o que é feito no polo "estar sujeito à aprovação de uma coordenação nacional" (Do.MNPEF-07). Esse engessamento decorre da menor "liberdade para fazer determinadas coisas", o que pode criar problemas, como no caso das defesas, que só podem ser realizadas após aprovação explícita da banca de defesa e da dissertação e produto educacional pela coordenação nacional (CPG/MNPEF). O coordenador também citou o fato de a matriz curricular ser fixa, de modo que o corpo docente do polo não pode criar disciplinas, mesmo que optativas. A única gerência do polo sobre a matriz curricular diz respeito à sua organização de dias e horários (no caso, as aulas são concentradas na sexta-feira de noite e sábado de manhã, o que viabiliza a conciliação com os horários de trabalho dos professores-cursistas). Ao longo da entrevista o coordenador fala, no entanto, de atividades realizadas no polo que não são previstas pela matriz curricular geral do MNPEF. Na sexta-feira, antes do início das aulas, os docentes do curso organizam a apresentação de seminários para os professores-cursistas. Um evento também planejado é o Simpósio de Ensino de Física na instituição, já citado ao longo dessa análise, que teria convidados de fora da instituição "para dar palestras, não só para nossos alunos, mas para outros professores da região" e com a apresentação de trabalhos dos projetos desenvolvidos ou em desenvolvimento no MP. 


\subsubsection{Corpo docente do MP.Local: dados gerais e análise com elementos narrativos}

O curso de MP.Local iniciou suas atividades em 2008, contando com um corpo docente que envolvia 7 membros (grande parte deles continuam atualmente credenciados). Os dados consultados em junho de 2017 na Plataforma Sucupira, da Capes, nos indicam a composição do corpo docente do programa neste ano. A fim de manter a identidade dos docentes em sigilo, utilizamos para nos referenciar a cada um, uma sigla que se inicia com Do.MP.Local (para identificar que trata-se de um docente do MP.Local), seguida de uma numeração "01", "02", "03" etc. Na Tabela 6 dispomos da identificação de cada docente, sua situação de credenciamento junto ao programa (como docente permanente, colaborador ou visitante) em 2017 e da especificação de formação básica e pós-graduada e de produção de pesquisa de cada um. Esses últimos dados foram todos obtidos por meio de consultas à Plataforma Lattes.

Tabela 6 - Dados, atualizados em junho de 2017, do corpo docente do MP.Local.

\begin{tabular}{|c|c|c|c|c|}
\hline DOCENTE & $\begin{array}{c}\text { SITUAÇÃO } \\
\text { NO } \\
\text { PROGRAMA } \\
\text { (ANO DE } \\
\text { CREDENCIA } \\
\text { MENTO) }\end{array}$ & $\begin{array}{l}\text { FORMAÇÃO } \\
\text { INICIAL }\end{array}$ & $\begin{array}{l}\text { FORMAÇÃO PÓS- } \\
\text { GRADUADA }\end{array}$ & $\begin{array}{l}\text { PRODUÇÃO GERAL } \\
\text { DE PESQUISA }\end{array}$ \\
\hline $\begin{array}{c}\text { Do.MP.Local- } \\
01\end{array}$ & $\begin{array}{l}\text { Permanente } \\
\text { (2008) }\end{array}$ & $\begin{array}{c}\text { Licenciatura } \\
\text { e } \\
\text { Bacharelado } \\
\text { em Física }\end{array}$ & $\begin{array}{c}\text { Mestrado e doutorado } \\
\text { em Física }\end{array}$ & $\begin{array}{l}\text { Trabalhos na área de } \\
\text { Física (área de sua } \\
\text { formação pós- } \\
\text { graduada) e em } \\
\text { Ensino (estratégias } \\
\text { didáticas e materiais } \\
\text { didático-pedagógicos) }\end{array}$ \\
\hline $\begin{array}{l}\text { Do.MP.Local } \\
-02\end{array}$ & $\begin{array}{l}\text { Permanente } \\
\text { (2008) }\end{array}$ & $\begin{array}{l}\text { Graduação } \\
\text { em Ciências } \\
\text { Sociais }\end{array}$ & $\begin{array}{l}\text { Mestrado e Doutorado } \\
\text { em Educação }\end{array}$ & $\begin{array}{l}\text { Em Ensino de } \\
\text { Ciências }\end{array}$ \\
\hline $\begin{array}{l}\text { Do.MP.Local- } \\
03\end{array}$ & $\begin{array}{l}\text { Permanente } \\
\text { (2008) }\end{array}$ & $\begin{array}{l}\text { Graduação } \\
\text { em Ciências } \\
\text { Biológicas }\end{array}$ & $\begin{array}{c}\text { Mestrado e Doutorado } \\
\text { em Biologia }\end{array}$ & $\begin{array}{l}\text { Na área de Ensino de } \\
\text { Ciências }\end{array}$ \\
\hline $\begin{array}{l}\text { Do.MP.Local- } \\
04\end{array}$ & $\begin{array}{l}\text { Permanente } \\
\text { (2008) }\end{array}$ & $\begin{array}{l}\text { Graduação } \\
\text { em Química } \\
\text { Industrial }\end{array}$ & $\begin{array}{c}\text { Mestrado e Doutorado } \\
\text { em Química }\end{array}$ & $\begin{array}{l}\text { Em Ensino de } \\
\text { Ciências } \\
\text { (continua) }\end{array}$ \\
\hline
\end{tabular}


(continuação)

Do.MP.Local- Permanente 05

(2008)

Licenciatura em Química

$\begin{array}{ccc}\begin{array}{c}\text { Do.MP.Local- } \\ 06\end{array} & \begin{array}{c}\text { Permanente } \\ (2008)\end{array} & \begin{array}{c}\text { Licenciatura } \\ \text { em } \\ \text { Matemática }\end{array}\end{array}$

Do.MP.Local- Permanente Graduação 07

(2009) em Zootecnia

$\begin{array}{cc}\text { Do.MP.Local- } & \text { Permanente } \\ \mathbf{0 8} & (2011)\end{array}$

Do.MP.Local- Permanente 09

(2012)

Do.MP.Local- Permanente 10

(2012)

Do.MP.Local- Colaborador 11 a (2012)

Do.MP.Local- Permanente 12 (2013)

Do.MP.Local- Permanente 13 (2013)
Licenciatura em Ciências (habilitação em Química)

\section{Graduação em Ciências Sociais}

Graduação em Farmácia

Graduação em História

Licenciatura em Física

Licenciatura em Matemática
Mestrado em Química; Doutorado em Engenharia Metalúrgica e de Materiais

Mestrado e Doutorado em Engenharia Nuclear

$$
\begin{aligned}
& \text { Mestrado em } \\
& \text { Desenvolvimento, } \\
& \text { Agricultura e } \\
& \text { Sociedade }
\end{aligned}
$$

Mestrado em Sociologia e Antropologia, Doutorado em Antropologia Social

Mestrado e Doutorado em Biociência e Saúde

Mestrado e doutorado em Química

Mestrado em Memória Social; Doutorado em História das Ciências e Saúde

Mestrado profissional em Ensino de Ciências e Matemática; Doutorado em Educação em Ciências e Saúde

\section{Mestrado e Doutorado} em Educação
Trabalhos tanto na área de Química quanto em Ensino de Ciências

Trabalhos recentes em Educação Matemática e Ensino de Ciências

\section{Em Ensino de Ciências}

\section{Em Ensino de Ciências}

Produção recente na área de Ensino de

Ciências

Maioria das publicações em Ensino de Ciências

Trabalhos em Ensino de Ciências e História da Ciência

$\mathrm{Na}$ área de Ensino de Ciências

Em Ensino de Ciências e Matemática

(continua) 
(continuação)
Do.MP.Local- Permanente
14
(2014)
Graduação
em Física

Do.MP.Local- Permanente

15

(2014)

Do.MP.Local- Permanente 16

(2014)
Mestrado e doutorado em Física; pósdoutorado em Física

\begin{abstract}
Bacharelado
$e$

Licenciatura

em Ciências

Biológicas
\end{abstract}

Graduação em Biologia

em Educação em

Ciências e Saúde
Mestrado e Doutorado em Ciências -

Educação, Gestão e

Difusão em

Biociências
Trabalhos na área de

Física (área de sua

formação pós-

graduada) e em

Ensino

Na área de Ensino de

Ciências

Na área de Ensino de

Ciências

Observamos na Tabela 6 a diversidade de formações dos docentes credenciados no MP. Primeiramente, é importante destacar que a diversidade nas áreas de formação desses docentes busca atender à demanda do curso que é orientado ao Ensino de Ciências (e não somente ao Ensino de Física - como o MNPEF). Essa diversidade também é coerente com a expectativa, presente nos documentos analisados previamente, de promover a interdisciplinaridade nesse curso.

Foi possível realizar três entrevistas com docentes desse MP: com os docentes identificados por Do.MP.Local-01, Do.MP.Local-03 e Do.MP.Local-08, sendo esta última docente a coordenadora do curso até atualmente (2019). As entrevistas foram realizadas entre março e outubro de 2017.

Ao roteiro de perguntas básicas da entrevista realizada com a coordenadora (apresentado no início do capítulo), acrescentaram-se questões específicas sobre: o fato do curso de MP estar inserido em uma instituição federal; a interação com os cursos de licenciatura do campus; a interação com o curso de MA, implantado no mesmo programa.

Apresentamos na sequência a análise com elementos narrativos derivada da transcrição integral e leitura analítica dessas três entrevistas. Assim como na primeira análise apresentada, destacamos falas da transcrição original da entrevista, como dados que embasam os pontos relatados. Continuamos, também, sublinhando questionamentos que foram surgindo ao longo da construção desse texto. Eles serão sintetizados ao final do capítulo. 
O MP.Local foi idealizado por um professor da instituição - atualmente aposentado - que era muito atuante na gestão, tendo assumido diversos cargos em coordenação, direção e reitoria em diferentes momentos. A docente Do.MP.Local-03 conta que esse professor identificou na instituição uma vocação que atenderia ao perfil proposto na modalidade de pós-graduação stricto sensu de mestrado profissional. Idealizou, na época, a implantação de dois programas de MP na instituição em dois campi diferentes - sendo um deles o MP em Ensino de Ciências. Para viabilizar essa implantação, conseguiu articular a abertura de um concurso público que visaria a contratação de recursos humanos para atuar no curso. Os docentes classificados no concurso deveriam ter perfil condizente com a proposta do MP e seriam responsáveis pela elaboração do projeto a ser submetido para a Capes. Assim, proporcionou a abertura de sete vagas de docentes para o campus que abrigaria o MP.Local. Do.MP.Local-03 e Do.MP.Local-01 são docentes que ingressaram na instituição nesse primeiro concurso e participaram da elaboração do projeto do MP.

Do.MP.Local-03 era a única do grupo inicial que tinha alguma experiência com mestrados profissionais, pois já havia atuado em um, em 2003. Conta que o projeto do MP em Ensino de Ciências foi submetido à Capes logo que os docentes tomaram posse de seus cargos na instituição e, enfim, o projeto foi aprovado em 2007, com o início das atividades em 2008.

A opção por um MP em Ensino em Ciências nesse campus faz parte da estratégia do professor que idealizou o programa. No campus já funcionavam os cursos de licenciatura. A ideia é que esses docentes teriam também o perfil para atuarem nas licenciaturas. A coordenadora Do.MP.Local-08 complementa dizendo que a região onde o campus se localiza é carente no oferecimento de oportunidades em cursos de pós-graduação para professores da educação básica. Assim, a abertura desse MP visou atender à demanda interna (dos egressos das licenciaturas) e dos profissionais da região, "um espaço completamente sem ser explorado em termos de você ofertar um curso que pudesse dar uma formação mais continuada" (Do.MP.Local-08).

Hoje, já consolidado, o MP.Local atende a uma grande demanda (revelada no grande número de inscritos em cada processo seletivo), não apenas de professores da região, como de cidades um pouco mais distantes. São profissionais de faixas etárias diversas e de diferentes perfis profissionais, apesar da maioria ser formada por professores que trabalham diretamente na sala de aula da educação básica. São professores de disciplinas de Ciências da Natureza (Ciências Biológicas, Física e Química) ou Matemática, mas também já foram admitidos no MP licenciados em 
outras áreas tais como Geografia, Letras e Pedagogia. Do.MP.Local-03 descreve outros perfis profissionais: "a gente tem às vezes gente de secretaria do Estado, ou de um espaço de divulgação científica, às vezes são técnicos que estão pensando mesmo na questão da gestão, e como que faz algum mecanismo...". Apesar dessa diversidade profissional, todos devem apresentar propostas de projetos que estejam vinculados com o Ensino de Ciências.

A diversidade profissional do público atendido no MP não gera maiores dificuldades no ponto de vista de Do.MP.Local-08. Para ela:

Do.MP.Local-08: [...] isso cria um diálogo interno, na dinâmica das aulas, que para mim é muito enriquecedor. Vem a interdisciplinaridade sendo vivida de fato! [...] Para mim, é uma riqueza dar aula para um grupo assim. Porque quando você fala de uma temática, você tem vários olhares em relação a essa temática. Eu acho que para um debate, enriquece, a dinâmica de uma aula enriquece.

Dessa maneira, com os dados apresentados e analisados sobre esse MP, podemos vislumbrá-lo como um curso interdisciplinar, cujo corpo docente reúne orientadores que têm formações diferenciadas entre si, que atende a profissionais de diferentes formações. Do.MP.Local-01, que também foi admitido neste primeiro concurso da instituição para formação do corpo docente para atuar no MP, ressalta a diversidade de formação dos docentes, sendo muitos, como ele mesmo, formados para a área de pesquisa básica científica, as áreas "duras". Para ele, a proposta do MP.Local era proporcionar "uma união de saberes":

Do.MP.Local-01: Pessoal da Educação, área "dura"... não tinha preconceito nesse sentido, era você unindo forças. [...] Que eu só trabalhei até então com pesquisa na área "dura", continuo até hoje. Mas o programa de MP, ele tinha essa flexibilidade, queriam profissionais com várias visões e saberes diferentes. E daí eu vim para acrescentar na área de Física.

Como já visto na análise documental, a interdisciplinaridade também é incentivada na escolha das disciplinas que compõem a matriz curricular do curso. Com base na fala de Do.MP.Local-08, a interdisciplinaridade desse programa é estimulada principalmente nas trocas proporcionadas nas discussões realizadas nas disciplinas do curso. Entendemos que para que isso aconteça, não basta reunir numa mesma turma, discentes de diferentes perfis profissionais. O professor responsável pela disciplina deve proporcionar abertura para o diálogo e levantar questões que suscitem o debate.

Como ocorre parcialmente na prática de Do.MP.Local-01. Ao relatar seu trabalho como professor da disciplina Debates Conceituais de Física, diz que num 
primeiro momento focou em abordar os conceitos de Física, mas logo mudou sua estratégia de ensino, propondo-se a caminhar rumo uma prática interdisciplinar:

Do.MP.Local-01: [...] depois parti para uma coisa que eu achei que deu muito certo. De você fazer o contrário. [...] como você poderia falar de Física na sua disciplina [disciplina de formação inicial do professor-cursista]. Eu quis dar um aspecto interdisciplinar, mas no sentido bem simples da palavra, não é um conceito pedagógico, profundo na interdisciplinaridade. Até mesmo essa coisa ainda não está muito clara, eu acho que você dá nuances de interdisciplinaridade em disciplinas. Isso não significa você fazer ser interdisciplinar. Então era só você trazer aspectos. Já que era em um mestrado em Ensino de Ciências, e eu estava em Física, você trazer à tona alguns elementos de Física. E foi uma experiência muito legal. Aí você começa a ver a criatividade das pessoas em cima disso, e às vezes viram até trabalhos, ou dissertações...

É a postura que a docente Do.MP.Local-03 adota em suas disciplinas. Um modo que ela encontra para colocar a interdisciplinaridade em prática é através da proposta de dupla docência:

Do.MP.Local-03: E eu particularmente amo dar aula em dupla. É uma coisa que eu gosto de fazer. Não é fácil... Porque eu não dou aula em dupla do tipo, essa aula eu dou, essa aula você dá. Eu dou aula, os dois, juntos. Então você tem que ter uma afinidade com essa pessoa, mas eu sou desapegada o suficiente para mesmo não te conhecendo 'Vamos lá, vamos fazer uma disciplina juntas? Vamos!' Pode dar muito certo, pode dar muito errado, beleza! Mas eu vou...[...] Esse desafio não é uma coisa que me amedronte. E no geral eu tenho tido bons resultados.

Ela diz que quando assume sozinha uma disciplina, sem a parceria com outro docente, investe na maior contribuição dos alunos. Ela está sempre disposta a "tentar fazer uma interlocução nas [suas] disciplinas, com as disciplinas de colegas, que já aconteceram, ou com a dissertação do aluno" (Do.MP.Local-03). Há uma razão também prática para essa escolha: o tempo disponível para a conclusão do curso.

Do.MP.Local-03: O movimento no caso comigo, no stricto sensu, e de alguns colegas, não todos, é sempre de tentar aproximar o trabalho que [os professores-cursistas] estão fazendo para tentar agilizar o processo, porque eles têm pouco tempo e ao mesmo tempo aproveitar esse processo. Gerar uma boa relação de custo benefício nessa leitura desse material.

A questão de se procurar interlocuções entre disciplinas e dissertações também é considerada por Do.MP.Local-01, que relata a emergência de temas de dissertações a partir de suas disciplinas, além da realização de outros tipos de trabalho (artigos, apresentações em congressos), dando destaque à autoria dos professores mestrandos na criação e escrita desses trabalhos.

As entrevistas com esses docentes ajudam a elucidar essas questões: até que ponto as disciplinas de fato dão lugar a esse diálogo interdisciplinar? Como esses docentes estimulam essa interdisciplinaridade em suas aulas? De que tipo de 
interdisciplinaridade se trata? Como visto, pode ser adotada uma perspectiva de interrelação entre assuntos de diferentes disciplinas da matriz curricular; ou com o tema da dissertação elaborada pelos mestrandos; ou, ainda, numa perspectiva mais aberta, de se considerar as contribuições diversas - e de certa forma imprevisíveis - que podem surgir pela referência à experiência profissional dos envolvidos na disciplina. Além disso, as entrevistas com os egressos esclarecerão quais são os resultados que obtém ao cursarem as disciplinas que incentivam a interdisciplinaridade. Há algum impacto em sua formação? E na elaboração da dissertação e do produto educacional?

O processo de orientação também pode colaborar para essa interdisciplinaridade. A docente Do.MP.Local-03 revela que procura se adequar ao perfil do seu orientando. Não impõe um projeto de pesquisa, mas escuta o que esse orientando quer pesquisar.

Do.MP.Local-03: No mestrado profissional, eu tenho mais dificuldade de trazer o aluno para a minha praia, do que o mestrado acadêmico. Por quê? Porque eu não quero perder, não quero que ele entenda que ele não tem valor. Que a experiência dele, o conhecimento dele, a prática dele vai ser desvalorizada por mim. Eu acho que esse respeito é importante para um docente de mestrado profissional. $\mathrm{E}$ isso eu vejo pouco. Se eu tenho uma crítica que eu tenho que fazer, essa é uma crítica. Poucos colegas fazem esse movimento da escuta.

A crítica apontada por Do.MP.Local-03 é relevante no sentido de revelar que não são todos os orientadores do MP que acatam o problema de pesquisa que o professor-cursista traz de sua própria prática. O professor Do.MP.Local-01 apresenta um discurso alinhado com essa preocupação ao expor a sua percepção a respeito dos objetivos do MP centralizado no professor-cursista: "Nossa preocupação era 0 professor na sala de aula. Ele ter um espaço onde ele pode promover o seu material educacional, para trabalhar na própria sala e ter, como se fosse uma formação continuada, mas em um nível de mestrado". O protagonismo dos professores-cursistas no que gostariam de desenvolver nos produtos educacionais e dissertações também é referida por Do.MP.Local-01: "E aí a gente vai moldando mais ou menos, sem fugir muito do que o aluno [professor-cursista] queria [...] normalmente o aluno aqui tem o produto mais ou menos definido, já entra, já sabe, já tem o que quer. O 'como' é que é o problema". Nesse sentido, caberia aos docentes orientadores esclarecer o percurso para a realização do projeto idealizado pelo professor-cursista.

Buscaremos desvelar melhor como seriam esses processos gerais de orientação desse corpo docente e o protagonismo assumido pelos professores-cursistas no desenvolvimento dos trabalhos com as entrevistas realizadas com egressos. Afinal de 
contas: em um MP, não se espera que sejam desenvolvidas pesquisas que busquem soluções que surgem da prática profissional? Como se definem os projetos do MP?

Essa docente não apela para o entendimento geral da finalidade do MP retomado no parágrafo anterior para justificar o mecanismo que adota em seu trabalho de orientação. Ela comenta que "com a minha prática, percebi que meus alunos produzem melhor tanto em termos de produto educacional quanto até academicamente, quando, no mestrado profissional, eu tenho esse movimento de escuta e acolhimento" (Do.MP.Local-03). Provavelmente isso ocorre, porque os orientandos têm uma clareza maior da finalidade de seu trabalho quando ele é desenvolvido dessa maneira.

Ainda sobre o público atendido nesse curso de MP, Do.MP.Local-08 afirma que muitos dos professores-cursistas estão "muito tempo na prática". Considera que o fato de eles estarem no MP, saindo "um pouco para pensar essa prática deles, "oxigeniza":

Do.MP.Local-08: Eu acho que isso dá um movimento na vida profissional desses discentes, que cria, não sei... aquela velha palavra... 'empoderamento'... Mas eu acho que mais que uma questão política, é uma questão subjetiva também. Que mexe com eles o fato de eles estarem revivendo, estudando, se atualizando... Então eu acho que isso faz com que eles saem, por isso mesmo, encantados com o curso.

Esse "encantamento" com o curso se traduz no sucesso do programa que atrai muitos profissionais inscritos em cada processo seletivo. Do.MP.Local-08 diz que têm "uma divulgação 'boca a boca' que é muito forte", certamente de mestres que saíram do curso satisfeitos e que fazem questão de divulgar o curso para colegas interessados. Aqui, essa docente se refere a um fator subjetivo - o de satisfação com o curso - não considerado no referencial de desenvolvimento profissional (BAROLLI et al., 2019), mas relacionado aos indicadores dedicação e responsabilidade do conceito de autoria docente desenvolvido por Maia (2017). A satisfação encontrada no MP.Local parece ser decisiva para o sucesso do curso nesse sentido. Fica em aberto investigar o que faz os professores-cursistas se sentirem satisfeitos com o curso e como o desenvolvimento profissional deles se manifesta a partir disso.

Do.MP.Local-01 se refere à baixa autoestima dos mestrandos e aponta "a transformação que você vê desse profissional, nosso discente, ao longo do curso, é impressionante [...] você vê a mudança de comportamento, a postura... é fantástico". Essa mudança de postura parece ser decorrente, em sua perspectiva, de uma conjunção da predisposição dos professores-cursistas em aprender, extraindo o máximo de conhecimentos e experiências do curso e o que se oferece em termos de realizações, entre elas, destaca a possibilidade que os professores-cursistas 
encontram de participar de eventos e congressos da área, a maioria pela primeira vez; a perspectiva que se abre ao egresso de continuar a formação pós-graduada em nível de doutorado e a oportunidade de continuar investindo em desdobramentos de seu trabalho de pesquisa, e sua posterior divulgação em outros espaços além do curso.

Esse reforço à autoestima dos professores-cursistas aparece também, segundo Do.MP.Local-08 na disciplina Prática de Ensino Supervisionada (PES). A docente, que já foi responsável por essa disciplina em alguns períodos, contou que a PES apresentou ao longo dos períodos diferentes formatos. Inicialmente, na disciplina eram planejadas visitas às escolas, onde realizavam-se palestras e outras atividades que visavam estabelecer o diálogo com as escolas dos professores-cursistas e com aquelas próximas à instituição, principalmente no sentido de "trocar também o que é pesquisa daquele professor, o que é uma pesquisa voltada para a sala de aula dele" (Do.MP.Local-08) além da divulgação do próprio MP para os outros professores dessas escolas. Com o desgaste desse modelo (os sujeitos das escolas não estavam mais se envolvendo tanto com as atividades promovidas), a PES foi reformulada. Nesse segundo formato, os professores-cursistas apresentavam seminários na própria instituição:

Do.MP.Local-08: Nessa PES que eu fiz, a ideia foi "vocês vão ter que trazer a escola para cá" [...] Era uma forma de a gente [corpo docente do $M P]$ conhecer, já que não estava funcionando a ida nas escolas em função dessa disparidade que nós temos de alunos que estão em todo canto e aí funcionou também, foi interessante.

Esse segundo formato, promovido por Do.MP.Local-08 como docente da PES, permitiu aos professores-cursistas ter voz (e serem ouvidos) em um ambiente acadêmico:

Do.MP.Local-08: A gente fazia questão de marcar no auditório. Porque assim: não é sala de aula. Você não vai falar para outras pessoas na sala de aula, você vai falar para o auditório. [...] Você tem que ver o ritual de falar mesmo em público e tal. E aí eles ficavam nervosíssimos... Mas quando eles pegavam aquele microfone e quando começavam a falar... E quando eles viam pessoas assistindo e depois fazendo pergunta [...] dava um gás também em relação a própria pesquisa. [...] Eu acho que isso criava também uma autoestima [...] desse aluno.

Após outro docente assumir a PES, novamente se estabeleceu uma nova dinâmica na disciplina, que voltou a se realizar nas escolas. Dessa vez, o foco é dado ao desenvolvimento do produto educacional que é acompanhado de perto pelo docente da disciplina. Em qualquer um desses modelos em que a disciplina se desenvolveu, houve também o envolvimento dos orientadores. 
No contexto desse MP, a aproximação com a escola parece se dar principalmente através da PES. É dúbio, no entanto, afirmar o quanto essa aproximação se torna parceria de fato, com os dados que dispomos dessas entrevistas. Do.MP.Local-01 ao discutir algumas dificuldades que identifica no curso, dá uma pista sobre essa questão, revelando a dificuldade que se tem em efetivar tais parcerias:

Do.MP.Local-01: E o que é legal [para o corpo docente do MP] é um acompanhamento nas escolas que trabalham, isso é uma coisa que eu sinto às vezes. A gente faz em poucos momentos, o acompanhamento do próprio estudante em seu trabalho [...] No Estágio Supervisionado [a disciplina PES] seria isso, se a gente tivesse mais tempo... Mas normalmente eles trazem um relatório, filmam e é suficiente.

Assim, qual é a contribuição que é gerada no contexto dessa disciplina, principalmente para os professores-cursistas? É uma pergunta em aberto que buscaremos elucidar com as entrevistas realizadas com os egressos.

Do.MP.Local-03 reforça também a questão de os professores-cursistas, muitas vezes, estarem longe da Academia por muito tempo. Por esse motivo, muitos, antes de se inscreverem no MP, buscam a reaproximação com a Academia em cursos de especialização (pós-graduação lato sensu) da própria instituição. É uma etapa que parece ser considerada por esses professores-cursistas como preparatória para o MP:

Do.MP.Local-03: Muitos [professores-cursistas] têm mais de um lato sensu inclusive. [...] São pessoas em constante busca de formação continuada. [...] quando descobrem que tem um mestrado aqui, por exemplo, muitos, primeiro, vão fazer o lato sensu da gente [da mesma instituição, em outro campus, curso de pós-graduação lato sensu em Ensino de Ciências], para eles se sentirem aptos a virem para o mestrado, porque acham que estão afastados há muito tempo da Academia, eles fazem primeiro esse movimento de ir para o lato sensu.

Esse dado nos revela que o público que busca o MP é formado por professores que se preocupam em planejar sua própria formação/seu desenvolvimento profissional. As entrevistas com os egressos auxiliarão na compreensão do valor que atribuem a essa busca por formação contínua, principalmente aqueles que escolheram realizar o curso de lato sensu antes de ingressarem no MP.

Esse é um percurso valorizado pelos professores que almejam ingressar nesse MP, provavelmente devido à aproximação do curso com o mestrado acadêmico, o que nos remete ao entendimento que os docentes têm sobre o MP e sua relação com o MA. Nesse quesito, o corpo docente do programa faz questão de que as exigências acadêmicas dos cursos sejam as mesmas, com apenas uma diferença: a obrigatoriedade do produto educacional no caso do MP. 
Do.MP.Local-08: [...] desde que eu entrei para cá, alguns professores não conseguem dar o pulo do gato em relação ao que torna 0 mestrado, profissional, principalmente em relação à dissertação, o produto, diferente do mestrado acadêmico. Do ponto de vista da formação, nós não distinguimos. Tirando algumas especificidades do curso, a atenção com o aspecto teórico, com o olhar da metodologia, é igual.

Do.MP.Local-01 expõe a preocupação em abordar o contexto prático profissional dos docentes, apesar da ênfase teórica e metodológica do curso. Inclusive, faz uma crítica a esse tipo de ênfase sem a interlocução com a prática, com a ressalva de se formarem "professores de gabinete" ao invés de professores preparados para a prática profissional bem fundamentada. Busca, assim, implicitamente, valorizar a relação teoria-prática, no sentido da teoria discutida no curso poder fornecer bases para enfrentamento de problemas e transformação da prática, na ampliação de dimensões do desenvolvimento profissional como organização e condução do ensino e sustentação da aprendizagem:

Do.MP.Local-01: Acho que as transformações em sala de aula, para mim é o grande pulo. Tem preocupação sim, com essa formação ali. Fazer o sujeito participativo, todas essas coisas que você lê em documentos da ONU, da UNESCO, para educação. Que eles têm um foco muito em sala de aula, não estão muito preocupados com filosofia. [...] Eu não gostaria que nosso programa abandonasse a escola. Essa é uma coisa que não tem como.

Do.MP.Local-01: Eles vêm com muitos problemas de sala de aula. Então, quando começam a estudar, começam a se aprofundar em aportes dos filósofos da educação, em práticas diferenciadas, em métodos diferenciados, e começam a ver, a aplicar isso em sala de aula, e ele perceber a transformação... eu acho que esse é o maior ganho [na formação e prática do professor-cursista].

A dissertação e o produto educacional proporcionam aos mestrandos o exercício defendido por Do.MP.Local-01 de resolver problemas da sala de aula com o aporte dos referenciais teóricos conhecidos e estudados no MP. Essa percepção lança luz ao processo, como o mais relevante para a formação do professor, e não ao produto. Do.MP.Local-03 sintetiza a sua percepção sobre o produto educacional enfatizando a formação proporcionada ao professor-cursista decorrente do processo de elaboração do produto educacional e não pelo produto em si:

Do.MP.Local-03: Eu não acho que o produto educacional exista para salvar o problema da educação brasileira, que é a visão de muitos, a expectativas de outros e a crítica de tantos outros. O produto educacional não foi pensado para você depois colocar lá pendurado na página do programa [...] O produto educacional, ele é importante como uma etapa metodológica para quê? Para a formação daquele recurso humano. [...] Estou preocupada pela forma como esse professor pensou a elaboração desse produto.

Do.MP.Local-03 considera esse processo como o "ponto principal ao final de uma dissertação de mestrado profissional". Processo que se desdobraria em 
contribuições em algumas dimensões do desenvolvimento profissional (em especial, a investigação sobre a própria prática, envolvendo também a escuta e a compreensão de seu contexto de atuação) como visto a seguir.

Do.MP.Local-03: Porque ao longo deste processo, de elaboração deste produto, ele [professor-cursista] aprendeu a diagnosticar 0 problema da sala de aula dele, o problema que ele tinha. Ele aprendeu a ouvir, a escutar, ou os alunos, ou os outros colegas, ou a direção, ou enfim, ver qual é a demanda que está vindo ali externa. [...] Então ele começa a olhar esse entorno, ele aprendeu que ele precisa desenvolver uma metodologia, um passo a passo no sentido de que não vai ser uma receita de bolo que vou estar sempre reaplicando, mas que eu tenho que olhar aquele novo objeto de incômodo, de estranhamento, e eu tenho que olhar, qual é o meu problema efetivamente.

Por esse motivo, essa docente vê a terminalidade como uma característica do MP, pois "em princípio, eu ensinei para aquele professor, no caso de um mestrado profissional em ensino a repensar a prática dele, e trazer para dentro da prática profissional dele o cuidado de uma pesquisa" (Do.MP.Local-03). O que não necessariamente ocorre com o MA, pois a pesquisa acadêmica muitas vezes vai exigir um maior tempo de dedicação (maior que os 24 meses disponíveis para a conclusão desse curso), o que exigirá a continuidade da formação e do trabalho de pesquisa em um curso de doutorado.

Apesar do programa ao qual o MP.Local ter sido fundado com a função de realizar um curso de MP, as docentes contam que existia o desejo de abrir o doutorado, o que levou à implantação do MA. São cursos com naturezas diferentes, mas as disciplinas do programa são estruturadas de modo a permitir a aproximação entre eles. Isso se revela na linha de pesquisa em comum que os dois cursos têm (a linha Formação de Professores de Ciências) e disciplinas que também podem ser realizadas por mestrandos matriculados em ambos os cursos. Nesses casos, Do.MP.Local-03 relata que se estabelece uma relação interessante entre os dois grupos, inclusive ocorrendo coautorias em alguns trabalhos (aparentemente publicados em periódicos ou apresentados em congressos), o que tem sido visto como bom resultado. $O$ incentivo à produção acadêmica se revela também em processos de orientação. Do.MP.Local-03 enfatiza em sua entrevista que ela incentiva seus orientandos à escrita da dissertação sob a forma de artigos e cita o caso de uma orientanda que concluiu o MP com a publicação de um artigo e submissão de outros dois. Aqui, a exigência pela produção acadêmica parece estar tão presente quanto em um programa acadêmico.

Devido à dificuldade enfrentada pelo programa na implantação do doutorado (que teve seu primeiro processo seletivo para ingresso apenas no primeiro semestre 
de 2019, na modalidade profissional), muitos egressos (de MA e MP, inclusive) têm buscado a inserção em outros programas de pós-graduação, conforme colocado por Do.MP.Local-03. Em grande medida, esses egressos têm obtido sucesso, segundo a docente, pela preocupação do corpo docente em oferecer uma formação próxima da acadêmica para esses mestrandos.

Isso nos remete à questão muito discutida na literatura a respeito do MP provocar a migração dos professores de educação básica das escolas para as universidades ou outros espaços de trabalho. Sobre isso, Do.MP.Local-03 vê que os que não permanecem nas escolas vão atuar justamente nas licenciaturas, o que conferiria um efeito multiplicador no trabalho desse professor: apesar de ele não estar mais na sala de aula, ele está atuando como formador de muitos outros professores que estarão. Do.MP.Local-08 conta que acompanham o destino de egressos em uma página do Facebook® do Programa e avalia que alguns egressos realmente saem da educação básica, em busca de trabalho em posições melhores, o que também foi reiteramente apontado por Do.MP.Local-01. Esses fatos apontam para a preocupação desses egressos na dimensão de planejamento de carreira. É importante observar que a saída desses professores da educação básica para outros cargos pode ser decorrente da falta de perspectiva de avanço na carreira docente em algumas redes de ensino.

Muitas vezes a realidade do professor que ingressa no MP, exige dele a conciliação de muitas atividades como se ele fosse um malabarista "com muitas laranjas na mão" (Do.MP.Local-03): "porque ele tem um monte de sala de aula, ele tem que dar conta das nossas leituras, e ele tem que estar aqui, e ele tem que produzir esse produto educacional e ele não tem fomento". A questão de não haver bolsas disponíveis para atender a todos os professores-cursistas é também uma dificuldade que Do.MP.Local-01 coloca para atrair mais alunos para o curso.

A fala de Do.MP.Local-03 destaca algumas das dificuldades enfrentadas pelo professor-cursista no MP. São dificuldades consideradas pelos docentes entrevistados. Inicialmente, falam sobre a matriz curricular do curso: "[...] a gente tem um volume de disciplinas grande, a gente já identificou isso" (Do.MP.Local-08). As disciplinas do curso, funcionam em blocos (têm a duração de um mês e uma semana dadas em uma manhã ou tarde inteiras) e se sucedem ao longo de três semestres, fazendo com que o professor-cursista faça cerca de dez disciplinas ao longo do curso:

Do.MP.Local-03: Que é pesado para o aluno, que é pesado para o professor. Então eu preciso me reinventar constantemente para eu conseguir manter a atenção desses alunos, esse batalhão de carga horária numa pancadona só. E conseguir pesar a mão nessa 
avaliação [da disciplina]. Porque ele tem cinco semanas. Em cinco semanas, ele muda o módulo.

Do.MP.Local-08 destaca um ponto positivo dessa organização curricular: "por outro lado, isso também dá a eles um contato com muitas disciplinas que vão, como um quebra-cabeça, ajudando ele a pensar". Considera-se assim que as disciplinas almejam a atualização dos conhecimentos acadêmicos e pedagógicos dos professores-cursistas, porém de forma articulada com a investigação realizada na elaboração do produto educacional. No quesito de infraestrutura, à parte os laboratórios e demais espaços tecnológicos disponíveis na instituição, Do.MP.Local01 lamenta a falta de um espaço de convivência entre os mestrandos.

Outras dificuldades citadas têm a ver com uma disputa interna por privilégios que parece existir na instituição entre docentes que são credenciados no MP.Local e os que não são e atuam apenas nos outros níveis de ensino. Esses privilégios estariam relacionados à disponibilidade de salas exclusivas para orientação, reuniões e outras atividades do mestrado e à distribuição de carga didática que supostamente seria menor para os docentes que atuam apenas na pós-graduação (sendo que eles acabam tendo que cumprir com muitas outras atividades de pesquisa extraclasse). Ao mesmo tempo, há a dificuldade de docentes que atuam também em cursos de graduação do campus que podem se sobrecarregar, embora, principalmente na visão de Do.MP.Local-08 isso possa também significar um enriquecimento das disciplinas do MP. No caso de Do-MP.Local-01, que também atua no curso de licenciatura em Física, participar do MP.Local significa levar às suas aulas da graduação as propostas de estratégias inovadoras de ensino discutidas com os professores-cursistas.

\subsubsection{Apreciações sobre as análises das entrevistas realizadas com docentes}

A análise documental dos dois MPs delineou dois programas bastante diferentes, tanto na estrutura curricular quanto nas finalidades, sendo o MNPEF focado no fortalecimento do conhecimento científico dos professores-cursistas e, possivelmente, no aprimoramento de metodologias de ensino. Por outro lado, o MP.Local mostrou uma perspectiva mais interdisciplinar e uma forte relação com a pesquisa em ensino. No entanto, na análise das entrevistas com o corpo docente, as diferenças nos parecem menores, por várias razões. Em primeiro lugar, a grande maioria dos docentes de ambos os programas tem uma formação acadêmica nas áreas disciplinares: no caso do MNPEF o doutoramento dominante é em Física, no caso do MP.Local o doutoramento é em alguma disciplina científica (Física, Química, 
Biologia,...). Apesar dessa formação distante do Ensino Fundamental e Médio, todos desejam atender à demanda de formação de muitos professores da região. Para tanto, estão dispostos a ensinar e ajudar no processo de formação desses professores. Poder-se-ia argumentar que os docentes do MP.Local têm uma produção em Ensino de Ciências bem maior do que os docentes do MNPEF. No entanto, é preciso ter presente que os docentes deste último curso começaram a atuar na área muito recentemente; assim é possível interpretar que a atuação dos docentes do MNPEF constitua uma primeira etapa de um caminho que os docentes do MP.Local já ultrapassaram.

As análises com elementos narrativos dão alguns indicativos de respostas a alguns questionamentos derivados da etapa de análise documental e levantam outros questionamentos que serão esclarecidos na etapa de entrevistas com egressos. Alguns desses questionamentos são comuns aos dois programas de MP objetos de estudo da pesquisa:

- Em ambos, não foi possível identificar nessas duas primeiras etapas de pesquisa como seria o processo de elaboração do projeto pesquisa/desenvolvimento de produto educacional. Nesses programas, parece ser importante, logo no ingresso, que o professor-cursista tenha uma ideia geral do que deseja desenvolver ao longo do curso, porém algumas falas destacadas ao longo das análises colocam em dúvida o quanto os orientadores influenciam na escolha dos objetivos de pesquisa. O projeto do produto educacional nasce efetivamente a partir de um problema oriundo da prática profissional do professor-cursista ou de uma sugestão dada pelo docente orientador?;

- Nos dois cursos há histórias de egressos que saem das escolas de educação básica e dão continuidade à formação acadêmica (no nível de doutorado) com o objetivo de migrarem para as universidades. Infelizmente, ainda não temos dados suficientes para apontar, quantitativamente, o quando isso é comum nos programas. Nem se esses percursos escolhidos pelos egressos são decorrentes da preocupação com o planejamento da carreira profissional e se a opção pela universidade é comum por causa da baixa perspectiva de desenvolvimento na carreira nas escolas de educação básica;

- Fica em aberto também a investigação de quais seriam as contribuições das disciplinas que promovem o contato com a escola de educação básica (Estágio Supervisionado, no caso do MNPEF e PES no MP.Local) para o desenvolvimento profissional dos professores-cursistas e a aproximação universidade-escola; 
- Por fim, há indicações de que os egressos dos dois programas ficam satisfeitos com o curso. O que significa essa satisfação? No que esse fator subjetivo pode influenciar concretamente no desenvolvimento profissional nas diferentes dimensões enfocadas por cada programa?

Discriminamos a seguir outras questões, particulares de cada programa. Primeiramente, na análise produzida a partir da entrevista com Do.MNPEF-07 e Do.MNPEF-01:

- Do.MNPEF-07 coloca como demanda dos professores-cursistas a busca por novas metodologias de ensino que ajudem a combater o desinteresse dos alunos da educação básica nas aulas de Física. Demanda essa identificada pelo corpo docente do campus que, a partir disso, decidiram propor a instalação do polo do MNPEF, justamente para que pudessem fornecer subsídios a esses professores no enfrentamento dessas questões com seus alunos. No entanto, quase todos os docentes não têm formação específica na área de Ensino de Física, pois são originários da área de pesquisa básica em Física. De que maneira, portanto, esses docentes se mobilizam para atender à demanda desses professores de educação básica? ${ }^{105}$ Como eles auxiliam os mestrandos para "corrigir eventuais desvios de rota" na aplicação de seus produtos educacionais nas escolas, se tem pouca ou mesmo nenhuma formação acadêmica em ensino ou experiência na educação básica? Para esses docentes, o que precisa ser mudado na prática dos professores de educação básica? Em alguns trechos destacados da entrevista de Do.MNPEF-07 é observada uma concepção aplicacionista, ainda mais por subestimar a importância da fundamentação teórica para a construção dos produtos educacionais. Nesse sentido, esses professores elegeriam determinadas metodologias de ensino, tomadas como modelos a ser seguidos e reproduzidos pelos professores-cursistas. Sendo assim, é um reforço à concepção do MNPEF como formação de professores baseada na racionalidade técnica;

- Ainda, não é todo o corpo docente que desenvolvia trabalhos de extensão em escolas de educação básica, embora uma motivação para a implantação do polo seria o de envolver a instituição no contato com essas escolas. Não fica claro como esses

\footnotetext{
${ }^{105}$ Villani (2016) adianta a hipótese de que, devido à constituição do corpo docente dos polos do MNPEF, como o analisado nessa pesquisa, ser em grande parte de cientistas da Física "dura", com pouca ou nenhuma experiência com Ensino de Física, "podemos duvidar de que se alcancem efetivamente as metas propostas [no MNPEF]". O autor completa inferindo que os idealizadores do MNPEF teriam enfatizado os conteúdos científicos em sua matriz curricular para viabilizar a adesão dos docentes com esse perfil, pois dessa forma facilitariam "a tarefa dos docentes (do MP), sobretudo os que já têm familiaridade com a docência nas disciplinas de 'conteúdo' da graduação" (p. 427).
} 
docentes mantiveram ou estabeleceram novas parcerias com as escolas de educação básica (por exemplo, no contexto da disciplina de Estágio Supervisionado) e o que significou o envolvimento institucional no relacionamento com as escolas com a implantação do MNPEF;

- Quais são as ações empreendidas no curso para apoiar os professorescursistas que encontram dificuldades em alterar suas práticas docentes? Uma fala de Do.MNPEF-07 nos remete à discussão presente na literatura da importância das parcerias entre universidades e escolas no apoio à implementação de novas práticas. O que se tem feito a respeito dessas parcerias no âmbito desse polo? Além disso, do ponto de vista do professor-cursista: o fato de ele estar cursando um MP confere a ele algum tipo de status ou prestígio que facilite a implementação das mudanças nas práticas desse professor na escola de educação básica, como Do.MNPEF-07 sugeriu na entrevista? Em outras palavras, o título de mestre profissional conferiria ao professor a legitimidade e apoio da gestão escolar para a realização de mudanças?

Já em relação ao MP.Local, os seguintes questionamentos emergiram na análise com elementos narrativos:

- Como a proposta de interdisciplinaridade perpassa as disciplinas do curso, o processo de orientação e elaboração da dissertação e produto educacional, as relações entre mestrandos, tanto do MP quanto do MA? Que impactos essa interdisciplinaridade preconizada no programa tem sobre a formação e a elaboração do produto educacional?;

- Como a ampliação dos conhecimentos acadêmicos e pedagógicos nas disciplinas é atrelada à investigação realizada pelos professores-cursistas para a elaboração da dissertação e produto educacional?

\subsection{Análise documental dos produtos educacionais e dissertações defendidos nos cursos de mestrado profissional}

Apresentamos análise documental do corpus composto por dissertações e Produtos Educacionais (PEs) produzidos pelos professores egressos dos dois cursos analisados. Os objetivos específicos dessa etapa de pesquisa foram:

- traçar um panorama geral dos trabalhos realizados pelos professores egressos no período determinado para a pesquisa, caracterizando os PEs produzidos (qual foi o problema que motivou a sua elaboração; quais foram os conteúdos abordados e 
recursos utilizados; em quais referenciais teóricos os professores se apoiaram entre outras características que serão detalhadas na sequência) e as dissertações vinculadas à produção desses PEs (que geralmente consistiram na avaliação da aplicação do PE em contexto real de sala de aula);

- identificar na escrita desses trabalhos indícios de desenvolvimento profissional e influências de elementos do curso (interação com orientadores, disciplinas realizadas, entre outros) no desempenho do trabalho e na formação docente;

- compilar outros questionamentos que pudessem orientar a realização das entrevistas semi-estruturadas com parte dos egressos dos dois cursos de MP, etapa de pesquisa final cujos dados serão apresentados mais adiante.

Primeiramente, esta etapa de pesquisa consistiu na organização dos documentos que fariam parte do corpus de análise. Para o polo do MNPEF, foi realizado um levantamento das dissertações e PEs defendidos de todos os egressos do curso até o ano de 2017. Dessa forma, foi possível estabelecer o total de trinta (30) trabalhos, defendidos entre 2015 e 2017, todos disponíveis online no site do polo. Todos esses trabalhos foram enumerados com a sigla MNPEF seguido por um número (MNPEF.01, MNPEF.02, e assim por diante). A numeração segue a ordem de disponibilização no site do programa, de modo que o MNPEF.01 é o primeiro trabalho disponibilizado e MNPEF.30, o último disponibilizado e defendido no ano de 2017. Aproveitamos o uso dessas siglas também para a identificação dos autores desses trabalhos.

Já em relação ao MP.Local, por ser um MP em Ensino de Ciências (e não apenas orientado à Física) que iniciou suas atividades anos antes que o polo do MNPEF, estabelecemos alguns critérios para a seleção dos trabalhos defendidos no curso a serem analisados, segundo as seguintes justificativas:

1. Dissertação/PE elaborado por egresso cuja formação inicial fosse Licenciatura em Física - mesmo que seu trabalho fosse genérico em relação à área de Ensino de Ciências (e não de Física), o foco seria investigar o desenvolvimento profissional desse professor que, possivelmente, atuaria como professor de Física nas escolas em que trabalha, dada sua formação inicial;

2. Dissertação/PE orientado por docente credenciado no MP.Local cuja especialidade fosse a área de Física - de modo a perceber possíveis ações desses orientadores que sustentaria a produção e formação dos professores-cursistas orientados por eles; 
3. Trabalho cujo conteúdo estivesse relacionado à disciplina de Física - mesmo que o trabalho fosse realizado por um professor com formação diversa a essa disciplina, de modo que fosse possível investigar se o trabalho seria interdisciplinar (característica tão preconizada pelo MP.Local), ou se o professor-cursista atuaria de fato como professor de Física, mesmo não tendo realizado a formação inicial em Licenciatura especificamente orientada para essa disciplina.

Assim, num universo total de noventa e quatro (94) trabalhos defendidos no MP.Local de 2010 a 2017 e disponíveis online, selecionamos um total de vinte e dois (22) que atendem ao menos a um desses critérios, compondo o nosso corpus de análise do MP.Local. Esses trabalhos, por sua vez, são identificados pela sigla MP.Local seguido da numeração que também indica a ordem em que cada trabalho foi disponibilizado no site do programa, do mais antigo (o MP.Local.01) ao mais recente (o MP.Local.22). Da mesma forma que no MNPEF, utilizamos essas siglas para nos referirmos aos professores mestrandos.

Realizamos uma leitura flutuante da integralidade de cada uma dessas dissertações e PEs alinhada com procedimentos de descoberta (BARDIN, 1977), utilizando para isso, uma ficha de leitura criada especificamente para este fim. Essa ficha (disponível no apêndice 3) foi criada a partir do estudo de análises e discussões empreendidas em artigos de nosso levantamento bibliográfico, de discussões empreendidas pelas fundamentações teóricas - em especial sobre desenvolvimento profissional - nas quais nos apoiamos, a partir de questionamentos e detalhes já levantados na análise de documentos do curso realizada nas primeira e segunda etapas de pesquisa e tendo em mente nossa questão de pesquisa e objetivos dessa terceira etapa.

Em suma, a ficha se organiza em quatro blocos:

- Bloco 1 - Dados gerais: identificação geral da dissertação/PE analisados (não apresentada nessa tese a fim de preservar a identidade dos egressos): título, egresso, orientadores, banca examinadora, ano de defesa da dissertação/conclusão do MP.

- Bloco 2 - O Produto Educacional (PE): dados concernentes ao PE. Entre eles: o problema que motivou o professor-cursista a elaborar o PE, os recursos utilizados, os conteúdos abordados, os referenciais teóricos que são mobilizados para sua criação.

- Bloco 3 - Dissertação: dados sobre a dissertação, tais como: objetivo ou questão formulada para a pesquisa realizada e relatada na dissertação, a metodologia e instrumentos de coleta de dados utilizados, os sujeitos participantes da pesquisa, 
referenciais teóricos utilizados na análise de dados, indicação de desdobramentos da pesquisa e/ou do PE.

- Bloco 4 - Outras... - bloco em que se localizam informações diversas relacionadas às questões de pesquisa centrais desta tese e outros questionamentos levantados nas etapas de pesquisa anteriores, tais como: referências eventualmente feitas no texto da dissertação às atividades do curso de MP; o processo de orientação e percepção do professor sobre a própria formação; se a proposta apresentada é interdisciplinar ${ }^{106}$, se ela está alinhada ao "paradigma da aprendizagem ativa" e outras observações e destaques interessantes obtidas na leitura do material.

Após as leituras extensas de todo o corpus de análise e elaboração das fichas, procedeu-se para um subnível de análise, mais refinado, dos dados registrados. Seguindo a organização das fichas discriminada acima, buscamos extrair o essencial com o auxílio de uma compilação de dados, mais abreviada e organizada em planilhas, dos aspectos mais importantes de cada item apresentado nas fichas - que nos permitisse traçar o panorama da produção dos MPs. Nessa parte final da presente etapa de pesquisa, destacamos o que há em comum e o que há em particular entre os trabalhos defendidos em um mesmo curso e entre os dois cursos. Desse procedimento, obtemos uma análise de caráter descritivo, porém com o esforço de ir além ao que é registrado em linguagem acadêmica nesses documentos, rumo a uma sistematização interpretativa e crítica de alguns desses dados. Os dados são apresentados e discutidos seguindo a organização em blocos da ficha. Ressalva-se que em alguns momentos, na discussão de um determinado bloco, dados pertinentes registrados em outros são utilizados para melhor embasá-la.

\subsubsection{Análise dos produtos educacionais e dissertações defendidos no polo do MNPEF até 2017}

\section{- Bloco 1: Dados gerais}

No período demarcado para a análise desta pesquisa, identificamos de 2015 (ano da primeira defesa do polo) a 2017, trinta defesas de trabalhos de egressos de

\footnotetext{
${ }^{106}$ Não nos preocupamos em avaliar, neste quesito, a forma como a interdisciplinaridade aparece nos trabalhos, já que ela pode se orientar a aspectos mais epistemológicos ou metodológicos. Além disso, a articulação entre disciplinas pode se dar através da multidisciplinaridade e da transdisciplinaridade, formas subjacentes à interdisciplinaridade. Análise desse tipo é realizado por Moreira et al. (2017) com um corpus composto de PEs de um MP em Ensino de Ciências.
} 
duas turmas diferentes de professores-cursistas, distribuídas conforme o ano de ingresso da seguinte forma:

Turma 2013 (1 1 turma) - total de 19 egressos: MNPEF.01, MNPEF.02, MNPEF.03, MNPEF.04, MNPEF.03, MNPEF.06, MNPEF.07, MNPEF.08, MNPEF.09, MNPEF.10, MNPEF.11, MNPEF.12, MNPEF.13, MNPEF.14, MNPEF.16, MNPEF.17, MNPEF.18, MNPEF.20, MNPEF.22;

Turma 2014 (2 $2^{\text {a }}$ turma) - total de 11 egressos: MNPEF.15, MNPEF.19, MNPEF.21, MNPEF.23, MNPEF.24, MNPEF.25, MNPEF.26, MNPEF.27, MNPEF.28, MNPEF.29, MNPEF.30.

Informações disponíveis no site do polo analisado nos permitiu observar que foram admitidos na primeira turma (2013), vinte e seis professores-cursistas, dos quais sete não concluíram o curso e tiveram suas matrículas canceladas e na segunda turma (2014), treze professores-cursistas, dos quais apenas um não concluiu o curso.

Foi possível observar também a distribuição de orientação entre os docentes credenciados no curso:

Do.MNPEF-01: participou de duas co-orientações (MNPEF.04 e MNPEF.08), por ser docente de outra instituição, atuou como docente colaboradora nos primeiros anos do curso;

Do.MNPEF-02: nenhuma orientação;

Do.MNPEF-03: uma orientação (MNPEF.27);

Do.MNPEF-04: sete orientações (MNPEF.02; MNPEF.05; MNPEF.13; MNPEF.14; MNPEF.16; MNPEF.19; MNPEF.30), mais uma co-orientação (MNPEF.15);

Do.MNPEF-05: sete orientações (MNPEF.01; MNPEF.04; MNPEF.08; MNPEF.09; MNPEF.18; MNPEF.20; MNPEF.21);

Do.MNPEF-06: quatro orientações (MNPEF.06; MNPEF.22; MNPEF.26; MNPEF.28);

Do.MNPEF-07: quatro orientações (MNPEF.03; MNPEF.07; MNPEF.17; MNPEF.29);

Do.MNPEF-08: uma orientação (MNPEF.24);

Do.MNPEF-09: uma orientação (MNPEF.25);

Do.MNPEF-10: uma orientação (MNPEF.15); 
Do.MNPEF-11: quatro orientações (MNPEF.10; MNPEF.11; MNPEF.12; MNPEF.23).

Excetuando-se os docentes que se credenciaram no curso a partir de 2015 (e tiveram apenas uma orientação no período cada um), observamos uma distribuição uniforme entre os demais docentes da instituição sede do polo do MNPEF credenciados desde 2013. A exceção é o docente Do.MNPEF-02 que não orientou nenhum professor-cursista das turmas analisadas.

Não analisamos exaustivamente o perfil dos docentes membros de bancas examinadoras dos trabalhos, mas foi possível perceber que entre os membros externos ao polo convidados, grande parte deles são de docentes que não se envolvem diretamente com a área de Ensino de Física, tendo suas pesquisas e estudos principais concentrados na área de pesquisa básica específica de Física.

Por último, em relação ao tempo para conclusão do curso, percebe-se uma média similar entre os concluintes da turma de 2013 e de 2014, de aproximadamente 30 meses desde 0 ingresso do curso. Entre os professores-cursistas da turma ingressante em 2013, seis defenderam em 24 meses de curso, prazo estipulado como o ideal (ou seja, o período de duração das bolsas de mestrado). Na turma ingressante em 2014, três professores defenderam em 23 ou 24 meses. O máximo de tempo para a titulação foi de 36 meses (total de seis professores-cursistas nas duas turmas).

- Bloco 2: O Produto Educacional (PE)

Os dados registrados nas fichas que caracterizam os resultados apresentados foram coletados principalmente pela leitura das dissertações, já que estas servem para relatar o processo de elaboração dos PEs (MOREIRA; NARDI, 2009).

Por conta da proposta dos MPs ser a de integrar teoria e prática dando suporte à prática profissional dos professores-mestrandos, foi nossa preocupação averiguar na leitura das dissertações qual problema da prática docente são apontados como os motivadores para a realização dos PEs para cada um dos professores-cursistas.

É importante notar que nem sempre esses problemas motivadores são explicitamente apontados. Em especial, a recomendação apontada por Ostermann e Rezende (2009) a respeito da determinação de questões-foco para nortear os projetos de desenvolvimento que sustentam a produção do PE foram identificadas em apenas dois trabalhos do universo de trinta analisados no polo do MNPEF, identificados abaixo: 
MNPEF.05 - (questões foco expostas no trabalho em um diagrama V da aplicação do produto): "O conhecimento científico é uma verdade absoluta? O que é o efeito fotoelétrico? Qual a natureza da luz?"

MNPEF.26 - (porém não explicita como questões foco em seu texto): "[...] a seleção de temas e aplicativos nasceram desta premissa: como o aluno pode entender a Física envolvida na produção de energia elétrica?" (grifos do autor)

Segundo as referidas autoras, as questões-foco devem "se relacionar a formas de se conceber, implementar e avaliar inovações didáticas (estando vinculadas a metodologias de ensino, conteúdos e avaliação)" (p. 72). Aponta-se que as questõesfoco desses trabalhos se concentram no modo de se conceber o PE. De fato, as questões de avaliação do PE são incipientes na maior parte dos casos, como será indicado e discutido ao longo de nossa análise.

Para facilitar a caracterização desses problemas motivadores, definimos algumas categorias para organizá-los, observando o que havia em comum entre eles. Juntamente com a apresentação desses dados, indicamos qual é a natureza do PE desenvolvido, ou seja, indicamos se ele era composto por uma sequência didática, um manual, um vídeo etc.

É notável os professores relatarem como motivador o desinteresse dos alunos para o estudo da Física, ora apontado de forma genérica, ora de forma particularizada fazendo referência à sua prática como professor. Essa é, inclusive, a demanda identificada pelo corpo docente da instituição para a implantação do polo, conforme foi indicado por Do.MNPEF-07 na análise apresentada anteriormente. Tal desinteresse dos estudantes está associado nos trabalhos à necessidade de renovação de metodologia/recursos de ensino, o que está alinhado aos objetivos preconizados para o MNPEF conforme estudado nos documentos do programa. Encontramos o professor MNPEF.27 destacando esse fato em sua dissertação:

MNPEF.27: "Um dos grandes desafios do MNPEF é mudar a maneira como a física vem sendo ensinada nas escolas e, dessa forma, conquistar o gosto do aluno para o saber científico. Esse desafio passa necessariamente pela implementação de novas estratégias de ensino que sejam capazes de transformar um ensino baseado em conceitos e fórmulas em um ensino mais dinâmico, lúdico, investigativo e contextualizado de modo a se aproximar da realidade vivida pelo aluno" (p. 9)

Nessa categoria aparecem a maior parte dos trabalhos (13 de um total de 30). Esses trabalhos apontam o uso de TICs (em especial simuladores PhET $^{107}$ ) e

\footnotetext{
${ }^{107}$ No site em português do projeto temos a seguinte apresentação: "Fundado em 2002 pelo Prêmio Nobel Carl Wieman, o projeto PhET Simulações Interativas da Universidade de Colorado Boulder cria simulações interativas gratuitas de matemática e ciências. As sims PhET baseiam-se em extensa pesquisa em educação e envolvem os alunos através de um ambiente
} 
experimentos como recursos inovadores e se materializam em PEs que apresentam sequências didáticas (a maioria) ou manuais, roteiros, apostila (caso de MNPEF.22, trabalho desenvolvido no contexto particular do regime socioeducativo, onde há carência de materiais instrucionais adaptados para os estudantes detidos) e ebook (MNPEF.29).

Em seguida, em segundo lugar no grau de importância dada pelos professorescursistas, está o atendimento às propostas curriculares. As Orientações Educacionais Complementares aos Parâmetros Curriculares Nacionais - $\mathrm{PCN}+$ de Física (documentos curriculares específicos sobre o Ensino de Física no Ensino Médio publicados em 2002) são extensivamente citados na maior parte das dissertações (desta ou de outras categorias), mas em especial, os sete trabalhos desta categoria se preocupam explicitamente em atender à proposta curricular estadual. Todos esses trabalhos apresentam sequências didáticas como PE. Alguns, que utilizaram propostas experimentais, também apresentam manuais de construção dos experimentos.

Com menor expressão, alguns professores-cursistas apontam as dificuldades de aprendizagem dos estudantes como problema motivador. São três trabalhos que se concentraram em propor roteiro de atividades e sequências didáticas. Também são três trabalhos que se preocuparam em instrumentalizar professores no uso de metodologias/estratégias considerados inovadores: a Peer Instruction ou Instrução pelos Colegas (com a apresentação de questões conceituais utilizadas em sala para a aplicação desta metodologia de ensino); a experimentação (com um PE que contém manual de construção dos experimentos) e, por fim, uma diferente estratégia para a dedução da Lei de Gauss (apresentada em um plano de aula). Identificamos também dois trabalhos que visavam buscar a contextualização do ensino e um trabalho focando à produção de material didático. Esses últimos trabalhos se preocuparam em apresentar sequências didáticas (ou planos de aula individuais).

Por fim, destaque-se o trabalho MNPEF.06 que foi o único que coloca como motivação a investigação da própria prática, demonstrando uma preocupação que vai além da elaboração do PE, destoando do conjunto de dissertações analisadas, e destacando o processo no qual o professor esteve envolvido em sua prática:

MNPEF.06: "Um dos desafios deste trabalho foi trazer para a prática professoral em sala de aula as contribuições da pesquisa-ação. Nossos objetivos iniciais foram: primeiro, um melhor entendimento da realidade em que a aula se sustenta (qual a estrutura cognitiva que os alunos trazem) e, segundo, identificar os possíveis problemas que afetam o desenvolvimento dos alunos no campo da aprendizagem

intuitivo, estilo jogo, onde os alunos aprendem através da exploração e da descoberta". Disponível em: <https://phet.colorado.edu/pt BR/>. Acesso em: 03 mai 2019. 
(sondar como a estrutura cognitiva dos alunos se reorganiza com as aulas)" (p. 53, grifos nossos).

É um exemplo que encontramos de trabalho do polo do MNPEF que vai além do esperado por uma formação que se enquadre como "racionalidade técnica". Desdobramentos de outros trabalhos são discutidos adiante na apresentação de dados e análise da "Parte 3 - Dissertação" da ficha de leitura. Um resumo dos problemas da prática docente motivadores para a realização dos PEs no contexto do polo do MNPEF é apresentado na Tabela 7:

Tabela 7 - Problemas da prática docente apontados como motivadores para a realização dos PEs defendidos até 2017 no contexto do polo do MNPEF.

\begin{tabular}{c}
\hline PROBLEMA MOTIVADOR PARA A REALIZAÇÃO DO PE \\
Desinteresse dos alunos para o estudo da Física \\
Necessidade de renovação de metodologia/recursos de ensino \\
Atendimento às propostas curriculares \\
Dificuldades dos estudantes \\
Instrumentalizar professores no uso de metodologias/estratégias \\
considerados inovadores \\
Buscar a contextualização no ensino \\
Produção de material didático \\
Investigação da própria prática
\end{tabular}

Antes de seguirmos com outra categoria de análise, destacamos a predominância de PEs no formato de sequências didáticas e planos de aula. Não foi possível identificar no conjunto analisado, PEs compostos de outros tipos de material tais como simulações inéditas (ou seja, criadas pelos professores-cursistas), vídeos, sites, entre outras possibilidades que se utilizam de outras mídias que não a tradicional do texto escrito (no caso, orientado, grande parte para o professor de ensino médio e não para os alunos). O mesmo resultado foi encontrado na análise de PEs de um MP em Ensino de Ciências empreendida por Moreira e coautores (2018), com estrutura diferenciada em relação aos Mestrados em Rede. Os autores observaram "lacunas em determinadas variáveis de PE previstas pelos documentos oficiais que norteiam a área de Ensino, tais como projetos de extensão e atividades de divulgação científica" (p. 351). Atribuem essas ausências possivelmente às linhas de 
pesquisa desenvolvidas no programa analisado, além da dificuldade de se levantar recursos financeiros junto à órgãos de fomento, necessários a projetos mais dispendiosos que a produção de material escrito. Acrescentamos como dificultadores a apropriação de ferramentas para a produção de materiais de mídias diferenciadas (por exemplo, de ferramentas que permitem a criação de uma simulação computacional ou um vídeo) que nem sempre se encontram disponíveis, além do tempo restrito dos professores para a produção desses materiais e planejamento e execução de projetos. A questão do tempo de dedicação é bastante referida nas entrevistas com os egressos, como veremos adiante. Moreira et al. (2018) acrescentam que a escolha por PEs da modalidade textual também esteja "ligada à familiaridade que os mestrandos possuem com recursos pedagógicos textuais, considerando a onipresença do livro didático nas salas de aula" (p. 350).

Ainda em relação à proposta dos MPs, preocupamo-nos em tentar identificar a origem desses problemas motivadores que podem ter levado os professores a procurar o MP. Devido à linguagem acadêmica (com pouco posicionamento pessoal do professor-cursista), foi difícil encontrar indicações a esse respeito. Dessa forma, em muitos trabalhos não foi possível responder a essa questão. Já em catorze trabalhos, há indícios de que as motivações dos professores partiram de suas práticas profissionais particulares. Destaques são mostrados abaixo:

MNPEF.03: "[...] o aluno não está tão envolvido com a disciplina [Física] quanto deveria e também que há um pré-conceito negativo já estabelecido, pois o aluno revela sua aversão antes mesmo de começar a aprender o conteúdo. Havia, portanto, uma necessidade e uma vontade grande de mudar esse quadro por parte dos professores de física do [Colégio em que o professor trabalha]. [...] O projeto [produto educacional] foi desenvolvido objetivando a quebra de muitos paradigmas trazidos pelos alunos ao longo da vida com relação à Física de um modo divertido e interativo" (p. 39).

MNPEF.11: "O interesse na elaboração da nossa sequência didática adveio de termos tomado conhecimento de uma pesquisa feita com alunos do Instituto Superior de Educação, em 2011, acerca dos recursos tecnológicos que estes consideravam tornar as aulas mais atrativas. [...] Este fato nos levou a fazer mesma pesquisa em nossa escola" (p. 25).

MNPEF.18: "A [Prefeitura Municipal], juntamente com a [Fundação Educacional] começaram a adotar, a partir de 2014 as provas do [avaliação externa do governo estadual] em turmas do nono ano do Ensino Fundamental, com o objetivo de verificar como está o percentual de acertos destes alunos nestas disciplinas. Num dos colégios da [Fundação Educacional], por exemplo, neste primeiro bimestre de 2015, [...] foi verificado junto à Equipe Pedagógica da Escola que os alunos tiveram muita dificuldade em resolver questões que envolvessem cálculos com razões e proporções, especificamente no conteúdo Teorema de Tales, onde este tema se faz presente. Como sou professor de Matemática deste Colégio, lido com alunos do sétimo e nono ano do Ensino Fundamental e presencio há sete anos 
a queixa do professor de Ciências do nono ano de que o aluno tem dificuldade em resolver questões que envolvam Razão e Proporção, em resolver questões que envolvam Movimento Uniforme, aceitei o desafio de desenvolver um programa de aulas que respondesse a estas ansiedades de forma mais dinâmica." (p. 12-13)

MNPEF.21: "A escolha feita neste trabalho pela utilização de experimentos na abordagem de ensino potencialmente significativo na óptica geométrica, deve-se ao fato de que em seus anos de experiência no ensino de física no ensino médio, o autor ter a sensação de que neste assunto em especial, as aulas serem de um modo geral muito teóricas e pouco práticas" (p. 10).

MNPEF.28: "O produto foi pensado com o intuito de facilitar o ensino para alunos que têm dificuldades em entender as relações matemáticas existentes nas Leis de Ohm. Como professor observamos que essa dificuldade é mais acentuada nos estudantes da rede pública, de forma geral [...] Sendo assim, por exemplo, notamos que é muito comum que alunos do terceiro ano do ensino médio tenham dificuldades em entender quando duas grandezas são diretamente ou inversamente proporcionais nas Leis de Ohm. Nosso produto então objetivou fazer uso de TICs para abordar as Leis de Ohm" (p. 20).

Dois professores-cursistas do polo do MNPEF, porém, se destacam por terem sido também incentivados por discussões empreendidas nas disciplinas do curso. Nos trechos destacados abaixo há indícios de influência do que é visto nas disciplinas na prática dos professores (por sua vez, indício de impactos na dimensão organização e condução do ensino de desenvolvimento profissional, além de atualização de conhecimentos pedagógicos) e incentivos à elaboração do PE:

MNPEF.04: "A ideia desse projeto nasceu a partir do Curso de Mestrado, iniciado em 2013, no qual o conhecimento sobre o construtivismo - em que o aluno passa de mero observador para um agente dentro da sala de aula - foi aprofundado e utilizado para desenvolver trabalhos nas escolas em que atuava como professor de Física"(p. 11, grifos nossos).

MNPEF.05: "Estávamos direcionados a desenvolver uma prática de ensino de Física Moderna e Contemporânea com uma abordagem em História e Filosofia da Ciência a ser aplicada em uma escola estadual [...]. Faltava, entretanto, escolher qual tema, presente no [currículo estadual], iríamos abordar. Durante o curso de mestrado, refazendo uma leitura da tese de doutorado [...], que nos serviu de inspiração para a escolha do tema, observamos que neste trabalho ela apresenta uma descrição histórica da natureza da luz em três episódios distintos. [...] Apesar de [a tese de doutorado] não abordar episódios de Física Moderna e Contemporânea, ficamos inspirados a abordar o efeito fotoelétrico e a dualidade da luz partindo de uma análise histórica da natureza da luz" (p. 14).

Não foi possível verificar motivações a partir de indicações de orientadores ou grupos de pesquisa a partir da leitura das dissertações e PEs. A entrevista realizada com o coordenador Do.MNPEF-07, no entanto, indica esse movimento, quando ele explicou as dificuldades para a escolha de projetos para desenvolvimento pelos mestrandos. Essa influência dos orientadores fica explícita nas entrevistas realizadas 
com alguns desses egressos (Etapa 4 da pesquisa). A Tabela 8 resume o que motivou os professores egressos do polo do MNPEF à construção dos PEs.

Tabela 8 - Motivações apresentadas pelos professores egressos do polo do MNPEF para a construção dos PEs propostos.

\section{MOTIVAÇÕES PARA A CONSTRUÇÃO DO PEs PROPOSTOS}

Problemas que partiram da própria prática profissional
Discussões empreendidas nas disciplinas do MP
Indicações de orientadores e grupos de pesquisa (dado obtido nas
entrevistas com egressos)

Aspectos de inovação curricular, em termos de reformulação da organização dos conteúdos disciplinares, puderam ser avaliados de forma preliminar nesse processo de análise. É notável a incidência de justificativas dadas para a elaboração do PE com base no currículo que é prescrito na rede estadual, o qual apresenta as seguintes características principais: a inserção de alguns tópicos de Física Moderna juntamente com tópicos da Física Clássica ao longo das séries do ensino médio; a abordagem de temas da Astronomia e Cosmologia; pouca ênfase dada ao conteúdo de Óptica Geométrica. Apesar das extensas e frequentes discussões relativas à inovação curricular em Física representada pela inserção de tópicos de Física Moderna e algumas dificuldades, entre elas a formação de professores e falta de materiais instrucionais (BARCELLOS; GUERRA, 2015), apenas três professores-cursistas deste polo do MNPEF (ou seja, 10\% do total) optaram por dedicar seus PEs a este tema. É mais presente a abordagem de temas da Astronomia (caso de seis, ou $20 \%$, dos trabalhos analisados). Todos os outros trabalhos (70 \% do total) dedicaram-se aos temas da chamada Física Clássica, já tradicionalmente presentes nos currículos oficiais de Física, o que indica a prevalência desses conteúdos nas escolhas dos professores. Além disso, como era de se esperar, a maioria (24 trabalhos, ou $80 \%$ do total) são orientados para o ensino médio. Há dois trabalhos para o ensino fundamental (ciclo 2), três para EJA (Educação de Jovens e Adultos) ${ }^{108}$, e dois que apresentam PEs aplicados em contextos muito específicos de educação: um para o ensino normal, e outro para turmas de instituições socioeducativas ${ }^{109}$.

Outra informação depreendida dessa etapa de pesquisa é em relação à originalidade do material produzido pelos professores-cursistas. Consideramos que

\footnotetext{
${ }^{108}$ Sendo que um destes trabalhos são contabilizados também para o ensino médio, já que o seu autor indica o uso do PE para esses dois níveis de ensino.

${ }^{109}$ Instituições socioeducativas recebem adolescentes que cometeram delitos com o objetivo de reintegrá-los na sociedade.
} 
a análise preliminar de originalidade e autoria na produção dos PEs pode indicar autonomia e criatividade dos professores em relação à própria prática, o que colabora para o desenvolvimento das dimensões de desenvolvimento profissional docente, principalmente ao mobilizar competências pedagógicas diferenciadas daquelas tidas como "tradicionais", com especial apropriação de suas próprias experiências (MOREIRA et al., 2018). Do ponto de vista das categorias de autoria docente (MAIA, 2017), o que nos referimos como um trabalho original é aquele que apresenta a potencialidade de proporcionar ao mestrando o alcance dos níveis reflexivo ou criativo de inovação de sua prática docente após a conclusão do mestrado. Assim, identificamos se os trabalhos realizados no produto educacional seriam parcialmente autorais (criação do material associado ao uso de materiais e outros recursos de outros autores) ou totalmente autorais (material totalmente criado pelo professorcursista). Quase dois terços dos trabalhos analisados (ou seja, 19 trabalhos) tem autoria parcial. Isso significa que nos PEs foram utilizados materiais de outros autores - principalmente vídeos, textos e simulações de computador (em especial os simuladores do PhET). Os professores-cursistas, em geral, buscam utilizar esses recursos já disponíveis se preocupando em dar sentido ao uso deles, como podemos observar nas passagens destacadas abaixo de duas dissertações:

\begin{tabular}{l} 
MNPEF.21: "Uma das ideias discutidas no programa [MNPEF é \\
incentivar os professores do ensino básico a utilizar nas salas de aula \\
\hline vários recursos, como, por exemplo, experimentos, pesquisa na \\
\hline Internet e as novas tecnologias disponíveis, como aplicativos na área \\
de ciências que podem ser utilizados em um computador ou mesmo \\
\hline nos celulares dos alunos, que inclusive, é visto por vários professores \\
atualmente como o 'grande vilão' da educação do século 21 . Visão \\
esta compartilhada com vários colegas das escolas onde o autor \\
trabalha, exposta nas conversas informais nas salas de professores. \\
Através de iniciativas como essa, podemos usar este recurso \\
tecnológico, bem como muitos outros a nosso favor nessa \\
empreitada, aproveitando não só as novas tecnologias vigentes como \\
também a grande aptidão que a nova geração tem com estes \\
recursos" (p. 13, grifo nosso). \\
MNPEF.26: "Concluindo, o produto educacional aqui proposto e \\
testado permitiu despertar interesses e construir conceitos a partir de \\
vídeos e práticas que, longe de serem inéditos, na verdade fazem \\
parte do acervo bem disponível na internet e em livros, porém sem \\
ordenamento. Em nosso produto foi possível constituir Unidades \\
coerentes, inclusive, contribuindo com novos vídeos produzidos a \\
partir de simulações disponíveis no PhET" (p. 71 , grifo nosso).
\end{tabular}

Os onze trabalhos restantes (pouco mais de um terço do total), podem ser considerados PEs totalmente criados pelos próprios professores-cursistas. Notamos que os PEs que propunham $o$ uso de atividades e protótipos experimentais representam pouco mais da metade dos trabalhos nessa categoria. Chamou-nos a 
atenção, também, um PE com um manual de aplicação de uma metodologia investigativa em sala de aula (MNPEF.04); um manual e roteiros de uma sequência didática que faz uso do software Tracker para vídeo análise ${ }^{110}$ (MNPEF.03, MNPEF.17 e MNPEF.19); uma apostila para turmas de alunos do sistema socioeducativo (MNPEF.22); um ebook com animações e vídeos (MNPEF.29).

Um dado subjacente a essa discussão é a respeito da realização de revisões bibliográficas de trabalhos semelhantes ao que se pretende realizar, que foi muito pouco observado nos trabalhos analisados. A revisão bibliográfica, no contexto de produção dos PEs e sua avaliação é importante para indicar caminhos que gerem bons resultados no uso do PE (caso de MNPEF.18) e contribuições para o ensino no sentido de aumentar o número de contribuições originais no repertório de materiais disponíveis aos professores de Física (apontado por MNPEF.30).

MNPEF.18: [relatando a aplicação de seu PE] "E discussão era
preciso que ocorresse para que a questão fosse resolvida pela turma,
deixei que eles ficassem livres para resolver a questão, assim como
fez [autora], em seu artigo [referência], quando ela acompanha a
resolução e promove a discussão de ideias" (p. 53, grifo nosso).
MNPEF.30: [ao apresentar um estado da arte de trabalhos sobre
Kepler] "Quanto ao produto educacional Leis de Kepler por meio de
sequências de atividades, parte integrante desta dissertação, o autor
não encontrou nada a que se assemelhe, o que o faz original no
sentido de tampar uma lacuna no ensino das Leis de Kepler para
alunos com alto desempenho acadêmico" (p. 20-21, grifo nosso)

As referências encontradas na revisão bibliográfica realizada pelos professores servem também para apontar caminhos iniciais de atuação, como utilizado por MNPEF.04, que se apoiou no trabalho de uma autora que "descreve uma proposta de atividade, dividida em seis etapas para o laboratório aberto", porém se propõe a diferir "da autora em alguns aspectos, principalmente no que se refere à etapa de elaboração do plano de trabalho" (p. 21). Dessa forma, os professores-cursistas podem se apropriar do que já foi produzido na área e ir além do que já foi concebido.

Por último, gostaríamos de indicar nos nossos resultados a questão do uso de referenciais teóricos pelos professores-cursistas para embasar a elaboração de seus PEs, criticada na literatura (NASCIMENTO; OSTERMANN; CAVALCANTI, 2017). Não nos preocupamos em fazer uma análise extensa do uso dos conceitos dos referenciais trazidos em cada dissertação, apenas visamos identificar quais seriam as principais fundamentações teóricas apontadas pelos professores-cursistas (o que,

\footnotetext{
${ }^{110}$ Do site oficial do software Tracker, encontramos que "Tracker é uma ferramenta gratuita de vídeo-análise e modelagem construído na plataforma Java do Open Source Physics (OSP). É desenhado para ser utilizado no ensino de física" (tradução nossa). Disponível em: <https://physlets.org/tracker/>. Acesso em: 03 mai 2019.
} 
para nossos propósitos, indica com quais teorias e discussões acadêmicas o professor pôde ter contato durante a realização do seu MP) e como esses referenciais puderam ser usados pelos professores (o que pode denotar, preliminarmente, a incorporação das ideias acadêmicas à prática docente).

O primeiro dado de destaque a esse respeito é a referência à Teoria da Aprendizagem Significativa (de David Ausubel) ou, ainda, da Teoria da Aprendizagem Crítica (com contribuições de Marco Antônio Moreira) presente em 2/3 dos trabalhos (totalizando vinte trabalhos). Observamos nas descrições dadas sobre a construção do PE nas dissertações lidas, como os conceitos da teoria foram mobilizados explicitamente pelos professores.

É notória a presença da ideia da importância do levantamento de conhecimentos prévios dos estudantes a respeito do assunto abordado no PE através de um questionário inicial, com o propósito de utilizá-los como subsunçores para o processo de ancoragem dos novos conhecimentos à estrutura cognitiva dos estudantes envolvidos. Porém quase todos os trabalhos que mostram essa preocupação com o levantamento dos conhecimentos prévios dos estudantes não informam como esses resultados afetaram a concepção do material didático/sequência didática presente nos PEs, o que levanta dúvidas de como os professores-cursistas entendem a transposição das recomendações dessa teoria educacional para a prática docente. Apenas o trabalho de MNPEF.28 coloca que a sequência didática elaborada no seu PE foi organizada a partir dos resultados do questionário de levantamento de conhecimentos prévios realizado com algumas turmas, mas não detalha como isso foi realizado. De fato, ao se analisar os processos de pesquisa (avaliação do PE) empreendidas nas dissertações, observa-se, como será mostrado com mais detalhes adiante, que o questionário inicial com o levantamento de conhecimentos prévios teve mais a função de pré-teste, no contexto da pesquisa e avaliação do PE - e não de parte integrante do processo de ensino. Em nenhum dos PEs que têm "manual de orientações" para professores, essa recomendação fica explícita.

O uso dos organizadores prévios, que dentro da Teoria da Aprendizagem Significativa, é uma forma de criar subsunçores, no caso de ser identificada a ausência deles na estrutura cognitiva dos alunos, é discutido nos capítulos de referenciais teóricos de diversos trabalhos, mas nem sempre os organizadores prévios são utilizados por todos, por exemplo MNPEF.13, que mesmo tendo checado ao longo da análise do roteiro aplicado com alunos, a ausência de muitos conhecimentos prévios importantes para a sequência didática proposta, deixou de discutir o uso de organizadores prévios ou da aprendizagem mecânica inicial desses conteúdos na 
consolidação de seu PE. Alguns trabalhos (MNPEF.06, MNPEF.14, MNPEF.16, MPNPEF.20, MNPEF.27) utilizam questionários iniciais e/ou realização de pequenos experimentos como organizadores prévios. Especificamente no trabalho de MNPEF.30 é dito que o PE foi organizado em blocos de modo que um servisse de organizador prévio para o seguinte, ou seja, demonstrou a preocupação explícita em trazer o conceito para estruturar a construção de seu PE como um todo.

Referenciais que discutem a avaliação em busca de indícios de aprendizagem significativa recomendam que ela deve ser realizada com o uso de situaçõesproblemas diferentes daquelas que foram utilizados no contexto de ensino, para não reforçar a aprendizagem mecânica, onde o aluno poderia apenas decorar e reproduzir a resolução do problema. Essa orientação fundamental da Teoria da Aprendizagem Significativa para a avaliação da aprendizagem dos alunos é considerada em apenas um trabalho (MNPEF.30). Muitos trabalhos acabam utilizando como avaliação final ("pós-teste") o mesmo questionário inicial de levantamento de concepções prévias. De fato, a discussão sobre avaliação de aprendizagem a partir da aplicação do PE é muito pouco desenvolvida nos trabalhos.

Dessa forma, compreende-se que em certos casos, o referencial é utilizado de forma rudimentar, demonstrando a dificuldade ainda enfrentada pelos professorescursistas em estabelecer a ponte entre a teoria e a sua prática. O estudo da teoria é realizado individualmente, no processo de estudo de cada professor-cursista para elaboração do texto da dissertação, mas também no contexto de uma disciplina da matriz curricular do MNPEF (a disciplina Fundamentos Teóricos em Ensino e Aprendizagem). As discussões empreendidas, no entanto, parecem não estar sendo suficientes para a formação desses professores e a mudança de suas práticas, muito provavelmente pela baixa carga horária da disciplina na matriz curricular do curso (de apenas 2 créditos). Caberia uma maior atenção dos orientadores para auxiliá-los nessa articulação. Ainda, alguns professores utilizam o termo "aprendizagem significativa" aparentemente como um jargão e não como um conceito. Como algo que se objetiva perseguir, mas sem grande clareza e entendimento do que ele de fato significa ou como alcançá-lo. O conhecimento e apropriação dos referenciais teóricos tendo em vista o seu uso prático é premente para esses casos.

Em sete trabalhos (MNPEF.04, MNPEF.10, MNPEF.11, MNPEF.12, MNPEF.18, MNPEF.20, MNPEF.21) não se identifica o uso dos conceitos de fundamentação teórica, apresentada ao longo do texto da dissertação, na construção do PE. Seja porque não há a apresentação de uma fundamentação teórica básica, ou porque os conceitos apresentados não guiam a concepção do PE, ou, ainda, são utilizados 
conceitos e metodologias em sua formulação que não são discutidos no trabalho. Dessa forma, os trabalhos apresentados pecam por não conseguir apresentar aos leitores a relação costurada entre teoria e prática pelos professores-cursistas, seja pela "falta" da teoria bem embasada, ou pelo "excesso de teoria", caso particular de MNPEF.12 que apresentou uma grande miscelânea de conceitos, sem utilizar efetivamente nenhum em seu PE (por sua vez, alguns conceitos citados na descrição do PE não são discutidos em sua fundamentação teórica). Também ocorrem apropriações que podem ser consideradas errôneas, como o trabalho de MNPEF.20 que fala de um conceito chamado "aprendizagem potencialmente significativa" (talvez uma confusão com o conceito "material potencialmente significativo" ou "unidade de ensino potencialmente significativa" utilizado dentro do universo da Teoria da Aprendizagem Significativa), misturando, ainda, conceitos de Piaget e Vygotsky sem expressar o entendimento de que as ideias desses dois teóricos podem conter divergências entre si, algo comum encontrado também por Antunes Jr. et al. (2015) na análise dos referenciais teóricos utilizados em dissertações defendidas no MP em Ensino de Física da UFRGS, utilizada como modelo para a proposição do MNPEF como já discutido anteriormente.

Paralelo ao discutido acima - e como muitos trabalhos fazem uma seleção de conceitos teóricos para compreender e embasar o PE - alguns professores-cursistas também chegaram a explorar referenciais de metodologias de ensino em seus trabalhos, a maioria assumindo uma preocupação com uma proposta de ensino ativo, entre eles o uso do Peer Instruction - ou Instrução por Colegas; do ensino por investigação; da teoria cognitiva de aprendizagem através de vídeos e animações de Mayer; da abordagem Ciência-Tecnologia-Sociedade (CTS); além de discussões diluídas sobre o uso de simulações, TICs, experimentação e vídeos no ensino de Física.

\section{- Bloco 3 - Dissertação}

Antes de adentrarmos a apresentação de dados dessa parte da análise, é pertinente diferenciar quais são os diferentes objetivos atendidos no MP pelos professores. O principal esforço do professor-cursista no MP é a criação do PE para atender demandas identificadas de sua prática profissional. Portanto, ele terá o compromisso de atender a objetivos em seu $\mathbf{P E}^{111}$, justamente para procurar respostas a tais demandas. Como já exposto, a dissertação é compreendida inicialmente como uma forma de apresentar um relato do processo de criação deste

\footnotetext{
${ }^{111}$ Atrelados ao que Ostermann e Rezende (2009) definem como questões-foco.
} 
PE. Porém, entendemos que a dissertação pode ir além da descrição do processo de elaboração do $\mathrm{PE}$, estando vinculada à realização de uma pesquisa com o uso do PE ou de outra natureza, de forma que apóie a elaboração do produto pretendido. Assim, os professores-cursistas podem ter definidos também objetivos de pesquisa ${ }^{112}$. Pesquisa que é realizada no contexto de elaboração e aplicação do PE e que tem, dessa forma, natureza aplicada, apoiando a construção e o refinamento do PE e podendo ter implicações para o desenvolvimento profissional docente por estar vinculada diretamente à prática profissional do professor.

Em termos da definição de objetivos de pesquisa, observamos que parte das dissertações defendidas no MNPEF (nove dessas dissertações) não os explicita. De todo modo, é identificado que essas dissertações se dedicam à avaliação do PE, incidindo sobre a análise de sua aplicação e resultados alcançados em condições reais de sala de aula. Esse é o objetivo de pesquisa explicitado por quase metade das dissertações (um total de treze dissertações), embora três dessas dissertações, não avaliem de fato o PE, realizando apenas uma descrição da aplicação do PE sem maiores análises sobre sua efetividade no alcance dos objetivos para o qual foi elaborado. Por fim, oito dissertações, além de se proporem à avaliação do PE, também explicitam questões de pesquisa particularizadas, ou seja, relacionadas aos problemas da prática levantados pelos professores. Esses objetivos de pesquisa incidem principalmente sobre a preocupação em se avaliar o efeito do recurso ou material criado no PE para a aprendizagem dos alunos de determinado conteúdo (de um ponto de vista um pouco mais geral que simplesmente a análise do PE), ou o seu uso para tornar o ensino mais atrativo para o engajamento dos alunos no processo de aprendizagem do conteúdo abordado. Dentre essas dissertações, destaca-se o de MNPEF.22, que visa também, através da pesquisa-ação empreendida "não só melhorar a prática de ensino de física em uma sala de aula da socioeducação, mas também através dele refletir sobre o papel da escola e do professor na socioeducação" (dissertação de MNPEF.22, p. 44, grifos nossos). Esse é um exemplo de dissertação representativo que vai de encontro aos resultados de Ostermann e Rezende (2009), pois claramente não é um trabalho que esteja alinhado à racionalidade técnica, dada a preocupação do professor-cursista em compreender e atuar sobre seu contexto de trabalho. É um trabalho que se aproximaria da perspectiva da racionalidade crítica.

\footnotetext{
112 Ostermann e Rezende (2009) acreditam que a formulação de questões de pesquisa estaria restrita apenas aos mestrados acadêmicos. Afirmam que elas "podem se reportar a práticas educativas estudadas à luz de pressupostos sustentados por referenciais teóricos, metodológicos, epistemológicos e terem como principal objetivo orientar a produção de conhecimento científico" (p. 72).
} 
Alarcão (2011), ao discutir a formação de professores reflexivos, atenta para o fato de que em contextos de formação com base na experiência, a expressão e o diálogo assumem grande relevância. Um diálogo que "não pode quedar-se a um nível meramente descritivo, pois seria extremamente pobre" ou seja, "tem que atingir um nível explicativo e crítico que permita aos profissionais do ensino agir e falar com o poder da razão" (p. 49). A partir da experiência emerge a capacidade da criatividade aliada à de "sistematizarmos conhecimento sobre o que fazemos e as condições em que agimos e que condicionam o quê e o como" (p. 38).

Identificamos nas dissertações analisadas do polo do MNPEF, mesmo naquelas que são compostas apenas por relatos descritivos da aplicação do PE, algumas que apresentam elementos que não podem ser negligenciados pelos professores-cursistas no exercício de sua expressão e diálogo e que podem bem servir aos membros da Academia, no sentido de permitir a eles uma melhor compreensão sobre a realidade das escolas de educação básica em que os professores-cursistas atuam. Muitos desses trabalhos descrevem problemas e fatos do cotidiano desses professores enquanto da aplicação dos PEs nas escolas em que atuam. Assim, registram-se, de um referencial privilegiado, esse cotidiano da escola, que merece, em nosso ponto de vista, maior atenção em seu registro, aprofundamento e divulgação como saberes experienciais $^{113}$ desses professores. Como exemplo, citamos a dissertação de MNPEF.07 que relata dificuldades decorrentes da própria escola e da relação com as famílias dos alunos para promover a colaboração dos responsáveis para ajudar a incentivar hábitos de estudo em casa, necessário para a metodologia Peer Instruction utilizada pelo professor em seu PE:

MNPEF.07: "Com o intuito de envolver a família na participação e no incentivo aos hábitos de estudo dos alunos que estariam envolvidos com uma nova metodologia a partir do segundo bimestre, a coordenação pedagógica foi consultada para que pudesse viabilizar uma reunião com os responsáveis dos alunos. Nesta reunião, que seria conduzida pelo orientador do presente trabalho, o orientado e a coordenação pedagógica da escola, a proposta de trabalho seria apresentada para que a partir de maiores esclarecimentos dos responsáveis, o incentivo ao estudo em casa fosse potencializado uma vez que isto era de grande importância, não só em metodologias tradicionais, mas também naquelas centradas no aluno.

A coordenação pedagógica desestimulou a marcação do encontro com argumentos bastante fortes na época. Alegou que as reuniões com responsáveis eram extremamente vazias, inclusive aquelas em que a escola, já no final do ano, convocava os responsáveis para notificar a já possível reprovação do aluno, com o intuito de buscar

${ }^{113}$ Saberes experienciais, na discussão de saberes docentes empreendida por Tardif (2000), são saberes específicos que "os próprios professores, no exercício de suas funções e na prática de sua profissão, desenvolvem [...], baseados em seu trabalho cotidiano e no conhecimento de seu meio" (p. 38-39). 
parcerias com as famílias na tentativa de incentivo e apoio a processos pedagógicos que viessem recuperar aqueles alunos. Tais motivos, ainda assim, não eram fortes o bastante para trazer as famílias a uma participação mais ativa na escola. Diante disso, a busca da parceria familiar no presente trabalho foi preterida" (p. 2425, grifos nossos).

O mesmo professor relata outros problemas tais como a impossibilidade de usar a metodologia just-in-time teaching em sua escola, pois não seria possível distribuir xerox de material extra para estudo dos alunos; o uso da sala de informática da escola como sala de aula devido ao grande número de matrículas recebidas na escola o que lotou as salas de aula de turmas já existentes. Tais problemas revelam limitações materiais que definem determinadas condições desfavoráveis para o trabalho dos professores.

A dissertação de MNPEF.15 também registra dificuldades de ordem estrutural e organizacional para a aplicação de seu PE no colégio estadual onde trabalha. Registra, por exemplo, que a sala de informática da escola, necessária para o uso de seu PE, não estava disponível quando quis utilizá-la e que também encontrou dificuldades decorrentes de falta de espaço no calendário escolar para sua disciplina por conta de muitas avaliações externas promovidas pelo governo.

A falta de apoio pedagógico nas escolas também surge nas dissertações. MNPEF.17, por exemplo, é claro na falta de compreensão para o uso de estratégias lúdicas com o uso de um jogo para o estudo de cinemática em uma turma de recuperação:

MNPEF.17: "Ao organizar as atividades foi percebido que parte dos professores, membros da direção e coordenação pedagógica não entendiam o real motivo da atividade. Os entes envolvidos tinham suposições de que os alunos estavam simplesmente jogando e não aprendendo Física, porém, os alunos sempre relatavam que realmente estavam aprendendo cinemática" (p. 64, grifos nossos).

Como outros exemplos,identificaram-se no contexto de trabalho de MNPEF.04, MNPEF.10 e MNPEF.30 resistências e a necessidade de se ter a permissão da coordenação do colégio para a aplicação do PE em suas turmas, o que implica em falta de autonomia didática do professor nestes colégios. MNPEF.04 relata a resistência que encontrou para a implementação de seu PE:

MNPEF.04: "A proposta no [colégio de aplicação] sofreu bastante resistência quanto à implementação dessa metodologia [de ensino por investigação]. Considerando os objetivos de interesse daquela comunidade escolar, focada em índices e resultados entendidos como positivos, como número de aprovações em Universidades, notas no ENEM, etc., havia uma defesa da utilização do laboratório tradicional, em que o professor executa e demonstra um experimento para os alunos, para que vejam, na prática, o que acontece na teoria, e essa recusa foi reafirmada mais de uma vez. Essa é uma realidade 
que vários outros professores podem encontrar. Mudar a forma de trabalho em uma escola implica em negociação e conflito. Contudo, após longa conversa com a coordenação, foi permitida a atividade em caráter experimental mediante a observação da coordenadora da escola. Com a aprovação da coordenação, a metodologia seria implementada nos anos seguintes" (p. 26).

MNPEF.10 coloca que conseguiu "a autorização da direção e da coordenação do colégio, onde planejava aplicar as atividades, para que fora do horário de meu expediente eu pudesse realizar os experimentos" (p. 22, grifos nossos). No caso de MNPEF.30, essa restrição foi identificada de forma implícita na seção de agradecimentos da dissertação desse professor, que agradece ao seu superior "pela permissão a mim concedida de poder aplicar [o $P E$, por dois anos consecutivos, nas instalações do [colégio]" (dissertação de MNPEF.30, p. iii, grifos nossos).

Dos exemplos invocados, reflexões podem ser empreendidas, aprofundando a produção de conhecimento pelos professores-cursistas, como a análise, em cada um de seus contextos, das situações que podem desfavorecer o processo de inovação das práticas docentes, decorrentes muitas vezes de ações da própria escola e governo como os exemplos destacados acima sugerem. Dessa forma, o caráter intervencionista do trabalho desenvolvido no contexto dos MP seria reforçado, e a ampliação das dimensões de desenvolvimento profissional participação na gestão escolar e participação na responsabilidade social ganharia destaque.

Há também expressões de saberes experienciais que envolvem a compreensão das dinâmicas nas salas de aula, e do comportamento dos alunos em diferentes situações, além de trechos de relato que indicam processos reflexivos sobre a atuação na sala de aula. São saberes construídos no contexto de aplicação dos PEs e o relato e a análise dos resultados observados, que refletem nas dimensões de desenvolvimento profissional organização e condução de ensino e sustentação da aprendizagem. Abaixo destacamos trechos retirados de diferentes dissertações que consideramos representativos desses saberes experienciais registrados pelos professores. Os trechos sublinhados são grifos nossos que indicam esses saberes:

MNPEF.02: "Duas alunas, posteriormente a discussão, declararam que foi legal, mas que prefeririam que tudo fosse feito em sua sala de aula e não no laboratório de informática, pois na sala elas tinham o seu lugar, sua cadeira. Admitiram a contribuição que a simulação trouxe, mas não queriam sair da posição de meras receptoras. Percebemos que os alunos precisaram sair da zona de conforto sendo exigido um papel mais ativo" (p. 33, grifos nossos).

MNPEF.02: "Houve participação de quase todos [alunos] e não houve nenhum problema de indisciplina. Precisamos ter consciência que aula interativa, com alunos participantes e atuantes no processo ensino-aprendizagem, não é uma aula estática, onde há um 
monólogo em que só o professor fala, mas uma aula onde tem interação aluno $x$ alunos e aluno $x$ professor, onde há conversas, barulho em prol de algo maior, a aprendizagem significativa" (p. 36, grifos nossos).

MNPEF.05: "Terminada esta atividade, passamos para a segunda parte deste encontro, em que apresentamos a perspectiva histórica do conceito sobre a luz. A princípio, esta etapa teria um caráter muito expositivo, porém, como ela veio na sequência de um momento em que os alunos estavam comprometidos com debates em seus grupos, isto proporcionou uma atitude por parte de muitos alunos das três turmas que não se esperava, pois não era o comportamento padrão dos mesmos. Eles participaram, realizando intervenções em diversos momentos da aula, com comentários a respeito do tema" (p. 43, grifos nossos).

MNPEF.07: "É possível que a sensação de que o estudante compreendeu melhor a disciplina em sala de aula ajude a arraigar um hábito claramente indesejável - o de não desenvolver hábitos de estudo em casa?" (p. 42) [...] "A parte o aluno 1, que parece estar significativamente envolvido com a tarefa de aprender, as respostas deixam evidente que os alunos associam os atos de aprender $e$ estudar a sua presença na escola. A metodologia PI [Peer Instruction], apesar de proporcionar uma sensação de maior compreensão e de tornar as aulas mais prazerosas e atraentes para os estudantes, não é suficiente para induzir hábitos de estudo nos alunos" (p. 53, grifos nossos).

MNPEF.14: "Inicialmente, reparou-se também que quando a informação é trabalhada através de uma apresentação de algo concreto, com relevância reduzida para contexto apenas teórico e passando para 0 prático, a compreensão e 0 entendimento são maiores por parte dos alunos, pois eles conseguem associar o que é visto em sala de aula, com os fatos do dia-a-dia" (p. 35, grifos nossos).

MNPEF.19: "De maneira geral, a segunda parte da sequência didática, foi marcada por uma mudanca na postura do professor, percebendo que muitos alunos da primeira série não estavam conseguindo responder as perguntas por uma ausência de subsunçores, assim para as turmas de primeira série na segunda parte da aula o professor explicou sem esperar o aluno responder as questões. Essa postura deu maior dinâmica a aula e os alunos se sentiram mais seguros, entendendo melhor os conceitos. A percepção do professor foi que os alunos nessa etapa da aula necessitavam de conteúdos de matemática que não tinham sido trabalhados com os alunos de primeira série, dentre eles o conteúdo de funções do $1^{\circ}$ e $2^{\circ}$ grau, que serão abordados ao longo da primeira série" (p. 48, grifos nossos).

Voltamos agora a atenção à questão da avaliação do PE, função a que grande parte das dissertações defendidas no polo do MNPEF se dedicam. A questão que levantamos neste momento é a seguinte: como esta avaliação está sendo realizada?

A ausência de referenciais teóricos para apoiar a avaliação do PE na maioria dos trabalhos (vinte e quatro deles) indica que não é reconhecida no polo do MNPEF a dimensão de pesquisa nessa análise ou é julgado pelos orientadores e professores- 
cursistas que não é necessária a adoção de algum tipo de fundamentação teórica para efetuá-la. É possível, entretanto, encontrar dissertações com essa preocupação (destaque de MNPEF.06 e MNPEF.29 que adotam pressupostos da Teoria da Aprendizagem Significativa para apoiar a realização de seus trabalhos) e professores que se esforçam em apresentar dados da avaliação do PE articulados com a literatura pertinente de pesquisa da área de Ensino de Física (MNPEF.04, MNPEF.09, MNPEF.12 e MNPEF.19). Não nos foi possível observar correlação do uso do referencial teórico e diálogo com a literatura das dissertações com o trabalho de orientação de algum docente específico do corpo de orientadores do curso.

As análises empreendidas nas dissertações dependem diretamente dos instrumentos para a coleta de dados que os professores elegem para suas pesquisas. Há a predominância do uso de pré e pós-testes, mas também em muitos trabalhos se usam dados obtidos através das atividades realizadas pelos alunos propostas pelo PE avaliado; de questionários para levantamento da opinião dos alunos sobre o uso do PE pelo professor; de avaliações da escola ou externas; de relato e observação do contexto de aplicação do PE; de entrevistas realizadas com professores e alunos.

É comum associar mais de um instrumento de coleta de dados para a avaliação do PE, porém, principalmente em trabalhos defendidos por professores-cursistas da turma de 2014, é comum apenas os pré e pós-testes serem utilizados como fonte de dados. Esse é um indício que mostra uma tendência dos orientadores (de modo geral, já que esse procedimento foi constatado em dissertações orientadas por diferentes docentes) em considerar e valorizar essa metodologia de coleta de dados.

A justificativa para o uso de pré e pós-testes é apresentada na maioria das vezes com referência à Teoria da Aprendizagem Significativa. O pré-teste permitiria ao professor o levantamento dos subsunçores da turma e o pós-teste seria utilizado para verificação de indícios de aprendizagem significativa. Porém não é claro nesses processos como o professor incorpora os dados obtidos no pré-teste ao seu PE ou a sua prática em sala de aula. Os dados do pré-teste só foram explicitamente utilizados por MNPEF.24 "para elaborar as estratégias de etapas posteriores" (p. 6). O mesmo pode ser dito para o uso dos dados obtidos no pós-teste, "com o intuito de reorientar para a aplicação destas aulas nas turmas futuras" (p. 78).

O que se percebe é que, em geral, os professores utilizam os resultados de pré e pós-teste apenas para comparação entre o que o aluno supostamente sabia sobre determinado conteúdo antes da aplicação do PE (apontado no pré-teste) e o quanto 
ele sabe após a aplicação do PE (pós-teste). O comparativo indicaria os ganhos em aprendizagem que poderiam ser atribuídos como efeito do uso do PE nas aulas. É o que MNPEF.25 acaba apontando no trecho destacado abaixo:

MNPEF.25: "Inicialmente a intenção era levantar o conhecimento prévio dos discentes sobre o tema energia, através do pré-teste apresentando no manual para este primeiro encontro. Entretanto, inicialmente a dificuldade foi convencer os alunos a responder um questionário, o qual eles serão avaliados no grau de conhecimento de um assunto, sem nenhuma fonte de consulta ou pesquisa prévia desse assunto. Foi explicado que essas respostas eram para ser comparada na terceira etapa de aplicação do produto, quando eles voltariam a responder essas mesmas perguntas. E, a partir disso, seria possível verificar a mudança ocorrida na aprendizagem, considerando que eles possuíam algum conhecimento prévio sobre 0 assunto energia e com o uso do produto o que mudou em seus conceitos" (p. 20-21, grifos nossos).

Os dados obtidos no pós-teste e na análise geral dos resultados alcançados com o uso do PE encaminham desdobramentos dos materiais criados pelos professores, o que é exercitado por muitos trabalhos (um total de doze), como no trabalho de MNPEF.26, que inclusive dedica um capítulo específico denominado "consolidação do produto" para isso. Em apenas quatro dissertações há indicações de pesquisas, aplicações futuras do PE e, ainda, a criação de outros materiais didáticos abordando outros conteúdos de Física no mesmo formato do PE apresentado no curso. Em apenas uma dissertação (MNPEF.07), há indicações de desdobramentos para a escola do professor-cursista (no caso, uma oficina sobre o uso do Peer Instruction para professores da escola). Importante destacar que no restante dos trabalhos analisados (catorze, ou seja, quase a metade deles) não fica claro se a aplicação do PE em situação real de ensino em sala de aula serviu ao professor como possibilidade de aperfeiçoamento do próprio PE.

Por fim, em relação aos sujeitos participantes da pesquisa, ou seja, em quais escolas e com quais alunos foram utilizados os PEs, observamos que a grande maioria dos trabalhos foi em colégios estaduais e em turmas regulares de ensino médio (em alguns casos, turmas regulares de ensino fundamental e de EJA também). A maioria dos trabalhos foi aplicada nos locais de trabalho dos professores. Aparecem em menor número outros contextos de trabalho além dos colégios estaduais: escolas técnicas estaduais, colégios e institutos federais e colégios particulares. Importante destacar que quatro professores (MNPEF.01, MNPEF.03, MNPEF.10 e MNPEF.17) utilizaram seus PEs em turmas extras com alunos voluntários ou em recuperação paralela, o que nos leva a questionar a efetividade na incorporação do produto em suas práticas em turmas regulares. 
- Bloco 4: Outras...

$\mathrm{Na}$ elaboração da planilha a partir das unidades de registro depreendidas da leitura das dissertações, percebemos que se repetem muitos temas que foram mencionados em etapas anteriores. Dessa forma, nesta parte nos concentraremos em indicar a questão da interdisciplinaridade, relação ensino-pesquisa-extensão, publicações e apresentações em congressos da área, menções ao processo de orientação e outras atividades do MP, indicações de impactos nas escolas dos professores mestrandos, e, por fim, menções aos impactos na formação docente.

Há menção à interdisciplinaridade em sete dissertações. Há PEs com elementos da matemática (MNPEF.03 e MNPEF. 17, trabalhando gráficos e MNPEF.18, trabalhando razão e proporção, todos no contexto de Cinemática). Dois trabalhos associam elementos de Ciências Humanas, levantando questões sociológicas e econômicas (MNPEF.09) ou filosóficas (MNPEF.24), junto ao conteúdo de Física. O trabalho de MNPEF.11 ressalta aspectos físicos, biológicos e químicos da visão, e, por fim, MNPEF.30, que dedica seu PE a um tema de astronomia reconhece o potencial de associá-lo com outras disciplinas, porém esse foco não é desenvolvido por ele.

Não se faz referência a projetos de extensão nas dissertações do MNPEF, assim como na análise documental da primeira etapa de pesquisa. Há algumas dissertações que apontam a realização de oficinas e apresentações de trabalho em eventos locais pelos professores mestrandos, o que contou como uma forma de divulgação dos PEs e também como um modo de obter opiniões de outros professores a respeito do material didático elaborado. Os eventos citados são a Semana Nacional de Ciência e Tecnologia da instituição que sedia o polo (MNPEF.01, MNPEF.03) e o Simpósio de Ensino de Física promovido pelo próprio polo (também citado por MNPEF.01, MNPEF.10, MNPEF.15 e MNPEF.23). Em pesquisa de campo que pudemos realizar ao participar do III Simpósio de Ensino de Física realizado pelo polo em novembro de 2018, é provável que mais outros professores possam ter apresentado pôsteres de seus PEs ou oficinas no evento, já que observamos que isso é comum no evento. Nele participam os professores mestrandos e egressos do polo, além de graduandos em Física e outros professores da região que têm interesse em ingressar futuramente no curso. Apenas um professor (MNPEF.15) cita outros eventos de nível regional e nacional (entre eles o SNEF, que teve a oportunidade de participar apresentando seu trabalho) e outro professor (MNPEF.19) que chegou a publicar um artigo na Revista do Professor de Física, revista editada pela Universidade de Brasília (UnB) com foco em publicar trabalhos que propiciam o contato entre conhecimento 
produzido nas IES e o professor de Física de educação básica. O professor MNPEF.29 faz menção na sua dissertação, como desdobramento futuro de seu trabalho, a publicação de artigos. Não há menções a outros tipos de atividades desenvolvidas no MP, nem ao processo de orientação dos trabalhos.

Anteriormente havíamos exposto que muitos professores relatam problemas na aplicação do PE nas escolas de educação básica onde trabalham, mas também há indicações, embora mais raras, de impactos diretos positivos nessas escolas. É o caso de MNPEF.03 que necessitava do uso de computadores para a aplicação de seu $\mathrm{PE}$, o que foi conseguido com a reforma de uma sala que era utilizada como depósito e foi transformada em "sala de recursos". O professor MNPEF.08 também encontrou apoio técnico da escola para manutenção dos softwares dos computadores e da internet na escola, quando "foi possível colocar 18 computadores em condições de uso" (p. 105). Nesses dois casos, pressupomos que a infraestrutura de informática das escolas que foram melhoradas tendo em vista a aplicação dos trabalhos, pôde ser aproveitada pelo professor ou seus colegas para a realização de outras aulas com outras turmas, aperfeiçoando, assim, as condições de ensino-aprendizagem dos alunos nessas escolas. Já o professor MNPEF.13, como culminância da sequência didática de seu PE, a apresentou juntamente com uma visita técnica com os alunos à uma represa e usina hidrelétrica.

Foi possível, por fim, identificar ao longo da leitura flutuante das dissertações, trechos em que os professores expressam impactos da realização do MP em suas próprias formações. MNPEF.21 no trecho destacado abaixo, atribui mudanças nas práticas docentes às disciplinas oferecidas no MNPEF:

MNPEF.21: "Na grade curricular do MNPEF (Disponível em
www.sbfisica.org.br), as disciplinas abordadas possibilitam uma
discussão entre os docentes e alunos do programa sobre as suas
práticas pedagógicas, havendo troca de experiências entre alunos e
professores do programa, possibilitando a construção de uma visão
panorâmica da educação nas escolas de ensino básico,
particularmente em nossa região, o [Estado], e envolvendo todos os
polos do programa em boa parte do país. Através da análise e
observação dessas práticas pedagógicas, vislumbra-se uma real
possibilidade de mudanças, algumas das quais já estão acontecendo
nas salas de aula dos docentes que se apropriam de diferentes
metodologias de ensino, visando um ensino mais dinâmico, no qual o
aluno possui uma maior participação e responsabilidade no seu
processo de ensino-aprendizagem" (p. 12/13, grifos nossos).

Há dois elementos a se considerar nesse processo de mudança de práticas. Primeiramente, temos que atentar para o fato de que não é simplesmente a apresentação dos conteúdos das disciplinas presentes na matriz curricular do MNPEF que permite o que o professor relata; mas o modo como essas disciplinas são 
preferencialmente conduzidas pelos docentes do polo. Lembramos que, segundo relato do docente Do.MNPEF-07, há o esforço por parte do corpo docente em trazer às disciplinas diferentes exemplos de metodologias e estratégias para abordagem de diferentes conteúdos na sala de aula de educação básica. MNPEF.21 ressalta a mudança de metodologias de ensino, trabalhada nas disciplinas, na direção de um processo ensino-aprendizagem no qual o aluno assume um papel ativo. Novamente, algo referido por Do.MNPEF-07 em sua entrevista como o "espírito do curso" que pauta o trabalho desenvolvido pelo corpo docente no polo.

Identificamos indícios de que o impacto do curso pode ir além da adoção de metodologias inovadoras pelos professores-cursistas. Para MNPEF.06, MNPEF.07, MNPEF.22 e MNPEF.24, o curso proporcionou o contato com a ideia e a atitude de serem professores pesquisadores da própria prática:

MNPEF.06: "Concluindo essa fundamentação teórica, podemos afirmar que a pesquisa e o trabalho desenvolvido nesta dissertação, assim como o de todo professor participante deste programa de mestrado profissional em ensino, é uma pesquisa-ação. Mais do que simplesmente constatar isso, entendemos como parte essencial deste trabalho a tomada de consciência deste novo papel. Ressaltamos que não se trata de um papel temporário, mas da transformação de um profissional que se via professor apenas, em um profissional que pautará doravante sua atividade de ensino na pesquisa, no aprimoramento de suas práticas e na pesquisa-ação" (p. 27, grifos nossos).

MNPEF.07: "O fato de não haver uma fórmula inovadora que vá resolver todas essas questões implica numa permanente reflexão da prática docente, investigação e diálogo constante. Os resultados devem ser compartilhados para que sejam discutidos e avaliados de modo a realimentar o processo de permanente discussão" (p. 12, grifos nossos).

MNPEF.22: "Por fim, tendo sido realizada uma pesquisa ação cabe refletir sobre o papel do professor pesquisador que conduziu esse trabalho. Ao escolher ser professor de física e matemática ninguém imagina que ser professor envolve muito mais coisas do que apenas lecionar, como, por exemplo, ser pesquisador em sua própria sala de aula. Dessa forma, esse trabalho foi de extrema importância para o crescimento profissional desse mestrando por permitir uma compreensão mais ampla da prática docente" (p. 57, grifos nossos).

MNPEF.24: "Ratificamos aqui, como dados para os professores que venham fazer uso do nosso trabalho, a certeza de que somente foi possível construir essas etapas utilizando as nossas próprias reflexões, digo sobre a nossa atuação enquanto docente e nitidamente inserir em nossas pesquisas questionamentos sobre 0 que nos foi apresentado em nossas formações" (p. 85, grifos nossos).

Esses relatos ao menos indicam a compreensão da importância de se manter uma atitude de pesquisa diante do ensino a fim de enfrentar os desafios inerentes à prática docente, além da importância de que esta atividade seja feita de forma compartilhada e coletiva entre os professores. São reflexos de indícios de impactos na 
dimensão investigação sobre a própria prática de desenvolvimento profissional. Indicamos como indícios, pois apenas na leitura destes trabalhos não temos como afirmar que isso de fato ocorre, como se processa na realidade prática desses professores e em qual intensidade. O exemplo de MNPEF.04 é um pouco mais concreto em relação a isso no contexto específico de aplicação do seu PE, o que desencadeou mudanças em sua prática profissional na adoção de uma nova metodologia de ensino:

MNPEF.04: "Depois de algum tempo, percebemos, então, que a falta de prática do autor na aplicação de atividades que utilizam a experimentação investigativa, fez com que a orientação dada aos alunos não fugisse do que já se era praticado nas aulas tradicionais, que era 0 intuito primeiro desse trabalho. Os experimentos funcionavam, então, como ilustrações para a compreensão dos princípios envolvidos, como meios de adquirir certa familiaridade com a ciência, ou seja, como Baptista (2010, p.81) descreve o laboratório tradicional. Foram necessárias reflexão e mudança de abordagem" (p. 26, grifos nossos).

O relato destacado aponta o empenho muitas vezes necessário para a renovação da prática desses professores, o que implica em muitas reflexões e tentativas práticas. A análise com elementos narrativos construída a partir da entrevista com Do.MNPEF-07 já nos apontava esse movimento dos professores, em que tinham de enfrentar dificuldades e resistências. Destacamos abaixo um trecho encontrado na dissertação de MNPEF.21 que expressa sua angústia em relação à mudança das práticas, e indica o caminho tomado para isso: o contato com os resultados de pesquisa e referenciais teóricos da Academia, mostrando a relevância das dimensões de desenvolvimento profissional atualização do conhecimento científico e do conhecimento pedagógico conjugadas no diálogo dos professores com a Academia, além do diálogo com a Escola com atenção à dimensão investigação da própria prática para o entendimento de como toda essa mudança pode se processar.

MNPEF.21: "Mudar sempre é difícil, pois requer muito trabalho,
estudo, reciclagem e adaptação a uma nova realidade. E temos que
aceitar também que não temos conviccão se o novo caminho
escolhido trará os resultados que esperamos. Mas, o fato é que de
acordo com pesquisas realizadas na área de ensino, como já exposto
acima, temos também que aceitar que algo talvez deva ser mudado.
E é importante, dessa forma, que utilizemos estes dados para nortear
o caminho que devemos adotar" (p. $69-70$, grifos nossos).

Há também um componente emocional para se considerar nesse processo. A satisfação e motivação provocadas pela renovação das práticas e pela participação e envolvimento com o grupo de professores integrantes do MNPEF é destacada diversas vezes por muitos professores-cursistas, e que acreditamos que sustente todos no caminho de desenvolvimento profissional traçado, o que será bastante destacado na nossa próxima etapa de pesquisa com a apresentação dos dados 
obtidos das entrevistas realizadas com egressos do MP. Tal envolvimento afetivo reflete na dimensão dedicação de autoria docente registrada como ativa no caso de diversos egressos, conforme indicaremos nas análises com elementos narrativos com egressos. Abaixo destacamos algumas demonstrações desse fator encontradas nas dissertações:

MNPEF.16:"A aplicação desse produto foi bem motivadora e agradável, porque foi uma maneira até então inédita para nós de ministrar uma aula de Física. Também foi para os alunos, conforme dito por eles próprios, assistir uma aula fora dos padrões tradicionais" (p. 108, grifos nossos).

MNPEF.05: [nos agradecimentos do trabalho] "Foram dois anos trilhados com uma mistura de sentimentos que começaram pela euforia de uma criança ao ganhar um brinquedo novo, sentimento que me dominava no início dessa maratona. [...] Agora no decorrer das últimas semanas começa a despontar um sentimento de saudades dos novos amigos conquistados durante o mestrado, e que sabemos que os nossos encontros para desabafos, trocas de experiências e brincadeiras já não serão mais tão comuns como foram nos últimos dois anos" (p. 5, grifos nossos).

MNPEF.06: [nos agradecimentos do trabalho] "[...] fiz minha inscrição para o Mestrado Nacional Profissional em Ensino de Física MNPEF e, ainda sem ter completa noção disso, estava iniciando uma das mais emocionantes etapas da minha vida, ao final da qual, sairia Mestre em Ensino de Física, além de ter conquistado a amizade de pessoas tão interessantes e interessadas na mesma busca em que eu me empenhava" (p. 6, grifos nossos).

MNPEF.12: "Há um tempo atrás não imaginava em fazer um curso de Mestrado, hoje encontro-me na reta final, isso é muito gratificante, fico até sem palavras para expressar minha emocão, muito obrigado a todos que estiveram comigo nesta caminhada [...]" (p. 6, grifos nossos).

\subsubsection{Análise dos produtos educacionais e dissertações defendidos no MP.Local até 2017}

- Bloco 1: Dados gerais

A análise de PEs e dissertações defendidos no MP.Local estudados envolveu vinte e dois (22) trabalhos defendidos entre 2010 e 2017, selecionados entre os noventa e quatro (94) trabalhos defendidos no curso no período conforme critérios já expostos. Os professores-cursistas que defenderam esses trabalhos ingressaram no curso em diferentes turmas, conforme a distribuição abaixo:

Turma 2008 (1ํㅡㄴ turma) - dois egressos: MP.Local.01, MP.Local.02;

Turma 2010 (3 $3^{\text {a }}$ turma) - seis egressos: MP.Local.03, MP.Local.04, MP.Local.05, MP.Local.06, MP.Local.08, MP.Local.10; 
Turma 2011 (4ª turma) - três egressos: MP.Local.07, MP.Local.09, MP.Local.11;

Turma 2012 (5ํㅡㄹ turma) - três egressos: MP.Local.12, MP.Local.13, MP.Local.14;

Turma 2013 (6 $6^{\underline{a}}$ turma) - um egresso: MP.Local.15;

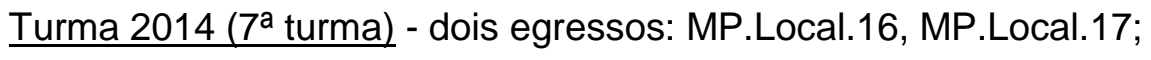

Turma 2015 ( $8^{a}$ turma) - cinco egresso: MP.Local.18, MP.Local.19, MP.Local.20, MP.Local.21, MP.Local.22;

Foi possível observar também a distribuição de orientação desses trabalhos entre os docentes credenciados no curso:

Do.MP.Local-01: nove orientações (MP.Local.02; MP.Local.03; MP.Local.05; MP.Local.08; MP.Local.11; MP.Local.14; MP.Local.16; MP.Local.18; MP.Local.21), além de uma co-orientação (MP.Local.07);

Do.MP.Local-06: três orientações (MP.Local.01; MP.Local.06; MP.Local.13);

Do.MP.Local-07: uma orientação (MP.Local.07), além de uma co-orientação (MP.Local.17);

Do.MP.Local-08: uma orientação (MP.Local.19);

Do.MP.Local-12: duas orientações (MP.Local.17 e MP.Local.20);

Do.MP.Local-14: uma orientação (MP.Local.22).

Cinco trabalhos dentro da amostra de análise foram orientados por docentes que não eram mais credenciados no curso quando essa pesquisa foi realizada, por terem se desligado da instituição. São eles:

- Trabalhos MP.Local.04; MP.Local.10 e MP.Local.12 orientados por um docente com formação inicial em Física, formação pós-graduada na área de pesquisa básica e interesse de pesquisa na área específica e em ensino de Física;

- Trabalhos MP.Local.09 e MP.Local.15 orientados por uma docente com formação inicial em Física (bacharelado), mestrado em Engenharia Metalúrgica e de Materiais e doutorado e pós-doutorado em Educação, desenvolve pesquisas envolvendo ensino de Física e formação de professores.

Como nossa amostra deixa de fora muitos outros trabalhos desenvolvidos no contexto do curso no período considerado, não há como considerarmos a distribuição de orientação entre esses docentes, pois cada um orienta outros trabalhos de fora da amostra. É notória a concentração de orientações pelo docente Do.MP.Local-01, ocorrida em especial por conta de sua formação e interesse de pesquisa ser 
especificamente, dentre os docentes considerados, em Ensino de Física e estar credenciado no curso desde a primeira turma.

Assim como no contexto do MNPEF, não analisamos exaustivamente o perfil dos docentes membros de banca examinadora dos trabalhos defendidos no MP.Local. Foi possível perceber, entretanto, a tendência de participarem das bancas docentes com pesquisa na área de Ensino de Física (muitos do próprio curso) e também professores com estudos concentrados na área de pesquisa básica específica de Física.

Por último, em relação ao tempo para conclusão do curso, não foi possível fazer uma análise assertiva, por falta de dados, já que não foi possível obter para todos os egressos de nossa amostra as datas de ingresso no curso e de defesa dos trabalhos. Para aqueles que conseguimos obter essas informações (dezessete egressos), há a média de 30 meses para a conclusão do curso.

\section{- Bloco 2: O Produto Educacional (PE)}

Ao contrário da amostra de dissertações defendidas no polo do MNPEF, é mais comum os professores-cursistas do MP.Local expressarem as intenções do trabalho desenvolvido no PE em torno de uma ou mais questões que conseguimos identificar como questões-foco ou questões de pesquisa de acordo com a definição proposta por Ostermann e Rezende (2009). Questões-foco relacionadas diretamente com inovações didáticas são apresentadas em três trabalhos (embora não sejam neles referidas como tais):

MP.Local.02: "[...] como introduzir o conteúdo Partículas Elementares no Ensino Médio?" (p. 76).

MP.Local.18: "[...] como o ensino de eletromagnetismo por meio da ação reflexiva e mediado por experimentos em um laboratório portátil, pode ser ministrado em turmas de EJA?" (p. 16).

MP.Local.20: "[...] quais as contribuições de uma sequência didática envolvendo o uso de simulações computacionais para o processo de ensino e aprendizagem do efeito fotoelétrico tendo por base os três momentos pedagógicos?" (p. 15).

A questão formulada por MP.Local.02 focaliza os modos de conceber o PE. Já MP.Local.18, do modo como foi enunciada sua questão, focaliza também o modo de implementação do PE, especificando um contexto (turmas de EJA) e metodologia didática (ação reflexiva, uso de experimentos). Por fim, a questão formulada por MP.Local.20, além dos modos de conceber e implementar, exprime a preocupação sobre a avaliação do PE, ao propor buscar as suas contribuições para o processo de ensino e aprendizagem do conteúdo específico. 
É comum o enunciado de questões que entendemos como questões de pesquisa, já que se conjugam a objetivos atrelados à produção de conhecimento na área. São os casos abaixo:

MP.Local.09: "Qual o papel do RPG para um ensino de ciências de qualidade?" (p. 20).

MP.Local.11: "Diante de nosso pressuposto, o problema de nossa pesquisa coloca-se: verificar o poder formativo ou potencializador da literatura no processo ensino-aprendizagem de ciências naturais" (p.15).

MP.Local.14: "Quais aspectos tornam possível um efetivo ensino de Ciências nas séries iniciais do Ensino Fundamental?" (p. 20).

Outros dois trabalhos lançam questionamentos mais gerais, que entendemos como motivadores para o trabalho desenvolvido e não como foco de sua realização:

MP.Local.06: "Como auxiliar professores nesta árdua tarefa [promover a aprendizagem significativa dos alunos]?" (p. 26).

MP.Local.20: "Nós, professores de física, sentimos inquietações que nos levam a refletir sobre a maneira que ensinamos nossa disciplina. Será que a física, do modo como é lecionada em nossas escolas, contribui para a formação social dos alunos, além de despertar seu interesse por ciências? Nossas aulas promovem espaços para debates, troca de ideias ou trabalho em grupo? Os estudantes produzem seu próprio conhecimento ou apenas o recebem já formatado, durante aulas expositivas?" (p. 16).

Os demais trabalhos não explicitam questões específicas, embora apresentem objetivos - alguns mais, outros menos claramente. Da mesma forma, novamente, nem sempre os problemas motivadores para a realização dos PEs são explicitamente apontados nas dissertações analisadas. Apresentamos as motivações identificadas na leitura das dissertações, discutindo também a aparente origem dessas motivações, além de traçar considerações a respeito da natureza do PE e quais recursos foram prioritariamente utilizados. Seguimos a mesma divisão de categorias de motivações dos professores-cursistas na elaboração de seus trabalhos proposta na apresentação de resultados do polo do MNPEF, salvo algumas particularidades verificadas no MP.Local.

Uma dessas particularidades refere-se à vinculação de sete trabalhos analisados (MP.Local.07; MP.Local.08; MP.Local.09; MP.Local.11; MP.Local.15; MP.Local.16; MP.Local.17) a projetos institucionais de grupos de pesquisa do curso aprovados no Programa Novos Talentos ${ }^{114}$ e no Programa Observatório da Educação da Capes ${ }^{115}$. A

\footnotetext{
${ }_{114}$ De acordo com o site do Programa Novos Talentos no portal da Capes, seu objetivo é "apoiar propostas para realização de atividades extracurriculares para professores e alunos da educação básica, tais como cursos e oficinas, visando à disseminação do conhecimento científico, ao aprimoramento e à atualização do público-alvo e à melhoria do ensino de ciências nas escolas públicas do país". Disponível em: <https://capes.gov.br/educacao-basica/novostalentos />. Acesso em: 15 mai 2019.
} 
maioria destes trabalhos indicam que os orientadores encaminharam as propostas dos projetos aprovados para potenciais mestrandos, convidando-os para aderir a eles. Essa particularidade pôde representar aos professores convidados a possibilidade de expandir seus horizontes, atuando em um projeto de extensão. É o que MP.Local.17 relata, ao escolher fazer parte de um subprojeto coordenado por uma das docentes que gostaria de que fosse sua orientadora:

MP.Local.17: "Querendo acompanhar uma docente [Do.MP.Local-07] que me despertou curiosidade desde o dia da entrevista [parte do processo seletivo do mestrado] fui à busca do novo, me arrisquei, me desafiei. A opção para acompanhá-la era participar do projeto Novos Talentos [...] Dessa forma, me inseri a um dos quatro subprojetos, denominado Cinema, Arte e Ciência, na qual ela era coordenadora juntamente com o [Do.MP.Local-12]. Tornaram-se meus orientadores e, assim, se deu início ao percurso desta pesquisa [...]" (p. 16, grifos nossos).

MP.Local.11 também foi colocada em uma nova posição, a de formadora de professores, ao trabalhar em um subprojeto do Projeto Novos Talentos que ocorreu em um curso normal. Essa nova perspectiva de trabalho a fez perceber nuances de sua prática importantes para a aprendizagem dos alunos, refletindo em contribuições para desencadear reflexões sobre a sua própria prática e a organização e condução de ensino:

MP.Local.11: "Como docente é comum estar diante de alunos, mas a
experiência do Projeto Novos Talentos nos proporcionou lidar com
um grupo diferente [professores em formação no curso formal].
Fomos levados a pensar em nossa própria prática, em entender como
o posicionamento, a postura e nossa participação na construção do
aprendizado são importantes" (p. 105, grifos nossos).

Embora alguns professores-cursistas tenham aderido aos projetos também por conta de questionamentos e indagações profissionais que encontraram ressonância nas motivações já formatadas para os projetos (casos de MP.Local.08, MP.Local.11 e MP.Local.15) todos eles aplicaram seus PEs em contexto diverso àquele de seu local de trabalho, ou seja, em subprojetos desenvolvidos em instituições e escolas parceiras dos referidos projetos e não nas escolas onde trabalhavam. De maneira geral, esses subprojetos buscavam abordar de forma interdisciplinar o ensino de Ciências com uso de diferentes recursos, como o audiovisual, jogos, narrativas, experimentação. Esses

${ }^{115}$ No site do programa disponibilizado no portal da CAPES, declara-se que "o Programa Observatório da Educação, resultado da parceria entre a Capes, o INEP e a SECADI, foi instituído [...] com o objetivo de fomentar estudos e pesquisas em educação, que utilizem a infra-estrutura disponível das Instituições de Educação Superior - IES e as bases de dados existentes no INEP. O programa visa, principalmente, proporcionar a articulação entre pósgraduação, licenciaturas e escolas de educação básica e estimular a produção acadêmica e a formação de recursos pós-graduados, em nível de mestrado e doutorado". Disponível em: <https://capes.gov.br/educacao-basica/observatorio-da-educacao />. Acesso em: 15 mai 2019. 
trabalhos apresentaram como PEs, sequências didáticas, livros paradidáticos e livros de relatos, além de um catálogo de pesquisas.

Outros cinco trabalhos não vinculados a esses projetos institucionais encontram relação direta com problemas levantados da própria prática docente (MP.Local.02, MP.Local.05, MP.Local.14, MP.Local.20 e MP.Local.22). São, portanto, oito trabalhos de um total de vinte e dois (ou seja, pouco mais de um terço do total de trabalhos analisados) que explicitamente fazem referências aos problemas da prática docente que motivaram o desenvolvimento da pesquisa e PE. Esses problemas se originam de diferentes aspectos do trabalho docente. MP.Local.02, MP.Local.14, MP.Local.20, MP.Local.22 se concentram na atuação em sala de aula centrado no aluno. MP.Local.05 e MP.Local.11 também se preocupam com a atuação em sala de aula, mas de modo mais geral, estando preocupadas com o aperfeiçoamento de suas práticas docentes através da adoção de novas metodologias e estratégias didáticas. Por fim, MP.Local.08 e MP.Local.15 se mostram preocupados com a formação continuada de professores de modo geral, respectivamente, por atuar no ensino normal, e por acreditar ser importante instigar nos professores em geral a continuidade dos estudos.

Independentemente de a motivação dos trabalhos estar colocada sobre problemas particulares da própria prática, os trabalhos fazem referência às questões gerais da prática docente que podem ser encontradas por qualquer professor. Elas são apresentadas a seguir.

Temos trabalhos que incidem em contornar o desinteresse dos alunos para 0 estudo da Física e Ciências em geral (MP.Local.03, MP.Local.06, MP.Local.10, MP.Local.21). Esses trabalhos dividem-se entre a proposição de material didático ou sequência didática, utilizando, em sua maioria, recursos das $\underline{\text { TICs }}$ ou pequenos experimentos.

Em particular, o trabalho de MP.Local.06 também faz referência à necessidade de renovação de metodologia/recursos de ensino pelos professores, o que é tema central de outros trabalhos: MP.Local.05, MP.Local.13, MP.Local.16, MP.Local.18. Todos esses trabalhos apresentam sequências didáticas, a maioria fazendo uso de experimentos. Há também o uso de redes sociais e história em quadrinhos. Um resumo dos problemas da prática docente motivadores para a realização dos PEs no contexto do MP.Loca é apresentado na Tabela 9: 
Tabela 9 - Problemas da prática docente apontados como motivadores para a realização dos PEs defendidos até 2017 no contexto do MP.Local.

\begin{tabular}{c} 
PROBLEMA MOTIVADOR PARA A REALIZAÇÃO DO PE \\
\hline $\begin{array}{c}\text { Construção de conhecimento científico na área, atrelado à formulação de } \\
\text { questões de pesquisa }\end{array}$ \\
Problemas levantados da própria prática docente \\
Atuação em sala de aula centrado no aluno \\
Aperfeiçoamento de práticas docentes através da adoção de novas \\
metodologias e estratégias didáticas \\
Desinteresse dos alunos \\
Necessidade de inovação curricular \\
Instrumentalizar professores no uso de metodologias/estratégias didáticas \\
consideradas inovadoras \\
Dificuldade de aprendizagem dos alunos
\end{tabular}

A problemática da inovação curricular aparece com ênfase em quatro trabalhos, MP.Local.02, MP.Local.04, MP.Local.12 e MP.Local.20. Todos eles abordaram temas de Física Moderna e Contemporânea: Partículas elementares e o LHC; Mecânica Quântica (interpretação de David Bohm); Teoria da Relatividade; Efeito Fotoelétrico. As propostas giraram em torno de sequências didáticas e elaboração de material $\underline{\text { didático }}$ com o uso de textos, vídeos, debates e simulação computacional. Interessante notar que os trabalhos MP.Local.04 e MP.Local.12 se preocuparam em produzir material orientado à formação continuada de professores.

MP.Local.12: "Este trabalho busca contribuir para o aprimoramento
docente através do desenvolvimento de um tema específico do
ensino médio, adotado a partir da implantação do [novo currículo
estadual], possibilitando uma construção do conhecimento a partir da
ideia de teoria de unificação tão presente na Física e tão pouco
explorada pelos professores em aulas de ensino médio. [...] O texto é
dirigido aos docentes que desejam se aprimorar buscando novos
elementos para prática profissional" (p. $12 / 13$, grifos nossos).

Três trabalhos concentram-se em instrumentalizar professores no uso de metodologias/estratégias didáticas consideradas inovadoras. MP.Local.09 fornece um roteiro de RPG para ser utilizado na discussão de fontes alternativas de energia, apresentado com uma explicação sobre a história e características do jogo; MP.Local.14 e MP.Local.19 se dedicam em levar temas da Física aos anos iniciais do ensino fundamental, etapa em que os professores têm formação generalista, no 
entanto, muitas vezes precária em relação aos temas científicos. Nesse sentido, há a apresentação de sequências didáticas com propostas de atividades com pequenos experimentos. MP.Local.19 especificamente apresenta um vídeo como PE, onde relata as atividades aplicadas na escola onde trabalhava e os resultados obtidos. Ambos trabalhos mostram a ciência de seus autores em relação às limitações dos PEs frente às situações problemáticas que pretendem solucionar:

MP.Local.14: "Assim, acredita-se que a pesquisa sobre a formação
obtida nos cursos iniciais, propiciando o desenvolvimento de uma
sequência didática, facilita o trabalho docente em sala de aula com as
séries iniciais. Não que a proposta venha a substituir deficiências ou
carências na formação de professores, mas que venha a ser um
recurso de contribuição qualitativa para o ensino de Ciências no
segmento em questão" (p. 16, grifos nossos).

Por último, apenas o trabalho de MP.Local.22 focaliza diretamente dificuldades de aprendizagem dos alunos, já que busca trabalhar conceitos da Física que foram identificados no curso técnico em que atua como de pouco domínio pelos alunos, o que prejudicava a abordagem de alguns conceitos nas disciplinas da área profissional. Não tivemos trabalhos onde eram definidas explicitamente e exclusivamente os objetivos de contextualização do ensino, produção de material didático e investigação da própria prática, como surgiu em nossa análise de dissertações e PEs defendidos no polo do MNPEF.

$\mathrm{Na}$ análise das motivações dos trabalhos, houve também identificação da influência de disciplinas ou outras atividades do curso em três trabalhos. MP.Local.02, além do fato de ter se motivado em produzir um PE que abordasse o conteúdo de interesse de seus alunos, também inspirou-se em uma palestra ministrada por um professor convidado no contexto do MP. Além disso, aponta a importância das disciplinas cursadas para o desenvolvimento do PE. Por sua vez, MP.Local.13 faz referência a discussões motivadas pela leitura de artigos no contexto de uma disciplina que cursou. Já MP.Local.19 se motivou por um trabalho realizado no contexto de uma disciplina do curso.

MP.Local.02: "[...] duas disciplinas cursadas no primeiro semestre do mestrado: Ciência, Tecnologia e Sociedade (CTS) e História e Filosofia da Ciência (HFC) foram muito importantes para juntar as peças na definição sobre o que desenvolver como pesquisa. A partir daí, começamos a elaborar o projeto para esse tema [...]" (p. 62)

MP.Local.13: "Tal escolha [tópico de átomos, estrutura da matéria e modelos] se deve principalmente ao fato de que durante a disciplina "Tópicos em química I", tivemos contato com propostas de trabalho na área e acesso a artigos [referências] que demonstravam a dificuldade de se trabalhar assuntos correlatos, e que nesse momento oportuno, veio à tona como mote para servir de eixo fundamental no intuito de diminuir esse distanciamento bem como evitar a formação de concepções alternativas por parte dos estudantes" (p. 10). 
MP.Local.19: "[...] busquei um curso que eu me identificasse e ingressei no [MP.Local] onde tinha a intenção de fazer um trabalho de pesquisa na área de ensino de biologia devido à minha formação na área, porém quando cursei, no mestrado, as disciplinas, comecei a me interessar por formas de incrementar as aulas de ciências. Em uma dessas disciplinas, Debates Conceituais em Ensino de Física, tive a oportunidade de realizar um trabalho onde tratei das confluências entre a física e a música, apresentando uma estratégia para ensinar alguns aspectos de acústica por meio da música, propondo a construção de um instrumento musical feito de caixa de MDF e elásticos. Esta experiência me auxiliou na escolha do caminho a ser seguido dentro do ensino de ciências" (p. 11, grifos nossos).

A disciplina referida por MP.Local.19, Debates Conceituais no Ensino de Física, é ministrada por Do.MP.Local-01, docente entrevistado nesta pesquisa. Lembramos que na análise com elementos narrativos escrita a partir das entrevistas com os docentes do MP.Local, destacamos o relato deste docente em relação ao modo em que conduzia essa disciplina. Esse docente expressou ter a preocupação em incentivar a prática interdisciplinar, e o trecho destacado da dissertação do egresso MP.Local.19 dá indícios de que há respostas positivas por parte dos professorescursistas a essa abordagem, que se desdobram até mesmo no desenvolvimento dos PEs. Enfatizamos que a disciplina parece ter tido uma grande importância para esse egresso no sentido da atualização da dimensão organização e condução de ensino de seu desenvolvimento profissional.

Diferentemente dos trabalhos do polo do MNPEF, no MP.Local destacaram-se trabalhos que promoveram práticas interdisciplinares envolvendo a Física (MP.Local.07, MP.Local.09, MP.Local.11, MP.Local.13, MP.Local.14, MP.Local.17, MP.Local.19) , conteúdos da Física Clássica tradicionais (MP.Local.01, MP.Local.03, MP.Local.05, MP.Local.08, MP.Local.10 , MP.Local.16, MP.Local.18, MP.Local.21, MP.Local.22), conteúdos inovadores da Física Moderna e Contemporânea ou da Astronomia (MP.Local.02, MP.Local.04, MP.Local.06, MP.Local.12, MP.Local.20). A maior incidência de PEs com propostas de práticas interdisciplinares em comparação com o polo do MNPEF é coerente com o perfil do MP.Local que além de ser um curso de MP em Ensino de Ciências, e não apenas de Física, dá grande destaque à prática interdisciplinar, segundo nossa análise dos documentos que caracterizam e orientam o funcionamento do curso. O trabalho de MP.Local.15 não se encaixa em nenhuma das situações apresentadas, por se tratar de um trabalho que investiga especificamente pesquisas sobre formação de professores.

A preocupação com a formação continuada de professores é outra característica que chama a atenção em relação à análise empreendida no polo do MNPEF, onde todos os trabalhos estavam orientados para a sala de aula de educação básica de forma direta ou indireta. No MP.Local, além de MP.Local.15, os professores 
MP.Local.04 e MP.Local.12 também se preocuparam em elaborar materiais direcionados à formação continuada de professores, e não à educação básica. Os trabalhos de MP.Local.07 e MP.Local.11, por envolverem o ensino normal, acabaram se preocupando também com a questão da formação inicial de professores. A Tabela 10 resume o que motivou os professores à construção dos PEs.

Tabela 10 - Motivações apresentadas pelos professores egressos do MP.Local para a construção dos PEs propostos.

\section{MOTIVAÇÕES PARA A CONSTRUÇÃO DO PES PROPOSTOS}

Vinculação à projetos institucionais relacionados à CAPES (Programa Novos Talentos e Observatório da Educação)

Discussões empreendidas nas disciplinas ou outras atividades do MP Preocupação com a formação continuada de professores

Em relação à autoria dos trabalhos apresentados no MP.Local, 17 trabalhos seriam totalmente autorais, ou seja, com material criado pelo professor-cursista; e cinco trabalhos (ou quase um quinto dos trabalhos) parcialmente autorais, que fazem uso de recursos, tais como simulações, já disponibilizados por outros autores. Consideramos trabalhos totalmente autorais aqueles que consistem em produtos elaborados pelos próprios professores-cursistas, tais como, nos PEs analisados: roteiros, história em quadrinhos, vídeos e textos didáticos. Incluímos nessa categoria as sequências didáticas originais, mesmo que fizessem uso de experimentos que podemos considerar de domínio público, por terem montagem facilmente conhecida pela comunidade de ensino de Física. Dentre os trabalhos considerados parcialmente autorais, encontramos também em algumas dissertações defendidas no MP.Local, a preocupação que alguns professores-cursistas do polo do MNPEF expressaram da necessidade de dar sentido aos recursos já disponíveis, ao invés de criar outros novos, como mostra o trecho abaixo. Assim, depreendemos este ser um entendimento comum entre professores de Física.

MP.Local.20: "Encontramos apenas cinco trabalhos sobre o ensino do efeito fotoelétrico publicados nos principais periódicos da área de ensino de ciências entre os anos de 2011 a 2016, evidenciando que há necessidade de se produzir estratégias didáticas e materiais para auxiliar os professores. Isso não significa necessariamente produzir mais uma simulação, mais uma animação nem mais qualquer outro recurso, mas sim problematizar e investigar estratégias didáticas que levem em consideração a aprendizagem da física que possa promover de fato uma alfabetização científica[...] Justamente por isso optamos por não desenvolver uma "inovação" como produto educacional, já que encontramos na rede mundial de computadores recursos como as simulações computacionais utilizadas na sequência didática que atendem satisfatoriamente o processo de ensino e aprendizagem do efeito fotoelétrico" (p. 69-70, grifos nossos). 
Finalmente, traçamos considerações a respeito dos referenciais teóricos utilizados pelos professores para embasar a construção do PE. Foi possível observar maior variedade de referenciais teóricos utilizados pelos professorescursistas no MP.Local em relação aos do polo do MNPEF. Por exemplo, no MP.Local, apenas cinco trabalhos se apoiaram na Teoria de Aprendizagem Significativa, enquanto outros trabalhos se apoiaram em outros referenciais do processo de ensinoaprendizagem e metodologias de ensino de Física. Além de apresentarem discussões gerais sobre o ensino de Física, formação de professores, currículo e demais temas pertinentes para cada trabalho, alguns têm a especificidade de trazer referenciais teóricos de áreas diversas ao do Ensino de Física, para auxiliar na contextualização teórica de seu PE. É o caso de MP.Local.17 que utiliza referenciais que discutem o uso de recursos audiovisuais, a semiótica e o conceito de polifonia de Bakhtin para contextualizar a produção de vídeos pelos alunos, incentivada em seu PE. A grande maioria dos trabalhos (quinze) utilizam os referenciais teóricos abordados na dissertação para realizar uma construção fundamentada do PE. Assim, algumas escolhas realizadas para proposições de atividades dos PEs são justificadas com base em referenciais teóricos, tais como nos exemplos abaixo:

MP.Local.07: [referenciais de ensino por investigação e conceitos da Teoria Socio-interacionista de Vygotsky] "A inclusão dos sujeitos alunos em regras de conduta e situações de pesquisa análogas ao trabalho dos cientistas consiste de oportunidades de participação na cultura científica, promovendo o momento fecundo para a criação de Zonas de Desenvolvimento Proximal" (p. 27, grifos nossos).

MP.Local.10: [referenciais de aprendizagem ativa] "Em contrapartida à montagem experimental, pode ser proposto que cada grupo, com base nos conceitos desenvolvidos, elabore um problema a ser resolvido por um outro grupo, a ser sorteado. $\underline{O}$ objetivo dessa tarefa é transferir para os alunos parte das atribuições que geralmente são delegadas ao professor; com isto, estaremos dando autonomia e transferindo responsabilidade aos alunos, tornando-os, por alguns instantes, ao mesmo tempo objeto e sujeito do processo ensinoaprendizagem" (p. 32, grifos nossos).

MP.Local.13: [conceitos da Teoria Socio-interacionista de Vygotsky] "Ao utilizar o Facebook como ferramenta para complementação dos estudos em classe, acredita-se contemplar a interação no sentido que os alunos estarão contribuindo constantemente com as proposições suscitadas pelo professor, neste caso o mediador principal, e ainda com os demais aprendizes, pois o ambiente se desenha como 0 contexto social do desenvolvimento e aprendizagem. E por vir na sequência do que foi trabalhado em classe, nos permitirá avaliar o que há de desenvolvimento real, para que as atividades propostas on-line contemplem o desenvolvimento proximal para subsequente continuidade em classe visto que as atividades estarão intercaladas (p. 25, grifos nossos). 
MP.Local.21: [referenciais sobre concepções alternativas e metodologia Peer Instruction] "Foram montados e apresentados aos alunos quatro tipos de circuitos, compostos por fontes de tensão elétrica e lâmpadas incandescentes idênticas. Cada um deles foi construído levando-se em conta as concepções alternativas mais frequentes no estudo dos circuitos. As apresentações desses experimentos foram associadas com a metodologia Peer Instruction, que permite, em hipótese, uma aprendizagem mais colaborativa. Desse modo, esperava-se que os estudantes que tivessem vencido suas dificuldades conceituais fossem capazes de compartilhar seus conhecimentos com os colegas que ainda não houvessem alcançado esse objetivo" (p. 30, grifos nossos).

MP.Local.22: "Os apontamentos de Ausubel em termos de aprendizagem significativa e as preocupações com uma relação ensino-aprendizagem mais eficiente são utilizados na estrutura do presente trabalho. A proposição de problemas para investigação em grupos ajuda na criação de ambientes favoráveis ao debate acadêmico, dinamizando a relação ensino-aprendizagem. Nessa perspectiva, as contribuições de Ausubel corroboram a estrutura da sequência didática proposta, se alinhando as ideias gerais de estímulo à colaboração e trabalho em equipe, apresentadas na dissertação presente" (p. 26-27, grifos nossos).

\section{- Bloco 3 - Dissertação}

Iniciamos a apresentação de dados desse bloco com a definição de objetivos de pesquisa presente nas dissertações. Nas dissertações do MP.Local fica mais evidente o apontamento feito anteriormente, por ocasião da apresentação e análise dos dados das dissertações defendidas no polo do MNPEF, de que não necessariamente os objetivos de pesquisa da dissertação se referem somente ao relato de aplicação ou avaliação do PE. No MP.Local, pouco mais da metade das dissertações (no total de treze trabalhos) se dedicam exclusivamente a essa tarefa, embora algumas delas não explicitem esse objetivo ao longo do texto. Mesmo dentre essas, alguns professores-cursistas (MP.Local.09 e MP.Local.19) também expõem a preocupação em se investigar o uso da metodologia didática apresentada no PE para a aprendizagem dos alunos, ou seja, se dedicam a coletar dados em suas pesquisas que transcendem o próprio $\mathrm{PE}$ :

MP.Local.09: "[...] objetivo geral da pesquisa que foi investigar o potencial didático do RPG para o ensino de Ciências de qualidade junto aos alunos do curso de formação de professores do [instituto onde foi aplicado o PE]" (p. 104, grifos nossos).

MP.Local.19: "Todas as atividades foram analisadas durante 0 processo a fim de identificar as facilidades e dificuldades existentes e se o objetivo estava sendo atingido. Trata-se de uma pesquisa que busca verificar a eficácia do uso da música no ensino de ciências, entrelaçando teoria e prática" [...] (p. 52, grifos nossos).

Observamos no MP.Local, quatro dissertações (MP.Local.01, MP.Local.05, MP.Local.07, MP.Local.17) que se dedicaram exclusivamente a questões de pesquisa 
para a compreensão do fenômeno educativo e contexto educacional, realizando investigações mais amplas que envolveram atividades além da aplicação do PE elaborado. Nesse sentido, o PE seria um meio para realizar a investigação pretendida, e não um fim em si mesmo.

MP.Local.01: "Este trabalho, seguindo os conceitos de experimentos de ensino, procura avaliar se a combinacão de mídias é favorável à construção do conhecimento, partindo das concepcões espontâneas do estudante. Objetiva-se a utilização da simulação de eventos com valores qualitativos e deseja-se o conhecimento dos conceitos envolvidos sem a utilização inicial da ferramenta matemática ou mesmo a coleta de valores de medida. Pretende-se a utilização de simulação de eventos físicos para a aprendizagem auxiliada por computador através de aplicativos em JAVA e ao final, analisar se a observação pura das simulações é suficiente para o aprendizado ou se a mediação do professor é fundamental para organizar e facilitar o processo cognitivo" (p. 38, grifos nossos).

MP.Local.05: "Preliminarmente, ressaltamos que essa pesquisa visou investigar, sob a perspectiva de professores de Ciências de uma escola pública de Ensino Fundamental, a adequação da formação inicial adquirida nos cursos de Licenciatura em Ciências Biológicas e a influência das propostas de conteúdos dos Livros Didáticos sobre o ensino de Física no nível Fundamental de ensino" (p. 41, grifos nossos).

MP.Local.07: "O objetivo da pesquisa, a partir do pressuposto aqui salientado, consistiu, portanto, em avaliar à luz da teoria vygotskyana o desenvolvimento do aprendizado dos sujeitos da pesquisa mediados por ferramentas e signos oriundos do campo das ciências naturais. Desta forma, busquei instrumentalizar os jovens alunos que serão futuros professores, para atuarem de modo crítico, autônomo e criativo nas salas de aula e nos meios onde se inserem" (p. 12, grifos nossos).

MP.Local.17: "Em decorrência dessas reflexões, esta pesquisa se atém com a facilidade e a motivação dos alunos-sujeitos do ensino médio utilizarem os recursos audiovisuais. Desta forma, surge o problema de investigação e as seguintes indagações: De que forma o recurso audiovisual pode contribuir no contexto escolar? Que construção do saber é mobilizada pela apropriação deste recurso? 0 que representa a ciência para esses alunos-sujeitos vista por meio das imagens?" (p. 18)

Diferentemente do analisado nas dissertações do polo do MNPEF, no MP.Local encontramos também a realização de pesquisas (algumas empíricas, além de bibliográficas) que apoiaram a construção do $P E$. Quatro dissertações se inserem nessa categoria: MP.Local.04, MP.Local.11, MP.Local.12 e MP.Local.14. Destacamos abaixo trechos da dissertação de MP.Local.14 que é representante dessa categoria:

MP.Local.14: "A proposta de estudo, após revisão bibliográfica de documentos de formação de professores e do livro didático adotado, foi verificar o que ocorre no cotidiano de uma instituição de aplicação da formação inicial docente: uma escola. [...] A partir destas análises surgiu uma sequência didática apresentada como produto final da pesquisa. Essa análise possuiu como objetivo verificar se a formação curricular oferecida para 0 Ensino de Ciências aos futuros 
professores está de acordo com os conteúdos presentes nos livros didáticos adotados" (p. 45).

Por fim, destacamos a dissertação de MP.Local.15, que não se inclui em nenhuma das categorias anteriores, por ser uma pesquisa de cunho mais acadêmico:

MP.Local.15: "No âmbito do projeto OBEDUC edital 2012, a pergunta de pesquisa é: Qual o impacto dos mestrados profissionais em ensino sobre a qualidade da educação científica, considerando-se a diversidade regional e cultural dos contextos educacionais de formação e atuação? Dentro dessa perspectiva, este trabalho é norteado pela seguinte pergunta de pesquisa: Quais as expectativas dos professores egressos de MPs acerca do curso de formação e da sua futura prática profissional?" (p. 18)

Talvez por conta da formação diferenciada dos orientadores do MP.Local em comparação aos do MNPEF, ou por conta da estrutura curricular que enfatiza elementos de pesquisa (com a disciplina obrigatória comum para o MP e o MA "Metodologia da pesquisa" e as disciplinas "Dissertação de Mestrado") e da proximidade com o curso de mestrado acadêmico que faz parte do mesmo programa, é possível distinguir em parte das dissertações do MP.Local a característica de serem pesquisas que se preocupam em produzir conhecimentos mais abrangentes e gerais do que realizar pontualmente a avaliação do PE em determinado contexto. Entretanto, da mesma forma que os professores do polo do MNPEF, encontramos indícios de que alguns professores do MP.Local também registram saberes experienciais adquiridos ao longo do processo de avaliação de seus trabalhos.

MP.Local.06: "[Na análise de respostas dos questionários pré-testes e do que ocorreu na aula, o pesquisador percebeu que] muitos alunos apresentaram concepcões que divergem quando são apresentadas de forma gráfica, escrita ou falada [...] A divergência de informações apresentadas pelos alunos indica que os mesmos não possuem uma formação conceitual bem fundamentada acerca do tema. Algumas concepções, mesmo que corretas, não são bem respondidas ou até mesmo não possuem explicação plausível na visão dos alunos. Isso se confirma quando os alunos não apresentam uma justificativa para sua afirmação de que os hemisférios da Terra possuem diferentes estações. Eles acreditam que as estações sejam diferentes, mas não sabem explicar por que" (p. 56, grifos nossos).

MP.Local.08: "Querendo saber a causa do fracasso, procurei os alunos para conversar sobre onde poderia estar o problema, já que havia dado certo em duas situações anteriores, muitos relataram que não se preocuparam, pois não cairia na prova. Será que o aluno de hoje somente se preocupa com assuntos que cairá na prova? Acredito que não. Faltou algo para motivar a turma. Os alunos das três turmas, em particular, nunca haviam entrado em um laboratório. Havia, realmente, de minha parte, uma desmotivação quando muitos alunos estavam no laboratório, sem manusear os experimentos, distantes inclusive dos olhares daqueles do próprio grupo quando esses estavam praticando, no caso do espelho mágico (onde somente um fazia o desenho) e de certa forma á demorado (sic), quanto na mistura das cores com tinta. Esse momento de dispersão foi visto por mim como o principal fator pelo desinteresse já que nos 
outros encontros haviam poucos alunos por grupo, fazendo com que todos interagissem" (p. 54-55, grifos nossos).

De qualquer forma, identificamos menor ênfase que a dada no MNPEF, a situações da prática dos professores, e a dificuldades encontradas por esses professores nas escolas em que atuam. Esse fato também pode estar ligado ao conjunto de professores que desenvolveram seus trabalhos em contextos que não o de sua própria sala de aula, como aqueles que se vincularam aos projetos institucionais.

As metodologias que guiaram as pesquisas, independente dos objetivos estabelecidos, foram variadas, mas incidiram principalmente em metodologias qualitativas. Apenas dois trabalhos (MP.Local.21 e MP.Local.22) fazem uso de metodologias quantitativas baseadas em métodos estatísticos. Chama a atenção a adoção da metodologia da pesquisa-ação em cinco dissertações (MP.Local.07, MP.Local.09, MP.Local.11, MP.Local.16 e MP.Local.19). Esses últimos trabalhos têm em comum a orientação de buscar contribuições ativas dos alunos que participaram da aplicação do PE para aprimoramento tanto da prática do professor quanto do próprio PE.

Em relação aos instrumentos de coleta de dados utilizados para a avaliação dos PEs, há o uso do pré e pós-testes, mas também uma variedade de outros instrumentos, como atividades desenvolvidas pelos alunos ao longo da aplicação do $P E$, depoimentos e entrevistas de alunos e professores, registros da aplicação em gravações, questionários de satisfação do uso da metodologia, anotações em diário de campo pelo professor que aplicou o PE, provas realizadas pelos alunos, entrevistas com professores. Há trabalhos que associam o uso de diferentes instrumentos de dados para estudo, como o trabalho de MP.Local.06 que além dos pré e pós-testes, coleta dados com a gravação da aula e ouvindo depoimentos dados por alunos após a sua aplicação.

Os referenciais teóricos adotados pelos mestrandos do MP.Local nas pesquisas desenvolvidas também são variáveis. Mesmo quando não há adoção de um referencial específico, é notável o esforço dos professores em dialogar com a literatura estudada e pertinente para o objeto de pesquisa. No entanto, encontramos seis trabalhos que não adotam referenciais para análise de dados, realizando apenas uma descrição da aplicação do PE (MP.Local.08, MP.Local.16, MP.Local.18, MP.Local.19) ou da pesquisa empírica/bibliográfica que apoiou sua construção (MP.Local.04, MP.Local.11 e MP.Local.12). 
Quanto aos desdobramentos dos PEs, apontados em quase a metade dos trabalhos analisados, predominam, em cinco dissertações (MP.Local.01, MP.Local.02, MP.Local.09, MP.Local.11 e MP.Local.17), indicações de adaptações do PE ao longo do desenvolvimento da pesquisa, o que sugere a preocupação com o aperfeiçoamento do produto a partir de ideias novas ou problemas não previstos que surgem no contexto de aplicação. Três trabalhos (MP.Local.01, MP.Local.20, MP.Local.21) indicam a possibilidade de adaptação dos PEs para outros conteúdos. Sete dissertações (MP.Local.09, MP.Local.13, MP.Local.14, MP.Local.16, MP.Local.17, MP.Local.20 e MP.Local.22) também apontam pesquisas futuras que poderiam ser desenvolvidas a partir do trabalho defendido. São propostas que aprofundam determinados aspectos do trabalho, sugerem novos referenciais de análise ou encaminham aprofundamentos de pesquisa como os destacados abaixo:

\begin{abstract}
MP.Local.09: "Esse trabalho constituiu-se em uma reflexão sobre o processo de ensino e aprendizagem por meio de uma estratégia lúdica inovadora no campo educacional, visto a partir do referencial teórico de Piaget. No entanto, durante a pesquisa e estudo foi percebido que novos desdobramentos, a partir de outros referenciais teóricos, como Vygotsky, por exemplo, são possíveis para contribuir para a análise da temática. Isto evidencia a amplitude do tema em questão, e este trabalho é apenas um recorte dentro destas possibilidades" (p. 115, grifos nossos).
\end{abstract}

MP.Local.16: "As aulas da sequência didática que envolvendo experimentações com coleta dados demandaram bastante tempo, a saber: tubo de Kundt e o Xilofone, sendo necessário análises posteriores mais detalhadas. Essas atividades precisam ser aprimoradas quanto à suas coletas de dados e adequação ao tempo disponível. $O$ aperfeiçoamento na coleta dos dados dessas atividades práticas, e análise mais aprofundada da sequência didática, que trace relações do que foi assimilado pelos alunos com um padrão de letramento científico, a verificações de possíveis mudanças conceituais esperado para esses alunos concluintes do ensino médio e os impactos desse tipo de formação na vida desses discentes e futuros profissionais abrem margem para continuidade deste trabalho em maior grau de estudo e detalhamento" (p. 73, grifos nossos).

MP.Local.17: "Temos a perspectiva da difusão da SD [sequência didática] junto aos professores da educação básica para posterior estudo sobre o domínio e apropriação desse material pelos educadores" (p. 87, grifos nossos).

Diferentemente das dissertações do MNPEF, que tiveram, em sua grande maioria, apenas alunos de diferentes modalidades e níveis de ensino como sujeitos participantes das pesquisas, por conta dos trabalhos se concentrarem na avaliação dos PEs em contextos de sala de aula, algumas dissertações do MP.Local também tiveram professores da educação básica como participantes. Em relação aos locais de aplicação dos PEs e realização das pesquisas, elas variam entre contextos de ensino médio-técnico, colégios públicos estaduais, escolas privadas, escolas de ensino fundamental (anos iniciais e anos finais), curso normal e EJA. Alguns trabalhos, 
direcionados ao ensino superior, também tiveram licenciandos como sujeitos de pesquisa. Muitos trabalhos não foram aplicados nos contextos de trabalho dos professores-cursistas.

- Bloco 4 - Outras...

Por ter a característica interdisciplinar, como expressos nos documentos que regem o MP.Local, o número de trabalhos que apresentam propostas interdisciplinares é maior que no caso do polo do MNPEF, totalizando nove trabalhos (MP.Local.02, MP.Local.05, MP.Local.07, MP.Local.08, MP.Local.11, MP.Local.14, MP.Local.16, MP.Local.17, MP.Local.19). São trabalhos que agregam conteúdos disciplinares da Física com o de outras Ciências da Natureza (Biologia, Química), mas também com Matemática, Língua Portuguesa, Literatura, História e Filosofia, além de alguns desses trabalhos terem intersecções com arte. São numerosos, porém, os trabalhos que não promovem a interdisciplinaridade, se concentrando apenas em conteúdos disciplinares da Física. Esses representam 59 \% da amostra analisada.

Outra característica marcante do curso é a preocupação com a extensão, que na nossa análise ficou mais evidente nos trabalhos que participaram do Programa Novos Talentos, naturalmente por este ser um projeto de ensino, pesquisa e extensão na parceria entre a instituição sede do MP e escolas de educação básica (colégio estadual e curso normal). A extensão esteve expressa na realização de palestras, visitas técnicas, feira de ciências, paralelamente à aplicação dos PEs com alunos dessas escolas nos subprojetos desenvolvidos nelas, além da distribuição gratuita de alguns desses PEs para outros professores das escolas parceiras e para os professores em formação do curso normal.

A preocupação com a divulgação dos trabalhos, que também guarda a característica de extensão, no sentido de divulgar à sociedade o que é produzido nas instituições acadêmicas, aparece no número de publicações a apresentações de trabalhos que é realizada pelos professores-cursistas em geral. Assim, além da distribuição gratuita de alguns desses PEs impressos, foi comum os professores relatarem participação e apresentação de trabalhos em congressos da área de Ensino de Física e de Ciências (como o Encontro Nacional de Pesquisa em Ensino de Ciências - ENPEC; e o Simpósio Nacional de Ensino de Física - SNEF); publicação de livro, ou capítulos de livro; publicação de artigos em periódicos da área. A preocupação com a divulgação do PE gira em torno de proporcionar o aperfeiçoamento da formação de outros professores que entram em contato com os 
materiais produzidos no contexto do MP, como expressos por MP.Local.09 e MP.Local.19:

\begin{abstract}
MP.Local.09: "É consciente do papel da divulgação científica que esta pesquisa já expôs alguns de seus resultados em trabalhos apresentados em congressos e, um deles, o SNEF, em que há a participação de alunos e professores em formação. Convém lembrar ainda que a pesquisa gerou um material didático (produto educacional) para utilização por professores e alunos. É o compromisso e a responsabilidade de 'devolver' à população os conhecimentos gerados nos centros acadêmicos" (p. 27, grifos nossos).
\end{abstract}

MP.Local.19: "[...] O estudo dos sons, por exemplo, abrange a física, a percepção sonora, a educação dos sentidos, a cultura musical, a paisagem sonora, envolve os sons naturais e artificiais, as 'vozes' dos animais, dentre outros. Com tantas possibilidades, a formação inicial e continuada dos professores torna-se imprescindível com a finalidade de fazer com que os mesmos possam refletir e ser estimulados a trabalhar com diversas estratégias no ensino de ciências explorando todas as possibilidades disponíveis no ambiente ao nosso redor. Por isso, experiências como essa, tratada nessa dissertação, devem ser compartilhadas por meio de artigos, cursos de capacitação, palestras, oficinas, mídias digitais e outros meios" (p. 37, grifos nossos).

Coincidentemente, os relatos nas dissertações de impactos nas escolas em que os PEs foram aplicados, se concentraram em casos onde foram envolvidos professores e turmas dos anos iniciais do ensino fundamental (MP.Local.05, MP.Local.14 e MP.Local.19). Nesses casos, além da distribuição de cópia do PE, professores das escolas envolvidas foram incentivados a mudarem suas práticas tendo em vista resultados observados com a aplicação do PE, além da participação em oficinas de formação promovidas pelo professor-cursista. Esses exemplos mostram o potencial latente que pode ser explorado, o de se envolver o coletivo da escola na renovação das práticas, refletindo seu desenvolvimento na dimensão participação e organização na gestão escolar:

MP.Local.14: "Durante o processo de validação da sequência didática elaborada através dessa pesquisa, houve modificação do planejamento e aplicação dos conteúdos por parte de docentes que atuam na escola pesquisada, uma vez que pôde ser observado aumento no interesse dos alunos pelos conteúdos ensinados através de atividades práticas e relacionando elementos do cotidiano através de conversas iniciais sobre o conteúdo" (p. 58, grifos nossos).

MP.Local.19: "No decorrer dos trabalhos com os alunos tivemos a ideia de realizar uma oficina de 4 dias (1 hora e 30 minutos por dia) para os professores da escola com o mesmo tema e a mesma dinâmica que a oficina dos alunos, com o objetivo de fazer uma interação deles com a pesquisa que estava sendo realizada $e$ estimulá-los a trabalhar fazendo uso de estratégias alternativas no ensino de ciências. A ideia foi bem aceita pelos docentes e a oficina foi realizada. Apesar da importância desse trabalho com os professores, bem como a interação que ele proporcionou e a base sólida que possa ter nos concedido para a elaboração do nosso 
produto educacional, o mesmo não constituiu o nosso principal elemento de pesquisa. Porém, a iniciativa foi relevante para estreitar os caminhos entre a teoria e a prática junto aos professores" (p. 3839 , grifos nossos).

Além desses professores, apenas MP.Local.22 relatou um movimento de discussão do currículo do curso técnico promovido pela aplicação de seu PE em seu contexto de trabalho. A adequação curricular das disciplinas de Física do curso aos conhecimentos demandados pelas disciplinas profissionais já era considerada pelo professor como um ponto de partida para a elaboração de seu PE.

Por fim, diversos excertos das dissertações poderiam ser destacados indicando impactos para a formação dos professores envolvidos no curso de MP. Eles destacam que o envolvimento com as disciplinas do curso e a elaboração do PE e da pesquisa, proporcionaram diferentes reflexões e investigações sobre a prática (MP.Local.01, MP.Local.20, MP.Local.21); mudanças de suas práticas de diferentes maneiras com a adoção de novos conteúdos e metodologias proporcionadas pelo contato com novos conhecimentos, no movimento de buscar o maior protagonismo dos alunos (MP.Local.14, MP.Local.18, MP.Local.20); além de percepções diferenciadas do que tinham sobre a disciplina que leciona, expandindo sua visão sobre o que é possível realizar em sala de aula (MP.Local.11). Os excertos de todos esses trabalhos são mostrados adiante:

MP.Local.01: "A interação dos alunos do quarto período com os aplicativos e com o professor-pesquisador foi muito enriquecedora para a própria experiência profissional do professor, pois foi possível avaliar a força do senso comum na formação do pensamento (lembrando que esses alunos já possuíam conhecimento teórico) e mostrou situacões onde o professor pode falhar em sua prática docente. Os conflitos de opinião que se apresentaram durante as interações com os aplicativos foram motivadores à curiosidade e à construção do conhecimento" (p. 88, grifos nossos)

MP.Local.11: "Estando o pesquisador também inserido como sujeito da pesquisa, cabe ressaltar que as propostas de leitura do texto literário aconteceram, para ele, com outro olhar. $\underline{A}$ literatura revelouse de outra maneira e libertou-se para além de seu potencial estético e/ou artístico e disciplinar (literatura como disciplina), tornando-se provocadora do conhecimento científico, até então pouco buscado por um professor de Língua Portuguesa e Literatura" (p. 67/68, grifos nossos).

MP.Local.14: "Iniciativas de melhorar o ensino com materiais de fácil acesso evidenciam possibilidades tanto de acertos, como de erros. Saber se os conteúdos foram realmente aprendidos em sua totalidade, como a aprendizagem das crianças foi afetada e todos os resultados alcançados, para o local onde a pesquisa foi realizada, demandaria tempo e esforços maiores que uma simples avaliação em forma de provas. No entanto, para além disso, pode ser afirmado que não somente as aprendizagens aconteceram de maneira diferente do que teriam sido caso a pesquisa não ocorresse, pois despertou o interesse das crianças para uma área considerada estranha até então 
e, mais além, a prática pedagógica de quem vos escreve foi totalmente modificada a partir dessa pesquisa. A pesquisa propriamente dita foi aplicada até dezembro de 2013, no entanto, as aulas sugeridas na sequência didática estão sendo reaplicadas $\mathrm{e}$ modificadas conforme as necessidades apresentadas, além de outras aulas terem sido planejadas com base nas primeiras" (p. 77 , grifos nossos).

MP.Local.18: "Fazendo uma comparação com as aulas em que não foi utilizado a reflexão na ação o professor pode perceber que os alunos não assimilaram os conteúdos da forma como se esperava. Dessa maneira, o professor deverá incluir esse método em suas futuras aulas, não privilegiando somente a modalidade EJA como também o ensino médio regular" (p. 73, grifos nossos).

MP.Local.20: "Durante todo o ano letivo utilizamos variados recursos e estratégias didáticas nas aulas, mas sempre de maneira expositiva e com pouco ou nenhum espaço para que os alunos construíssem o seu conhecimento, isto é, apenas transmitimos um conhecimento que já estava pronto, dando a ideia de uma ciência pronta, inquestionável e não como produção humana. [...] Ao contrário das listas de exercícios e pesquisas sobre um determinado tema, atividades predominantemente objetivas realizadas ao longo do ano letivo, essas atividades sugeridas durante a aplicação da sequência didática exigiram dos alunos a observação do fenômeno, a criação de hipóteses e a aplicação de conhecimentos em uma situação mais próxima do real. O surgimento desses elementos, inéditos até então para os alunos (e para o próprio professor que, até então, não tinha aplicado nenhuma estratégia planejada como a do produto educacional desenvolvido), contribuíram para a superação de obstáculos como a abstração, a matemática e a interpretação de problemas" (p. 63-64, grifos nossos).

MP.Local.20: "Por fim, este trabalho proporcionou um crescimento profissional bastante significativo, pois foi possível aprofundar em um tema que não sentia segurança em trabalhar com os alunos, e foi possível ainda incorporar a história que envolveu a descoberta do efeito fotoelétrico e desenvolvimento da teoria que explicava esse fenômeno, consolidando os conhecimentos adquiridos durante a formação inicial e até mesmo pela experiência com os anos de docência. Nos fez refletir sobre a nossa própria prática, que até então se encontrava inerte e acomodada frente aos avanços na área de ensino de física, pois passamos a conhecer diversas teorias de aprendizagem e diversos recursos pedagógicos que fundamentaram o desenvolvimento da sequência didática apresentada neste trabalho, e, dessa forma, considero que o curso de mestrado profissional teve seu êxito. A partir daí nossas aulas passaram a ter um foco maior no aluno e na sua vivência, procurando fazer da física uma disciplina mais interessante e aplicável ao cotidiano deles" (p. 72, grifos nossos).

MP.Local.21: "Outro aspecto positivo observado foi a possibilidade de, aula a aula, o professor repensar sua prática pedagógica. Se, numa determinada turma, alguma questão apresentasse dificuldade acima do esperado, o pesquisador modificava a explanação teórica ou mesmo a maneira de apresentar o circuito, nas demais salas, aprimorando o processo ensino-aprendizagem" (p. 44, grifos nossos). 


\subsubsection{Apreciação sobre a análise dos produtos educacionais e dissertações}

Encerramos a etapa de análise de dissertações e PEs dos dois MPs estudados com apreciações mais gerais sobre pontos referidos nas análises particulares de cada curso. Procuraremos levantar questões em diálogo com a literatura e utilizando exemplos de trabalhos estudados na pesquisa para apoiar a discussão. Muitas delas são apontadas como reflexões a serem realizadas pelos cursos de MP em conjunto com seu corpo docente, orientadores dos professores mestrandos. Não perdemos de vista também questões que tangenciam o desenvolvimento profissional proporcionado pelos MPs aos seus professores-cursistas, objetivo geral de nossa pesquisa.

Um ponto de discussão decorrente da análise das dissertações e produtos educacionais realizada nessa pesquisa e presente em outras publicadas na literatura, diz respeito ao papel da pesquisa e referenciais teóricos na produção e avaliação do PE e, consequentemente, na formação do professor mestrando. Nessa direção, tendo em vista as discussões já empreendidas, refletimos sobre qual é o significado atribuído à pesquisa que é realizada pelos professores-cursistas no caso dos dois MPs estudados.

Vemos que grande parte das dissertações se dedicam a avaliar o PE tendo em vista a aplicação dele em contexto real de sala de aula. Especificamente no MP.Local, houve também a intenção de produção de conhecimento. Apesar de vislumbrarmos em alguns casos a emergência de saberes experienciais dos professores sobre 0 comportamento dos alunos, seu contexto de trabalho e sua atuação a partir desses estudos, percebemos também a tendência da avaliação da efetividade do produto principalmente através de comparações entre pré e pós-testes aplicados à turma de alunos da educação básica e a ocorrência, muitas vezes, de análises insuficientes para realizar tal avaliação, por apenas focalizarem a atividade desenvolvida pelos alunos nos processos de implementação dos PEs.

$\mathrm{Na}$ realidade, notamos a pouca discussão sobre esse processo de avaliação, fundamental para o estudo desenvolvido no contexto de um MP em Ensino, segundo Ostermann e Rezende (2009). De acordo com essas autoras, "a avaliação deveria ser a forma pela qual verificamos se o ensino e a aprendizagem estão integrados [...] Essa integração exige que examinemos a questão tanto do ponto de vista do professor quanto do aluno" (p. 73). 
Ressalta-se dessa discussão a importância do referencial teórico para a realização dos trabalhos, pois caso ignorassem "estudos relacionados e conhecimentos já produzidos pelos pesquisadores em ensino" os trabalhos defendidos nos MPs estariam correndo o risco de fomentar "práticas baseadas em metodologias e recursos didáticos ultrapassados, já superados pelos avanços investigativos" (OSTERMANN; REZENDE, 2009, p. 70-71). A título de exemplo retirado de nosso espaço amostral, isso é o que ocorre com MNPEF.25, que apesar de objetivar a renovação das práticas docentes e propor o uso de experimentos como recursos de ensino, propõe para "verificar a utilidade do produto", a "operacionalidade do produto de forma autônoma [pelos alunos], seguindo o roteiro [que compõe o $P E$ ] e com interferência mínima do docente" (dissertação de MNPEF.25, p. 22). O mesmo ocorre com MP.Local.01, que se propôs a avaliar "se a observação pura das simulações [presentes no PE] é suficiente para o aprendizado ou se a mediação do professor é fundamental para organizar e facilitar o processo cognitivo" (dissertação de MP.Local.01, p. 38). São exemplos que se apoiam em propostas de auto-instrução baseadas em teorias comportamentalistas, já consideradas, pelo campo investigativo do Ensino de Ciências, estratégias de ensino obsoletas e inócuas. O estudo mais pormenorizado e atualizado dos referenciais teóricos e de pesquisas desenvolvidas na área poderia ajudar os professores a evitar tais estratégias ultrapassadas, muitas vezes ainda presentes em seu imaginário e prática.

Acrescentamos, portanto, que o contato dos professores com referenciais teóricos e discussões acadêmicas atualizadas beneficia diretamente o seu desenvolvimento profissional, primeiramente através da atualização dos conhecimentos científicos e pedagógicos e com possível renovação nas dimensões de organização e condução de ensino e sustentação da aprendizagem. O MP se mostra como espaço privilegiado para isso, por significar a volta do contato do professor com o ambiente acadêmico, do qual, muitas vezes, ele esteve afastado por anos, desde a conclusão de sua formação inicial. Nessa reaproximação, ele pode fazer descobertas de novas possibilidades e aprofundar questões que já desejava investigar, como MP.Local.03 que se propôs a criar analogias sociais para uso na abordagem de conteúdos de Eletricidade "sem imaginar que o estudo acerca das analogias no ensino era uma área de consideráveis publicações" (Dissertação de MP.Local.03, p. 13).

Em última análise, o contato com os referenciais teóricos para a realização do PE significa a desejada aproximação entre mundo acadêmico e mundo profissional, como o professor MP.Local.13 a reconhece como objetivo de seu trabalho: "Além do objetivo prático no que diz respeito a evolução cognitiva dos discentes e evolução dos 
processos de ensino e aprendizagem, agrega a intenção de aproximação efetiva do que é produzido no âmbito acadêmico à esfera escolar básica" (p. 7, grifos nossos). Em um aspecto mais amplo, a extensão, destacada no MP.Local, também proporciona essa aproximação, procurando, inclusive, envolver a comunidade escolar de forma mais participativa nos projetos e promovendo, neste movimento, alguns impactos nas escolas, como o oferecimento de oficinas pelo professor egresso aos seus colegas.

Outra questão importante a respeito dessa avaliação é em relação aos instrumentos de coleta de dados utilizados. Repensando o objetivo da avaliação dos PEs, visualizamos que este poderia focalizar "concomitantemente nos processos de ensino (professor), de aprendizagem (alunos) e na interação entre todos e o PE avaliado" (SILVA, 2018, p. 5), além das descrições sobre o contexto de aplicação e influências positivas que o trabalho pôde ter sobre ele. Novamente, segundo Ostermann e Rezende (2009):

Os processos avaliativos devem desempenhar uma função no sentido de que possam ser formulados juízos de valor sobre o produto educacional e sua implementação no contexto escolar. É essa etapa que vai conferir relevância social ao produto desenvolvido. É preciso, portanto, descrever o resultado da utilização do produto educacional com alunos, apresentando os resultados das avaliações. Não é preciso "provar" nada. Trata-se de relatar, com dados, como ocorreu a experiência didática, incluindo indicadores negativos, contraexemplos, se for o caso. Tais resultados devem ser não só apresentados, mas também discutidos, comentados e interpretados à luz do referencial teórico e do contexto no qual foi desenvolvido o trabalho (p. 76).

O exposto nos conduz a duas indicações: a necessidade de se utilizar múltiplos instrumentos de coleta de dados para a compreensão da interação entre professor, alunos e material produzido pelo professor-cursista; além do levantamento de dados que ajudem o professor descrever - e melhor compreender - o contexto de aplicação, que pode ser determinante para avaliação dos resultados obtidos em sua pesquisa de implementação do PE. No universo de dissertações analisadas que buscaram avaliar os PEs em situações de sala de aula, poucos são os professores que se preocupam com os pontos referidos acima. Encontramos como exemplo, MP.Local.06, que estabelece como objetivo o estudo das "relações de interação entre os diferentes atores envolvidos no ambiente multimídia socio-interacionista: os alunos, o professor mediador e o objeto de aprendizagem desenvolvido" (dissertação de MP.Local.06, p. 12) e para isso faz uso de múltiplos instrumentos de coleta de dados (levantamento bibliográfico, pré e pós-teste, observação participante, gravação da aula, coleta de depoimento de alunos); e MNPEF.09 que faz uma análise interessante a partir de um questionário socioeconômico dos alunos e aponta informações relevantes que influem 
na aprendizagem dos alunos, como o fato de trabalharem e morarem longe da escola, o que acarreta em poucas horas de estudo disponíveis para eles.

A análise aponta para pouca referência as questões coletivas e sociais, significando pouco diálogo do professor com a escola e com a sociedade ao longo de seus estudos no MP. É coerente com a crítica de alguns autores que o investimento da pós-graduação stricto sensu significaria uma formação individual do professor. No entanto, ressaltamos que, apesar de escasso, esse diálogo não é ausente, tendo em vista o relato de alguns impactos positivos proporcionados pela implementação dos PEs de alguns professores-cursistas nas escolas de educação básica em que atuam.

Neste mérito, chamamos a atenção para o uso da metodologia da pesquisa-ação pelos professores-cursistas, principalmente do MP.Local. A metodologia, ao associar uma capacidade de aprendizagem ao processo de investigação (THIOLLENT, 2011), parece ser adequada para uso no âmbito dos MPs, com a particularidade de que um membro interno à própria comunidade a ser estudada, o professor, realiza a função central de pesquisador. Os professores parecem se apropriar da metodologia concentrando-a ao micro-contexto de sala de aula, ou seja, visando a problemática de aperfeiçoamento das aulas do professor, pela renovação das metodologias de ensino utilizadas por ele, sem contemplar a escola como um todo e condições sociais dos alunos que podem ser determinantes sobre sua aprendizagem. As pesquisas categorizadas como pesquisa-ação são limitadas no estabelecimento de canais de investigação e divulgação do que foi estudado no próprio contexto, carecendo do preparo de "mudanças coletivas nas representações, comportamentos e formas de ação" (THIOLLENT, 2011, p. 86) dos membros da escola como um todo. O aspecto de mudança coletiva da pesquisa-ação está restrita à mudança individual dos professores-mestrandos, pois na grande parte das vezes o vínculo institucional com a escola e outros membros da escola no desenvolvimento da pesquisa é frágil ou mesmo inexistente, sem contar que muitas vezes, pode até mesmo oferecer resistências à realização daquela pesquisa.

Os trechos abaixo, destacados das dissertações de MP.Local.17 e MP.Local.19, que se apoiam na pesquisa-ação para realizar a aplicação do PE e sua avaliação, mostram a prioridade que os professores dão à transformação da sala de aula apenas pela mudanças de metodologia e práticas docentes:

MP.Local.17: "A análise das informações coletadas no trabalho foi executada usando um recorte dentro da metodologia proposta, este recorte se enquadra nos moldes de uma pesquisa-ação. Isto por que essa metodologia visa aprimorar essa prática do docente" (p. 26, grifos nossos). 
MP.Local.19: "[Foi escolhida a metodologia da pesquisa-ação] pelo fato da mesma possibilitar um diálogo entre a prática de campo e os pressupostos teóricos podendo levar ao aprimoramento das práticas em sala de aula por meio de uma investigação da mesma" (p. 38, grifos nossos).

Dessa forma, apontamos a reflexão sobre o uso da pesquisa-ação para o contexto mais amplo que a da sala de aula do professor-cursista, como um caminho possível para maior engajamento das dimensões de desenvolvimento profissional participação na gestão escolar e na responsabilidade social e mesmo para a promoção de transformações mais fecundas e duradouras nas escolas desses professores. Afinal, o uso da pesquisa-ação sinalizaria formas de envolver

uma reflexão sobre um problema educacional vivido pelo professor em uma dada realidade escolar e que levaria ao desenvolvimento de atividades curriculares alternativas (projetos interdisciplinares envolvendo toda a escola, problematização de problemas ambientais, problemas sociais, tais como questões de gênero, etc.), que exigissem a reflexão sobre as finalidades e o significado da educacão em ciências na contemporaneidade (OSTERMANN; REZENDE, 2009, p. 71, grifos nossos).

O que destacamos da citação anterior, é o que visualizamos também como um grande trunfo do trabalho a ser desenvolvido pelos professores-cursistas tanto no sentido de dar destaque à relevância social das dissertações e PEs produzidos, quanto da colaboração que esses professores seriam capazes de dar à comunidade acadêmica nas instituições de ensino superior.

Registramos o quanto o processo de pesquisa pode ser relevante para os professores-cursistas, em termos de formação. Abaixo destacamos trecho da dissertação do professor MP.Local.13, onde ele exprime a importância que estar inserido num contexto de pesquisa num curso de pós-graduação stricto sensu teve para sua formação:

MP.Local.13: "O ingresso no curso de Mestrado Profissional em Ensino de Ciências, do qual se origina e se destina o presente trabalho, nos proporciona expectativas de formação e desenvolvimento de práticas e competências que efetivamente contribuam para o nosso crescimento profissional e pessoal. $\mathrm{Da}$ mesma forma, a necessidade de atrelamento do percurso no mesmo (sic) a uma linha de pesquisa, nos incita a reflexões e associações de forma a desenvolver e produzir conhecimento relacionado ao eixo geral do curso, das disciplinas oferecidas bem como das nossas aspirações prévias. Desses fatores emergem as especificidades de cada produção, no caso específico, a opcão pelo ensino de química se deve tanto pela aproximação adquirida no exercício profissional como docente, pela necessidade de aprofundamento dos conhecimentos adquiridos na graduação e pelo desafio de investigar um tema que julgamos relevante para a formacão dos nossos alunos. A conexão desse com a vertente associada aos recursos de informática se deve a afinidade e principalmente a continuidade de uma formação anterior" (p. 37, grifos nossos). 
Finalmente, é importante destacar que muitas das análises realizadas na presente etapa são parciais, pois nem sempre as dissertações fornecem informações detalhadas em relação às motivações, ao percurso de formação, e aos impactos sobre a prática dos professores-cursistas, embora tenham dado indicações importantes sobre diversos aspectos aqui discutidos e que rondam a questão do desenvolvimento profissional proporcionado pelos MPs, em suas diversas dimensões, aos professores mestrandos. Assim, buscaremos o aprofundamento desses quesitos nas entrevistas realizadas com parte dos egressos dos dois cursos, o que fornecerá dados que nos levarão à culminância da investigação que empreendemos. 


\section{Os egressos dos cursos de mestrado profissional}

Apresentamos nesse capítulo os resultados obtidos através de entrevistas semiestruturadas realizadas com egressos dos cursos de MP estudados, objetivando traçar o perfil desses egressos, suas impressões sobre o curso, como participaram das disciplinas e demais eventos acadêmicos do MP, detalhes sobre o desenvolvimento do PE e da dissertação e os aprendizados obtidos ao longo dessa trajetória formativa de seu ponto de vista, entre outras informações pertinentes à pesquisa.

A realização das entrevistas se concentrou no segundo semestre de 2018 . Os egressos foram contatados a partir de dados obtidos na etapa anterior de pesquisa, em seus PEs e dissertações, além de, em alguns casos, consultas ao currículo Lattes e redes sociais. Eles foram convidados para participar dessa pesquisa e foram informados sobre os objetivos pretendidos, mediante a leitura e assinatura de Termo de Consentimento Livre e Esclarecido de Uso de Dados em Pesquisa. A maioria das entrevistas foram realizadas presencialmente em locais e horários de preferência dos entrevistados. Algumas, por conta de incompatibilidade de horários e dificuldades de deslocamento, foram realizadas online. Todas as entrevistas foram gravadas em áudio para posterior transcrição integral e fidedigna.

A base do roteiro utilizado nas entrevistas com os egressos é apresentada no apêndice 4. Assim como nos roteiros já apresentados, utilizados nas entrevistas com os coordenadores e membros do corpo docente dos cursos, cada pergunta principal se desdobrou em outras, que a detalham, de modo a fornecer um guia padronizado para a realização de todas as entrevistas, levando em conta nossos objetivos de pesquisa.

Os dados obtidos são apresentados em pequenas análises com elementos narrativos, onde se procura destacar os pontos-chaves para responder as nossas questões de pesquisa, juntamente com interpretações pertinentes para cada caso individual, nos mesmos moldes das escritas a partir das entrevistas com coordenadores e docentes. Apreciações sobre os impactos no desenvolvimento profissional proporcionados pelo MNPEF e pelo MP.Local decorrem da leitura conjunta das análises elaboradas a partir das entrevistas dos dois grupos de egressos e são apresentadas ao final da seção. Ao longo das análises buscamos articulações entre dados fornecidos pelos egressos; dados das etapas anteriores de pesquisa (análise documental, entrevistas com coordenadores e docentes e análise de PEs e dissertações); referenciais teóricos que discutem os MPs e desenvolvimento 
profissional docente, em especial, as dimensões de desenvolvimento profissional apresentadas por Barolli et al. (2019) e as de autoria docente apresentadas por Maia (2017).

\subsection{O desenvolvimento profissional de egressos do polo do MNPEF}

Dez egressos das turmas de 2013 e 2014 do polo analisado aceitaram o convite para participação nessa pesquisa. Eles são identificados na Tabela 11, juntamente com uma breve descrição de suas formações, ano de defesa no MP e atuação profissional atual (nos anos de 2018 e 2019, quando foram realizadas as entrevistas), informações obtidas nas entrevistas ou em seus currículos Lattes.

Tabela 11 - Apresentação geral dos egressos do polo do MNPEF entrevistados.

\begin{tabular}{|c|c|c|c|c|}
\hline $\begin{array}{l}\text { IDENTIFICAÇÃO } \\
\text { DO EGRESSO }\end{array}$ & $\begin{array}{l}\text { FORMAÇÃO } \\
\text { INICIAL }\end{array}$ & $\begin{array}{l}\text { FORMAÇÃO PÓS- } \\
\text { GRADUADA }\end{array}$ & $\begin{array}{l}\text { ANO DE } \\
\text { DEFESA } \\
\text { NO MP }\end{array}$ & $\begin{array}{l}\text { ATUAÇÃO } \\
\text { PROFISSIONAL } \\
\text { ATUAL }\end{array}$ \\
\hline MNPEF.01 & $\begin{array}{l}\text { Licenciatura } \\
\text { em Física }\end{array}$ & $\begin{array}{l}\text { Anterior ao MP: } \\
\text { especialização na } \\
\text { área de ensino } \\
\text { Ingressou em } \\
\text { doutorado em Física } \\
\text { Básica após o MP }\end{array}$ & 2015 & $\begin{array}{l}\text { Atua no ensino } \\
\text { médio da rede } \\
\text { estadual e em } \\
\text { universidades } \\
\text { particulares }\end{array}$ \\
\hline MNPEF.05 & $\begin{array}{l}\text { Licenciatura } \\
\text { em Física }\end{array}$ & --- & 2015 & $\begin{array}{l}\text { Atua no ensino } \\
\text { médio da rede } \\
\text { estadual }\end{array}$ \\
\hline MNPEF.07 & $\begin{array}{l}\text { Licenciatura } \\
\text { em Física }\end{array}$ & $\begin{array}{c}\text { Ingressou em } \\
\text { doutorado em Ensino } \\
\text { de Física após o MP }\end{array}$ & 2015 & $\begin{array}{l}\text { Atua em curso de } \\
\text { Licenciatura de uma } \\
\text { instituição federal } \\
\text { (afastado por conta } \\
\text { do doutorado) }\end{array}$ \\
\hline MNPEF.08 & $\begin{array}{l}\text { Licenciatura } \\
\text { em Física }\end{array}$ & --- & 2015 & $\begin{array}{l}\text { Atua no ensino } \\
\text { médio e em escola } \\
\text { técnica da rede } \\
\text { estadual }\end{array}$ \\
\hline MNPEF.09 & $\begin{array}{l}\text { Graduação } \\
\text { em Eng. } \\
\text { Civil e } \\
\text { Licenciatura } \\
\text { em } \\
\text { Matemática }\end{array}$ & $\begin{array}{c}\text { Anterior ao MP: } \\
\text { especialização em } \\
\text { Engenharia e } \\
\text { Segurança do } \\
\text { trabalho e em Ensino } \\
\text { de Ciências }\end{array}$ & 2015 & $\begin{array}{l}\text { Atua no ensino } \\
\text { médio estadual }\end{array}$ \\
\hline
\end{tabular}


(continuação)

\begin{tabular}{|c|c|c|c|c|}
\hline MNPEF.10 & $\begin{array}{c}\text { Licenciatura } \\
\text { em Física }\end{array}$ & $\begin{array}{c}\text { Anterior ao MP: } \\
\text { curso de } \\
\text { aperfeiçoamento de } \\
\text { professores de Física }\end{array}$ & 2016 & $\begin{array}{l}\text { Atua em colégio } \\
\text { técnico estadual e } \\
\text { escolas/cursinhos da } \\
\text { rede privada }\end{array}$ \\
\hline \multirow[t]{2}{*}{ MNPEF.15 } & $\begin{array}{c}\text { Licenciatura } \\
\text { em Física }\end{array}$ & $\begin{array}{l}\text { Anterior ao MP: } \\
\text { especialização em } \\
\text { Gestão Escolar e } \\
\text { Coordenação } \\
\text { Pedagógica; } \\
\text { especialização em } \\
\text { Meio Ambiente e } \\
\text { Desenvolvimento } \\
\text { Sustentável e } \\
\text { especialização em } \\
\text { Educação Jesuítica }\end{array}$ & 2016 & $\begin{array}{l}\text { Atua em colégio } \\
\text { estadual e em } \\
\text { colégio privado de } \\
\text { elite }\end{array}$ \\
\hline & & $\begin{array}{l}\text { Ingressou em } \\
\text { doutorado em } \\
\text { História da Ciência } \\
\text { após o MP }\end{array}$ & & \\
\hline MNPEF.17 & $\begin{array}{c}\text { Graduação } \\
\text { em } \\
\text { Matemática }\end{array}$ & $\begin{array}{c}\text { Anterior ao MP: } \\
\text { especialização em } \\
\text { Matemática } \\
\text { Avançada e } \\
\text { Computacional }\end{array}$ & 2016 & $\begin{array}{l}\text { Atua em escola da } \\
\text { rede pública, } \\
\text { também como } \\
\text { diretor }\end{array}$ \\
\hline MNPEF.19 & $\begin{array}{l}\text { Graduação } \\
\text { em Física }\end{array}$ & $\begin{array}{l}\text { Anterior ao MP: } \\
\text { especialização em } \\
\text { Gestão Escolar e } \\
\text { Coordenação } \\
\text { Pedagógica }\end{array}$ & 2016 & $\begin{array}{c}\text { Atua em escola } \\
\text { técnica da rede } \\
\text { pública e em colégio } \\
\text { privado de elite }\end{array}$ \\
\hline MNPEF.28 & $\begin{array}{c}\text { Licenciatura } \\
\text { em Física }\end{array}$ & --- & 2017 & $\begin{array}{l}\text { Atua no ensino } \\
\text { médio da rede } \\
\text { pública estadual }\end{array}$ \\
\hline
\end{tabular}

As análises com elementos narrativos são apresentadas a seguir. Em geral, elas apresentam estrutura semelhante ao do roteiro de entrevistas utilizado, com pequenas modificações entre elas. Serão fornecidos e analisados os seguintes dados: motivações e expectativas iniciais em ingressar no MP (com um contexto inicial de sua situação profissional e de formação nesse primeiro momento); impressões gerais sobre o MP e sobre o desenvolvimento do PE e dissertação; auto-avaliação em relação aos aprendizados e mudanças na prática docente e avaliação do curso de MP realizado. Outras informações relevantes apresentadas pelo egresso em sua 
entrevista são acrescentadas ao longo da análise. São destacadas também trechos de suas falas, de modo a apoiar e ilustrar os dados apresentados e analisados.

\subsubsection{Análise com elementos narrativos de MNPEF.01: o professor astrônomo}

MNPEF.01 já tinha iniciado dois cursos de mestrado anteriores ao MNPEF, na área de Astrofísica, que tem grande interesse. Nas duas instituições em que tentou iniciar sua pesquisa de mestrado, encontrou dificuldades financeiras: seja por falta de apoio da instituição (ausência de bolsas e outros auxílios), seja pelo horário de disciplinas e de dedicação ao curso que o obrigaria a ter que deixar algumas aulas que lecionava, o que impactava diretamente em seus ganhos financeiros.

Esse egresso já era professor em escolas da rede estadual e em universidades particulares, estando bastante envolvido com educação. Diz que chamou muito sua atenção no MNPEF, que foi apresentado por uma amiga, a questão dos horários de aulas, concentradas na sexta-feira à tarde e noite e no sábado de manhã. Essa organização do curso viabilizava a continuidade de sua carga horária de trabalho nas escolas e universidades.

No início do curso, esteve inseguro em relação às disciplinas que considerava mais pesadas: "um pouco de medo com relação a dar conta de tudo, de estudar, de cumprir suas coisas de trabalho, porque você tem que deixar um tempo para estudo" (MNPEF.01). Apesar disso, o fato da proposta do MP ser diferente em relação ao MA sustentou sua escolha.

MNPEF.01 aponta no desenvolvimento do curso também dois fatores cruciais para sua permanência e êxito no curso. O primeiro destaque é dado ao corpo docente do MNPEF: "aí eu encontrei professores que me deram aula de como ser professor" (MNPEF.01). Destaca a postura dos docentes no desenvolvimento do curso, que apesar de não serem professores da área de Ensino de Física, eram "muito preocupados com a didática, muito preocupados com a maneira como iam avaliar, muito preocupados com a nossa construção na área de Ensino... Sempre o protagonista, foi o aluno" (MNPEF.01). Ressalta também a maneira que os docentes os avaliavam, cujas propostas visavam o que os professores-cursistas já estavam produzindo e estudando, o que favoreceu o ganho de conhecimento de MNPEF.01, além de consequências para sua prática como professor:

MNPEF.01: "[...] depois lá dentro, eu fui ganhando muito conhecimento, mas muito conhecimento mesmo. Até porque quando 
você se motiva a pesquisar e não tão preocupado com as notas, é algo diferente. Esse é um dos legados que hoje eu deixo para os meus alunos. [...] Claro, eu cobro uma parte que é individual, mas o maior legado do mestrado [...] no tocante à aula é justamente isso. É você, uma parte de suas avaliações, ou talvez a metade, que é o que eu faço, [...] [avaliar] no tocante à pesquisa, no tocante a sua evolução na busca por conhecer alguma coisa, pelo o que você produz..."

Com esse relato, percebemos que aquilo que Do.MNPEF-07 chama de "espírito do curso", visando a renovação metodológica das práticas docentes, é incorporado pelos docentes do MP em suas disciplinas não apenas como conteúdo de discussões (apesar de não estarem presentes de forma explícita nas ementas de todas as disciplinas na matriz curricular do curso), mas como prática dos próprios docentes. Por exemplo, visando com que os professores-cursistas começassem a atuar em suas salas de aula seguindo um "paradigma da aprendizagem ativa", característica do MNPEF que já apontamos, eles mesmos faziam com que os mestrandos assumissem maior protagonismo durante as aulas, alterando até mesmo as formas mais tradicionais de avaliação. Por ter passado por essa experiência de maior protagonismo em sua própria aprendizagem e observando os resultados positivos no ganho de conhecimento, na posição de aluno, MNPEF.01 se sentiu incentivado a adotar essa mesma postura como professor, um impacto direto na dimensão organização e condução de ensino de seu processo de desenvolvimento profissional. A fala destacada também dá indícios de uma dedicação ativa, pois o professor diz ter sido motivado a envolver-se de fato com as atividades previstas no curso, sem se preocupar com "notas", ou seja, sem meramente fazer o que deve ser feito para agradar ao docente responsável pela disciplina para ter um bom desempenho e fazer jus à titulação pretendida.

O segundo destaque que MNPEF.01 dá para conseguir vencer as inseguranças iniciais em relação ao curso tem a ver com o ambiente acolhedor e os vínculos afetivos formados também entre os colegas de sua turma. Diz que era uma turma ingressante muito grande e que havia muitos membros de fora da cidade onde estava instalado o polo. Ele mesmo era de outra cidade. Por conta disso, eles se hospedavam juntos em um hotel de sexta-feira para sábado. Esse fato colaborou para que se criasse uma grande coesão entre todos: "eu nunca encontrei uma turma tão homogênea, e tão interessante assim como nessa turma. [...] o pessoal de 2013 era totalmente coeso, e um dando a mão para o outro de todas as formas possíveis" (MNPEF.01). De fato, como será mostrado no decorrer das análises com elementos narrativos dos egressos do MNPEF, esses dois fatores (docentes/orientadores interessados e acolhedores; turma coesa) são mencionados em praticamente todas as 
entrevistas, se tornando um grande marco deste MP. A união entre os professores é algo que perdurou após o curso: "A gente se comunica até hoje, mas todo mundo com muita saudade um do outro. $E$ onde a gente sabe onde o outro está, a gente faz 0 possível para estar junto, para estar conversando, para saber como é que foram as coisas... Foi fantástico" (MNPEF.01).

Em relação ao desenvolvimento do PE, MNPEF diz que "já tinha em mente o que queria fazer", pois investiu na criação de um PE que envolvesse a construção de um protótipo para aulas de Astronomia, que, além de ser a área de pesquisa que lhe agradava, era uma área que sempre trabalhou em suas aulas na educação básica. Assim, seu PE abordou algo que era desenvolvido constantemente em sua prática docente. A grande contribuição da elaboração do PE para MNPEF.01 pareceu ser a questão da necessidade de se fundamentar teoricamente essa prática:

MNPEF.01: "Sim, eu fazia isso [a construção de materiais para o uso em Ensino de Física] o tempo todo, então eu já tinha isso em mente também. Eu só não tinha em mente o que é que eu ia escrever como fundamentação teórica para tudo. E daí eu fui estudar Vygotsky, fui estudar outros autores que falavam, principalmente usei muito o livro do [Prof. da licenciatura] [...] Ele [Prof. da licenciatura] foi o meu professor também, então foi uma pessoa que me influenciou muito. Então aquilo que eu imaginava eu já sabia onde ia buscar [...]"

De certa forma, a escolha do referencial teórico já estava latente para MNPEF.01, já que se baseou em referenciais adotados no livro de um professor de seu curso de licenciatura que o influenciou em sua formação. Porém ela foi ampliada pelo que MNPEF.01 aprendeu no curso de MP, além de o curso ter proporcionado essa prática de articulação entre o trabalho principal do PE (o material para ser utilizado nas aulas de Astronomia) com a fundamentação teórica. O aprofundamento desse estudo pressupõe uma atualização dos conhecimentos pedagógicos de desenvolvimento profissional, e também, de certa forma, um amadurecimento tendo em vista a pesquisa em Ensino de Física (dimensão investigação da própria prática de desenvolvimento profissional), no entendimento da importância de referenciais teóricos de educação na fundamentação da proposta de ensino planejada e avaliada no MP.

MNPEF.01 destaca que participou do Simpósio de Ensino de Física promovido no polo, apresentando uma oficina com o uso do material que compõe seu PE, além da participação em um workshop regional que integrou diferentes polos do MNPEF, organizado pela comissão central do programa, em 2014. Destaca que essas participações tiveram principalmente a função de divulgação do PE: "Alguma colaborações vieram, claro, dando umas ideias, pode mudar aqui, você pode fazer aquilo e tal. Mas nos seminários e no próprio simpósio, a ideia era mostrar para os 
professores uma alternativa para se ensinar Astronomia no Ensino Básico" (MNPEF.01). Apesar dos documentos do MNPEF não fazerem menção à extensão, na prática, os mestrandos do polo se envolveram com a participação e divulgação de seus trabalhos em eventos, como um modo de divulgar seus trabalhos para um maior público.

MNPEF.01 dá vários exemplos de aprendizados resultantes da realização do curso de MP. Alguns já eram questões presentes em sua prática, como a questão de avaliação, que para ele era "uma percepção que tinha muito tempo antes e [...] isso ficou muito em evidência para mim depois desse contato todo com o pessoal [do MP] " (MNPEF.01). Como aplicou seu PE no contraturno dos alunos, numa das escolas que trabalhava, deu liberdade aos alunos de suas turmas que quisessem participar. Dessa forma, fez uma avaliação mais informal, diferente do modelo tradicional:

MNPEF.01: É que quando você muda o contexto de sala de aula, você deixa a avaliação mais solta. Solta no sentido de que você sai do modelo de prova, daquele modelo tradicional de 'aquele dia vai ser a prova, aquele dia você tem que responder essas questões, estudar isso e tal'. Você tem outros métodos de avaliação, que você pode usar sem precisar passar por esse modelo tradicional, que você consegue obter mais resultados. Então um dos modelos, ou praticamente o modelo que eu usei, foi justamente tentar compreender como é que eles entenderam isso tudo, buscando absorver cada item, cada questão que eu tinha planejado, de uma forma muito informal e não deixando em evidência para os alunos que eu estava avaliando todos eles, muito pelo contrário. Em nenhum momento aquilo lá surgiria como avaliação para eles. Para mim, eu estava avaliando o tempo todo. [...] o fato deles não olharem como avaliação formal, eles produziram muito mais. Produziam muito mais, produziam com mais leveza. Ficava tudo mais leve. O relacionamento mudou [...] Não que você tenha que ser aquele professor que não cobra nada, que leva tudo de qualquer jeito. Mas você pode elaborar etapas, prazos, construções, de uma forma muito bem elaborada, muito didática, mas sem ter que ter o mesmo peso que o aluno tem que vir fazer uma prova com aquela coisa toda..."

MNPEF.01: "[...] já tinha feito [...] esses modelos que eu andava fazendo de construções experimentais nessa escola que eu trabalhei, eu avaliava por isso. [...] [mas] eu não tinha parâmetro para entender até que ponto aquele método de avaliação poderia ser eficaz ou não [...] E aí nessas aplicacõoes do produto é que eu fiz e eu vi que dá certo".

Aparentemente esse modo de avaliação, que MNPEF.01 diz ser mais informal, tenha tido também influências do modo de avaliação utilizado pelos docentes no contexto do MP, como relatado anteriormente. De qualquer forma, foi no contexto do MP que o professor pôde sistematizar e aprofundar esse conhecimento, que era, antes, apenas uma "percepção". O processo de aplicação do PE abriu a oportunidade de investigações sobre a própria prática, fazendo o professor experimentar procedimentos não usuais, e notar os resultados obtidos em termos de aprendizagem 
de seus alunos. Esse processo conduziu à sistematização de saberes experienciais como relatado na sua fala destacada anteriormente, e também registrada na apresentação de resultados de sua dissertação, o que indica que foi algo relevante para o professor em seu processo de investigação sobre o uso do PE, e um resultado incorporado a sua prática. É um exemplo do potencial de processos de investigação sobre a própria prática para a renovação das práticas. Porém, fatores relativos às condições do trabalho docente apresentaram limites para sua efetiva renovação. Nesse sentido, as condições de trabalho docente são determinantes para que sua responsabilidade se mantenha no nível eventual. Nas palavras do professor:

MNPEF.01: "Isso eu ainda procuro fazer. O grande problema é que a gente vive em um país onde o professor não tem tempo para nada. $\mathrm{Se}$ a gente quiser ganhar um pouquinho mais a gente tem que dar aula em milhões de escolas, com poucas aulas. Falta muito tempo para isso, para planejar, para você aplicar do jeito que você quer, mas eu acho que para mim, isso seria o melhor modo de avaliar".

Ainda assim, MNPEF.01 enumera alguns impactos importantes em sua prática nos aspectos metodológicos e de uso de recursos didáticos, atribuídas ao curso realizado no polo do MNPEF, ou que desenvolveu após seu término. Diz que utiliza "metodologias diferentes em sala de aula", como o Peer Instruction, que segundo ele, é uma "maneira de se relacionar com os alunos de forma bem diferente do modelo tradicional, e que se torna mais eficaz, mais produtiva [...] do que essa maneira tradicional da gente". Também utiliza nas suas aulas o PhET, o simulador virtual que foi muito utilizado por seus colegas em seus trabalhos, além do uso do plickers ${ }^{116}$ como ferramenta de resultados. Em suma, diz que "muito da minha prática docente hoje é fruto de lá [do MP]" (MNPEF.01). Isso nos indica que MNPEF.01 se implicou em uma inovação reflexiva.

Para concluir, destaca como pontos positivos do MP as mudanças em sala de aula que puderam se efetivar a partir da realização do curso. Enfatiza a questão da aprendizagem em relação à pesquisa acadêmica, que não teve tanta dificuldade, por conta de anteriormente já ter entrado em contato com o mundo acadêmico, mas que julga ser essencial, indo ao encontro do que Do.MNPEF-01 defende, a inclusão na matriz curricular do MNPEF de uma disciplina sobre Metodologia Científica para apoiar os professores-cursistas na realização de pesquisa em Ensino de Física.

\footnotetext{
${ }^{116}$ O plickers é um aplicativo de smartphone baseado na leitura de cartões que coleta e registra respostas dos alunos à perguntas de múltipla escolha elaboradas pelo professor. Logo após o registro dos códigos dos cartões mostrados pelos alunos, o professor tem acesso à estatística de quantidade de acertos e erros. É uma metodologia de avaliação instantânea muito utilizada em aulas elaboradas com base na metodologia do Peer Instruction.Disponível em: $<$ https://get.plickers.com/>.
} 
MNPEF.01: "Pontos positivos [...] engloba tudo isso que já falei. Mudança de dinâmica de sala de aula, mudança no sistema de avaliação, mudança na forma como você conduz o processo de pesquisa na área educacional, como você aplica um produto com alunos do Ensino Básico, como você obtém resultados, como você praticamente muda o contexto da informalidade, jogando isso depois para o contexto da formalidade, de você realmente fazer uma pesquisa acadêmica, com resultados, que você possa avaliar tudo isso [...] O que senti falta lá [...] aula sobre Metodologia Científica, como você elaborar um artigo, como você escrever de forma científica. Como é um mestrado, seja ele qual for, você tem que produzir alguma coisa científica, né?"

\subsubsection{Análise com elementos narrativos de MNPEF.05: o professor reflexivo}

MNPEF.05 entrou no MP logo após ter terminado o curso de licenciatura. Também teve o conhecimento sobre o mestrado através de um amigo. Não conhecia muito a respeito do MP, ainda mais por ser a primeira turma que ingressaria no polo do MNPEF recém-inaugurado. Sua principal motivação havia sido "justamente a questão de me capacitar mais [...] a possibilidade de continuar aumentando a bagagem de conhecimento" (MNPEF.05). Sendo atrativo também a ênfase do curso sobre a prática docente, já que afirma que "desde o início do curso de licenciatura, sempre tive vontade de estar com o pé na sala de aula" (MNPEF.05). Tinha como expectativa inicial, além da ampliação de seus conhecimentos, "dar um up no currículo" (MNPEF.05).

O egresso MNPEF.05 enfatiza a questão do desenvolvimento de pesquisa acadêmica no contexto do MP. Considera que foi fundamental ao longo do curso o desenvolvimento da perspectiva do professor reflexivo, proporcionada ao longo das disciplinas e do desenvolvimento do PE:

MNPEF.05: "Conforme a gente ia caminhando com as disciplinas, depois mais tarde com projetos de pesquisa mesmo, foi vendo que dá para juntar essas duas vertentes. Você ser professor, você fazer um bom trabalho como professor e ainda enriquecer um pouquinho refletindo a respeito da sua postura, tentando trabalhar com pesquisa [...] O que é interessante na vida em sala de aula, o como pesquisar para dar uma aula melhor, o como desenvolver um curso melhor, e poder pegar esses frutos desse trabalho, ter um pouco assim de olhar crítico para poder ver o que você está desenvolvendo e tentar trabalhar nisso daí também como pesquisa".

É algo que impactou sua prática no sentido da dimensão investigação sobre a própria prática de desenvolvimento profissional, principalmente ao optar por adotar uma postura de atenção aos resultados que obtém com o que faz em sala de aula. Essa questão fica ainda mais clara no trecho de seu relato destacado a seguir: 
MNPEF.05: "Hoje, quando começo um trabalho na sala de aula, eu não começo com a intenção de 'disso vai sair uma pesquisa'. Mas o olhar do tipo, quando está desenvolvendo 'pô, está saindo algumas coisas boas daqui...' [...] E isso me fez, justamente essa postura de começar a observar os alunos, me fez não só observar o que eu considero de bom no meu trabalho, mas também essa observação, essa reflexão, me fez observar também, o que não está dando certo. Isso daqui não ficou legal, então isso eu posso melhorar... Isso eu posso mudar".

MNPEF.05, então, após passar pela experiência de pesquisa proporcionada pelo MP, moldou essa postura atenta de investigador, que contrapõe uma postura passiva e automática de um profissional reprodutor. Isso Ihe auxilia também no trabalho que desempenha como supervisor do PIBID ${ }^{117}$.

Ao descrever as disciplinas do curso, MNPEF.05 chama a atenção para o fato de que "o tempo todo tinha os professores tentando buscar um vínculo para a prática de ensino também de Física" (MNPEF.05). Cita o caso da disciplina Física Estatística, que apesar de ter sido trabalhosa e estar distante da realidade do ensino médio, a turma sempre era provocada pelo docente responsável a pensar como as ideias discutidas poderiam ser trabalhadas no contexto de educação básica. "O tempo todo, acho que uma pergunta que esteve presente, é o como que isso pode ser trabalhado. 'Como vocês fariam?'" (MNPEF.05).

O egresso MNPEF.05 também considera primordial o contato que teve com os outros colegas do curso. Considera que a coesão da turma também teria sido motivada pela dinâmica das disciplinas:

MNPEF.05: "O corpo das disciplinas em si, dos professores
começarem a estimular a gente a trabalhar junto com muitos
seminários, trabalhos em grupos, a provocação dos professores do
tipo, mesmo quando não eram dentro das disciplinas, dos seminários
que a gente apresentava, mas provocando [...] 'todo mundo tem que
assistir, todo mundo tem que estar junto', isso acabou gerando uma
coletividade muito grande no grupo. Muita troca de informação, muita
coisa que eu vejo ali que eu fui ajudado muito pelos meus colegas ali
e também tive oportunidade de ajudar".

A relação entre os mestrandos se fortificou ao ponto de se reunirem em momentos de lazer e descanso, após as aulas de sexta-feira de noite, para continuarem "discutindo, falando, buscando soluções juntos ali". Todos dividiam os mesmos problemas e dificuldades, mas ao encontrar um colega mais desanimado, "todo mundo tentando animar e trazer ele de volta, isso foi muito importante para a gente" (MNPEF.05). A coletividade criada foi importante para vencer dificuldades

117 Programa Institucional de Bolsas de Iniciação à Docência, programa da CAPES que incentiva a relação universidade-escola integrando alunos de licenciatura, docentes da universidade (coordenadores de área) e professores da escola de educação básica (supervisores). 
encontradas na elaboração de algo novo para os professores (conteúdos das disciplinas, elaboração do PE, realização de uma pesquisa); além da própria consolidação do grupo e do curso de mestrado em si. Esse grande envolvimento coletivo demonstra uma dedicação ativa. O egresso MNPEF.05 como muitos outros, faz questão de destacar na entrevista que mantém contato com todos (colegas e docentes) do curso após a defesa.

Ainda no contexto das disciplinas, MNPEF.05 afirma que elas o fizeram "abrir mais a visão de outros conteúdos", atualizando seus conhecimentos científicos e pedagógicos em termos de desenvolvimento profissional, satisfazendo suas expectativas iniciais em relação ao MP. No entanto, mais do que as ementas das disciplinas, parece que o essencial para esse aperfeiçoamento foram as discussões coletivas:

MNPEF.05: "As discussões [...] os próprios colegas que estavam
entrando ali, foram muito ricas, então você tinha colegas ali de
diferentes faixas de idade, formados em diferentes épocas, dando
aula em diferentes regiões, em diferentes escolas, no caso [...] você
vê, alguns problemas são comuns a todos, e vê que apesar de ter
muitos problemas comuns a todos, os caminhos que cada um busca
são muito diferentes, aí você vê novos horizontes para isso".

MNPEF.05, para a realização do seu PE, parte de um trabalho anterior (sua monografia do curso de licenciatura) que versou sobre a inserção de conteúdos de Física Moderna no currículo estadual. Além de discutir as razões de se inserir tais tópicos no Ensino Médio, aborda a sua proposta a partir da História e Filosofia da Ciência. Por sugestão de seu orientador, também faz uso de simulações virtuais. É possível verificar a construção coletiva, com trocas com orientador e colaborações externas para seu PE:

MNPEF.05: "É claro, como qualquer trabalho, teve muita quebra de braço, às vezes o orientador puxando para um lado, a gente puxando para o outro, aí nos seminários uma outra visão diferente que a nossa às vezes [...] Mas em si foi muito bom, essa questão de desenvolver o trabalho com o orientador olhando [...]"

Em termos de fundamentação para o desenvolvimento de seu trabalho, faz uso do referencial da aprendizagem significativa, que diz ter conhecido através do mestrado, uma característica que comenta ter sido muito ressaltada no programa, de forma que outros colegas também utilizaram essa teoria como fundamentação. Algo que vimos ser, de fato, muito comum nas dissertações do MNPEF. Entrar em contato com teorias educacionais que antes lhe eram desconhecidas, indica a atualização de conhecimentos pedagógicos de desenvolvimento profissional.

Ao ser questionado sobre os maiores impactos do MP que vê em sua prática, MNPEF.05 retoma a ideia de ter se formado como um profissional reflexivo, formação 
apoiada, principalmente, pela elaboração do PE. É um relato que reforça a visão de Moreira et al. (2018) que vêem no contexto dos MPs o processo de elaboração do PE para a formação de recursos humanos qualificados como mais importante do que o PE em si, para ser divulgado e disponibilizado para uso por outros professores. Para esses autores: "a importância do PE, desenvolvido por um profissional nesse contexto, reside na possibilidade de gerar ensinamentos aos alunos e na própria práxis do professor, tornando-a mais crítica, reflexiva, fundamentada e contextualizada" (p. 345).

Ao mesmo tempo, MNPEF.05 cita que essa postura só se faz presente em sua prática profissional, por conta do contexto favorável encontrado na escola em que trabalha, indicando, com um exemplo positivo, como as condições do trabalho docente podem ser determinantes para a renovação das práticas e para alcançar uma responsabilidade sistemática. Em suas palavras:

MNPEF.05: "A grande contribuição do mestrado foi [...] o fato [...] [de] me cobrar o produto. Ele me cobrar alguma coisa que tenha sido aplicada em sala de aula. Isso daí me fez, como eu disse anteriormente, me fez refletir a respeito da minha postura como professor. O fato de estar o tempo todo antenado de como ensinar, como trabalhar com isso daqui, e uma outra coisa boa que acontece comigo é [...] a coordenação da escola, ela dá uma liberdade muito grande para a gente de como trabalhar, como agir com os alunos em sala de aula. [...] eu estava numa escola nova, com matrícula nova no Estado, e ao mesmo tempo começando a compreender essa questão de ser reflexivo como professor. Aquela questão de poder analisar os meus atos como professor, e não agir de forma mecânica ali na hora de agir. Então isso contribuiu muito, no caso, esse conjunto, liberdade da escola, com essa visão nova que eu... nova no sentido, para [mim], estava me trazendo ali, isso contribuiu muito para mim como professor e no meu desempenho dentro de sala de aula".

A satisfação de MNPEF.05 com o curso se traduz no trabalho de percepção de sua autonomia diante do trabalho docente, pois "vê que apesar de você ter que seguir um currículo, [...] você poder colocar o seu toque ali, o que você acredita como a melhor forma de trabalho" (MNPEF.05). Isso nos indica uma inovação criativa, proporcionada por tal percepção de autonomia, ou melhor, de autoria, fazendo menção ao referencial teórico que adotamos. Porém, critica a questão da relação entre universidade-escola, que é praticamente inexistente. Acredita ser fundamental essa aproximação, de forma a, do ponto de vista do MP, fazer com que o professor se identifique com o que é discutido, com o que é preconizado como inovações para o ensino. Pois, "se o professor não se identifica, ele não abraça. Ou às vezes abraça a ideia de forma distorcida" (MNPEF.05). Assim:

MNPEF.05: "[...] não só esse programa, mas qualquer programa na verdade, que esteja voltado para o ensino, ele tem que ser vivo no sentido de estar sempre mudando, sempre pensando no que está acontecendo, e ao mesmo tempo tem que caminhar junto com a 
escola. A escola tem que estar dentro da universidade, e a universidade tem que estar dentro da escola. Se não tiver essas trocas, não adianta de nada".

Questionado sobre a estruturação da disciplina de Estágio Supervisionado no polo, que poderia servir como canal para essa aproximação, MNPEF.05 relata que não houve grande aproximação, além da discussão promovida nessa disciplina sobre a aplicação dos PEs desenvolvidos pelos mestrandos:

MNPEF.05: "Nós pegamos esse tempo de estágio, justamente para poder discutir nosso produto dentro de como foi aplicado dentro da escola, e o como ler isso daqui para poder trazer para a dissertação, ou seja, como é que você vai interpretar esses dados, como é que você vai interpretar o que você tirou do produto"

\subsubsection{Análise com elementos narrativos de MNPEF.07: o professor que encontra a superação}

MNPEF.07 tinha uma grande necessidade de realizar um curso de pósgraduação, pois dava aulas em um curso de licenciatura e era, ainda, o único membro do corpo docente que não era pós-graduado. Por indicação de um amigo envolvido no curso, optou em realizar o processo seletivo para o polo. Também diz que o ganho salarial e a questão da bolsa foram outros atrativos que o influenciaram em sua decisão.

Suas expectativas iniciais eram "tentar potencializar alguma coisa que eu tivesse de bom em relação à sala de aula [...] alguma coisa que eu já fizesse usando o senso comum, intuitivamente, e que de alguma forma pudesse transformar aquilo num trabalho de pesquisa" (MNPEF.07). Isso exprime a demanda dos professores por referenciais teóricos que o permitam embasar suas práticas, ou ainda, a necessidade da formação para a pesquisa. Ele adianta, porém, que teve grandes dificuldades na realização do trabalho acadêmico. Na realidade, antes do MNPEF, tinha tentado outros cursos de mestrado: "eu já havia fracassado antes em mais de um mestrado, de passar, ser aprovado, fazer disciplinas e não conseguir escrever" (MNPEF.07). Tais dificuldades foram superadas com o auxílio muito próximo de seu orientador que "foi muito parceiro, ele literalmente pegou na minha mão" (MNPEF.07). Ao relatar sobre como o orientador e colegas de trabalho e de curso foram importantes para apoiá-lo em sua preparação para a defesa de sua dissertação, o professor quase se emociona. Diz que essa vez, na entrevista, teria sido "a primeira vez que eu consegui falar sobre isso sem desabar". De fato, o envolvimento emocional no contexto do MP é uma constante nas entrevistas e se manifesta de diferentes maneiras, principalmente 
através da coletividade gerada nesse curso, já relatada nas análises com elementos narrativos anteriores. Todo esse envolvimento nos indica uma dedicação ativa em relação à sua formação no contexto do MP.

A franqueza com que os docentes do curso conduziram as disciplinas, conforme relatada por MNPEF.07, sempre na busca de relacioná-las com a prática dos professores, de quererem verificar "se o caminho que eles estavam seguindo, estava de acordo com o que a gente pensava em levar na sala de aula, e vice-versa" (MNPEF.07) parece ter sido o ingrediente principal para consolidar a relação estreita entre docentes do curso e professores-cursistas. MNPEF.07 diz que os docentes compartilhavam as dificuldades e diz que "a experiência que a gente trazia, no sentido até de reformularem o que eles pensavam que seriam as disciplinas, a profundidade do curso" (MNPEF.07) indica também, a valorização do conhecimento dos professores, a questão de que, nesse contexto, docentes da universidade e professores da educação básica poderiam ser colocados no mesmo patamar, em termos de estabelecimento de uma real parceria e troca de conhecimentos em um terceiro espaço que une os dois mundos de forma não hierárquica (ZEICHNER, 2010).

MNPEF.07: "Havia sempre a possibilidade do retorno, eles queriam sempre saber se eles estavam indo no caminho. [...] O MNPEF já tinha tudo organizado, o conteúdo, a bibliografia, a forma de abordar, ok, isso estava lá no papel. Mas de qualquer maneira, havia isso, porque era uma experiência nova para todo mundo, estava todo mundo ali vivendo uma experiência nova. $\mathrm{E}$ as aulas eram muito participativas [...] não havia aula que não houvesse discussão".

Essa postura dos docentes fez com que as disciplinas fossem significativas para os professores-cursistas: "não havia uma aula, que a gente não saísse dela melhor do que entrou" (MNPEF.07). Esse egresso também ressalta que mantém o vínculo com o curso e com os colegas, voltando à instituição, sempre que pode, para participar do Simpósio de Ensino de Física do polo e apresentando seminários a convite do corpo docente: "Foi um vínculo afetivo forte, não só comigo, mas com outros também. $\mathrm{E}$ a gente está querendo estar sempre por perto, acompanhando o que está acontecendo..." (MNPEF.07).

A escolha de tema e de orientador para o desenvolvimento de seu PE se deu após assistir a uma aula de um docente do MNPEF em que utilizava a metodologia de Peer Instruction, que despertou muito o seu interesse. Assim, apesar da temática não ter partido de sua realidade profissional, ou seja, não se pautar na busca de soluções de um problema de sua prática, MNPEF.07 se propôs em aplicar o Peer Instruction numa "escola que retrata a maior parte da realidade brasileira", que seria a escola estadual que dava aulas antes de ingressar na rede federal. 
Os estudos e planejamentos para a realização do PE permitiram inovações na dimensão organização e condução de ensino de desenvolvimento profissional de MNPEF.07. Além do Peer Instruction, o professor havia também estudado a metodologia Just-in-time teaching, que acabou não incorporando em seu PE devido à algumas dificuldades apresentadas em sua execução. Sobre o estudo dessas novas metodologias por ocasião da elaboração do PE e a inclusão delas em suas práticas docentes, MNPEF.07 relata:

MNPEF.07: "[O PE] Não foi nada assim, grandioso, mas eu penso
que funciona. Eu uso até hoje nas minhas turmas. Aliás, eu uso até
mais o Just-in-time que o Peer Instruction. [...] Física Ondulatória,
uma aula de Termodinâmica... Eu uso o Just-in-time. E no final de um
semestre, eu fiz um estudo disso, antes de eu me afastar [do trabalho
para a realização do doutorado], ao longo de um semestre, eles já
tinham me respondido quase duzentas questões conceituais, porque
toda aula eu propunha [...] foi a primeira experiência assim mais
profunda do Just-in-time que eu usei que funcionou, mas logo depois
eu saí, de afastamento. Mas é algo do meu mestrado, que eu vou
manter quando eu retornar, eu vi que deu certo".

Dessa forma, há a possibilidade de o egresso dar continuidade aos projetos iniciados no MP, o que indica ter alcançado uma responsabilidade sistemática.

Essas experiências com uma nova metodologia no contexto de aplicação do seu $P E$, uma proposta que coloca os alunos de forma mais ativa no processo de ensinoaprendizagem e uma experiência com alunos posterior, dada no contexto de seu doutorado, conduziu MNPEF.07 à sistematização de um saber experiencial, relacionado à dimensão sustentação da aprendizagem de desenvolvimento profissional. Ele diz que conseguiu "perceber uma movimentação muito positiva, uma expectativa positiva com minha presença em sala de aula" no contexto de aplicação de seu PE:

MNPEF.07: "Eu acho que talvez tenha sido uma das poucas vezes que eles se sentiram alunos participantes [...] eu não vou dizer para você que eu acredito que eles tenham guardado coisas de Física, mas eu acredito que eles guardaram muito a capacidade argumentativa que eles têm 'eu sou capaz. Aquele professor está interessado no que eu tenho a dizer'. [...] o que percebi, foi que definitivamente o aluno não acredita de forma genuína em que o professor faz as suas perguntas, eles pensam que são apenas retóricas, ou seja, eu te faço uma pergunta, não importa o que você vai responder, eu quero conduzir você para uma resposta certa. $E$ já que é assim, por que é que ele vai responder? Eles não acreditam na honestidade do nosso desejo de ouvir. Não importa o que seja. Então, eles não acreditam. E lá, falando isso agora para você, eles acreditavam que eu realmente queria ouvir a opinião deles. Então eles não se importavam, eventualmente ficavam mais acalorados, uns palavrões, uns gritos, mas... você finge que não ouve, ou então... 'gente, vamos maneirar e tal', mas era um sentimento de inclusão [...] Eu tenho mais de 30 anos de sala de aula e não escutava o meu 
aluno. Ou pelo menos, não fazia com que ele acreditasse que eu queria ouvir".

MNPEF.07: "Eu não sei exatamente como vai ser a minha aula quando eu voltar, mas uma coisa eu tenho muito profunda. Eu preciso fazer, seja por que caminho for, que ele acredite que o que ele vai falar, é relevante para mim. E isso está muito forte. [...] Você vê, você veio aqui me entrevistar, mas eu queria saber quem era você. Eu podia ter sentado aqui, 'está bom, vamos conversar', eu não quero, eu quero saber quem é você. $E$ eu quero saber quem é o meu aluno. $\mathrm{E}$ isso, para mim, foi algo que talvez tenha começado, esse processo tenha começado no mestrado, e agora eu tenha me dado conta disso".

Dessa forma, considerando todos os aspectos expostos, a conclusão que MNPEF.07 chega é de que "o mestrado foi muito transformador". Como impacto na sua profissão, na verdade expressando-o como uma expectativa futura, deseja que com o título de mestre (e futuro título de doutor, já que se encontra no curso de doutorado em Ensino de Física), possa participar de bancas de avaliação de trabalhos acadêmicos. É uma expectativa que denota a ampliação das suas funções como professor de graduação, o que demonstra o alcance da autoria indicada por uma inovação criativa em termos de perspectivas para sua carreira.

Por último, ao finalizar a entrevista, o egresso MNPEF.07 traça algumas considerações pessoais em torno da questão política que envolve a criação do MNPEF. Cita que chegou a fazer um convite a uma amiga para participar de sua banca de defesa do MP, mas que foi declinada, justamente pela questão política, de ser uma defesa do Mestrado em Rede, que, conforme criticado por muitos pesquisadores, teria enfraquecido os mestrados profissionais locais já consolidados. MNPEF.07 defende a realização do MP no MNPEF, que encara como uma oportunidade que seria irrecusável, ainda mais em seu contexto pessoal, de desistência de outros cursos de mestrado. Seria essa "uma briga política muito maior do que eu, cujo desdobramento independe de eu estar lá ou não" (MNPEF.07).

\subsubsection{Análise com elementos narrativos de MNPEF.08: o professor intelectual}

O egresso MNPEF.08 cursou licenciatura em Física em um universidade federal fora de sua cidade natal. Quando retorna, decide reingressar no curso de bacharelado em Física, oferecida na instituição sede do polo do MNPEF, pois diz que se "quisesse sair fora da [da área de] educação, deveria manter um estudo paralelo numa outra linha" (MNPEF.08). Entretanto, encontrou dificuldades em conciliar o bacharelado com o trabalho nas escolas. Além disso, muitas questões da sala de aula começaram a 
chamar sua atenção. Era também supervisor do PIBID nessa época. Foi então que decidiu largar o bacharelado e ingressar no MP.

Inicialmente, ingressou no MP.Local, também analisado nesta pesquisa. Porém, era um curso sediado em outra cidade, tinha gastos com transporte e teve que diminuir sua carga horária de aulas, o que impactou em sua renda. Sendo sócio da SBF, recebeu por e-mail a informação sobre a abertura do polo do MNPEF, no que largou imediatamente o MP.Local a fim de se preparar para o processo seletivo do novo programa. Para esse professor, o MNPEF teria as vantagens de ser na mesma cidade em que mora e trabalha, de ter o auxílio financeiro com a possibilidade da bolsa de estudos, além do horário do curso que cabia em sua realidade.

A decisão em persistir em cursar o MP foi respaldada por seu desejo de investir na carreira, e a oportunidade que vislumbrava de assumir a posição de um profissional intelectual. Em suas palavras:

MNPEF.08: "[...] são essas duas questões, questões pragmáticas, a carreira, a carreira é uma questão importante, e a segunda, é exercer a condição de um profissional intelectual. Porque é isso que a gente está perdendo um pouco. Aliás, não estamos perdendo não, estão tentando nos tirar. [...] Não somos reprodutores, não somos transmissores, nós somos intelectuais, nós devemos pensar a nossa prática. Então dentro dessa questão da necessidade de eu pensar a minha prática, da necessidade de carreira, eu me inscrevi no mestrado, na condição de quem trabalha, no MP, com forte estímulo financeiro".

Dentro das questões em sala de aula que começaram a "atiçar a reflexão, angústia", estava a diferença cultural que percebeu entre si mesmo e o modo que os alunos encaravam os estudos. Diz que era muito sistemático e "caxias" e que sempre se questionava "como é que eu vou coagir - pela minha experiência - coagir o aluno a estudar?" (MNPEF.08). Diz que era muito conteudista e que tinha ficado "obcecado pela avaliação": "como é que eu vou fazer uma avaliação que seja significativa, que de fato ela avalie o aluno, avalie a aprendizagem do aluno, e o coage a estudar" (MNPEF.08). Depois de ter passado pelo MP, encara esse pensamento como "reduzido" e considera que mudou muito, com os aprendizados derivados da experiência do curso que comentaremos adiante.

Comentando sobre como foi desenvolvido o curso, afirma que considerou as disciplinas "pouco rigorosas [...] pouco conteudistas". Ao mesmo tempo que elogia a questão de terem sido voltadas para a prática docente, diz que sentiu falta da abordagem de maior conteúdo:

MNPEF.08: "tem o mérito de ser todas as disciplinas voltadas para metodologias de ensino-aprendizagem. Todas as avaliações eram como apresentar isso, como abordar isso com os alunos. Então, ou 
seja, isso é coerente com a proposta. Porque é um MP! [...] É para você resolver o seu problema na prática. Resolver a sua prática. Agora, eu achei... como eu vi como era o MP.Local, eu comparei com o de lá. Eu achei que as disciplinas foram pouco conteudistas. Talvez devesse cobrar mais leituras".

Em relação ao MP.Local, MNPEF.08 considera que havia uma alta carga de conteúdos de "educação, em currículo, essas coisas". Compara que o MNPEF "ficou muito voltado para metodologia", mas avalia que essa característica tenha contemplado o perfil dos professores ingressantes no MNPEF. Pressupõe que o formato do MP.Local não seria totalmente adequado a esse perfil, por considerá-lo "altamente acadêmico", uma das dificuldades que encontrou no MP.Local, em relação ao estudo das disciplinas. Nesse sentido, pensando o percurso nos dois cursos de MP desse professor, vemos que no MP.Local, sua dedicação tornou-se nula levando em conta as dificuldades materiais e apresentadas pelas disciplinas, o que o levou a ponderar a troca de curso, onde pôde, finalmente, dedicar-se de forma ativa, revelada principalmente por sua iniciativa em superar dificuldades na elaboração do PE, como veremos adiante.

Voltando-se às disciplinas do MNPEF, por sua vez, considera que a carga de conteúdos específicos tenha sido pequena, embora relate como negativo o caso de um docente de uma disciplina do polo que destoou totalmente dos demais, pois abordou o conteúdo com grande profundidade, fazendo uso de ferramental matemático ("derivadas parciais de segunda, terceira ordem") que não eram de domínio da maioria dos professores-cursistas. Assim, MNPEF.08 pareceu demandar das disciplinas do MNPEF mais conteúdos tanto de conhecimentos pedagógicos quanto de conhecimentos científicos, abordados de forma a "encontrar o equilíbrio, o objetivo adequado à realidade e que seja significativo e que tenha conteúdo [...] $\mathrm{O}$ conteúdo cobrado da gente das disciplinas, eu achei que deixou a desejar um pouquinho" (MNPEF.08). É um caso, portanto, de não aperfeiçoamento das dimensões conhecimentos pedagógicos e conhecimentos científicos no contexto do MP, pela particularidade de sua trajetória formativa e profissional.

MNPEF.08 afirma que o desenvolvimento do curso foi doloroso. Isso porque teve dificuldades em sua orientação para desenvolvimento do PE. Conta que no início do curso, optou por convidar Do.MNPEF-01 para ser sua orientadora, por ela ser a única docente com formação em Ensino no curso naquela época. Porém, a docente, que terminava sua pesquisa de doutorado e tinha outras tarefas de seu trabalho, estava "altamente indisponível" em parte do curso. MNPEF.08 iniciou, assim, seu trabalho de forma isolada, sem poder "praticamente [...] trocar essa minha angústia com ela" (MNPEF.08). Chegou a desenvolver um material escrito sobre energia nuclear na 
perspectiva histórica e com base na abordagem CTS, porém sua orientadora, posteriormente, pediu para que fizesse outro tipo de trabalho. Nessas condições, diz que teve pouco mais de seis meses para planejar e aplicar o PE e escrever a dissertação até sua defesa em agosto de 2015: "o que era para ter sido em dois anos... Foi uma loucura, uma loucura. Mas assim, não me matou, só me fortaleceu. Mas eu aprendi muito. Mas foi doloroso" (MNPEF.08).

Neste processo, considera que a participação no Simpósio de Ensino do polo e no workshop do MNPEF apresentando o seu PE tenha sido fundamental para ter orientações externas: "foram as duas primeiras orientações que eu recebi!" (MNPEF.08). Destaca o contato que teve com Marco Antônio Moreira no workshop do MNPEF. Ao apresentar seu PE, naquele momento, ele não iria aplicá-lo em suas aulas, porque teria dificuldades com o tempo: o currículo da escola não abordava o conteúdo de seu PE no bimestre que teria para aplicá-lo em sala de aula. O egresso MNPEF.08 conta que nessa apresentação, Moreira teria sido muito objetivo em relação a isso, dizendo que ele estaria "prejudicando o programa" se não o aplicasse. Outra professora, presente na discussão, então, sugeriu a ele inverter os conteúdos de dois bimestres, para que pudesse aplicar seu PE no bimestre que precisaria aplicar, antes de sua defesa. A respeito dessa experiência no workshop do MNPEF, MNPEF.08 diz: "a objetividade me ajudou nesse sentido, minha e do Moreira, porque assim, ele falou 'você vai prejudicar o programa', ele foi objetivo. O programa precisa disso, precisa do produto, precisa da avaliação do produto, da aplicação do produto". Com essas dificuldades que precisou enfrentar, e com o objetivo de aplicar o produto, MNPEF.08 acelerou a escrita de sua dissertação:

MNPEF.08: "Eu sei que tinha que escrever sobre CTS para fundamentar o produto, e o caminho que eu encontrei, eu não refleti muito, porque não dava tempo, não sei o que deu aqui na minha cabeça, que eu só pensei no que eu ia escrever, e não porquê".

É um caso relatado que indica a prioridade que o MNPEF dá à elaboração e aplicação do PE. Ilustra também dificuldades que os professores-cursistas podem encontrar em relação ao tempo que têm para esse processo, além da necessidade de orientação. É um processo que pode angustiar, pode ser doloroso, e, em última análise, tornar-se de certa forma indesejavelmente automatizado, contradizendo a ideia de o MP ser um espaço de reflexão docente, pois esta demanda tempo para ser realizada.

Apesar disso, o egresso MNPEF.08 destaca inúmeros aprendizados oriundos desse processo. $O$ primeiro que destaca, tem a ver com suas angústias de início de carreira, referentes a sua relação com o aluno: "A primeira coisa é justamente 
entender que a gente não opera na cabeça do aluno. No máximo propicia condições para ele aprender. A gente não tem esse poder. Então, perceber isso, foi um alívio para mim" (MNPEF.08). De modo concreto, em relação à mudanças em sua prática, diz que "hoje, eu tendo a trabalhar delegando mais o protagonismo ao aluno. Eu tendo a comportar dentro de sala de aula mais como monitor. E assim, o aluno desenvolve a atividade, e processualmente eu estou avaliando o aluno" (MNPEF.08). A prática atual contrapõe a prática inicial relatada pelo professor, que seria de maior controle sobre o estudo e tarefa dos alunos, indicando desenvolvimento na dimensão sustentação da aprendizagem. Avalia, porém, que esse aspecto de mudança não seria atribuído exclusivamente ao mestrado "porque assim, existem muitas variáveis ao mesmo tempo", como o seu envolvimento político com sindicato e greves, que seguiu paralelamente à realização do MP, aparentemente um impacto na dimensão participação na responsabilidade social movida por questões pessoais. Outro indício do desenvolvimento de sua organização e condução de ensino diz respeito ao "domínio de produtos alternativos além do livro didático", embora ainda pondere que, devido ao alto investimento realizado pelo governo, não deixe de utilizar o livro didático:

MNPEF.08: "Aí eu busco, principalmente dentro da minha linha CTS... tem o livro lá de práticas de CTS compiladas que Do.MNPEF-01 participa. Então eu uso algumas aulas ali, algumas atividades... eu saber que existe esse tipo de material. [...] Contribuiu de fato para eu diversificar a minha prática. Para além do livro didático, da mesmice. [...] [Embora tenha] o Programa do Livro Didático. É muita grana gasta nisso. E aí a gente não vai lá usar o livro? Está lá pronto! Eu vou imprimir mais coisas? É, eu penso muito sobre isso. Então assim, ainda assim eu uso muito o livro. [...] quando eu sinto falta de alguma coisa a mais, aí eu trago produtos diversificados, abordagens diversificadas".

Essas reflexões se relacionam, de certa forma, com a motivação inicial de MNPEF.08 de se reconhecer como profissional intelectual. Neste quesito, relata que o MP também o auxiliou em adquirir uma autoridade sobre seu próprio trabalho em termos do conteúdo e da metodologia de ensino, novamente aspectos trabalhados no desenvolvimento da dimensão organização e condução de ensino de desenvolvimento profissional:

MNPEF.08: "Do conseguir refletir sobre a relevância do conteúdo e do método em Física. Conseguir me desapegar de determinados conteúdos mesmo, desapegar... a autoridade também dá nisso, porque se o professor recebe uma grade curricular para trabalhar, e recebe um livro para trabalhar, se ele não tem autoridade sobre 0 próprio trabalho, aí ele vai ser um mero reprodutor conforme ele colocou. Porque ele não reflete sobre sua condição e essas coisas todas". 
As falas destacadas indicam o alcance de MNPEF.08 do nível de inovação criativa e responsabilidade sistemática em seu trabalho docente, configurando maior grau de autoria coerente com a atuação como profissional intelectual pretendida pelo professor. A questão do envolvimento com a pesquisa, com a escrita acadêmica reforçou a ele esse papel:

MNPEF.08: "A questão do método. O método de pesquisa e de escrita, ele exige cuidado. Então aí, eu desenvolvi muito a minha escrita, a minha leitura, e um cuidado para falar, para colocar e para fundamentar, para sistematizar. Uma coisa que eu já tinha mais ou menos, mas ali, em pesquisa não. E tudo isso, essa instrumentação, me empoderou no meu trabalho".

Diz ter percebido uma mudança nas relações em uma das escolas que trabalha, onde passou a ter maior autonomia após titular-se mestre perante as cobranças de sua diretora. Como se o título tivesse legitimado seu trabalho como professor intelectual. É algo já referido por Do.MNPEF-07: de que o título de mestre conferiria maior status para o professor nas escolas para a implementação de novas práticas docentes:

MNPEF.08: "[...] a minha relação com a escola, era uma relação de poder mesmo. Ninguém assim me enchia o saco. Na escola que eu dava aula [...] a diretora era altamente autoritária, entendeu? Ela cercava professor, dava ordem, essa coisa. $O$ pessoal achava muito estranho a diferença de tratamento que era comigo, por conta desse poder que eu adquiri que vem da instrumentação do mestrado, do conteúdo, e dessa coisa toda".

Por fim, MNPEF.08 se considera satisfeito com o MNPEF, por conta do curso contemplar a realidade do professor: "a formação continuada precisa construir condições concretas, que ele [professor] receba o incentivo de uma bolsa, que ele tenha o horário flexível, que ele tenha os objetivos adequados a sua realidade" (MNPEF.08). Considera que o grupo teve um envolvimento muito grande, pois estava "todo mundo ali, na busca de seus problemas, que às vezes é um problema que é comum de um monte" (MNPEF.08). Aponta, entretanto, que a renovação e inovação das práticas docentes não é uma consequência unânime entre os professorescursistas, pois alguns "vão entrar para esse mestrado para propor metas para reproduzir o mesmo". Descreve o caso de um professor que é seu colega que trabalha na escola técnica. Esse professor, apesar de também cursar o MP, mantém suas concepções pedagógicas rígidas em relação aos alunos: "o cara engana o programa, ele profana a ideia, [...] ele só está fingindo" (MNPEF.08) no sentido de produzir um $P E$ alinhado às atuais tendências pedagógicas preconizadas no curso, mas que, de volta à sua própria prática, continua a realizar mais do mesmo. 


\subsubsection{Análise com elementos narrativos de MNPEF.09: o professor interessado nos PEs}

O egresso MNPEF.09 é o primeiro professor entrevistado que não é licenciado em Física, tendo formação inicial em Engenharia Civil, no final da década de 1970. Escolheu esse curso quando era jovem, sem perspectiva de poder estudar Física, que era um curso inexistente nas instituições de ensino superior instaladas em sua cidade na época. Algum tempo depois, faz a Licenciatura em Matemática, com habilitação para dar aulas de Matemática, de Física e de Desenho Técnico. Finalmente, presta concurso para dar aulas de Física na rede estadual no final dos anos 1990. Concomitantemente, permanece como servidor técnico da prefeitura de sua cidade.

O interesse em seguir sua formação na área de Ensino é evidenciado, pois ao longo de sua carreira docente, participou de cursos de curta duração oferecidos, por exemplo, durante as férias, para professores. Em 2000, relata que fez um curso com um grupo de uma universidade federal, sobre inserção de História da Ciência no Ensino de Física, que de pronto impactou sua prática, pois o que tinha aprendido, começou aplicar em suas turmas, com adaptações para sua realidade. Aparentemente foi um curso marcante na sua carreira, pois conta que tinha planos de, assim que se aposentasse do cargo de técnico da prefeitura, quando poderia ter mais tempo para estudos, ingressaria em um mestrado em História da Ciência. Além dos cursos de curta duração, chegou a fazer uma especialização em Ensino de Ciências, em meados dos anos 2000.

Quando soube que abriria o curso do MNPEF em sua cidade e teria a possibilidade de abordar a questão do ensino com a História da Ciência nele, decidiu investir nesse curso. Na época, ainda estava trabalhando na prefeitura, e lecionando nas escolas no turno noturno, porém os horários do curso favoreceram seu ingresso. Estava muito motivado em prosseguir seus estudos como já havia planejado há anos, embora apreensivo pois sabia que "o curso seria difícil, que haveria muita exigência da parte da organização" (MNPEF.09).

Realmente, diz que enfrentou muitas dificuldades nas disciplinas, por não ter formação inicial em Física. Cita como exemplo, as disciplinas com conteúdos de Física Moderna, que "nunca tinha estudado de forma [...] convencional [...] [apenas] estudando sozinho, lendo sozinho, lendo mais livros de divulgação científica" (MNPEF.09) e sem ter tido contato anterior com a bagagem matemática necessária para estudar esse conteúdo, o que lhe causou a dificuldade enfrentada. Porém, conta que com o apoio e a didática dos docentes, tenha conseguido se desenvolver. 
Claramente, as disciplinas proporcionaram a atualização de conhecimentos científicos, por conta da especificidade de sua formação inicial diversa à de Física.

O egresso MNPEF.09 relata a sua participação no workshop do MNPEF como muito profícua, principalmente pois "nós pudemos relacionar com colegas de outros setores, ver até as dificuldades que eles tinham" (MNPEF.09), além das apresentações de trabalhos, banners e palestras. Esse contato com professores de outros polos do MNPEF foi muito importante para MNPEF.09 até mesmo reconhecer e valorizar o seu próprio polo:

MNPEF.09: "Na interação com outros professores, colegas, e ver
também, uma coisa que me chamou muito a atenção foi o seguinte...
Aqui na [instituição], nós tivemos a sorte de termos professores assim
bem... que captaram a intenção do MP. [...] Os professores aqui na
[instituição], por exemplo... nessa parte da Física Moderna, que eu
tinha dificuldade. Eles iam fundo na matemática, na explicação, na
matematização dos assuntos todos, e na teoria. E aí depois surgiu, o
que era mais legal, surgia a discussão das equações, a parte
conceitual da Física. E o que eles cobraram de nós, e aí é por isso
que eu digo que eles entenderam na Física o objetivo do MP. O que
eles cobravam de nós, alunos? Era como nós íamos pegar esse
ensino, esse conhecimento, e esmiuçar para trabalhar no ensino
médio. Justamente sem essa matematização. [...] Isso foi muito
importante, por isso que eu acho que esse mestrado é muito
importante, porque de uma forma coletiva, milhares de professores do
ensino médio estão pegando isso e traduzindo esses conceitos
modernos para ensinar no ensino médio. [...] Eu vi que outros colegas
de outros polos, os professores dos outros polos não entenderam o
objetivo do MP, porque cobravam dos alunos, alunos-professores,
aquela matemática, aquela matematização toda nas provas [...] Até
alguns polos, o pessoal falando, que os professores desistiram.
Porque não tinham tempo para estudar, de voltar atrás naquela parte
matemática toda lá e também viram, falar que isso não vai me servir
para nada, esse mestrado não vai me servir para nada na minha
prática, na minha práxis profissional".

Provavelmente por conta dessas divergências entre os polos descritas por MNPEF.09 que Moreira publica uma nota no site da SBF em março de 2015 com "Orientações sobre o currículo do MNPEF"118, onde, como criador dos mestrados profissionais em ensino na Capes, ressalta a particularidade do MP, que "é diferente de um mestrado acadêmico clássico", sendo uma proposta "centrada no professor da educação básica, na sala de aula, nos conteúdos e nas tecnologias, não na pesquisa acadêmica" (MOREIRA, 2015). Nessas orientações, Moreira dá vários exemplos, que estão de acordo com o "espírito do curso" implementado no polo estudado desde 2013 e que pareceu não ter sido alcançado em outros polos, principalmente em um primeiro momento, como percebido por MNPEF.09 em conversas com mestrandos de outros polos:

118 Disponível em: <http://www1.fisica.org.br/mnpef/?q=orienta\%C3\%A7\%C3\%B5es-sobre-0curr\%C3\%ADculo />. Acesso em: 09 jun 2019. 
Ministrar uma disciplina de Quântica para professores de um MP em ensino não é "dar o Messiah" ou algum outro clássico. Não é ficar resolvendo indefinidamente a Equação de Schrödinger. Ao contrário, é ocupar-se de conceitos como estado, superposição de estados, emaranhamento, sempre pensando em como os professores poderiam abordar esses e outros conceitos quânticos no Ensino Médio. É ocupar-se de fenômenos quânticos, na mesma perspectiva.

[...] Enfim, as possibilidades são muitas. O importante é que os professores alunos aprendam esses conteúdos de maneira significativa e sejam capazes de abordá-los com seus alunos no Ensino Médio. É preciso dizer não ao formalismo. Esses professores não serão físicos e seus alunos também não (MOREIRA, 2015).

A respeito da elaboração do seu PE, MNPEF.09 descreve como um processo que "foi muito trabalhoso, muito, muito, mas foi muito prazeroso também [...] valeu a pena porque fez eu me exigir estudar bastante". Apesar de enfatizar as dificuldades das disciplinas e do processo de elaboração do PE, é possível perceber seu esforço em superá-las, de forma que podemos determinar um nível ativo para sua dedicação no MNPEF, coerente com o que o moveu em direção a realizar o curso.

Em seu PE, abordou os temas de fissão e fusão nucleares, focando a alfabetização científica com elementos experimentais e de História da Ciência, além do uso de simulações e outros recursos. O professor MNPEF.09 distingue a produção da dissertação (mais acadêmica e aprofundada) do PE (mais prático):

MNPEF.09: "Eu fiz uma pesquisa bem longa da parte do porquê da alfabetização científica, como que ela nasceu, a evolução desse ensino, e depois também a parte da Física, da questão da fissão, da fusão. Porque, lógico, na dissertação, eu fui num nível acadêmico, não em um nível de ensino médio. [...] ficou bem aprofundada mesmo. O produto que a gente... Lógico, para facilitar para 0 professor que a gente procurou enxugar o máximo possível, o produto ficou palatável. Mas a dissertação em si, ficou bem acadêmica mesmo".

Esse estudo aprofundado, para escrever na dissertação a fundamentação teórica sobre o uso da alfabetização científica, foi um dos aspectos citados pelo professor como impacto em sua prática, em termos de conhecimento e adoção de estratégias de ensino (dimensão organização e condução de ensino de desenvolvimento profissional). Entretanto, não foram conhecimentos totalmente novos para ele, por conta dos cursos que já tinha realizado antes do MP:

MNPEF.09: "A parte de estratégias, eu já tinha essa pós que fiz, [...] já tinha me dado bastante [subsídios]. [...] [Além disso], eu fiz curso lá... eu fiz uns três cursos, aqueles cursos rápidos de férias, de três dias... [...] e o mestrado acrescentou [...] como por exemplo essa estratégia da alfabetização [científica]. Que é na realidade uma extensão que eu já tinha visto lá na pós".

Incluir essas estratégias novas em sua prática, em certa medida, parece ter relação com a utilização dos PEs elaborados no contexto do MNPEF, para este 
professor. Afirmou que continua utilizando o seu PE em suas aulas, embora com algumas perdas, por exemplo, sem poder utilizar mais o laboratório de informática de sua escola, por problemas de infra-estrutura, e de alguns experimentos utilizados ao longo da sua sequência didática que acabaram se desmontando e não sendo repostos. Na fala abaixo, vemos que o professor se esforça por assumir uma responsabilidade sistemática, embora encontre dificuldades conforme as apontadas, mantendo-se, portanto, num nível eventual.

\begin{tabular}{l} 
MNPEF.09: "[...] melhorou muito a minha prática... Agora eu, vamos \\
dizer assim, aí a falha é minha [...] eu não utilizo ainda o que os \\
outros colegas fizeram. Eu até esses dias estava pensando 'poxa \\
vida, vou aproveitar essas férias agora, e vou fazer um plano, vou \\
fazer um plano assim: assunto tal. Aí vou procurar na plataforma do \\
mestrado, o que eu posso pegar para poder aplicar. Um produto de \\
outro colega, eu usar aquele produto ali [...] logo no início, quando \\
terminamos o mestrado, eu já fui fazer isso, só que o pessoal [...] da \\
SBF, eles demoraram muito para colocar na plataforma os produtos... \\
[...] porque, por exemplo, para eu fazer, para eu preparar uma série \\
de aulas dentro dessa concepcão que eu gosto de trabalhar, de \\
alfabetizacão científica, é muito trabalhoso, é muito trabalhoso, muito \\
muito! Então, o que é que temos que fazer? Aproveitar o que o outro \\
\hline colega fez, porque é o que foi desenvolvido no objetivo do mestrado".
\end{tabular}

Com esse comentário, vemos que MNPEF.09 responde à proposta principal do MNPEF, a de fomentar a elaboração e divulgação de PEs que, ao serem utilizados por outros professores, com adaptações as suas realidades, proporcionaria a inovação do ensino de Física nas escolas de educação básica brasileira. No entanto, é interessante destacar que, no caso particular desse egresso que exprimiu o interesse de acessar os PE e utilizá-los, já era uma atitude realizada pelo professor, por conta do histórico de formação em outros cursos sobre ensino de Física de curta duração, além da especialização. Além disso, por ter passado pelo MP, e ter estudado muito sobre, por exemplo, a alfabetização científica, tem domínio suficiente para entender e trabalhar na prática outras propostas que também se baseiam na alfabetização científica. O que não é verdade para muitos professores da educação básica. Como o PE, com razão, é mais sucinto e prático, não se aprofundando nos aspectos teóricos do trabalho, como o próprio MNPEF.09 ressalta, esses professores, não tendo acesso aos conhecimentos necessários para pensar as propostas dos PE nas dissertações ou por outros meios formativos, podem ter dificuldades no uso dos PEs. Dessa forma, podemos refletir que o uso dos PEs por outros professores, além de seus próprios autores, nunca é uma certeza. Ainda mais que, como ilustrado no próprio caso de MNPEF.09, há dificuldades referentes à divulgação desse material e no tempo para se organizar para buscá-los e estudá-los. É importante o debate acerca disso, embora, como MNPEF.09 discute, materiais com estratégias inovadoras, como aqueles elaborados nos preceitos da alfabetização científica, são muito mais trabalhosos para 
os professores, se eles tiverem que iniciar o planejamento da proposta "do zero". Materiais prontos, já disponíveis nessa abordagem, facilitam o seu uso.

Há ainda a dificuldade de PEs que se encontram, na visão de MNPEF.09, "fora da realidade do ensino médio". Isso, em termos, aparentemente, da abordagem de conteúdo da Física que enfocam:

\begin{abstract}
MNPEF.09: "Tem coisas que, tem coisas, tem assuntos, que não dá para aplicar na rede estadual, no ensino médio. Não dá. [...] que é aquilo que te falei, a minha dissertação, eu procurei fazer acadêmica, o meu produto não, para o professor trabalhar. Então, não adianta você fazer alguma coisa que agrade a Academia, mas que não tenha um valor prático. Vai ficar lá na prateleira, agora é a prateleira eletrônica, mas vai ficar tomando poeira lá na prateleira".
\end{abstract}

Há uma certa contraposição comum entre Academia e a prática profissional docente em termos objetivos, mas como discutido, os conhecimentos proporcionados por uma (a Academia) apoiam a realização da outra (a prática profissional docente), algo que MNPEF.09 parece estar ciente, atuando dessa maneira. Aparentemente, MNPEF.09 teria uma inovação reflexiva de sua prática, refletindo sobre o uso dos PEs frente à sua realidade de sala de aula.

Por fim, MNPEF.09 destaca a importância de maior divulgação do Simpósio de Ensino de Física do polo nas escolas da região, justamente para integrar os professores de Física que não fizeram o MP. É um evento que MNPEF.09 frequenta, mesmo após ter se formado, mantendo ainda seu acesso ao pessoal do polo.

\title{
5.1.6 Análise com elementos narrativos de MNPEF.10: 0 professor que se descobriu criativo
}

O egresso MNPEF.10, assim como outros, tinha iniciado anteriormente um curso de mestrado, porém acadêmico, na área de Física básica, que abandonou pois não viu outra vantagem na sua formação naquele contexto além de "pessoal", pois não tinha interesse em seguir carreira acadêmica. Além disso, os horários das disciplinas do MA eram desfavoráveis para aqueles que continuavam trabalhando. Assim, se interessou em prestar o processo seletivo para o polo do MNPEF, que foi indicado por um primo, pois "ele é voltado para o que eu já faço [...] eu queria algo que melhorasse o que eu já estava fazendo" (MNPEF.10). Assim como outros egressos, considera também como pontos positivos, a questão dos horários e a disponibilidade de bolsa.

Vê que em relação à matriz curricular do MNPEF, "houve o casamento perfeito" entre disciplinas de conteúdo específico de Física e disciplinas com teor pedagógico: 
MNPEF.10: "Eu tive disciplinas que me ensinaram 'as Físicas', e eu também tive disciplinas que melhoraram na minha prática, meu olhar como professor. E essas disciplinas que me ensinaram mais Física, por exemplo, Termodinâmica, Eletromagnetismo, Quântica... $\underline{\mathrm{O} \text { modo }}$ deles cobrarem, tinha mais a ver com a minha prática! Por exemplo, quando a gente estudou Quântica, eu tive que apresentar um seminário de como apresentar a Equação de Schröndiger para um grupo de alunos do terceiro ano. Foi apaixonante. Eu tive que entender todas aquelas probabilidades, do que significa a função de onda, todas aquelas interpretações, e bolar um modo de apresentar aquilo para uma garotada de terceiro ano que [...] muitos nunca tinham visto nada de Quântica... Então eu achei que foi muito bom esse casamento. Entre a parte pedagógica, didática, que eu obteria num mestrado, numa pós em Ensino... E o casamento com as disciplinas ditas pesadas, de Física pura, que eu só conseguiria se fosse fazer um mestrado na área de Física".

Essa característica da matriz curricular representa um dos principais pontos positivos que MNPEF.10 destaca do curso, característica que inclusive colaborou muito à ampliação de seus conhecimentos científicos e pedagógicos que relata:

MNPEF.10: "aprendi muita coisa, dentro de Física, claro... Além da Lei de Resfriamento de Newton [...] Por exemplo, o Efeito Peltier [conceitos utilizados em seu PE], eu só fui aprender no mestrado. E a parte pedagógica, certas discussões mais acirradas sobre aprendizagem significativa, eu também só ali no mestrado, durante a graduação, eu não tive essa discussão toda. Eu acho que Ausubel, Marco Antônio Moreira, Rogers, foi no mestrado que as teorias desse pessoal ficou mais clara para mim, a gente discutia bastante. E isso, claro, é positivo, eu preciso saber mais, eu preciso conhecer mais técnicas para apresentar essas ideias. Então eu aprendi muito sobre essas teorias".

Ao discorrer sobre o desenvolvimento do seu $\mathrm{PE}$, diz que mudou o projeto várias vezes. O projeto inicial que tinha sido apresentado à banca de seleção do mestrado, era influenciado pela experiência que teve ao participar de uma visita ao CERN. Tinha um projeto de adaptar uma atividade lúdica para abordar partículas elementares no ensino médio que havia sido apresentada no curso que realizou. Porém, seu orientador fez com que mudasse o projeto, de modo a abranger a introdução de novas tecnologias no ensino. Na verdade, diz que

MNPEF.10: "todos nós [mestrandos] acabamos alterando o nosso projeto para algo mais voltado para o uso de computadores, celulares, ou de outras tecnologias em sala de aula. Então foi uma pressão do grupo, mas uma pressão positiva. Eles foram nos convencendo e esse é o progresso... esse é o futuro".

Essa ênfase às novas tecnologias, na leitura de MNPEF.10, estaria relacionada às linhas de pesquisa que eram trabalhadas pelos docentes, mais próximos de pesquisas em computação quântica e tecnologias. Seria algo que queriam levar para as salas de aula. Na verdade, é também uma diretriz nacional do MNPEF, como ilustrado por Moreira em suas "Orientações sobre o currículo do MNPEF" 
apresentadas na análise com elementos narrativos de MNPEF.09. Neste documento, em relação ao uso de novas tecnologias no ensino, Moreira escreve:

[...] o MNPEF é um espaço com muito potencial para mudança. As aulas no MNPEF devem usar, rotineiramente, recursos tecnológicos (simulações, modelagem computacional, internet, celulares, vídeos, fotos digitais, ebooks, redes sociais,...). Não tem mais sentido o ensino apenas de giz e lousa.

Isso, no entanto, não significa ensino a distância. O MNPEF é presencial, mas deve incorporar as TICs e estimular seus alunos a usarem essas tecnologias nas suas práticas no Ensino Médio.

MNPEF.10, então, visando abordar ferramentas tecnológicas em seu PE, planejou a criação de um protótipo de câmara de nuvens. Para a construção desse aparato, conheceu as pastilhas Termopar, indicadas por seu orientador, que funcionariam com base no Efeito Peltier. Devido à limitações de recursos para dar prosseguimento à construção do protótipo, preferiu realizar uma aula experimental para discutir curvas de aquecimento de substâncias, a Lei de Resfriamento de Newton e o Efeito Peltier, conteúdos de Física que, conforme exposto, o professor veio a conhecer apenas no MP. O investimento do professor em elaborar um PE alterando seu projeto inicial e abordando um conteúdo novo para si nos indica uma dedicação no nível ativo.

Realizou a aplicação de seu PE com alunos voluntários em horário extra às aulas regulares, por conta de ser um horário em que poderia retomar esse conteúdo, que já havia sido estudado nas suas turmas no momento que o professor utilizou seu PE na sala de aula e pela questão do uso do laboratório de eletrônica do colégio, indisponível no horário das aulas regulares. Foi bem sucedido em alcançar seus objetivos com esse grupo de alunos, porém informou que não chegou a utilizar o seu PE novamente na turma do ano seguinte para abordar com eles o mesmo conteúdo. $O$ motivo dessa desistência teria sido dificuldades do próprio colégio: "nós estamos vivendo umas mudanças muito radicais lá no colégio. Certas coisas que se faziam, atualmente já não está sendo muito fácil para fazer não, sabe? Então eu não retomei essas aulas não" (MNPEF.10). Com base nesse dado e no fato, apresentado a seguir, de o egresso relatar insegurança em utilizar algumas inovações aprendidas no MNPEF em suas aulas, consideramos que sua responsabilidade tenha se mantido no nível eventual com a inserção pontual de novas práticas em seu trabalho.

Como principal impacto em sua prática profissional, considera a "vontade de fazer diferente". Teve acesso ao longo do mestrado a diferentes estratégias e recursos que não conhecia, que o motivou a pensá-las como poderiam ser aplicadas na realidade de suas aulas. Seu relato traz dois movimentos realizados para 0 
aperfeiçoamento de sua organização e condução de ensino: primeiramente, o acesso ao conhecimento de tais estratégias e recursos inovadores para o professor e a necessária investigação de como poderiam ser inseridas em sua realidade, usando de sua criatividade para realizar adaptações, o que, por sua vez, nos indica uma inovação reflexiva. Este último fator é determinante, pois, para o egresso:

MNPEF.10: "É meio chocante que quando a gente volta para a sala de aula, descobre que não dá para aplicar isso. Você tem que fazer uma adaptação a sua realidade, ao grupo com o qual você se encontra. Dentro do possível, eu fui trazendo novidades, eu fui mudando a minha maneira de avaliar, até o modo de apresentar o assunto para o aluno. Coisas desse tipo. [...] Pegar uma ideia, uma teoria, e querer aplicar do jeito que ela nos é dada, eu considero como uma das coisas que eu aprendi: uma grande pobreza. Eu posso me inspirar em trabalhos dos outros, eu posso me inspirar em ideias, mas na hora de eu levar isso para o meu dia-a-dia, tem que fazer as adaptações adequadas. E eu nem sabia que eu era tão criativo assim! Mas eu consegui usar bastante, estou usando bastante daquilo".

MNPEF.10 explica, no trecho seguinte, as estratégias e os recursos aprendidos no MP que renovaram suas práticas, embora relate insegurança em utilizar em suas aulas alguns deles:

MNPEF.10: "Eu vi muitas possibilidades que eu não conhecia. Por exemplo: eu nunca tinha montado aulas com simuladores. Aquele do Phet, né? [...] Eu já tinha usado, mas nunca pensei em montar uma aula sobre aquilo. $O$ Tracker também. $O$ Tracker eu nem conhecia. [...] Até hoje tenho meio medo de levar para a sala, porque eu não aprendi tudo, dominar aquilo, eu baixei no meu computador, mas está tudo em inglês, para ficar mais difícil ainda. Mas ainda pretendo usar, achei aquele programa bárbaro. Eu conhecia Arduino, não sabia de todas as possibilidades didáticas que eu poderia explorar. O Peer Instruction, que eu achei uma maneira muito bacana de se trabalhar com os alunos também. Eu vi possibilidades de se fazer algo diferente. [...] Por exemplo, Peer Instruction, que foi uma das coisas que eu aprendi lá no mestrado que eu mais usei depois. Eu usei em várias escolas, inclusive até em uma de fundamental que eu estava trabalhando, e em todas as escolas que eu usei, eu fazia modificações, eu botava a minha assinatura ali, o meu jeito de trabalhar. E eu vi que, poxa, dá para se criar muito".

Essas necessidades de adaptação dão margem a novas criações. Porém, muitas vezes são decorrentes da desvinculação das propostas iniciais com a realidade da sala de aula. Embora seja natural a necessidade de adaptações, mesmo entre turmas diferentes de um mesmo contexto, por conta da complexidade do trabalho pedagógico, algumas propostas, pensadas por pessoas que não conhecem de perto a realidade das escolas, o perfil dos alunos da educação básica, os recursos geralmente disponíveis, entre outras características do trabalho docente, podem ser tão deslocadas da realidade que são inviáveis. É um reflexo da distância entre a universidade (docentes da área acadêmica, algumas vezes até mesmo distantes de 
discussões sobre educação) e a escola (professores de educação básica) já mencionada em análises anteriores. É o que o egresso MNPEF.10 destacaria como ponto negativo do curso. Em suas palavras:

\begin{abstract}
MNPEF.10: "[...] nós fomos bombardeados, ou recebemos muitas ideias bacanas, mas eu percebi também que o pessoal que estava no comando, não tinha muita visão do que é que estava acontecendo nas escolas. Então, certas discussões, certas cobranças eram totalmente inviáveis para nosso dia-a-dia. Eu lembro até quando eu tive que apresentar a função de onda... Aí o colega do grupo falou assim: 'ah, é difícil, professor, adaptar isso para o terceiro ano, porque o pessoal não estuda isso'... 'Como? O pessoal do terceiro ano no ensino médio não estuda função de onda!' Ele assustou, sabe, para ele, não tinha noção, do que o pessoal do terceiro ano estudava! Então isso também eu acho que gerou uma discussão muito boa, e deixou bem claro o quanto que esse pessoal... assim, alguns, que trabalham na formação de professores, o quanto eles estão muito longe da nossa realidade".
\end{abstract}

\title{
5.1.7 Análise com elementos narrativos de MNPEF.15: o professor que valoriza as relações
}

O egresso MNPEF.15 conta que nunca achou viável fazer mestrado, considerava "uma coisa muito distante". A principal razão dessa percepção que tinha em relação a si mesmo, pareceu vir da relação que tinha com os professores que teve na época de sua graduação, no curso de licenciatura em Física, que "se colocavam em um patamar acima dos alunos". Dessa forma, ele não se sentia "capaz de terminar uma graduação, $[e]$ vindo de uma licenciatura, ingressar no mestrado" (MNPEF.15). A possibilidade de se fazer um mestrado acadêmico the parecia distante também pelas dificuldades em conciliar a dedicação à pós-graduação com seus horários de trabalho como professor.

Quando começou a trabalhar em um colégio privado de elite, realizou alguns cursos de pós-graduação lato sensu, principalmente porque o colégio valorizava e incentivava a formação continuada do seu corpo docente. Assim, fez três especializações distintas: em Gestão Escolar e Coordenação Pedagógica; MBA em Meio Ambiente e Desenvolvimento Sustentável e, por fim, em Educação Jesuítica.

Sendo associado da SBF, ele recebeu em 2013 a notícia da abertura do processo seletivo para o MNPEF. A possibilidade de fazer o curso oferecido no polo do MNPEF lhe atraiu a atenção, principalmente pelos horários das disciplinas, que o permitiria manter seus trabalhos sem redução de carga horária. Diz ter ponderado que seria uma boa opção, pois percebia que com a maturidade e crescimento pessoal que já tinha alcançado com as especializações, tinha chegado a hora de "parar de fazer o 
lato sensu e ir pro stricto sensu". Considera que logo no início do curso, percebeu ter sido uma ótima escolha, principalmente pela relação que estabeleceu com colegas $e$ professores do polo:

MNPEF.15: "A oportunidade que também surgiu, foi justamente para o MP. O que foi fantástico, assim, porque os contatos com os colegas, enfim, as trocas que a gente tinha no curso, o ambiente que eu encontrei na [instituição] foi muito favorável, os professores se colocavam assim... Lógico, com conhecimento maior, mas no mesmo patamar do aluno, para tirar dúvida, para atendimento, para disposição. Eu fiquei muito feliz lá [...]"

MNPEF.15, ao longo da entrevista, conta alguns casos de acolhimento do corpo docente, que têm a ver com a compreensão dos docentes em relação à realidade de trabalho dos professores-cursistas, além de pequenas ações, como adiantar aulas e discutir horários que favorecessem a todos, que expressam a preocupação do corpo docente do MP com o bom desenvolvimento do corpo discente. Essa é a primeira característica que encontrou no MP que MNPEF.15 coloca como positiva, em comparação com sua experiência em cursos de formação. É notável, principalmente pelo contraste com a realidade que havia encontrado na sua graduação. $O$ egresso expressa:

MNPEF.15: "Você tinha essa parceria, esse entendimento maior. [...] O acolhimento dos professores foi um ponto alto. Tanto para orientar, quanto para ajudar, para conversar, para tomar um café, para falar sobre coisas aleatórias, enfim, para formar uma parceria... [...] A outra coisa que eu achei muito legal do curso, é que mantém as turmas sempre unidas".

A comunidade que MNPEF.15 encontrou no MP the foi muito relevante, principalmente porque foi essencial para lhe mostrar que era capaz de realizar o curso. Os vínculos formados entre os colegas e os docentes foram o que mais the marcou. Em relação ao contato com os colegas, o egresso coloca que todos puderam interagir entre si e crescer academicamente e profissionalmente em conjunto. É uma indicação de sua dedicação ativa no curso:

MNPEF.15: "[...] depois do primeiro período, todo mundo já sabia no que 0 outro era bom, no que o outro tinha dificuldade, e a gente conseguiu cada um tentar melhorar o outro naquele que ele tinha de pior... Não digo de pior... de menos potencial, e o que o outro tinha de potencial, a gente sentava e sugava do outro essas questões. Essa troca que a gente tinha entre nós, fez um grupo muito legal".

Essa característica encontrada no polo do MNPEF o faz recomendar a realização do curso aos colegas professores de Física das escolas que trabalha. Vêse, de certa forma, como um "exemplo para os demais", no sentido de mostrar a esses professores que também podem realizar o mestrado, que "não é só para seres especiais e super inteligentes". Isso mostra sua superação em relação à visão que 
tinha no contexto de sua graduação, o que o impulsionou a buscar o curso de doutorado após a conclusão do MP: "sempre tive vontade, o mestrado me abriu essa coisa, eu sou capaz, eu posso fazer, e eu posso continuar" (MNPEF.15). É um desdobramento que impacta seu planejamento de carreira, pois além de poder se beneficiar de um aumento de salário por conta do título de mestre adquirido no MP, poderá também, caso seja de seu interesse, expandir seus contextos de trabalho após a conclusão de seu doutorado.

Independentemente dessas questões de carreira, no entanto, o egresso expressa uma motivação intrínseca para a realização do MP, e aponta que a boa relação entre os envolvidos no curso incentiva a transformação das práticas:

MNPEF.15: "[...] porque acho que quando você está em sala de aula e essa relação é uma relação humana, tudo o que a gente aprende de diferente, a gente quer trazer para a sala de aula. A gente quer somar, a gente quer acrescentar [...] quer dar uma aula diferente do que deu no passado"

Nessa direção, considera importante a criação de um repositório central do MNPEF para disponibilizar online os produtos educacionais. Primeiramente para dar visibilidade ao programa, no sentido de justificação do investimento realizado para seu funcionamento. Mas principalmente porque pensa ser interessante disponibilizar de forma facilitada todo o material produzido pelos mestrandos, pois seriam esses materiais de qualidade, que passaram "por um crivo acadêmico" e que, ademais, pode fazer com que os professores que consultem esses materiais para utilizá-los em suas aulas se vejam incentivados em realizar eles mesmos o curso de MP.

Ao comentar sobre as disciplinas do curso, vê como muito importante a questão de que elas contribuam diretamente para a formação na sala de aula. Pensa que isso é muito bom, pois "potencializa melhor o ensino como um todo". Diz que o conteúdo abordado nas disciplinas contribuiu para sua didática e de seus colegas, e até na "mudança da nossa mentalidade" através das discussões que eram feitas e trabalhos produzidos. A dinâmica das aulas exigia a dedicação dos mestrandos, mas "não de uma forma exacerbada" (MNPEF.15). Muitos trabalhos propostos eram realizados no tempo de aula, para não deixar que trabalho extra, além da construção do PE, uma preocupação paralela às disciplinas, tivesse que ser realizado no decorrer da semana pelos professores-cursistas. Novamente, é uma preocupação expressa pelo corpo docente, de modo a considerar a realidade de trabalho dos mestrandos.

MNPEF.15 contou alguns exemplos de trabalhos desenvolvidos no contexto das disciplinas do MP que colaboraram para sua prática docente. Destaca-se um exemplo que indica o potencial para o aperfeiçoamento da organização e condução de 
ensino, além de apontar uma possibilidade do MP de romper com a hegemonia (ou melhor, homogeneização) do uso do livro didático pelos professores de educação básica. Moreira et al. (2018) atribuem aos PEs desenvolvidos nos MPs um contorno "subversivo" à onipresença do uso do livro didático nas escolas. Apontamos, pelo exemplo dado por MNPEF.15, que tal "subversão" não está restrita ao PE tão somente, mas também pode estar presente e ser incentivada nas disciplinas do MP. No caso de MNPEF.15, tal "subversão" foi materializada na disciplina Mecânica Quântica, onde temas de Física Moderna foram sorteados para que pequenos grupos de professores-cursistas planejassem uma aula para abordá-los no ensino médio. Em sua pesquisa para este trabalho, MNPEF.15 descobriu um fenômeno da luz, chamado "reflexão frustrada", que não lhe era conhecido e não é registrado em livros didáticos, para poder falar sobre o conceito de tunelamento quântico. É um fenômeno que teve que buscar em outras fontes, "coisa que nenhum livro de ensino médio fala, e é uma coisa que eu demonstro em sala de aula agora" (MNPEF.15). É notável essa maior independência do livro didático para MNPEF.15, pois ele disse ao longo da entrevista que coleciona livros didáticos de diferentes épocas, e que sempre os consulta para suas aulas. Inclusive, o tema de seu PE foi inspirado em um método alternativo apresentado em um livro da década de 1980 para a determinação da Lei de Gauss. Pelos casos que narrou de inovações proporcionadas pelo curso a sua prática e seu uso constante, vemos que o professor assumiu uma responsabilidade sistemática em relação ao curso realizado.

Optou, para seu PE, planejar uma aula e materiais didáticos para a determinação da Lei de Gauss por esse método alternativo. Inicialmente, iria utilizar como recurso para as aulas, por indicação de seu co-orientador, papel milimetrado. Porém, também pensou em adaptar a aula para o uso de ferramentas das TICs, no caso, o uso de simulações de banco óptico do PhET e o software Geogebra, que permite a construção de gráficos. Preocupou-se em pensar a realidade que pode ser encontrada nas escolas, que nem sempre dispõem de computadores, mantendo, portanto, a sugestão inicial do uso do papel milimetrado. Isso porque reconhece que "enquanto professor, a gente encara essas realidades diferentes" e, então, para não deixar de abordar os conteúdos educacionais com as turmas, "o que é cruel", pensa ser importante investir no planejamento de diferentes abordagens, para serem utilizadas em diferentes contextos. Por dar aulas em dois contextos diferentes entre si (uma escola privada de elite e uma escola estadual), o professor se envolve nesses processos de adaptação das propostas de ensino, de modo que a inovação de suas práticas se encontra em um nível reflexivo. 
Além disso, a proposta do uso das TICs foi balizada "justamente para tentar estimular mais o aluno a levar o roteiro pedagógico até o fim", estimulá-lo a tomar dados para a construção do método para estudo da Lei de Gauss de forma ativa. MNPEF.15 aponta que não conhecia o software Geogebra, que encontrou ao procurar programas que poderiam ser utilizados para desenhar gráficos no computador. Essa pesquisa para a realização do seu PE se desdobra em aumento do seu repertório de recursos que podem ser utilizados nas suas aulas, que impactam diretamente, no caso, na dimensão organização e condução de ensino do desenvolvimento profissional.

Sua entrevista, no entanto, indica alguns fatores limitantes para tal impacto. MNPEF.15 cita, por exemplo, que em uma disciplina, chegou a conhecer outro recurso, que permite a realização de aplicativos na plataforma Scratch. Por fatores intrínsecos ao próprio recurso, que demanda tempo para sua programação e paciência para resolver os "bugs", ou seja, problemas que podem surgir, afirmou que não é algo que utiliza em suas aulas.

Indagado sobre impactos na sua prática profissional proporcionados pelo MP, MNPEF.15 aponta que a aplicação do seu próprio PE nas suas aulas foi significativa para melhorá-las, além de aperfeiçoar seu produto, pela análise de sua avaliação. Aproveitando uma das escolas que trabalha ser de referência e "aberta a novas temáticas, novos paradigmas", chegou a utilizar os PEs de todos os seus colegas de sua turma do mestrado. Diz que teve essa atitude para contribuir para a formação de seus colegas, aplicando na escola e registrando dados. Não aponta, no entanto, se ainda utiliza esses PEs nas aulas, e que tipo de enriquecimento essas aplicações lhe proporcionaram.

Ainda em relação aos PEs, considera de grande importância a participação no Simpósio de Ensino de Física promovido no polo. Por ser da turma de 2014, diz que foi muito bom ver trabalhos mais adiantados da turma de 2013, justamente para pensar seu próprio trabalho.

Outro impacto do MP ressaltado por MNPEF.15 em seu desenvolvimento profissional tem relação com o acesso às fontes acadêmicas, com o estudo de textos científicos. É um desdobramento que tem relação com a atualização dos conhecimentos científico e pedagógico, mas também guarda relação com a superação da hegemonia do livro didático, discutida por Moreira et al. (2018), além da perspectiva da formação do professor como profissional pesquisador. Indica, também, 
a importância da aproximação dos profissionais com o mundo acadêmico, apesar do contexto de formação ser justamente o de um mestrado profissional:

\begin{abstract}
MNPEF.15: "[...] No meu caso, eu buscava formação com livro antigo que eu comprava, eu sempre gostei a ler, gosto de pesquisar... Mas num caráter mais didático, digamos assim. E no mestrado não, no mestrado eu tinha feito uma coisa acadêmica. Pegava dissertacões mais antigas, pegar artigos, na minha relação profissional, até eu entrar no mestrado, eu não pesquisava em artigo, eu pesquisava em livro. Porque eu, professor, quero aplicar em sala! Então, assim, acabou ampliando um pouco mais esse meu olhar. E na [instituição] a gente era assim estimulado a olhar um artigo, a pesquisar um artigo, dentro das próprias disciplinas [...] vamos discutir isso daqui, vamos ler isso daqui, tinha uma hora que a gente pegava o jeito, de escrita, de metodologia, maneira... Então isso foi um ponto alto da [instituição], essa imersão da gente no mundo acadêmico, mesmo sendo um mestrado altamente profissional".
\end{abstract}

\title{
5.1.8 Análise com elementos narrativos de MNPEF.17: o professor que se tornou mais seguro de si
}

O egresso MNPEF.17 é taxativo ao dizer a razão que teve em ingressar no MP. Sentia-se desmotivado em relação a sua profissão, após trabalhar como professor da educação básica por quase 20 anos: "chegou num limite que você para, não consegue mais ir adiante e você quer um novo desafio [...] Eu queria fazer o mestrado para ter também outras possibilidades de trabalho" (MNPEF.17). A perspectiva em superar 0 patamar estanque que tinha alcançado no desempenho de suas funções e carreira aparece também quando diz que tinha prestado um concurso para tornar-se diretor, função que acabou assumindo em uma escola no decorrer do curso de MP.

Relata que tinha tentado realizar anteriormente outros cursos de pós-graduação. Por ser graduado em Matemática, ele tentou ingressar no mestrado em Matemática pura. Também tentou o mestrado em Ensino da Física, desvinculado do MNPEF, na capital do estado em que reside. Porém, encontrou diversas dificuldades para realizar esses cursos, entre eles, a questão de ser residente em uma cidade do interior, e as limitações financeiras e de tempo.

Apesar dessas dificuldades com os cursos de pós-graduação stricto sensu, nunca deixou de investir em cursos de formação continuada ao longo da carreira, tendo realizado alguns à distância oferecidos por diferentes instituições, além de uma especialização em Matemática Avançada e Computacional. Pelo interesse prévio em investir em sua própria formação e pela estagnação que se encontrava em sua profissão, ao saber do processo seletivo para o polo do MNPEF, avisado pelo diretor da escola em que trabalhava, decidiu participar da seleção. Sendo aprovado, 
ingressou no polo na primeira turma, em 2013. Apesar do polo estar sediado em outra cidade, e, na época, MNPEF.17 trabalhar em outras duas cidades diferentes, decidiu investir nessa formação. A possibilidade de bolsa de estudos foi um fator significativo, também, para essa decisão. Mas o grande apelo era o crescimento profissional que almejava: "era algo que eu necessitava para tentar crescer, porque profissionalmente eu cheguei num ponto que eu achava que não ia conseguir crescer, e [o mestrado] era dentro da minha área, que era Ensino" (MNPEF.17).

MNPEF.17 é mais um egresso que destaca a integração do grupo de professores-cursistas e o apoio mútuo que encontrou no curso. Destaca a questão de nenhum deles considerar-se concorrentes um do outro. Sobre a turma, diz que:

MNPEF.17: "Em nível de mestrado, foi uma turma muito diferente.
Todas as diferenças políticas, sociais e de distância (mas) a gente se
dava muito bem. A relação humana... Cada um ajudava... cada grupo
ajudava o outro [...] Depois que a gente solidificou, teve dois ou três
alunos que tentaram parar o curso. Teve quem não defendesse, uma
outra situação. De terminar as disciplinas, a gente tentava se ajudar e
perguntar porque ele, fulano, beltrano, sicrano, ele desistiu? Aí eles
mandavam mensagem, entendeu? [...] eu acho que uma turma como
a minha, acho que vai ser difícil acontecer novamente"

Ao discorrer sobre o desenvolvimento do curso, pondera que foi desgastante, por estar envolvido em trabalhos em cidades diferentes, e ter que organizar toda uma logística de horários. Além das questões de organização pessoal, considera que foi um curso exigente. Sobre as disciplinas, diz que os docentes "criaram uma dinâmica que a gente ralou muito, que era fazer seminário ou resumo de tudo que a gente lia, para entregar para eles, mais provas, avaliações, experimentações [...]" (MNPEF.17).

O desenvolvimento do PE também Ihe foi exigente. Conta que seu orientador indicava inúmeras leituras, incluindo literatura em outros idiomas. No entanto, ao descrever como era o processo de orientação, declara que teve muito apoio do seu orientador em todo o processo: "eu cheguei acho que no final também da minha tese, de conseguir defender, porque ele me apoiou muito. Faz a diferença" (MNPEF.17). Apesar de resumir o curso todo utilizando a palavra "trágico", reconhece que "essa caminhada toda foi muito boa porque você começa a adquirir conhecimento. [...] você comeca a forcar a aprender outras coisas" (MNPEF.17). Ou seja, o MP atendeu suas expectativas de encontrar um novo desafio para motivar-se, deslocando-o de sua zona de conforto e, assim, dedicou-se ativamente em seu percurso formativo. Colaborando para vencer o desafio e todas as dificuldades, juntamente com o esforço necessário, foram fundamentais tanto o apoio do grupo de professores-cursistas o qual fez parte, quanto o apoio do seu orientador. 
O PE partiu de uma sugestão do próprio orientador, que lhe agradou. A proposta era trabalhar com jogos e vídeo-análise para abordar conteúdos de Cinemática. MNPEF.17 relata que "a aposta dele [orientador] me fascinou no primeiro dia de aula, porque ele falou, 'dá para aprender Física usando um jogo...' [...] aí eu olhei e achei interessante... eu fui conversar sobre isso". Apesar da problemática do PE não ter partido de sua própria prática, o tema levantado pelo orientador parece se adequar a uma inquietação prévia de MNPEF.17.

Ao explanar sobre algumas reflexões decorrentes da aplicação de seu PE, MNPEF.17 expressa a questão da renovação de metodologia de ensino, em contraposição à metodologia considerada tradicional. Reflete sobre a questão de se observar se a nova metodologia foi determinante para o aprendizado do aluno, influindo diretamente em sua cognição, ou se ela incidiu sobre a sua motivação, que por sua vez, fez o aluno se engajar mais na sua própria aprendizagem, alcançando melhores resultados. Pondera que não teria como avaliar isso a partir dos dados obtidos com a avaliação do PE em sua dissertação, mas observa que os alunos de fato criaram uma melhor relação com o professor, e uma mudança de hábito pois eles ficaram mais engajados em suas aulas. Relata casos particulares de alunos que mudaram de postura, quando ele começou a usar o jogo e a vídeo-análise na recuperação paralela de suas turmas de Física. Essa contraposição entre o método de ensino tradicional e o inovador, que permite maior engajamento dos alunos, é algo que marcou a prática do egresso:

MNPEF.17: "Esse ano [de aplicação do PE na escola], eu fui muito tradicional enquanto professor. Não dei nada de extraordinário, aula normal, basicamente passei um vídeo ou dois no máximo, não fugi do professor tradicional. [...] E aí você vê as dificuldades da aula tradicional, que um ou dois alunos, que eram mais revoltados... Eles foram que quiseram fazer o trabalho [aplicação do PE]. Quando fiz aquela apresentação [reprodução em tamanho real de cenas do jogo com os alunos], eles sempre insistiram, eles sempre quiseram fazer a aula, e depois eles mudaram o comportamento comigo. [...] Foi perceptível a mudança de comportamento deles, dentro de sala de aula, após fazer o trabalho dentro de uma sala de informática".

Essa mudança de comportamento dos alunos é relatada em outros episódios, que partiram da própria iniciativa deles. Como o estudo que fizeram das imagens de um acidente do avião que tinha virado notícia àquela época, para estimar pela vídeoanálise, a velocidade do avião instantes antes do acidente. O egresso conta que notou que o envolvimento dos alunos nas atividades desenvolvidas no PE foi marcante para os mesmos. Após um ano de desenvolvimento da atividade, eles ainda recordavam dela. Essa vivência ampliou a percepção do professor em relação ao aluno, refletindo 
nas dimensões organização e condução de ensino e sustentação de aprendizagem de seu desenvolvimento profissional.

Em relação à organização e condução de ensino, MNPEF.17 cita diversas metodologias e alguns recursos que utilizou em sala de aula que estão distantes da abordagem tradicional de ensino. Conta que já utilizou o smartphone em sala de aula em contexto de avaliação dos alunos, que já ensinou simulando um talk show em sala e que com as simulações virtuais do PhET vislumbrou que "existem outras variações de você explicar" determinado conteúdo. Por limitações de carga horária da disciplina na escola, não descarta o uso de aulas mais expositivas, mas considera como melhor caminho ser "intermediário", diversificando o quanto possível o uso de metodologias e recursos de ensino. Dessa forma, assumiu uma responsabilidade sistemática frente as suas aulas, após a realização do MP, pois confessou durante a entrevista que era um professor que raramente fazia uso de outros tipos de aulas além da expositiva antes do curso.

O seu olhar para os alunos e o desempenho deles se apura ainda mais, indicando o desenvolvimento na dimensão sustentação da aprendizagem. Indo além disso, o professor diz se sentir seguro em agir de acordo com suas percepções para apoiar a aprendizagem de seus alunos. Aplica os conhecimentos obtidos no mestrado para apoiar suas escolhas nas situações com as quais se depara na prática, indicando uma inovação reflexiva das mesmas:

MNPEF.17: "E aí você vai se frustrando com aqueles alunos que você não conseguiu recuperar, porque você poderia ter tido um outro olhar, um outro modo, para você perceber esse aprendizado. Eu já tinha isso. Só que eu não tinha, ou não teria, na época, coragem, de assumir determinadas coisas. Hoje eu tenho."

Essa coragem tem a ver com o modo que suas ações como professor são recebidas na escola que trabalha, em relação aos colegas professores e à gestão escolar. MNPEF.17 afirma que, apesar de "ridículo", sente que "quando você tem pós, as pessoas já te olham de outra forma", mesmo que defenda as mesmas ideias que defendia quando não tinha ainda o título de pós-graduação. Assim, a realização do mestrado faz com que os colegas de trabalho enxerguem o professor de forma diferente, com maior reverência e credibilidade. Particularmente, MNPEF.17 percebe que a realização do curso, de fato, faz com que ele desenvolva uma melhor argumentação para defender o que faz, porque leu mais, adquiriu maior conhecimento acadêmico para apoiar seu trabalho. Essa questão incide sobre a maior valorização do professor enquanto profissional especializado. 
Em contraposição, MNPEF.17 encontrou também incompreensão, o que provocou desconforto entre ele e seus colegas de trabalho. MNPEF.17 expõe que encontrou resistências por parte do diretor e coordenador da escola, onde aplicou seu PE. Teve que enfrentar algumas dificuldades referentes ao uso da sala de informática e em relação à metodologia que estava sendo aplicada, que não era levada à sério. Nas palavras de MNPEF.17:

MNPEF.17: "Você começa a ver que as pessoas começam a olhar você de forma que você está fazendo uma palhaçada na visão deles, porque não conseguem entender. Até você explicar, até você mostrar que você está fazendo algo que é uma dissertação de mestrado, é complicado. [...] Propriamente dito, a gente começa a ter dificuldades aí. Começa a querer minar o seu trabalho, Ihe prejudicando em tempo, em relação ao que fazer... não acha interessante. Ele acha, a pessoa acha porque não está fazendo o mestrado, que você é o 'bambambam', não é, não sou o 'bambambam', ninguém é".

Apesar das dificuldades em seu ambiente de trabalho, alterou sua percepção em relação ao aluno, conforme já dito, e alterou algumas rotinas de trabalho. MNPEF.17 se refere à mudança de percepção em relação à avaliação do aluno, à necessidade de uma abordagem mais conceitual da Física, além do rompimento com o que é estabelecido como padronizado e tecnicista em livros didáticos, de modo a facilitar o entendimento dos conceitos por parte dos alunos. São mudanças de atitudes que reforçam o desenvolvimento desse professor nas dimensões organização e condução do ensino e sustentação da aprendizagem. MNPEF.17 apresenta a consciência da percepção de todas essas modificações do seu modo de agir e pensar:

MNPEF.17: "Essa modificação que teve na minha vida. Eu não sou mais a mesma pessoa. Eu penso de outra forma. Antes a gente é meio duro e calculista, hoje eu sou mais maleável em relação ao que eu acho. Eu acho que a gente pode experimentar para ensinar o aluno. Fazer um teatro para ensinar História, Geografia, Física, Matemática... Eu era assim, mas eu não me aceitava muito. Eu só comecei a aceitar determinadas coisas depois".

Atribuímos essa auto-aceitação referida pelo MNPEF.17 às leituras e discussões realizadas no contexto das disciplinas e de elaboração do PE no MP, além das trocas proporcionadas entre todos os mestrandos. O MP proporcionou a esse professor a visão de que é possível fazer diferente. A importância em se viver, enquanto "aluno de mestrado", as práticas docentes que se pretende incorporar, enquanto professor parece ser fundamental para esse movimento. Esse é um ponto positivo do curso destacado pelo egresso:

MNPEF.17: "Nós tivemos tanta prova, mas tivemos muita aplicabilidade daquilo que a gente estava aprendendo. Acho que tem que ter sim, a matéria 'dura'. A forma de avaliar, eu acho que foi perfeita. Porque a gente não traumatizou e aprendeu, exatamente isso que a gente está fazendo fora do mestrado, a gente tem que 
ensinar usando de alguma forma essas técnicas todas de tal conteúdo, vamos ver o resultado, vamos fazer de outra forma..."

Por fim, MNPEF.17 sinalizou o desejo de fazer um doutorado, no que ainda não investiu porque precisaria de mais tempo para se dedicar aos estudos o que, na configuração atual de seu trabalho, sendo diretor de uma escola, não encontraria tão facilmente.

\subsubsection{Análise com elementos narrativos de MNPEF.19: o professor que se sentiu valorizado}

Para ingressar no MP, o egresso MNPEF.19 enumera três grandes motivações: o plano de carreira da escola estadual onde trabalha, que beneficia com melhor remuneração os docentes mestres; a busca por retomar os conhecimentos da universidade, pois fazia doze anos que tinha se formado na graduação e, em sua visão, "você perdendo o contato com a universidade, você perde um pouco também de conteúdo, você acaba esquecendo algumas coisas" (MNPEF.19); e, por fim, a busca por sanar algumas deficiências de sua prática, em relação à inserção de conteúdos de Física Moderna no Ensino Médio. O polo do MNPEF foi escolhido por conta dos horários e pela questão de conseguir com maior facilidade uma bolsa de estudos. Tinha expectativas "altíssimas", pois esperava encontrar no polo professores que fossem referências da área, já que a instituição que sedia o polo é uma instituição renomada. Gostaria de, no MP, ampliar seus conhecimentos para melhorar a sua sala de aula, promovendo, por exemplo, práticas mais elaboradas de laboratório, já que trabalhava com aulas experimentais nas escolas.

Nesse sentido, as disciplinas, oferecidas em todos os semestres do curso, atenderam suas expectativas, pois não se apresentavam como uma "coisa assim utópica, fora do quê a gente vive realmente na escola" (MNPEF.19). MNPEF.19 descreve da seguinte forma a sua experiência com as disciplinas do curso:

MNPEF.19: "Eu fiz uma disciplina com um professor [do MNPEF, que
ele fez o curso dele todinho, baseou o curso dele todinho em
experiências vividas pelo professor. Então, a maior parte do curso era
com professores muito engajados com a questão do ensino. [...] Eles
procuravam pegar o que a gente trazia da sala de aula, para poder
desenvolver o curso deles em cima disso".

O egresso dá o exemplo da disciplina Mecânica Quântica, com a proposta de elaboração, em duplas e trios, de propostas de aula para abordar conteúdos de Física Moderna no Ensino Médio, complementando a descrição dada pelo egresso MNPEF.15, que além de ter sido seu colega no MP, é colega de trabalho no colégio 
privado de elite. MNPEF.19 diz que o docente responsável apoiou o trabalho dos professores-mestrandos dando "referências de vários artigos para a gente poder ler [...] e aí ele ia orientando a gente e a gente apresentava esse trabalho". Em sua visão, foi uma dinâmica bastante produtiva que ampliou a discussão entre professores. É uma estratégia adotada em outras disciplinas: "pegar as nossas experiências em sala de aula e trazer sempre em cima de artigos, já consagrados no ensino de Física" (MNPEF.19). Foi também uma oportunidade de atualização de seus conhecimentos científicos e pedagógicos, e ter o contato com artigos acadêmicos, indicados pelos docentes das disciplinas. Pelo envolvimento relatado, inferimos que sua dedicação ao longo do curso tenha sido ativa.

As disciplinas também deram suporte para MNPEF.19 buscar um tema para que pudesse desenvolver em seu PE. Um dos artigos indicados em uma das disciplinas que cursou, sobre concepções alternativas no ensino de Física, Ihe chamou a atenção. Relacionou a discussão do artigo com a questão do ensino dos conceitos de força e movimento em Física, que apesar de considerar um assunto "batido", vê que ainda é um problema para os alunos, pois eles confundem muito esses conceitos. Dessa forma, vemos que o professor se debruçou sobre um problema de sua prática, utilizando um referencial teórico, para entender as dificuldades de aprendizagem de seus alunos, conhecido no contexto das disciplinas do MP. Para o PE, planejou uma prática de laboratório, com a gravação de uma situação de movimento e vídeo-análise com o uso do software Tracker.

Como resultados da aplicação do PE, diz que percebeu uma maior motivação dos alunos e a oportunidade de os alunos conseguirem associar melhor o conteúdo com o fenômeno que acontece na prática, algo mais difícil de ocorrer com uma aula expositiva, em sua opinião. MNPEF.19 percebeu o maior envolvimento dos alunos na aula, e maior proximidade com as turmas. Entende que "a proximidade com o professor, também ajuda, porque aí você tem um contato, você consegue perceber no aluno qual é a dificuldade dele, e consegue atuar de forma mais incisiva" (MNPEF.19). É uma fala que expressa indícios da preocupação do professor em perceber as dificuldades dos alunos, que reflete no desenvolvimento da dimensão sustentação da aprendizagem. Trabalhando dessa forma em suas turmas, acredita que "não consegue resolver todos os problemas, mas a gente vê que [...] criando esses espaços, fica no caminho de melhorar o ensino de Física" (MNPEF.19).

Como impactos em sua prática, MNPEF.19 primeiramente comenta sobre aspectos gerais. Ressalta a percepção que teve de valorização da profissão ao realizar o MP. É interessante apontar que a valorização percebida por ele não foi 
decorrente da imagem que colegas de seu ambiente de trabalho passaram a ter dele e de seu trabalho após ter cursado o MP, como ocorreu com outros egressos. Ao longo do curso, ao participar dos seminários semanais com a participação de docentes de outras instituições convidados, e do Simpósio de Ensino de Física do polo, MNPEF.19 diz que teve a oportunidade de conversar pessoalmente com pesquisadores que são referências na área, incluindo Marco Antônio Moreira, mentor do MNPEF. Sentiu-se valorizado ao poder conversar com esses pesquisadores de igual para igual.

A aproximação entre universidade e escola de educação básica é algo que MNPEF.19 enfatiza como muito importante no MP. Percebe que "esse mestrado serve para aproximar a universidade da escola. A gente traz pesquisa de ponta lá em ensino para dentro da escola, para a realidade da escola, isso daí de fato faria toda a diferença" (MNPEF.19). Assim, o MP proporciona a atualização dos conhecimentos pedagógicos decorrente do contato das pesquisas atuais em ensino de Física, conhecimentos esses que são transpostos pelos mestrandos à realidade das escolas. Esse seu envolvimento com os resultados de pesquisa indica uma inovação reflexiva em relação à sua prática.

Em termos mais restritos, o curso pareceu atender às demandas iniciais desse egresso. Comenta aspectos, grande parte das vezes adquiridos nas disciplinas, que influem sobre a dimensão organização e condução de ensino de seu desenvolvimento profissional, traduzidos em novos recursos e novas abordagens que podem ser levadas para sua prática. Envolvem não apenas a questão de uso de determinados recursos, mas também mudanças de concepções:

MNPEF.19: "Tive várias ideias para aplicar no laboratório, depois que eu fiz o curso no mestrado. Aplicativos novos... Tem vários recursos que eu utilizo, por exemplo, estava dando aula agora nesse tempo anterior [antes da realização da entrevista] sobre eletrodinâmica, corrente elétrica, circuito elétrico. Aí na época que eu fiz o curso de eletrodinâmica do mestrado, o professor lá na ocasião, o Do.MNPEF06 mostrou vários aplicativos que eu uso em sala de aula agora, aplicativos que eram estrangeiros, de fora do Brasil, desenvolvido por universidades... Colorado, que é o PhET... outras, da Inglaterra e tal, que a gente usa para dar em sala de aula do ensino médio, é muito legal. E uma forma didática para passar para o aluno, às vezes 0 vídeo que você viu lá, o documentário que você usa".

MNPEF.19: "Às vezes a Filosofia da Ciência, que você estuda um artigo, a gente consegue ter uma visão... assim, amplia um pouco a visão, de repente fazer um trabalho interdisciplinar, com o professor de Filosofia da escola. [...] O mestrado me deu essa visão maior para mim, ampliou minha visão, e a questão do laboratório, me deu essa alternativa de fazer um laboratório que não precise de tanto recurso [material]".

Seus relatos acima indicam a transformação de suas práticas após a realização do MP, indicador de responsabilidade no nível sistemático. Conta, além disso, que 
percebe alguns impactos nos próprios colegas professores de Física nas escolas que trabalha. Acredita que, de forma indireta,

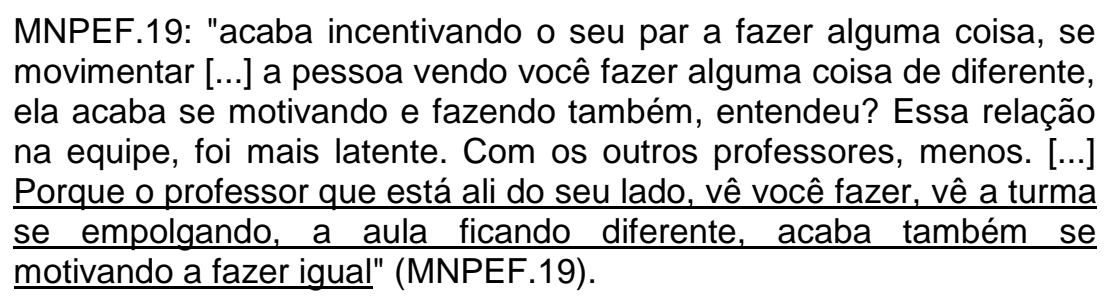

São possíveis impactos nas escolas de educação básica nas quais os professores mestres trabalham. Impactos que, no entanto, partiriam de uma iniciativa individual.

MNPEF.19 também é um egresso que ressalta como ponto alto do curso o acolhimento dos professores, o que considerou fundamental para a sua conclusão, por conta de todo esforço físico e mental que dedicava para seu trabalho nas quatro escolas que leciona. Essa questão subjetiva é de extrema importância para fazer o curso atender as demandas que se propõe:

\begin{abstract}
MNPEF.19: "[O acolhimento dos professores] foi o ponto alto do mestrado, porque como você é muito bem acolhido, você se sente confortável para botar as suas angústias ali, e colocar os seus problemas, porque é isso que o mestrado se propõe, o MP, resolver a angústia do professor que está em sala de aula ali, tentando desenvolver o ensino de Física. Então esse foi o ponto alto do mestrado que me fez continuar na universidade até o final [...] e concluir rápido [...] Para divulgar o trabalho, e a gente se sente motivado também, para poder de repente continuar estudando, fazer um doutorado, isso influencia também na continuação da formação do professor. É importante".
\end{abstract}

\title{
5.1.10 Análise com elementos narrativos de MNPEF.28: o professor que mudou sua visão
}

O egresso MNPEF.28 buscava no MP aprender sobre o uso de novas tecnologias em sala de aula, e outras abordagens novas que pudesse aplicar em suas aulas. A escolha do polo do MNPEF se deu por conta da distância favorável em relação à cidade que residia e trabalhava e a facilidade dos horários.

Reconhece as dificuldades estruturais das escolas públicas para a utilização de novas tecnologias nas aulas, mas acha que "é importante a gente estar buscando e tentando um caminho novo para ajudar os nossos alunos do ensino médio no aprendizado de Física" (MNPEF.28). Entre as dificuldades, aponta a falta de conexão de internet ou conexão insuficiente para acesso em todas as salas, falta de datashow nas salas de aula, muitos alunos que não possuem smartphones. Algumas as quais 
considera que podem ser contornadas, utilizando programas de computador que podem funcionar offline e propondo o trabalho dos alunos em duplas.

Um fator limitante para esse egresso é o pouco tempo que tem disponível para o planejamento de atividades com metodologias inovadoras, por trabalhar todos os dias da semana, de manhã e de tarde. Diz que, inclusive por conta da rotina exaustiva de trabalho, teve que pedir prorrogação para a elaboração do PE e dissertação para a conclusão do curso. Por conta disso, diz o quanto o curso foi trabalhoso, mas se sente recompensado por tê-lo realizado. A realização do MP no polo do MNPEF the proporcionou o contato com discussões, principalmente no âmbito das disciplinas, que o fizeram enxergar questões que não percebia em seu cotidiano, o que revela a possibilidade de uma inovação reflexiva de sua prática:

MNPEF.28: "[...] pude ter contato com coisas que na correria do dia a dia a gente acaba não conseguindo, por exemplo, mais atenção aos nossos alunos. Entender também que eles passam por situações, por dificuldades que muitas das vezes a gente acaba não enxergando e no meio dessas discussões assim, você para um pouco para refletir sobre isso e ter um olhar diferente para o aluno, tentando ajudar ele a caminhar, a crescer, a se desenvolver para contribuir com a nossa sociedade como um todo".

Assim, o conteúdo abordado nas discussões fez com que esse egresso desnaturalizasse sua prática e se preocupasse mais em perceber as necessidades de seus alunos, indicando o aprimoramento na dimensão sustentação da aprendizagem de desenvolvimento profissional. O efeito dessas discussões em suas próprias concepções pressupõe uma dedicação ativa ao curso. Essa mudança de atitude parece estar relacionada com outra visão que começou a ter com os conhecimentos pedagógicos adquiridos no curso, em especial, com o estudo do livro sobre teorias de aprendizagem de Marco Antônio Moreira, indicada por Do.MNPEF-01 como leitura obrigatória na disciplina Fundamentos Teóricos em Ensino e Aprendizagem.

MNPEF.28: "Eu tinha um certo... não sei se a palavra correta é preconceito com relação às teorias de ensino e aprendizagem. [...] 0 pessoal de 'exatas' às vezes fica um pouco distante disso. Eu acho que o mestrado me levou um pouco mais para esse lado, ver isso de uma maneira diferente. [...] contribuiu de enxergar de maneira diferente 0 aluno e de tentar entender melhor de como é que esse aluno aprende. De como chegar nesse aluno para que ele tenha 0 aprendizado".

Porém, ainda permanece em aberto para o egresso, a questão de renovação de suas práticas de modo que sua responsabilidade se revela no nível eventual. Não basta adquirir o conhecimento de novas metodologias, novos recursos e conteúdo, mas é preciso criar condições para que o professor possa inseri-las nas suas escolas. 
O fator limitante para MNPEF.28, como já exposto, é a falta de tempo suficiente para preparar suas aulas:

MNPEF.28: "você ter uma aula diferente, às vezes não basta ter o conhecimento, você precisa ter tempo. E a realidade do professor no Brasil é trabalhar em muitas escolas ou uma carga horária pesada para conseguir um retorno para se sustentar. $\mathrm{E}$ isso acaba inviabilizando um pouco a aplicação dessas novas informações que você recebe [...] abriu a minha mente, eu comecei a enxergar o ensino de Física de uma maneira diferente do que antes do mestrado [...] e aí falta tempo para você preparar algo diferente. Às vezes você consegue fazer alguma coisinha, mas não chega a atingir o que eu gostaria de fazer, entendeu?"

Também pela falta de tempo para dedicar-se, em termos de eventos acadêmicos, chegou a participar apenas do Simpósio de Ensino de Física do polo. Sobre esse evento, aponta que ficou mais restrito à participação de quem já cursava 0 mestrado, e considera que seria melhor se pudesse contar com a participação de mais professores externos ao curso. MNPEF.28 comenta de alguns colegas que publicaram artigos e apresentaram seus trabalhos em eventos da área, como o SNEF. MNPEF.28 diz que ainda recebe e-mails da secretaria do polo com divulgações de eventos da área e do Simpósio em Ensino de Física do polo: "caso queira escrever um trabalho, queira participar de alguma coisa, mantém, o contato é mantido e eles continuam sempre alimentando isso" (MNPEF.28).

Para finalizar, aponta a importância do desenvolvimento do trabalho escrito, ou seja, ter a "prática da escrita que não estava fazendo parte do meu dia a dia por conta de só 'aula, aula, aula"' (MNPEF.28). A realização do MP proporcionou ao professor, portanto, a oportunidade de se envolver com uma nova atividade, que provavelmente nunca assumiria fora do curso, por dificuldades, novamente, com a rotina de trabalho. Descreve uma disciplina no final do seu curso que o auxiliou na escrita da dissertação. O egresso não informou o nome da disciplina, mas provavelmente a disciplina referida é a de Estágio Supervisionado, que foi utilizada como um espaço para os docentes do curso auxiliarem os professores-cursistas de forma coletiva com a aplicação dos PEs nas escolas, como informado por MNPEF.03 em sua entrevista.

\subsection{0 desenvolvimento profissional de egressos do MP.Local}

Dez egressos de turmas que ingressaram no MP.Local desde sua criação e defenderam até o ano de 2017 aceitaram o convite para participação nessa pesquisa. Eles são identificados na Tabela 12, juntamente com uma breve descrição de suas formações, ano de defesa e atuação profissional atual (no ano de 2018, quando as 
entrevistas foram realizadas), informações obtidas nas entrevistas ou em seus currículos Lattes.

Tabela 12 - Apresentação geral dos egressos do MP.Local entrevistados.

\begin{tabular}{|c|c|c|c|c|}
\hline $\begin{array}{l}\text { IDENTIFICAÇÃO } \\
\text { DO EGRESSO }\end{array}$ & $\begin{array}{l}\text { FORMAÇÃO } \\
\text { INICIAL }\end{array}$ & $\begin{array}{l}\text { FORMAÇÃO PÓS- } \\
\text { GRADUADA }\end{array}$ & $\begin{array}{l}\text { ANO DE } \\
\text { DEFESA } \\
\text { NO MP }\end{array}$ & $\begin{array}{c}\text { ATUAÇÃO } \\
\text { PROFISSIONAL } \\
\text { ATUAL }\end{array}$ \\
\hline MP.Local.01 & $\begin{array}{l}\text { Graduação } \\
\text { em } \\
\text { Engenharia } \\
\text { Elétrica e } \\
\text { Licenciatura } \\
\text { em Física }\end{array}$ & --- & 2010 & $\begin{array}{l}\text { Atua em um instituto } \\
\text { federal }\end{array}$ \\
\hline MP.Local.02 & $\begin{array}{c}\text { Licenciatura } \\
\text { Plena em } \\
\text { Matemática } \\
\text { e } \\
\text { Licenciatura } \\
\text { em Física }\end{array}$ & $\begin{array}{c}\text { Anterior ao MP: } \\
\text { especialização em } \\
\text { Matemática } \\
\text { Avançada e } \\
\text { Computacional } \\
\text { Posterior ao MP: } \\
\text { doutorado em Física } \\
\text { básica }\end{array}$ & 2010 & $\begin{array}{c}\text { Atua em um instituto } \\
\text { federal }\end{array}$ \\
\hline MP.Local.03 & $\begin{array}{l}\text { Graduação } \\
\text { em Física }\end{array}$ & $\begin{array}{l}\text { Anterior ao MP: } \\
\text { mestrado em } \\
\text { Radioproteção e } \\
\text { Dosimetria }\end{array}$ & 2012 & $\begin{array}{l}\text { Atua em um colégio } \\
\text { da rede federal }\end{array}$ \\
\hline MP.Local.04 & $\begin{array}{l}\text { Licenciatura } \\
\text { em Física }\end{array}$ & $\begin{array}{c}\text { Posterior ao MP: } \\
\text { doutorado em Física } \\
\text { básica }\end{array}$ & 2012 & $\begin{array}{c}\text { Atua em um instituto } \\
\text { federal }\end{array}$ \\
\hline \multirow[t]{2}{*}{ MP.Local.06 } & $\begin{array}{l}\text { Licenciatura } \\
\text { em Física }\end{array}$ & $\begin{array}{c}\text { Anterior ao MP: } \\
\text { especialização em } \\
\text { Novas Tecnologias } \\
\text { no Ensino da } \\
\text { Matemática }\end{array}$ & 2012 & $\begin{array}{c}\text { Atua em um instituto } \\
\text { federal }\end{array}$ \\
\hline & & $\begin{array}{l}\text { Posterior ao MP: } \\
\text { doutorado } \\
\text { profissional em } \\
\text { Ensino de Ciências }\end{array}$ & & \\
\hline MP.Local.12 & $\begin{array}{l}\text { Licenciatura } \\
\text { em Física }\end{array}$ & --- & 2014 & $\begin{array}{l}\text { Atua no ensino } \\
\text { médio da rede } \\
\text { pública estadual }\end{array}$ \\
\hline
\end{tabular}

(continua) 


\begin{tabular}{|c|c|c|c|c|}
\hline MP.Local.14 & $\begin{array}{c}\text { Graduação } \\
\text { em } \\
\text { Pedagogia }\end{array}$ & $\begin{array}{c}\text { Anterior ao MP: } \\
\text { especialização em } \\
\text { Orientação } \\
\text { Educacional } \\
\text { Posterior ao MP: } \\
\text { Ingressou em } \\
\text { doutorado em } \\
\text { Educação }\end{array}$ & 2014 & $\begin{array}{c}\text { Atua como técnica } \\
\text { em assuntos } \\
\text { educacionais em } \\
\text { uma universidade } \\
\text { federal }\end{array}$ \\
\hline MP.Local.15 & $\begin{array}{c}\text { Licenciatura } \\
\text { em Física }\end{array}$ & $\begin{array}{c}\text { Anterior ao MP: } \\
\text { especialização em } \\
\text { Educação em } \\
\text { Ciências e } \\
\text { Tecnologia } \\
\text { Posterior ao MP: } \\
\text { doutorado em } \\
\text { Educação em } \\
\text { Ciências }\end{array}$ & 2015 & $\begin{array}{c}\text { Dedica-se } \\
\text { integralmente à } \\
\text { pesquisa }\end{array}$ \\
\hline MP.Local.16 & $\begin{array}{c}\text { Licenciatura } \\
\text { em Física }\end{array}$ & --- & 2016 & $\begin{array}{l}\text { Atua no ensino } \\
\text { superior como tutor } \\
\text { de educação à } \\
\text { distância e professor } \\
\text { de universidade }\end{array}$ \\
\hline MP.Local.18 & $\begin{array}{l}\text { Graduação } \\
\text { em Física }\end{array}$ & --- & 2017 & $\begin{array}{c}\text { Atua no ensino } \\
\text { médio da rede } \\
\text { pública estadual e } \\
\text { privada }\end{array}$ \\
\hline
\end{tabular}

As análises com elementos narrativos são apresentadas a seguir. Assim como nas análises dos egressos do MNPEF, elas apresentam estrutura semelhante ao do roteiro de entrevistas utilizado, com pequenas modificações entre elas. Analisamos também as mesmas classes de dados.

\subsubsection{Análise com elementos narrativos de MP.Local.01: o professor prático}

O egresso MP.Local.01 coloca como única motivação para a realização do curso a melhoria salarial no cargo que tinha acabado de assumir em um instituto federal. A questão de ampliar os próprios conhecimentos aparece de forma secundária. Particularmente, esse professor era engenheiro eletricista com grande experiência na área durante anos, estando quase no momento de se aposentar. No entanto, acabou 
ingressando no curso de licenciatura em Física após anos de trabalho como engenheiro eletricista e posteriormente, prestes a terminar a graduação, passou no concurso para dar aulas nos cursos técnicos oferecidos pelo instituto federal. Destaca que inegavelmente, no desenrolar do MP, aprendeu muita coisa, em especial no convívio com outros docentes da instituição e na publicação de artigos, muito incentivada nas disciplinas.

A cobrança na leitura e produção de artigos é destacada por MP.Local.01 como ponto positivo do curso. Explica que os docentes de cada disciplina exigiam a produção de artigos, realizadas em parceria com colegas mestrandos ou com os próprios docentes. É uma característica mais acadêmica presente no curso de MP. Diz que no começo do curso tinha detestado essa exigência. Mas, com a publicação de alguns de seus trabalhos em congressos, "deu uma motivação maior, me deu um senso crítico de como fazer um bom trabalho acadêmico" (MP.Local.01).

Tais orientações e exigências acabaram sendo incorporadas em seu trabalho como orientador de TCC e de iniciação científica de seus alunos. Percebe que se viu fazendo aquilo que os professores do mestrado faziam consigo.

MP.Local.01 fez parte da primeira turma de ingressantes do MP.Local. Pela característica interdisciplinar do curso, conviveu com professores-cursistas de diferentes formações iniciais, tendo apenas mais um colega também com formação específica em Física. Aparentemente, por conta disso, teve um distanciamento em relação aos colegas, de acordo com seu relato.

A diversidade de formações iniciais do corpo discente é indicada por MP.Local.01 como um ponto negativo do mestrado, em especial no contexto de disciplinas do curso que são compartilhadas. Conta o caso de uma disciplina específica da área de Física, em que havia professores de diferentes formações na turma. Por conta disso, o docente responsável não aprofundou nos conceitos e resoluções matemáticas da Física, para que todos pudessem acompanhar as aulas. Tendo em vista essa situação, MP.Local.01 considera ter sido prejudicado. Acredita ser complicado querer "tratar igual, coisas que não são iguais" (MP.Local.01).

Apesar de não apontar como motivação principal para o ingresso no mestrado a aquisição de novos conhecimentos e aprofundamento de seus conhecimentos científicos, essa questão parece ser relevante para este egresso, por conta da crítica realizada à organização da matriz curricular do curso frente às disciplinas específicas da área de Física. 
Além da disciplina em Física em cuja turma havia a presença de professorescursistas de diferentes formações, MP.Local.01 descreve outra disciplina específica da área. Ao contrário da anterior, essa apresentava um grande nível de exigência e pareceu se concentrar nos conteúdos de Física básica, sem promover discussões sobre ensino:

MP.Local.01: "[nessa disciplina] quanto à resolução de questões, não eram questões que você resolvia em uma hora, você levava horas! Eu lembro de uma questão de Astronomia, na verdade não, foi uma questão de movimento de satélite natural. [...] Uma tremenda integral, porque tinha as variáveis na mudança de massa, com o deslocamento do combustível. Queima de combustível, deslocamento de massa. [...] eram cálculos gigantescos mesmo!"

Em relação aos conhecimentos adquiridos durante a realização do MP, que tenham colaborado com sua prática docente, MP.Local.01 destaca que são aprendizagens que não estão no programa curricular das disciplinas do curso, mas que foram decorrentes da "soma de contextos, a soma de vivências, a soma de experiências passadas" (MP.Local.01). Nesse sentido, ao menos em relação às disciplinas, o egresso parece ter tido uma dedicação passiva. Dentre esses aprendizados destaca aqueles derivados de seu trabalho de TCC de sua graduação (que foi a base para a elaboração de seu PE) que refletiu na orientação que o egresso dá a seus alunos; a percepção de que se deve atentar que nem sempre se expõe determinado conceito ou assunto de forma clara aos seus ouvintes; o hábito de escrita de um diário de bordo; a observação de relações entre pessoas em um ambiente de trabalho, que passou a enfatizar na orientação de estagiários do curso técnico:

MP.Local.01: "Eu digo que [o mestrado] foi a base para isso. Não foi o todo que me levou a isso, mas digo que foi a base que foi me ajudando a construir. $O$ mestrado me ajudou também nesse ponto. $E$ eu estou falando que não foram as disciplinas".

No seu PE, elaborou uma continuação de um trabalho iniciado em sua graduação, que foi apresentado como TCC. MP.Local.01 conta que em uma disciplina, o professor da graduação tinha indicado a leitura de um artigo sobre fluidodinâmica do Caderno Brasileiro em Ensino de Física. O artigo explorava uma situação que causou desconfiança em MP.Local.01, pois trazia conclusões contrárias ao que ele acreditava que resultaria do fenômeno descrito. Para elucidar a questão, MP.Local.01 chegou a fazer um protótipo experimental para observação do fenômeno físico. Quando viu na prática um resultado de acordo com o explanado no artigo, MP.Local.01 se dá conta de que havia caído em um erro conceitual, e se motiva a elaborar seu TCC em torno dos erros conceituais que podem ser identificados ao se abordar conteúdos de fluidodinâmica. No seu PE, ele cria uma hipermídia e uma animação em Java que ilustra o mesmo fenômeno que lhe causou espanto na graduação. 
É possível perceber um impacto grande na prática do egresso decorrente da realização desses trabalhos em associação. MP.Local.01 enfatiza que ficou como uma marca para ele a importância da prática no ensino da Física:

MP.Local.01: "Eu passei a ser alquém que procura muito, se possível,
fazer a prática. Então, a questão do fundamento teórico, eu passei a
achar importante, mas tem que ter a prática [...] a prática é
considerada fundamental. Porque o quê que eu vejo? O que eu
aprendi ao longo do mestrado? Que as pessoas falam muita coisa,
declaram muita coisa, afirmam muita coisa... escrevem muito o que
'fulano' disse, mas esquecem o principal: comprovar se aquele fato
verdadeiro [...] Afetou porque eu passei a ser um professor, que eu já
gostava de atividades lúdicas, de Física, daqueles experimentos de
Física, mesmo antes de minha formação em Física, eu sempre fui
alguém curioso com aparatos [...] com isso eu passei a ser uma
pessoa muito mais dedicada a laboratório de Física".

Esse impacto, no entanto, parece ter sido gestado em sua formação em momento anterior ao curso de MP e que a relação que teve com outros colegas e docentes no MP apenas confirmara essa tendência particular. Nesse sentido, em relação ao que o curso poderia lhe proporcionar em termos de novos conteúdos e novas reflexões, sua autoria permanece nos níveis mais baixos em relação aos indicadores responsabilidade e inovação.

O egresso chega em sua entrevista a descrever em detalhes um exemplo de aula no contexto do curso técnico que trabalha. Na construção dos conceitos, faz uso das concepções prévias dos alunos, algumas vezes colocando em destaque erros conceituais para colocar em conflito com situações experimentais: "eu usava o erro... assim, aquela construção equivocada para desconstruir e ver. Não é que aquilo que aprendeu lá na base esteja errado. É que aquela coisa é outra! Só é parecida, não é igual" (MP.Local.01). Com as informações obtidas, é possível atribuir esse aprendizado não ao mestrado diretamente, pois é algo que foi despertado durante a sua graduação e favorecida pelo sua formação e trabalho em engenharia. É um aspecto relacionado à dimensão organização e condução de ensino de seu desenvolvimento profissional.

Por fim, por ter cursado um MP em Ensino de Ciências, chama a atenção a ausência de comentários a respeito dos conhecimentos pedagógicos apresentadas durante o curso no contexto das disciplinas, ou então na elaboração do PE. MP.Local.01 diz que não teve nenhum tipo de contribuição nesse sentido. 


\subsubsection{Análise com elementos narrativos de MP.Local.02: o professor que seguiu carreira acadêmica}

O egresso MP.Local.02 sempre teve vontade de seguir carreira acadêmica, desejando se formar pesquisador em Matemática ou Física básica. Até que surgiu a oportunidade de ingressar na primeira turma do mestrado em Ensino de Ciências. Por ser de uma cidade do interior, onde não havia oportunidades de cursar a pósgraduação, não era clara para ele a distinção entre mestrado acadêmico e o profissional. $\mathrm{Na}$ realidade, considera que essa questão não era muito clara para ninguém na época. Porém, como já dava aulas há seis anos naquele momento, decidiu cursar esse MP.

Quanto às disciplinas cursadas no MP.Local, diz que cursou todas muito bem, mas tendo muito trabalho. Teve disciplinas da área de Física "dura" "que castigavam bastante, no sentido de que você tinha uma ementa bem puxada. [...] $E$ também na parte de ensino, o pessoal tinha um ritmo de leitura bem pesado" (MP.Local.02). Seu relato condiz com o observado no estudo da matriz curricular do curso, sendo este rigoroso e exigente. É o que MP.Local.02 definiu como "errar a mão para cima", em relação à exigência do curso: "O curso tinha essa característica, que me agradava muito. Particularmente, eu gostei bastante da Física que eu estudei como da parte de Ensino que eu tive a oportunidade de estudar também" (MP.Local.02).

Foi um curso que rendeu muitos frutos. Por exemplo, o PE de MP.Local.02 chegou a ser publicado em livro. Durante o mestrado, esse professor também chegou a participar do SNEF, publicou pequenos artigos e entregou a dissertação no prazo estabelecido. $O$ envolvimento nessas atividades demonstra uma dedicação ativa ao curso.

Diz que se sentiu "em casa" no curso: "me sinto em casa nesse ambiente. Talvez por isso eu persegui isso tanto, desde novinho" (MP.Local.02). Por ter planejado seguir uma carreira acadêmica, considera que uma das maiores contribuições do curso foi justamente ter sido o primeiro passo para sua formação pósgraduada: "[O MP.Local] foi onde abriu as portas para mim, porque dificilmente eu faria em outro lugar, ou não teria condição" (MP.Local.02). Ele critica o posicionamento que atribuiu à Marco Antônio Moreira de o MP ter caráter terminal ${ }^{119}$, pois após o curso, fez doutorado em Física básica oferecido em um programa de uma universidade federal em sua cidade natal, conseguindo a premiação de melhor tese dessa universidade pela pesquisa que pôde desenvolver. A Do.MP.Local-03 destacou em sua entrevista,

\footnotetext{
${ }^{119}$ Na verdade, uma posição da própria CAPES, conforme apontado por Menandro (2010).
} 
apresentada na análise das entrevistas com os docentes do curso, a consideração do MP em Ensino de Física como um curso terminal, no sentido de que o curso deveria ser o suficiente para oferecer ao egresso todas as ferramentas necessárias para aperfeiçoamento da prática profissional docente, ou seja, não ser meramente uma etapa propedêutica. MP.Local.02 decidiu migrar de área em seu doutorado, o que foi possível por ser admitido no programa em que fez parte. De qualquer forma, com a abertura do doutorado profissional no mesmo programa, não há mais razões para atribuir ao MP um caráter terminal, no sentido de desconsiderar que o profissional titulado mestre não queira considerar um possível doutorado em sua área ou em áreas afins para continuidade de sua formação.

Atualmente, MP.Local.02 é professor de um instituto federal e coordena também um curso de MP em Ensino de Física. Continua publicando pesquisas na área de Física básica em que se dedicou no doutorado e também na área de Ensino de Física, área que se preocupa em buscar colaborações com pesquisadores mais experientes: "para que eu possa também amadurecer algumas ideias que eu tenho com relação ao ensino. Até para poder orientar o aluno [do MP que coordena] com muita clareza sobre o que a gente está fazendo" (MP.Local.02).

Outras consequências da realização do curso se desdobram em contribuições para o desenvolvimento da dimensão organização e condução do ensino. MP.Local.02 explica que conduz de maneira diferenciada em suas aulas da graduação, aprofundando com seus alunos discussões conceituais e não apenas o formalismo matemático, próprio das disciplinas de Física básica:

\begin{abstract}
MP.Local.02: "Eu acho que você muda a sua forma de dar aula. Porque você passa a olhar para as coisas de uma perspectiva diferente. Eu tenho certeza, mesmo quando eu dou uma disciplina do curso de graduação... eu dou uma disciplina de Mecânica Quântica, que ela é uma disciplina bem teórica, vamos dizer assim, tem pouco recurso para discutir... Não tem como fazer práticas de laboratório, esse tipo de coisa... A gente sempre procura dialogar. A gente procura levar simulações, para que os alunos façam perguntas, discute com eles muito a parte conceitual em tudo o que se faz, são coisas que começaram a nascer aí. Você pensa numa aula, sempre numa aula diferente e não simplesmente colocar conta no quadro. Você passa a discutir mais Física, a de repente levar isso numa perspectiva de ensino para o ensino de Mecânica Quântica no ensino médio, como é que essas discussões podem ser feitas... Então assim, tratando do formalismo matemático da Mecânica Quântica, e de tudo que tem que se dar, justamente a gente olha para isso de uma perspectiva diferente, por exemplo, na Licenciatura. Mas é assim também no ensino médio. Você muda mesmo o jeito de dar aula".
\end{abstract}

Não temos dados concretos em sua entrevista para determinar os níveis dos indicadores responsabilidade e inovação de autoria docente que MP.Local.02 se envolveu decorrente da sua participação no curso, principalmente porque o egresso 
está trabalhando no ensino superior e na pós-graduação, enquanto o MP.Local se propõe a discutir o contexto da educação básica com os professores mestrandos. De qualquer forma, aparentemente, o curso proporcionou ao egresso a mudança de postura em relação a dar aulas de forma mais dialogada e com maior preocupação com a parte conceitual da Física, orientação que parece lhe acompanhar na prática desde que concluiu o curso.

Para a elaboração do PE, decidiu trabalhar com um tema que os alunos estavam perguntando em sala de aula, sobre Física de Partículas. Na época, o LHC (Large Hadron Collider, acelerador de partículas do CERN) era noticiado na mídia. MP.Local.02 escolheu, em conjunto com o orientador, escrever um material que abordasse os conteúdos relacionados ao acelerador de partículas e à detecção do Bóson de Higgs, utilizando a abordagem CTS e elementos da História e Filosofia da Ciência. Considera que essas escolhas tenham sido realizadas em função das disciplinas que tinha cursado. Com o olhar mais maduro, avalia que anos após sua defesa, faria muitas coisas de forma diferente em seu produto, principalmente na escolha dos referenciais de ensino que se apoiaria. Conclui que o processo de elaboração do PE contribui para "você amadurecer mesmo [...], então você sempre fica com uma visão crítica daquilo que você está fazendo" (MP.Local.02).

Particularmente, MP.Local.02 não avaliou seu PE em situação real de sala de aula, conforme explica:

MP.Local.02: "[...] se o produto precisava ser levado ao aluno, se o produto de fato precisava ser aplicado, tudo isso não era claro. Como eu fui da primeira turma, a gente tinha essa questão. Você sabia que tinha que ter o produto [...] mas como amarrar de fato não era claro para mim [...] eu acho que o nosso foco estava muito mais no produto, tanto que a gente escreveu o livro, do que necessariamente [...] você ter uma atividade amarrada para sala de aula".

Nesse sentido, MP.Local.02 informa que apresentou o PE a alguns grupos de professores e alunos de escolas indicadas por seu orientador, mas sem uma análise apurada sobre a relação entre professores, alunos e o PE, numa situação mais sistematizada para a sala de aula.

O contato com colegas de formações diferenciadas não necessariamente promoveu práticas interdisciplinares, na experiência de MP.Local.02. Porém, foi interessante para incentivar discussões a respeito de diversos espaços de educação (como o ensino fundamental), que era alheio ao espaço de atuação profissional de MP.Local.02 enquanto era mestrando, concentrado no ensino médio e superior:

MP.Local.02: "A gente discutia isso sem assim... não tinha uma distinção: você é físico, eu sou físico, você é biólogo, você é 
matemático, você é pedagogo... A gente trabalhava independentemente destes rótulos, esse é um outro ponto positivo até. Não estou dizendo que disso tenha surgido propostas interdisciplinares, porque estava, em geral, limitado a uma disciplina, então ela tinha um objetivo claro. Mas isso possibilitava que a gente discutisse coisas assim, do tipo, como é o ensino fundamental, o ensino de Ciências para o ensino fundamental, esse é um ponto legal, eu acho essa coisa de você trabalhar com pessoas de outra área interessante".

Em sua avaliação, MP.Local.02 destaca a atuação do corpo docente no curso:

MP.Local.02: "Os professores sempre preocupados com essa questão, todo mundo pé no chão, entendendo que era tudo novo, você tinha que entender, que todo mundo tinha que se entender... Tudo isso que eu estou falando aqui era porque você tinha essas questões na época, de se fazer um trabalho identificado com a proposta do curso. [...] Em todas as aulas eu tinha uma oportunidade de aprender alguma coisa nova, então eu podia sair falando de todos os professores e gostei bastante, para mim foi um curso muito bom. [...] E uma equipe muito disposta a entender esse processo todo, que também às vezes isso não acontece. Você entra no mestrado e vai continuar fazendo aquilo que você faz ou sempre aprendeu a fazer".

\subsubsection{Análise com elementos narrativos de MP.Local.03: o professor extrovertido}

O egresso MP.Local.03 já tinha mestrado na área de Física Médica, porém trabalhava como professor quando decidiu investir no curso do MP.Local. Não tinha se identificado com a rotina de trabalho no hospital onde estagiou, portanto, continuou seu trabalho como professor na rede estadual e particular naquela época. Tinha como principal objetivo "escapar da rotina" e ampliar suas oportunidades de trabalho:

MP.Local.03: "Você cai na rotina rapidamente, dois, três anos, a gente cai numa rotina, e como a gente sabe que professor não é tão valorizado, na rede estadual então... era um clima muito estranho. As pessoas, você fica vendo que as pessoas iam para sobreviver e a gente quer alguma coisa a mais, então tem que continuar estudando [...] Só de ter o contato com os professores da universidade, aquele negócio todo, vai motivando mais a gente".

Optou pelo MP.Local, por conta da localização da instituição que oferecia o curso, em cidade vizinha à que residia e pela questão de horários das disciplinas. $\mathrm{O}$ MP.Local concentrava a oferta de disciplinas nas quintas e sextas-feiras, de modo que os professores poderiam concentrar sua carga horária de trabalho no restante dos dias da semana. Buscava no mestrado em Ensino um impacto direto em sua sala de aula e a possibilidade de fazer justamente o tipo de pesquisa que gostaria, o que o motivou a ter uma dedicação ativa em relação ao curso. O fato de já ter o título de mestrado, mesmo que em outra área, favoreceu a ele essa busca:

MP.Local.03: "[...] entrei sem perspectiva de [...] fazer a pesquisa só pela pesquisa. Queria exatamente alguma coisa que eu fosse 
realmente usar para a sala de aula. [...] Como eu já tinha o mestrado, eu não tinha aquela cobrança [...] o que propor, eu vou fazer, só porque eu preciso do título... [...] fiz exatamente o que eu queria. [...] você junta as duas coisas: a coisa que você realmente quer fazer, com a parte de formação acadêmica".

Por ser um professor extrovertido, iniciou o mestrado com a ideia de transformar essa sua característica pessoal em algo mais "acadêmico". Gostava de abordar os conceitos físicos de forma lúdica, contando histórias, criando analogias com situações e objetos que fazem parte do cotidiano de seus alunos. Era a criação de analogias utilizando situações sociais para abordar conceitos de Física que MP.Local.03 queria abordar em seu trabalho. Ao entrar em contato com o arcabouço teórico desenvolvido na Academia, surpreendeu-se: "eu não imaginava que as analogias de ensino tinha tantos artigos, eu não fazia ideia. Foi só tendo contato lá com o mestrado que eu fui 'caraca, existe linha de pesquisa realmente nisso?'" (MP.Local.03).

A questão do contato com produções acadêmicas e a noção da importância do registro de conhecimentos oriundos da prática em pesquisas publicadas em artigos e nos produtos educacionais, no contexto dos MPs (ou de outra forma, que seja mais acessível a outros professores da educação básica), mostra o olhar que MP.Local.03 desenvolveu para a perspectiva de se enxergar como um professor pesquisador. $O$ MP.Local forneceu subsídios e um estímulo inicial para que o professor passasse a registrar suas ideias e publicá-las de alguma forma. Como informação adicional ao que é afirmado nessa análise, o contato com esse egresso para convidá-lo para a entrevista foi possibilitado pelo acesso a um artigo que publicou após a conclusão do mestrado. Assim, levou adiante em sua profissão o que iniciou no curso de MP, mostrando uma autoria com responsabilidade sistemática. Era um artigo que discutia avaliação e mostrava exemplos de questões utilizadas por MP.Local.03 em provas escritas, desenvolvidas de forma criativa a partir de histórias de super-heróis. A experiência desse egresso mostra a importância da aproximação do mundo profissional com o mundo acadêmico no contexto do trabalho docente:

MP.Local.03: "No dia a dia você vê, tem vários professores que têm ideias fantásticas e por não ter esse lado acadêmico, eles não registram, se perde... fica aquela cultura de índio... enquanto ele estiver falando aquilo ali, aquilo ali existe e funciona... Aí nesse sentido é bom, porque aí de vez em quando... escrever um artigo sozinho, vou e boto... O ruim é essa rotina que a gente dá muita aula, a gente nem sempre tem tempo para fazer isso. Na universidade você tem aquela... faz parte da sua carga horária, sentar, escrever, fazer pesquisa. Aqui a gente faz, tipo, no amor... vamos sentar aqui, vamos nessa. [...] só de você fazer uma pesquisa qualquer, de experimento, de qualquer coisa, é muita ideia que tem registrada. Só que às vezes o professor [...] não tem esse contato, não tem esse hábito. Eles não param para ler artigo. Talvez a forma de divulgar, talvez também não seja a melhor". 
O MP.Local ofereceu terreno fértil para que o professor MP.Local.03 frutificasse nas ideias que tinha a partir de suas experiências docentes. Os artigos e linhas de pesquisa que pôde conhecer, the proporcionou atualizar seus próprios conhecimentos pedagógicos e a partir desses novos conhecimentos, sistematizar e compreender melhor a própria prática, que foi reforçada:

MP.Local.03: "Eu acho que só reforcou o que eu já fazia. Como eu
falei, eu já tinha ideias, eu já tinha uma prática pedagógica, mas eu
$\underline{\text { não fazia ideia de que tinha tanta coisa na literatura, na área }}$
acadêmica. Quer dizer, de certa forma foi um reforço 'olha, então eu
não estou no caminho errado...' Então uma coisa, alguma coisa está
certo aí, só falta lapidar, lapidar melhor, melhorar. [...] Aqui [no colégio
da rede federal que trabalha] eu posso falar de Ensino à vontade,
porque se por um acaso refutarem, criticarem... 'não, você sabia que
existe uma linha de pesquisa...', a gente tem argumento, a gente tem
base para tudo..."

Tais conhecimentos da área acadêmica adquiridos no mestrado, de certa forma, empoderaram o professor, dando a ele argumentos para defender sua própria prática frente a questionamentos e exigências possíveis de ocorrerem em seu contexto de trabalho.

Resistência ao desenvolvimento de seu trabalho, porém, foi encontrada dentro do próprio MP.Local. O egresso diz que na ocasião da avaliação de seu PE no exame de qualificação, um dos docentes de Física do curso se contrapôs ao seu projeto, que fugia dos moldes "tradicionais" do ensino de Física. Foi o primeiro momento em que MP.Local.03 pôde colocar à prova os conhecimentos adquiridos para argumentar e defender seu trabalho.

Outro fator determinante para o desenvolvimento de seu trabalho foi o tempo disponível para criar o PE e a dissertação, fator crucial principalmente quando se planeja investir em algo mais original, mais complexo, que foge de formatos préestabelecidos:

MP.Local.03: "é muito corrido, é muito curto [...] às vezes dependendo da proposta do seu trabalho, às vezes dá. Mas como eu queria pensar uma coisa nova, fazer... tinha que ter tempo. Queria pegar toda a minha bagagem de algum jeito e condensar em alguma coisa. [...] eu queria amadurecer mais algumas ideias que não foi possível. Aí eu vendo meus colegas, várias coisas maneiríssimas assim que eram mais focadas, eram mais simples... acho que foi isso, eu devia fazer alguma coisa mais direta desde o início, eu queria viajar muito na maionese [risada]. Aí fiquei um pouco perdido nesse sentido".

MP.Local.03: "Se um produto final é exatamente um site [...] independente de se aquilo dê trabalho, você tem plena noção do que você quer fazer no final. Eu só sabia o que eu queria era melhorar algumas coisas sobre, sobre o discurso do professor mesmo, de como instigar os alunos, de como fazer uma abordagem mais lúdica, aí é muito amplo, muito mais aberto, então foi aí que eu fiquei 
patinando um pouquinho até fechar uma coisa que eu pudesse... que eu tinha que apresentar".

$\mathrm{Na}$ realidade, essa é a única crítica que MP.Local.03 faz em relação ao desenvolvimento do MP: "se tivesse mais tempo, acho que daria para trabalhar alguns projetos melhor. Daria para construir o PE... Até a construção da dissertação poderia ficar melhor. Porque a gente sabe que a gente sempre faz correndo..." (MP.Local.03).

Em relação ao desenvolvimento do curso como um todo, MP.Local.03 comenta que as disciplinas foram interessantes e ressalta "algumas disciplinas que até deixavam você bastante livre para pesquisar, incrementar dentro de sua linha de pesquisa" (MP.Local.03). De fato, conclui que elas o auxiliaram a "embasar todo o discurso que eu uso hoje" (MP.Local.03). Teve uma boa relação com o orientador, Do.MP.Local-01, que considera ser alguém de fácil acesso. No decorrer do curso, teve a oportunidade de apresentar trabalho no SNEF e participar em conjunto com outros mestrandos de um evento em outra instituição, entretanto, pondera que seria mais interessante que houvessem mais eventos promovidos pelo próprio curso. Entre os colegas, destaca que teve mais contato com aqueles que moravam nas imediações da cidade em que residia, todos professores de Física. Não desvaloriza, porém, as trocas com os colegas de outras áreas:

MP.Local.03: "Grande parte da formação, acho, está exatamente nisso daí. Porque as disciplinas lá, eles obrigavam você fazer tipo um artigo, tem que fazer em grupo, quer dizer, nem todo mundo ali era de Física, então ali você vê como é que as pessoas pensam diferente, fazem coisas diferentes. É muito legal"

Apesar de valorizar o conhecimento proporcionado pelas disciplinas do curso, MP.Local.03 parece ser seletivo em relação a aplicar os conhecimentos adquiridos nas disciplinas em suas aulas, concentrando-se somente naqueles que embasam sua prática já existente:

MP.Local.03: "Parte de Educação Ambiental, CTS, que lá eles falam bastante... Teve sim. [P: Você chegou a aplicar depois em suas aulas?] Não, porque eu estava muito focado em desenvolver essa parte lúdica. Sim, foi interessante conhecer, tinha outros colegas da minha turma que estavam exatamente pesquisando nessa linha... $\underline{\text { }}$ contato foi muito interessante, saber que existe..."

Retoma essa questão quando explana os pontos positivos do MP.Local. Diz que é um curso que tem como grande mérito "aceitar o professor do jeito que ele é", propondo discussões voltadas para a prática profissional, para "desenvolver exatamente o que você já faz, o que você está buscando aqui é melhorar o seu arcabouço profissional" (MP.Local.03). Abaixo, o egresso explica como toda a proposta era desenvolvida: 
MP.Local.03: "Se só falasse teoricamente do que é o CTS, você ia ficar só lendo, lendo, lendo e... muito diferente do que você faz em sala de aula, você continuaria ainda dando a mesma aula. Nesse sentido lá não, lá eles pegam... Sempre ficam te instigando 'e o que é que você faz? Como é que você pode mudar? Vamos ler esse artigo, ver qual ideia que tem aqui, fazer um trabalho em cima disso'".

Apesar dessa dinâmica de discussões que MP.Local.03 reconhece como potencializadora da renovação da prática docente, ele afirma que apenas reforçou o que já realizava, não incluindo novos elementos do que aprendera durante o MP. Essa situação nos mostra que a transposição dos conhecimentos do mestrado para a prática em sala de aula depende também de fatores intrínsecos ao mestrando, relacionados às suas preferências e crenças profissionais. Dessa maneira, em termos de suas práticas docentes, a inovação é nula, por mais que, como relatado, o professor tenha se envolvido com pesquisas sobre sua própria prática a partir do mestrado.

\subsubsection{Análise com elementos narrativos de MP.Local.04: o professor que busca desenvolver PEs}

O egresso MP.Local.04 cursava um mestrado na área de Física básica, que teve que ser interrompido por questões de saúde. Casualmente, ao encontrar um professor que teve em sua graduação que era docente credenciado no MP.Local, é informado do processo seletivo do curso. Foi uma oportunidade que o agradou, já que a instituição sede do MP.Local é mais próxima da sua residência que aquela do mestrado acadêmico que teve que interromper e, escolhendo esse docente como seu orientador, poderia trabalhar numa área de pesquisa que lhe agradava. Na época em que ingressou no MP.Local, era professor da rede estadual e tutor à distância de uma instituição estadual. Também tinha trabalhado como professor substituto em uma instituição federal. Entretanto, tinha em mente um planejamento de carreira e tinha a expectativa de fazer concurso para ser professor em uma instituição pública. Portanto: "por ter feito uma licenciatura, e por buscar uma instituição para lecionar, o mestrado [profissional] ajudaria mais nesse sentido" (MP.Local.04).

O trabalho desenvolvido em seu PE foi sugerido pelo seu orientador. Essa relação sugere uma dedicação passiva em relação ao curso. No PE desenvolvido, aborda uma interpretação alternativa para a Mecânica Quântica. O objetivo era preparar um material que fosse dedicado ao ensino superior, incluindo a formação de professores, de modo a dar maior visibilidade a essa interpretação pouco referenciada em livros da área e nos cursos de Física em geral. Foi um PE que focou o conteúdo 
em si, não propondo nenhum tipo de metodologia inovadora de ensino. Inspirado pelo colega da turma anterior de mestrado (MP.Local.02), MP.Local.04 decide fazer como produto um material escrito que poderia se tornar também um livro, assim como o PE desse colega. Tanto é que após a defesa do trabalho, MP.Local.04 relata que recebeu o convite de duas editoras para publicar seu PE, o que ainda não foi realizado, pois gostaria de fazer uma revisão e adaptação juntamente com seu orientador a partir do material defendido em seu mestrado.

Essa experiência parece ter incentivado MP.Local.04 a buscar transformar suas ideias para aulas em produtos, o que destaca como a maior contribuição do MP para sua prática:

\begin{tabular}{l} 
MP.Local.04: "[...] o MP tem esse caráter de você por a mão na \\
massa, principalmente por você construir o seu produto. Então, hoje, \\
eu vejo o seguinte, tudo o que eu puder transformar... uma aula, uma \\
ideia, num produto, eu tento fazer. [...] se você puder transformar uma \\
ideia em uma simulação, uma ideia num experimento, então... eu tô \\
fazendo! Tudo que eu puder tirar do papel e botar a mão na passa, eu \\
tô fazendo. Então esse caráter experimental, eu ganhei um pouco \\
\hline mais, eu agucei durante o MP. Apesar de ter feito o mestrado na \\
parte teórica, mas eu vi os colegas trabalhando [...] os materiais que \\
eu preparo em sala, escritos ou montagem de algum experimento... \\
se eu enxergar a possibilidade, por exemplo, de eu montar um livro, \\
ou uma cartilha, qualquer coisa, eu faço, eu tô fazendo, é uma ideia \\
que eu aprendi durante o mestrado, essa ideia de transformar as \\
coisas em PE".
\end{tabular}

São produtos realizados a partir de sua prática atual como professor que diz que divulga publicando na forma de artigos, apresentações em eventos, em jornadas científicas, e através de projetos de extensão.

Em relação mais direta com sua prática, MP.Local.04 adota uma pluralidade de estratégias de ensino, usando "um pouco de tudo" em termos de recursos, entre eles, ferramentas multimídia, quadro, experimentos em laboratório, simulações virtuais: "eu tento buscar alternativas que de fato possam esclarecer aquele assunto que estou tratando em sala, entendeu? Eu não fico preso a uma metodologia só, eu uso ferramentas que eu tenho" (MP.Local.04). No entanto, não é claro em sua entrevista, se essa foi uma orientação que obteve a partir do mestrado ou se era algo já praticado por ele anteriormente, de modo que não nos é possível avaliar o nível de responsabilidade e inovação proporcionada pelo curso à autoria docente em seu caso.

Ao discorrer sobre o curso, MP.Local.04 elogia a diversidade ali presente, em termos de disciplinas e na possibilidade de contato com profissionais de diferentes formações. Considera o currículo do curso diversificado e apropriado para atender os mestrandos oriundos de diferentes áreas. A colaboração com os colegas de outras 
áreas em trabalhos interdisciplinares realizados em conjunto o levou a ter um "olhar diferenciado". Inclusive é o que destaca como ponto mais positivo do curso:

MP.Local.04: "[...] a questão da interdisciplinaridade. $\mathrm{Na}$ multidisciplinaridade. Da possibilidade de trabalhar em outras áreas. De eu utilizar a minha área de domínio, minha área de pesquisa, minha área de formação, de alguma maneira eu estar auxiliando, ajudando um colega de outra área"

O egresso, no entanto, não dá indicações de que a interdisciplinaridade tenha sido levada à sua prática como professor, ou se continua realizando trabalhos interdisciplinares com colegas de outras áreas.

Provavelmente o maior desdobramento que o MP teve para MP.Local.04 teria sido a oportunidade que teve ao prestar um concurso após a obtenção do título, que Ihe conferiu pontuação no certame o suficiente para ser classificado e convocado para uma vaga em um instituto federal, onde atualmente está lotado. O mestrado também o permitiu o ingresso ao doutorado em uma instituição de pesquisa em Física básica.

Um destaque final ao curso dado por MP.Local.04 é em relação à estrutura oferecida aos mestrandos para a realização dos seus trabalhos. Sobre esse quesito, comenta: "O MP.Local deu esse apoio para todos os estudantes, ele tem estrutura [...] biblioteca tinha livros à vontade [...] tinha um setor que era só para o mestrado. [...] Isso é difícil de encontrar em outros programas, entendeu?" (MP.Local.04).

\subsubsection{Análise com elementos narrativos de MP.Local.06: o professor que obteve ferramentas para seu trabalho}

O egresso MP.Local.06 soube da possibilidade de ingressar no MP.Local por ter se formado no curso de licenciatura também ofertado na mesma instituição. Ele destaca a facilidade dos horários do curso, com disciplinas e atividades concentradas em dois dias da semana, o que the facilitou a conciliação com horários de trabalho, embora tenha dito que precisou diminuir sua carga horária e renda mensal. Para viabilizar a realização do curso, precisou ser dispensado de algumas escolas privadas que trabalhava, permanecendo com aulas em turmas de uma escola privada e de escolas da rede estadual. Outra motivação era a localização da instituição, próximo de sua residência. É um ponto de grande destaque para esse professor, principalmente pelo curso estar instalado numa região carente, o que, em sua visão, proporciona oportunidade de formação de qualidade que as pessoas que ali moram não encontrariam tão facilmente: "a região como um todo é considerada como uma 
comunidade carente. Você conseguir ter instituições assim que proporcionam esse tipo de contato para um aluno, eu acho de suma importância" (MP.Local.06).

Em termos de desenvolvimento profissional, MP.Local.06 buscava no MP aprimorar suas técnicas de ensino, tendo por ênfase o uso de novas tecnologias de ensino, que acabou sendo o recurso que utilizou na elaboração do seu PE: "o MP por estar focado mais nessa questão de quem já trabalha, de você ter um produto que pode ser funcional para aquilo que você está atuando já... Então isso me atraiu bastante" (MP.Local.06). Tinha também em mente um planejamento de carreira: "me senti motivado a tentar melhorar a minha prática docente e visando também entrar em outra esfera [de trabalho], como consegui entrar depois virando professor da casa" (MP.Local.06). No momento da realização da entrevista para esta pesquisa, no ano de 2018, MP.Local.06 fazia parte do corpo docente da instituição e tinha interesse em prestar o processo seletivo para algum curso de doutorado ligado à área de ensino.

É possível notar que a realização do curso contribuiu para a aquisição de conhecimentos, que por sua vez proporcionou ao egresso o acesso a ferramentas para utilizar em sua prática, afetando o desenvolvimento de sua organização e condução do ensino. Por ferramentas, entende algo que vai além de conhecimentos teóricos, tanto científicos quanto pedagógicos, abrangendo o conhecimento e o uso de recursos de ensino. Tais ferramentas permitiriam ao professor maior autonomia em seu trabalho e maiores chances de sucesso na aprendizagem de seus alunos.

Afirma que teve contato com conteúdos de outras áreas tais como Ciências Ambientais, Química e Biologia, de forma bem entrelaçada nas disciplinas da matriz curricular do MP.Local. Diz que teve disciplinas do núcleo optativo, específico para cada área, em que os docentes se concentravam unicamente no conteúdo disciplinar, o que na sua visão destoavam um pouco de como ele via a proposta do mestrado, que deveria ser centrado no ensino. A abordagem de questões de ensino é o que mais lhe chamou a atenção no curso em termos de conhecimento:

\begin{tabular}{l} 
MP.Local.06: "No quê o mestrado foi útil para mim? Ele foi útil por \\
causa da parte de Ensino! O que de Física que eu aprendi ali, eu já \\
sabia, ou então, foi alguma coisa que aprendi por 'conhecimento'. \\
\hline Não o que vou usar [nas próprias aulas]. Agora, a parte de ensino é o \\
\hline que eu uso bastante, entendeu? Por isso que eu queria ir por aí".
\end{tabular}

Isso não significa que MP.Local.06 não valoriza os conteúdos disciplinares, pois acredita, e é um pensamento que diz que adota desde o início de seu curso de graduação, que precisa dos dois tipos de conhecimento sem a prevalência de um sobre o outro: "uma das coisas que eu vejo como muito importante para mim, é além de eu saber o que ensinar, é eu saber o como ensinar. Então eu sempre tive essa 
meta para mim, juntar o 'como' com 'o quê"' (MP.Local.06). O egresso enfatiza que o mestrado o ajudou a lapidar o seu domínio nos conhecimentos que o guiam no "como" abordar os assuntos de Física com seus alunos. Essa era uma demanda que tinha como um profissional em busca da formação pós-graduada:

MP.Local.06: "[...] tive essa cobrança comigo mesmo. No sentido,
quero aprender a mostrar aquilo que eu sei, e de uma forma simples.
[...] era uma meta minha. [...] o fato de ele [o mestrado] ter sido
profissional, me ajudou a ter contato com a mão na massa, vamos
dizer assim. [...] eu estava focando em outras dificuldades,
dificuldades práticas. [...] cada sala é de um jeito, cada aluno é de um
jeito, cada escola é de um jeito, então eu nunca espero entrar numa
sala e ter o mesmo tratamento ou trabalhar da mesma forma na sala
que eu entrei anteriormente. Isso é uma coisa que eu não tenho.
Então isso me permite trabalhar melhor. E a ideia do MP me ajudou
muito nisso: a ter essas ferramentas. Agora, eu acho que você
aprende de verdade mesmo é na sua prática docente. Eu acho que
tanto o mestrado, quanto possivelmente o doutorado, ou a
graduação, ela vai te fornecer ferramentas. Para quando você
precisar usar, você ter onde buscar. Eu vejo dessa maneira. E tem
me ajudado".

A elaboração do seu PE envolveu o contato com ferramentas de desenvolvimento de material didático digital. Quando ingressou no mestrado, tinha interesse em trabalhar com tecnologias educacionais, por ter afinidade com o uso desses recursos em sala de aula. Com base nessa predileção e selecionando um tema a ser abordado a partir de uma revisão bibliográfica, que lhe apontou concepções alternativas a respeito das estações do ano, conteúdo de astronomia que seria abordado no $9^{\circ}$ ano do ensino fundamental, programou um aplicativo interativo que apresentava um modelo do movimento de translação da Terra. Apesar de ter contado com o apoio do LAC, laboratório oferecido pelo curso que tinha computadores potentes e softwares disponíveis para uso, declara que teve que aprender sozinho como desenvolver esse aplicativo, com o apoio de tutoriais e vídeos que encontrou na internet.

Foi um conhecimento que não foi adquirido através de atividades planejadas no contexto do MP. Foi adquirido para atender à demanda colocada para a execução do seu PE. A experiência resultante desse esforço influenciou seu trabalho posterior como professor de um curso de licenciatura:

MP.Local.06: "Hoje eu estou totalmente envolvido com tecnologia lá na graduação. Tem uma disciplina que eu estou lá de Tecnologias Digitais, que eu propus para o Colegiado, e está indo muito bem assim, eu gosto, porque acho que estou conseguindo passar esse contato para os alunos de ter a tecnologia dentro do ensino, mas isso tudo começou lá no mestrado. Para mim, foi onde eu consegui tirar a ideia da cabeça e começar a trabalhar com ela na prática". 
Dessa forma, a ampliação de conhecimentos não ocorreu apenas no contexto das disciplinas do curso, mas também no contato que teve com os colegas e o corpo docente, que destaca como um ponto alto do MP, pela possibilidade de contato com pessoas com conhecimentos de outras áreas e detentoras de conhecimentos altamente qualificados. Seu relato indica um envolvimento profícuo com todas essas esferas no contexto do curso, o que indica uma dedicação ativa ao mesmo.

MP.Local.06: "[...] eu senti bastante diferença no meu trabalho, não
na minha didática em si, mas porque você acaba ampliando sua
gama de conhecimentos, assim, tem contato com outras pessoas,
outros horizontes, surgem novas perspectivas, isso sempre influencia
sua maneira de trabalhar. O professor é meio que uma esponja,
absorve conhecimento de tudo quanto é lado e você in loco vê como
vai aplicar aquilo. Tem técnica que funciona numa escola, não
funciona na outra, ou funciona numa turma, não funciona na outra. E
aí você tem que testar. Aí eu acho que vale a pena a gente ampliar o
leque de opções e na hora ver o que vai ser melhor".

MP.Local.06: "Foi importante porque o fato de ter professores de outras disciplinas, ou gente até de outras áreas, mas relacionadas à Educação, dá uma visão diferente de determinadas situações. E isso às vezes também ajuda a gente a evoluir, a aprender... Eu sempre acho que o contato é positivo".

Como exemplo mais concreto, diz que o modo que foi orientado no mestrado o influenciou também no modo que ele orienta seus próprios alunos no curso de licenciatura, em especial no processo de escrita, tarefa acadêmica que teve grande contribuição de seu orientador. Essa questão de mudança do modo de se pensar indica uma autoria com responsabilidade sistemática, pois a nova percepção sobre os assuntos relacionados ao seu trabalho e a experiência que teve como aluno do mestrado orienta, após o curso, todas as suas ações como profissional.

O egresso valoriza o contato com a Academia, dada principalmente através do incentivo que recebeu do corpo docente do MP, para escrever e apresentar trabalhos em congressos maiores dos que chegou a ter a oportunidade de participar na graduação, como o ENPEC:

MP.Local.06: "Pude apresentar trabalho em forma oral em congresso, pude assim, ter contato com essa parte da pesquisa, que é importante, hoje me considero um professor pesquisador. [...] $\mathrm{O}$ mestrado me ajudou muito nisso, a essa questão de ter contato sempre com o meio acadêmico. Hoje eu não tenho mais dificuldade para escrever, não tenho dificuldade de pesquisar, de achar referência, tudo porque o mestrado me deu contato com isso. Através dos congressos e tal... Nem tanto por causa das exigências do próprio mestrado no sentido de ter que escrever artigo, ter que fazer aquilo e tal... Mas era mais pelo contato mesmo que a gente teve com esses eventos. [...] um ou outro que a gente já participa, já dá esse estalo na gente que já é legal". 
O egresso parece que começou a se enxergar como um professor pesquisador a partir do mestrado, pelo contato com a literatura acadêmica de diferentes linhas de pesquisa, o que ampliou seu horizonte em relação a ela. A aproximação com o meio acadêmico, permitiu ao egresso MP.Local.06 maior independência e posicionamento crítico em relação ao livro didático que adota em suas turmas e também esclareceu o que significaria a necessidade de formação contínua para um professor. Esse contato com as pesquisas acadêmicas dá margem ao professor para envolver-se com uma inovação criativa de sua prática:

\begin{abstract}
MP.Local.06: "A gente sempre ouve aquele jargão, de que o professor precisa continuar estudando a vida toda. Mas eu não tinha essa certeza de como fazer isso, além de só estudar o livro, vamos dizer assim. $E$ na realidade você vê às vezes que tem muito livro que está errado, que tem muitas concepções alternativas... que são passadas para o aluno de forma errada... E aí você começa a desconstruir isso... Porque eu leio artigo, eu leio as pesquisas educacionais mais recentes [...] Por isso a importância do professor ser pesquisador também. Porque você não vai ficar com uma fonte de trabalho, não é só aquele livro que você adota que vai ser a 'bíblia' que você vai usar. Isso é importante para mim. Eu vou ler outras fontes, eu vejo livros que às vezes o autor tem uma linguagem mais complexa [...] então você completa melhor seu argumento, melhora sua aula [...] E esse compromisso todo vem da forma como o mestrado me lapidou também. Essa questão do professor pesquisador"
\end{abstract}

\title{
5.2.6 Análise com elementos narrativos de MP.Local.12: o professor que mudou sua relação com os alunos
}

O egresso MP.Local.12 é mais um dos professores que realizaram o curso de licenciatura na mesma instituição que o MP. Tinha como intenção a busca de aprimoramento, que para ele está relacionado com o contato com a pesquisa na área de ensino, pois diz que depois que saiu da faculdade, "esse contato com pesquisa fica vago, você entra no mercado e você não tem muito isso" (MP.Local.12). Ingressou na carreira docente dando aulas em cursinho preparatório para exames vestibulares, mas após alguns anos, tornou-se professor da rede estadual. Vislumbrava no MP uma possibilidade de melhorar sua prática como professor, ter acesso a novas atividades e aprender a como lidar com seu novo público, estudantes das escolas da rede estadual.

MP.Local.12 não quis dar muitos detalhes em sua entrevista em relação às disciplinas ou ao desenvolvimento de outras atividades do MP, se referindo a elas de modo genérico como "boas". Assim, não é possível dizer o nível de sua dedicação ao longo do curso. Como desdobramento das disciplinas, diz que pôde ampliar a visão 
que tinha sobre "o que é ser professor, como atuar na sala de aula, me trouxe outras possibilidades de prática" (MP.Local.12). Questionado sobre exemplos dessas novas possibilidades de práticas, ele descreve uma atividade que estava desenvolvendo em uma escola, em parceria com um professor de Química, que envolvia a realização de pesquisas por parte dos alunos que planejariam e apresentariam seus trabalhos em uma Feira de Ciências na escola. Da forma como colocado pelo egresso, as disciplinas não necessariamente trouxeram novidades, no sentido de atualizar seus conhecimentos científicos e pedagógicos, mas foram apresentadas fazendo referência à prática docente, o que lhe permitiu o aperfeiçoamento que procurava: "foram práticas que foram apresentadas... Não que nós já não tivéssemos conhecimento, mas foram apresentadas de uma forma diferente, ativa para os alunos [...] exatamente voltada para a prática" (MP.Local.12).

A questão da apresentação das atividades de forma prática tem relação com a visão de o MP fornecer ferramentas aos professores, tomada como uma necessidade do professor:

MP.Local.12: "Mesmo estando preparado para uma aula sobre os assuntos mais de Física Contemporânea, mais Moderna e Contemporânea, faltava alguma coisa ainda. A forma de abordar. Não necessariamente o preparo quanto ao assunto, mas como abordar um assunto complexo em turmas de ensino médio, e aí o mestrado supriu essa necessidade".

O seu produto educacional foi desenvolvido visando oferecer um material direcionado para professores que explorasse como abordar conteúdos de Física Moderna e Contemporânea no ensino médio. O egresso expressa a preocupação de que este não fosse um material em que qualquer professor, em qualquer turma e escola pudesse aplicá-lo diretamente, mas que o material fornecesse ao professor que Ihe fizesse uso, subsídios para a abordagem do tema, adaptando a metodologia e a abordagem do conteúdo a sua realidade:

MP.Local.12: "[...] foi uma sequência didática, e essa sequência visava muito mais preparar 0 professor do que necessariamente 0 aluno. [...] quando você foca [a elaboração do $\mathrm{PE}$ ] diretamente ao aluno, você acaba assumindo que todos eles são de realidades que são iguais. Aí optamos por trabalhar com o lado do professor, e cada professor adaptar isso a sua própria realidade".

O egresso MP.Local.12 disse que continuou utilizando o PE que criou em suas aulas, bem como colegas professores aos quais tinha apresentado seu trabalho, indicando uma responsabilidade sistemática em sua prática, ao menos em relação ao PE. Porém, relata ter utilizado o material criado com alterações, visando adaptá-lo ao que pensava ser prioridade para suas turmas. Assim, o professor expressa preocupação em adaptar-se conforme as demandas dos alunos, o que reflete nas 
dimensões organização e condução de ensino e sustentação da aprendizagem, além de, em termos de autoria, indicar uma inovação criativa. É importante destacar que ao longo de sua prática, esse egresso também tenha rompido com uma abordagem mais matematizada do conhecimento físico, comum na cultura de ensino mais tradicional dessa disciplina, alterando sua forma de avaliar os alunos e priorizando um enfoque histórico do conhecimento, que julgou ser mais relevante para seus alunos:

MP.Local.12: "Continuo aplicando [o PE], mas algumas coisas foram mudando. A própria forma de avaliação que inicialmente foi o que eu pensei, mudou. Principalmente a avaliação. Eu não vejo como um tema tão importante para eles [inaudível] turma de ensino médio. [...] eu trabalhava muito mais a questão histórica do que a questão das equações e das contas".

Como impactos em sua prática profissional, que podem ser atribuídos à realização do curso de MP, MP.Local.12 destaca a mudança na relação professoraluno e sua visão sobre avaliação:

MP.Local.12: "Acho que [alterou] basicamente a forma como é a relação aluno-professor. Ela hoje é bem diferente. Basicamente 0 'como' eu dou aula, acho que mudou bastante. Eu tenho uma visão bem diferente do aluno, de possibilidades de trabalho. [...] eu era extremamente fechado para avaliação. Ao formalismo matemático, à avaliação tradicional, e aí eu comecei a ver que eu tenho outras formas de avaliar, que eu posso fazer um trabalho diferente, e ainda assim ter essa troca com o aluno".

Em relação ao seu modo de dar aulas, o egresso cita duas alterações de sua prática: a utilização de artigos acadêmicos em sala de aula e a maior facilidade que adquiriu em contextualizar o conhecimento físico com o cotidiano dos alunos:

MP.Local.12: "[...] eu prefiro trabalhar artigos acadêmicos em sala de aula que eu achava que eu nunca conseguiria fazer. Eu seleciono os artigos, trago esses artigos para a gente ler em sala de aula juntos, e aí a gente vai analisando alguns pontos. Nem tudo vai ser compreendido, mas uma boa parte desperta a curiosidade dos alunos. E apresenta [inaudíve] uma forma de escrita mais acadêmica também, para eles terem essa visão".

MP.Local.12: "Eu só comecei a ter uma noção da relação entre a Física com o dia-a-dia, anos depois de formado. A gente tem muito disso de transpor para o dia-a-dia do aluno na licenciatura, mas a verdade é que a gente ainda não tem isso [inaudível] essa relação bem clara, isso vem com a prática, e o curso de mestrado me ajudou bastante nisso".

\subsubsection{Análise com elementos narrativos de MP.Local.14: a professora que encontrou segurança}


A egressa MP.Local.14 difere dos egressos das análises anteriores, pois tem formação inicial em Pedagogia. Ela procurava um curso de pós-graduação stricto sensu após ter sido admitida como professora da rede municipal na cidade onde morava. Como o MP.Local era próximo de sua casa e reconhecido pela qualidade, a professora escolheu ingressar nesse curso. Tinha expectativas de ascensão profissional e ter maior conhecimento por meio da pesquisa de sua própria prática.

Logo após ter ingressado no mestrado, ela passou em um concurso e assumiu a função de orientadora educacional em uma escola de ensino fundamental, onde percebeu que faltavam funcionários e professores. Quando tinha a disponibilidade, substituía os professores que faltavam, assumindo as turmas. Nesse trabalho, percebeu que os professores não ensinavam às crianças os conteúdos de Ciências. Por conta disso, orientou a elaboração de seu produto educacional para suprir essa carência. Em suas substituições, desenvolveu diversas atividades lúdicas para abordar conteúdos científicos com as crianças utilizando materiais de fácil acesso. Parte das atividades colocadas em prática são descritas no $\mathrm{PE}$, com a preocupação de apoiar 0 trabalho de professores de ensino fundamental que muitas vezes não têm formação conceitual dos conteúdos científicos suficiente para abordá-los com os alunos.

MP.Local.14 se coloca entre esses professores com carências formativas em relação aos conteúdos científicos. Tanto que teve dificuldades em estudar determinadas disciplinas da matriz curricular do MP, com conteúdos específicos: "eram debates conceituais, eram coisas mais voltadas mesmo também para essa questão da prática, mas eu tinha que ter atenção redobrada, porque eu não tinha conhecimento das disciplinas" (MP.Local.14). Porém, destaca como positiva a convivência com professores-mestrandos de outras áreas. Interagindo com eles, sente que pôde auxiliar trocando seus conhecimentos com eles:

MP.Local.14: "Era até bom porque tinha uma certa troca com alguns
professores dessas disciplinas, alguns colegas da Biologia que
chegavam para perguntar 'poxa, eu tenho um aluno assim, assim...
ele lê, mas ele não entende...' Aí, eu falava... Analfabetismo
funcional... 'Ah, o que eu posso fazer?' Aí eu já conversava, dava
algumas dicas para o desenvolvimento do trabalho".

Em termos do que o curso pôde lhe proporcionar de aprendizado, MP.Local.14 destaca a aprendizagem sobre a escrita acadêmica. A parceria com o orientador, o professor Do.MP.Local-01, foi fundamental para isso também, incentivando a continuidade da divulgação de seus trabalhos em eventos acadêmicos. Apesar das dificuldades com as disciplinas, aparentemente o contato próximo com colegas e com seu orientador apoiou a professora a desenvolver uma dedicação ativa ao MP: 
MP.Local.14: "Eu entrei no MP.Local, vamos dizer assim... bastante crua. No sentido de ter que aprender a fazer artigos, trabalhos para entregar, resenhas, essas coisas. [...] eu senti uma melhora nessa questão de entregar... de passar para o papel o que está em nossa mente [...] eu lembro que o meu primeiro artigo deu quatro páginas, meu último deu dezoito! Um crescimento... não só quantitativo, mas qualitativo também. Aprender a fazer uma revisão de literatura, aprender... Claro que quando eu saí, eu precisava aprender bastante, mas nesse sentido acadêmico, eu tive... embora seja um MP, eu tive bastante oportunidade de conhecimento".

MP.Local.14: "Como orientador, [Do.MP.Local-01] é muito bom, porque ele deu liberdade e autonomia para que eu pudesse fazer algumas coisas... E ao mesmo tempo, quando ele tinha que me corrigir, ele corrigia. [...] Eu vou apresentar agora um trabalho no Simpósio Nacional de Ensino de Ciências e Tecnologia, ainda com Do.MP.Local-01, e ainda sobre o trabalho desenvolvido na dissertação".

Percebemos uma continuidade na participação de eventos acadêmicos e realização de trabalhos escritos pela professora. $\mathrm{Na}$ verdade, ela prosseguiu sua formação acadêmica, pois ingressou em um doutorado em Educação, desenvolvendo uma pesquisa em Políticas Públicas, área relacionada a sua função de técnica de assuntos educacionais em uma universidade federal que passou a realizar após passar em concurso para o cargo alguns anos após a conclusão do mestrado. No entanto, apesar de ter se afastado mais ainda das salas de aula, informou que ainda continua dedicada ao Ensino de Ciências, como algo à parte, voltando à escola onde trabalhava para atividades pontuais. Dessa forma, podemos apontar que sua autoria é caracterizada por uma responsabilidade eventual. No entanto, apesar de não trabalhar mais diretamente com o Ensino de Ciências no ensino fundamental, expressa o desejo de poder retornar ao doutorado no mesmo programa do MP.Local. Teve muitas dificuldades em prosseguir em um curso de doutorado desenvolvendo pesquisas sobre ensino de Ciências no ensino fundamental. Percebe uma difícil inserção com esse projeto de pesquisa nos cursos de doutorado em Ensino de Ciências que poderia ingressar, por haver "certo preconceito" com sua formação inicial que não é ligada a nenhuma disciplina da área de Ciências da Natureza. Porém, na busca por retomar e atualizar os conhecimentos de sua própria área, e mais condizente com o seu trabalho como técnica de assuntos educacionais, MP.Local.14 realiza o doutorado na área de Educação.

Como impactos diretos da realização do curso, MP.Local.14 desenvolve-se nas dimensões atualização de conhecimentos científicos, atualização de conhecimentos pedagógicos, organização e condução de ensino e sustentação da aprendizagem. Num primeiro momento, por ter pouca experiência em sala de aula no momento que ingressou no MP, ela se sentia muito insegura em relação às aulas. 
Nesse sentido, ela pensa que também foi beneficiada por estar na posição de orientadora educacional, ou seja, não tinha o compromisso de dar aulas todos os dias, não sendo obrigada a assumir aulas quando não se sentisse preparada para isso. Em suma, ela aponta o MP.Local como responsável por ter ampliado sua segurança como professora:

MP.Local.14: "Na prática, eu tinha uma certa insegurança. E depois, assim, eu consegui melhorar. Não vou dizer zerar, mas eu consegui melhorar essa insegurança em sala de aula. [...] E eu não digo só segurança em relação ao conhecimento, segurança em relação a tudo: a lidar com as crianças, a ter o controle da turma, a deixar também que os alunos tenham a autonomia, eu aprendi tudo mais nesse sentido".

O estágio supervisionado do MP também auxiliou a professora MP.Local.14 nesse sentido, colocando-a em uma escola que não era a sua. Afirma que o estágio foi realizado em uma escola próxima da instituição de MP.Local, através da aplicação de aulas pontuais pelos mestrandos.

Em termos objetivos, a egressa MP.Local.14 cita algumas aprendizagens obtidas no MP.Local. Ao se referir ao trabalho da professora Ana Maria Pessoa de Carvalho, que estuda o ensino de Ciências no contexto do ensino fundamental, diz que se sentiu inspirada. Entretanto, permitiu-se ter autonomia de planejar atividades próprias, sem reproduzir diretamente a metodologia proposta por Carvalho, o que mostra a autoria com inovação reflexiva de MP.Local.14 frente ao conhecimento adquirido:

MP.Local.14: "Por exemplo, Ausubel, era um autor que eu não tinha
lido muito. A questão de ir para o laboratório para você sintetizar uma
teoria científica, para mim é novo, era algo novo. Também essa
questão de você utilizar coisas simples [...] para fazer a aula. Para
mim, isso era uma novidade também. [...] O Do.MP.Local-01 que
sugeriu e também tinha uma disciplina assim, que falava da
professora Ana Maria Pessoa de Carvalho, lá da USP, do LAPEF ${ }^{120}$.
[... Foi o primeiro contato, vamos dizer, teórico. Eu assisti uns vídeos
numa plataforma [...] sobre esse trabalho e fiquei encantada, a partir
daí, comecei a pensar em algo parecido, mas não segui a
metodologia do trabalho dela".

Como consequência dos estudos e trabalhos desenvolvidos no âmbito do MP, MP.Local.14, aponta que passou a ver um aumento no interesse das crianças que participaram de suas atividades, o que refletiu no maior aprendizado delas, além do engajamento maior dos outros professores daquela escola para também sugerir atividades diferenciadas. A egressa conclui que a realização do MP foi "uma fase muito boa de conhecimento, de produção" e que "a Orientação Educacional e a Pedagogia seriam coisas muito chatas se não tivesse esse mestrado", indicando a complementação que MP.Local deu a sua formação e trabalho.

${ }^{120}$ Laboratório de Pesquisa em Ensino de Física, instalado na Faculdade de Educação, USP. 


\subsubsection{Análise com elementos narrativos de MP.Local.15: a professora acadêmica}

A egressa MP.Local.15 tinha grande interesse em prosseguir sua formação na pós-graduação stricto sensu, realizando o mestrado e o doutorado. Tinha interesse na obtenção do título, mas não tinha muita noção da diferença entre o MP e o MA, apenas de que no MP era obrigatório estar trabalhando em escolas. Prestou o processo seletivo de alguns cursos de mestrado e foi aprovada no MP.Local, o que teve a vantagem de ser o curso mais próximo de sua residência.

Antes de ingressar no MP.Local, conta que começou a trabalhar em uma escola de zona rural logo após ter concluído a graduação. Ali, encontrou um cenário para o qual não estava preparada, tendo dificuldade em motivar seus alunos para o estudo da Física. Nesse momento, busca a formação continuada e, assim, começa um curso de pós-graduação lato sensu de formação de professores em Ensino de Ciências. Foi nesse curso que teve despertado seu lado acadêmico.

A proposta que a professora MP.Local.15 traz para o MP é a de dar continuidade ao seu trabalho do lato sensu que foi um estudo de caso sobre o uso da interdisciplinaridade para motivar os alunos ao estudo das disciplinas científicas, focalizando seu interesse na formação de professores. Uma das docentes do curso, integrante de um projeto do OBEDUC, gostou da proposta de MP.Local.15 e a convidou para fazer parte do projeto: "ela me convidou, eu aceitei, fui bolsista do OBEDUC, e eu tive que dar uma redirecionada na minha pesquisa, porque eu tive que trabalhar os MPs, mas eu busquei a formação de professores" (MP.Local.15). O projeto, que congregava pesquisadores de outras instituições, investigava a formação de professores no contexto dos cursos de MPs. Apesar de ser um contexto num primeiro momento desconhecido de MP.Local.15, atendia a sua expectativa de trabalhar na linha de pesquisa de formação de professores.

A egressa MP.Local.15, por ter estudado a legislação dos cursos de MP, é muito crítica em relação ao próprio MP.Local. Considera-o como um curso que "não tem um viés tão profissional assim", e considera como um sintoma disso o fato de as disciplinas serem simultaneamente compartilhadas pelas turmas de MA e MP. Aponta que não viu a questão da prática docente ser tão abordada nas disciplinas, e cita, por exemplo, as disciplinas específicas de Física, que estiveram demasiadamente focadas no conteúdo, sem pensar em sua aplicação no trabalho do professor; e outras que estiveram focadas mais em discussões acadêmicas, por exemplo, sobre CTS e 
educação ambiental crítica. Em seu ponto de vista, "tem uma dicotomia dentro do próprio programa disso. Ele é profissional, mas ele te ensina pesquisa" (MP.Local.15). Nesse sentido, a egressa desconsidera a indicação, discutida por autores que pensam a modalidade de mestrado profissional, como um lugar para o desenvolvimento de pesquisas, em especial de natureza aplicada (BARROS; VALENTIM; MELO, 2005), que também é referida na legislação da Capes a respeito dos MPs (por exemplo, logo na Portaria Normativa no 17, de 2009). De qualquer forma, como discutido na análise documental sobre o curso de MP.Local, o corpo docente adota a postura de nãodualidade entre o MA e o MP, de forma que valorizam o MP como também um espaço para pesquisa. Pela divergência apontada entre a proposta formativa e o que a professora tinha como expectativa, infere-se que a professora tenha tido uma dedicação passiva ao curso.

Porém, ela destaca um impacto do MP que teve em sua prática, pensando como uma docente de licenciatura que almeja ser, enquanto formadora de professores. Ela diz que o trabalho desenvolvido no contexto de seu PE, que foi um catálogo com produtos educacionais defendidos em cursos de MP que envolveram a formação de professores, e as disciplinas cursadas a ajudaram a adotar uma postura reflexiva diante de sua prática, favorecida pela atualização de conhecimentos acadêmicos proporcionada no curso:

MP.Local.15: "[...] afeta uma questão assim, o que eu penso a respeito do que eu quero ensinar. [...] o refletir a minha prática, isso sempre vai servir, porque dentro da minha pesquisa eu falo muito dessa questão das racionalidades. Então a gente é muito tecnicista dentro da área da Física. Essa questão reflexiva faz muita diferença dentro do meu viés de ensino. [...] eu hoje seria uma pessoa bem diferente dentro da construção teórica que eu recebi [...] eu revejo formas de como eu chego em novas práticas. Meu olhar se abriu mais para uma maior discussão, por exemplo, vamos supor... Eu nunca tinha visto CTS... Ah, eu vi CTS lá dentro. Então, hoje a minha pesquisa, meu grupo de pesquisa trabalha com construção de situações de estudo, e tem momentos que essa do CTS entra. [...] isso me auxilia na minha reflexão da prática, o quê que eu posso produzir".

Considera que o MP foi um meio para ela se constituir como uma pesquisadora e prosseguir com sua formação acadêmica:

MP.Local.15: "[...] me constituí pesquisadora só com as disciplinas que tiveram lá dentro? Não. Eu acho assim, que a contribuição para o meu olhar hoje, ela veio mais a partir do que ele me proporcionou, por exemplo, eu só conheci... eu só tive acesso à minha orientadora, por causa dele. A partir da orientadora, eu fui para o OBEDUC, e conheci muitos outros professores da área do Ensino de Física que me deram um bom aporte teórico para eu me constituir como pesquisadora. Então ele foi um meio. [...] Ele foi o meio que eu posso ressaltar pontos positivos assim que me auxiliaram e que eu tenho, que eu ainda trago no meu trabalho até hoje". 
Pela particularidade dos interesses em comparação com a proposta formativa do MP.Local e pelos percursos profissional e formativo de MP.Local.15 almejar a inserção na Academia e no ensino superior, não pudemos avaliar a autoria da egressa em termos dos indicadores responsabilidade e inovação.

\subsubsection{Análise com elementos narrativos de MP.Local.16: o professor universitário}

Logo após terminar a graduação, o egresso MP.Local.16 tinha certeza que gostaria de prosseguir sua formação no nível de pós-graduação stricto sensu, alcançando a posição de professor universitário. Por conta disso, e do desejo de aperfeiçoamento, decidiu realizar o curso de MP. Diz que não tinha muita noção inicial da diferença entre as modalidades acadêmica e profissional, nem sabia que na mesma instituição do MP.Local também era oferecido o curso de MA. Num primeiro momento, percebia que o MP tinha maior visibilidade. Num segundo momento, ao saber mais sobre o que era proposto pelo curso, aprova-o, despertando seu interesse pela elaboração do produto, sua grande expectativa na realização do curso. Chegou a trabalhar como monitor de extensão em seu curso de graduação, trabalhando com experimentação, e, portanto, decidiu dar continuidade a essa linha de pesquisa no MP.

A pretensão de trabalhar nessa linha o levou a ser convidado por Do.MP.Local01, que se tornou seu orientador, a fazer parte do Projeto Novos Talentos, do qual muitos docentes do MP.Local faziam parte, conforme já discutido em outras etapas dessa pesquisa. A adesão ao Projeto Novos Talentos era uma oportunidade de captação de recursos para a construção das atividades experimentais que proporia em seu PE:

MP.Local.16: "ele [seu orientador] deixou muito claro, ele frisou muito bem que era uma oportunidade de ter um aporte financeiro. Porque ele disse assim 'oh, o que você quer, demanda um investimento, que é bem provável que você vai ter uma certa dificuldade, se você não for por esse caminho'".

A participação no Projeto Novos Talentos é avaliada por MP.Local.16 como positiva, pois além de ter o aporte financeiro, pôde fazer a montagem prévia de seu material em um contexto de educação não-formal, através das atividades realizadas no colégio parceiro do projeto. Foi também por meio do projeto que pôde participar de diversos eventos para apresentação e publicação de trabalhos, sempre visando a questão da "evolução de etapa" de sua carreira profissional. Além disso, o egresso considera a parceria que foi possível estabelecer com escolas da educação básica por meio do Projeto Novos Talentos, como muito válida para alcançar os professores de 
educação básica que se envolvem com seus alunos nas atividades e eventos desenvolvidos, tendo contato com os PEs e também com o mestrado em si: "por exemplo, nesse edital, trabalhamos com professores do colégio, que não estavam fazendo mestrado e inclusive depois se interessaram por fazer o mestrado!" (MP.Local.16). É um desdobramento positivo do investimento que o curso se propõe a fazer com projetos de extensão.

A participação no Projeto Novos Talentos exigiu maior esforço por parte de MP.Local.16. O egresso conta que o início de seu curso foi mais voltado à realização das atividades do Projeto e, por conta disso, teve que planejar coisas que não estavam no escopo do mestrado, não podendo dar maior atenção ao desenvolvimento de sua pesquisa. $O$ envolvimento com essas atividades extras indicam uma dedicação ativa ao MP.Local:

MP.Local.16: "No final, eu tive que empreender um esforço gigantesco... [...] no meu caso, foi extremamente sacrificante. Por exemplo, teve professores que reclamaram da minha ausência em algumas aulas [do mestrado], inclusive eu tive que faltar, porque conflitou, o programa não tinha essa coisa, essa obrigação de liberar em dias que tinha intervenção... [...] Alguns professores não trabalhavam [no Projeto], então esses foram piores, como não estavam ligados diretamente ao projeto, falou 'você tem que dar... tem que dar produção aqui, eu quero que você faça esse trabalho, e isso, aquilo...' Isso foi complicado..."

Apesar das dificuldades em acompanhar as disciplinas, o egresso MP.Local.16 destaca que elas foram produtivas. Inclusive cita que muitas discussões no âmbito da disciplina Metodologia de Pesquisa foram incorporadas a sua prática como professor orientador de TCCs: "você percebe onde você pode pisar com segurança, onde você não pode. Foi isso a principal [contribuição]" (MP.Local.16). Ele percebe que, no geral, as disciplinas do curso serviram como suporte indireto para desenvolver sua pesquisa, no sentido de lhe conceder autonomia para pensar seu trabalho:

MP.Local.16: "Eu tinha outra visão. Eu achava que as disciplinas iriam funcionar semelhante como eram as da graduação. Tipo, você passou, e aquele conhecimento de Física, diretamente você vai usar. 'Ah, eu sei resolver problemas de Leis de Newton...' E não foi bem assim. Eu percebi que realmente foi um suporte indireto. Aquilo me dava condições de eu pensar no meu trabalho. [...] eu ganhei um suporte para poder desenvolver o trabalho".

Inicialmente, o seu orientador o deixou livre para escolher o referencial teórico que utilizaria para apoiar o desenvolvimento e avaliação do PE. MP.Local.16 conta que depois, acabou optando por trabalhar com a Teoria da Aprendizagem Significativa, entendida pelo orientador como mais adequada para seu trabalho. Uma das orientações dadas pela teoria aparece de modo concreto em seu PE com o desenvolvimento de uma História em Quadrinhos para ser utilizada como organizador 
prévio. Essa questão de como quantificar e utilizar os conhecimentos prévios dos alunos para abordar determinado conteúdo é algo que marcou a prática do professor, o que incide na sua dimensão organização e condução do ensino:

MP.Local.16: "[...] quando eu comecei a ler sobre a Aprendizagem Significativa, e isso é uma das coisas que permanece em mim até hoje, toda vez que começo um trabalho em Física agora, um legado que eu tive do meu trabalho, é... E isso está nos referenciais teóricos que eu tenho lido agora [...] a Teoria da Aprendizagem Significativa fala dessa questão da necessidade de você trabalhar com organizadores prévios, para que você traga essa... que você quantifique, você mapeie de alguma forma esses conhecimentos que o aluno traz, para que você depois monte sua aula e dê seguimento retroalimentando isso. Então a minha pesquisa foi montada assim. Eu quero que o organizador prévio, que é uma coisa que existe na teoria, ele faça parte da sequência, e que ele me forneça dados para retroalimentar".

Outro destaque dado por MP.Local.16 envolve o aprimoramento da dimensão sustentação da aprendizagem destacando a necessidade de motivar os alunos para a aprendizagem, sobre a ameaça de recair em uma aprendizagem mecânica. Para isso, o professor destaca que procura trabalhar com o protagonismo dos seus alunos, trabalhando sob a visão de metodologias ativas de ensino-aprendizagem:

MP.Local.16: "[...] tem que trabalhar sempre com motivação, porque uma das minhas conclusões... [...] É que eu ganhei uma visão de que, a motivacão é o eixo principal do seu trabalho. Se o aluno não estiver motivado e não estiver consciente de que isso interfere no processo, nada vai à frente, porque se ele não estiver entendendo que ele precisa querer aprender, 'ah, você precisa querer! Se não vamos ficar naquela coisa de eu boto, você faz uma prova, eu faço a coleta de dados através... eu vejo o que você acertou, o que você errou, te atribuo aquela nota, aí você passa ou não passa' [...] e aí como trabalho com isso? Eu trabalho olhando para o próprio aluno. [...] Ele vai ser o protagonista, o professor olhando para o aluno como um agente desse trabalho. Eu vou usar o próprio aluno para ensinar o aluno, eu vou trabalhar com uma visão que algumas teorias chamam de sala de aula invertida. Ou seja, ele tem que buscar 0 conhecimento".

Apesar de adotar essa visão, confessa que não trabalha, ainda, dessa forma na instituição onde dá aulas no ensino superior, por limitações decorrentes do próprio local de trabalho, de sua organização como um todo. Isso indica uma autoria com uma responsabilidade eventual:

MP.Local.16: "Apesar de eu estar trabalhando no Ensino Superior, eu estou lidando com uma dinâmica de ensino, que é puramente tradicional. Eu estou lidando muito pouco, pelo menos no que se refere às intervenções, à forma como eu aplico, muito pouco do que eu aprendi. Está mais no campo das ideias, na maneira de como eu monto minha aula. Mas a maneira como eu construo as intervencões. ela tem um pouco essas limitações de tempo, de condições de estrutura, por exemplo, eu gostaria de estar trabalhando com laboratório, a instituição tem, mas eu não pude preparar nada, então por isso eu optei por não introduzir na minha dinâmica". 
Em suma, esse egresso vê o MP.Local como decisivo para estar trabalhando com o ensino superior. Destaca também, por fim, a atualização dos conhecimentos pedagógicos, que apóia a sua preocupação em sempre ter um aporte teórico que sustente a sua prática. Também expressa a preocupação de sempre registrar sua prática docente:

MP.Local.16: "[o MP] me possibilitou olhar de uma forma diferenciada o próprio conhecimento sobre o ensino. Hoje, toda vez que eu vou montar qualquer coisa, de uma forma indireta [...] eu vou montar uma atividade pensando em que aporte teórico isso vai ter por trás $[. .$.$] isso$ aqui é uma intervenção. Isso aqui eu posso fazer de uma forma que depois eu até guarde essas informações para usar futuramente. Tudo que eu tenho feito agora, na medida do possível, eu tenho feito dessa maneira".

A preocupação em ter uma prática fundamentada expressa uma autoria com inovação reflexiva, já que o diálogo com os referenciais permite ao professor adaptar indicações da teoria para sua prática e, ao mesmo tempo, buscar subsídios para auxiliar na solução de problemas da prática, além da possibilidade de produzir conhecimento com suas intervenções.

Por fim, MP.Local.16 destaca como vantajoso o fato de a instituição contar com vários níveis de ensino, dando chances de aqueles que terminam a graduação, ingressar na pós-graduação no mesmo local, se assim o desejarem. O que de fato é aproveitado por alguns licenciados em Física pela instituição, entre os que entrevistamos, os professores MP.Local.01, MP.Local.04, MP.Local.06 e MP.Local.12. Considera que já estaria cursando o doutorado no mesmo programa, se ele já tivesse aberto o processo seletivo para a primeira turma, o que ocorreu meses após a sua entrevista. Como ponto desfavorável, julga o fato de não haver bolsas disponíveis para os mestrandos do MP. Também sugere que seria interessante existir no curso uma orientação maior sobre gestão de carreira. Entende que há pesquisas realizadas pelos docentes do programa sobre o que os egressos fazem após sair do curso, mas não vê "a preocupação em orientar o egresso do mestrado" em relação a sua profissão.

\subsubsection{Análise com elementos narrativos de MP.Local.18: a professora pesquisadora}

A egressa MP.Local.18 optou em dar continuidade a sua formação no MP.Local porque buscava respostas as suas muitas dúvidas sobre sua prática. Por ter estudado numa licenciatura no formato $3+1$, considerava ter muitas carências em sua formação. O MP foi a oportunidade de aprender coisas que faltaram em sua 
graduação, além de tê-la ajudado a crescer como pesquisadora. No MP, conseguiu "ter olhos de pesquisadora, não só de professor" (MP.Local.18).

Ser pesquisadora, em um primeiro momento, para MP.Local.18, significou ter conhecimento de onde poderia buscar referências de atividades e conteúdos para suas aulas:

MP.Local.18: "Essa questão da pesquisa, de leitura, de compreender materiais, eu acho que isso me ajudou muito [...] porque a gente precisa disso, a gente precisa saber onde pesquisar, saber procurar [...] quando eu aprendi a pesquisar isso, aí eu acho que hoje em dia eu posso até falar que estou me tornando uma professora um pouquinho melhor. Um pouquinho! Porque agora eu preciso pesquisar e ver o que eu consigo utilizar na minha aula".

Assim, em termos práticos, aprender a pesquisar está relacionado ao aperfeiçoamento na dimensão organização e condução de ensino. MP.Local.18 conta o percurso para planejar seu PE. A professora elaborou um laboratório portátil para abordar conteúdos de eletromagnetismo em turmas da EJA. Não tinha utilizado experimentação nas suas aulas até que um dia, em uma aula de turmas de nono ano, do ensino fundamental, fez um protótipo que mostrava de forma análoga 0 deslocamento de corrente elétrica em um condutor: "foi quando despertou essa questão dos experimentos. Falar 'caramba, e não é que funciona? Não é que vale a pena a gente investir nisso?' Aí fui criando, fui pegando na internet, fui buscando em artigos, fui pesquisando..." (MP.Local.18).

Dessa forma, considera esse o maior legado do MP para sua prática. A pesquisa Ihe ajuda a planejar aulas com maior sentido aos alunos:

MP.Local.18: "[...] me ajudou com a questão da pesquisa, que eu não sabia antes disso, agora eu já sei onde eu consigo pesquisar, onde eu posso achar, então eu acho que isso ajudou a preparar essas aulas com uma finalidade, um objetivo, não vou lá só falar ' $F=m \cdot a$ ' e que se dane! Não! Eu quero que ele compreenda aquilo ou no cotidiano dele, ou... que ele veja que aquilo ali não é um 'ah, porque é que eu preciso aprender?'... Fazer um sentido para ele".

Como consequência, a professora percebe uma mudança na relação com os alunos, que começam a se interessar mais pelas aulas. Essa relação com os alunos torna-se importante para a professora, indício de impacto na dimensão sustentação da aprendizagem:

MP.Local.18: "Eu acho que acabou tendo mais paixão. [...] Os alunos se encantarem mais com aquela matéria, verem que aquilo não é um bicho de sete cabecas, que é difícil pra caramba, vai reprovar, igual a gente pensava antigamente. Acho que essa foi a mudança que eu percebi neles". 
Outro impacto na prática citado por MP.Local.18 é a abordagem interdisciplinar de conteúdos em suas aulas. Essa postura tem a ver diretamente com as disciplinas cursadas. MP.Local.18 considera ter sido muito bom ter diferentes disciplinas que abordavam conteúdos de Biologia, de Química e outras, além das de Física. Porém, destaca como negativo o fato das disciplinas terem um formato condensado, tendo duração de cinco encontros cada: "é muito bom porque você está vendo várias coisas, em vários pontos de vista diferentes, mas quando você pega um gosto, e você 'ah, quero aprender', não tem mais!" (MP.Local.18). Esse desejo por "aprender mais" indica uma dedicação ativa da professora no curso. Cita como um exemplo, a disciplina Debates Conceituais em Ensino de Química, na qual a docente responsável propunha atividades para que os professores de diferentes áreas relacionassem o conteúdo da Química apresentado com a sua própria área de formação. Também cita discussões empreendidas pelo docente da disciplina Debates Conceituais em Educação Ambiental que ela mesma aproveita em suas aulas de Física. Além da questão de conteúdos a serem abordados nas aulas que leciona, as disciplinas também deram suporte para a realização do seu PE. O referencial teórico principal que adotou em sua pesquisa também foi fruto de uma disciplina do curso. Em suma, no contexto das disciplinas, MP.Local.18 declara: "você cresce ali dentro, como professor, como... da área de Física, tendo essa troca, é muito bacana. [...] Você sai dali com uma bagagem muito grande" (MP.Local.18).

Em relação ao PE, MP.Local.18 enfrentou algumas dificuldades, pois precisou trocar de orientador, o que a fez perder um pouco de tempo. Somado ao fato de ter perdido as turmas de ensino fundamental que lecionava (e sua ideia inicial era a de criar um livro para turmas de nono ano), teve que trocar o público a quem seria direcionado seu PE e sua natureza, para algo que fosse de mais rápida elaboração. Foi então que MP.Local.18 opta em trabalhar experimentação para abordar conteúdos de eletromagnetismo na EJA.

A narração sobre a aplicação do PE revela uma outra faceta da formação de MP.Local.18 como pesquisadora, que pode não estar ainda clara para ela mesma, já que quando comenta na entrevista sobre a formação para pesquisa, se refere sempre à questão de saber onde procurar artigos e outros materiais para implementar em suas aulas. Na aplicação do PE, percebeu um rendimento muito baixo dos alunos na avaliação em um dos conteúdos abordados por um experimento de um motor elétrico. $O$ resultado negativo a fez questionar-se a respeito do que poderia ter dado errado no processo de ensino-aprendizagem e como ela poderia melhorar sua abordagem do referido experimento. Aos poucos, foi refletindo sobre sua prática e aperfeiçoando-a. É 
um indicador que envolve o aperfeiçoamento na dimensão investigação sobre a própria prática:

\begin{abstract}
MP.Local.18: "Na primeira vez que eu apliquei, quando eu fui falar de motor elétrico, eu acho que eu devo ter me enrolado, não sei, porque as respostas de motor elétrico foram um desastre [...] E aí isso foi uma coisa que me fez pesquisar. Por que será que a explicação não deu de nada? E aí eu comecei a pesquisar, pesquisar, pesquisar, a explicar de outras formas em outras turmas, e vendo essa evolução. Que aí hoje em dia, eu já consigo explicar de uma forma em que eu obtenho um resultado satisfatório".
\end{abstract}

Concluindo, diz que a realização do MP, para ela, "foi um sonho". Principalmente aos olhos de seus alunos, vê uma grande valorização de seu trabalho, pois ao contrário de alguns outros professores, os alunos apontam à professora que ela sempre está animada, preparando aulas com algo diferente. Essa fala dos alunos indica que a professora teve uma responsabilidade sistemática em relação ao que aprendeu no MP. MP.Local.18 vê como essencial para professores a continuidade dos estudos em nível de pós-graduação:

MP.Local.18: "É importante falar, é importante passar, é importante conversar e é importante sempre incentivar, então eu acho que isso me incentivou a incentivar mais. Me incentivou a melhorar mais. Me incentivou a produzir mais. Acho que por isso que foi um sonho".

O fato de dizer estar motivada para produzir mais indica, por fim, que a professora tenha alcançado o nível criativo no aspecto de inovação de sua autoria docente.

\title{
5.3 Apreciações sobre as análises: o que revelam sobre os cursos de MP e o desenvolvimento profissional dos egressos
}

Encerramos a análise dos dados com uma apreciação geral sobre as análises com elementos narrativos apresentadas, tendo em vista o entendimento de como foi a realização dos cursos e quais foram os resultados alcançados na perspectiva dos egressos entrevistados.

É possível perceber diversas semelhanças nas perspectivas em relação ao MP; no modo como os egressos realizaram as disciplinas, o PE, a dissertação e demais atividades acadêmicas; e quais foram os impactos de toda essa vivência proporcionada pelo MP entre os dois grupos de egressos entrevistados, apesar de terem realizado cursos com propostas curriculares diferenciadas entre si. No geral, prevalece a questão de que ambos os cursos são mestrados na modalidade 
profissional e, portanto, perseguem objetivos próximos: o compromisso com a atividade prática docente e a elaboração obrigatória do PE. Há alguns aspectos particulares que diferenciam os impactos no desenvolvimento profissional de cada egresso entrevistado, levando em conta cada percurso pessoal anterior e posterior à realização do MP. Tal aspecto individual fica principalmente explícito quando analisamos aspectos da autoria docente dos professores em relação aos cursos de MP. Há egressos com diferentes níveis de envolvimento nos indicadores dedicação, responsabilidade e inovação nos dois cursos.

No tocante aos resultados semelhantes encontrados em nossas análises, foi comum nos dois grupos o não entendimento inicial do que seria um MP: suas características, objetivos, qual seria a finalidade do PE. No polo do MNPEF, segundo o relato dos egressos, o corpo docente era franco a esse respeito, ou seja, os docentes deixavam claro que o curso era algo novo em que todos estavam envolvidos. Por estarem comprometidos em fazer com que o curso fosse bem sucedido e fizesse a diferença para a formação dos mestrandos, embora a maioria não tivesse formação ou experiência com a área de Ensino de Física, se mostravam em geral preocupados em acolher e requisitar dos mestrandos uma participação ativa para a construção e consolidação do curso. Essa postura favoreceu a criação de um clima de parceria entre docentes e discentes, que é citada por todos os egressos desse MP que puderam ser entrevistados. Essa parceria foi fundamental para todos se desenvolverem e concluírem o curso, como o relato emocionado do egresso MNPEF.07 indica. No MP.Local há menção da mesma postura por parte do corpo docente, embora com menor ênfase nas entrevistas, provavelmente por conta do menor número de entrevistados que participaram nas primeiras turmas do curso, antes de sua consolidação.

O envolvimento dos discentes com as disciplinas foi intenso nos dois cursos. É marcante a questão de se observar como o currículo prescrito se realiza na prática, no caso do polo do MNPEF. Alguns dos egressos entrevistados que participaram do workshop regional promovido pela CPG Central do MNPEF para congregar docentes e mestrandos de diversos polos do Mestrado em Rede apontam as diferenças que perceberam em relação aos outros polos. No polo em que se matricularam, os docentes ressignificaram a ementa das disciplinas da matriz curricular, a maioria delas, conforme já discutido, abordando conteúdos avançados de Física. A diferença se deu pelo cuidado que os docentes tiveram em relacionar os conteúdos abordados com o trabalho dos professores na educação básica. Escolheram fomentar discussões sobre como os professores-cursistas abordariam aqueles conteúdos nas turmas de 
educação básica, ao invés de discutirem os conteúdos "pelos conteúdos". Essa diretriz possibilitou aos mestrandos o contato com recursos e metodologias (inovadores, para muitos), e a mudança nos modos de pensar o seu trabalho.

O que significa "mudar a visão sobre ensino" que muitos egressos relatam? Nas análises com elementos narrativos de MNPEF.08, MNPEF.17 encontramos subsídios para entender o que significa essa mudança. Ambos os professores contam que antes da realização do curso, eram professores mais "duros", exigentes, se preocupavam com o formalismo matemático; em suma, eram professores que se identificavam com uma cultura de ensino tradicional da Física. Com a realização do MP, tornam-se mais "maleáveis", pois vêem outras possibilidades de se abordar a Física, entendem a importância das discussões mais conceituais, se envolvem com outras formas de avaliar seus alunos, além da tradicional prova escrita com a realização exaustiva de exercícios. Isso também ocorre com egressos do MP.Local, por exemplo, o egresso MP.Local.12 e MP.Local.16. Essa "mudança de visão" também aparece fortemente correlacionada com a interação entre colegas nos dois cursos.

A interdisciplinaridade encontrada no MP.Local aparece também como elemento instigador dessas mudanças nos professores-cursistas, e surgem principalmente nas disciplinas do curso, se refletindo pouco nas dissertações e PEs dos professores, ao menos na amostra analisada nessa tese. Essa interdisciplinaridade surge mais nos contextos das disciplinas, realização de artigos e discussões entre colegas do curso.

A maioria dos docentes - dos dois cursos - propunham nas disciplinas atividades que suscitavam discussões sobre a prática em sala de aula dos professores. As disciplinas do MNPEF abordavam a discussão sobre como abordar os conteúdos na educação básica. No MP.Local, também havia o foco na produção de atividades e a escrita de artigos em conjunto com os colegas de outras formações além da Física, de modo a incentivar atividades interdisciplinares, característica fundamental desse programa. Disciplinas que focaram apenas o conteúdo científico surgiram nos dois cursos, quase sempre sendo criticadas pelos egressos como destoante dos cursos como um todo.

As vivências dos professores-cursistas enquanto alunos dos MPs parecem ser fundamentais para o impacto do desenvolvimento profissional deles em termos de mudanças nas práticas docentes. Os professores passam a utilizar em sala de aula com seus alunos não apenas o que viveram nas disciplinas na posição de alunos de mestrado, como também o que experimentaram com seus orientadores, na posição de orientandos. Indício para essa afirmação é a menção que alguns entrevistados fazem 
de que mudaram o modo de avaliar seus alunos. Apesar de o tema "avaliação" não ser conteúdo principal de nenhuma ementa de disciplina dos dois cursos, os professores-cursistas foram avaliados nas disciplinas de maneira diferenciada. A experiência de criar e avaliar um PE também pode ter corroborado essa mudança.

Outra semelhança entre os resultados alcançados pelos cursos na formação de seus egressos diz respeito à auto-percepção dos professores como professores pesquisadores, ou profissionais reflexivos. Foi fundamental para isso o contato com as produções acadêmicas por meio das disciplinas ou por indicação de orientadores e da literatura de base consultada para a elaboração dos PEs. A aproximação com 0 mundo acadêmico significou para os professores dos dois cursos tanto o contato com artigos e pesquisas atualizadas da área, quanto o exercício da escrita acadêmica, o que para a maioria, era uma novidade.

Temos, como desdobramentos, egressos que relataram um exercício de pesquisa sobre a própria prática e de registro de suas atividades docentes, mesmo que de forma rudimentar. Outro ponto muito ressaltado é a independência que muitos assumiram dos livros didáticos. O contato com os artigos acadêmicos ampliou as referências dos professores, já que antes da realização dos cursos, muitos tinham apenas o livro didático como base para seu trabalho. Após o MP, adquirem como referências também artigos de pesquisadores da área e os PEs. Além disso, a aproximação com as discussões empreendidas na Academia ampliaram o olhar dos professores sobre seu próprio cotidiano e seus alunos.

Outro dado que surgiu com semelhante destaque nos dois cursos é a questão da localização das instituições dos cursos, descentralizados da capital. No caso de MNPEF, o polo se localiza no interior do estado e no caso do MP.Local, se localiza na periferia da região metropolitana. É um fato de extrema relevância para acesso dos mestrandos ao curso, sendo que muitos deles provavelmente teriam maiores dificuldades em fazê-los, e possivelmente nem poderiam realizá-los, se estes se concentrassem apenas nos grandes centros.

Em relação às diferenças identificadas nos contextos dos dois cursos, temos como principal o investimento maior em bolsas de estudos no MNPEF. Esse fator foi determinante para grande parte dos egressos realizarem o MP. No MP.Local, as dificuldades com a captação de recursos e bolsas foram parcialmente resolvidas em um primeiro momento com a inscrição de projetos em editais da Capes, no caso, no Observatório da Educação e no Projeto Novos Talentos. 
Além de servirem à captação de recursos, a adesão a esses projetos também serviram à aproximação entre a universidade e escolas de educação básica, da mesma forma que as experiências realizadas no âmbito do Estágio Supervisionado no MP.Local, cujos relatos indicam a realização de atividades pelos mestrandos em escolas das imediações da instituição que sedia o curso. A aproximação entre os mundos acadêmico e da educação básica é um ponto ainda crítico para os MPs. É importante ressaltar, no entanto, que a aproximação entre o MP.Local e as escolas, dada principalmente na realização das atividades do Projeto Novos Talentos, não envolveu as escolas onde os professores-cursistas que participaram das atividades do projeto trabalhavam.

De qualquer forma, essa interação com as escolas teve um efeito multiplicador e de divulgação do curso. Os professores dessas escolas puderam entrar em contato com os PEs e pesquisas em desenvolvimento pelos professores-cursistas e também, conforme relato de MP.Local.16, se interessaram em eles mesmos realizarem o curso.

O Simpósio de Ensino de Física do polo do MNPEF é um evento anual que serve também como multiplicador e divulgador das atividades desenvolvidas no MP, porém, aparentemente, em menor escala, provavelmente por ser um evento ainda em fase de consolidação no curso. Num trabalho de campo desenvolvido no contexto dessa pesquisa de doutorado, em visita à edição do ano de 2018 do Simpósio, foi possível perceber a participação de licenciandos de outras instituições, de egressos do MNPEF e de mestrandos de diferentes turmas apresentando seus trabalhos. Além da extensão, esse evento teve grande importância para os mestrandos: pelo seu efeito agregador da comunidade que se formou em torno do curso; pela possibilidade de divulgar e discutir seus PEs em desenvolvimento e, por fim, pelo contato com pesquisadores da área de Ensino de Física que são convidados para ministrarem palestras e oficinas aos participantes. No MP.Local não há a realização de um evento anual nesses moldes, embora no final do ano de 2017 tenha sido promovido um evento em comemoração aos 10 anos do curso que teve propósitos semelhantes: divulgar trabalhos e promover o encontro entre mestrandos, egressos e pesquisadores da área de Ensino de Ciências.

No conjunto das análises com elementos narrativos, encontramos respostas aos questionamentos particulares a cada curso derivados das outras etapas de pesquisa, que esclarecem o funcionamento dos mesmos. Abaixo, estão compiladas as respostas para cada conjunto de questionamentos. 
No MNPEF permanece marcante o distanciamento universidade-escola, pelo pouco contato do seu corpo docente com a realidade das escolas de educação básica, embora, como já apontado, os docentes se mostrem engajados em aprender e discutir as questões relativas ao ensino. O Estágio Supervisionado, que poderia ser um espaço para essa maior aderência entre docentes e as escolas, é utilizado como um espaço para a discussão da aplicação dos PEs e orientação a respeito da escrita da dissertação. A gestão centralizada do MNPEF não parece ser uma característica dificultadora para o bom andamento do curso, no olhar dos egressos, já que não citam espontaneamente nas entrevistas nenhum problema em relação a isso. Provavelmente não é um problema, pois localmente, foi construído um grupo coeso entre corpo docente e discente no polo. De modo geral, os egressos expressaram a satisfação em participar de um encontro regional promovido no início do curso entre polos do MNPEF e entrar em contato com Marco Antônio Moreira. Por último, a titulação de mestre fez com que alguns professores fossem tratados de forma diferenciada nas escolas em que trabalham, mas não necessariamente tinham apoio da gestão escolar para a realização de seus trabalhos, como no caso de MNPEF.17.

No MP.Local, a intersecção entre os cursos de MP e MA, do mesmo programa, ocorrem nas várias disciplinas compartilhadas entre eles. Os egressos relatam que consideram o MA menos exigente que o MP, pois neste último há a elaboração obrigatória do $\mathrm{PE}$, além do cumprimento das mesmas disciplinas, com poucas diferenças. A produção acadêmica parece ser algo muito estimulada no curso, em especial nas disciplinas, com a realização de trabalhos interdisciplinares entre colegas. A publicação de artigos é vista, de modo geral, como positiva pelos egressos, levando em conta que muitos deles tinham como objetivo dar prosseguimento à formação acadêmica e alguns, a seguir uma carreira acadêmica e como docentes do ensino superior e dos institutos federais. As disciplinas do MP.Local também apoiaram no caso de muitos egressos a escolha de referenciais teóricos que embasaram seus PEs e suas dissertações.

Para finalizar, observamos as dimensões de desenvolvimento profissional cujos indicadores de aperfeiçoamento são apontados ao longo das análises com elementos narrativos.

Majoritariamente, por conta da natureza do MP, as dimensões organização e condução do ensino e sustentação da aprendizagem são as mais afetadas nos percursos formativos dos egressos entrevistados. Os indicadores de desenvolvimento nessas dimensões apontam tanto novidades que são aprendidas nos MPs e incorporadas à prática dos professores, quanto um reforço de práticas que já eram 
realizadas por alguns deles. De modo geral, os MPs impactam nessas dimensões também dando maior visibilidade aos saberes experienciais dos professores. Importante ressaltar que, apesar de Barolli et al. (2019) colocarem essas duas dimensões como desenvolvidas a partir do diálogo com a Escola, na prática dos egressos, na maioria das vezes, são desenvolvidas de forma solitária e restritas ao domínio de suas salas de aula. A outra dimensão considerada pelos autores como também envolvida no diálogo com a Escola, a participação na gestão escolar, é incipiente nos casos dos egressos entrevistados.

O diálogo com a Academia, um ponto central para os MPs, tem como consequência o aprofundamento e atualização das dimensões conhecimento científico e conhecimento pedagógico. O conhecimento que essas dimensões abarcam não é apenas teórico, mas prático também, em especial permitindo o acesso a recursos e ferramentas pedagógicas anteriormente desconhecidas pelos professores. Essas dimensões estão intrinsecamente relacionadas também às dimensões anteriores, porém vemos que não necessariamente o acesso aos conhecimentos acadêmicos acarretam na renovação das práticas docentes, já que alguns egressos encontram fatores limitantes na escola e por questões relacionadas à organização do trabalho docente. Porém, em geral, a apropriação e aprofundamento dos conhecimentos abordados em disciplinas, discussões, eventos e na elaboração do PE e da dissertação, concede aos professores uma maior segurança sobre o seu próprio trabalho, além de maior valorização.

A dimensão investigação sobre a própria prática surge com maior ou menor ênfase no percurso formativo de todos os entrevistados, em especial para aqueles que afirmam com destaque a percepção que têm de si mesmos como professores reflexivos e professores pesquisadores. A dimensão planejamento da carreira profissional aparece já latente para muitos professores que apontam como motivações para a realização do curso de MP, o desejo de continuidade dos estudos em nível de doutorado e, embora não seja um desejo de todos, é frequente egressos que alcançaram ou buscam alcançar uma posição como professores de ensino superior. O planejamento da carreira profissional já era algo considerado por muitos antes da entrada nos cursos de MP, por conta da realização de cursos de formação continuada e de pós-graduação lato sensu.

A escassez de indicadores nos dois grupos de egressos referentes à dimensão participação na responsabilidade social, indica a ausência ou a carência do diálogo entre os professores e a Sociedade, ignorada ou abordada de forma tímida em ambos os cursos de MP analisados nesta pesquisa. 


\section{Conclusões e perspectivas abertas pela pesquisa}

Analisando dois cursos de MP, um polo do MNPEF e o MP.Local, buscamos nessa pesquisa responder às seguintes questões: Quais são os impactos dos cursos de MP estruturados de diferentes formas sobre o desenvolvimento profissional (em termos de formação e mudanças na prática profissional) de seus professorescursistas? Como os professores-cursistas interagem com o currículo proposto e praticado nesses cursos?

A pesquisa, de cunho qualitativo, foi estabelecida em quatro etapas interdependentes a fim de elucidar o funcionamento dos cursos, a atuação do corpo docente, o envolvimento dos professores-cursistas com cada MP, e, por fim, os principais impactos do curso no desenvolvimento profissional dos egressos entrevistados. Essas etapas foram as seguintes: 1. análise dos documentos que regulamentam os cursos; 2. entrevistas com coordenadores e membros do corpo docente; 3. análise das dissertações e PEs defendidos nos cursos até o ano de 2017; 4. entrevistas com egressos. Encerramos este trabalho traçando considerações a partir dos dados obtidos e análises empreendidas, procurando responder às questões de pesquisa e muitas outras que nasceram de seu próprio desenvolvimento e sintetizando outros questionamentos que abrem possibilidades de novas pesquisas.

Partimos do pressuposto de que apesar das propostas diferenciadas entre os dois MPs, ambos poderiam proporcionar processos semelhantes de desenvolvimento profissional para seus professores, salvo diferenças nas dimensões de desenvolvimento profissional enfatizadas decorrentes das trajetórias individuais dos mestrandos e de quais elementos dos currículos proposto e realizado nos cursos lhes poderiam ser mais relevantes para proporcionar tal desenvolvimento profissional. Nosso interesse foi lançar luz para além do proposto e verificar o vivenciado pelos professores-cursistas e também explorar outros fatores que influenciariam nos resultados de formação alcançados. Nesse sentido, obtivemos resultados que corroboraram muitos de outras pesquisas apresentados em nossa revisão de literatura; e aprofundamos outras questões ainda não exaustivamente exploradas, tais como a análise de dissertações e PEs.

Primeiramente, em termos objetivos, as principais motivações que levaram os professores a cursarem os cursos de MP envolveram a facilidade que a forma que esses cursos estavam estruturados davam para a sua realização. Muitos egressos entrevistados apontaram a importância dos horários, a localização dos cursos e a 
possibilidade de bolsas (principalmente no caso do polo do MNPEF) como fatores relevantes para suas escolhas, mais do que a própria proposta formativa do curso. As condições objetivas de realização do MP são extremamente importantes, ainda mais ao considerarmos que muitos egressos entrevistados relataram que tinham iniciado outros cursos de mestrado anteriormente, sem conseguir concluí-los. Uma diferença marcante entre os cursos foi que muitos egressos do MP.Local ingressaram nele com a intenção prévia de dar prosseguimento à formação no doutorado e de tornarem-se professores de ensino superior. Alguns egressos do MNPEF também seguiram esse caminho formativo, porém a maioria deles manteve-se nas escolas de educação básica.

Outro fator que se mostrou relevante para ambos os cursos, desta vez de caráter subjetivo, se refere à importância da vivência em ambiente positivo, resultado que já havia sido indicado em pesquisa de Shuck et al. (2016). Nos dois cursos, em maior ou menor grau, pudemos observar, principalmente através das falas dos egressos, o envolvimento emocional que tiveram com orientadores, docentes do curso e colegas mestrandos, que serviu para muitos como apoio para o término do curso e realização das disciplinas e da dissertação e PE; além de proporcionar trocas de experiências e reflexões coletivas e profícuas a respeito dos problemas enfrentados pelos professores em sua profissão e no cenário mais geral da educação brasileira. Tal conexão foi particularmente concretizada entre professores-cursistas do MNPEF. Os dados indicam que características da organização do MP.Local, principalmente o fato de as disciplinas do curso (momento em que os professores-cursistas têm para interagir mais profundamente uns com os outros e com outros docentes do curso) terem formato condensado; e a ausência de um evento local de periodicidade anual como o Simpósio de Ensino de Física do polo do MNPEF, podem ter desestimulado a formação de tais vínculos. Outra particularidade que favoreceu a integração entre os professores-cursistas do MNPEF foram os momentos de interação que tiveram nas pousadas onde se hospedavam e em momentos de descanso e lazer entre os dias de disciplinas do curso.

Outro fator que rendeu impactos de cunho psicológico e estimulante para os professores-cursistas foi a possibilidade de interagir com pesquisadores que são referências na área de ensino, o que fez com que muitos do polo do MNPEF se sentissem valorizados. Para isso, foram muito importantes as participações no Simpósio de Ensino de Física promovido localmente pelo polo e no workshop regional promovido pela coordenação nacional do MNPEF. É importante destacar que o Simpósio é uma atividade particular desse polo, de modo que não podemos extrapolar 
esses resultados para todos os outros do MNPEF. No caso dos egressos do MP.Local, surgiu na fala de alguns a oportunidade que tiveram de apresentar trabalhos em eventos regionais e nacionais da área de ensino de Ciências, que, em última análise, significou também o contato com pesquisadores da área, a apresentação de seus trabalhos para um público mais amplo e, enfim, a valorização de seu próprio trabalho e formação. No entanto, ao contrário dos egressos do MNPEF, poucos egressos do MP.Local entrevistados se referiram a esse fato, pois aparentemente não foram todos que, realmente, tiveram a oportunidade de participar de eventos e atividades acadêmicas desse tipo.

Uma questão particular em relação à experiência de formação do polo do MNPEF, diz respeito à formação dos docentes do curso, que majoritariamente não é na área de Educação ou de ensino de Física. Nas entrevistas com Do.MNPEF-01 (docente da área de ensino de Física) e Do.MNPEF-07 (docente da área de Física) é possível perceber uma diferença de concepção do papel da fundamentação teórica e da pesquisa em ensino na formação dos professores. Enquanto Do.MNPEF-07 ressalta o papel do MNPEF como espaço de pesquisa aplicada (ou seja, dá ênfase à construção do PE, sem necessidade do aprofundamento teórico), Do.MNPEF-01 lamenta o pouco espaço para a formação em pesquisa em ensino de Física e aprofundamento teórico dado no curso. Essas diferentes concepções revelam diferentes posicionamentos dos docentes frente às diferentes racionalidades na formação continuada de professores. Tendo em vista as diferentes formações e experiências profissionais dos docentes orientadores, surgiram os seguintes questionamentos ao longo do trabalho: como os orientadores do polo do MNPEF, majoritariamente formados na área de Física, com pouca ou nenhuma experiência na área de ensino, podem auxiliar os professores-cursistas na construção do PE? Que contribuições podem efetivamente dar para a formação desses professores?

Percebemos, nas falas dos egressos, que foi um fator relevante a orientação que o corpo docente do polo do MNPEF procurou dar às disciplinas de conteúdo disciplinar predominantes na matriz curricular do MP. Apesar dos docentes serem predominantemente da área de Física, portanto, propícios a seguirem à risca as ementas dessas disciplinas com ênfase no conteúdo, as falas dos docentes entrevistados e os relatos dos egressos indicam que as disciplinas foram organizadas de modo a proporcionar, afinal de contas, o alcance dos objetivos preconizados para o MNPEF, concentrados nos processos de ensino. Assim, eram incentivadas discussões sobre como abordar os conteúdos de Física nas aulas da educação básica, o "espírito do curso" na visão de Do.MNPEF-07. Aparentemente, em alguns momentos, os 
próprios professores-cursistas, apoiando-se em suas próprias experiências docentes e na troca estimulada no curso, puderam suprir parte da inexperiência dos formadores com as questões relacionadas ao ensino de Física. Há indícios de que os orientadores também passaram a estudar e a se formar neste processo, adotando referenciais padronizados e indicados, em especial, pelos responsáveis pela gestão do MNPEF. Isso se reflete, por exemplo, na adoção, mesmo que muitas vezes incompleta, ou problemática, da Teoria da Aprendizagem Significativa - muito propagada por Moreira, mentor do MNPEF - em grande parte das dissertações e PEs orientados por este grupo. Nesse sentido, o processo de atualização na área de ensino foi sendo realizado simultaneamente por professores-cursistas e membros do corpo docente do curso. Além disso, nesse processo de trocas, os orientadores tiveram a oportunidade de aprenderem juntamente com os professores-cursistas a respeito da realidade da escola de educação básica, as necessidades formativas, e as possibilidades de superação das dificuldades do trabalho docente.

Nesse contexto, em que os docentes do MNPEF fizeram o papel principal de estimuladores de discussões, os professores-cursistas puderam entrar em contato com a produção acadêmica da área; conhecer estratégias e recursos inovadores de ensino; e interagir com os pares. Mais do que isso, os professores-cursistas puderam experimentar como se sente um aluno quando participa de um procedimento de ensino no qual ele pode interagir continuamente, adotando uma postura ativa diante de sua própria formação. Daí a adotar com seus alunos essa mesma forma de ensinar, o passo é muito pequeno, como alguns professores-cursistas salientaram. Além disso, destacamos a importância da interação com os orientadores, fundamentais para apoiar o desenvolvimento do PE - apesar de, em grande parte, inexperientes na área de ensino, como dito a respeito dos orientadores do polo do MNPEF - e o domínio da escrita acadêmica, uma novidade para grande parte dos egressos entrevistados. Nos dois cursos, houve relatos de professores que estreitaram os laços com seus orientadores, formando parcerias.

Por outro lado, no caso do MP.Local, a formação e a experiência dos docentes, um pouco mais próximas à Educação e ao Ensino de Ciências, se refletiu mais nos trabalhos desenvolvidos pelos professores-cursistos nas dissertações e nos PEs. Por terem o perfil de pesquisadores, em grande parte, da área de Ciências Humanas, os trabalhos, conforme discutido, apresentaram maior fundamentação teórica, por exemplo. 
Ainda à respeito da estruturação do polo do MNPEF, a questão de o programa ter uma coordenação centralizada não pareceu ser tão relevante para os professorescursistas, que conseguiram ter grande parte de suas demandas satisfeitas pelo modo que o curso foi realizado no polo. Provavelmente, a preocupação de se formar uma parceria entre corpo docente e discente tenha sido relevante para isso. Houve apenas a queixa de Do.MNPEF-07 em relação à impossibilidade de oferecer novas disciplinas optativas devido à matriz curricular unificada. Com isso, o corpo docente tem uma atuação limitada para satisfazer plenamente todas as demandas formativas dos professores que conseguem identificar em seus contextos de atuação. O Simpósio de Ensino de Física e os seminários semanais promovidos no polo são as alternativas encontradas para auxiliar nessa questão.

Observando, nas análises com elementos narrativos dos egressos, as dimensões de desenvolvimento profissional e os níveis dos indicadores de autoria docente alcançados por eles por meio dos cursos, verificamos que em ambos se operaram mudanças na formação e na prática profissional docente. Todavia, discutimos as diferenças na orientação dessas mudanças.

O polo do MNPEF, com objetivos concentrados nos processos de ensino do professor, focalizou justamente essa atuação em sala de aula. Participando das atividades propostas no curso, os professores puderam, de modo geral, passar de uma condição de desmotivação e, de certa forma, de impotência diante dos desafios da prática para uma condição de maior estima, valorização e conhecimento. Apropriando-se de novos recursos, conhecimentos e estratégias e até mesmo alterando suas concepções e modos de pensar, puderam encontrar no curso a possibilidade de buscar o aperfeiçoamento de sua eficiência - em sala de aula - como professores de Física.

O MP.Local, tendo objetivos mais abrangentes e devido à proximidade com o curso de MA do mesmo programa (e também nos preceitos próximos à formação pósgraduada acadêmica expressas no currículo e funcionamento do curso), conseguiu ir ao encontro do desejo de muitos mestrandos, permitindo-os pavimentar o percurso rumo ao doutorado e à carreira no ensino superior. Embora no conjunto de dados do polo do MNPEF, percebemos que alguns professores do Mestrado em Rede se desenvolveram como professores pesquisadores, essa característica foi muito mais realçada no MP.Local, por conta de sua organização e história de consolidação.

É importante notar lacunas nos dois cursos no que diz respeito às dimensões de desenvolvimento profissional participação na gestão escolar e participação na 
responsabilidade social. O pouco envolvimento da dimensão participação na gestão escolar é sintoma do fato de o MP ser uma formação individualizada e os cursos analisados não serem plenamente capazes, ainda, de promover a maior aproximação com as escolas de educação básica - apesar dos projetos de extensão que foram desenvolvidos no MP.Local, por exemplo, se proporem a essa busca. Na realidade, questões que ultrapassam o micro-contexto de sala de aula não parecem ser conteúdo de discussões em disciplinas e outras atividades dos cursos - há a ausência dessas temáticas principalmente no contexto do polo do MNPEF, por não serem pautadas nas ementas das disciplinas e não surgirem na fala dos docentes e egressos entrevistados. Essas questões aparecem de forma tímida nas dissertações de alguns professores dos dois cursos, ainda que as condições estruturais físicas, materiais e organizacionais das escolas sejam extremamente relevantes para que os professores consigam alcançar um nível de responsabilidade sistemática e de inovação reflexiva/criativa em seu trabalho docente, conforme pudemos observar na análise de seus trabalhos. Os níveis de dedicação e responsabilidade nulas também encontram-se relacionadas às limitações enfrentadas pelos professores em seu contexto de trabalho, e o formato dos cursos de MP parecem não favorecer a discussão de tais fatores limitantes e a busca de sua superação. É um sinal, então, da existência de um descompasso entre os objetivos de um mestrado profissional e o que é realmente focado nos cursos de MP em ensino analisados.

Relembramos Day (2001) que esclarece que o desenvolvimento profissional promove mudanças em diversos níveis: de pensamento dos professores, de suas práticas e dos contextos de atuação. Em certa medida, os cursos estudados nesta pesquisa apresentaram potencialidades em relação às mudanças de pensamento e de práticas dos professores - porém, ainda há carências em relação às mudanças nos seus contextos de atuação. Essa falha, conforme Schäfer e Ostermann (2013), seria inerente à própria ideia dos MPs em ensino, da maneira que ela se estabeleceu no Brasil: uma proposta de formação que se vincularia à hipótese de que o professor seria o único responsável pelo desempenho de seus alunos.

Sob o referencial das dimensões de desenvolvimento profissional de Barolli et al. (2019), no entanto, podemos transformar tal concepção dos MPs. O desenvolvimento profissional ocorreria a partir do diálogo do professor com a Escola, a Academia e a Sociedade, de modo que o MP poderia ser estruturado para buscar facilitar ao professor 0 estabelecimento do diálogo com esses outros agentes. Um questionamento que surgiu ao longo do trabalho foi: como proporcionar ao professor o 
acesso a essas diferentes esferas e o estabelecimento desses diálogos? Seriam, afinal, possíveis no contexto dos MPs?

A pesquisa aqui apresentada mostra que os cursos são promissores em relação ao diálogo dos professores com a Academia. Apesar de algumas dificuldades verificadas na pesquisa, podem também articular-se com a Escola. Nesse quesito, ressaltamos que é importante que os cursos estimulem os seus professores-cursistas a perseguir uma compreensão contextual de onde eles estão inseridos (SHUCK et al., 2016) - e que forneçam as ferramentas teóricas e metodológicas mais adequadas para esta tarefa. Nesse sentido, a construção do PE é central e a escrita da dissertação é fundamental para a descrição dos contextos de aplicação dos PEs, conforme já discutido por Ostermann e Rezende (2009). Portanto, o foco do MP não é o PE em si, mas a formação proporcionada ao professor por intermédio da construção e investigação sobre a aplicação do PE em seu contexto de trabalho (MOREIRA et al., 2018).

Ao contrário do preconizado em documentos oficiais do MNPEF, os dados de nossa pesquisa indicam poucas implicações dos PEs nos contextos escolares dos professores egressos dos cursos analisados. É certo que, devido à formação proporcionada pelos cursos de MP, mudanças se operaram no micro-contexto de sala de aula - na atuação direta do professor em processos de ensino e na sua relação com seus alunos -, porém mudanças mais abrangentes nos locais de trabalho dos professores são incipientes. Seriam as propostas dos professores ainda muito tímidas e pequenas, ao se restringirem, em grande parte, à busca de novos recursos e estratégias para a abordagem de determinado conteúdo em sala de aula? Faltaria maior ousadia aos professores - e aos seus orientadores - para buscar soluções mais abrangentes para os problemas enfrentados diariamente por eles em suas salas de aula? Esses últimos questionamentos, ao nosso ver, nos fazem pensar no papel que os doutorados profissionais poderiam exercer. Para lançar um olhar mais audacioso ao seu trabalho de pesquisa, é preciso, primeiramente, que os professores sintam-se competentes, fornecendo soluções exitosas no nível do micro-contexto de sala de aula. O que, como vimos, os mestrados profissionais proporcionaram a esses professores.

Por fim, fechando a discussão sobre as lacunas nas dimensões de desenvolvimento profissional, a escassez nos cursos estudados, de ações e discussões relacionadas à participação na responsabilidade social também indica a dificuldade de se pensar além do micro-contexto em sala de aula. É o diálogo com a 
Sociedade que os cursos ainda não estão sendo capazes de proporcionar - ou não estão, ainda, preocupados em fomentar. Para isso, é importante que se pense um MP com formação baseada na racionalidade crítica. Ação que não pode ser negligenciada nos currículos propostos dos MPs para que eles possam de fato fomentar a transformação da educação - devido ao potencial transformador dessa dimensão do desenvolvimento profissional, tanto em relação às concepções e práticas docentes, quanto em relação à busca de superação dos problemas organizacionais e estruturais das escolas.

Outros questionamentos realizados no decorrer do desenvolvimento da pesquisa foram de cunho político. No contexto da Capes e da história de estabelecimento dos Mestrados em Rede: por que investir no MNPEF e não nos cursos de MP em Ensino já consolidados? Apesar da pesquisa aqui desenvolvida não ter objetivado explorar diretamente tais questões, consideramos que a opção pelo investimento em MPs em Rede foi a busca pela massificação da formação pós-graduada dos professores, objetivando o maior impacto sobre os índices educacionais, no menor tempo possível. É certo que o MNPEF alcançou, em pouco tempo, sucesso em número de polos implantados e em abrangência territorial (conforme Figura 2, apresentado no capítulo 2 da tese). Porém, apesar dos resultados de formação, que, como o estudo de caso do polo do MNPEF indica, podem ser promissores para determinadas dimensões de desenvolvimento profissional, é importante repensar ainda mais em que bases continuará se estabelecendo essa formação frente aos objetivos desses Mestrados em Rede. A situação é ainda mais crítica quando tal preferência de investimento significa a estagnação financeira de diversos outros MPs (locais) já consolidados.

Para encerrar, apontamos alguns pontos que surgiram no transcorrer da pesquisa que indicam questionamentos e perspectivas de pesquisas futuras e de autoavaliação dos cursos de MPs orientados para professores de Física e de Ciências:

- Qual é o papel da pesquisa e dos referenciais teóricos na produção e avaliação dos PEs?;

- O que significa avaliar o PE? Quais são os instrumentos mais adequados para isso? Nossa discussão sugere a importância do uso de múltiplos instrumentos e a necessidade de fornecer subsídios teóricos e metodológicos para os professores melhor descrever - e compreender - os contextos de aplicação do PE que, muitas vezes, é o de seus próprios contextos de trabalho; 
- No contexto do MP, o uso da metodologia de pesquisa-ação seria o mais adequado? Como ela se daria? Seria um caminho facilitador para a transformação das práticas e da realidade das escolas dos professores mestrandos?;

- Como promover maior aproximação entre universidade e escola de educação básica nos cursos de MP? Para isso, as disciplinas de Estágio Supervisionado e o envolvimento com projetos de extensão podem indicar caminhos promissores;

- Como fortalecer a interação e o estabelecimento da coletividade entre os professores? Mostramos ao longo da pesquisa a importância de eventos como o Simpósio de Ensino de Física do polo do MNPEF. Nesses eventos se promovem: o contato entre professores de educação básica e pesquisadores acadêmicos; a ampliação de espaços de convivência entre professores mestrandos e docentes do curso; a possibilidade de participação de professores que não estão no MP e de licenciandos, de forma que o curso passe a ser um centro de referência para professores da região; uma orientação suplementar dos trabalhos dos mestrandos através da apresentação de pôsteres, comunicações orais e oficinas de suas pesquisas em andamento. 


\section{Referências}

ANDRÉ, M. O que é um estudo de caso qualitativo em educação? Revista da FAEEBA - Educação e contemporaneidade, v. 22, n. 40, p. 95-103, 2013.

ANTUNES JR., E. et al. Sobre dissertações no contexto do Mestrado Profissional em Ensino de Física. In: Encontro Nacional de Pesquisa em Ensino de Física (ENPEC), $X$ Águas de Lindoia, 2015. Anais... Disponível em: <http://www.abrapecnet.org.br/enpec/x-enpec/anais2015/resumos/R1223-1.PDF />. Acesso em: 18 mai 2019.

ALARCÃO, I. Professores reflexivos em uma escola reflexiva. 8 ed. São Paulo: Cortez, 2011. 110 p. (Coleção questões da nossa época; v. 8).

ALFERES, M. A.; MAINARDES, J. A formação continuada de professores no Brasil. In: Seminário de Pesquisa do PPE [Programa de Pós-graduação em Educação], 2011, Maringá. Anais... Disponível em: <http://www.ppe.uem.br/publicacoes/seminario ppe 2011/pdf/1/001.pdf />. Acesso em: 12 jun. 2017.

ARAÚJO, M. S. T.; AMARAL, L. H. Impactos do Mestrado Profissional em Ensino de Ciências e Matemática da Unicsul sobre a atividade docente de seus estudantes: do processo de reflexão às transformações na prática pedagógica. Revista Brasileira de Pós-graduação, v. 3, n. 5, p. 150-166, jun. 2006.

ARAÚJO, C. M.; ARAÚJO, E. M.; SILVA, R. D. Para pensar sobre a formação continuada de professores é imprescindível uma teoria crítica de formação humana. Cadernos Cedes, Campinas, v. 35, n. 95, p. 57-73, 2015.

ARAÚJO, C. M.; SILVA, E. M. Formação continuada de professores: tendências emergentes na década de 1990. Educação, Porto Alegre, v. 32, n. 3, p. 326-330, 2009.

BARCELLOS, M.; GUERRA, A. Inovação curricular e Física Moderna: da prescrição à prática. Revista Ensaio, v. 17, n. 2, p. 329-350, 2015.

BARDIN, L. Análise de conteúdo. Lisboa: Edições 70, 1977. 229 p.

BAROLLI, E. et al. Desenvolvimento Profissional de Professores de Ciências: um esquema de análise. In: Encontro Nacional de Pesquisadores em Ensino de Ciências, XI, Florianópolis, 2017. Anais...

BAROLLI, E. et al. Desarrollo profesional de profesores de ciencias: dimensiones de análisis. Revista Electrónica de Enseñanza de las Ciências, v. 18, p. 173-197, 2019.

BARRETTO, E. S. S. Políticas e práticas de formação de professores da educação básica no Brasil: um panorama nacional. Revista Brasileira de Política $e$ Administração da Educação, v. 27, n. 1, p. 39-52, 2011.

BARROS, E. C.; VALENTIM, M. C.; MELO, M. A. A. O debate sobre o mestrado profissional na CAPES: trajetórias e definições. Revista Brasileira de Pós-graduação, v. 2, n. 4, p. 124-138, 2005.

BOGDAN, R.; BIKLEN, S. Investigação qualitativa em educação: uma introdução à teoria e aos métodos. Tradução Maria João Alvarez, Sara Bahia dos Santos e Telmo Mourinho Baptista. Porto: Porto Editora, 1994. 336 p. 
BRANDÃO, M. A.; DECCAHE-MAIA, E.; BOMFIM, A. M. Os desafios da construção de um Mestrado Profissional: um panorama dos sete anos do Propec. Polyphonía, v. 24, n. 2, p. 319-336, 2013.

BRASIL. Decreto $n^{\circ} 6.755$, de 29 de janeiro de 2009. Institui a Política Nacional de Formação de Profissionais do Magistério da Educação Básica, disciplina a atuação da Coordenação de Aperfeiçoamento de Pessoal de Nível Superior -CAPES no fomento a programas de formação inicial e continuada, e dá outras providências. Diário Oficial da União, Brasília, 30 jan. 2009. Seção 1, p. 1.

BRASIL. Portaria normativa no 17, de 28 de dezembro de 2009. Dispõe sobre o mestrado profissional no âmbito da Fundação Coordenação de Aperfeiçoamento de Pessoal de Nível Superior - CAPES. Diário Oficial da União, Brasília, 29 dez. 2009. Seção 1, p. 20-21.

BRASIL. Portaria no 289, de 21 de março de 2011. Dispõe sobre a concessão de bolsas de formação para professores da rede pública matriculados em cursos de Mestrado Profissional. Diário Oficial da União, Brasília, 22 mar. 2011 a. Seção 1, p. 14.

BRASIL. Portaria no 209, de 21 de outubro de 2011. Aprova o Regulamento do Programa de Mestrado Profissional para Qualificação de Professores da Rede Pública da Educação Básica (PROEB). Diário Oficial da União, Brasília, 26 out. 2011b. Seção 1, p. 14.

BRASIL. Portaria no 389, de 23 de março de 2017. Dispõe sobre o mestrado e doutorado profissional no âmbito da pós-graduação stricto sensu. Diário Oficial da União, Brasília, 24 mar. 2017a. Seção 1, p. 61.

BRASIL. Portaria o 131, de 28 de junho de 2017. Dispõe sobre o mestrado e o doutorado profissionais. Diário Oficial da União, Brasília, 30 jun. 2017b. Seção 1, p. 17.

BRASIL. Portaria ํo 60, de 20 de março de 2019. Dispõe sobre o mestrado e doutorado profissionais, no âmbito da Coordenação de Aperfeiçoamento de Pessoas de Nível Superior - CAPES. Diário Oficial da União, Brasília, 22 mar. 2019. Seção 1, p. 26.

CANÁRIO, R. A prática profissional na formação de professores. In: Campos, B. P. (Org.). Formação profissional de professores no ensino superior. Porto: Porto Editora, 2002.

CANÁRIO, R. Trabalho e formação de adultos: entre o ser e o ter. Revista Contemporânea de Educação, v. 11, n. 22, p. 264-280, 2016.

CAPES (Coordenação de Aperfeiçoamento de Pessoal de Nível Superior). Mestrado no Brasil - a situação e uma nova perspectiva. Revista Brasileira de Pós-graduação, v. 2 , n. 4 , p. 139-144, 2005a.

CAPES (Coordenação de Aperfeiçoamento de Pessoal de Nível Superior). Portaria no 47 de 17 de outubro de 1995. Revista Brasileira de Pós-graduação, v. 2, n. 4, p. 147$148,2005 b$.

CAPES (Coordenação de Aperfeiçoamento de Pessoal de Nível Superior). Portaria no 80 de 16 de dezembro de 1998. Revista Brasileira de Pós-graduação, v. 2, n. 4, p. 149-150, 2005c. 
CASTRO, C. M. A hora do mestrado profissional. Revista Brasileira de Pósgraduação, v. 2, n. 4, p. 16-23, 2005.

CASTRO, M. M. C.; AMORIM, R. M. A. A formação inicial e a continuada: diferenças conceituais que legitimam um espaço de formação permanente de vida. Caderno Cedes, v. 35, n. 95, p. 37-55, 2015.

CEVALLOS, I. O mestrado profissional em ensino de matemática e o desenvolvimento profissional de professores: um desafio institucional. 2011. $247 \mathrm{f}$. Tese (Doutorado em Educação Matemática) - Pontifícia Universidade Católica de São Paulo, São Paulo, 2011.

CEVALLOS, I. PASSOS, L. F. O mestrado profissional e a pesquisa do professor. Revista Diálogo Educacional, v. 12, n. 37, p. 803-822, 2012.

CIRANI, C. B. S.; CAMPANARIO, M. A.; SILVA, H. H. M. A evolução do ensino da pós-graduação senso estrito no Brasil: análise exploratória e proposições para pesquisa. Avaliação, v. 20, n. 1, p. 163-187, 2015.

COLARES, M. I. S.; BRYAN, N. A. P. Políticas de regulação de formação continuada de professores no Brasil e na Argentina. In: Congresso Ibero-Americano de Política e Administração da Educação, IV, Porto, 2014. Anais... Disponível em: $<$ http://www.anpae.org.br/IBERO AMERICANO IV/GT6/GT6 Comunicacao/MariaLilia Colares GT6 integral.pdf/>. Acesso em: 12 jun 2017.

CONTRERAS, J. A autonomia de professores. 2ª Ed. São Paulo: Cortez, 2012. 327 p.

COSTA, N. M. L. A formação contínua de professores - novas tendências e novos caminhos. Holos, v. 3, p. 63-75, 2004.

COUTINHO, R. X.; FOLMER, V.; PUNTEL, R. L. Aproximando universidade e escola por meio do uso da produção acadêmica na sala de aula. Ciência \& Educação, v. 20, n. 3, p. 765-783, 2014.

CUNHA, M. I. Lugares de formação: tensões entre a academia e o trabalho docente. In: DALBEN, A. I. L. F. et al. (Org.). Convergências e tensões no campo da formação e do trabalho docente: didática, formação docente, trabalho docente. Belo Horizonte: Autêntica, 2010. p. 129-149. (Coleção Didática e Prática de Ensino).

CURY, C. R. J. Quadragésimo ano do parecer CFE n 977/65. Revista Brasileira de Educação, n. 30, p. 7-20, 2005.

DAY, C. Desenvolvimento profissional de professores: os desafios da aprendizagem permanente. Porto, Portugal: Porto, 2001. 352 p.

DELIZOICOV, D. Pesquisa em ensino de ciências como ciências humanas aplicadas. Caderno Brasileiro de Ensino de Física, v. 21, p. 145-175, 2004.

DINIZ-PEREIRA, J. E. Da racionalidade técnica à racionalidade crítica: formação docente e transformação social. Perspectivas em diálogo: revista de educação e sociedade, v. 01, n. 01, p. 34-42, 2014.

FÉTIZON, B. A. M. Educar professores? Um questionamento dos cursos de licenciatura da Universidade de São Paulo. São Paulo, FEUSP, 1984. (Estudos e Documentos, v. 24). 227 p. 
FISCHER, T. Seduções e riscos: a experiência do mestrado profissional. RAE Revista de Administração de Empresas, v. 43, p. 119-123, 2003.

FISCHER, T. Mestrado profissional como prática acadêmica. Revista Brasileira de Pós-graduação, v. 2, n. 4, p. 24-29, 2005.

FORMOSINHO, J. Ser professor na escola de massas. In: (Coord.). Formação de Professores: Aprendizagem profissional e acção docente. Porto: Porto Editora, 2009. p. 37-69.

FREITAS, M. A. O.; CUNHA, I. C. K. O. Pós-graduação lato sensu: retrospectiva histórica e política atual. In: Congresso Nacional de Educação - EDUCERE, IX, 2009, Curitiba. Anais... Disponível em: <http://www.pucpr.br/eventos/educere/educere2009/anais/pdf/2036 1004.pdf/> Acesso em: 03 abr. 2017.

FREITAS, M. T. M.; FIORENTINI, D. As possibilidades formativas e investigativas da narrativa em educação matemática. Horizontes, v. 25, n. 1, p. 63-71, 2007.

GALVÃO, C. Narrativas em educação. Ciências \& Educação, v. 11, n. 2, p. 327-345, 2005.

GARNICA, A. V. M. Algumas notas sobre pesquisa qualitativa e fenomenologia. Interface - comunic., saúde, educ., 1997.

GATTI, B. A. Formação de professores no Brasil: características e problemas. Educação \& Sociedade, Campinas, v. 31, n. 113, p. 1355-1379, 2010.

GIACOMAZZO, G.; LEITE, D. O mestrado profissional no âmbito das políticas públicas na educação: reflexões sobre a produção do conhecimento científico. ETD Educação Temática Digital, v. 16, n. 3, p. 475-493, 2014.

GUERRA, A. Algumas considerações sobre a formação docente na perspectiva dos mestrados profissionais. In: GARCIA, N. M. D.; AUTH, M. A.; TAKAHASHI, E. K. (Orgs.). Enfrentamentos do ensino de física na sociedade contemporânea. São Paulo: Editora Livraria da Física, 2016. P. 193-203.

HOSTINGS, R. C. L. Os Planos Nacionais de Pós-graduação (PNPG) e suas repercussões na Pós-graduação brasileira. Perspectiva, v. 24, n. 1, p. 133-160, 2006.

IMBERNÓN, F. La formación y el desarrollo profesional del profesorado. Hacia uma nueva cultura profesional. 3ª ed. Barcelona: Editora Graó, 1998. 163 p.

LEITÃO, A.; ALARCÃO, I. Para uma nova cultura profissional: uma abordagem da complexidade na formação inicial de professores do $1^{\circ}$ CEB. Revista Portuguesa de Educação, v. 19, n. 2, p. 51-84, 2006.

MACIEL, R. G. A.; NOGUEIRA, H. G. P. Mestrado profissional: desenvolvimento pessoal e profissional. Revista Brasileira de Pós-graduação, v. 9, n. 17, p. 461-487, 2012.

MAIA, J. Investigando o desenvolvimento profissional docente em Mestrados Profissionais em Ensino de Ciências. 2017. 189 f. (Doutorado em Ensino de Ciências) - Instituto de Física - Universidade de São Paulo, São Paulo, 2017. 
MARCELO GARCÍA, C. Formação de professores para uma mudança educativa. $1^{\text {a }}$ Ed. Porto: Porto Editora, 1999. 271 p.

MARCELO, C. Desenvolvimento Profissional Docente: passado e futuro. Sísifo: Revista de Ciências da Educação, Lisboa, n. 8, p. 7-22, 2009.

MARTINS, R. X.; RIBEIRO, C. M. Mestrado profissional em Educação e inovação na prática docente. Revista Brasileira de Pós-graduação, v. 10, n. 20, p. 423-446, 2013.

MAUÉS, O. C. Reformas internacionais da educação e formação de professores. Cadernos de Pesquisa, n. 118, p. 89-117, 2003.

MAZOTTI, T. B. Formação de professores: racionalidades em disputa. Revista Brasileira de Estudos Pedagógicos, v. 74, n. 177, p. 279-308, 1993.

MELO, K. V. A.; OLIVEIRA, R. R. Origens e desenvolvimento institucional de um mestrado profissional. Revista Brasileira de Pós-graduação, v. 2, n. 4, p. 105-123, 2005.

MENANDRO, P. R. M. Réplica 2 - Mestrado Profissional, Você Sabe Com Quem Está Falando? Revista de Administração Contemporânea, v. 14, n. 2, p. 367-371, 2010.

MILHEIRO, A. R. F. P. A avaliação do impacto da formação pós-graduada nos professores e na escola: dois estudos de caso. $2017.377 \mathrm{f}$. Tese de Doutorado, Instituto de Educação - Universidade de Lisboa, Lisboa, 2017.

MOREIRA, M. A. O mestrado (profissional) em ensino. Revista Brasileira de Pósgraduação, n. 1, p. 131-142, 2004.

MOREIRA, M. A.; NARDI, R. O mestrado profissional na área de Ensino de Ciências e Matemática: alguns esclarecimentos. Revista Brasileira de Ensino de Ciência e Tecnologia, v. 2, n. 3, p. 1-9, 2009.

MOREIRA, M. A. Metodologias de pesquisa em ensino. São Paulo: Editora Livraria da Física, 2011. 243 p.

MOREIRA, M. C. A. et al. A interdisciplinaridade em Produtos Educacionais de um Mestrado Profissional em Ensino de Ciências. In: Congresso Internacional sobre Investigación en didáctica de las ciencias, X, Sevilla, 2017. Anais...

MOREIRA, M. C. A. et al. Produtos Educacionais de um curso de Mestrado Profissional em Ensino de Ciências. Revista Brasileira de Ensino de Ciência e Tecnologia, v. 11, n. 3, p. 344-363, 2018.

NARDI, R. A pós-graduação em ensino de ciências e matemática no Brasil, o ensino de ciências e as licenciaturas na área: encontros e desencontros. TED - Tecné, Episteme y Didaxis, n. 30, p. 53-67, 2011.

NASCIMENTO, F. S.; PIÑEIRO, M. G. R.; RAMOS, I. S. Inovação e pós-graduação: um estudo específico sobre o primeiro mestrado profissional em Educação da Bahia. Revista Brasileira de Pós-graduação, v. 10, n. 20, p. 369-390, 2013.

NASCIMENTO, M. M.; OSTERMANN, F.; CAVALCANTI, C. Análises multidimensional e Bakhtiniana do discurso de trabalhos de conclusão desenvolvidos no âmbito de um mestrado profissional em ensino de Física. Ciência \& Educação, v. 23, n. 1, p. 181196, 2017. 
NASCIMENTO, S. S. O Mestrado Nacional Profissional de Ensino em Física: a experiência da Sociedade Brasileira de Física. Polyphonía, v. 24, n. 2, p. 255-268, 2013.

NERES, C. C.; NOGUEIRA, E. G. D.; BRITO, V. M. Mestrado profissional em Educação e sua interseção com a qualificação docente na educação básica. Revista Brasileira de Pós-graduação, v. 11, n. 25, p. 885-909, 2014.

NÓVOA, A. Professores: imagens do futuro presente. Lisboa, Portugal: Educa, 2009. $96 \mathrm{p}$.

OLIVEIRA-FORMOSINHO, J. Desenvolvimento profissional dos professores. In: Formosinho, J. (Coord.). Formação de Professores: Aprendizagem profissional e ação docente. Porto: Porto Editora, 2009. p. 221-284.

OSTERMANN, F.; REZENDE, F. Projetos de desenvolvimento e de pesquisa na área de ensino de ciências e matemática: uma reflexão sobre os mestrados profissionais. Caderno Brasileiro de Ensino de Física, v. 16, n. 1, p. 66-80, 2009.

PACCA, J. L. A.; VILLANI, A. A formação continuada do professor de Física. Estudos Avançados, v. 32, n. 94, p. 57-71, 2018.

PASSOS, C. L. B.; et al. Desenvolvimento profissional do professor que ensina Matemática: uma meta-análise de estudos brasileiros. Quadrante, v. 15, n. 1-2, p. 193-219, 2006.

PASSOS, L. F. O trabalho do professor formador e o contexto institucional: desafios e contribuições para o debate. Educação \& Linguagem, v. 10, n. 15, p. 99-116, jan./jun. 2007.

PILATTI et al. Mestrado profissional em Ensino da Matemática: identificação de seus produtos educacionais. Revista Brasileira da Pós-graduação, v. 12, n. 28, p. 335 356, 2015.

PIMENTA, S. G.; GHEDIN, E. (Org.). Professor reflexivo no Brasil: gênese e crítica de um conceito. 4. ed. São Paulo: Cortez, 2006.

PIQUET, R.; LEAL, J. A. A.; TERRA, D. C. T. Mestrado profissional: proposta polêmica no Sistema Brasileiro de Pós-graduação - o caso do planejamento regional urbano. Revista Brasileira de Pós-graduação, v. 2, n. 4, p. 30-37, 2005.

PIRES, C. M. C.; IGLIORI, S. B. C. Mestrado profissional e o desenvolvimento profissional do professor de matemática. Ciência \& Educação, v. 19, n. 4, p. 10451068, 2013.

PONTE, J. P. O desenvolvimento profissional do professor de Matemática. Educação e Matemática, n. 31, p. 9-20, 1994.

PONTE, J. P. Da formação ao desenvolvimento profissional. In: Actas do ProfMat 98, Lisboa: APM, p. 27-44, 1998.

QUELHAS, O. L. G.; FARIA FILHO, J. R.; FRANÇA, S. L. B. O mestrado profissional no contexto do sistema de pós-graduação brasileiro. Revista Brasileira de Pósgraduação, v. 2, n. 4, p. 97-104, 2005. 
REZENDE, F.; OSTERMANN, F. O protagonismo controverso dos mestrados profissionais em ensino de ciências. Ciência \& Educação, v. 21, n. 3, p. 543 - 558, 2015.

RIBEIRO, C. R. R. A universidade como disputa de reprodução social: contribuição ao debate sobre os mestrados profissionais. Revista Brasileira de Pós-graduação, v. 7, n. 14, p. 433-450, 2010.

RIBEIRO, R. J. O mestrado profissional na política atual da Capes. Revista Brasileira de Pós-graduação, v. 2, n. 4, p. 8-15, 2005.

RÔÇAS, G. et al. O Mestrado Profissional em Ensino de Ciências do Instituto Federal de Educação, Ciência e Tecnologia do Rio de Janeiro: O Desafio do Ensino de Pósgraduação na Região da Baixada Fluminense do Rio de Janeiro. Ensino, Saúde e Ambiente, v. 4, n. 2, p. 2-16, 2011.

RÔÇAS, G.; MOREIRA, M. C. A.; PEREIRA M. V. "Esquece tudo o que te disse": os mestrados profissionais da área de ensino e o que esperar de um doutorado profissional. Ensino de Ciências e Tecnologia em Revista, v. 8, n. 1, p. 59-74, 2018.

SALEM, S. Perfil, evolução e perspectivas da Pesquisa em Ensino de Física no Brasil. 2012. 385 f. Tese de Doutorado, Instituto de Física, Instituto de Química, Instituto de Biociências e Faculdade de Educação - Programa Interunidades em Ensino de Ciências, Universidade de São Paulo, São Paulo, 2012.

SANTOS, E. O. Políticas de formação continuada para os professores da educação básica. In: Simpósio Brasileiro de Política e Administração da Educação, XV, 2011, São Paulo. Anais... Disponível em: <http://www.anpae.org.br/simposio2011/cdrom2011/PDFs/trabalhosCompletos/comuni cacoesRelatos/0141.pdf /> Acesso em: 15 jun 2017.

SANTOS, L. L. C. P. A implementação de políticas do Banco Mundial para a formação docente. Cadernos de Pesquisa, n. 111, p. 173-182, 2000.

SANTOS, L. L. C. P. Dilemas e perspectivas na relação entre ensino e pesquisa. In: André, M. (Org.). O papel da pesquisa na formação e na prática dos professores. Campinas: Papirus, 2012. p. 11-25.

SAVIANI, D. Formação de professores: aspectos históricos e teóricos do problema no contexto brasileiro. Revista Brasileira de Educação, v. 14, n. 40, 2009.

SILVA, L. F. Uma análise preliminar de dissertações e produtos educacionais de dois Mestrados Profissionais em Ensino de Ciências e Física do estado do Rio de Janeiro. In: Encontro Nacional de Didática e Práticas de Ensino, XIX, 2018, Salvador. Anais... Disponível

em: $<$ http://www.xixendipe.ufba.br/modulos/consulta\&relatorio/rel download.asp?nome=99 121.pdf />. Acesso em: 18 mai. 2019.

SILVA, P. A. D. Um panorama da evolução da modalidade mestrado profissional no sistema nacional de pós-graduação. 2016. 96 f. Tese de Doutorado, Instituto de Ciências Básicas da Saúde - Programa de Pós-graduação em Educação em Ciências: Química da Vida e Saúde, Universidade Federal do Rio Grande do Sul, Porto Alegre, 2016. 
SILVEIRA, V. O.; PINTO, F. C. S. Reflexões necessárias sobre o mestrado profissional. Revista Brasileira de Pós-graduação, v. 2, n. 4, p. 38-47, 2005.

SCHÄFER, E. D. A.; OSTERMANN, F. Autonomia profissional na formação de professores: Uma análise de entrevistas realizadas num mestrado profissional em ensino de física. Revista Electrónica de Enseñanza de las Ciencias, v. 12, n. 2, p. 287312, 2013.

SHUCK, R. J. et al. Ensino em mestrado profissional de Ciências Exatas: concepções e saberes de professores em formação. Revista Brasileira de Pós-graduação, v. 13, n. 31, p. $491-506,2016$.

SOUSA, C. P.; PLACCO, V. M. S. Mestrados profissionais na área de educação e ensino. Revista da FAEEBA - Educação e Contemporaneidade, v. 25, n. 47, p. 23-35, 2016.

SUCUPIRA, N. Da faculdade de filosofia à faculdade de educação. Revista Brasileira de Estudos Pedagógicos, Rio de Janeiro, v. 51, n. 114, p. 261-276, abr./jun. 1969.

TARDIF, M. Saberes profissionais dos professores e conhecimentos universitários: elementos para uma epistemologia da prática profissional dos professores e suas consequências em relação à formação para o magistério. Revista Brasileira de Educação, n. 13, p. 5-24, 2000.

TARDIF. M. Saberes docentes e formação profissional. Petrópolis: Vozes, 2002.

THIOLLENT, M. Metodologia da pesquisa-ação. São Paulo: Cortez Editora, 2011.

VELLOSO, R. V. Desafios para a formação de professores nas universidades públicas. Revista Eletrônica de Educação, v. 6, n. 2, p. 427-439, 2012.

VILLANI, A. Mestrado Profissional em Ensino de Ciência e Matemática: uma Interpretação. Revista Ibero-Americana de Estudos em Educação, v. 11, n. esp. 1 (Dossiê: X Encontro Ibero-Americano de Educação), p. 418-433, 2016.

VILLANI, A. et al. Mestrados Profissionais em Ensino de Ciências: estrutura, especificidade, efetividade e desenvolvimento profissional docente. Investigações em Ensino de Ciências, v. 22, n. 1, p. 127-161, 2017.

ZEICHNER, K. Repensando as conexões entre a formação na universidade e as experiências de campo na formação de professores em faculdades e universidades. Educação, v. 35, n. 3, p. 479-504, 2010. 


\section{Apêndice 1 - Base do roteiro de entrevistas semi-estruturadas realizadas com os coordenadores dos cursos de MP}

\section{Como o programa de mestrado profissional foi criado?}

- o que motivou sua criação?

- quais foram os professores envolvidos?

- quais eram as expectativas dos professores envolvidos com essa iniciativa?

- algo teve que ser mudado de acordo com o projeto inicial, para que o programa pudesse ser fundado?

- quais foram as dificuldades enfrentadas? Como foram superadas?

\section{Como o programa de mestrado profissional se desenvolveu desde a sua criação} até os dias atuais?

- como foi o seu reconhecimento institucional? O reconhecimento na comunidade de professores da região atendida pelo programa? Na comunidade de ensino de ciências como um todo?

- sobre o processo de consolidação do programa: quais foram as possíveis dificuldades enfrentadas pelo corpo docente no estabelecimento de um curso de "mestrado profissional"?

- como foi o crescimento do programa (em número de professores inscritos nos processos seletivos? De alunos ingressantes e egressos? De orientadores credenciados? De produção acadêmica?)

\section{Como o programa de mestrado profissional está estruturado? Qual é o seu} currículo?

- quais são as atividades previstas (aulas, disciplinas obrigatórias/optativas, estágio supervisionado, seminários, eventos...)?

- houve mudanças ao longo do desenvolvimento de seu currículo? O quê? Por quê?

- na avaliação do coordenador, o quanto essas atividades - o currículo do MP - estão próximas da sala de aula do professor mestrando?

\section{Como foi sua entrada no MP?}

- Por que resolveu participar?

- Já orientou algum mestrando? Já ministrou disciplinas no MP?

- Que dificuldades encontrou na orientação? E nas disciplinas? Em que foi bem sucedido?

\section{Quais foram/são os desafios de sua gestão como coordenador do MP?}

- quais são as suas propostas (ou propostas do grupo de orientadores) para o MP? - Por que aceitou coordenar o MP? Que dificuldades encontrou? Em que se considera bem-sucedido?

- qual é a relação com outros programas de pós-graduação (principalmente: programa de mestrado acadêmico em ensino de ciências) do mesmo campus (ou instituição como um todo)?

- na percepção do coordenador como os colegas gestores da instituição (direção do campus, órgãos centrais) vêem o MP? (incentivo, valorização?)

\section{Em sua opinião, tendo em vista os objetivos iniciais do MP e o status atual do} programa: ele tem sido bem-sucedido?

- tem sido bem sucedido do ponto de vista formativo (curricular), ou seja, para formar professores mestres com o perfil estabelecido pelo grupo de orientadores do programa? - tem sido bem-sucedido do ponto de vista da produção acadêmica (produtos educacionais)?

- observa (direta ou indiretamente) algum tipo de impacto dos trabalhos desenvolvidos no programa na comunidade acadêmica de ensino de ciências? Nas salas de aulas dos professores egressos do programa e/ou em suas escolas como um todo?

- há interesse crescente dos professores da rede de educação básica no curso (número de inscritos nos processos seletivos)? Há evasão de professores mestrandos no decorrer do curso? Qual é o motivo dessas evasões (caso existam)?

- qual é a avaliação geral que os professores mestrandos e egressos fazem do curso? 


\section{Apêndice 2 - Base do roteiro das entrevistas semi-estruturadas realizadas com os docentes dos cursos de MP}

\section{Como foi sua entrada no MP?}

- Há quanto tempo?

- Como foi o convite?

- Já estava ligado a outro programa de mestrado?

- Por que resolveu participar? (suas expectativas iniciais)

\section{O seu trabalho como professor e orientador do MP:}

- Já ministrou disciplinas no MP? Quais? Como foram?

- Existem discussões com o corpo docente (e discente...) sobre as perspectivas das disciplinas?

- São trabalhadas de formas diferentes com o MA?

- Já orientou algum mestrando? Como é a dinâmica de orientação/grupo de pesquisa? (há diferenças em relação à outras áreas de pesquisa em que atua? - no caso de o docente ter pesquisa na área "dura" e na de ensino) $\rightarrow$ há impactos na sua produção acadêmica?

(há diferenças em relação ao MA - caso atue?)

- Como o produto educacional é orientado e avaliado?

- Que dificuldades encontrou na orientação? E nas disciplinas? Em que foi bem-sucedido?

- Destaque alguma orientação de MP e o que a caracterizou como fundamental.

3. Em sua concepcão, o que, de essencial para sua prática profissional, o professorcursista poderá desenvolver no MP? (Quais são os objetivos do MP?)

- Processo de seleção dos mestrandos: qual é a opinião sobre o perfil dos professores que o MP está formando?

- Quais são os maiores desafios que o professor de educação básica enfrenta, no seu entendimento?

- Em sua concepção, o que é necessário, em termos de conhecimentos e práticas, ser abordado num MP para qualificar o professor de educação básica?

- Quais são as abordagens do Ensino de Física/Ciência que deverão ser privilegiadas nas salas de aula de educação básica? Com qual finalidade?

- O que os orientadores do MP sabem (que é de domínio da Academia) que o professorcursista deve aprender? (e vice-versa?)

- O curso tem espaço para os mestrandos discutirem o que eles fazem em sala de aula?

- O professor-cursista deve mudar sua prática em qual sentido? O que significa "mudar a prática"?

\section{Como o MP alcança seus objetivos de formação?}

- No que as disciplinas (conteúdo programático, metodologias utilizadas, discussões realizadas...) podem colaborar para o alcance desses objetivos?

- No que o processo de orientação e elaboração do produto educacional/dissertação podem colaborar para o alcance desses objetivos?

- Em sua opinião, qual é o "diferencial" oferecido no MP em que atua (em termos de estrutura, atividades, conteúdos abordados...)?

- Acredita que os professores-cursistas mantém as mudanças proporcionadas pelo MP em suas práticas? O que tem ouvido a respeito disso? 
Apêndice 3 - Ficha de leitura utilizada para coleta de dados das dissertações e produtos educacionais dos cursos de mestrado profissional analisados

\begin{tabular}{|c|c|}
\hline \multicolumn{2}{|c|}{ MODELO DE FICHA GERAL - ANÁLISE DE DISSERTAÇÕES E PRODUTOS EDUCACIONAIS } \\
\hline Curso: ( ) MNPEF ( ) MP.Local & Dissertação e PE: no \\
\hline \multicolumn{2}{|l|}{ PARTE 1 - Dados Gerais } \\
\hline \multicolumn{2}{|l|}{ Título da dissertação / PE } \\
\hline \multicolumn{2}{|l|}{ Professor(a) cursista } \\
\hline \multicolumn{2}{|l|}{ Orientador(a) } \\
\hline \multicolumn{2}{|l|}{ Banca examinadora } \\
\hline \multicolumn{2}{|l|}{ Ano de Defesa } \\
\hline \multicolumn{2}{|l|}{ PARTE 2 - O PRODUTO EDUCACIONAL (PE) } \\
\hline Problema a ser resolvido & \\
\hline \multicolumn{2}{|l|}{$\begin{array}{l}\text { ( ) oriundo da prática profissional } \\
\text { ( ) sugestão do orientador / relacionado ao grupo } \\
\text { de pesquisa do MP } \\
\text { ( ) não é possível responder } \\
\text { ( ) de natureza mais geral }\end{array}$} \\
\hline \multicolumn{2}{|l|}{ Natureza do PE } \\
\hline $\begin{array}{l}\text { Há relação entre a natureza do PE e o problema a } \\
\text { ser resolvido? }\end{array}$ & $\begin{array}{l}\text { ( ) Sim ( ) Não } \\
\text { Justificativa: }\end{array}$ \\
\hline $\begin{array}{l}\text { Há relação entre a natureza escolhida e a proposta } \\
\text { do curso? }\end{array}$ & $\begin{array}{l}\text { ( ) Sim ( ) Não } \\
\text { Justificativa: }\end{array}$ \\
\hline \multicolumn{2}{|l|}{ Conteúdo abordado } \\
\hline \multicolumn{2}{|l|}{ Recursos utilizados } \\
\hline $\begin{array}{l}\text { Os recursos utilizados foram criados pelo(a) } \\
\text { autor(a)? }\end{array}$ & $\begin{array}{l}\text { ( ) Sim ( ) Não ( ) Parcialmente } \\
\text { Justificativa: }\end{array}$ \\
\hline $\begin{array}{l}\text { O PE apresenta material para os alunos e/ou } \\
\text { professor? }\end{array}$ & $\begin{array}{l}\text { ( ) somente alunos ( ) somente professores } \\
\text { ( ) para alunos e professores } \\
\text { ( ) destinado para outros sujeitos } \\
\text { Justificativa: }\end{array}$ \\
\hline \multicolumn{2}{|l|}{$\begin{array}{l}\text { Referenciais teóricos considerados na elaboração } \\
\text { do PE }\end{array}$} \\
\hline \multicolumn{2}{|l|}{$\begin{array}{l}\text { Como os referenciais teóricos foram mobilizados } \\
\text { para a elaboração do PE }\end{array}$} \\
\hline \multicolumn{2}{|l|}{ PARTE 3 - DISSERTAÇÃO } \\
\hline \multicolumn{2}{|l|}{ Objetivo ou questões formuladas } \\
\hline \multicolumn{2}{|l|}{ Metodologia de pesquisa utilizada } \\
\hline \multicolumn{2}{|l|}{ Instrumentos de coleta de dados } \\
\hline \multicolumn{2}{|l|}{$\begin{array}{l}\text { Sujeitos participantes (participação da instituição } \\
\text { de trabalho do prof. cursista?) }\end{array}$} \\
\hline \multicolumn{2}{|l|}{$\begin{array}{l}\text { Referenciais teóricos utilizados na análise da } \\
\text { pesquisa }\end{array}$} \\
\hline $\begin{array}{l}\text { Há indicação de desdobramentos futuros da } \\
\text { pesquisa / PE? }\end{array}$ & $\begin{array}{l}\text { ( ) Sim ( ) Não } \\
\text { Justificativa: }\end{array}$ \\
\hline Pesquisa / PE atinge o que propõe? & $\begin{array}{l}\text { ( ) Sim ( ) Não ( ) Parcialmente } \\
\text { Justificativa: }\end{array}$ \\
\hline \multicolumn{2}{|c|}{ PARTE 4 - OUTRAS... (questionamentos específicos de etapas de pesquisa anteriores) } \\
\hline \multicolumn{2}{|l|}{ Interdisciplinaridade } \\
\hline Relação ensino-pesquisa-extensão & \\
\hline
\end{tabular}


Referência a outras atividades do MP

Referência ao processo de orientação

Referência ao processo de formação (influências

em sua prática docente... ao seu DP)

Impactos relatados na instituição escolar do prof.

cursista (ou onde foi aplicado o PE)

PE alinhado ao "paradigma da aprendizagem

ativa"?

) Sim ( ) Não

Produções subsequentes (eventos, periódicos...)

Outras observações / destaques interessantes 


\section{Apêndice 4 - Base do roteiro das entrevistas semi-estruturadas realizadas com os egressos dos cursos de MP}

\section{1) O que te motivou a ingressar no curso de MP?}

- Por que o MP (e não MA)?

- Quais foram as expectativas iniciais?

- Por que escolheu esse curso em específico (e não outro MP)?

\section{2) Como foi o seu desenvolvimento no curso de MP?}

Aspectos sobre:

- disciplinas cursadas

- escolha e relação com professor orientador

- contato com demais professores-cursistas, seus colegas

- relação com as escolas em que trabalhou concomitantemente à realização do MP

- demais atividades acadêmicas (participação de eventos, seminários promovidos pelo MP, etc)

\section{3) Como foi o processo de elaboracão do produto educacional e dissertacão?}

\section{Aspectos sobre:}

- problemática levantada

- referenciais teóricos

- metodologia utilizada

- aplicação, coleta de dados

- o processo de orientação

\section{4) Perguntas específicas originadas a partir da dissertacão/produto educacional do professor entrevistado}

5) Em que medida a realização do MP e do PE afetou sua prática profissional? Como sua prática docente é hoje, tendo em vista o que era antes do MP? Alguma mudança?

- novos conteúdos?

- novas estratégias e metodologias didáticas?

- pesquisa sobre a própria prática?

- novas relações entre alunos, colegas professores, gestores da escola, comunidade...?

- nova visão das relações pedagógicas?

- o que os resultados da aplicação do PE trouxe para sua prática?

\section{6) Como avalia a realizacão do MP nesse curso? Quais são os pontos mais} favoráveis? E os desfavoráveis?

- o que significa a "satisfação" com o curso em termos concretos?

\section{Questões específicas de cada curso levantadas em outras etapas de pesquisa que também poderiam ser abordadas nas entrevistas:}

\section{MNPEF:}

- orientadores que não são da área de Ensino

- reivindicações de necessidades formativas (mudanças no currículo proposto ou nos procedimentos) para a CPG central do MNPEF

- avaliação do plano de trabalho ao longo do curso

- infraestrutura oferecida para apoiar o trabalho dos professores-cursistas

- contribuições da disciplina de estágio supervisionado

- parcerias com docentes do polo para apoiar mudanças nas práticas (aumento do interesse dos alunos da educação básica para o estudo da Física) 
- título de mestre profissional confereria ao professor a legitimidade e apoio da gestão escolar para a realização de mudanças?

MP.Local:

- relações com o curso de MA

- relações ensino, pesquisa e extensão preconizada no curso; relação com

interdisciplinaridade

- exigência de produção acadêmica (publicação de artigo)

- há relação entre o que é discutido nas disciplinas com a realização do produto educacional/pesquisa? 